\title{
PHYLOGENETIC SYSTEMATICS, BIOCHRONOLOGY, AND PALEOBIOLOGY \\ OF LATE NEOGENE HORSES (FAMILY EQUIDAE) OF THE GULF \\ COASTAL PLAIN AND THE GREAT PLAINS
}

By

RICHARD CHARLES HULBERT, JR.

A DISSERTATION PRESENTED TO THE GRADUATE SCHOOL

OF THE UNIVERSITY OF FLORIDA IN

PARTIAL FULFILLMENT OF THE REQUIREMENTS

FOR THE DEGREE OF DOCTOR OF PHILOSOPHY

UNIVERSITY OF FLORIDA 


\section{ACKNOWL EDGMENTS}

The members of my supervisory committee, Drs. Bruce J. MacFadden, S. David Webb, and Douglas S. Jones, aided the completion and improved the content of this study in many ways. Dr. MacFadden suggested the initial proposal, a study of the Love Site Equidae, but has masterfully guided the project through its convoluted evolution to its present form. He has continually gone the extra step to provide me with support and equipment. Dr. Webb has shared with me his considerable expertise of ungulate evolution and Florida's prehistory. Not the least was a suggestion to take a close look at the holotype of "Merychippus" westoni. The manuscript has greatly benefited from their combined editorial skill. I also thank Drs. Ronald Wolff and Jon Reiskind, who also participated in the qualifying and final exams, and provided insightful criticism.

Without the fossil specimens, this study would not exist. The following individuals and institutions allowed me access and permission to study specimens in their collections during the course of this study: R. H. Tedford, American Museum of Natura 1 History; $M$. R. Voorhies, University of Nebraska State Museum; E. L. Lundelius, Texas Memorial Museum; G. E. Schultz, West Texas State Universtiy; J. H. Hutchison, Universtiy of California, Berkeley; D. P. Whistler, Los 
Angeles County Museum; C. Smart, Academy of Natural Sciences of Philadelphia; T. M. Bown, United States Geological Survey, Denver; W. W. Dalquest, Midwestern State University; L. D. Martin, University of Kansas; and J. S. Waldrop. Ron and Pat Love and John Shimfessel graciously notified the Florida State Museum of fossils discovered on their respective properties, and allowed museum field crews to collect additional specimens. The following individuals donated fossil specimens to the Florida State Museum that were used in this study: Donald Crissinger, John Waldrop, Danny Bryant, Frank Garcia, Larry Martin, George Heslep, Jerry Case, Howard Converse, Gale Zelnick, James Ranson, Joe Larned, Craig Patrick, Mark Patrick, Earlene Mitche11, Jeff Walker, Roy Burgess, Clifford Jeremiah, Eric Kendrew, Larry Lawson, Jon Bryan and Rick Carter. The latter individual in particular has made numerous unselfish contributions of Bone Valley specimens in the last few years. Collectively, this group of individuals has increased our knowledge of Bone Valley horses manyfold.

The excellent specimen illustrations are by Wendy Zomlefer and Gerald Masters. Dr. R. Tedford has allowed me use of unpublished illustrations prepared by Frick personel in the 1960s. Russell McCarty and Howard Converse prepared many of the specimens, and sectioned numerous teeth. During the early phases of the study, curation of the Love Site equids was aided by Diderot Gicca and Troy Storey. 
Dr. M. 0. Woodburne provided a copy of J. P. Quinn's Master's thesis. Or. Charles Smart took the time to locate the lectotype and paratype of Protohippus supremus at a rather hectic moment during the SVP meetings. I also benefited from discussions with Jack Wilson on Gulf Coast biostratigraphy.

My tenure as a graduate student at Florida has been blessed with close camaraderie with my fellow students and the museum VP staff, and this study bears witness to their helpful support and input. Specifically, I thank Gary Morgan, Ann Pratt, Jon Becker, Steve Emslie, Mary Ellen Ahearn, David Wright, Roger Portell and Art Poyer for their many and diverse contributions.

Finally, I thank my family for their support, and for offering temporary refuge from the world of academia and fossil horse teeth. My visits to various museums across the country, a crucial aspect of this study, were financed by a bequest from my grandmother, Mary Peterson. This study is what results from taking an impressionable young child to see the dinosaurs at the Field Museum. Once again, my companions from Richard Adams to Roger Zelazny, inclusive always provided a necessary escape from reality when called upon. 
TABLE OF CONTENTS

$\underline{\text { Page }}$

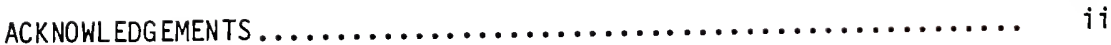

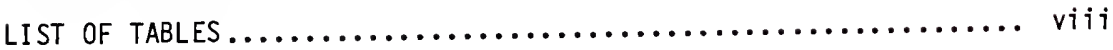

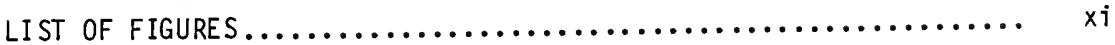

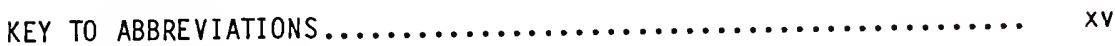

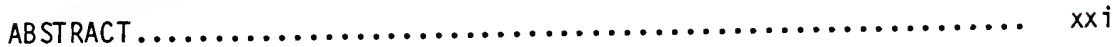

CHAPTERS

1 INTRODUCTION................................... I

2 HISTORY OF PREVIOUS WORK ON GULF COASTAL PLAIN EQUIDS...... 5

Florida............................................ 5

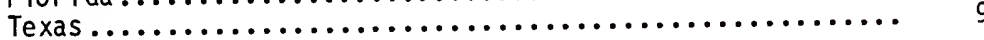

3 MATERIALS, METHODS AND TERMINOLOGY.................. 11

Materials........................................ 11

Systematic Methodology............................ 12

Terminology................................... 17

Ontogenetic and Individual Variation in Equid

Cheekteeth.................................. 21

4 DESCRIPTION OF GULF COASTAL PLAIN EQUID LOCALITIES........ 25

Northern Peninsular Florida....................... 25

Southern Peninsular Florida......................... 34

Texas Gulf Coastal Plain.......................... ${ }_{40}$

5 SYSTEMATIC PALEONTOLOGY......................... 43

Order Perissodactyla Owen, 1848

Fami ly Equidae Grey, 1821

Subfami ly Equinae Steinmann and Döderlein, $1890 \ldots \ldots \ldots .43$

Tribe Hipparionini Quinn, $1955 \ldots \ldots \ldots \ldots \ldots \ldots \ldots \ldots . . .64$ 
Genus Neohipparion Gidley, $1903 \ldots \ldots \ldots \ldots \ldots \ldots \ldots . .46$

Neohipparion affine (Leidy), $1869 \ldots \ldots \ldots \ldots \ldots . .48$

Neohipparion trampasense (Edwards), $1982 \ldots \ldots \ldots \ldots . .67$

Neohipparion eurystyle (Cope), $1893 \ldots \ldots \ldots \ldots \ldots \ldots .677$

Genus Pseudhipparion Ameghino, $1904 \ldots . . \ldots \ldots \ldots . . . .96$

Pseudhipparion sp. $\ldots \ldots \ldots \ldots \ldots \ldots \ldots \ldots \ldots \ldots \ldots, 91$

Pseuchipparion curtivailum (Quinn), $1955 \ldots \ldots \ldots \ldots . . .62$

Pseudhipparion skinneri Webb and Hulbert, $1986 \ldots . . .99$

Pseuchipparion simpsoni Webb and Hulbert, $1986 \ldots \ldots .94$

Genus Nannippus Matthew, $1926 \ldots \ldots \ldots \ldots \ldots \ldots \ldots \ldots . . \ldots 6$

Nannippus fricki new species.................... 99

Nannippus sp., cf. Nannippus fricki.............. 112

Nannippus westoni (Simpson), 1930 new combination... 117

Nannippus minor (Sellards), $1916 \ldots \ldots \ldots \ldots \ldots \ldots . .136$

Genus Cormohipparion Skinner and MacFadden, 1977...... 156

Cormohipparion sphenodus (Cope), $1889 \ldots \ldots \ldots \ldots \ldots .159$

Cormohipparion occidentale (Leidy), $1856 \ldots \ldots \ldots \ldots .164$

Cormohipparion plicatile (Leidy),

1887 new combination ........................ 174

Cormohipparion ingenuum (Leidy),

1885 new combination ......................... 218

Cormohitiparion emsliei new species.............. 238

Genus Hipparion de Christol, $1832 \ldots \ldots \ldots \ldots \ldots \ldots \ldots . .262$

Hipparion shirleyi MacFadden, $1984 \ldots . . \ldots \ldots \ldots \ldots . . .263$

Hipparion tehonense (Merriam), $1916 \ldots \ldots \ldots \ldots \ldots \ldots . . . .265$

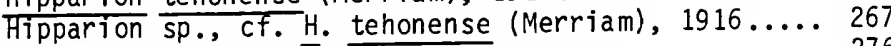

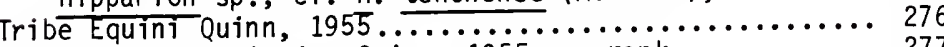

Subtribe Protohippina Quinn, 1955 new rank........... 277

Genus Calippus Matthew and Stirton, $1930 \ldots \ldots \ldots \ldots \ldots .277$

Subgenus CaTippus Matthew and Stirton, $1930 \ldots \ldots \ldots \ldots 282$

Cal. (CaTippus) proplacidus (Osborn),

1918 new combination......................... 283

Cal. (Calippus) placidus (Leidy), $1869 \ldots \ldots \ldots \ldots \ldots .298$

CaT. (Calippus) $\frac{\text { regutus Johnston, } 1937 \ldots \ldots \ldots \ldots \ldots . . .}{} 304$

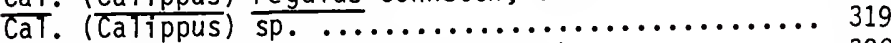

CaT. (CaTippus) elachistus new species............ 320

subgenus Grammohi ppus new subgenus............... 331

?Cal. (Grammohippus) circulus (Quinn),

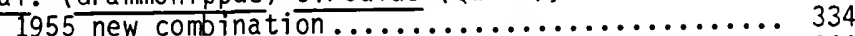

Cal. (Grammohippus) martini Hesse, $1936 \ldots \ldots \ldots \ldots . . .341$

CaT. (Grammohippus) cerasinus new species.......... 360

CaT. (Grammohippus) hondurensis ( 01 son and $\ldots \ldots 377$

McGrew), 1941 new combination .................... 377

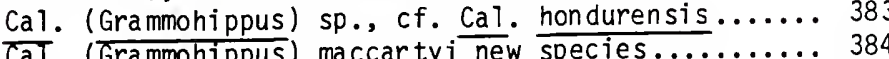

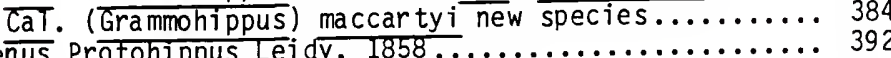

Genus
Protohippus perditus Leidy, $1858 \ldots \ldots \ldots \ldots \ldots \ldots \ldots . . . \ldots \ldots$
394

Protohippus supremus Lei dy, $1869 \ldots \ldots \ldots \ldots \ldots \ldots \ldots .410$

protohippus gidleyi new species................... 423 
Subtribe Equina new subtribe................. 436

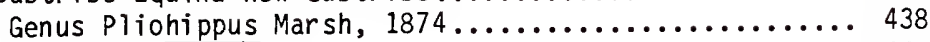

cf. Pliohippus sp...................... 440

Genus Astrohippus Stirton, $1940 \ldots \ldots \ldots \ldots \ldots \ldots \ldots \ldots . \ldots 443$

Astrohippus stockii (Lance), $1950 \ldots \ldots \ldots \ldots \ldots \ldots . . . . . . .444$

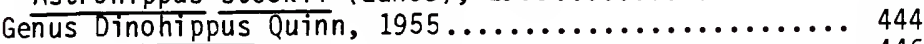

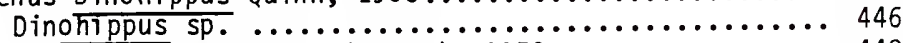

Dinohippus mexicanus (Lance), $1950 \ldots \ldots \ldots \ldots \ldots \ldots \ldots 448$

6 PHYLOGENETIC ANALYSIS AND CLASSIFICATION ............. 449

Introduction and Historical Perspective............ 449

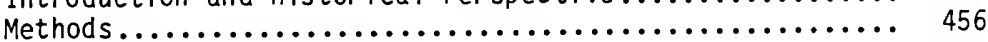

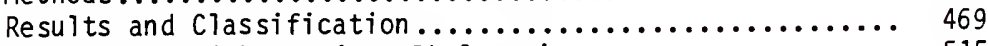

Comparisons with Previous Phylogenies.............. 515

7 BIOCHRONOLOGY, BIOSTRATIGRAPHY, AND SPECIES DYNAMICS...... 519

Biostratigraphy........................... 523

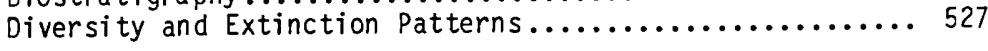

8 CONCLUSIONS AND SUMMARY...................... 532

REFERENCES CITED ............................ 551

BIOGRAPHICAL SKETCH.......................... 570 


\section{LIST OF TABLES}

Page

Table 1. Moss Acres Racetrack Site faunal 1ist ............. 32

Table 2. Neohipparion affine upper cheekteeth statistics...... 53

Table 3. Neohipparion affine lower cheekteeth statistics....... 55

Table 4. Neohipparion trampasense upper cheekteeth statistics... 65

Table 5. Neohipparion trampasense Tower cheekteeth statistics.... 71

Table 6. Neohipparion eurystyle upper cheekteeth statistics..... 82

Table 7. Neohipparion eurystyle lower cheekteeth statistics..... 84

Table 8. Measurements of individual Nannippus cheekteeth....... 105

Table 9. Nannippus fricki upper cheekteeth statistics ......... 108

Table 10. Nannippus westoni upper cheekteeth statistics......... 121

Table 11. Measurements of medial metapodials of Nannippus........ 129

Table 12. Inventory of Moss Acres skeletons of Nannippus minor.... 140

Table 13. Nannippus minor upper cheekteeth statistics.......... 141

Table 14. Nannippus minor lower cheekteeth statistics......... 147

Table 15. Measurements of individual Cormohipparion cheekteeth.... 163

Table 16. Mandibular measurements of hipparionines ........... 168

Table 17. Frequency of plications in lower cheekteeth

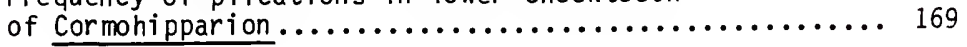

Table 18. Cormohipparion plicatile upper cheekteeth statistics.... 180

Table 19. Cormohipparion plicatile and Cor. ingenuum lower

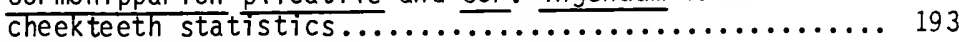

Table 20. Variation in basal tooth length in equid populations.... 198 
Table 21. Median values of Cormohipparion fossette plications.... 210

Table 22. Cormohipparion ingenuum upper cheekteeth statistics.... 223

Table 23. Cormohipparion emsliei upper cheekteeth statistics..... 249

Table 24. Cormohipparion emsliei lower cheekteeth statistics..... 250

Table 25. Measurements of medial metapodials of

Cormohipparion emsliei and other equids........... 257

Table 26. Comparison of unworn crown height of equids......... 258

Table 27 . Hipparion upper cheekteeth statistics............. 268

Table 28. Measurements of individual cheekteeth of Hipparion ..... 270

Table 29. Calippus proplacidus and Cal. placidus upper

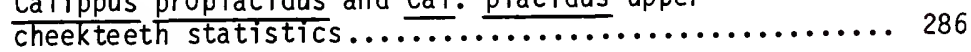

Table 30. Calippus proplacidus and Cal. placidus lower

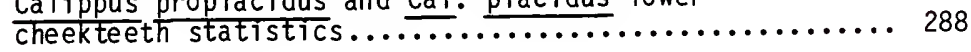

Table 31. Measurements of cheekteeth of Calippus proplacidus ..... 290

Table 32. Calippus regulus and Calippus elachistus upper cheekteeth statistics............................ 310

Table 33. Calippus regulus and Calippus elachistus lower

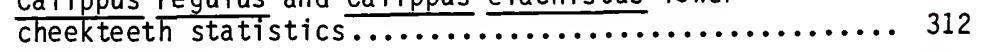

Table 34 . Measurements of cheekteeth of Calippus sp. ......... 318

Table 35. Measurements of cheekteeth of Calippus elachistus...... 327

Table 36. Measurements of cheekteeth of Calippus (Grammohippus) ... 338

Table 37 . Calippus martini upper cheektooth statistics.......... 348

Table 38. Calippus martini lower cheektooth statistics......... 350

Table 39. Calippus cerasinus upper cheektooth statistics........ 370

Table 40 . Calippus cerasinus lower cheektooth statistics........ 372

Table 41. Protohippus spp. upper cheektooth statistics.......... 399

Table 42. Protohippus spp. lower cheektooth statistics......... 401 
Table 43. Measurements of cheekteeth of Protohippus.......... 405

Table 44. Comparison of cranial characters of Protohippus and Pliohippus............................. 407

Table 45 . Measurements of cheekteeth of Florida equines........ 442

Table 46. Character matrix for 57 equid species............. 459

Table 47. Description of characters and character states....... 463

Table 48. Consistency indices for characters in Figure $69 \ldots \ldots . .479$

Table 49. Classification of the Hipparionini and Equini ........ 513

Table 50. Equid species diversity analysis ................ 528

Table 51. Summary of late Neogene equid distributions.......... 534 


\section{LIST OF FIGURES}

$\underline{\text { Page }}$

Figure 1. Dental nomenclature and measurements............. 19

Figure 2. Map of Florida with Tocations of major fossil sites... 27

Figure 3. Neohipparion affine cheekteeth from Texas........... 52

Figure 4. Facial region of Neohipparion trampasense........... 61

Figure 5. Neohipparion trampasense toothrows ............... 62

Figure 6. Neohipparion trampasense upper cheekteeth........... 64

Figure 7. Neohipparion trampasense lower cheekteeth........... 70

Figure 8. Neohipparion eurystyle cheekteeth from Florida........ 81

Figure 9. Type palate of Nannippus fricki ................ 102

Figure 10. Nannippus fricki upper cheekteeth from Nebraska....... 104

Figure 11. Nannippus sp., cf. Nan. fricki cheekteeth........... 115

Figure 12. Nannippus westoni upper cheekteeth............... 123

Figure 13. Nannippus westoni lower cheekteeth............... 124

Figure 14. Medial metapodials of Nannippus from Florida......... 128

Figure 15. Late Hemphillian Nannippus minor upper cheekteeth..... 143

Figure 16. Late Hemphillian Nannippus minor lower cheekteeth..... 144

Figure 17. Outline of partial skull of Nannippus minor......... 151

Figure 18. Nannippus minor cheekteeth from Moss Acres.......... 153

Figure 19. Cormohipparion sphenodus cheekteeth............. 162

Figure 20. Principal components analysis of Cormohipparion
occidentale and Neohipparion affine $\ldots \ldots \ldots \ldots \ldots \ldots 1$ 
Figure 21. Cormohipparion plicatile maxilla $\ldots \ldots \ldots \ldots \ldots \ldots \ldots, 182$

Figure 22. Cormohipparion plicatile upper toothrows........... 183

Figure 23. Cormohipparion plicatile upper cheekteeth........... 185

Figure 24. Cormohipparion plicatile ramus showing diastema....... 190

Figure 25. Cormohipparion plicatile lower toothrows............ 191

Figure 26. Cormohipparion plicatile lower cheekteeth........... 192

Figure 27. Histograms of Cormohipparion plicatile and Cor. ingenuum upper premolars........................ 201

Figure 28. Histograms of Cormohipparion plicatile and Cor.

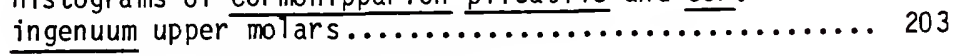

Figure 29. Results of discriminant analysis................ 205

Figure 30. Histograms of premolar fossette plications.......... 212

Figure 31 . Histograms of molar fossette plications........... 214

Figure 32. Histograms of fossette plications of Cormohipparion occidentale from Nebraska........................ 215

Figure 33. Cormohipparion ingenuum maxilla ................ 225

Figure 34. Cormohipparion ingenuum upper toothrows........... 226

Figure 35. Cormohipparion ingenuum lower toothrows........... 227

Figure 36 . Cormohipparion ingenuum lower cheekteeth............ 228

Figure 37. Cormohipparion emsliei holotype and topotypes........ 243

Figure 38. Cormohipparion emsliei upper cheekteeth........... 246

Figure 39. Cormohipparion emsliei lower cheekteeth............ 248

Figure 40 . Cormohipparion emsliei metatarsal III............. 256

Figure 41. APL vs. TRW for Cormohipparion and Nannippus species... 259

Figure 42. Maxilla and cheekteeth of Florida Hipparion.......... 272

Figure 43. Plot of equid toothrow length vs. muzzle width....... 281 
Figure 44. Calippus proplacidus cheekteeth from Texas.......... 291

Figure 45. Calippus sp. and Calippus proplacidus from Florida..... 292

Figure 46. Molar BAPL vs. PRL for four species of Calippus........ 293

Figure 47. Molar APL vs. unworn crown height for Calippus........ 294

Figure 48. Calippus placidus upper cheekteeth from Texas........ 301

Figure 49. Calippus regulus skull and mandible.............. 309

Figure 50. Molar BAPL for four populations of Calippus.......... 317

Figure 51. Calippus elachistus cheekteeth from the Love Site..... 324

Figure 52. Calippus elachistus holotype mandible............. 325

Figure 53. Early Hemphillian Calippus elachistus cheekteeth...... 326

Figure 54. ?Calippus circulus upper cheekteeth.............. 337

Figure 55. Calippus spp. from Florida .................. 347

Figure 56. Molar BAPL vs. PRL for four species of Grammohippus.... 352

Figure 57. Calippus cerasinus holotype skull and referred jaw..... 365

Figure 58 . Calippus cerasinus upper cheekteeth.............. 367

Figure 59. Calippus cerasinus lower cheekteeth............... 369

Figure 60. Calippus maccartyi cheekteeth from Florida.......... 387

Figure 61. Calippus maccartyi holotype mandibular symphysis...... 388

Figure 62. Protohippus upper cheekteeth from Florida........... 404

Figure 63. Protohippus supremus upper cheekteeth from Nebraska.... 415

Figure 64. Protohippus gidleyi toothrows from the Love Site...... 428

Figure 65. Protohippus gidleyi cheekteeth from the Love Site..... 429

Figure 66. Timing of protocone connection and hypocona 1 groove closure in upper premolars of Protohippus gidleyi .... 431

Figure 67 . Cladograms of previous phylogenetic hypotheses regarding the Equinae ................................ 
Figure 68 . Forsten's cladogram of the Hipparionini............ 454

Figure 69. Computer-generated cladogram of 45 equid taxa....... 472

Figure 70 . Computer-generated cladogram of 45 equid taxa using on ly highily consistent characters.................. 474

Figure 71. Computer-generated cladogram of genotypic species..... 476

Figure 72. Computer-generated cladogram of Barstovian species,.... 478

Figure 73. Most parsimonious cladogram of the Hipparionini....... 484

Figure 74. Preferred cladogram of the Hipparionini........... 486

Figure 75. Most parsimonious cladogram of the Equini........... 503

Figure 76. Preferred cladogram of the Equini............... 505

Figure 77. Chronologic distribution of equid species.......... 521

Figure 78 . Equid diversity patterns in the late Neogene........ 530 


\section{KEY TO ABBREVIATIONS}

Institutional Collections

AMNH--Department of Vertebrate Paleontology, American Museum of Natura 1 History, New York. ANSP--Academy of Natural Sciences. Philadelphia. F:AM--Frick American Mammals, now housed with AMNH collection. JWT--C. S. Johnston collection, housed in PPM. KUVP--University of Kansas Museum of Paleontology, Lawrence. LACM--Natural History Museum of Los Angeles County, Los Angeles. LACM(CIT)--California Institute of Technology collection, now housed with LACM collection. MSU--Midwestern State Universtiy, Wichita Falls, Texas. PPM--Panhandle-Plains Historical Museum, Canyon, Texas. SDSM--Museum of Geology, South Dakota School of Mines and Technology, Rapid City.

TAMU--Texas A \& M University collection, now housed with TMM collection.

TMM--Texas Memorial Museum, University of Texas, Austin. 
TR0--Timberlane Research Organization, private collection of John Waldrop, Lake Wales, Florida. UCMP--University of California Museum of Paleontology, Berkeley. UCR--Department of Earth Sciences, University of California, Riverside. UF--Florida State Museum, University of Florida, Gainesville. UF/FGS--Florida Geological Survey collection of fossil vertebrtes, now housed with UF collection. UNSM--University of Nebraska State Museum, Lincoln. USNM--National Museum of Natural History, Smithsonian Institution, Washington, D.C. WM--Walker Museum collection, now housed at the Field Museum of Natura 1 History, Chicago. WT--West Texas State University collection, housed in PPM.

Morphological Characters and Terms

DPOF--dorsal preorbital fossa (= lacrimal or nasomaxillary fossa). MF--malar fossa. IOF--infraorbital foramen. MT--metatarsa 1. MC--metacarpa 7 . R, L--right, left. I/i--upper/lower incisor. c/c--upper/lower canine. 
P/p--upper/lower premolar (e.g. P4 is an upper fourth premolar). M/m--upper/lower molar (e.g. $\mathrm{m} 2$ is a lower second molar).

D/d--upper/lower deciduous tooth (e.g. dp2 is a deciduous lower second premolar).

P34, p34, DP34, dp34, M12, m12--collective terms for indistinguishable isolated teeth (e.g. P34 refers to upper third or fourth premoiars).

$\mathrm{HI}$--hypsodonty index (=maximum M12 MSCH/mean M12 BAPL)

\section{Measurements}

Those in uppercase refer to upper dentitions; lowercase to lower dentitions. Measurements taken on oclusal surfaces of cheekteeth are iliustrated in Figure 1.

APL--maximum anteroposterior length, excluding the ectoloph and hypocone.

BAPL--anteroposterior length at the base of the crown.

TRW--transverse width from mesostyle to lingual-most part of the protocone.

PRL--maximum length of the protocone, excluding spur and connection to protoselene.

PRW--maximum width of the protocone perpendicular to PRL. MSCH--crown height measured from the occlusal surface to the base of the crown along the mesostyle.

UTRL-- upper toothrow length from the anterior-most projection of the P2 to the posterior-most part of the M3. 
UDL-- upper postcanine diastema length, measured between the alveoli of the $C$ and the P2 (excludes DP1 if present). ROC--radius of curvature, measured on the mesostyle (Skinner and Taylor, 1967). apl--maximum anteroposterior length from the paralophid to the hypoconulid. bapl--anteroposterior length at the base of the crown. atw--transverse width from the protoconid to the metaconid. ptw--transverse width from the hypoconid to the metastylid. ent 1--anteroposterior length of the entoflexid. $\mathrm{mml--length}$ from the anterior-most point of the metaconid to the posterior-most point of the metastylid. mcch--crown height measured from the occlusal surface to the base of the crown along the metaconid. 1trl-- lower toothrow length measured from the anterior-most part of the p2 to the posterior-most point of the $\mathrm{m} 3$. 1d1--lower postcanine diastema length measured between the alveoli of the $c$ and $p 2$ (excluding dpl if present).

\section{Statistical}

$\underline{\bar{x}}$--sample mean.

s--sample standard deviation.

V--sample coefficient of variation expressed as a percentage.

r--sample correlation coefficient.

n--sample size.

OR--observed range of a sample. 
As several genera in this study start with the same letter, the use of the usual abbreviation for a genus (the first letter) might cause confusion in some cases. Therefore, the following abbreviations are uniformly used throughout the study to resolve any possible conflicts.

Pseud. - Pseudhipparion.

Pro.--Protohippus.

Plio.--Pliohippus.

Para.--Parahippus.

Cor.--Cormohipparion.

Cal.--Calippus

Nan.--Nannippus.

Neo. - Neohipparion.

Miscellaneous

ma--megaanna, millions of years before present on the radioisotopic time scale.

as soc.--as soc jated.

1.f.--local fauna, used in the sense of Tedford (1970).

s.s.--sensu stricto.

s.1.--sensu 1ato.

n. sp.--new species.

n. subg.--new subgenus.

n. comb.--new combination. 
CI--consistency index, used in comparing cladograms.

NB--Nebraska.

TX--Texas.

FL--Florida.

FSM VP loc.--Florida State Museum Vertebrate Paleontology collection locality code. 


\section{Abstract of Dissertation Presented to the Graduate School of the University of Florida in Partial Fulfillment of the Requirements for the Degree of Doctor of Philosophy \\ PHYLOGENETIC SYSTEMATICS, BIOCHRONOLOGY, AND PALEOBIOLOGY OF LATE NEOGENE HORSES (FAMILY EQUIDAE) OF THE GULF COASTAL PLAIN AND THE GREAT PLAINS}

\section{By}

Richard Charles Hulbert, Jr. May 1987

Chairman: Bruce J. MacFadden

Major Department: Zoology

Ten genera and thirty-four species of the subfamily Equinae (Mammalia, Perissodactyla, Equidae) are described from the late Miocene-early Pliocene (late Barstovian-latest Hemphillian) of the Gulf Coastal plain of Florida and Texas, including new species of Nannippus, Cormohipparion, Protohippus and Calippus. Hippotherium ingenuum Leidy and $\underline{H}$. plicatile Leidy are referred to Cormohipparion, and Merychippus westoni Simpson to Nannippus. These referrals are based on voluminous new material from the latest Clarendonian Love Site (Alachua County, Florida). Nine species of equids are recognized at the Love Site, and are described in detail. This site plays a major role in understanding North American equid systematics, phylogeny and paleoecology in the late Miocene. The horses of the following sites or faunas are also extensively reviewed: Cold Spring, Lapara Creek, Mixson's Bone Bed, Moss Acres Racetrack, 
Withlacoochee River $4 \mathrm{~A}$, and the Bone Valley Region. Five distinct faunal assemblages in stratigraphic superposition are recognized from the Bone Valley Formation, each with a diagnostic suite of equids. Comparisons with equid faunas from the Great Plains reveals little distinctive provinciality between these two regions in the late Miocene, as they have many species in common. This similarity allows a biochronologic zonation of the period between 16.5 and 4.5 million years ago (ma) into nine biochrons based on concurrent range zones of two or three equid species.

Phylogenetic analysis indicates that the advanced Equinae form a monophyletic group comprised of two tribes, the Hipparionini and Equini. The Hipparionini consists of two major clades, one with Neohipparion and Pseudhipparion, the other with Hipparion, Cormohipparion and Nannippus. Two clades are also recognized in the Equini, one with Protohippus and Calippus, the other with Pliohippus, Astrohippus and Equus. Species previously assigned to the paraphyletic grade "Merychippus" are classified in their phylogenetically correct positions. Equid evolution is characterized by frequent parallelisms and character reversals that complicate phylogenetic reconstruction. Thus, computer-generated, most parsimonious cladograms sometimes produce evolutionarily unlikely scenarios. Hipparionines and protohippines numerically and taxonomically dominated North American equid faunas until about $6.5 \mathrm{ma}$; then equines predominated. Protohippines became extinct about $6.2 \mathrm{ma}$, and hipparionines about $2.0 \mathrm{ma}$. 
CHAPTER 1

INTRODUCTION

During the later part of the Miocene, between about 14 and $6 \mathrm{ma}$, numerous lineages of equids flourished in apparent sympatry across North America. By the middle Pliocene (at about $4 \mathrm{ma}$ ), only a remnant was left of this great radiation. Living horses, represented by the single 01d World genus Equus, display little of the morphological (and presumably ecological) diversity that once characterized the family Equidae. Therefore, our comprehension of the rise and fall of North American equid diversity must be based primarily on their fossilized remains, supplemented with information derived from other components of the biota, and from various geological disciplines. For tunately, the fossil record of the Equidae is relatively complete and abundant, sometimes overwhelmingly so. This has led to a proportionaliy large body of literature concerning fossil equids, yet their systematics and phylogenetic relationships are not well understood. Most previous studies have either dealt with equids from a 1 imited geographic region, often from a single site (e.g. Leidy, 1885; Merriam, 1919; Richey, 1948; Stirton, 1955; Forsten, 1975; Edwards, 1982), or present overviews of equid evolution at the generic level (e.g. Gidley, 1907; Matthew, 1926; Stirton, 1940). While not impuning the importance and value of such studies, they do not provide the detailed, comprehensive, integrated information necessary to fully understand the 
late Miocene equid radiation and subsequent decline. Comprehensive generic reviews of some taxa have recently appeared (MacFadden, 1984a; Webb and Hulbert, 1986), and for the first time modern phylogenetic systematic methods have been used with this group of horses. Rigorous phylogenetic (cladistic) analysis is now recognized as a necessary prerequisite to meaningful derivative studies can be attempted (Cracraft, 1981). Most of the present study (Chapters 5 and 6) documents the results of this type of systematic analysis. They in turn provide the foundation for Chapter 7 , which presents the results of studies into various aspects of the late Miocene equid radiation.

This study originated as an analysis of an equid community recovered from a single locality in north-central Florida, the late Clarendonian Love Site. A preliminary review by other investigators indicated that seven types of horses were represented at this one site, and that most were closely related to well known species (Webb et a1., 1981). Detailed study, based on more specimens, however, did not confirm these conlusions. Eventually, I have come to recognize nine species at this site, of which five were undescribed when I started this project in 1981, and three that belong to previously poorly known species (see Chapter 5 for details). During the course of this study it became apparent that an analysis of a single site, no matter how detailed, was too limited. Instead, lineages had to be traced through time, to produce a much broader understanding of changes in diversity and faunal composition. Also, this period (ca. 1981-1986) witnessed much more widespread application of phylogenetic systematic methods in vertebrate paleontology, and a deeper 
appreciation of the information they produce (Wiley, 1981; Cracraft, 1981). With this in mind, it became obvious that a rigorous phylogenetic analysis of the Equinae was needed before broader questions could be answered.

The scope of this project was therefore widened to encompass the equids from the last of the three great Miocene chronofaunas, the Clarendonian Chronofauna (Webb, 1977). This interval includes the late Barstovian, Clarendonian, and early Hemphillian Land Mamma 1 Ages, and lasted from about 14 to 6 million years ago. I have not attempted to study a 11 North American equids from this extensive period in equal detail, but have focused on particuiar groups and geographic regions. Geographically, the regions analyzed in greatest detail are the Gulf Coastal Plain and the Great Plains. Earlier in the Miocene, these two regions differed substantially in some aspects of their vertebrate communities (Webb, 1977, and references therein), although they had similar equids in common. Later, by about $15 \mathrm{ma}$, these differences ceased, and the two exhibited broad faunal continuity (Webb, 1977; Tedford et al., in press). It will be documented in Chapter 5 that for the next ten million years they shared many equid species. As for taxa, principal attention is given to two groups of advanced equids, the hipparionines and the protohippines. Together they contributed to most of the diversity witnessed during the height of the Clarendonian Chronofauna (Chapter 7). Equines were apparently much rarer in the Gulf Coastal Plain than these two groups, and did not undergo significant diversification until the middle Hemphillian. They are treated in much less detail in Chapter 5 than the others. I have also 
chosen to ignore the anchitherine (browsing) equids of this period. They are also rare in the Gulf Coastal Plain, and are in great need of taxonomic revision, which would be a large study in itself. 
CHAPTER 2

HISTORY OF PREVIOUS WORK ON GULF COASTAL PLAIN EQUIOS

\section{Florida}

The history of vertebrate paleontology in Florida spans little more than a century. During this period many important Neogene localities have been discovered, along with literally thousands of specimens. From the beginning, equids have played a major role in biochronological correlation of Florida's vertebrate-bearing deposits with those of the West, as well as correlation of localities within the state. Their abundance at most terrestrial sites, wide distributions and rapid evolution enable them to be useful biostratigraphic indicators. Knowledge of Florida's fossil equids is quite dynamic, and shows no sign of stopping. Indeed, since the initiation of this project in 1981, several new lower horizons in the Bone Valley Region with horse remains were discovered, and the extremely important Moss Acres Racetrack Site with its associated skeletons was first worked in 1984. Joseph Leidy described the first two species of equids to be named from Florida in 1885 and 1887 . They both were based on isolated teeth from Mixson's Bone Bed (see Chapter 4 for detailed discussions of the geology, fauna and biochronology of this and other localities mentioned in this chapter), the first major late Neogene site discovered in Florida. Although based on rather inadequate material by modern standards, and described without adequate comparison with 
other North American equids, both of Leidy's species (Hippotherium ingenuum and $\underline{H}$. plicatile) are still valid (Chapter 5). Cope (1889) synonymized $\underline{H}$. ingenuum with an older name of Leidy, $\underline{H}$. gratum, and this synonymy was followed by Lucas in his posthumous collaborative review of the Mixson 1.f. with Leidy (Leidy and Lucas, 1896). Gidley (1907) disagreed, and considered $\underline{H}$. ingenuum a valid species, as have a11 subsequent authors.

In the first decades of the 20 th Century, vertebrate fossils began to be routinely recovered as a by-product of large-scale phosphate mining in Florida. This occurred in both the "hard-rock" phosphate deposits of northern peninsular Florida (e.g. Hay, 1916), and in the southern, "land-pebble" deposits (Sellards, 1910; 1916). The 1atter area, better known as the Bone Valley Region, has ever since been a valuable source of vertebrate fossils, as its name implies. Sellards (1915; 1916) reported on the first remains of horses recovered from the Bone Valley Formation. He recognized three species in these deposits, the two previously named by Leidy, $\underline{H}$. ingenuum and $\underline{H}$. plicatile, and a new species, the very small $\underline{\mathrm{H}}$ minor. $\underline{\mathrm{H}}$. minor is now known to be the most abundant horse in the Upper Bone Valley Fauna. Simpson (1930) later reviewed the Bone Valley Fauna, recognized the same three species as had Sellards (1916), and established a fourth, H. (Neohipparion) phosphorum. Sellards (1916) and Simpson (1930) both thought that the faunas from Mixson's, from the nor thern phosphate deposits (other Alachua Formation sites), and from the Bone Valley Formation were all roughly contemporaneous, and that they shared many species in common (including equids). Simpson (1930) also described 
"Merychippus" westoni from Gilchrist County, from what he thought was the Hawthorn Formation. This geologic assignment was primarily based on his interpretation of the morphology and stage of evolution represented by the heavily worn type specimen. Further discoveries suggest that Simpson was incorrect in his assessment of the specimen's age and morphology ( see Chapter 5).

Following Simpson's (1930) study, little original work was done on late Neogene equids from Florida for over 30 years. The simplest explanation for this was a lack of major new localities. During this interval attention was primarily focused instead on the very important early Miocene Thomas Farm Site, and on Pleistocene localities. This period did see the most intensive (and final) excavations at Mixson's Bone Bed by Frick field crews. A number of equid specimens were collected, but the F:AM sample from Mixson's was not studied until very recentiy.

This drought in the study of late Neogene equids was broken by the discovery in 1962 of the McGehee Farm Site, the first major late Neogene locality found in north-central Florida since Mixson's. Equids are moderately diverse at McGehee, although represented mostly by isolated teeth. Two genera were initially identified (Calippus and either Pliohippus or Dinohippus) by Webb (1964). These are notable as the first nonhipparionines reported from the late Neogene of Florida. Later, three additional equids were listed as members of the fauna (Hirschfeld and Webb, 1968). The discovery of McGehee was quickly followed by further new localities with late Neogene equids, especially the Withlacoochee River sites, the Haile sites, and the 
Manatee County Dam Site. The latter produced the first record of Pseudhipparion (=Griphippus) from Florida (Webb and Tessman, 1967; 1968). Interest was also rekindled in the Bone Valley Region at this time, with emphasis on collecting in situ material (see Webb, 1969b, p. 274). The equids from all these sites furnished the basis for Waldrop's (1971) unpublished thesis, but until very recently have not appeared in the literature (MacFadden, 1984a; Webb and Hulbert, 1986).

The next major discovery, the Love Site, is certainly the most important late Neogene vertebrate fossil locality in Florida. For the first time, material rivaling in quantity and quality the most productive quarries from the Great Plains was recovered from Florida. Excavation at the Love Site began in 1974, and continued to June, 1981. Afterwards, there was an almost two year period when its voluminous equid material was identified, curated and catalogued. The first report of equids from the Love Site was in Jackson's (1978) study of Deirochelys. He noted the presence of Leidy's two classic "Alachua Clays" species, $\underline{H}$. plicatile and "Nannippus" ingenuus. Webb et al. (1981) recognized at least seven taxa of equids in their preliminary review of the fauna, but oddly did not include either of the two species recognized by Jackson (1978). More recently, Love Site equids were studied by Hulbert (1982), MacFadden (1984a), and Webb and Hulbert (1986), and also provide the major basis for this study.

In the last 10 years, a number of other studies have investigated late Neogene Florida equids. MacFadden and Waldrop (1980) described specimens of Nannippus "phlegon" and proposed a neotype for Nan. 
minor. MacFadden (1982) described a new species of Hypohippus from a lower horizon of the Bone Valley Formation, while Berta and Galiano (1984) illustrated a tooth of "Astrohippus" martini also from the lower Bone Valley. MacFadden (1986) referred specimens from the Upper Bone Valley and from the newly discovered Lockwood Meadows 1.f. to Dinohippus mexicanus and Astrohippus stockii, and discussed their biochronological significance. The most important locality discovered subsequent to the Love Site is the Moss Acres Racetrack Site. It was first worked in December, 1984, and excavated sporadically through at least 1987. Unlike all the other late Neogene localities in Florida, specimens from Moss Acres often consist of associated and/or articulated elements. Equids are diverse at Moss Acres, and many species are represented by more complete material than at any other site. The Moss Acres equids are reported here for the first time.

\section{Texas}

The record of late Neogene mammals, including equids, from the Texas Gulf Coastal Plain is less complete than that of Florida. However, they are deposited in traceable stratigraphic units, that can be placed in direct superposition, thereby aiding correlation. The earliest studies of Miocene equids from this region are those of Leidy (e.g. $1869 ; 1873$ ), but the described specimens are isolated finds. They are not very important except to generally indicate the age of the deposits. Increased geological reconnaissance of the region in the early 1900 s resulted in the discovery of several substantial localities that contained equids (e.g. Cold Spring 1.f. and Burkeville 
1.f.). Hay (1924) described "Merychippus" francisi from the Noble Farm Site, but did not compare it with Great Plains forms. Hesse (1943) first reviewed the biostratigraphic relationships of the faunas from southeastern Texas. He referred the equids from the Burkeville and Cold Springs Faunas to "M." francisi and Protohippus perditus.

Quinn (1955) analyzed in detail the nonhipparionine portion of the Texas Gulf Coastal Plain equids. His study included the faunas previously known to Hay and Hesse, but also the younger and more productive Lapara Creek Fauna. Quinn's systematic methodology was highly unorthodox, and his work engendered much controversy and criticism le.g. Webb, 1969a). The entire equid fauna (including hipparionines) was restudied by Forsten (1975), whose approach (in terms of alpha-level systematics) was the diametrical opposite of Quinn's. While he divided the equids from any particular fauna into many species, she tended to lump many of the se together. In my opinion (as documented in Chapter 5), the "real" number of species generally lies somewhere between their two extreme viewpoints. Unlike the situation in Florida, no major late Neogene localities have been discovered on the Texas Gulf Coastal Plain in the last 30 years. The differences in classification of its equids by Quinn (1955), Forsten (1975) and this study reflect differences in interpretation, and are not based on new material. 


\section{CHAPTER 3 \\ MATERIALS, METHODS AND TERMINOLOGY}

\section{Materials}

Equid crania, mandibles, and isolated teeth of late Barstovian through Blancan age (excluding Equus, Blancan Nannippus, and anchitheriines) from the Gulf Coastal Plain of Florida and Texas were examined and measured. Specimens from major localities and faunas (e.g. Love Site, Lapara Creek Fauna) were analyzed quantitatively with univariate statistics. Specimens from this region are principally housed in the UF, UF/FGS, TMM, TAMU, and F:AM collections. The USNM and ANSP have a few historically important specimens. In general, post-cranial elements were not studied, except in the rare instances when they could be unambiguously assigned to a species. Types or casts of type specimens of all species known from this period were examined from the AMNH, ANSP, USNM, TMM, TAMU, UCMP, LACM, PPM, UF, and UF/FGS collections. Comparative material of equids from outside of the Gulf Coastal Plain was similarly studied, principally from the Great Plains but also including specimens from Mexico, Nevada and California. A primary goal was to obtain data from large quarry samples of well known faunas, e.g. Burge, Clarendon, Minnechaduza, Yepomera and Coffee Ranch. The se provided standard ranges of individual and ontogenetic intraspecific variation. In many cases 
they also supplied additional information concerning cranial morphology. Equid skulls are relatively much rarer in the Gulf Coastal Plain than in the Great Plains, and those present in the former area are usually crushed or incomplete. The comparative material was especially useful in associating upper and lower dentitions of the same species, and in determining character states for the phylogenetic analysis.

\section{Systematic Methodology}

Alpha-level Systematics

The following systematic procedures were performed for each major Gulf Coastal Plain equid fauna (i.e. the Cold Spring, Lapara Creek, Archer and Palmetto Faunas, see Chapter 4). First, each specimen was assigned to a morphological group. Initially, upper and lower, juvenile and adult dentitions were all treated separately. Thus for any fauna, there would be $n_{1}$ morphs for upper adult dentitions, $n_{2}$ morphs for upper juvenile dentitions, $n_{3}$ morphs for lower adult dentitions, and $n_{4}$ morphs of lower juvenile dentitions. All the $n_{i}$ 's were not necessarily the same. Each morph was made up of teeth of similar size and enamel pattern. The next step was to determine which morphs merely represented different wear-classes of the same population. These were matched using sectioned teeth, individuals in intermediate wear-stages, and measurements of basal crown length (BAPL and bap1) which are uncorrelated with age. Once this was accomplished, there were then $x_{1}$ populations represented by upper 
adult dentitions, $x_{2}$ by upper juvenile dentitions, $x_{3}$ by Tower aduit dentitions, and $x_{4}$ by lower juvenile dentitions. In theory each of the $x_{i}$ 's should now be the same. In practice, they often differed by one or two, either because a rare taxon was not represented in all four groups, or because some populations were still divided into more than one morph for one or more of the groups. Juveniles were then paired with the appropriate adult populations using size, morphology, and, most importantly, older juvenile specimens with erupted first and second molars. Finally, upper and lower dentitions were paired. Criteria such as size and relative abundance were used to eliminate most of the possible combinations. For example, a population with a mean UTRL of $140 \mathrm{~mm}$ could not correspond to a group of lower dentitions with a mean $7 \mathrm{trl}$ of $105 \mathrm{~mm}$. Nor is it likely that a very rare group based on maxillae would correspond to an extremely common population based on mandibles (although this is possible in certain taphonomic sorting regimes). Prior to the discovery of the Moss Acres Racetrack Site, no associated upper and lower dentitions of Neogene equids were known from Florida (one mandible from the Withlacoochee River $4 \mathrm{~A}$ Site is possibly associated with a maxilla, but there is no field evidence to substantiate this). Final judgements regarding pairings were made with associated individuals of related species from Texas or the Great Plains, or by identifying what genus each morph represented. For example, if in a fauna there was a group of maxillae of genus $A$, and a similar-sized group of mandibles of genus $A$, then they were assumed to belong to the same species. 
After these steps, for each fauna, most of the specimens could be placed into one of these populations. A few specimens, either because they were unworn, or very heavily worn, could not be assigned to a population. There were also usually a few teeth whose size and morphology did not quite fall within the range observed in any group. It is possible that they represented very rare taxa, but unless they closely matched a we11-known species from a contemporary fauna, it was assumed that they were rare variants of one of the well represented taxa. It was also assumed that each of these populations from a large quarry sample or fauna represented a "biological" species.

Once this was accomplished for all faunas, there remained the following systematic problems: what binomen to apply to each population; and how to determine if populations from two faunas are conspecific or not? Actually these are identical problems, as one can determine the proper name of a population by determining with which topotypic sample it is conspecific. Determining if two, similar, allopatric populations are conspecific, or if they belong to two closely related species, or if they only share many primitive traits and are in fact not especially closely related is not a straightforward procedure. This is true for modern as well as fossil populations. In my analyses, I have assumed that geographically and/or chronologically separated populations can differ significantly from one another, and still be conspecific. Species boundaries were placed only at cladogenetic events (phylogenetic branching), or, in instances with no evidence of branching, at nonarbitrary, punctuated jumps in a chronoclinal lineage. This approach differs from that of Gingerich (1985) 
and Rose and Bown (1986) who advocated arbitrary division of clinally evolving lineages. Traditionally, species-level studies of equids have emphasized the differences between populations, and often each population from a major fauna has been placed in its own species (see Dalquest, 1981 for a good example of this). As noted by Mayr (1969, p. 187), statistically significant differences between allopatric populations should be taken for granted, and are not justification for splitting them into separate species. The alpha-level systematic approach used here usually results in fewer species with much larger geographic and chronologic ranges than in previous studies.

\section{Phylogenetic Analysis}

The phylogenetic interrelationships of equid species and genera were determined using cladistic methodology (Hennig, 1966; Wiley, 1981). Common ancestry is determined by the distribution of derived character states among the taxa being studied. Polarity of character states can be assessed by several methods (Wiley, 1981), of which the out-group method is among the most widely applied. Character polarity assessment is a critical step in cladistic analysis, as an error in judgement can result in a completely false tree. The out-group method was used here to determine polarities. In this method one or more taxa that are closely related to but not among the taxa under study make up an "out-group." Their character states are assumed to be plesiomorphous. At the present time there is no generaliy accepted upon procedure for choosing which of the many possible cladograms best represents the true evolutionary history of the group. One commoniy 
used criterion is parsimony (Sober, 1983; Swofford, 1985). The most parsimonious cladogram (i.e. that with the fewest reversals and parallelisms) is considered optimal by some, although slightly less parsimonious cladograms can be more realistic biologically or chronologically (Clark and Curran, 1986). Moreover, when parallelism among ingroup clades is great, then use of the parsimony criterion may even be misleading (Gosliner and Ghiselin, 1984). The equid species under study were subjected to phylogenetic analysis using both a computer program that generates most parsimonious cladograms (PAUP; Swofford, 1985), and cladograms configured "by hand" (see Chapter 6 for further details on methods employed in the phylogenetic analysis).

\section{Measurements and Counts}

Measurements were primarily taken on individual, adult cheekteeth. As crania of equids are so scarce from the primary study area, no attempt was made to take any of the large number of traditional equid sku11 measurements (e.g. Osborn, 1912; Eisenmann, 1986). On 1y diastema lengths, toothrow lengths and muzzle widths were routinely measured. Metapodial measurements were taken as described by Eisenmann (1979). All measurements were taken with dial calipers to the nearest $0.1 \mathrm{~mm}$. For purposes of quantitative analysis, cheekteeth were sorted into six categories: P2, P3 or P4, M1 or M2, P2, p3 or $\mathrm{p} 4$, and $\mathrm{m} 1$ or $\mathrm{m} 2$. Third molars were usually not measured, nor were deciduous teeth. Using the methods of Bode (1931), it is theoretically possible to identify most isolated cheekteeth as to exactly where they were positioned on the toothrow, given a large 
enough sample of "knowns." However, these procedures are timeconsuming, and do not always result in an unambiguous determination for each specimen. Moreover, it has not been shown that lumping first and second molars (for example) in any way adversely affects the statistical results. In fact, some studies (e.g. Forsten, 1975) have combined the P3 through $M 2$ into a single class. Six measurements were taken on each upper cheektooth, and seven on each lower tooth (Figure 1). Except for the basal lengths and crown heights, all measurements were taken on occlusal surfaces, excluding cement. Altogether about 8000 specimens were measured (5000 upper teeth and 3000 lowers). The data were stored on CMS files on the University of Florida's (NERDC) mainframe IBM computer. Statistical computations were done using SAS sorting and analytical subroutines (SAS Institute Inc., 1985a; 1985b). Counts of meristic characters were also recorded for individual cheekteeth, and form the basis of much of the dental descriptions given in Chapter 5 .

\section{Terminology}

Stirton (1941) is the standard reference for equid dental terminology. However, the meanings of some terms have recently been changed to conform to 01d World usage. The most important of these, the structure Stirton (1941) referred to as the protostylid, is now called the ectostylid. The term protostylid now refers to what Stirton (1941) called the parastylid. Dental nomenclature employed in this study is shown in Figure 1. The rudimentary first upper and lower 
Figure 1. Schematic occlusal views of upper and lower cheekteeth of equids demonstrating nomenclature and measurements used in this study. A. Upper left second premolar (anterior to left, labial up): 1 , anterostyle (found on P2s and DP2s on $7 y$ ); 2, hypoconal groove; 3 , hypocone; 4 , parastyle; 5 , mesostyle; 6 , metastyle; 7 , pli caballin; 8 , pli hypostyle; 9 , pli postfossette; $10, p 7 i$ prefossette; $11, \mathrm{pli}$ protoloph; 12, postfossette; 13 , prefossette; 14 , prefossette loop; 15, preprotoconal groove; 16, protocone; 17, protoselene. B. Upper right third or fourth premolar (P34) showing the four measurements made on the occlusal surfaces of upper cheekteeth: 1, APL, maximum anterior-posterior length, excluding the ectoloph and hypocone; 2, TRW, transverse width from mesostyle to lingual-most part of protocone; 3, PRL, maximum protocone length, excluding spur or connection to protoselene (if present); 4 , PRW, protocone width perpendicular to PRL. C. Lower left molar (anterior to left, lingual up): 1, antisthmus; 2 , ectoflexid; 3 , ectostylid (generally found only on deciduous teeth in North American taxa); 4, entoconid; 5, entoflexid; 6 , hypoconid; 7 , hypoconulid; 9 , linguaflexid; 10 , metaconid; 11 , metaflexid; 12 , metastylid; 13 , paralophid; 14, pli caballinid; 15 , postisthmus; 16 , protoconid; 17 , protostylid. $D$. Lower right third or fourth premolar (p34) showing the five measurements made on the occlusal surface of lower cheekteeth: 1, ap1, maximum anterior-posterior length, excluding protostylid; 2, atw, anterior width from metaconid to protoconid; 3 , ptw, posterior width from metastylid to hypoconid; $4, \mathrm{mml}$, metaconid-metastylid length; 5 , ent 1 , length of entoflexid; 8 , isthmus, the combined antisthmus and postisthmus when the ectoflexid is shallow. 

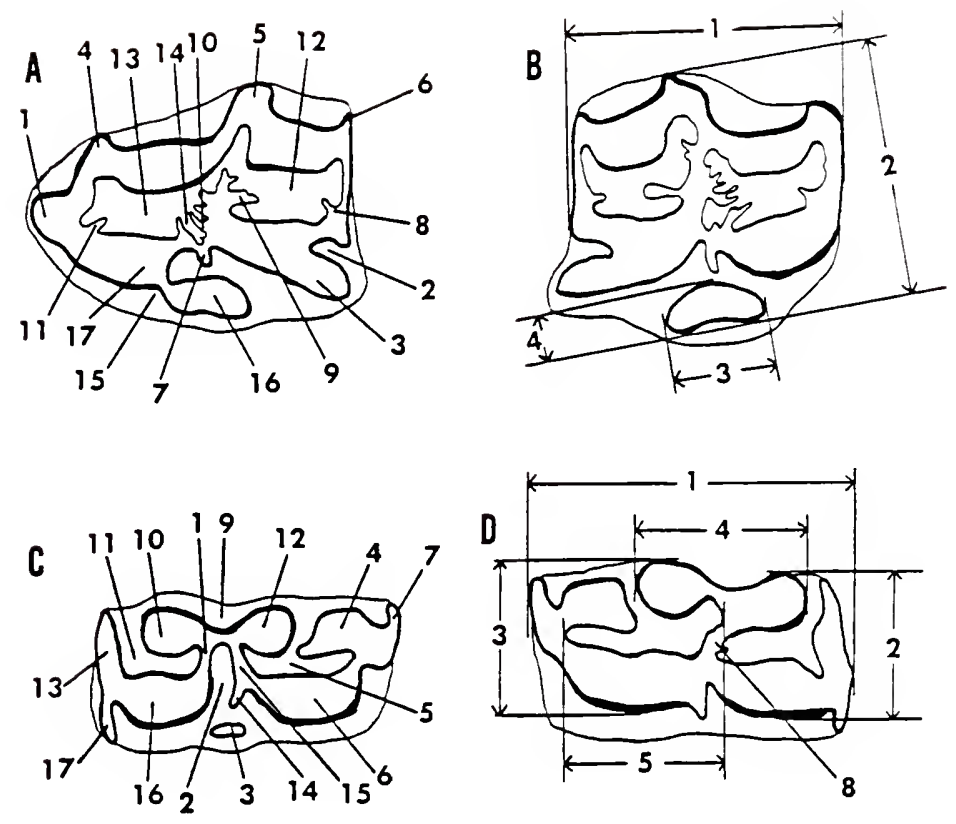
cheekteeth are referred to as the DP1 and dp1 (rather than P1 and p1), as they erupt with the deciduous rather than the permanent premolar series (Skinner and Taylor, 1967).

Definitions and boundaries of North American Land Mammal Ages follow the revisions of Tedford et al. (in press). Unless specified otherwise, ages of Neogene faunas outside the Gulf Coastal Plain are as determined by Tedford (1981) and Tedford et al. (in press). Boundaries and subdivisions of Cenozoic epochs follow those of Harland et al. (1982).

General terms used to describe different ontogenetic phases are very early (=earliest), early, moderate or middle, and late wearstages. Very early wear-stage refers to the period between onset of wear and the time the occlusal surface is fully worn and reaches its maximum length. At the end of this stage the tooth retains about $90 \%$ of its original crown height. Early wear-stage refers to the period after the very early wear-stage until the tooth is worn to about $75 \%$ of its original crown height. Middle wear-stage refers to the period following the early wear-stage until the tooth is worn to about $25 \%$ of its original crown height. Teeth with less than $25 \%$ of their original crown height are referred to as heavily worn or as being in the late wear-stage. These arbitrary classes are useful in describing the changes in enamel pattern associated with wear. When more precise information is required regarding exactly when during ontogeny a given event takes place, it will be described in terms of "with $x \mathrm{~mm}$ of crown height remaining" or "with $x \%$ of original crown height remaining." The adjective persistent will be used to refer to a 
character that appears at the onset of wear and remains visible on the occlusal surface to at least the end of the moderate wear-stage. A very persistent character lasts well into the late wear-stage. A nonpersistent character disappears either during the early wear-stage or the first half of the moderate wear-stage. When qualitative characters vary within a population or species, a percentage may be given to quantify each character state, or terms such as common or rare may be used. By these I mean that if a sample was chosen randomly from a population, a very rare character state would be expected in less than $3 \%$ of the sample, a rare character state would be expected in about 3 to $10 \%$ of the sample, a common character state in about 40 to $75 \%$ of the sample, and a usual or very common character state in about 75 to $90 \%$ of the sample.

\section{Ontogenetic and Individual Variation in Equid Cheekteeth}

For historical and practical reasons, most of the characters used in equid systematics (especially at the species level) are those of the cheekteeth. Historicaliy, many of the first specimens discovered and described were isolated cheekteeth or maxillary fragments with a few teeth. These specimens became the name bearers with which all subsequent material was compared. Practically, at many Tertiary localities, equid cheekteeth and toothrow fragments are much more common than skulls, which in many instances are unknown altogether. Actually, paleontologists studying equids are probably on ly as guilty of overemphasizing cheekteeth as many others in their profession, or on Ty slightly more so. Other characters commoniy used in this study 
include relative diastema lengths, muzzle width, incisor morphology, depth of the nasal notch, and the depth and arrangement of the facial fossae. For Gulf Coastal Plain equids, however, detailed descriptions of cheekteeth are essential for intraspecific and intrageneric comparisons. As size and enamel pattern of equid cheekteeth change in a predictable manner with wear, descriptions of them must include all ontogenetic phases.

Gidley (1901) presented a lucid discussion of both ontogenetic (wear-related) and individual variation in Equus. He noted significant changes in enamel complexity and occlusal dimensions as horse cheekteeth are worn down. He further noted that toothrow length was strongly affected by the decreasing anteroposterior lengths of the P3-M2 with wear. Gidley (1901) also showed that intraspecific variation in features of the enamel pattern was much greater than previously supposed. Unfortunately, Gidley's study was based on specimens of domesticated horses (E. caballus), so it did not necessarily demonstrate natural variation. Even more unfortunately, authors such as Merriam, Hay and Osborn continued to describe new species of equids on isolated teeth with little or no regard for the results of Gidley's study. It took another generation, and studies such as those of Matthew (1924), Bode (1934) and McGrew (1944b) to check the flood of new equid species names based on isolated finds.

A detailed account of the enamel morphology of upper and lower cheekteeth is given for each well represented species in Chapter 5. Descriptions are divided into groups with similar morphology, e.g. the M1 and M2. This is because, for most species, certain groups of teeth 
can differ not only in size and morphology, but also in the stage of ontogeny at which a certain morphology may appear $(\mathrm{e} . \mathrm{g}$. connection of the protocone or loss of the pli caballinid). Upper cheekteeth are divided into three groups for descriptive purposes, P2s, P34s, and M1M3s. In Chapter 5, the following are described for each group with respect for ontogenetic and individual variation: relative shape and orientation of the protocone; when (if at all) the protocone connects to the protoselene; presence/absence of a pli caballin and whether or not it is bifurcated or multiple; strength and morphology of the styles; degree of fossette complexity (counts of plications); and whether or not the hypoconal groove is open. Descriptions of lower cheekteeth are generally divided into two major classes, premolars (p2-p4) and molars $(m 1-m 3)$. In Chapter 5, the following are described for each group with respect for ontogenetic and individual variation: presence/absence of a pli caballinid, and whether or not it is bifurcated or multiple; presence/absence of a protostylid; presence/absence of plications from the paralophid or isthmus; the depth, length, and persistence of the ectoflexid, entoflexid, linguaflexid, and metaflexid; and the relative size, shape, and degree of separation of the metaconid and metastylid. When available, the common morphology exhibited by deciduous upper and lower premolars is also described, but usually in less detail than their permanent replacements.

Unworn crown height is an important characteristic of each equid species. It differs among tooth positions, and is subject to individual variation as are all size characters. An estimated unworn 
crown height (either $\mathrm{MSCH}$ or mCch) is given for the P2, P34, M12, p2, p34, and m12 for each species when available. Estimates rather than actually measured values are given because complete, unworn but identifiable teeth are not known for most species. When unworn, the base of the crown is made of very thin and fragile enamel that is often broken in otherwise well preserved specimens. Unworn teeth extracted from crypts usually are not fully formed, and their crown heights can underestimate the true maximum value by 5 or $10 \mathrm{~mm}$. My practice was to measure large samples of isolated cheekteeth, and include in these samples the least worn specimens for which crown height could be measured. If the specimens with greatest MSCH and mcch were truely unworn, then their values are given as the estimated unworn crown height. If, as was typically the case, these specimens were slightly worn, than a few (two to five, depending on my subjective assessment of their degree of wear) millimeters were added to their measured crown height to estimate the unworn value. If no slightly worn (very early wear-stage) specimens for a species are known, then no unworn crown height is reported. Instead, a maximum observed crown height is given. For most species, the unworn crown height estimated for the corresponding upper and lower teeth are equal or insignificantly different. In order to compare relative unworn crown height between species of different sizes, a hypsodonty index (HI) was computed. It is obtained by dividing a species' estimated M12 unworn crown height by its mean M12 BAPL. 


\section{Northern Peninsular Florida}

Neogene vertebrate fossil localities in northern peninsular Florida consist of sinkhole and fissure fillings or channel deposits incised into Eocene limestone. Usually they are geologically isolated from one another, and sites in close proximity are not necessarily the same age. The following localities produced the majority of the specimens from this region that were examined during the course of this study. Listed for each are its location, associated fauna, age, geology, previous studies, and what collection(s) house the fossils produced there. Localities mentioned in the text that are not described here produced only a few isolated teeth. The general positions of all these localities are indicated in Figure 2.

Ashville Site. The Ashville Site (FSM VP 10C. JEO2) is located in the SE1/4, sec. 1, T. 2 N, R. 6 E, Ashville Quadrangle, at an exposed roadcut in Jefferson County. The site was first discovered in 1961 and subsequently collected in 1963. 01sen (1964), citing state geologist William Yon, described the fossiliferous unit as a clayey, pebbly, poorly sorted quartz sand with clay stringers, and suggested a bay or estuary as the environment of deposition. This was suggested by the transported, fragmentary appearance of the land vertebrates, and by the presence of marine vertebrates (sharks and rays) in the 
Figure 2. Map of northern and central peninsular Florida (between $27^{\circ}$ and $30^{\circ} \mathrm{N}$ ) depicting approximate locations of fossil sites mentioned in the text. Late Barstovian and early Clarendonian: A, Phosphoria Mine, Polk Co. Early Clarendonian: A, Hookers Prairie Mine, Polk Co. Very late Clarendonian: B, Love Site, Alachua Co. Late Clarendonian or early Hemphillian: C, Coffrin Creek, Alachua Co.; C, VA Hospital Site, Alachua Co.; D, Nichols Mine, Polk Co. (other ages too); E, Peace River near Gardner, Hardee Co.; F, Cummer Mine, Gilchrist Co. Early Hemphillian: F, Haile Sites 5B and 19A, Alachua Co.; F, McGehee Farm Site, Alachua Co.; G, Mixson's Bone Bed, Levy Co.; $H$, Moss Acres Racetrack Site, Marion Co. Late early Hemphillian: I, Withlacoochee River Sites $4 A$ and $4 X$, Marion-Citrus county line; J, Manatee Dam Site, Manatee Co.; K, L, Dunnellon Phosphate Mine sites, Marion and Citrus Co. Late Hemphillian: M, Lockwood Meadows, Sarasota Co.; N, Bone Valley Region (within general outline), Polk and adjacent counties; 0, SR64 Site, Manatee Co.; P, Kissimmee River 6, Okeechobee Co. Late Blancan: $M$, Macasphalt Shell Pit, Sarasota Co.; F, Haile 15A, Alachua Co. 


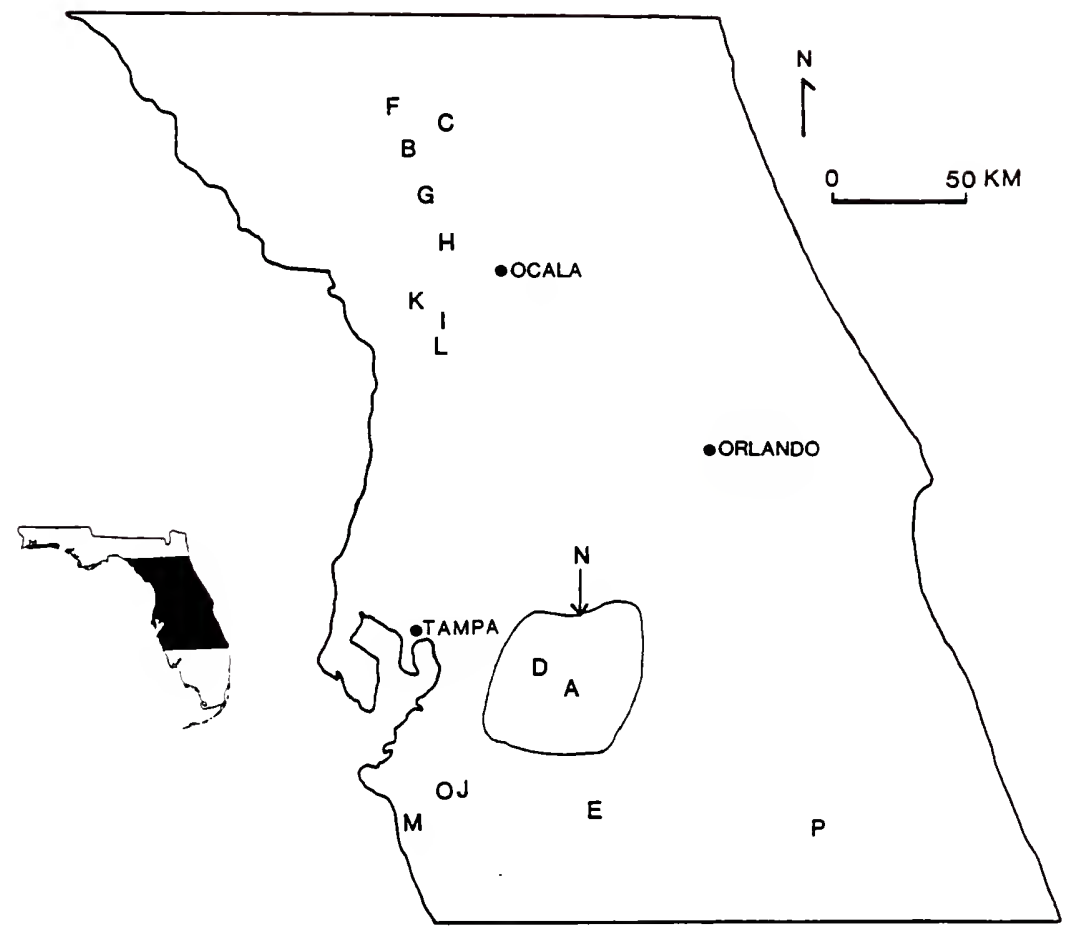


same deposit. 01 sen (1964) included the following in the fauna:

Merychippus sp., Diceratherium sp., and indeterminant large and small artiodactyls. Based on the stage of evolution of the horse teeth, 01 sen suggested an age intermediate between those of the lower Snake Creek and lower Valentine Faunas in Nebraska. As currently perceived, this would be early late Barstovian (about $14 \mathrm{ma}$ ). Tedford and Hunter (1984) suggested a slightly younger age (about $13 \mathrm{ma}$ ), and a general correlation with the Cold Spring Fauna of Texas. Vertebrate remains from Ashville consist primarily of isolated teeth. These are poorly preserved and often crushed, making identifications uncertain. Specimens are in the UF/FGS collection.

Love Site. The Love Site (or Love Bone Bed; FSM VP 1OC. ALO1) is located in the NW1/4, SW1/4, NW1/4, sec. 9, T. 11 S, R. 18 E, Archer Quadrangle, Alachua County. It was discovered as the owner of the property, Ron Love, tilled his okra crop in 1974. Subsequent excavations by FSM personnel revealed a complex fluvial deposit incised to a depth of $4 \mathrm{~m}$ in the Eocene 1 imestone bedrock (Webb et a1., 1981, provide a detailed discussion of the geology of the site). Over 80 taxa of vertebrates from a variety of paleoenvironments were recovered, and these are represented by thousands of specimens. Taxa previously studied include pond turtles (Jackson, 1976; 1978), a heron (Becker, 1985a), an osprey (Becker, 1985b), a vulture (Becker, 1986), a dromomerycid (Webb, 1983), a tapir (Yarne11, 1980), canids (Baskin, 1980b), a felid (Baskin, 1981), a nimravid (Baskin, 1981), procyonids (Baskin, 1982), a mylagaulid (Baskin, 1980a), and a cricetid rodent (Baskin, 1986). Major elements of the fauna that are as yet unstudied 
include the fish, tortoises, amebelodontine gomphotheres, rhinoceratids, camelids, tayassuids, and the remainder of the rodents. Although many of the vertebrates are similar, even conspecific, with those from Mixson's Bone Bed and McGehee Farm, a slightly older, latest Clarendonian age is suggested for the Love Site (Webb et al., 1981). The site lacks all of the early Hemphillian indicator taxa of Tedford et al. (in press), and detailed study of traceable lineages strongly suggest that Love Site populations display more primitive characters than those from Mixson's or McGehee. The best correlative of the Love Site from the Great Plains is the very late Clarendonian Xmas-Kat Fauna of Nebraska (Skinner and Johnson, 1984). Specimens are in the UF collection.

McGehee Farm Site. McGehee Farm (FSM VP 10c. AL27) is located in the southern half of the NE1/4, sec. 22, T. $9 \mathrm{~S}, \mathrm{R} .17 \mathrm{E}$, Newberry Quadrangle, Alachua County. Hirschfeld and Webb (1968) described the sediments as phosphatic sand and gravel deposited over the eroded surface of the Ocala Limestone, and interpreted the environment of deposition as estuarine. In addition to equids, the mammalian fauna includes sloths (Hirschfeld and Webb, 1968; Webb, in press), canids (Webb, 1969b), a mylagaulid (Webb, 1966), Synthetoceras (Patton and Taylor, 1971), camelids, rhinos, Tapirus (Yarne11, 1980), and amebelodontine gomphotheres. An early Hemphillian age is indicated by the presence of sloths (Marshall et al., 1979; Tedford et al., in press), and the stage of evolution of the canids, equids, camelids, and rhinos. Specimens are in the UF collection. 
Haile 19A Site. Haile 19A (FSM VP 10C. AL34) is located in the NW1/4, SE1/4, NE1/4, sec. 26, T. 9 S, R. 17 E, Newberry Quadrangle, Alachua County. It very possibly represents the same depositional system as the sedimentologically similar nearby McGehee Farm Site. The Haile 19A vertebrate fauna is predominantly comprised of sharks, te leost fish, and Gavialosuchus. Terrestrial vertebrates are relatively rare and consist primarily of isolated, durable elements like teeth. The mostly unstudied mammalian fauna includes Epicyon validus, Pliometanastes, Aphelops, Pediomeryx hamiltoni, and Procamelus, as well as a diverse equid fauna. The fauna most closely resembles those from McGehee and Mixson's, and indicates an early Hemphillian age. Several other of the Haile sites have produced late Miocene vertebrates, but of these Haile 19A is the most productive. Specimens are in the UF collection.

Mixson's Bone Bed. Mixson's (FSM VP Toc. LVO9) is located in the NE1/4, SW1/4, sec. 29, T. 12 S, R. 19 E, Williston Quadrangle, Levy County. The site represents a massive clay-filled sinkhole. The vertebrate fauna was initially described by Leidy in a series of short papers from 1884 to 1890, and summarized by Leidy and Lucas (1896). The site was extensively excavated in the late 1930 s and early 1940 s by Frick field crews, who amassed much more complete material than earlier workers, and made several additions to the fauna. The F:AM material has only been partially described (Webb, 1969b; 1983; in press; MacFadden, 1984a; Harrison and Manning, 1983; Harrison, 1986), and no up-to-date faunal list has been published. Biochronologically important taxa present are Thinobadistes segnis (Hay, 1919; Webb, in 
press) and Epicyon validus (Webb, 1969b; generic assignment follows Baskin, 1980b); they both indicate an early Hemphillian age. Specimens are in the USNM, F:AM and UF/FGS collections.

Moss Acres Racetrack Site. Moss Acres (FSM VP 10c. MR12) is located in the NW1/4, NE1/4, sec. 11, T. 14 S, R. 19 E, Morriston Quadrangle, Marion County. It was discovered in December, 1984, during the construction of a practice racetrack for thoroughbred horses. Geologically and topographically it resembles the descriptions for Mixson's given by Leidy and Lucas (1896). The sediments are a massive bluish-green clay filling a depression in the limestone. Vertebrate remains were found on $1 y$ in a limited region of about $50 \mathrm{~m}$ by $25 \mathrm{~m}$. Even within this area fossils were scarce relative to other Florida sites. Although some isolated elements and teeth were found, many specimens consist of associated or articulated bones. Usually these were limbs or strings of vertebrae, although some partial skeletons, and associated skulls and skeletons were recovered. Preservation is typically excellent, although skulls and other fragile elements are badly crushed. The entire vertebrate fauna as known through April 1987 is listed in Table 1. Most common is the longlegged rhino Aphelops, represented by about ten skulls or palates. The fauna indicates a slightly but significantly younger age than Mixson's or McGehee, the gomphothere, Aphelops, Pediomeryx, Neohipparion, Nannippus and Calippus all being represented by more progressive species. The stage of evolution of the horses suggests a slightly older age than the Withlacoochee River $4 \mathrm{~A}$ site. An early 
Table 1. Preliminary list of the vertebrate fauna from the Moss Acres Racetrack Site, Alachua Formation, Marion County, Florida (early Hemphillian, about 7.0 to $7.5 \mathrm{ma}$ ).

Class 0steichthyes

Order Lepisosteiformes

Family Lepsisosteidae

Lepisosteus sp.

Class ReptiTia

Order Crocodilia

Family Alligatoridae

Alligator mississippiensis

Order CheTonia

Family Trionychidae

Trionyx ferox

Famity Emydidae

Pseudemys sp.

Class MammaTia

Order Edentata

Fami ly Megalonychidae

Pliometanastes protistus

order carnivora

Family Canidae

Osteoborus sp.

Order Perissodactyla

Family Equidae

Neohipparion eurystyle

Nannippus minor

Cormohipparion plicatile

Cormohipparion ingenuum

Hipparion sp., $\mathrm{cf}$. H. tehonense

Calippus maccarty $\bar{n}$. sp.

Dinohippus sp.

very smalT equid, gen. indet.

Family Rhinoceratidae

Aphe lops mutilus

Order Artiodacty a

Family Tayassuidae, gen. indet.

Family Camelidae

cf. Procamelus

"Hemiauchenia" sp., cf. "‥ ." minima

Fami $\longdiv { \text { Dromomerycidae } }$

Pediomeryx n. sp. (?)

Famity Gelocidae, gen. indet.

Order Proboscidea

Family Gomphotheri idae

Amebelodon n. sp., near A. fricki 
Hemphillian age of about 7.0 to $7.5 \mathrm{ma}$ seems to best fit the currentiy available data. Specimens are in the UF collections.

Withlacoochee River Site 4A (= With 4A). With 4A (FSM VP 10C. MR02) is located in the Withlacoochee River in the NW1/4, NW1/4, sec. 30, T. $17 \mathrm{~S}$, R. $20 \mathrm{E}$, Stokes Ferry Quadrangle, on the Marion-Citrus county line. Like Mixson's and Moss Acres, this site is a massive clay deposit filling a sinkhole (Webb, 1969b). Besides equids, the mammalian fauna includes Indarctos (Wolff, 1978), Machairodus, Osteoborus (Webb, 1969b), Enhydritherium (Berta and Morgan, 1985), Pliometanastes (Hirschfeld and Webb, 1968), Thinobadistes (Webb, in press), and Hexameryx (Webb, 1973). Becker (1985a) reported a new species of heron from with $4 A$, and reviewed the site's age (also see Berta and Morgan, 1985). The co-occurrence of Indarctos and Machairodus is limited to the brief late early Hemphillian interval ( 6 to $7 \mathrm{ma}$ ), according to Tedford et al. (in press). The horses also suggest an intermediate age between the well known faunas of the "Alachua Clays" to the north and the Upper Bone Valley Fauna to the south. Specimens are in the UF collection.

Withlacoochee River Site $4 X(=$ With $4 X)$. With $4 X$ (FSM VP 10c. MR24) is also located in the Withlacoochee River in the NE1/4, NW1/4, sec. 30, T. 17 S, R. 20 E, Stokes Ferry Quadrangle. Depositionally identical to with $4 A$, the fauna of With $4 X$ is less diverse but does include several well preserved horse teeth, a progressive species of Thinobadistes (Webb, in press), and a large Aphelops. They indicate a Hemphillian, probably late early Hemphillian age. Specimens are in the UF collection. 


\section{Southern Peninsular Florida}

Neogene vertebrate deposits in southern peninsular Florida are found in more widespread geologic horizons than those in the north, particularly in the area known as the Bone Valley Region. Numerous ephemeral exposures created by large-scale phosphate mining in this $900 \mathrm{~km}^{2}$ region have long produced vertebrate fossils. Along the southwest coast of Florida, seaward extensions of the Bone Valley Formation are sometimes encountered and may produce vertebrate fossils as well. The general locations of these are indicated in Figure 2.

Bone Valley Region. The Florida State Museum has specimens from dozens of vertebrate-bearing localities from this region on file. Early studies of the area's vertebrates (e.g. Sellards, 1910; 1916; Simpson, 1930) usually considered them a cohesive fauna of approximately the same age as Mixson's Bone Bed. In the 1960s, FSM personnel began precise stratigraphic studies of the Bone Valley. Over the last twenty years, an increasingly clearer and more complex geologic history has emerged for the region. A definitive biostratigraphic summary is planned (Waldrop and Webb, in prep.). For now, at least six distinct vertebrate faunas are recognized from the Bone Valley Formation, with ages of: early Barstovian; early late Barstovian; late Barstovian; latest Barstovian-earliest Clarendonian; late Clarendonian-early Hemphillian; and very late Hemphillian (MacFadden and Webb, 1982; Webb and Crissinger, 1983; Berta and Morgan, 1985; MacFadden, 1986; Webb and Hulbert, 1986). In addition to these, the underlying Hawthorn Formation has produced earliest Barstovian vertebrates (A. E. Pratt, pers. comm.), and the overlying 
sand and gravel beds contain fossils of Pleistocene age. Obviously, specimens of unknown stratigraphic provenience from the region are not necessarily the same age. In situ vertebrate concentrations discovered by David Webb, John Waldrop and Don Crissinger now permit the determination of natural faunal assemblages. This was impossible with most of the older collections, as they were recovered out of stratigraphic context and contained temporally mixed assemblages. The faunal terms used below are not yet formally named, but were previously used by Webb and Hulbert (1986) to collectively refer to approximately contemporaneous small local faunas and isolated finds in the region.

The Bradley Fauna is represented only by a few localities from the Kingsford and Nichols Mines in Polk County southwest of Mulberry. The age of this fauna is late, but not latest, Barstovian based on the presence of Gomphotherium calvertensis, Procranioceras sp., cf. P. skinneri, and horses such as Pro. perditus and Megahippus sp. Stratigraphically, the fauna originates from sediments underlying those producing the Agricola Fauna in at least one section of the Kingsford Mine (Waldrop and Webb, in prep.). The equid component of the Bradley Fauna contains less progressive taxa than the lower Agricola Fauna (Red Zone), and indicates genera 1 biochronological correlation with the upper Burkeville Fauna of Texas, the Norden Dam 1.f. of Nebraska, and the Pawnee Creeks Fauna of Colorado.

The Agricola Fauna is known from a number of mines in the region, including the Nichols, Kingsford, Hookers Prairie, Silver City, Brewster Haynesworth, and Phosphoria mines. It is best represented 
from the latter, where modest in situ collections were made by John Waldrop and associates in the late 1970s, and subsequently transferred to the UF collection. The Phosphoria section has two distinct, stratigraphically superposed assemblages that both belong in the Agricola Fauna. The lower unit, the Red Zone, compares most favorably with the Cold Spring Fauna of Texas and the Devil's Gulch Fauna of Nebraska. The overlying Grey Zone correlates best with the Lapara Creek Fauna of Texas and the Burge Fauna of Nebraska. The suggested age for the Agricola Fauna is thus late Barstovian through earliest Clarendonian. As the evidence rests almost entirely on its equid fauna, its age will be further discussed in Chapters 5 and 7. Pliocyon robustus Berta and Galiano (1984) is also a member of this fauna.

Unlike the other faunas, the third late Neogene terrestrial vertebrate assemblage recognized in the Bone Valley Region is represented by isolated elements recovered without stratigraphic context relative to the others. The most productive source for this fauna in the Bone Valley are regions in the Nichols Mine where Donald Crissinger (geologist for Mobil Chemical Company) collected about 75 specimens from a "stream matrix." These specimens are uniformly preserved (the enamel is a light grey), and appear to represent a cohesive fauna intermediate in age between the Agricola and Palmetto Faunas. The equids are conspecific with those of the Love, McGehee and Mixson's localities, and together these sites are all referred to as the Archer Fauna (Webb and Hulbert, 1986). 
The Palmet to or Upper Bone Valley Fauna is the most widespread and abundant in the region. In situ collections of this fauna are known from the Palmetto, North Palmetto, Kingsford, Nichols, Gardinier, and Payne Creek mines. A very late Hemphillian (about 5.0 to $4.5 \mathrm{ma}$ ) age is indicated by the combined presence of Megalonyx curvidens, Hexameryx simpsoni (Webb, 1973), advanced Teleoceras, Agriotherium schneideri (Sellards, 1916), Megantereon hesperus (Berta and Galiano, 1983), Felis rexroadensis (MacFadden and Galiano, 1981), Plesiogulo marshalli (Harrison, 1981), Enhydritherium terraenovae (Berta and Morgan, 1985), and Osteoborus dudleyi (Webb, 1969b). The equid fauna also supports this age assignment (MacFadden, 1986; Chapter 7). The Palmet to Fauna's vertebrates represent a diverse suite of marine, estuarine, freshwater and terrestrial habitats (Berta and Morgan, 1985). The Upper Bone Valley Formation consists of a complex of channel deposits, often with coarse phosphatic gravel lag deposits, fining upwards into unconsolidated beds of sand and clay (Webb, 1981; Webb and Crissinger, 1983). These are interpreted as deltaic-fluvial environments that drained into estuarine and nearshore marine habitats when sea level stood about $50 \mathrm{~m}$ higher than at present (MacFadden and Webb, 1982; Webb and Crissinger, 1983). Equids are primarily represented in the Palmetto Fauna by isolated cheekteeth, and these durable elements make up a high percentage of the terrestrial vertebrate specimens. Partial mandibles and post-cranial elements of equids are uncommon; maxillae are very rare. To date, one partial equid skull (of Nannippus minor, UF 67000) has been recovered from the fauna. Unfortunately, it lacks the diagnostic facial region and is 
badly crushed. However, it at least suggests a potential for further discoveries of more complete specimens. Equids from the Palmet to Fauna examined during the course of this study are from the UF, UF/FGS, TRO, AMNH, F:AM, and UCMP collections.

Manatee County Dam Site. The Manatee Dam Site (FSM VP 10C. MA10) is located in sec. 30, T. $34 \mathrm{~S}, \mathrm{R} .20 \mathrm{E}$, Verna Quadrangle. The geology of the site was described by Webb and Tessman (1968), who also presented a geologic section. Based on the site's sedimentology, they concluded that it represents a westward extension of the Bone Valley Formation. The mammalian fauna includes (besides equids) camelids, Teleoceras, Tapiravus, and Rhynchotherium (Webb and Tessman, 1967; 1968). These suggest a Hemphillian age for the fauna. The low elevation of the site implies that deposition occurred at a period when sea level was as low as the present. This suggests an older age than the Palmetto Fauna, which was deposited during the very early Pliocene when sea level was substantially higher than the present (Harland et al., 1982). The presence of Pseud. skinneri (Webb and Hulbert, 1986) and Calippus (Chapter 5) also indicates an older age, probably late early Hemphillian, approximately equivalent to that of With 4A. Specimens are in the UF collection.

Lockwood Meadows Site. Lockwood Meadows (FSM VP 10c. S004) is located in the NW1/4, NW1/4, sec. 16, T. 36 S, R. 18 E, Sarasota Quadrangle, Sarasota County. It is primarily a marine vertebrate fauna that was recovered from a phosphatic gravel deposit. Terrestrial vertebrates are represented by isolated, usually waterworn or fragmentary elements. The fauna includes several equids, a 
camelid, a rhino, a gomphothere, a mammutid, and cetaceans (MacFadden, 1986; MacFadden and Mitche11, in prep.), and has been assigned a late Hemphillian age. Specimens are in the UF collection.

Macasphalt She 11 Pit. The Macasphalt She 11 Pit (FSM VP 10C. S007) is located in the SW1/4, sec. 12, T. $36 \mathrm{~S}, \mathrm{R} .18 \mathrm{E}$, Bee Ridge Quadrangle, Sarasota County. The quarry has been known by at least three names, the Warren Brothers, Macasphalt and APAC Shel1 Pit. Two different horizons exposed by quarrying operations at Macasphalt produce vertebrate fossils. Low in the quarry, marine vertebrates, including mammals, are found in the Tamiami Formation. The other vertebrate-bearing horizon in the quarry is a thin unit in the overlying Pinecrest beds. It is this latter horizon, Unit 4 of Petuch (1982), that has produced equids, and other, locally concentrated vertebrate remains. When abundant, they consist primarily of Siren, water snakes, turties, Alligator, many species of fish, and aquatic birds. Terrestrial mammals are relatively much rarer, but 22 taxa identifiable to at least the family level are known (Morgan and Ridgeway, in press). Nineteen of these have been collected in situ from Unit 4 by FSM personnel, and appear to represent a temporally unmixed fauna. Biochronologically important mammals recovered from Unit 4 are Nannippus peninsulatus, advanced Equus sp. (not Dolichohippus), Dasypus bellus, Holmesina floridana, Megalonyx leptostomus, Glossotherium chapadmalense, Neochoerus dichroplex, Sigmodon minor, Mylohyus floridanus, and Trigonictus sp. Co-occurrence of these taxa indicates a late Blancan (about 3.0 to $2.0 \mathrm{ma}$ ), latest Pliocene age for Unit 4 (Marshall et al., 1979; Tedford, 1981; Galusha 
et a1., 1984), postdating the formation of the Panamanian land bridge that connected North and South America. Stanley (1986; pers. comm.), however, dates the entire Macasphalt section as early Pliocene $(>3.0$ ma) based on biochronologic ranges of selected bivalve taxa. Multidisciplinary efforts to resolve this conflict and to date this section using micropaleontological and geochemical techniques are currently underway by Florida State Museum personne 1 .

\section{Texas Gulf Coastal Plain}

Scattered vertebrate fossils have been reported from the Texas Guif Coastal Plain for over a century. Wilson (1956) summarized previous geologic interpretations, and recognized three Neogene lithostratigraphic units (the Oakville, Fleming and Goliad Formations) that have produced vertebrates. They outcrop in narrow bands that run roughty parallel to the present coastline (see Quinn, 1955, Figure 5 or Patton, 1969, Figure 1). Wilson (1956) recognized four principal vertebrate faunas in these three formations; these are, from oldest to youngest, the Garvin Gully, Burkeville, Cold Spring and Lapara Creek Faunas. He used the term "fauna" to indicate a group of local faunas of simitar composition found in the same stratigraphic unit. The Hemingfordian Garvin Gully Fauna is excluded from this study by its early age. Estimates of the ages for the other three faunas have varied greatly (Hesse, 1943; Stenzel et a1., 1944; Quinn, 1955; Wilson, 1956; Patton, 1969 ; Patton and Taylor, 1971; Forsten, 1975 ; Slaughter, 1981; Tedford and Hunter, 1984; Tedford et a .., in press). 
The Burkeville Fauna of Wilson (1956) contains a number of local faunas which date from the early Barstovian (about $16 \mathrm{ma}$ ) to the early late Barstovian (about $13.5 \mathrm{ma}$ ), a considerable period of time during which significant changes occurred in the equid fauna. As this study is limited to equids from the late Barstovian through Hemphillian, only material from the younger local faunas of the Burkeville Fauna was studied in detail. This excludes the Point Blank, Moscow, and Trinity River local faunas, but not the Burkeville 1.f. In fact, the equids from the Burkeville 1.f. much more closely resemble those of the Cold Spring Fauna than they do those of the older Point Blank or Trinity River sites. The Burkeville 1.f. is of early late Barstovian age, equivalent to the Pawnee Creeks Formation sites in Colorado and some of the lower faunas of the Valentine Formation in Nebraska (Tedford et al., in press). This correlation is based on the presence of Anchitheromys and Proboscidea (Tedford and Hunter, 1984; Reinhardt, 1976). The overlying Cold Spring Fauna is also comprised of a number of local faunas. They are thought to transcend the later part of the late Barstovian ( 13.5 to $12.0 \mathrm{ma}$; Tedford et al., in press). The equids from these local faunas are generally similar, and the material is not adequate to document detailed microevolutionary changes. The Cold Spring Fauna is similar in age to, and contains many of the same equids as, the Devil's Guich Fauna of Nebraska.

The Lapara Creek Fauna is derived from more southerly exposures that stratigraphically overlie Burkeville and Cold Spring equivalents (Wilson, 1956). Tedford et al. (in press) divide this fauna into two units, citing evidence of significant in situ species-level evolution 
of the equids. Forsten (1975) found no such differences, and my examinations also do not support such a major division. I therefore treat the entire fauna as a single sample for purposes of quantitative analyses. I do follow Tedford et al. (in press) in their age assignment for the Lapara Creek Fauna (earliest Clarendonian), intermediate between the Burge and Clarendon Faunas. Texas Gulf Coastal Plain equids studied during the course of this project are in the TMM, TAMU and F:AM collections. 
CHAPTER 5

SYSTEMATIC PALEONTOLOGY

$\frac{\text { Order Perissodactyla Owen, } 1848}{\text { Family Equidae Gray, 1821 }}$
Subfamily Equinae Steinmann and Döder lein, 1890

Type genus. Equus Linnaeus, 1758.

Included taxa. Archaeohippus Gidley, 1906b; Parahippus s.1.

Leidy, 1858 (including Desmatippus Scott, 1893); "Parahippus"

leonensis Sellards, 1916; "Merychippus" gunteri Simpson, 1930;

"Merychippus" primus Osborn, 1918; Hipparionini Quinn, 1955; and

Equini Quinn, 1955.

Revised diagnosis. Equids with relatively elongated facial regions; orbit posteriorly placed relative to toothrow (anterior margin dorsal to $M 3$ or entirely posterior to M3); labial cingulum on permanent upper cheekteeth vestigial or absent; metaloph usualiy plicated; lateral metapodials tightly bound to median metapodial, not able to move independently; relatively elongate first medial phalanx with strong oblique scar for ligament attachment; shaft of ulna very reduced; fibular shaft vestigial.

Discussion. The Subfamily Equinae traditionally includes only the horizontal grade "Merychippus" and its "descendants," the hipparionines and equines (e.g. Simpson, 1945). In this arrangement, Archaeohippus and Parahippus are placed in the Anchitheriinae. This 
classification is paraphyletic, and does not represent a natural phylogenetic grouping. Matthew (1926 and especially 1932) first noted the number of progressive (relative to Mesohippus and anchitheriines) post-cranial features shared by Parahippus, Archaeohippus, and advanced equids. He concluded that the two should be grouped with the protohippines rather than the anchitheriines. These postcranial characters were further documented, and this classification was also advocated by Sondaar (1968, pp. 63-65). The features noted by these two authors were used to compile the revised diagnosis.

\section{Tribe Hipparionini Quinn, 1955}

Calippini Quinn, 1955, p. 27 (in part).

Type genus. Hipparion de Christol, 1832.

Included North American genera. Pseudhipparion Ameghino, 1904 ;

Neohipparion Gidley, 1903; Merychippus s.s. Leidy 1857; Nannippus Matthew, 1926; Cormohipparion Skinner and MacFadden, 1977.

Revised diagnosis. Tridactyl equids with we 11 cemented, subhypsodont to hypsodont cheekteeth and wel1 formed fossettes. Differ from equines and protohippines by having much better separated metaconids and metastylids (except for Equus and progressive species of Protohippus); protocone usually isolated from protoselene until at least middle wear-stage; and fossette borders more persistentiy and usually more complexly plicated.

Discussion. In addition to the advanced genera common ly recognized as hipparionines (e.g. MacFadden, 1984a), I include 
Pseudhipparion and "Merychippus" in the tribe. Chapter 6 details the phylogenetic relationships among hipparionine genera, and documents synapomorphies used to support their inclusion in the tribe. Hipparionines are a monophyletic group (Forsten, 1982; 1984), not a paraphyletic assemblage (MacFadden, 1984a). Their first appearance is late Hemingfordian (about $17 \mathrm{ma}$ ). Skinner et al. (1977, p. 343) recognized two primitive populations in the Sheep Creek Fauna of Nebraska as "Merychippus insignis tertius (Osborn)" and "Merychippus isonesus quintus (Osborn)." Hemingfordian and Barstovian species of hipparionines have traditionally been referred to the grade "Merychippus." I restrict usage of this name to the population described by Skinner and Taylor (1967) from Echo Quarry as M. insignis, and a very limited number of species (see Chapter 6). Evander's (1986) suggestion that the genoholotypic specimen of Merychippus is diagnostically inadequate deserves serious consideration. Unfortunately, there is no readily available replacement name, nor did Evander suggest one for this limited monophyletic group of Barstovian species. I therefore refer to it as Merychippus s.s. The alpha-level systematics of North American hipparionines were greatly clarified by MacFadden (1984a). There are some differences between his interpretations and mine, but for the most part the se are based either on new material unvailable to him (e.g. Moss Acres); on the Love Site material, which he purposefully did not examine in great detail; or on previously unstudied material that I found uncatalogued in the F:AM and UCMP collections. 
Genus Neohipparion Gidley, 1903

Neohipparion GIDLEY, 1903, p. 467.

Hesperohipparion DALQUEST, 1981, p. 506

Type species. Neohipparion whitney Gidley, 1903 (now considered a junior synonym of Neo. affine (Leidy), 1869).

Included species. Neo. trampasense (Edwards), 1982; Neo. leptode Merriam, 1915a; Neo. eurystyle (Cope), 1893; Neo. gidleyi Merriam, $1915 a$.

Revised diagnosis. Medium to large-sized hipparionines with poorly developed, shallow, unrimmed DPOF, or lacking DPOF. Protocones elongate-oval or very elongated; isolated to near base of crown except in P2. Well developed pli caballinids on p2-p4 and dp2$\mathrm{dp} 4$ (and on $\mathrm{m} 1-\mathrm{m} 3$ of advanced species) that often extend further labially than the base of the protoconid or hypoconid; relatively elongated and well separated metaconids and metastylids; labial borders of protoconid and hypoconid flattened; ectostylids weakly developed or absent on deciduous premolars. Siender metapodials. Discussion. Gidley (1903) based Neohipparion on the superb type skeleton of Neo. "whitneyi" (AMNH 9815), at the time the most completely known hipparionine individual. He included most of the previously described North American species of "Hipparion" in his new genus, in what was probably the first attempt to classify these horses phylogenetically. Gidley $(1903 ; 1907)$ used both facial and dental characters to distinguish Neohipparion from Hipparion, a very modern approach. Except for Merriam (e.g. 1915a), most other authors 
did not recognize Neohipparion as a distinct genus until 1935. However, it was often used as a subgenus of Hipparion, even though the two were thought to have separate merychippine origins (Matthew and Stirton, 1930, p. 356). Beginning in 1935, Stirton and McGrew began to separate Neohipparion and Nannippus at the generic level from Hipparion (Stirton and McGrew, 1935; McGrew, 1938; Stirton, 1940), and its generic status has seldom been questioned since (Forsten, 1982, is an exception, but she has subsequently [1984] used it as a valid genus).

Traditional7y, two species-groups comprise Neohipparion: one composed of the predominantly Clarendonian taxa Neo. affine ( Neo. whitneyi), Neo. coloradense, and Neo. occidentale; and the other of the Hemphillian species Neo. leptode, Neo. eurystyle, Neo. phosphorum, Neo. gidleyi, and a number of Mexican species named by Stirton (1955) and Mooser $(1960 ; 1964)$. Neo. occidentale is referred to a separate genus, Cormohipparion, based on its deep DPOF, deep ectoflexids, rounded protoconid and hypoconid labial borders, and strong dp ectostylids (Skinner and MacFadden, 1977). "Neo." coloradense is here recognized as the sister-taxon to Neohipparion and Pseudhipparion, and thus cannot be placed in either genus (Chapter 6). Thus, of the first species-group, on ly the genotype is still considered a valid member of Neohipparion. It has long been recognized that $\underline{\text { Neo. }}$ affine is less progressive in many of its denta 1 features than other members of the genus (Stirton, 1940; MacFadden, 1984a). This morphologic gap led Dalquest (1981) to formally separate the Neo. eurystyle species-group as a distinct genus, 
Hesperohipparion. Apparently unknown to Dalquest, there then existed an undescribed population of late Clarendonian and early Hemphillian Neohipparion morphologically and chronologically intermediate between the two species-groups. It was formally described by Edwards (1982) as Hipparion trampasense. MacFadden (184a) transferred it to Neohipparion and illustrated cranial material of this new species. Thus Dalquest's Hesperohipparion is unnecessary, and its use would render Neohipparion either paraphyletic or monotypic.

Neohipparion affine (Leidy), 1869

Hipparion affine LEIDY, 1869, p. 286; OSBORN, 1918, p. 178. Hippotherium occidentale (Leidy), COPE, 1889, p. 434 (in part). Neohipparion whitneyi GIDLEY, 1903, p. 467.

Neohipparion affine (Leidy), GIDLEY, 1903, p. 467; GIDLEY, 1907 , p. 887-888; STIRTON, 1940, p. 183; MACFADDEN, 1984a, p. 90. Hipparion (Neohipparion) affine Leidy, MATTHEW and STIRTON, 1930 , p. 362 .

Equus laparensis QUINN, 1955, pp. 58-60 (in part).

Equus sp. or Neohipparion sp., QUINN, 1955, p. 62.

Neohipparion occidentale (Leidy), FORSTEN, 1975, pp. 65-69 (in part).

Type specimen. USNM 584, five apparent7y associated upper cheekteeth.

Type locality. Exact locality unknown, "from the Niobrara River" region according to Leidy (1869). Skinner et al. (1977) provided 
evidence that the type locality might be Porcupine Butte, South Dakota.

Stratigraphic occurrence and age of type locality. Probably Ogallala Group; Clarendonian, about 9.5 to $11.5 \mathrm{ma}$. Distribution. Very late Barstovian to late Clarendonian of the Great Plains; early Clarendonian of the Texas Gulf Coastal Plain; possibly Clarendonian of Oregon.

Referred Gulf Coastal Plain specimens. Lapara Creek Fauna (see Quinn, 1955 and Wilson, 1956). Bridge Estate Site, Bee Co., TX: TMM 31132-432 R P34; -616 R M12; Buckner Ranch Site, Bee Co., TX: TMM 30896-572 L P34; -571, -395 2 L M12; -576, -577 2 R P2; $-578,-5792$ L P2; -392 L M3; -480 R mandible with p2-m3 (Quinn, 1955, Plate 14.5); -454 R p34 (Quinn, 1955, Plate 14.3); $-573,-5742$ L p34; -580 $\mathrm{R} \mathrm{m} 12$.

Revised diagnosis. Larger than Neo. trampasense or Neo. eurystyle, toothrow lengths about 135 to $150 \mathrm{~mm}$. Unworn M12 MSCH about $56 \mathrm{~mm}$, thus less high crowned than all other species of Neohipparion. Relatively simple fosettes; pli caballin single; pli caballinid prominent only on slightly worn p2-p4 only. Shallow, poorly developed DPOF posteriorly includes large lacrimal bone. Description. Neohipparion affine is a large species of Neohipparion with a distinct, shallow, unrimmed DPOF on the lacrimal, nasal and maxillary bones (Osborn, 1918, Plate 32.1). Its upper cheekteeth are characterized by elongate-oval, narrow protocones, rarely with protoconal spur; relatively simple fossettes; and wide hypoconal groove open to the base of the crown (Fig. 3A). The upper 
premolars have large, broad, usually single plicaballins; they are generally smaller and less persistent in molars. Fossette plications are simple, not bifurcated. The pli protoloph is absent or single, except in the P2 where 39\% $(n=19)$ have two loops. The posterior hatf of the prefossette usualiy has a long prefossette loop, and one to four sma11, simple plications. The anterior half of the postfossette usually has only two or three plications. A pli hypostyle is generally either absent ( $35 \%$ of premolars, $53 \%$ of molars) or single (64\% of premolars, $43 \%$ of molars). In earliest wear-stages, the lower premolars have very shallow ectoflexids and well developed pli caballinids (Fig. 3B); with wear the ectoflexid rapidly deepens and the pli caballinid gradually disappears. The latter usually occurs near the beginning of the moderate wear-stage, much earlier in on togeny than in other species of Neohipparion. AMNH 9815 (holotype of Neo. whitneyi, Osborn, 1918, Fig. 144) is an example of the usual morphology of moderately worn lower cheekteeth. Pli caballinids are rare on molars, and then only found in early wear-stages and are rather small (e.g. TMM 30896-480). A distinctive generic character are the flattened bases of the hypoconid and protoconid, especially evident on the premolars. The protoconid and hypoconid of the molars may retain the primitive rounded state, or have flattened bases. In early wear-stages, the isthmus of the lower premolars is often plicated, but there are no well developed plications extending posteriorly from the paralophid. Ectostylids of deciduous premolars are very reduced. Crown heights of very slightly worn teeth are $4043 \mathrm{~mm}$ for P2s, 48-51 mm for P34s, 55-58 mm for M12s, and 54-56 mm for $\mathrm{m} 12 \mathrm{~s}$. 
Discussion. The Lapara Creek specimens listed above are referred to Neo. affine, rather than to one of the more abundant hipparionines in the fauna (Cor. occidentale, Nannippus sp., cf. Nan. fricki, or Hipparion tehonense), primarily on the basis of size (Tables 2 and 3), protocone shape, relatively simple fossettes, and pli caballin development for uppers, and flattened labial protoconid and hypoconid borders and size for the lowers (Fig. 3B). They were originally referred by Forsten (1975) to Cor. occidentale, and some (but not a11) could represent extremes in that variable taxon. The differences in size among the three referred populations (Tables 2 and 3 ) are exaggerated by small sample sizes and differing age-class distributions. The recognition of Neo. affine in the Lapara Creek Fauna is not surprising. It is a consistent, although typically rare member of many similar age faunas in northern Texas, Nebraska and South Dakota (MacFadden, 1984a). The latest appearance of Neo. affine is late Clarendonian, in the Xmas-Kat faunal zone of Nebraska (Skinner and Johnson, 1984). However, it has not yet been recorded from Florida. As the time period during which it is most common is still poorly known in Florida, this absence could well be the artifact of a deficient record. 

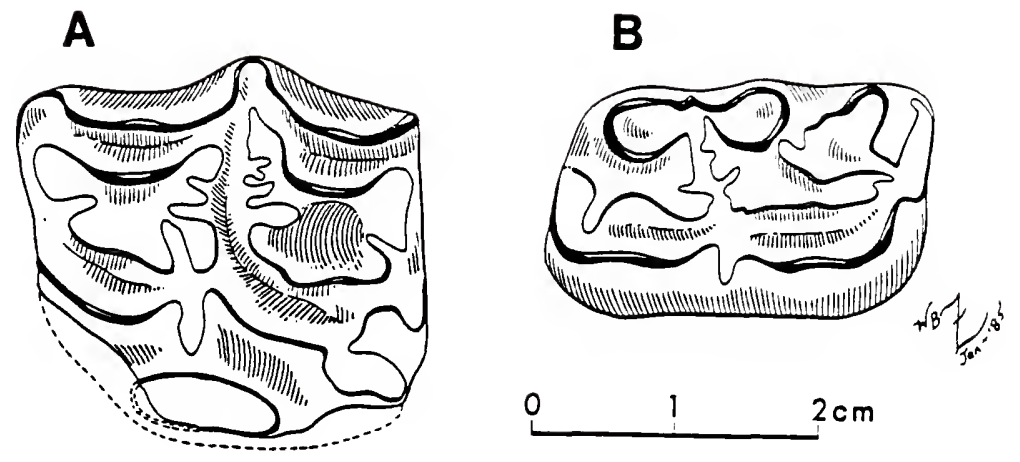

Figure 3. Occlusal views of cheekteeth of Neohipparion affine from the Buckner Ranch Site, Bee County, Texas (early Clarendonian, Lapara Creek Fauna). A. TMM 30896-395, L M1, early to moderate wear-stage. B. TMM 30896-574, L p3 or p4, early wear-stage. 
Table 2. Standard univariate statistics for upper cheekteeth of Neohipparion affine. Measurements defined in Chapter 3 . The first Tine for each entry gives $\bar{x}$, s and $n$, the second line $O R$ and $\underline{V}$. Populations are LC, Lapara Creek Fauna, Bee County, Texas; CLA $\bar{A} R$, Clarendon Fauna, Don ley County, Texas; and NEB, combined sample of Clarendonian localities from Nebraska and South Dakota.

FAUNA

LC

CLAR

NEB

P2

APL

$28.5,0.85,3$

$27.5-29.1,2.99$

$29.2,1.73,10$

$29.2,0.90,5$

BAPL
TRW
PRL
PRW

$22.6,0.50,2$

$22.2-22.9,2.20$

$27.0-32.4,5.93$

$28.8-31.1,3.02$

$24.1,0.70,3$

$23.6-24.9,2.91$

$22.2,--, 1$

$20.3,1.48,4$

$18.5-21.8,7.33$

$22.0,1.12,9$

$22.1,0.52,5$

$19.8-23.4,5.07$

$21.3-22.6,2.34$

$7.1,0.47,4$

$6.5-7.5,6.57$

$7.4,1.06,10$

$4.9-8.4,14.37$

$8.4,0.41,5$

$8.1-9.1,4.86$

$$
3.8,0.47,4
$$

$3.4-4.4,12.15$

$4.3,0.45,10$

$3.9-5.0,10.57$

4. 3, 0.52,5

$3.9-5.2,11.93$

P34

APL

$24.3,0.78,2$

$23.7-24.8,3.21$

$24.5,1.53,22$

$21.2-27.1,6.24$

$23.9,1.32,11$

$22.1-25.9,5.52$

BAPL

$18.7,0.50,2$

$18.3-19.0,2.65$

$19.3,1.18,9$

$19.8,0.74,3$

$17.8-21.8,6.08$

$19.0-20.4,3.72$

TRW

$21.8,0.64,2$

21.3-22.2,2.92

$23.4,1.54,21$

$23.3,0.60,11$

$20.6-25.7,6.57$

22.0-24.5, 2.57

PRL

$8.5,0.35,2$

$8.2-8.7,4.18$

$9.7,0.96,22$

$7.1-11.1,9.86$

$9.5,0.93,11$

$7.7-11.0,9.80$

PRW

$$
\begin{aligned}
& 4.1,0.35,2 \\
& 3.8-4.3,8.73
\end{aligned}
$$

$4.2,0.28,20$

$4.1,0.27,11$

$3.6-4.8,6.66$

$3.4-4.4,6.65$ 
Table 2--continued

\begin{tabular}{llll} 
& \multicolumn{3}{c}{$M 12$} \\
APL & $24.3,0.38,3$ & $22.5,1.47,18$ & $21.9,1.49,12$ \\
& $24.0-24.7,1.56$ & $20.0-24.5,6.56$ & $20.1-24.2,6.81$ \\
BAPL & $17.5,--, 1$ & $18.9,1.11,4$ & $17.7,0.69,4$ \\
& & $17.6-20.3,5.84$ & $17.1-18.6,3.90$ \\
TRW & $20.7,2.54,3$ & $21.9,1.23,18$ & $21.5,1.08,12$ \\
& $17.9-22.8,12.26$ & $20.3-25.4,5.59$ & $19.2-22.9,5.02$ \\
PRL & $9.8,1.20,2$ & $9.2,0.63,18$ & $9.3,0.80,12$ \\
& $8.9-10.6,12.33$ & $8.3-10.4,6.85$ & $8.0-10.3,8.56$ \\
PRW & $3.5,0.21,3$ & $4.0,0.38,18$ & $3.9,0.22,12$ \\
& $3.3-3.7,6.00$ & $3.6-5.3,9.59$ & $3.5-4.3,5.68$
\end{tabular}


Table 3. Standard univariate statistics of lower cheekteeth of Neohipparion affine. Measurements defined in Chapter 3. Format and samples as in Table 2. No lower second premolars measured from Lapara Creek sample.

FAUNA

LC

CLAR

p2

ap 1

bap 1

atw

ptw

$\mathrm{mm} 1$

ent1

$----$
$25.6,1.34,10$

$23.6-28.2,5.23$

$19.4,--, 1$

$9.2,0.74,10$

$8.2-10.5,8.02$

$11.9,0.64,10$

$11.2-13.1,5.17$

$9.9,1.11,10$

$7.7-11.8,11.20$

$11.8,0.93,10$

$10.0-13.1,7.88$

p34

ap 1

22.8,0.71, 2

$22.3-23.3,3.10$

bap 1

atw

$11.2,0.00,2$

$11.2-11.2,0.0$

ptw

$11.5,0.14,2$

$11.4-11.6,1.23$

$\mathrm{mm} 1$

$11.5,0.28,2$

$11.3-11.7,2.46$

ent 1
$25.6,0.76,17$

24.1-27.2, 2.95

$20.5,0.92,2$

$19.8-21.1,4.50$

11.6,1.12,17

9.4-13.6,9.67

$12.1,0.94,17$

$10.3-13.6,7.81$

$13.9,0.89,17$

$12.4-15.1,6.39$

$12.1,0.73,17$

$10.8-13.7,6.03$
$11.4,0.92,2$
$10.7-12.0,8.1$
$26.2,1.46,3$

$25.0-27.8,5.57$

$22.4,--, 1$

$9.3,0.47,3$

$8.9-9.8,5.10$

$12.1,0.95,4$

$11.0-13.3,7.84$

$12.1,2.54,3$

$10.0-14.9,21.04$

$11.7,0.89,4$

$10.4-12.2,7.54$

$22.3,2.03,7$

$19.1-24.2,9.10$

$12.1,0.80,7$

$11.1-12.9,6.60$

$11.8,0.51,7$

$11.1-12.5,4.33$

$13.7,0.83,7$

$12.6-15.0,6.06$

$10.9,1.73,7$

$7.9-12.2,15.92$ 
Table 3--continued

m12

$\begin{array}{llll}\text { ap1 } & 22.8,0.28,2 & 24.8,1.26,19 & 20.5,1.06,6 \\ & 22.6-23.0,1.24 & 21.9-26.6,5.08 & 18.9-21.7,5.20 \\ \text { bap1 } & 18.7,0.07,2 & 18 \cdot 0,0.70,4 & --- \\ & 18.6-18.7,0.38 & 17.1-18.8,3.88 & \\ \text { atw } & 9.4,0.28,2 & 9.9,1.11,19 & 10.3,0.26,6 \\ & 9.2-9.6,3.01 & 8.2-11.9,11.15 & 9.9-10.6,2.60 \\ \text { ptw } & 9.0,0.21,2 & 9.3,0.89,19 & 9.6,0.46,6 \\ & 8.8-9.1,2.37 & 7.6-11.0,9.62 & 8.9-10.1,4.83 \\ \text { mm1 } & 12.9,0.92,2 & 13.6,0.85,19 & 12.1,0.34,6 \\ & 12.2-13.5,7.15 & 11.9-15.2,6.23 & 11.5-12.5,2.81 \\ \text { ent1 } & 9.1,0.85,2 & 9.6,1.04,19 & 8.0,1.66,6 \\ & 8.5-9.7,9.32 & 8.0-11.9,10.75 & 6.0-9.8,20.75\end{array}$


Neohipparion trampasense (Edwards), 1982

Neohipparion $n r$. N. eurystyle (Cope), HIRSCHFELD and WEBB, 1968, p. 249 .

Neohipparion cf. leptode Merriam, WEBB et a1., 1981, p. 526;

HULBERT, 1982, pp. 159-160 (in part).

Hipparion trampasense EDWARDS, 1982, p. 174 (in part).

Neohipparion trampasense (Edwards), MACFADDEN, 1984a, p. 97.

Type specimen. UCMP 58234, a left upper molar.

Type localtiy. UCMP V6107, Bolinger Canyon, Contra Costa Co.,

California; Kendal1-Mallory 1.f.

Stratigraphic occurrence and age of type locality. Contra Costa

Group (undifferentiated), about 1300 feet above the top of the Neroly Formation; late Clarendonian, about $10 \mathrm{ma}$.

Topotypic sample. As listed by Edwards (1982), except as qualified below.

Distribution. Late Clarendonian of California; late Clarendonian and early Hemphillian of Nebraska and Florida; early Hemphillian of Kansas.

Referred specimens. J. Swayze Quarry, Clark Co., Kansas: F:AM 113734 L P2; 113735 R P2; 113736 R P34; 113737-113739 3 R M12; 113740 R p2; 113741 L p34; 113742-113743 2 R m12.

Xmas-Kat Fauna, Cherry Co., NB (see Skinner and Johnson, 1984, for discussion of the geology and location of these quarries). Xmas Quarry: F:AM 113756 P34; 114151 R mandible with p2-m3. Machaerodus 
Quarry: F:AM 114152 assoc. R \& L mandibles with dp2-dp4. Line Kat Quarry: F:AM $71854 \mathrm{R}$ mandible with p2-m3. Hans Johnson Quarry: F:AM $114154 \mathrm{R}$ mandible with dp2-dp4. East Kat Quarry: F:AM $113749 \mathrm{R}$ maxilla with P4-M3. Trailside Kat Quarry: F:AM 114155 L mandible with dp2-dp4. Leptarctus Quarry: F:AM 113752, 1137532 assoc. R \& L mandibles with p2-m3; 113754 assoc. R \& L mandibles with p2-m2; $113751 \mathrm{~L}$ mandible with p2-p4; 113750 R P34; 113757 R M12.

Kepler Quarry No. 1 (UNSM 10c. MO-101), Morril1 Co., NB: UNSM 42449 (= AMNH 107595, cast) skull with R \& L P2-M3 (MacFadden, 1984a, Fig. 63).

McGehee Farm: UF 17211 R P34; 9607, 17132, 171343 R M12; 17129, 171332 L M12; 17135 R M3; 17136, 455942 L M3; 17159 assoc. R \& L mandibles with p2-m3; $45593 \mathrm{R}$ mandible with p2-p3; 9500 assoc. $R$ m1-m3 \& L p4-m1; 65177 L dp34; 45598 L p2; 17166, 17170, $456053 \mathrm{~L}$ p34; 17141, 17143, 17171, 45601-45604, $534538 \mathrm{~L} \mathrm{m12;17142,} 17146$,

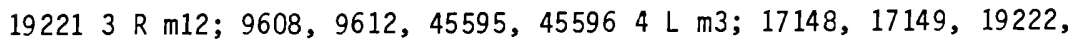
$456324 \mathrm{R} \mathrm{m} 3$.

Love Site: UF 32249 partial sku11 with R \& L DP2-M1; 32291 partial skull with R \& L DP2-M2; 25637 partial skul1 with R P4,M1,M3 \& L P4-M3; 32248 assoc. maxillae with R DP2-DP4 \& L DP2-M2; 32252 assoc. maxillae with $R$ \& L P2-M3; 32258 assoc. maxillae with R P3-M3 \& L P2-M1,M3; $32251 \mathrm{R}$ maxilla with M1-M3; $32272 \mathrm{~L}$ maxilla with P3-M2; 32253 L maxilla with P4-M3; 53427 L maxilla with P4-M1; $53428 \mathrm{~L}$ maxilla with M2-M3; 32277 assoc. R DP2-DP4 \& L DP2-DP3; 27991, 27992, 322563 assoc. R \& L P2-M3; 32284 assoc. R P2-M1 \& L P2,M2-M3; 53204/53207 assoc. R P3-P4; 32273 assoc. L P3-M2 \& R M1; 32280 assoc. 
L M1-M3; 32159 assoc. R \& L mandibles with c,p2-m3; 27317 assoc. mandibles with $\mathrm{R} i 1, i 3, c, p 4-\mathrm{m} 3$ \& L p2-m3; $32148 / 32153$ assoc. mandibles with $R$ p2-m3 \& L p3-m3; 32193 assoc. mandibles with $R$ p4-m3 \& L $m 1-m 3 ; 32192$ assoc. mandibles with $R$ p2-m3 \& L p2-p4; $32121 R$ mandible with dp2-dp4; $32145 \mathrm{~L}$ mandible with dp2-dp4,ml; 32213, 32216, 32218, $321624 \mathrm{R}$ mandibles with p2-m3; 32110, 32216, $321523 \mathrm{~L}$ mandibles with p2-m3; $32186 \mathrm{~L}$ mandible with p2-p3,m1-m3; $32179 \mathrm{R}$ mandible with p2-p3,dp4,m1-m2; $32175 \mathrm{R}$ manidble with $\mathrm{p} 3-\mathrm{m} 2 ; 32127$, $321842 \mathrm{~L}$ mandibles with p2-m2; 32164, 32109, $322173 \mathrm{~L}$ mandibles with p3-m3; $32168 \mathrm{~L}$ mandible with p2-p3,dp4,m1-m2; 32106, 32122, $32126,32142,32156,32210,32211,32222,32224,32310,32311,36275$, 36281,3628814 partial $R$ mandibles; $32131,32149,32166,32188$, $32246,35899,36273,36273,362748$ partial L mandibles; 32228 , $32230,32233,32234,32235,32238,32240,35896,36278,68788-68791$, 13 assoc. lower dentitions; over 850 individually catalogued isolated cheekteeth.

Revised diagnosis. Medium-sized hipparionine with toothrow lengths between 110 and $130 \mathrm{~mm}$; DPOF very shallow depression set well anterior to lacrimal. Unworn M12 MSCH about $60 \mathrm{~mm}$; higher crowned than Neo. affine, lower crowned than Neo. eurystyle, Neo. leptode or Neo. gidleyi. Fossettes moderately complex; pli caballin strong, often double on premolars; metastyle present but much weaker than in Neo. eurystyle; pli caballinid persistently well developed on p2-p4 and dp2-dp4, on m1-m3 on ly in early wear-stages.

Description of Florida and Nebraska specimens. Other than fragments, no cranial meterial was recovered with the topotypic 
sample of Neo. trampasense (Edwards, 1982). The most complete referable skull of Neo. trampasense is UNSM 42449 from the late Clarendonian of Nebraska. It along with less complete cranial material from the Love Site (UF 32251) demonstrate that Neo. trampasense has a relatively small, very shallow DPOF developed only on the maxiliary and nasal bones, dorsal and posterior to the IOF. It is located far anterior of the lacrimal, which is reduced in size (Fig. 4). The malar region may have a slight depression (UF 32251 , Fig. 4), although this feature is absent in F:AM 113749 and UNSM 42449. The nasal notch is not deeply retracted, and lies over the postcanine diastema. Mandibular and maxillary toothrow lengths in moderate to early wear vary from 108 to $130 \mathrm{~mm}$ (1trl of combined sample from the Love Site and McGehee Farm, excluding heavily worn individuals, has a $\underline{\bar{x}}$ of $115.8 \mathrm{~mm}, \underline{s}=4.42, n=7)$. Individuals from the Great Plains average 5 to $10 \%$ larger. Lower diastema lengths range from 53 to $59 \mathrm{~mm}$ for males $(\underline{\bar{x}}=55.3 \mathrm{~mm}, \underline{s}=2.48, n=5)$, while the on $7 y$ measurable female had a $1 \mathrm{dl}$ of $64.4 \mathrm{~mm}$.

Upper cheekteeth of Neohipparion trampasense are generality characterized by moderately complex fossettes, moderately elongated protocones, deep hypoconal grooves, and well developed parastyles and mesostyles. P2s in early wear-stages have well developed, pinchedoff anterostyles, slightly recurved parastyles, and small metastyles (Fig. 5A). The P2 protocone is elongated, but shorter than that of the $\mathrm{P} 34$, and typically connects to the protoselene during moderate wear-stages. Complexity of fossette plications and pli caballin development of the $P 2$ rival or exceed slightly that of the P34. 

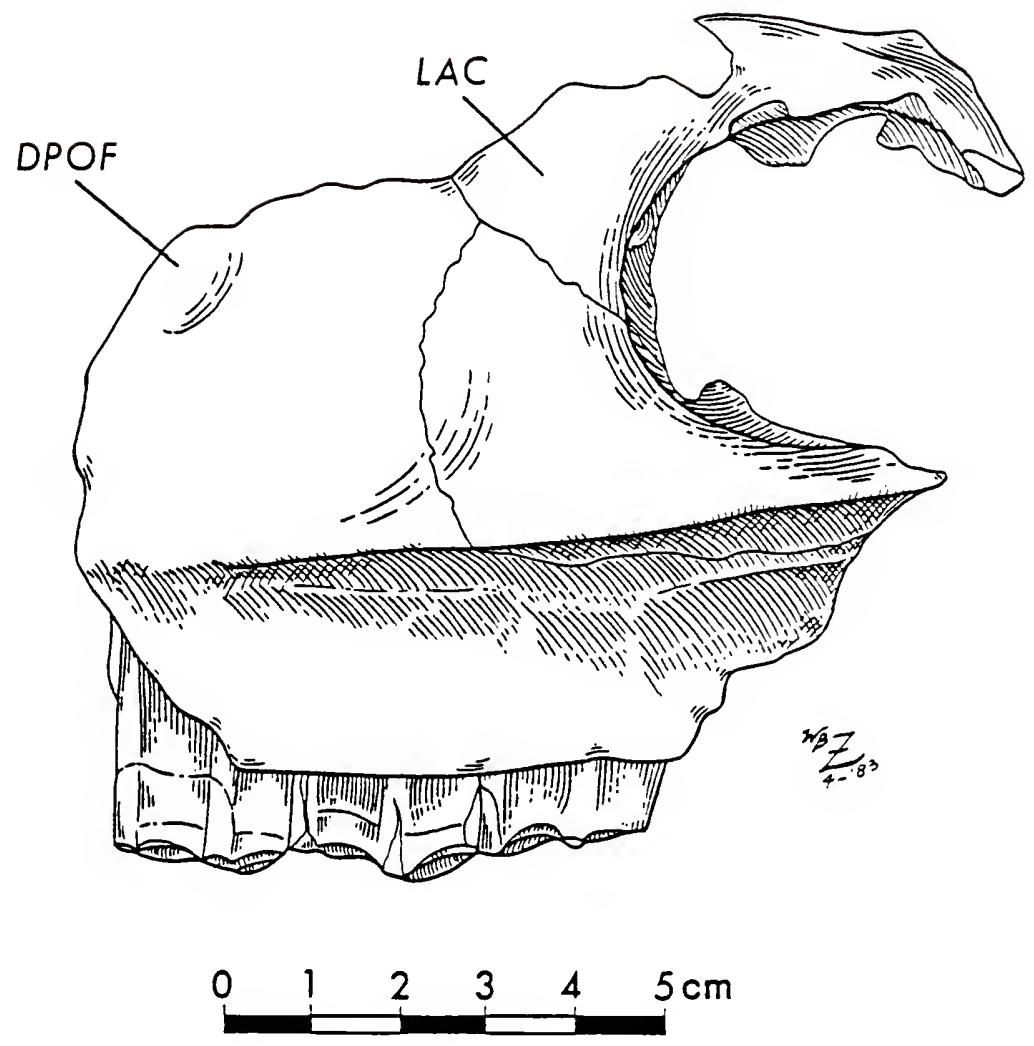

Figure 4. Lateral view of right (reversed) facial region of Neohipparion trampasense (UF 32251) from the Love Site, Alachua County, Florida. LAC, Tacrimal bone; DPOF, dorsal preorbita fossa. Teeth in lateral view are the i11-43. 
62
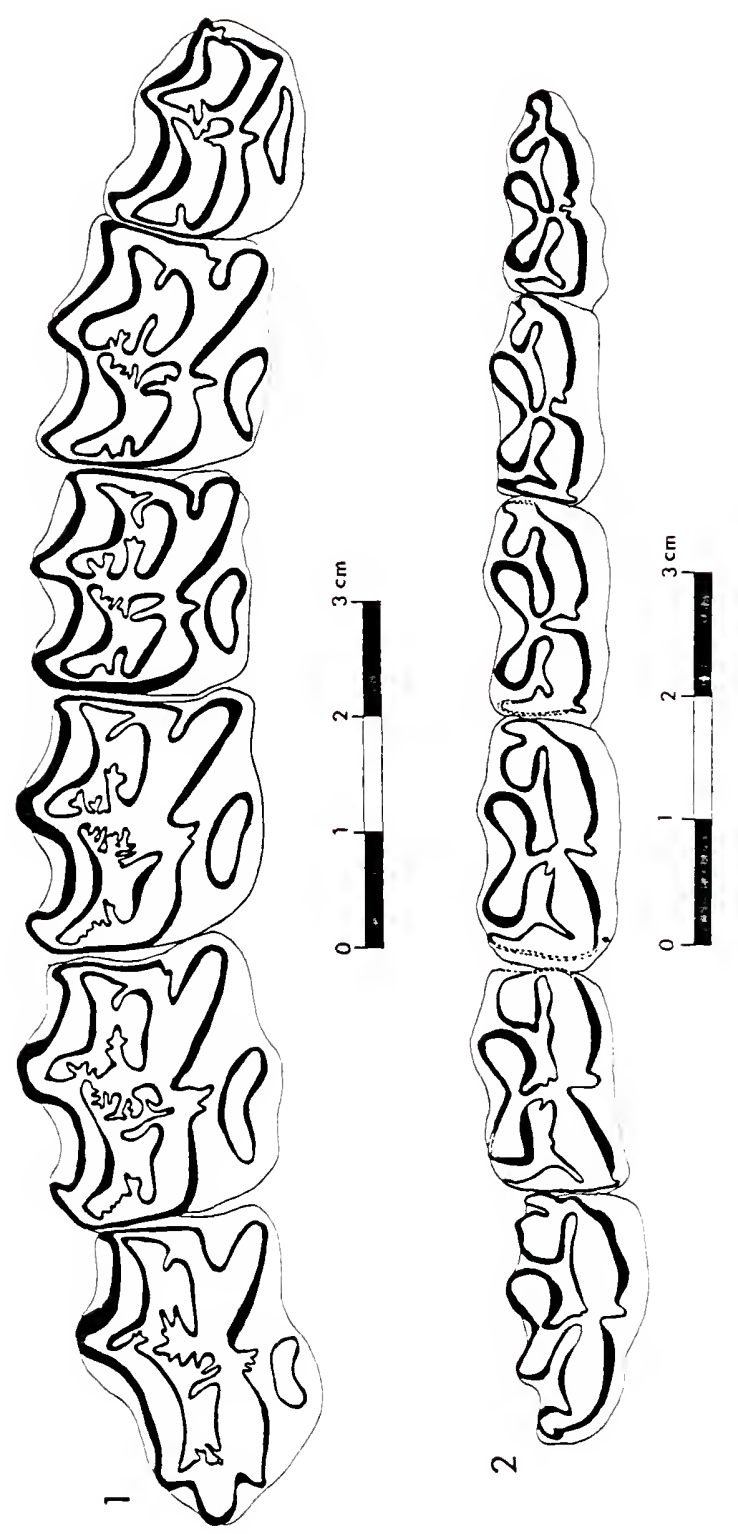

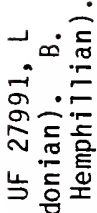

<这交

. 00

ڤิ山

⿹勹巳

읕잔

部

등중 동

$5=0$

흥으

도일

文㤝示

ᄂ

돌

过

茟它它

ปه

$1 \div$

出

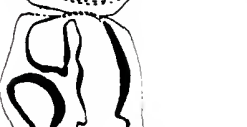

으 힌

동

ه

बे

윽 1

$4 \frac{1}{3}$

ᄂ

$\backsim$

娄出

$>$ 을

б

옹

군

으

เீ ชั

เง ल

至监

汇㟔 


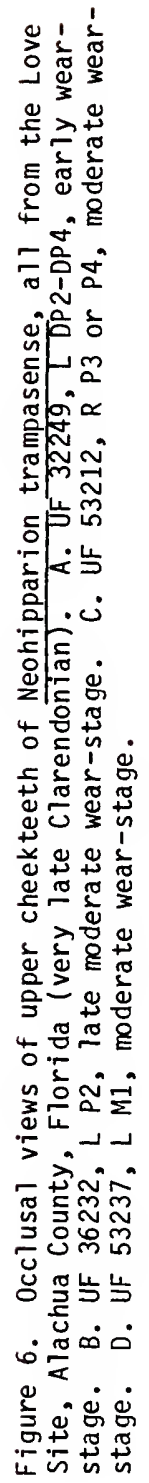



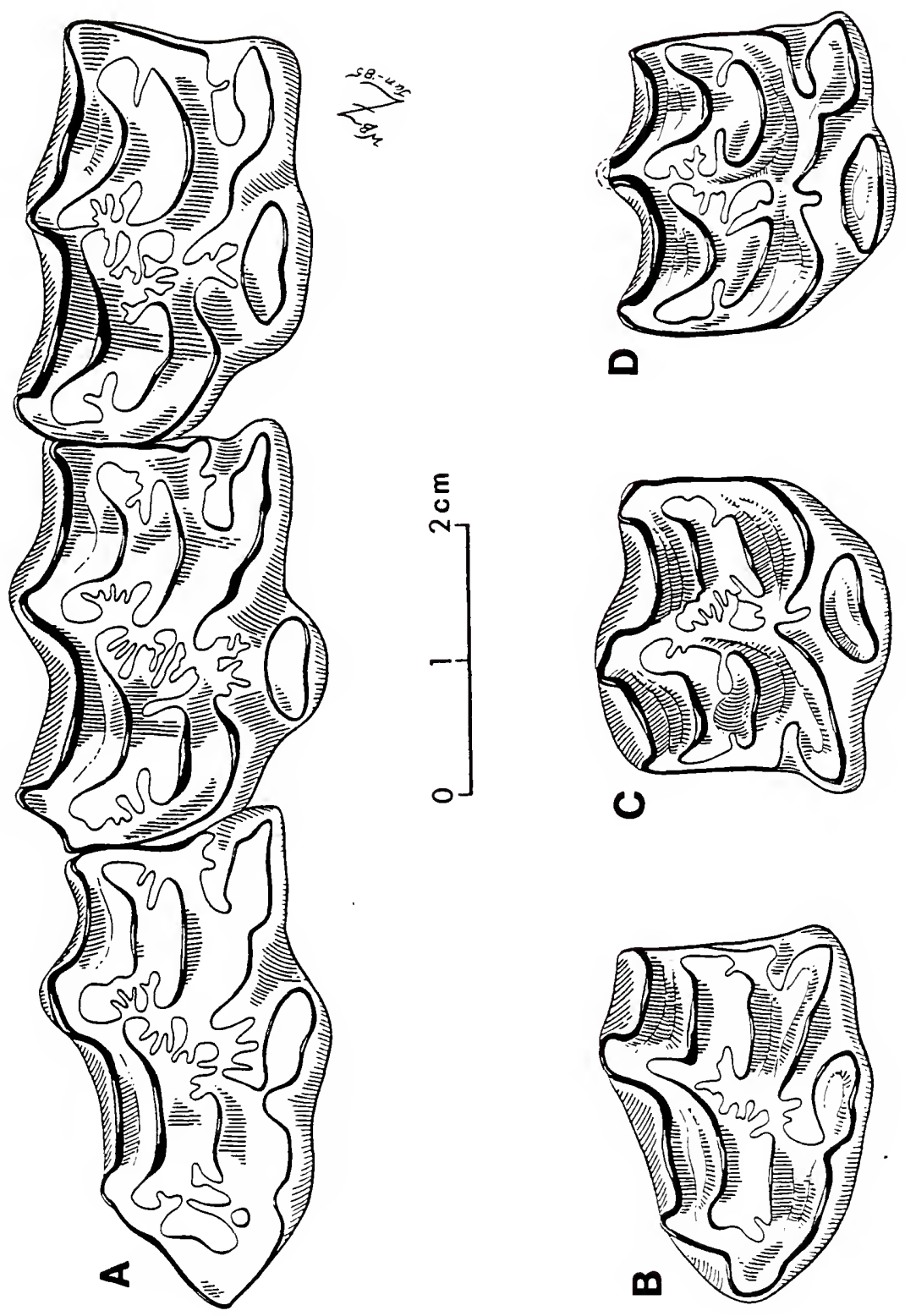
Table 4. Standard univariate statistics for upper cheekteeth of Neohipparion trampasense. Format as in Table 2. Populations are LOV, Love Site, A Tachua County, Florida; KM, Kendall-Mallory l.f., Contra Costa County, California (type locality); NEB, Xmas-Kat Quarries Faunal Zone, Cherry County, Nebraska; and KAN, combined sample from the J. Swayze Quarry, Clark County, Kansas and Arens Quarry, Norton County, Kansas.

FAUNA LOV KM NEB KAN

P2

\begin{tabular}{|c|c|c|c|c|}
\hline APL & $\begin{array}{l}24.9,1.28,50 \\
22.5-27.1,5.12\end{array}$ & $24.8,--, 1$ & $26.4,--, 1$ & $\begin{array}{l}27.7,2.11,4 \\
26.3-30.8,7.63\end{array}$ \\
\hline BAPL & $\begin{array}{l}20.2,0.82,48 \\
18.0-21.7,4.07\end{array}$ & --- & ---- & $\begin{array}{l}21.5,0.84,5 \\
20.6-22.6,3.89\end{array}$ \\
\hline TRW & $\begin{array}{l}17.8,0.76,51 \\
16.0-19.4,4.26\end{array}$ & $18.6,--, 1$ & $19.1,--, 1$ & $\begin{array}{l}20.6,1.10,4 \\
19.5-22 \cdot 1,5.37\end{array}$ \\
\hline PRL & $\begin{array}{l}7.3,0.60,51 \\
5.9-8.9,8.22\end{array}$ & $7.1,--, 1$ & $6.3,--, 1$ & $\begin{array}{l}7.4,1.19,5 \\
5.8-8.6,15.95\end{array}$ \\
\hline PRW & $\begin{array}{l}3.6,0.33,51 \\
3.0-4.5,9.15\end{array}$ & $4.2,--, 1$ & $3.7,--, 1$ & $\begin{array}{l}4.0,0.36,4 \\
3.7-4.4,8.90\end{array}$ \\
\hline
\end{tabular}

P34

$\begin{array}{lllll}\text { APL } & 20.3,1.33,136 & 22.0,0.99,6 & 21.9,0.46,4 & 24.8,0.76,4 \\ & 17.5-23.4,6.56 & 20.5-23.1,4.47 & 21.4-22.5,2.08 & 23.9-25.5,3.07\end{array}$

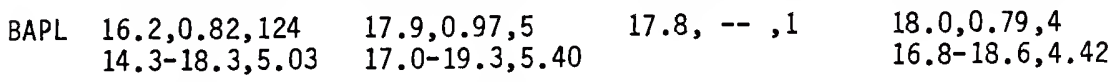

$\begin{array}{lllll}\text { TRW } & 18.9,0.92,135 & 20.3,1.02,5 & 20.6,0.63,4 & 21.8,0.60,5 \\ & 14.0-20.8,4.86 & 19.3-22.0,5.02 & 19.9-21.4,3.04 & 21.1-22.5,2.74\end{array}$

$\begin{array}{lllll}\text { PRL } & 8.2,0.81,139 & 8.1,0.48,6 & 8.0,0.22,4 & 10.4,0.96,5 \\ & 6.4-10.5,9.83 & 7.3-8.8,5.97 & 7.7-8.2,2.70 & 9.3-11.5,9.30\end{array}$

$\begin{array}{lllll}\text { PRW } & 3.5,0.32,139 & 3.8,0.15,6 & 3.7,0.22,4 & 4.1,0.29,5 \\ & 2.8-4.5,9.09 & 3.6-4.0,3.87 & 3.4-3.9,6.03 & 3.9-4.6,6.93\end{array}$ 
Table 4--continued

M12

APL $\quad 19.3,1.50,154 \quad 19.2,1.49,4$ $16.1-23.1,7.79 \quad 17.4-21.5,7.77$

BAPL $15.2,0.71,138 \quad 16.1,0.70,2$ $13.6-16.8,4.66 \quad 15.4-16.8,4.35$

TRW $17.1,0.97,152 \quad 18.6,0.46,5$ $12.8-19.4,5.56 \quad 18.1-19.2,2.39$

PRL $\quad 7.8,0.62,158$ $6.5-9.4,7.97$

$8.3,0.58,5$ $7.8-9.4,7.06$

PRW $\quad 3.2,0.34,155$ $2.4-4.1,10.38$

$$
3.6,0.26,5
$$$$
3.2-3.9,7.08
$$

$19.3,0.45,4$ $18.9-19.9,2.34$

$21 \cdot 0,0.90,3$

$20.0-21.6,4.26$

$15.8,0.29,3$

$15.5-16.0,1.82$

$19.6,0.76,4$

$18.7-20.5,3.90$

$18.5,1.15,3$

$17.2-19.4,6.23$

$8.0,0.69,4$

7. 4-8.9,8.62

$8.8,1.62,3$

$7.9-10.7,18.3$

$3.7,0.49,4$

$3.1-4.2,13.52$
$3.6,0.21,3$

$3.4-3.8,5.73$ 
After moderate or heavy wear, the anterostyle becomes broadly connected with the rest of the tooth, the protocone connection also broadens, and the parastyle becomes less distinct (Fig. 6B). Estimated unworn P2 MSCH is about $37-40 \mathrm{~mm}$, based on a large sample of slightly worn teeth (e.g. UF $36009,36155,36189$ ). The P34 (Figs. $5 \mathrm{~A}, 6 \mathrm{C})$ are characterized by broad, well developed styles; elongated, obliquely oriented (anterolabial-posterolingual) protocones isolated until very near the base of the crown and rarely with spur; 1 ingual protocone borders generally concave; well developed, persistent, often branched or double pli caballins; anterior half of prefossette generally has a deep, unbranched pli protoloph, and one to three labial accessory plications; the posterior half of the prefossette is complexly plicated in early to moderate wear-stages, with a long, secondarily plicated prefossette loop, and two to five plis prefossette of varying depth and complexity; the anterior half of the postfossette is strikingly less complex, with a deep, only rarely branched pli postfossette, and one to three, most often one, small accessory plications; and the posterior half of the postfossette general has a single, deep, unbranched pli hypostyle. The hypoconal groove is deep and broad in early wear-stages, shallower with wear but open to the base of the crown. The DP2-DP4 (Fig. 6A) are more complex than their permanent counterparts, typically with multiple or branched pli caballins; intricately plicated fossettes in early wear; and more oval protocones with flat or convex lingual borders. The DP1 is very rudimentary and lost prior to the replacement of the DP2 
by the P2 (e.g. UF 32291). Estimated unworn P34 MSCH is about 52 to $55 \mathrm{~mm}$.

The upper molars are distinctly smaller than the premolars (Table 4; Figs. 5A, 6D); with elongate-oval, isolated protocones not so obliquely orientated; and less pronounced styles. The lingual borders of molar protocones are generally flat or convex, on ly occassionally concave. Pli caballins are generally single, and. smaller than in the premolars. The anterior half of the prefossette most often has a moderately deep, unbranched pli protoloph without accessory plications. The posterior half of the prefossette has a long prefossette loop and one to four shallow plis prefossette. The anterior half of the postfossette has a deep, sometimes branched pli postfossette and up to four accessory plications. The posterior half of the postfossette generally has a single, unbranched pli hypostyle. About $32 \%$ of all observed molars in early and early-to-moderate wearstages ( $M S C H>35 \mathrm{~mm} ; n=93$ ) resemble the holotype, UCMP 58234, in having one or two accessory plications in addition the pli protoloph. Estimated unworn M12 MSCH about 57 to $60 \mathrm{~mm}$. The hypsodonty index of the Love Site population is 3.9 .

The Love Site sample of associated and isolated lower teeth is large enough to provide numerous examples of every wear-stage (Table 5 ; Figs. 5B, 7). Deciduous lower premolars have very elongated metaflexids and entoflexids; well developed pli caballinids; shallow ectoflexids; very small or absent ectostylids (the tooth is shed before they are exposed to wear); and less frequent isthmus plications than on the permanent premolars (Fig. 7E). The dpl is 


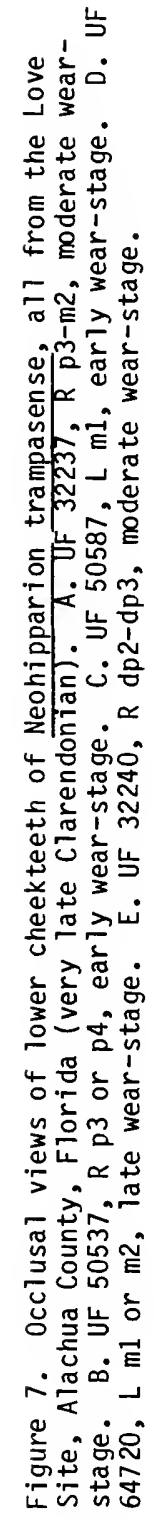



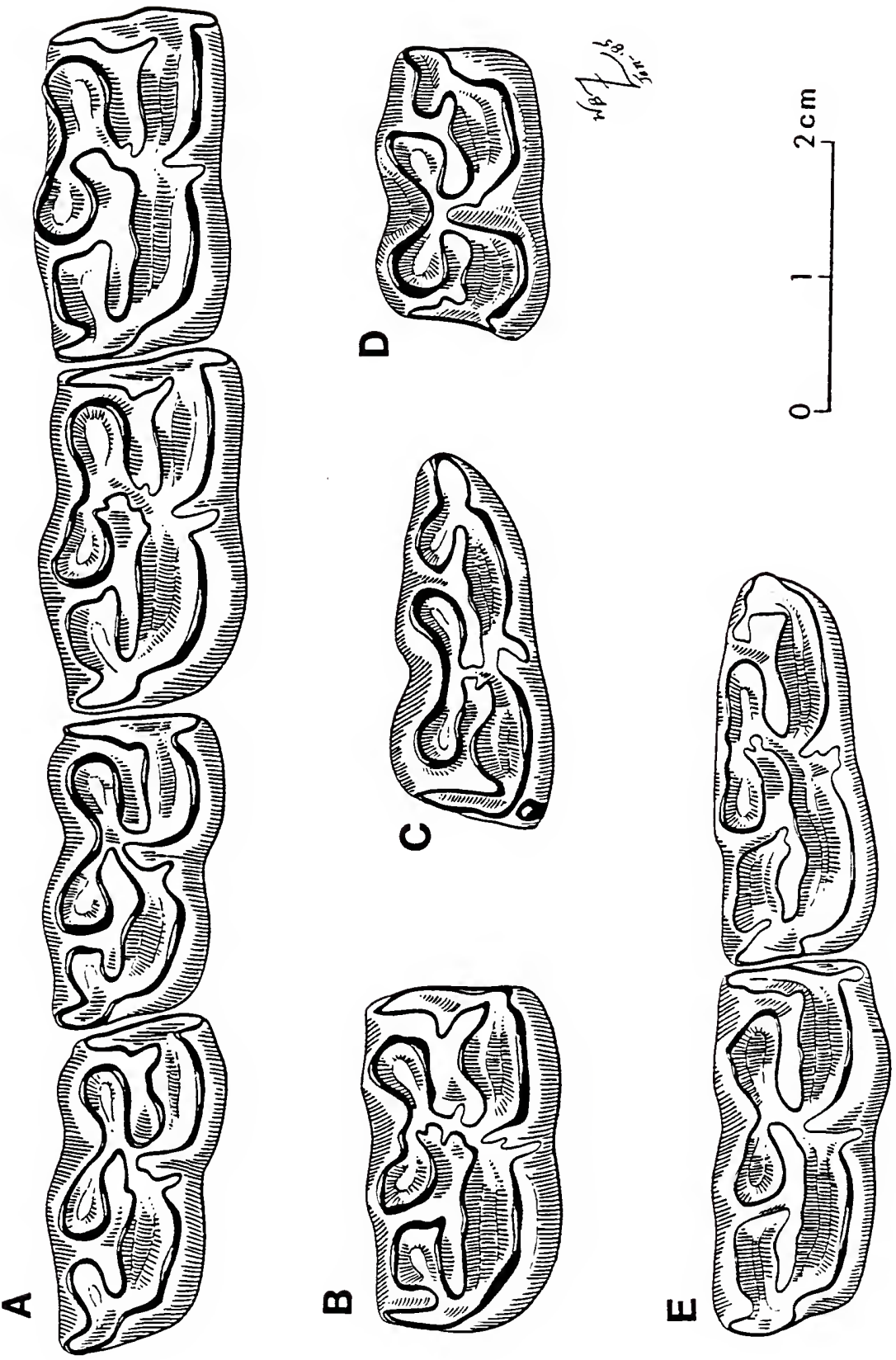
Table 5. Standard univariate statistics of lower cheekteeth of Neohipparion trampasense. Format as in Table 2, sample populations as in Table 4.

FAUNA LOV KM NEB p2

\begin{tabular}{|c|c|c|c|c|}
\hline apl & $\begin{array}{l}21.5,1.03,67 \\
19.0-23.7,4.79\end{array}$ & $21.9,--, 1$ & $\begin{array}{l}23.1,1.17,5 \\
21.7-24.6,5.06\end{array}$ & $\begin{array}{l}24.9,1.42,7 \\
22.9-27.1,5.70\end{array}$ \\
\hline bapl & $\begin{array}{l}18.0,0.68,59 \\
16.3-20.1,3.79\end{array}$ & ---- & ---- & $19.4,--, 1$ \\
\hline atw & $\begin{array}{l}8.2,0.47,63 \\
6.8-9.1,5.79\end{array}$ & $8.5,--, 1$ & $\begin{array}{l}8.3,0.47,5 \\
7.9-9.0,5.60\end{array}$ & $\begin{array}{l}9.6,0.52,7 \\
8.8-10.4,5.35\end{array}$ \\
\hline tw & $\begin{array}{c}10.2,0.77,65 \\
7.3-11.8,7.51\end{array}$ & $9.8,--, 1$ & $\begin{array}{l}10.0,0.78,5 \\
8.9-11.0,7.75\end{array}$ & $\begin{array}{l}11.4,0.42,6 \\
11.1-12.0,3.65\end{array}$ \\
\hline $\mathrm{m} 1$ & $\begin{array}{l}9.6,0.87,64 \\
7.2-12.0,9.04\end{array}$ & $8.7,--, 1$ & $\begin{array}{l}9.9,0.61,5 \\
9.0-10.6,6.19\end{array}$ & $\begin{array}{l}11.7,0.67,7 \\
10.6-12.8,5.69\end{array}$ \\
\hline ent 1 & $\begin{array}{c}10.4,0.80,64 \\
8.4-12.0,7.71\end{array}$ & $9.5,--, 1$ & $\begin{array}{l}10.8,0.76,5 \\
9.9-11.8,7.02\end{array}$ & $\begin{array}{l}11.9,1.50,7 \\
9.7-13.9,12.6\end{array}$ \\
\hline
\end{tabular}

ap

$$
\begin{aligned}
& 20.7,1.27,71 \\
& 18.1-23.6,6.14
\end{aligned}
$$

$21.6,1.18,6$

$20.1-22 \cdot 6,5.45$

bapl $16.8,0.68,63$

$15.3-18.7,4.01$

$17.8,0.71,2$

$17.3-18.3,3.97$

atw $10.2,0.61,71$

$9.0-11.9,5.94$

$10.5,0.90,6$

$8.7-11.2,8.58$

$10.2,1.14,6$

ptw $\begin{gathered}10.2,0.63,71 \\ \\ 8.5-11.6,6.19\end{gathered}$

$8.1-11.1,11.24$

$12.0,0.75,6$

$\begin{array}{ll}\text { mm1 } & \begin{array}{l}12.2,0.73,71 \\ \end{array} \quad 10.5-14.1,5.97\end{array}$

$10.6-12.6,6.19$

ent1 $10.2,0.74,71$

$7.8-11.9,7.18$
$10.0,0.58,6$

$9.2-10.9,5.85$
$22.8,1.21,9$

$20.9-25.0,5.32$

$22.8,1.49,15$

$20.0-25.7,6.52$

$18.3,1.21,3$

$17.0-19.4,6.63$

$10.1,0.80,9$

$8.8-11.4,7.95$

$11.6,0.85,15$

$10.3-13.3,7.34$

$10.3,0.98,9$

$8.8-11.4,9.50$

$11.7,0.99,15$

$9.7-13.9,8.45$

$12.1, .073,9$

$10.6-12.9,6.01$

$13.6,1.13,15$

$11.6-15.9,8.34$

$10.4,0.61,9$

$9.7-11.6,5.85$
$10.8,1.01,15$

$9.2-13.1,9.34$ 
Table 5--continued

$\mathrm{m} 12$

$\begin{array}{lllll}\text { ap1 } & 20.0,1.74,68 & 20.2,1.58,6 & 22.4,1.98,8 & 21.7,2.27,18 \\ & 16.9-23.9,8.69 & 18.0-22.1,7.81 & 19.3-25.1,8.85 & 17.9-26.4,10.5 \\ \text { bap1 } & \begin{array}{l}15.9,0.62,67 \\ \text { 14.4-17.8,3.96 }\end{array} & 16.2,--, 1 & ---1 & 17.1,0.22,6 \\ & & & & 16.9-17.5,1.28 \\ \text { atw } & 8.7,0.67,68 & 9.2,0.64,4 & 9.0,0.66,8 & 9.7,0.91,17 \\ & 6.7-10.1,7.72 & 8.3-9.7,6.93 & 8.0-10.4,5.35 & 8.1-11.5,9.35 \\ \text { ptw } & 8.2,0.81,68 & 8.8,0.54,6 & 8.6,0.88,8 & 9.3,0.84,18 \\ & 5.8-9.9,9.80 & 7.8-9.3,6.15 & 7.3-9.8,10.24 & 7.9-10.6,8.67 \\ \text { mm1 } & 11.6,0.73,68 & 11.9,0.91,6 & 12.0,0.80,8 & 12.9,0.82,18 \\ & 9.4-13.6,6.32 & 10.9-12.8,7.65 & 10.7-13.1,6.68 & 11.5-14.2,6.36 \\ \text { ent1 } & 8.5,1.25,68 & 8.4,0.65,6 & 9.2,1.08,8 & 9.0,1.30,18 \\ & 6.0-11.2,14.72 & 7.4-9.1,7.75 & 7.6-10.8,11.84 & 6.3-11.3,13.8\end{array}$


sma 11, rudimentary, and shed with the eruption of the p2. Lower permanent premolars (Figs. 5B, 7A, 7B) are characterized by shallow ectoflexids that do not penetrate the isthmus even in late wearstages; persistent pli caballinids; well developed protostylids; plicated isthmuses and paralophids; expanded, subequal metaconids and metastylids well separated throughout all wear-stages; linguaflexid very broad, shallow, "U"-shaped in early wear (occassionally with a lingual plication), with wear, narrower and more "V"-shaped; labial borders flat in early wear, with heavy wear they may take on a more rounded appearance. Lower molar morphology changes even more dramatically with wear. In very early wear-stages the $\mathrm{ml}$ and $\mathrm{m} 2$ are very long, with many features similar to those observed in the premolars, such as shallow ectoflexids and well developed pli caballinids (Fig. 7C). Following the eruption of the $\mathrm{m} 3$, the $\mathrm{m} 12 \mathrm{APL}$ becomes shorter; ectoflexids deepen with gradual penetration of the entire isthmus (Figs. 5B, 7A); pli caballinids fade, although in moderate wear-stages their appearance is somewhat variable; metaflexids and entoflexids shorten; and the labial borders of the protoconid and hypoconid become rounder. In late wear-stages (Fig. 7D), molars lack or have only rudimentary pli caballinids; have deep, "V"-shaped linguaflexids and ectoflexids; and have oval metasylids and metaconids. Unworn mech about 36 to $37 \mathrm{~mm}$ for p2, 48 to $51 \mathrm{~mm}$ for $\mathrm{p} 34$, and 58 to $60 \mathrm{~mm}$ for $\mathrm{m} 12$.

Discussion. As noted by MacFadden (1984a), Neo. trampasense is clearly a member of Neohipparion based on its cranial, facial and dental features. For many characters, Neo. trampasense is 
intermediate between those found in basal hipparionine stock or Neo. affine, and those in the Neo. eurystyle species-group. The topotypic Bolinger Canyon sample of Neo. trampasense is the oldest population referred to the species (about $10 \mathrm{ma}$, Edwards, 1982), and the least progressive as wel1. When compared with the Nebraska and Florida samples, its protocones are more oval and have flat lingual borders (rarely concave); the lower premolars tend to lose the pli caballinids with heavy wear (e.g. UCMP 77031); and the molars have only rudimentary pli caballinids in moderate wear-stages (e.g. UCMP 58244). However, in many features, such as size (Tables 4, 5), hypsodonty, fossette complexity, metastyle development, reduction of ectoflexid depth in premolars, and flattened labial borders of lower premolars, the Bolinger Canyon sample so closely approaches or equals that seen in later Clarendonian and early Hemphillian samples that they are considered the same species.

Several specimens refered by Edwards (1982) to Neo. trampasense from the type locality clearly do not belong with that species as it is now defined. These include UCMP 77032 (L P3-M1), UCMP 58223 (L M1-M2, not P4-M1 as stated by Edwards, 1982, p. 174), UCMP 58225 (L P34), UCMP 112771 ( $L$ p34) and UCMP 112154 (R \& L dp2-dp4). The upper cheekteeth of these specimens are characterized by short, oval protocones with well developed spurs and convex lingual borders. In protocone morphology, as well as size, fossette complexity, and stylar development they match the topotypic sample of Hipparion forcei (Richey, 1948; e.g. UCMP 94815, a L M1). The associated lower dentition is also probably referable to $\underline{H}$. forcei because of its lack 
of pli caballinids, moderately developed ectostylids, rounded labial borders, and relatively short metaflexids and entoflexids. UCMP 112154 does not differ significantly from the large sample of deciduous lower premolars of $\underline{H}$. forcej from Black Hawk Ranch. Perhaps the inclusion of the se Hipparion teeth in his sample contributed to Edwards placing his new species in Hipparion rather than Neohipparion. Finally, Edwards (1982) 1isted UCMP 58239 as both a L p4-m1 (p. 174) and a $L$ m2-m3 (p. 182). The specimen is clearly a L p3-p4 (of Neo. trampasense), as the more anterior tooth is undoubtedly a premolar, and thus the very slightly worn posterior tooth cannot be a molar (as the $\mathrm{m} 1$ erupts well prior to the $\mathrm{p} 4$ in all equids).

MacFadden (1984a) on 1y referred one specimen from the Xmas-Kat Fauna of Nebraska to Neo. trampasense. Examination of previously uncatalogued material in the $F: A M$ collection revealed a number of specimens referable to this species from this fauna, and from other sites in Nebraska and Kansas. Neo. trampasense is thus more common in the Great Plains than previously thought, and apparently is a useful biochronological indicator of the late Clarendonian and early Hemphilitian across North America.

A number of derived dental character states found in Neo. trampasense, some on $7 y$ in early wear-stages, indicate a close relationship with later Hemphillian species of Neohipparion. In the upper dentition these include the flattened protocones, often with concave lingual borders, and the well developed styles. Small metastyles are much more frequent than in Neo. affine. However, it is in the lower cheekteeth that Neo. trampasense best shows its 
advanced features. In the premolars, the ectoflexids do not penetrate the isthmus, even with heavy wear, nor is there reduction of the pli caballinids. The labial borders tend to be very flat, and the metaconids and metastylids are long and well separated. In molars, pli caballinids are consistently found in early wear-stages, and there is some reduction of the depth of the ectoflexids. However, in late wear, the molars take on the primitive hipparionine morphology (Fig. 7D). The lower dental morphology in the sequence Neo. affine - Neo. trampasense - Neo. eurystyle details the evolution of a caballoid dental pattern (sensu Forsten, 1982; 1984) from the primitive hipparionid pattern. This pattern evolved independently several times to varying degrees in equid lineages during the Late Neogene. In some respects, that attained by Neohipparion was the most advanced in the Equidae (Rensberger et al., 1984). The chronological sequence of Neo. trampasense populations demonstrates a possible mechanism (heterochrony) of how this ultimate pattern evolved. Younger populations (early Hemphillian) of Neo. trampasense tend to retain advanced characters such as reduced depth of the ectoflexid and pli caballinid development in molars through later wear-stages than do older populations (late Clarendonian). Referred specimens of Neo. trampasense from early Hemphillian localities in Kansas ( $J$. Swayze and Arens Quarries) also have significantly larger tooth dimensions (Tables 4, 5); the se combined suggest an evolutionary trend that resulted in the western species Neo. leptode. The relatively early (and most primitive) appearance of Neo. eurystyle is in Florida (see below) from Moss Acres and With 4A. This suggests that 
Neo. eurystyle evolved from eastern populations of Neo. trampasense, perhaps in the Gulf Coastal Plain.

Neohipparion eurystyle (Cope), 1893

Equus eurystylus COPE, 1893, pp. 43-45.

Hipparion eurystylus (Cope), GIDLEY, 1901, p. 125.

?Hipparion eurystylus (Cope), GIDLEY, 1907, p. 918.

Neohipparion eurystyle (Cope), MERRIAM, 1915, p. 4; STIRTON, 1940; p. 183; MACFADDEN, 1984a, p. 105 (in part).

Hipparion eurystyle (Cope), OSBORN, 1918.

Hipparion phosphorum SIMPSON, 1930, p. 189.

Hipparion (Neohipparion) eurystyle (Cope), MATTHEW and STIRTON, 1930, p. 362.

Neohipparion floresi STIRTON, 1955, p. 886.

Neohipparion arellanoi STIRTON, 1955, p. 888.

Neohipparion otomi i MOOSER, 1960, p. 376; DALQUEST and MOOSER, 1980, p. 11 .

Neohipparion monias MOOSER, 1964, p. 394; DALQUEST and MOOSER, 1980, p. 12.

Neohipparion cf. phosphorum (Simpson), WEBB and TESSMAN, 1968, p. 806 .

Hesperohipparion stirtoni DALQUEST, 1981, p. 510.

Type specimen. TMM 40289-1, a partial left lower molar. Type locality. Palo Duro Canyon, Randa 11 Co., Texas. Possibly the Currie Ranch Site (Schultz, 1977; Dalquest, 1981). 
Stratigraphic occurrence and age of type locality. Ogallala Group; late Hemphillian, about 5 ma.

Distribution. Early late to latest Hemphilitian of Mexico, Texas, Oklahoma, Kansas and Nebraska. Late early through latest Hemphillian of Florida. Possibly California.

Referred Florida specimens. Moss Acres Racetrack Site: UF 95410 assoc. R M2 \& L M2-M3; $65250 \mathrm{R}$ mandible with dp3-m1; $69969 \mathrm{R}$ mandible with $p 2-m 3$ and $R i 1-i 3 \& L i 1$.

With 4A: UF 45518 R P2; 45520 R M3; 45546 R pd2; 17306 R p2.

With 4X: UF 53524 R P34.

Mutual Mine, near Dunnelion, Marion Co., FL: UF/FGS V-7175 L M12; -7176 R P34; -7179 R p34; -7180 L p34; -7178 R m12; -7177 R m3.

Manatee Dam Site: UF 11940 R P2.

Lockwood Meadows: UF 64116 R P34.

Palmetto Fauna, Bone Valley Region. Palmet to Mine: UF 17154 assoc. R m1-m3; 17114 L P2; 17115, 53529, 53534-53537, 535417 R P34; 53530,535402 R M12; 17116, 17118, 53531, 53538 4 L M12; 53532 R M3; 17119, 53542, 535433 L M3; 17162 R dp3; 53479 L p2; 53509, 53496, 2 $\mathrm{R} \mathrm{p} 34 ; 17157 \mathrm{R} \mathrm{m12} ; 12501,535002 \mathrm{~L} \mathrm{m12} ; 12061,534992 \mathrm{R} \mathrm{m} 3 ; 17158$ L m3. North Palmet to Mine: UF 18725 L M3; 18728 L m3. Payne Creek Mine: UF 18318 assoc. R \& L P4-M3; AMNH 113755 L p34. Chicora Mine: UF $17155 \mathrm{R}$ m12. Fort Green Mine: UF 53902, 53903, 57342, $583094 \mathrm{R}$ M12; 24657 L M3; 53506 R m12. Nichols Mine: UF 24629 L P34. Agrico Mine: UF/FGS V-5505 R P34; -1423 L M12 (holotype Neo. phosphorum); -5473 L m3; AMNH $95627 \mathrm{R}$ m12. Silver City Mine: UF $65698 \mathrm{R}$ M3. Kingsford Mine: UF 17120 L P2; 53544 L M12; 17151 L p2; 53559 R m12; 
53560 L m12. Mineco Mine: UF 91202 L P2; 91203 R P34. Gardinier Mine: UF 90524-90525 2 L M12. Hookers Prairie Mine: UF $93208 \mathrm{~L}$ P34. Phosphoria Mine: UF 93214 R M1. Tiger Bay Mine: UF 25709 L P2. Brewster Phosphate Mine: UF 65744 R M12. Specific locality unknown: UF 53851 R M12; UCMP 130129, UF/FGS V-6605 2 L P34; UF 53545, 53852, 929303 L M12; UCMP 130128 L M3; UF 61502 R p34; UF 69915, UCMP 1301302 L m12; UF 61503, $699142 \mathrm{R} \mathrm{m} 12$.

Revised diagnosis. Medium-sized hipparionine with toothrow lengths of about 115 to $135 \mathrm{~mm}$; DPOF absent; unworn M12 MSCH about 73 mm. Fossette plications moderate to very complex; pli caballin strong on premolars; constricted mesostyle; well developed metastyle; very elongate protocone. Pli caballinid persistently well developed on molars and premolars, often multiple or branched; ectoflexid shallow.

Description of Florida specimens. Detailed dental descriptions of referred populations of Neo. eurystyle can be found in Stirton (1955) and Dalquest (1981). This description of Florida specimens is divided into two sections. The first describes the late Upper Bone Valley sample of Neo. eurystyle (topotypic sample of Neo. phosphorum), which is very similar to referred western poputations of the species both morphologically and chronologically. The second describes the sample from Moss Acres, the oldest known sample of Neo. eurystyle.

The upper cheekteeth of the Bone Valley population of $\mathrm{NeO}$. eurystyle are characterized by well developed parastyles and metastyles (that often curve posteriorly and anteriorly, respectivley); large, expanded, lingually constricted mesostyles; long, of ten 
sinuous protocones with straight or concave borders (Figs. 8A, 8B); and moderately complex fossettes (but less complex than in Cor. emsliei n. sp.). The protocone is usually isolated except on the P2 and DP2, which can have narrowly connected protocones. One otherwise typical P34 (UF 91203), however, has a connected protocone at a MSCH of $35.7 \mathrm{~mm}$. The pli protoloph is usually a single deep fold (rarely absent), occassionally with one or more rarely two much smaller accessory plications. The long prefossette loop often extends lingually past the base of the prefossette and is secondarily plicated. The remainder of the posterior half of the prefossette generally bears two to five (eight is maximum) small plications, usually including one fairly deep fold. A deep pli hypostyle in found in over $85 \%$ of all upper teeth. The hypocone is notably smaller than protocone, with its main axis oriented in a posterolingual direction. The hypoconal groove is open to near the base of the crown and " $\mathrm{V}$ "-shaped. The pli caballin is strong, usualiy multiple on premolars, much smaller, occassionally absent on molars. Unlike most other hipparionines, the P34 are often not much larger in occlusal dimensions than the M12, and curve posteriorly in the anterior-posterior plane similar to molars. The P34 are distinguished from the M12 by their larger and more complex pli caballin, more widely opened mesostyle, and the larger, often grooved or bifurcated parastyle. Unworn M12 MSCH exceeds $70 \mathrm{~mm}$.

Lower cheekteeth (Fig. 8C) are characterized by well developed, often branched or multiple pli caballinids that extend labially 

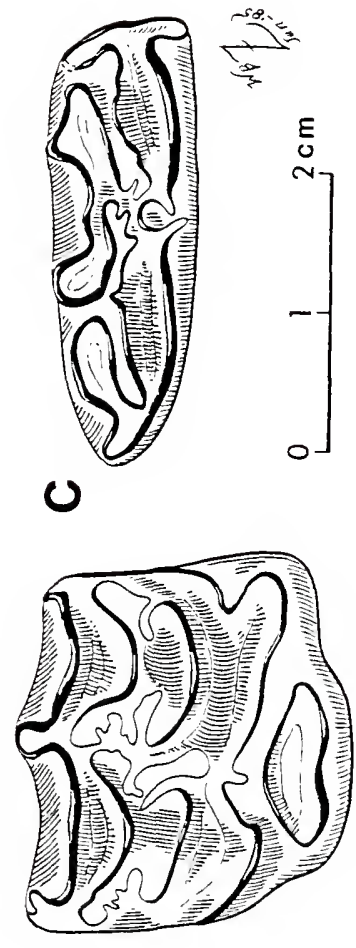

ต

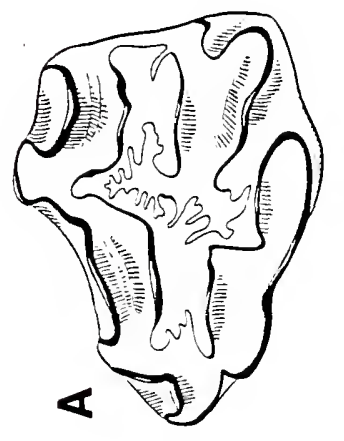

莴

造这

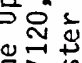

옫는

틍

更

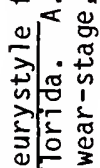

다.

ปั

웡을

일 눈

tᄂ.

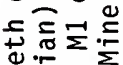

$\Phi=-1$

중

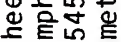

表䓃

过的。

용

व

>

此茫

응인

4ᄂ

웅

导出号

>

ㅇํ

ฏ。유

는

ठํ.

. 约呇

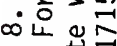

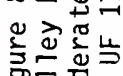

काँ 
Table 6. Standard univariate statistics for upper cheekteeth of Neohipparion eurystyle. Format as in Table 2. Populations are UBV, Palmetto Fauna, Bone Valley Region, Florida; YEP, Yepomera localities, Chihuahua, Mexico; and CR, Coffee Ranch 1.f., Hemphill County, Texas.

FAUNA

UBV

YEP

CR

P2

\begin{tabular}{|c|c|c|c|}
\hline APL & $\begin{array}{l}27.0,1.35,4 \\
25.5-28.7,4.99\end{array}$ & $\begin{array}{l}24.1,1.37,21 \\
21.7-26.5,5.69\end{array}$ & $\begin{array}{l}26.0,0.71,3 \\
25.4-26.8,2.73\end{array}$ \\
\hline BAPL & $\begin{array}{l}21.5,1.46,3 \\
20.0-22.9,6.77\end{array}$ & $\begin{array}{l}20.1,1.38,15 \\
18.1-22.3,6.83\end{array}$ & $\begin{array}{l}21.5,1.20,2 \\
20.3-22.7,5.58\end{array}$ \\
\hline TRW & $\begin{array}{l}19.4,0.66,4 \\
18.6-20.0,3.73\end{array}$ & $\begin{array}{l}18.6,0.94,22 \\
17.4-21.0,5.02\end{array}$ & $\begin{array}{l}19.8,1.47,3 \\
18.1-20.9,7.46\end{array}$ \\
\hline PRL & $\begin{array}{l}7.8,0.56,4 \\
7.2-8.5,7.18\end{array}$ & $\begin{array}{l}7.8,0.60,22 \\
6.9-8.9,7.66\end{array}$ & $\begin{array}{l}8.5,0.49,3 \\
8.2-9.1,5.78\end{array}$ \\
\hline \multirow[t]{2}{*}{ PRW } & $\begin{array}{l}3.7,0.25,4 \\
2.4-3.9,6.62\end{array}$ & $\begin{array}{l}3.8,0.26,22 \\
3.1-4.3,6.82\end{array}$ & $\begin{array}{l}3.7,0.10,3 \\
3.6-3.8,2.70\end{array}$ \\
\hline & & P34 & \\
\hline APL & $\begin{array}{l}21.6,1.06,10 \\
20.1-22.8,4.92\end{array}$ & $\begin{array}{l}20.6,1.10,51 \\
18.5-22.7,5.32\end{array}$ & $\begin{array}{l}20.4,1.49,10 \\
18.0-22.8,7.30\end{array}$ \\
\hline BAPL & $\begin{array}{l}16.8,0.82,9 \\
15.7-18.1,4.89\end{array}$ & $\begin{array}{l}16.4,0.94,40 \\
14.7-18.0,5.71\end{array}$ & $\begin{array}{l}14.7,0.56,9 \\
13.8-15.6,3.80\end{array}$ \\
\hline TRW & $\begin{array}{l}20.4,0.69,10 \\
19.4-21.4,3.40\end{array}$ & $\begin{array}{l}20.0,1.02,51 \\
18.0-22.6,5.10\end{array}$ & $\begin{array}{l}20.1,0.65,9 \\
18.8-21.0,3.26\end{array}$ \\
\hline PRL & $\begin{array}{l}9.9,0.71,9 \\
8.7-11.0,7.16\end{array}$ & $\begin{array}{l}10.2,0.84,51 \\
8.7-12.1,8.28\end{array}$ & $\begin{array}{l}10.3,0.99,10 \\
8.8-12.0,9.63\end{array}$ \\
\hline$R W$ & $\begin{array}{l}4.1,0.22,10 \\
3.8-4.5,5.36\end{array}$ & $\begin{array}{l}4.1,0.32,51 \\
3.5-5.1,7.82\end{array}$ & $\begin{array}{l}3.8,0.25,10 \\
3.4-4.1,6.54\end{array}$ \\
\hline
\end{tabular}


Table 6--continued

M12

$\begin{array}{llll}\text { APL } & 20.5,0.75,15 & 19.6,1.08,47 & 20.1,1.65,21 \\ & 19.0-21.5,3.65 & 17.8-23.1,5.52 & 17.0-22.7,8.20 \\ \text { BAPL } & 17.1,1.06,11 & 16.2,0.78,33 & 15.2,0.77,19 \\ & 15.3-19.4,6.23 & 14.6-18.4,4.84 & 14.3-17.1,5.05 \\ \text { TRW } & 18.9,0.61,13 & 18.4,0.75,48 & 18.6,1.24,21 \\ & 18.0-19.9,3.24 & 16.7-19.8,4.08 & 16.9-21.1,6.66 \\ \text { PRL } & 9.8,0.73,15 & 9.8,0.88,48 & 8.8,0.54,21 \\ & 9.0-11.5,7.44 & 8.3-11.9,8.90 & 8.0-10.0,6.19 \\ \text { PRW } & 3.9,0.29,14 & 3.8,0.34,48 & 3.5,0.34,20 \\ & 3.5-4.5,7.36 & 3.1-4.7,8.82 & 3.1-4.5,9.73\end{array}$


Table 7. Standard univariate statistics for lower cheekteeth of Neohipparion eurystyle. Format as in Table 2, sample populations as in Table 6 .

\begin{tabular}{|c|c|c|c|}
\hline FAUNA & UBV & $\begin{array}{l}\text { YEP } \\
\text { p2 }\end{array}$ & $C R$ \\
\hline apl & $\begin{array}{l}23 \cdot 3,0.50,2 \\
22.9-23 \cdot 6,2.13\end{array}$ & $\begin{array}{l}21.7,1.11,24 \\
20.0-24.0,5.13\end{array}$ & $\begin{array}{l}21.5,1.09,7 \\
19.4-22.8,5.08\end{array}$ \\
\hline bapt & $18.5,--, 1$ & $\begin{array}{l}17.5,0.75,10 \\
16.3-18.6,4.26\end{array}$ & $\begin{array}{l}17.0,0.21,3 \\
16.8-17.3,1.21\end{array}$ \\
\hline atw & $\begin{array}{l}9.0,0.07,2 \\
8.9-9.0,0.79\end{array}$ & $\begin{array}{l}9.5,0.49,25 \\
8.7-10.4,5.18\end{array}$ & $\begin{array}{l}8.9,0.27,7 \\
8.4-9.2,2.98\end{array}$ \\
\hline ptw & $\begin{array}{l}11.2,0.21,2 \\
11.0-11.3,1.90\end{array}$ & $\begin{array}{l}11.3,0.68,24 \\
10.1-12.6,6.04\end{array}$ & $\begin{array}{l}11.4,0.55,6 \\
10.7-12.4,1.86\end{array}$ \\
\hline $\mathrm{mml}$ & $\begin{array}{l}13.6,0.21,2 \\
13.4-13.7,1.57\end{array}$ & $\begin{array}{l}12 \cdot 0,0.94,25 \\
10.5-14.0,7.86\end{array}$ & $\begin{array}{l}11.9,1.02,7 \\
10.6-13.3,8.56\end{array}$ \\
\hline \multirow[t]{2}{*}{ entr } & $\begin{array}{l}13.3,0.85,2 \\
12.7-13.9,6.38\end{array}$ & $\begin{array}{l}11.5,1.02,25 \\
10.3-13.8,8.88\end{array}$ & $\begin{array}{l}11.4,0.90,7 \\
10.1-13.1,7.86\end{array}$ \\
\hline & & p34 & \\
\hline apt & $\begin{array}{l}20.0,1.01,7 \\
18.6-21.7,5.07\end{array}$ & $\begin{array}{l}21.4,1.35,51 \\
18.1-25.4,6.32\end{array}$ & $\begin{array}{l}21.5,2.02,16 \\
18.8-25.1,9.37\end{array}$ \\
\hline bap1 & $\begin{array}{l}16.6,0.89,5 \\
15.6-17.9,5.34\end{array}$ & $\begin{array}{l}17.2,0.66,17 \\
16.0-18.4,3.83\end{array}$ & $\begin{array}{l}16.3,0.75,9 \\
14.7-17.0,4.63\end{array}$ \\
\hline atw & $\begin{array}{l}10.7,0.50,7 \\
9.8-11.2,4.68\end{array}$ & $\begin{array}{c}10.9,0.70,50 \\
8.2-12.4,6.40\end{array}$ & $\begin{array}{c}10.5,0.48,13 \\
9.4-11.2,4.56\end{array}$ \\
\hline ptw & $\begin{array}{l}10.5,0.59,5 \\
9.6-11.1,5.59\end{array}$ & $\begin{array}{l}11.2,0.85,50 \\
8.4-12.8,7.56\end{array}$ & $\begin{array}{c}10.8,0.66,15 \\
9.3-11.9,6.11\end{array}$ \\
\hline $\mathrm{mm}]$ & $\begin{array}{l}13.4,1.11,7 \\
11.3-14.5,8.32\end{array}$ & $\begin{array}{l}14.2,0.74,51 \\
11.9-15.9,5.23\end{array}$ & $\begin{array}{l}13.5,0.75,15 \\
12.5-15.7,5.57\end{array}$ \\
\hline ent & $\begin{array}{l}10.3,0.59,7 \\
9.4-11.5,7.63\end{array}$ & $\begin{array}{c}10.8,0.79,51 \\
9.5-13 \cdot 1,7.27\end{array}$ & $\begin{array}{c}10.5,1.01,15 \\
8.8-12.0,9.63\end{array}$ \\
\hline
\end{tabular}


Table 7--continued

\begin{tabular}{llll} 
& \multicolumn{3}{c}{$\mathrm{m} 12$} \\
ap1 & $21.7,1.97,8$ & $20.9,1.74,65$ & $21.0,1.59,21$ \\
& $19.4-25.7,9.09$ & $18.3-25.5,8.29$ & $18.3-24.7,7.57$ \\
bap1 & $17.8,0.88,4$ & $16.7,0.81,23$ & $16.3,0.70,12$ \\
& $17.0-19.0,4.67$ & $14.2-17.8,4.85$ & $15.0-17.5,4.29$ \\
atw & $9.6,0.99,8$ & $9.6,0.75,65$ & $9.5,0.74,20$ \\
& $8.0-11.2,10.33$ & $7.6-11.1,7.86$ & $8.0-10.9,7.81$ \\
ptw & $8.8,0.97,6$ & $9.2,0.86,64$ & $9.3,0.70,22$ \\
& $7.3-9.7,11.08$ & $6.9-11.1,9.30$ & $7.9-10.5,7.50$ \\
mm1 & $12.7,0.97,9$ & $12.9,0.61,65$ & $13.6,0.87,22$ \\
& $10.5-13.9,7.66$ & $11.9-15.9,4.69$ & $11.4-15.0,6.44$ \\
ent & $10.6,1.00,9$ & $10.9,0.98,65$ & $10.2,1.08,22$ \\
& $9.6-12.7,9.45$ & $9.3-13.0,9.02$ & $7.7-12.5,10.54$
\end{tabular}


beyond the bases of the protoconids and hypoconids for almost the entire crown; shallow ectoflexids not penetrating isthmuses (molars as well as premolars); plicated isthmuses and paralophids; well developed, posteriorly recurved protostylids, always connected to protoconid; and large, widely flairing metaconids and metastylids. Lower premolars broader than molars, with well developed, persistent hypoconulids that curve anteriorly. Deciduous premolars show even more markedly elongated features and well developed pli caballinids than permanent teeth. Unworn mech exceeds $65 \mathrm{~mm}$ for p34 and $75 \mathrm{~mm}$ for $\mathrm{m} 12$.

\section{Description of early Hemphillian samples. Four pre-late} Hemphillian samples of Neo. eurystyle are known from Florida, Moss Acres, With 4A, With 4X, and Mutual Mine. The latter three are a 11 from southwestern Marion County, and are collectively much more similar to late Hemphiliian populations. The limited Moss Acres sample consists of the remains of three individuals. The initially discovered mandibles were first thought to represent extremely progressive individuals of Neo. trampasense. Recovery of upper teeth suggest instead that they represent the oldest known sample of Neo. eurystyle, and merely retain many primitive features. UF 95410 represents a young adult individual with a moderately wor M3. The most striking features of UF 95410 are its relatively short protocones. On the M2, PRL is on ly $7.7 \mathrm{~mm}$. This is $1.3 \mathrm{~mm}$ less than the shortest protocone observed from the Bone Valley Neo. eurystyle sample, and almost three standard deviations below the mean (Table 6). The mean PRL of the Love Site Neo. trampasense sample is a 
simitar $7.8 \mathrm{~mm}$. The Tingual border of the M2 protocone of UF 95410 is concave, and the ends of the protocone are rounded, not pointed. On the $M 3$, the more elongated protocone ( $P R L=8.7 \mathrm{~mm}$ ) has a flattened to slightiy concave lingual border, and pointed ends. There is a well formed, but small pli caballin on both the M2 and M3; it is double on the M2. The fossettes are well plicated, and the prefossette loop of the M3 extends further lingualiy than the prefossette base. The long axis of the hypocone is directed obliquely, posterolingually; thus the hypoconal groove is distinctly "V"-shaped. The styles are well developed. On the M2, the parastyle is curved posteriorly, and the metastyle is small but distictly curved anteriorly. The mesostyle is constricted at its base.

The two individuals represented by lower cheekteeth are of substantially different ages, thus providing more information. UF 65250 includes a well worn dp3 and dp4, and a slightly worn ml. UF 69969 is in the later half of the moderate wear-stage (ml mcch about $35 \mathrm{~mm})$. They both display many of the elongated features characteristic of advanced Neohipparion. The protostylid is strong and slightly curved posteriorly. The pli caballinids are all single on UF 69969, but are much stronger on the molars than in any comparably worn inidividual of Neo. trampasense. The linguaflexids of the m12 are also broader and more "U"-shaped, at a crown height when molars of Neo. trampasense have "V"-shaped linguaflexids. The hypoconulids are strong and curved anteriorly; those of the premolars remain separated from the entoconid by a deep, "U"-shaped valley. The $1 \mathrm{trl}$ of UF 69969 is $128.4 \mathrm{~mm}$; within the OR of Neo. trampasense 
and Neo. eurystyle, but smaller than those of Neo. leptode, Neo. gidleyi, or Neo. affine. UF 69969 has the incisors associated with the cheekteeth. They have broad, cement-filled infundibula. That of the $i 3$ is completely enclosed, not open posteriorly as that of many equids, including UCMP 27126, a specimen of Neo. leptode (Merriam and Stock, 1928, Fig. 5). The incisors are not grooved (nor are they in UCMP 27126; Forsten, 1984, has listed grooved incisors as a generic character for Neohipparion, but I have never observed this in any North American specimen of the genus).

Discussion. After Simpson's (1930) original description of Neo. phosphorum, little mention was made in the literature concerning samples from Florida of Neo. eurystyle until MacFadden (1984a). He discussed the probable age of Simpson's type (very late Hemphillian), and synonymized the two species. Simpson (1930) did not compare his new species with that from the Texas Panhandle, but his sample did not contain any lower teeth, and uppers of Neo. eurystyle were not described until Matthew and Stirton's (1930) paper. The Bone Valley Neohipparion compares favorably in size and morphology with the large samples from Yepomera and Coffee Ranch (MacFadden, 1984a; Tables 6, 7). Stirton (1955) thought the proportions of Simpson's type indicated a larger size for the Florida population. Although the means for APL and TRW of the Bone Valley sample are larger than those of the Coffee Ranch and Yepomera populations, the differences are not great (usually nonsignificant), and the observed ranges overlap considerably (Tables 6,7$)$. As no quantitative or qualitative differences can be found to consistently separate the Yepomera, 
Coffee Ranch and Bone Valley Neohipparion samples, MacFadden's (1984a) synonymies are followed.

A7t previously described populations of Neo. eurystyle have been of late Hemphillian age, except for MacFadden's (1984a) referral (without discussion) of the Neohipparion from UNSM locality Ft-40, a late early Hemphillian site from Nebraska. Neohipparion from Ft-40 and the similarly aged 0shkosh fauna are significantly larger than Neo. eurystyle, and also lack its very derived styles. In all dental features these equids closely resemble Neo. leptode from the early Hemphillian of Nevada, and are referred to that species. MacFadden (1984a) also synonymized Neo. molle with Neo. eurystyle. Neo. molle was described from a single waterworn M3 (Merriam, 1915a), a specimen that cannot be confidently distinguished from Neo. trampasense, Neo. eurystyle, or Nan. lenticularis. It is best considered a nomen dubium.

Untike the Ft-40 specimens, the Moss Acres sample is not larger than late Hemphillian individuals, and shares with Neo. eurystyle and Neo. gidleyi derived characters like constricted mesostyles and anteriorly curved metastyles. It shares with these two species and Neo. Teptode the obliquely oriented hypocone in molars, a "V"-shaped hypoconal groove in molars, more persistently shallow molar ectoflexids, and broader molar linguaflexids. The early appearance of Neo. eurystyle in Florida suggests a southeastern origin for the species. 
Genus Pseudhipparion Ameghino, 1904

Pseudhipparion AMEGHINO, 1904, p. 262.

Griphippus QUINN, 1955, p. 42.

Type species. Pseudhipparion retrusum (Cope), 1889.

Included species. Pseud. curtivallum (Quinn), 1955; Pseud. gratum (Leidy), 1869 ; Pseud. hessei Webb and Hulbert, 1986; Pseud. skinneri Webb and Hulbert, 1986; Pseud. simpsoni Webb and Hulbert, 1986.

Diagnosis. Small hipparionine with shallow, unpocketed, generally poorly defined DPOF located far anterior to the orbit. Malar region variably with shallow depression, true fossa absent. Muzzle region short, but more elongated than in Calippus, with deep nasa 1 notch retracted to point dorsal to P2. Protocone relatively large, elongate-oval, connects to protoselene during early or moderate wearstages; connects to hypocone in molars of some species. Fossettes relatively simple for a hipparionine, $\mathrm{pli}$ protoloph and pli hypostyle rarely present. Hypoconal groove closes to form fossette; completely lost usually before late wear-stage. Ectoflexid of premolars shallow; entoconid of molars small, unexpanded, producing relatively broad lingual opening of entoflexid. Protostylid moderately developed on $\mathrm{p} 3-\mathrm{m} 3$, not isolated from protoconid; ectostylid present on dp2-dp4 in all but one species. [STightly modified after Webb and Hutbert, 1986.]

Chronologic and geographic distribution. Late Barstovian through late Hemphillian of the Great Plains and Gulf Coastal Plain. Very 
abundant in the latest Barstovian and Clarendonian of the Great Plains.

Discussion. Ameghino (1904) described Pseudhipparion in a general work of comparative odontology of mammalian herbivores. It was overlooked until the late 1960s (Skinner et a1., 1968; Webb, 1969a), and by then an alternate name (Griphippus) had been proposed by Quinn (1955). Webb (1969a) and Webb and Hulbert (1986) formally synonymized the two names. Gulf Coastal Plain populations of Pseudhipparion were described in detail in the latter study, using identical measurements and similar terminology to those employed here. They recognized four successive species of the genus in the Gulf Coastal Plain: Pseud. sp.; Pseud. Curtivallum; Pseud. skinneri; and Pseud. simpsoni. Their work will not be duplicated in this section; rather their diagnoses are repeated for the sake of comparison with species of other genera, followed by brief descriptions. Only specimens collected since completion of their study (January, 1986), or subsequently recognized as belonging to Pseudhipparion are listed here. A detailed and updated phylogenetic analysis of all species of Pseudhipparion is presented in Chapter 6 .

Pseudhipparion sp.

Distribution. Known only from the Bradley Fauna, lower Bone Valley Formation, Florida; late Barstovian, about $14 \mathrm{ma}$.

Description. This sample represents a very smal1, low crowned species of Pseudhipparion, that does not correspond to any named 
species. Webb and Hulbert (1986) refrained from naming it due to the paucity of material. No further specimens have been added to the sample since.

\section{Pseudhipparion curtivallum (Quinn), 1955}

Distribution. Known only from the Gulf Coastal Plain, from the Lapara Creek Fauna of southern Texas, and the upper Agricola Fauna of southern peninsular Florida.

Diagnosis. Moderate-sized species of Pseudhipparion, with toothrow lengths of about $95 \mathrm{~mm}$. Estimated unworn M12 MSCH $42 \mathrm{~mm}$. Protocone remains isolated until about $50 \%$ of the crown removed; hypoconal groove closes to form a fossette during early wear-stages, lost only with heavy wear. Connection of protocone and hypocone much rarer than in Pseud. retrusum, usually occurs after connection with protoselene. Ectoflexids relatively shallow; protostylids relatively strong.

Discussion. Webb and Hulbert (1986) referred a moderately large sample of teeth and jaws from the Lapara Creek Fauna to Astrohippus curtivallus Quinn (1955) under the new combination Pseud. curtivallum. A smaller number of isolated teeth from Florida also seem to represent the same species. No cranial or facial material of Pseud. curtivallum is known. The species is possibly ancestral to younger species of Pseudhipparion. 
Pseudhipparion skinneri Webb and Hulbert, 1986

Additional referred specimens. With 4A Site: UF $95374 \mathrm{R} \mathrm{m} 2$. Manatee Dam Site: UF 95365 R P34; UF 95772 R m12. Archer Fauna, Bone Valley Region, Nichols Mine: UF 95776 R M1.

Distribution. Late Clarendonian of the Great Plains. Late Clarendonian through early Hemphillian of peninsular Florida.

Diagnosis. Small species of Pseudhipparion with average toothrow lengths of $86 \mathrm{~mm}$. Estimated unworn M1 MSCH $47 \mathrm{~mm}$. Simple fossettes; protocone connects to protoselene during moderate wear-stage, on average earlier than in Pseud. gratum or Pseud. Curtivallum; protocone never connects to hypocone; hypoconal groove closed in early or moderate wear-stages, soon lost altogether. Protostylid reduced.

Discussion. This species was typified by Webb and Hulbert (1986) with the Pseudhipparion from the Xmas-Kat Fauna of Nebraska. They referred specimens from a number of late Clarendonian and very early Hemphillian faunas from Florida to the new species. They tentatively referred a few late early Hemphillian specimens to the species as we11. Three of the specimens listed above were not previously recognized as belonging to Pseud. skinneri. The upper premolar from the Manatee Dam Site is waterworn and broken, but shows the following diagnostic features: small size; simple fossettes; obliquely orientated, elongate-oval protocone; and isolated hypoconal fossette. These prevent it from belonging to either of the two other small equids in the fauna, Nan. minor or Cal. elachistus. The two lower 
molars both are small (apl of UF 95374 is approximately $13.6 \mathrm{~mm}$; atw $=6.7 \mathrm{~mm} ; \mathrm{mml}=9.1 \mathrm{~mm}$; all of these parameters are within the OR of Pseud. skinneri from the Love Site); have rounded, well separated, hipparionine metaconids and metastylids; and very smal1, retracted entoconids. In both Nan. westoni and Nan. minor, the entoconids are large (see Figs. 13, 16, 18). In morphology and size, the se two lower molars are identical to the older referred samples of Pseud. skinneri. UF 95374 from With $4 \mathrm{~A}$ represents the third late early Hemphillian locality that has produced this species. With the increased sample of specimens of this age, it seems that a more definite referal to Pseud. skinneri is allowable than was conservatively put forth by Webb and Hulbert (1986) for these populations. They also re-enforce their suggestion that the highly advanced species Pseud. simpsoni evolved in a very short interval of time, between about 6.5 and $5.0 \mathrm{ma}$.

The fourth specimen listed above, UF 95776, represents one of the limited number of identifiable specimens from the Archer Fauna in the Bone Valley Region. It is referred to Pseud. skinneri based on its small size (TRW=12.6 mm), very simple fossettes, and isolated hypostylar lake.

Pseudhipparion simpsoni Webb and Hulbert, 1986

Additional referred specimens. Palmetto Fauna, Bone Valley Region, Gardinier Mine: UF $95775 \mathrm{R} \mathrm{m} 12$. Bone Valley Region, 
specific locality unknown: UF $93217 \mathrm{~L}$ p34; $93631 \mathrm{~L} \mathrm{m12;} 17572$ (?) L I1; 95773 R I3; 95774 (?) L I2.

Distribution. The late Hemphillian of Florida and Kansas.

Diagnosis. Smallest and most hypsodont species of Pseudhipparion, with incipiently hypselodont cheekteeth. Estimated total potential M12 MSCH about $110 \mathrm{~mm}$. Very simple enamel patterns; fossettes lost in later wear-stages; large, elongated protocone connects to protoselene in middle wear-stages; protocone does not connect to hypocone; hypoconal groove closes on premolars, persistently open on molars. Metaconid and metastylid very elongated and curved lingually; protostylid reduced and present on iy in early wear-stages; deciduous premolars very hypsodont and lack ectostylids.

Description. This bizarre little species was based on the large sample of isolated cheekteeth, a few associated dentitions, two incisors, and several metapodials from the Upper Bone Valley (Palmetto) Fauna. The three lowers listed above add little to the knowledge of the morphology of the species, but the Gardinier Mine record is an additional specimen recovered in situ in the Upper Bone Valley Formation. The incisors are more important, as they more than double the known sample. Webb and Hulbert (1986) previously referred to UF 57315 as an I3, but it now seems more likely to be an I2. The occlusal shape of UF 95773 is much more like that of normal equid I3s, with a flat medial side for occlusion with the I2, and a pointed posterolateral side. The infundibutum is very small in UF 95773; most of its former area is occupied by concentric rings of replacement dentine. UF 17572, 95773, and 95774 a11 have narrow 
dentine tracts running down the entire length of their lateral and medial sides (as does UF 57315), not just on the medial side as was reported by Webb and Hulbert (1986). The tracts widen towards the base of the crown; this is very evident in UF 95774 which has the enamel and dentine preserved in highly contrasting colors. UF 95774 is $29.6 \mathrm{~mm}$ tall (the open, growing base in well preserved), with occlusal dimensions of $7.5 \times 5.2 \mathrm{~mm}$ (width $\times$ depth). The hypothesis of Webb and Hulbert (1986) that the incisors were ever-growing in Pseud. simpsoni is not disproven by these new specimens.

Genus Nannippus Matthew, 1926

Nannippus MATTHEW, 1926 , p. 165.

Type species. Nannippus phlegon (Hay), 1899 (now considered the junior synonym of Nan. peninsulatus (Cope), 1885, see MacFadden, 1984a).

Included species. Nan. fricki n. sp.; Nan. westoni (Simpson), 1930, n. comb.; Nan. lenticularis (Cope), 1893; Nan. minor (Sellards), 1916; Nan. beckensis Dalquest and Donovan, 1973. Revised diagnosis. Very small to medium-sized, hypsodont, hipparionine, with toothrow lengths ranging from about 85 to $117 \mathrm{~mm}$. Relatively elongated rostrum, with markedly procumbent incisors in younger species. DPOF varies from being deep, continuously rimmed, and pocketed in primitive species to completely absent in younger species. DP1 conical, very reduced, lacks lophs, single rooted; possibly absent in younger species. Protocones isolated from 
protoselene for first 80 to $90 \%$ of the crown, except for P2s which usually have rapidly connected protocones. Hypoconal groove open to near base of crown, does not form isolated lake. Relative to other hipparionines, moderately developed pli caballin and plications on the isthmus and fossettes (less than in Cormohipparion and advanced Neohipparion; more than Pseudhipparion and Hipparion); pli caballinids poorly developed or absent except in older species. Anterostyle of P2 and DP2, and p2 paraconid poor 1y developed, thus these teeth are not especially longer than other premolars. Metapodials relatively slender and elongated.

Discussion. Matthew (1926) originally described Nannippus as a subgenus of Hipparion on the basis of its small size and a combination of dental and post-cranial characters. The former were very hypsodont teeth with isolated, oval protocones, the latter were its "...slender limbs and feet, in which the side toes are complete but no trace remains of the fifth digit and trapezium." Central to Matthew's concept of the genus were the Mt. Blanco specimens he and G. G. Simpson had recently collected in 1924 (see account in Simpson, 1986). These included the first known crania and articulated feeth of Nannippus phlegon, a species previously so poorly known that its generic affiliation was enigmatic (Gidley, 1907; 0sborn, 1918). The new material established the species' hipparionine affinities for the first time, but was not illustrated or described unti1 1968 (Sondaar, 1968 ; the manus) and 1980 (MacFadden and Waldrop, 1980; cranium and teeth). Matthew (1926) did not specifically list any other species besides the subgenotype Nan. phlegon as belonging in Nannippus, but it can be inferred that he generally equated it with a group of 
species he had previously informally called the Hipparion gratum group (e.g. Matthew, 1924).

In Matthew and Stirton (1930), Nannippus was still regarded as a subgenus of Hipparion (along with Neohipparion and Hipparion s.s.), but all three were considered independent lineages of "equal value" and "...all are derivable from different species of Merychippus..." (p. 356). Matthew and Stirton (1930) specifically included an additional five species in Nannippus, and repeated Matthew's (1926) original generic characters. They also described the DPOF as "deep but contracted" (p. 354), apparently basing this on the supposed "neotype" skull of "Nan." Ienticularis (AMNH 10584) from the Clarendon. This specimen (and many others from the Clarendon Fauna) are now referred to Hipparion tehonense (MacFadden, 1980; 1984a). For unknown reasons, no mention was made of the Mt. Blanco skull of Nan. phlegon, which lacks a DPOF (AMNH 104708; MacFadden, 1984a, Fig. $89 \mathrm{~A})$. Matthew and Stirton (1930, pp. 363-364) regarded the Clarendon "Nannippus" (i.e. $\underline{H}$. tehonense) as ancestral to $\underline{H}$. (Nan.) lenticularis of the Hemphillian. It in turn was thought to give rise to $\underline{H}$. (Nan.) phiegon. Stirton $(1940 ; 1947)$ and Webb (1969) continued to follow this phylogenetic scenerio, with other species of Nannippus representing sidebranches. Webb (1969), however, excluded "Nan." retrusus and "Nan." gratus from Nannippus, and resurrected the genus Pseudhipparion Ameghino for them. This genus is now recognized as being more closely related to Neohipparion than Nannippus (Webb and Hulbert, 1986 and Chapter 6). MacFadden (1980; 1984a) concluded that "Nan." tehonensis and "Nan." forcei should also be removed from Nannippus, and placed them in the 01d World genus Hipparion based on 
the configuration of the DPOF. These exclusions produced a "Clarendonian gap" in what had once been viewed as an unparalleled example of successional evolution (Stirton, 1947, Figs. 1 and 2). MacFadden (1984a) recognized this problem and noted (p. 126) "...with lack of adequate crania the origin of Nan. minor and hence the genus remains enigmatic. It is not clear whether Nan. minor is most related to some other hipparion or to a species within the merychippine complex..." The recognition of a new species of Nannippus from the Clarendonian of Nebraska, and a newly discovered partial skull of Nan. minor permit a reevaluation of the relationships of Nannippus with other hipparionine genera.

\section{Nannippus fricki new species}

Probably Hipparion gratum Leidy, MATTHEW, 1924, p. 175 (in part).

Type specimen. F:AM 117046, partial palate of juvenile individual with right DP2-M1 and Teft DP1-M1. The unworn crowns of the paracone and metacone of the M1s just erupted through the maxiliary bone. Col Tected in 1962 by Ted GaTusha and party.

Type locality. Gallup Gulch Quarry, Cherry County, Nebraska. W1/2, SW1/4, SE1/4, SW1/4 sec. 24, T33N, R38W, Merriam Quadrangie.

Stratigraphic occurence and age of type locality. Lower part of the Merritt Dam Member, Ash Hollow Formation, Ogallala Group (Skinner and Johnson, 1984). About $10 \mathrm{ma}$, middle Clarendonian, Tate Miocene. 
Topotypic sample. F:AM $117048 \mathrm{R}$ maxi1la with we11 worn P2-M2; 117049-117050 P2s; 117052-117054 P3 and P4s; 117051, 117055-117063 M1 and M2s; $117064 \mathrm{M} 3$.

Etymology. Patrynomic for Childs Frick, whose efforts led to the collection of the type material of this and many other species.

Distribution. Middle to late Clarendonian (about 10 to $11 \mathrm{ma}$ ) of Nebraska. Possibly early to middle Clarendonian of Texas and Florida Gulf Coastal Plain (see below).

Referred specimens. East Clayton Quarry, Brown County, NB: F:AM 117045 assoc. L P2-M3 (sectioned); 117066 M1 or M2.

01cott Quarry, Sioux County, NB: F:AM 117067-117068 M1 and M2s. Kilpatrick Quarry, Sioux County, NB: AMNH 117072 P3 or P4; AMNH 117068-117071 M1 and M2s.

Diagnosis. Relatively large species of Nannippus with estimated TRL and trl of about $110 \mathrm{~mm}$. Mean M12 TRW $17.1 \mathrm{~mm}$, BAPL $14.2 \mathrm{~mm}$. Estimated unworn molar crown height about $45 \mathrm{~mm}$. Elongate-oval protocones with pointed or rounded ends, generally isolated on a11 cheekteeth except P2; moderate fossette complexity; p1i hypostyle rarely absent except in heavily worn teeth; P2 anterostyle less reduced than in other species of Nannippus; pli caballin strong, frequently double; deep hypoconal groove. Deep, pocketed DPOF with well defined anterior margin as in Cormohipparion. Anterior-most point of DPOF lies dorsal to parastyle of P3 and DP3, and directly overlies infraorbital foramen.

Description. The holotype consists of the juvenile palate of a very young individual (Fig. 9). The posterior part of the DP4 was not yet in wear, and the M1 had on Ty just begun to erupt. Based on 


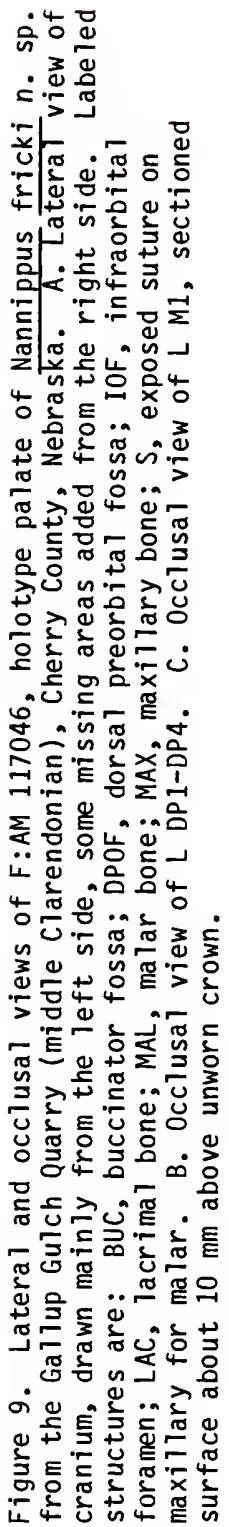



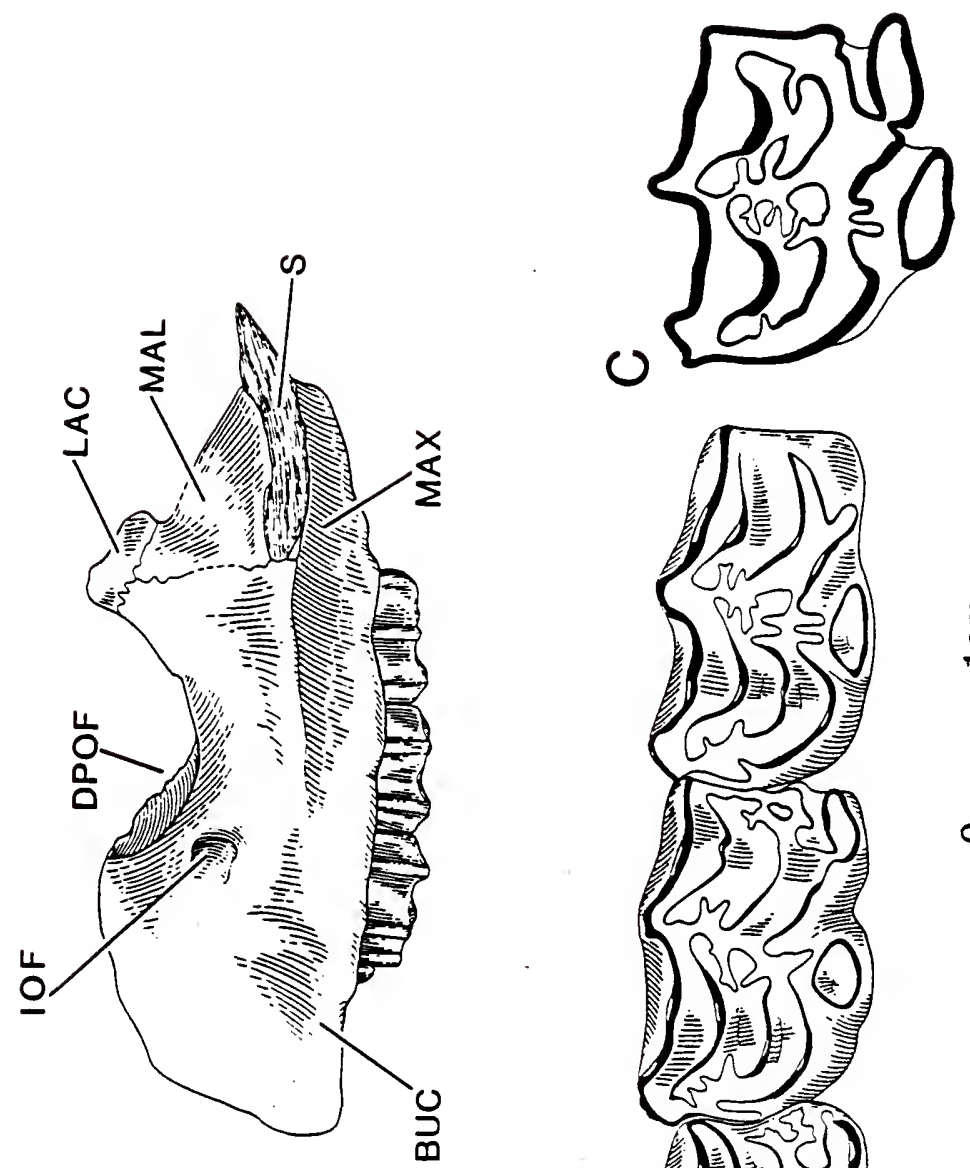

$\alpha$
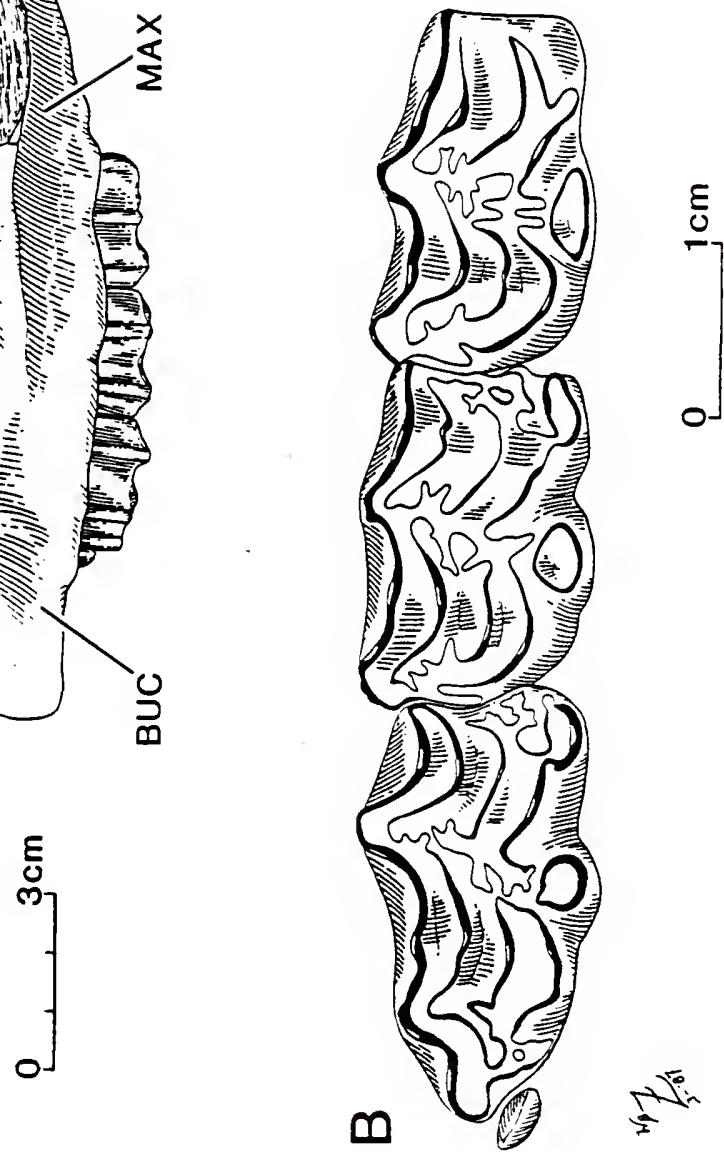


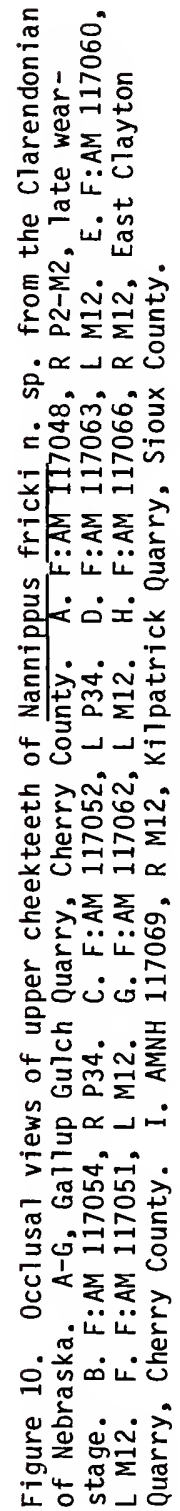




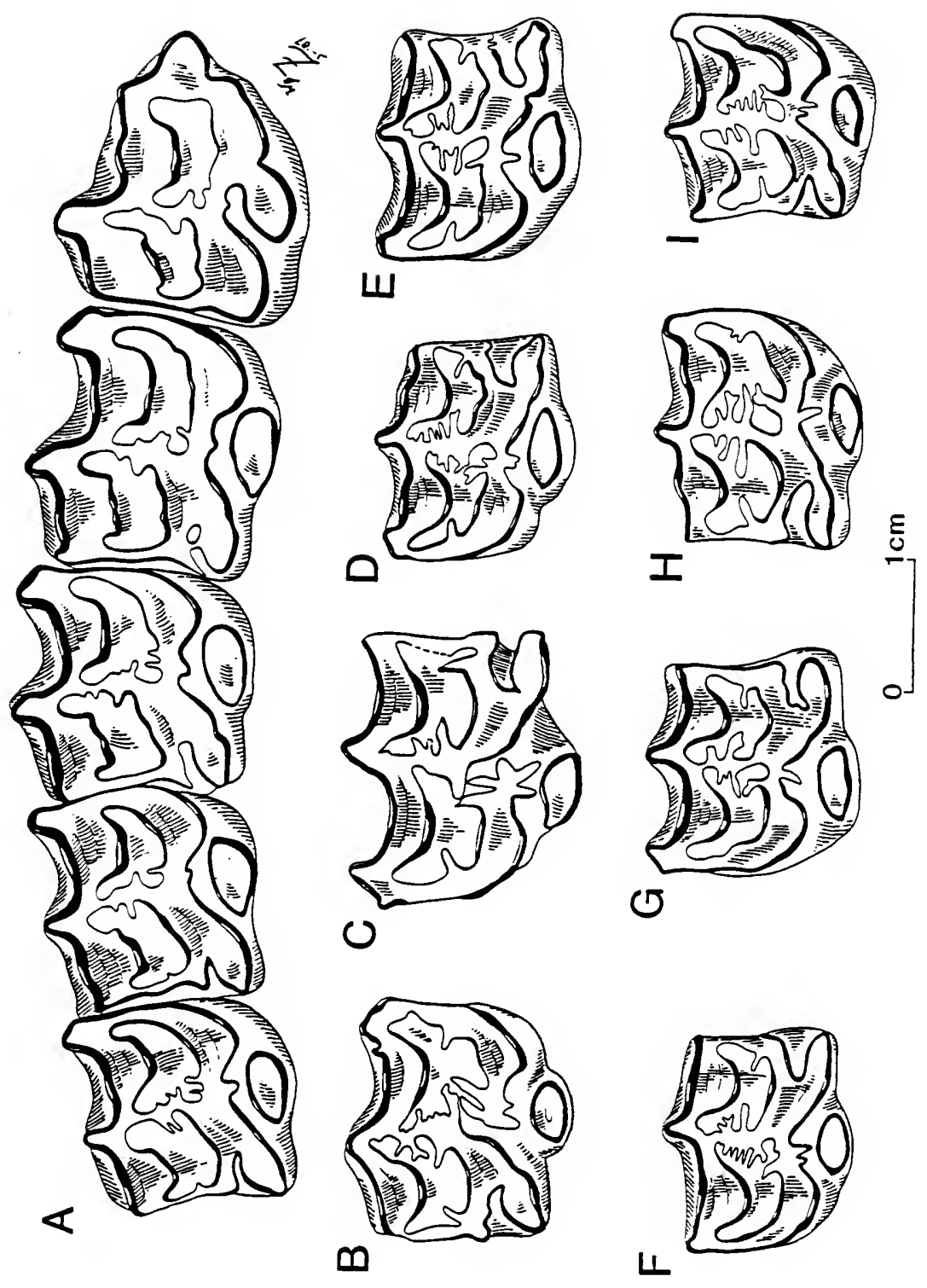


它

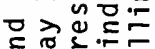

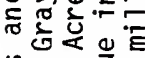
宁电 ชั่ นิ ब인

- .. ${ }^{2}$ 年 ه广户

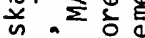

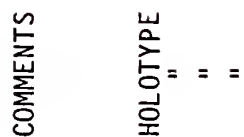

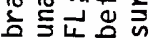

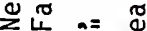
ह \&出的完示

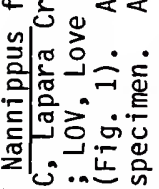
는 둘 웡 4 난

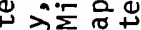

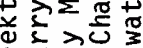
ब

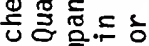
헌응멍

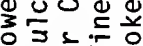
은ㅎㄴ원 을ㅇํㅇ 을 元山䒯

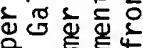
告氜㤩 4 ๒心气 舟 थ iิ山里 $\stackrel{5}{5}$. .

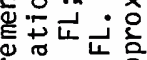
인.는믐 乌ิ

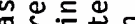

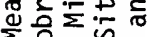
ช

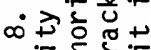
ब $=\frac{2}{2}$

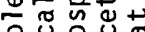
은응음

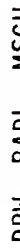

$\stackrel{\omega}{\Sigma}$

$\frac{1}{2}$

중

-F $\quad$ वा momon

u $\dot{m} \dot{\sim} \dot{\sim} \dot{\sim} \dot{m} \dot{m}$

$\frac{\alpha}{\alpha}$

$\underline{z}$

$\vec{a}$

$\stackrel{\circlearrowleft}{0}$

남

点

동

ت্ّ

\lrcorner$-\lrcorner-\propto-\propto \propto$

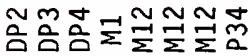

n) $\infty$,

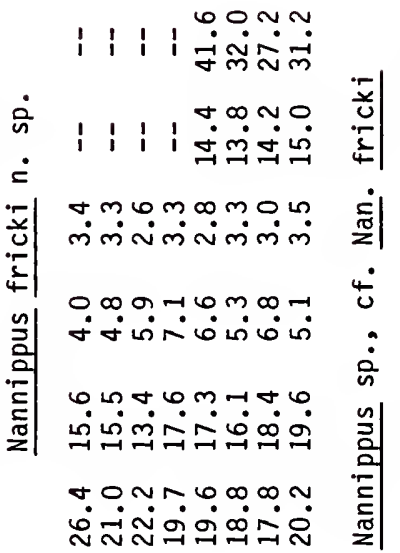

$-\overline{0}$
$\frac{0}{4}$

宛

4

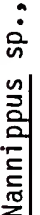

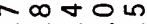
نَ نم نمان

o 0 or ن $N-\infty \infty \infty$ N

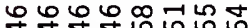

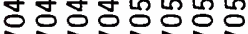

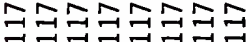

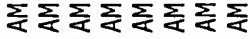
$\because \ddot{1} \ddot{1} \ddot{1} \ddot{1} \ddot{1}$

9. ல் ๑NO \% $\dot{m} \dot{m} \dot{m} \dot{\dot{H}}$

Nmo i் $\dot{m} \dot{m}$ $\propto \propto+\propto-1$

$\underset{\Sigma}{N} \underset{\Sigma}{N} \underset{\Sigma}{N} \underset{\Sigma}{N}$ 고 $\pm m$ $1 \stackrel{1}{1}$ 유웅 뉴메 @ $\infty$ 는는 主

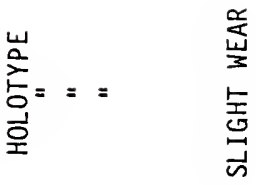

1 11 i

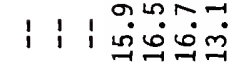
OUNNNN6

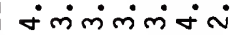
Nm $\infty N m m$ ن | $00.0 \mathrm{n}$.

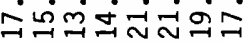

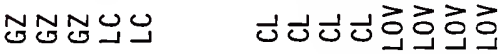
$\propto \propto \propto \propto \alpha-\propto \alpha$

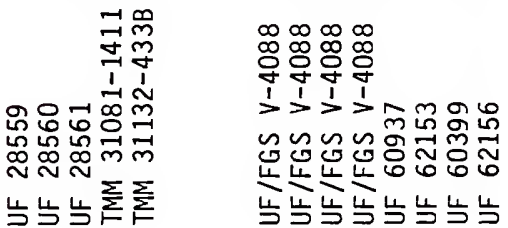


$m \sim \forall n$ ํㅓㄹㅛㅛ

ต $0 \infty \simeq$ บ $\underset{\sim}{\sim} \underset{\sim}{\sim} \underset{\sim}{\sim}$

मेंm,

H\& $\tan$

ن்

กากก

車守吉守

$\because \infty 0+m$

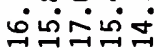

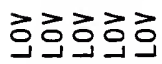

\lrcorner$\propto-\propto ⿻$

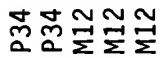

ํํㅇำ 근규메 ฟิธี็ ชิ

䒓岇岁䒓岇
1 1, , $\infty \infty \cdots$ लై

$111,0-1+\infty$ 떠표

帝 | |

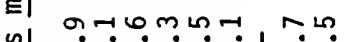
气 சن் 空

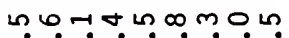

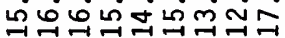

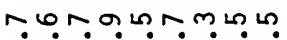

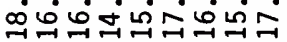

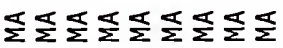

$\propto \propto \propto \propto \propto \propto \propto \propto\lrcorner$

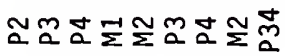

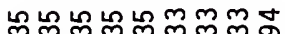

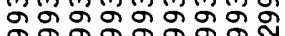
잉용요용 용

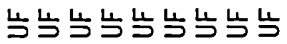




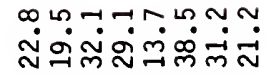

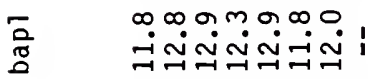

†

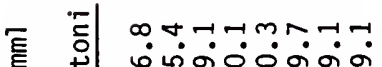

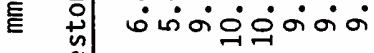

$\underset{3}{\stackrel{3}{0}}$

$\underset{\pi}{\stackrel{3}{7}}$

3
0

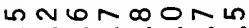
$\dot{0} \dot{0} \dot{\infty} \dot{\infty} \dot{\infty}$

कान का 00000 ن்

$\overrightarrow{0} \overrightarrow{0} \overrightarrow{0} \overrightarrow{0}$ 00000000

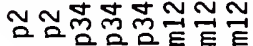

$0.0 \div \%, 4 \div 4 \div$ Nóள் । 4

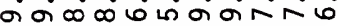

เ $0, \%, m \leftarrow \infty \infty$ \%

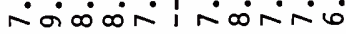
นก เก ம்

$\sum \sum \sum \sum \sum \sum \sum \sum \sum \sum$ $\perp-\perp-\perp-\perp-\perp-\perp$

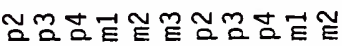

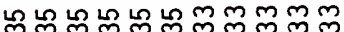

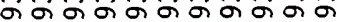

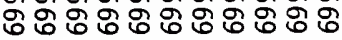

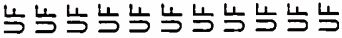


Table 9. Standard univariate statistics for upper cheekteeth of Nannippus fricki n. sp. from the middle Clarendonian of Nebraska. Combined sample from the Gallup Gulch, East Clayton, 01cott, and Kilpatrick Quarries. Format as in Table 2.

P2

APL

$22.3,1.06,2$ $21.5-23.0,4.77$

BAPL

$$
18.0,--, 1
$$

$17.8,1.42,3$ $16.9-19.4,7.97$

PRL

$5.6,1.00,3$

$4.8-6.7,17.99$

PRW

TRW

$4.5,0.42,2$
P34

$19.8,0.98,5$

$18.6-21.2,4.92$

$15.4,0.81,3$

$14.8-16.3,5.30$

$4.2-4.8,9.43$
$19.3,1.09,6$

$17.6-20.5,5.66$

$6.0,0.96,6$

$4.9-7.4,16.03$

$3.8,0.63,6$

$3.1-4.6,16.59$
M12

$18.3,0.84,14$

$17.0-19.9,4.59$

$14.2,0.38,13$

$13.7-15.0,2.70$

$17.1,0.84,14$

$15.5-18.5,4.94$

$6.4,0.53,14$

$5.3-7.3,8.17$

$3.3,0.36,14$

2.8-4.2,11. 18 
the eruption sequence in modern Equus, it was Tess than one year old at death, and most likely between 6 and 10 months old. The cranium is undistorted and well preserved in a matrix of poorly cemented, medium to coarse quartz sandstone. The top and rear portions of the skull are missing. The right and left DPOF are equally incomplete: only the ventral halves are present. The DPOF is well rimmed ventrally and pocketed posteriorly (Fig. 9A). It is about $44 \mathrm{~mm}$ in total length, located a minimum of $31.7 \mathrm{~mm}$ above the labial alveolar margin (measured at the DP3 mesostyle). The fossa narrows anteriorly, but its anterior margin is well defined with a moderate rim. The lacrimal bone makes up the rear portion of the DPOF, if the feature on the right side is correctly interpreted as a suture. The appearance of the fossa, and its relative position to the infraorbital foramen (IOF) is like that of Cormohipparion sphenodus (e.g. USNM 1352, MacFadden, 1984a, Fig. 124). In a much less complete adult specimen, F:AM 117048, the anterior-most portion of the DPOF is also located dorsal to the IOF, and has a well defined anterior margin. It is about $40 \mathrm{~mm}$ above the labial alveolar margin; in the type juvenile specimen the anterior margin of the DPOF is about $35 \mathrm{~mm}$ above the alveolar border.

In F:AM 117046, the malar ridge extends anteriorly to a point dorsal to the DP3 metacone. The ridges are not prominently inflated (as in Pseudhipparion). Only the portion of the facial crest made of the maxilla is present, as most of the jugals disarticulated from the specimen along the maxillo-jugal suture. There is no trace of a ventral depression on the posterior cheek portion of the maxillary 
bones. The maximum width measured across the skult on the facial crest at the posterior-most point of the maxillae is $90.2 \mathrm{~mm}$.

The teeth preserved on F:AM 117046 include the DP1 on the left side (only its alveolus on the right). This tooth is extremely small (maximum length about $4.5 \mathrm{~mm}$ ), and simple with on ly one central cusp. It does not contain the series of lophs typically found on equid DP1s (see e.g. Osborn, 1918, Plate 12 for Cor. sphenodus or Skinner and Taylor, 1967, Fig. 5E for "M." insignis) and is much smaller. The OP2 through DP4 are of the advanced equid type, with a heavy coat of cement and fully formed fossettes (Fig. 9B). The maximum length from the DP2 to the DP4 is $70.5 \mathrm{~mm}$, very similar to that of Nan. beckensis (Dalquest and Donovan, 1973, p. 40). The enamel pattern of the DP2-DP4 show many unusual and complex features, some due to the early wear-stage. Perhaps the most strange are the projections eminating lingually from the parastyles, especially on the DP3 (Fig. 9B). The fossettes are moderately complex, with prominent prefossette loops. The protocone is round on the DP2 with a slight anterolabial spur, oval on the DP3, and elongate-oval on the DP4. The parastyles and pli caballins are well developed.

The left MI was extracted from the holotype maxilla and sectioned about $10 \mathrm{~mm}$ above the unworn occlusal surface to reveal its enamel pattern (Fig. 9C). It resembles the referred upper molars (Figs. 10D-10I) in its isolated, elongate-oval protocone; strong pli caballin; persistently open, deep hypoconal groove; large, elongate hypocone; and moderately complex fossettes. The referred $\mathrm{P} 2 \mathrm{~s}$ have relatively unexpanded anterostyles. The protocone of the premolars bears a spur in early wear-stages, a primitive hipparionine feature 
(MacFadden, 1984a). In the P2, the spur connects the protocone with the protoselene in early to moderate wear-stages. However, it fades with wear on the P34 and even very heavily worn individuals retain isolated protocones (Fig. 10A). The protocone of the molars tends to be longer (relatively and absolutely, Table 9) with angular ends. Parastyles, particularly in the P34, are large and often grooved in early wear. The hypoconal groove is almost always deep and retained until very late wear-stages. The hypocone of the molars is not reduced as in other species of Nannippus.

Relative to other hipparionines, the fossettes are moderately complex in Nan. fricki. The internal fossette margins combined usually bear between seven and ten plications (Figs. 9C, 10). These are deep, but with less tendency to bifurcate than those of Cormohipparion. A pli protoloph and pli hypostyle are present in the majority of specimens (Fig. 10).

Discussion. Nanippus fricki is distinguished from its sympatric hipparionine contemporaries Cor. occidentale, Neo. affine, Pseud.

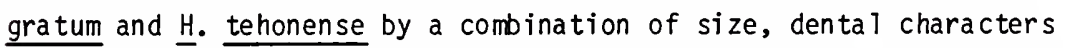
and DPOF morpholgoy. Upper cheekteeth of Pseud. gratum are easily distinguished by their more rapidly connected protocones, tendency to close the hypoconal groove, and simpler fossettes (Webb, 1969). Isolated upper cheekteeth of $\underline{H}$. tehonense more closely resemble those of Nan. fricki, but are on average larger, have simpler fossettes (greater tendency to lose pli protoloph and pli hypostyle), and more rapidly connected protocones. Neohipparion affine is much larger than Nan. fricki, and has simpler fossettes. Cor. occidentale is also much larger, with more complex fossettes and without protoconal 
spurs. All four retain larger DP1s than Nan. fricki. Neohipparion, Pseudhipparion and Hipparion have shallower DPOFs without well defined anterior margins (Webb and Hulbert, 1986; MacFadden, 1980; 1984a).

Nanippus fricki is evidently extremely rare in middle Clarendonian faunas of the Great Plains, and is only recognized from three localities in Nebraska. While Pseud. gratum is represented by hundreds of teeth in the Snake Creek Fauna, on ly six specimens of Nan. fricki were found. No lowers are referred to Nan. fricki in the type region, because of the difficulty in unambiguously distinguishing them from those of the similarly sized Pseud. gratum. However, some of the mandibles from the Gallup Gulch Quarry can probably be shown to belong to Nan. fricki with further study. As described below, lowers from southern faunas can be referred to a very similar, if not conspecific, species of Nannippus, because the associated species of Pseudhipparion is much smaller than Nan. fricki. The phylogenetic implications of the facial and dental features of Nan. fricki are discussed in Chapter 6.

$$
\text { Nannippus sp., cf. Nannippus fricki }
$$

Nannippus cf. Nan. ingenuum (Leidy), FORSTEN, 1975, pp. 61-65 (in part).

Referred specimens. Lapara Creek Fauna, Bee County, TX. Farish Ranch Site: TMM 31081-660 assoc. R P2-P3; -630 assoc. R P2,M1-M2; -1159 assoc. L M1-M2; $-319,-825$ P34s; $-658,-659,-1411,-1413$, -1421 A M12s; $-16,-27,-176,-566,-675,-735,-1511$ mandibles; -1506 
L dp2; $-168,-953,-956$ p34s; $-1413,-1424$ m12s. Buckner Ranch Site: TMM 30896-450 assoc. L M1-M2; -400 M12; -455 m12. Bridge Estate Site: TMM 31132-402 P34; -433B M12; -306 juvenile mandible.

Agricola Fauna, Bone Valley Region. Gray Zone, Phophoria Mine: UF 28564 P2; 28568 P34; 28569-28571 M12s; 28562-28563 M3s; 28573, 28577, $28578 \mathrm{ml2s} ; 28678 \mathrm{~m} 3$. Hookers Prairie Mine: UF $93207 \mathrm{R} \mathrm{ml}$.

Description. These two populations consist of isolated cheekteeth, and in the case of the Texas sample, a number of mandibles. No cranial material is known. The upper cheekteeth resemble those of Nan. fricki from Nebraska in size (Table 8) and genera 1 enamel morphology (Figs. 11A-11D, 11F-11I). This includes frequent double pli caballins, elongate-oval protocones on molars, moderate fossette complexity, strong parastyles, large hypocones, and deep hypoconal grooves. The Florida sample is on average smaller than that from Nebraska, but this is often the case for populations considered conspecific from the two regions (Webb and Hulbert, 1986). The Phosphoria Mine sample is also probably less high crowned. A very slightly worn M1 has a MSCH of on ly $38.3 \mathrm{~mm}$.

The lower cheekteeth are of the primitive hipparionid pattern (Forsten, 1984), with well developed, rounded metastylids that remain well isolated from the metaconids throughout ontogeny. Protostylids are well developed on the p3-m3 and dp34 (Figs. 11E, 11J, and 11K), and sometimes project further labially than does the base of the protoconid. The ectoflexid is shallow in the premolars, not penetrating the isthmus, very deep in the molars and deciduous premolars. The entoconid is large, and in slightly worn premolars often has a prominent anterior plication that lies labial to the 


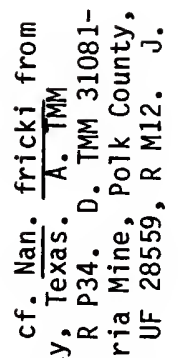

녇

으웡 응

乌i

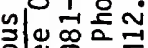

이잉

- m

旁部部

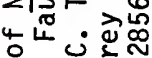

○过恣

穴

过・当

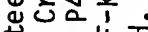

羊山止

i

ฮั

两罂量

ช.

3 以

인 $1-1$

-

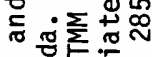

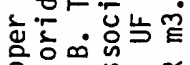

魚步

ษ 뭉

ต ก่

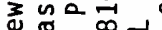

$\stackrel{\square}{x} \propto \mathscr{O}^{\infty}-$

沜再号

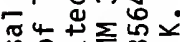

ஸ口․․․․

过究总山光

윰

- $₫$

ธิ

凹

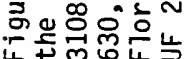



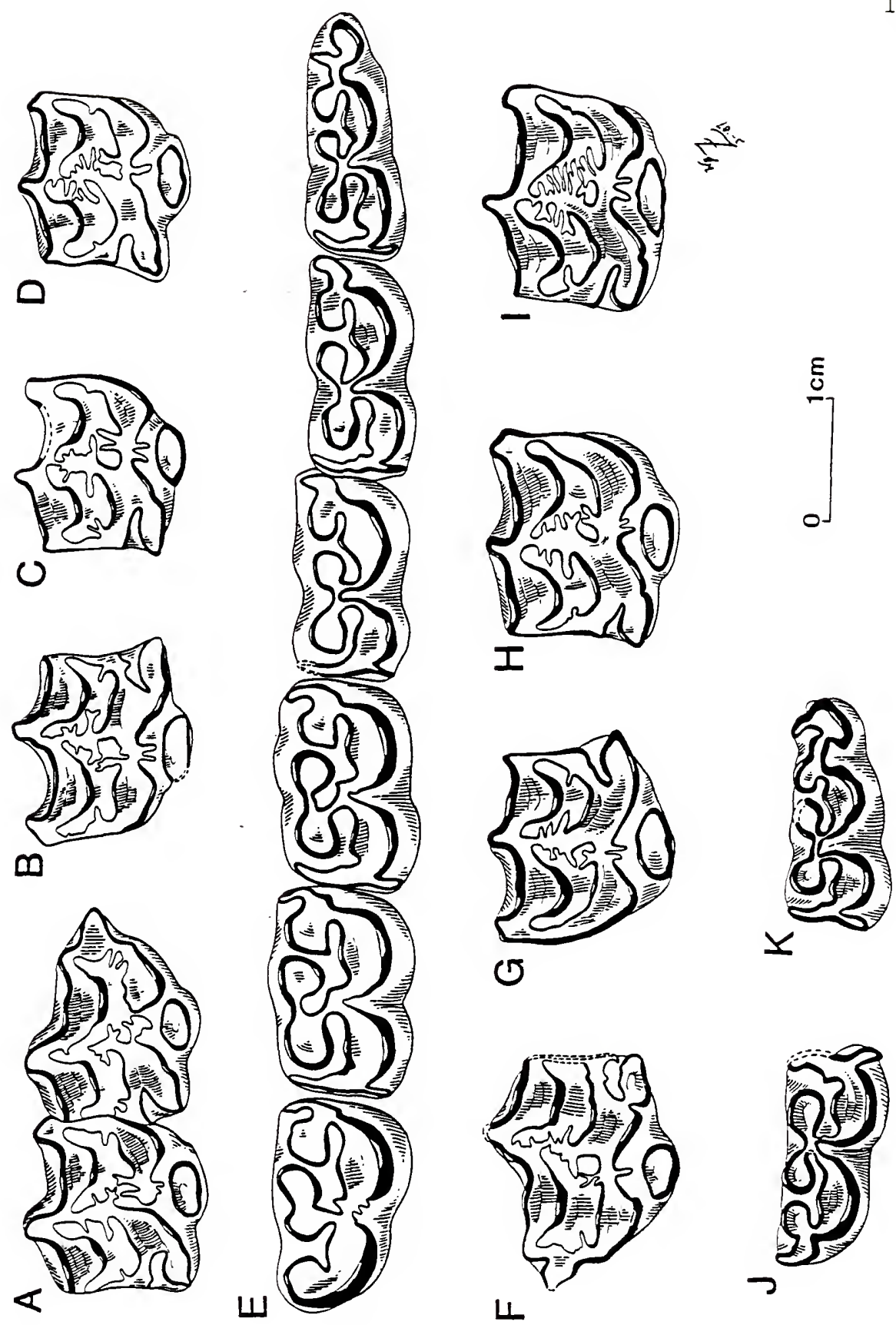

4 
metastylid. Premolars have small but distinct pli caballinids in early wear-stages. They do not extend further labially than the base of the hypoconid. Pli caballinids are absent or ephemeral on molars (e.g. TMM 31081-566, m2). Isthmus and paralophid plications are frequent in slightiy and moderately worn premolars, absent on molars. The p2 paraconid is relatively poorly developed, such that the tooth is rather short (Table 8 ).

None of the Lapara Creek mandibles preserve the entire symphyseal region, nor do any possess incisors, but the postcanine diastema can be estimated on TMM 31081-27 (about $52 \mathrm{~mm}$ ) and TMM 31081-16 (about 55 $\mathrm{mm})$. This is approximately half the $\operatorname{trl}$. The depth of the ramus measured between the $\mathrm{p} 4$ and $\mathrm{m} 1$ is 43.0 and $46.2 \mathrm{~mm}$ for 31081-16 and 31081-27, respectively. The deciduous lower premolars are wel1 cemented and possess moderately large ectostylids.

Discussion. Forsten (1975) referred the entire Lapara Creek sample of medium-sized hipparionines to a single taxon, "Nannippus cf. N. ingenuum" [sic]. The dental morphology of the topotypic and other referred Florida samples of "Nan." ingenuus are described beolw. They have enlarged $P 2$ anterostyles and $p 2$ paraconids, very complex enamel plications, more persistently isolated protocones without spurs, and relatively broader premolars. "Nan." ingenuus belongs in the genus Cormohipparion. For the most part, the specimens from the Lapara Creek and Clarendon faunas that Forsten (1975) assigned to Nan. Cf. ingenuus are referable to a single species, namely $\underline{H}$. tehonense (MacFadden, 1980). They differ from those here referred to Nannippus by being (on average) larger, having 
less complex fossettes, deeper premolar ectoflexids, fewer isthmus and paralophid plications, more poorly developed pli caballinids (usually absent), weak protostylids, and more poorly developed ectostylids on dp2-dp4. As noted above, teeth of $\underline{N a n}$. fricki and $\underline{H}$. tehonense generally resemble one another, and a sizable proportion of the Lapara Creek sample is indeterminate between the two. Most of the associated dentitions and lesser worn teeth are referable to one or the other, based on both size and morphology.

The Lapara Creek and Phosphoria Mine samples of Nannippus are on ly provisionally referred to Nan. fricki, because they lack cranial material, and the type locality of Nan. fricki has no referable lower cheekteeth. Although the three samples differ slightly in size and morphology, they are within the general accepted range of variation for a widely distributed equid species. The relatively lower unworn crown heights of the Florida sample probably reflect their greater age (early, possibly very early Clarendonian).

\section{Nannippus westoni (Simpson), 1930 new combination}

Merychippus westoni SIMPSON, 1930, p. 164; STIRTON, 1940, p. 178; FORSTEN, 1975, 40.

Nannippus cf. minor (Sellards), WEBB et a1., 1981, p. 526. Nannippus minor (Sellards), MACFADDEN, 1984a, p. 123 (in part).

Type specimen. UF/FGS V-4088, right maxillary fragment with heavily worn P3-M2.

Type locality. Phosphate mine of the Cummer Lumber Company, located about $7 \mathrm{~km}$ west-northwest of Newberry, GiTchrist County, 
Florida. Probably NW1/4 sec. 25, T9S, R16E, Waters Lake Quadrangle (Simpson, 1930, pp. 155-156).

Stratigraphic occurence and age of the type locality. Uncertain, but here interpreted to probably be early Hemphillian. Previously thought to be significantly older, i.e. equivalent to the Quincy and Midway local faunas, or late Hemingfordian.

Topotypic sample. None other than holotype, UF/FGS V-4088.

Distribution. Known only from the latest Clarendonian through the early Hemphillian (about 8.0 to $9.5 \mathrm{ma}$ ) of northern peninsular Florida.

Referred specimens. Love Site: UF 96575 assoc. L DP2-DP3; 62155 assoc. R P3-P4; 96760-96774, 96813-96816 DP2s; 96775-96809 DP34s; 60247, 60397-60400, 62151-62154 P2s; 53157, 53398, 62156-62164, $62166-62170,62179,62421,95387$ P34s; 50351, 50352, 62171, 6217362178, 62180-62194, 90265 M12s; 96308-96319 M3s; 32187 L mandible with dp3-m1; 32130 assoc. R p2-m3 and probably assoc. L p3, p4, and m2; 63984 p2; 59162, 63986-63989, 63989, 63992, 63993, 64920, 64921, 92978 p34s; 63994-63998, 64502, 92976,92977 m12s; 63999, 64000, 92970-92975 m3s; 96567-96569 dp2s; 92979-92981, 92985, 96571-96574, 96576 dp34s; 66800, 33818, 33849-33851, 33967, 33986, 34029-34034, 34036 MC III; 33411, 33432, 33448, 33609, 33631 MT III.

McGehee Farm Site: UF 95376, 95377 P34s; 17126, 95378, 95379 M12s; 95380 p34; 95381-95384 m12s; 95385 m3.

Mixson's Bone Bed: F:AM 104871 M1(?); 104870 p34.

Haile 5A: UF 17294 P34.

Haile 19A: UF 47324 p2. 
Revised diagnosis. Moderate-sized species of Nannippus with estimated trl of about $100 \mathrm{~mm}$. Smaller than Nan. fricki, Nan. lenticularis or Nan. beckensis; Targer than Nan. minor; similar in size to Nan. peninsulatus. Mean M12 TRW $14.9 \mathrm{~mm}$; mean BAPL $12.7 \mathrm{~mm}$. Unworn M12 MSCH about $43 \mathrm{~mm}$. Differs from Nan. fricki in its simpler fossette pattern; smaller, rarely double pli caballins; shallower hypoconal groove; and reduced molar hypocone. Differs from Nan. minor and all other advanced species of Nannippus by its lower unworn crown height; protoconal spur on P34 in early wear: simpler fossette plications; strong protostylids on p3-m3 and dp34; well developed pli caballinids and isthmus plications in slightly worn premolars; and ectostylids on dp2-dp4.

Description. The P2s have oval or rounded protocones that are connected to the protoselene in all known specimens, including the slightly worn UF 60397 (Figs. 12D-12E). The anterostyle varies from being on iy moderately reduced as in Nan. fricki (e.g. UF 62154 and 60400) to very reduced as in Nan. minor (e.g. UF 62152). The hypoconal groove is occasionally deep but usually shallow and narrow. Fossettes are moderately to simply plicated. Pre- and postfossettes are frequentiy confluent, a common feature of equid P2s. PIi caballin is single, not well developed. Mesostyle is strong (Fig. 12D). Unworn $P 2 \mathrm{MSCH}$ estimated to be at least $30 \mathrm{~mm}$.

The P3 and P4 are notably low-crowned relative to molars, with unworn MSCHs of on ly about $35 \mathrm{~mm}$. The parastyle is grooved through much of the crown. It and the mesostyle are very strong, but the metastyle is weak or absent. The protocone is oval to elongate-oval, rarely rounded (UF 62166 is such an exception), with a moderate 
anterolabial spur in early wear-stages (Fig. 12F). The pli cabalitin is usually single, only occassionally bifurcated, but persists until late wear-stages. The hypoconal groove is initially deep and wide, shallows with wear, but remains persistently open until MSCH of about $10 \mathrm{~mm}$ or less. Fossette borders are relatively simple: pli protoloph either single ( $50 \%$ of Love Site sample, $n=16$ ) or absent (50\%); prefosette loop poorly developed; and pli hypostyle either single (63\%) or absent (37\%). The posterior half of the prefossette generally has only two, or more rarely three, plications in teeth with MSCHs greater than $15 \mathrm{~mm}$; the opposing face of the postfossette usually has one, occasionally two or three, plications (Figs. 12F$12 G)$.

The M1 and M2 are moderately hypsodont $(H I=3.4)$, with unworn $M S C H$ about $43 \mathrm{~mm}$. The parastyle is weaker than that of P34, and on ly grooved during earliest wear-stages. Protocones are oval or elongate-oval, often with lenticular ends, usually isolated until MSCH less than $13 \mathrm{~mm}$; during early wear-stages, a protoconal spur is absent or much smaller than that of premolars. The pli cabalitin is single, unbifurcated, lost at MSCHs of about $20 \mathrm{~mm}$. The hypocone is usually relatively small, as in Nan. minor, but occasionally unreduced (e.g. UF 62189). Hypoconal groove depth varies with wear, but remains persistently open, unti] latest wear-stages (MacFadden, 1984a, Fig. 96). Fossette borders resemble those of the premolars (Figs. 12I-12J).

Lower premolars are characterized by large, rounded to oval metaconids, metastylids and entoconids. The entoconid is closely 
Table 10. Standard univariate statistics for upper cheekteeth of Nanni ppus westoni from the Love Site, Alachua County, Florida (very Tate (Tarendonian). Format as in Table 2.

P2

APL

$20.7,1.52,10$

$17.6-22.7,7.36$

BAPL

$16.7,0.80,10$

$15.3-17.8,4.77$

TRW

$16.0,0.83,10$

$14.9-17.4,5.20$

PRL

$4.5,0.54,10$

$4.0-5.7,12.00$

PRW
P34

$17.1,1.19,16$

$15.3-19 \cdot 6,6.94$

$12.9,0.62,16$

$11.6-14.1,4.78$

$16.1,0.85,16$

$14.4-17.4,5.28$

$5.4,0.77,17$

$3.9-6.7,14.34$

$3.3,0.45,17$

$2.4-4.2,13.88$
M12

$16.2,1.04,27$

$14.3-18.3,6.38$

$12.7,0.55,24$

$11.6-13.7,4.31$

$14.9,1.02,25$

$12.5-17.1,6.85$

$5.3,0.59,27$

$4.3-6.7,11.23$

$3.1,0.41,25$

$2.3-3.9,13.13$ 


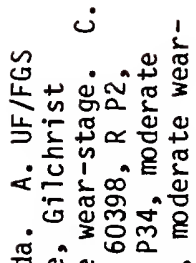
ชิ

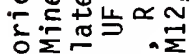

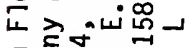
트웜ำ

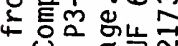
- $\propto \stackrel{0}{4}$

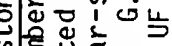

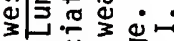
纯皆

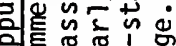

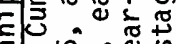
.ด 造云文 $40 \propto \pm$

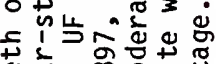
ㄴ. 윻 必舟 萡

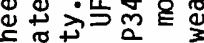
ن

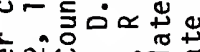
ฮิ ก

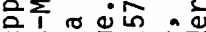
m a정 4 U十口月 的至 30 \%

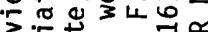
u- On+.

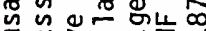
๖ บ. ำ Uั口̆ 事岁 음요 $\sim$ 오. 쇼ㅇㅛㅛ Q >N 녹

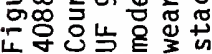



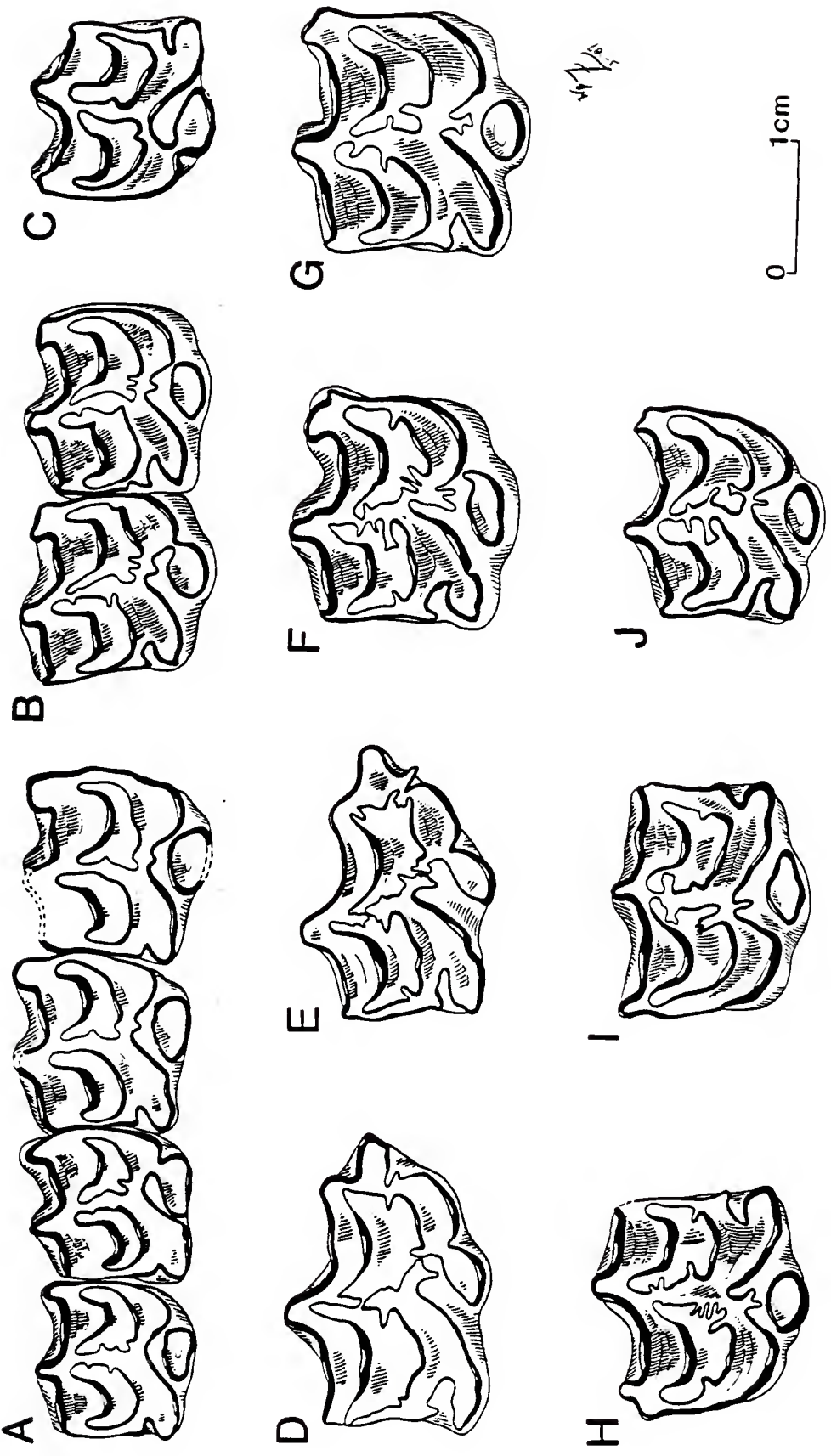

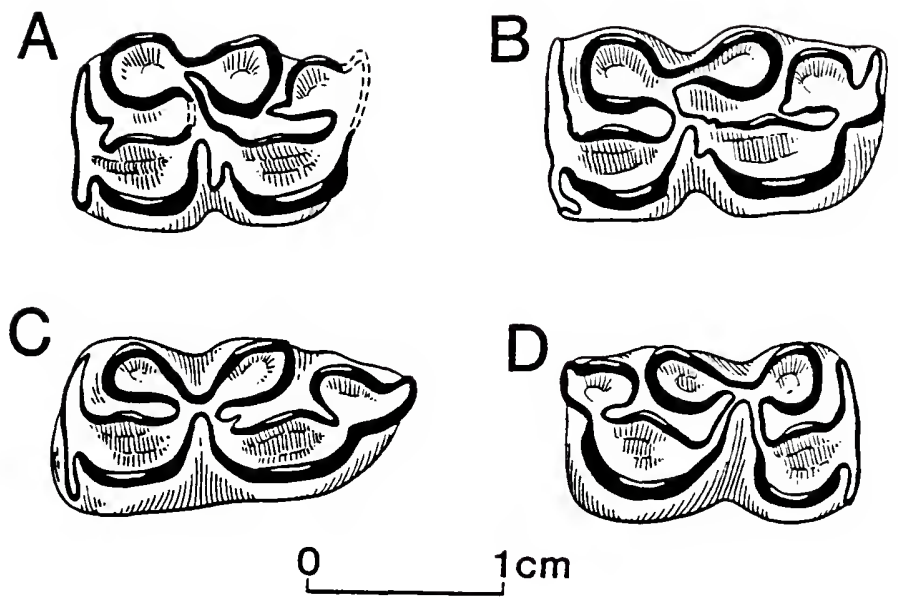

Figure 13. Occlusal views of lower cheekteeth of Nannippus westoni from Florida. A. F:AM 104870, R p34, late wear-stage; Mixson's Bone Bed, Levy County. B-D, Love Site, Alachua County. B. IJF 64921, L p34, early wear-stage. C. UF $64501, \mathrm{~L}$ m12, early wear-stage. D. UF $63997, \mathrm{R} 12$, moderate wear-stage. 
appressed to the metastylid, leaving only a very narrow lingual opening for the entoflexid (Figs. 13A-13B). The p2 has a strong p1i caballinid, a small pli entoflexid and a very shallow ectoflexid. The p2 apl is less than that of the p34 (Table 10). The ectoflexid of the p34 is deeper and broader than that of the p2, penetrating just up to the base but not into the isthmus. The p34 pli caballinid varies from absent (UF 59162) to weak (UF 64921) to strong (UF 92978), and is usually present through the first two-thirds of the crown. The p34 always have a protostylid that first appears on the occlusal surface after the first $5 \mathrm{~mm}$ or so of crown wears off. The protostylid is usually prominent, often extending further labially than the base of the protoconid (Fig. 13B); sometimes curved posteriorly; and is always connected to the protoconid except for its initial few millimeters. Isthmus and paralophid plications are generally restricted to the upper half of the crown. A slightly worn p4 has a mech of $35.8 \mathrm{~mm}$ (UF 32130), indicating that lower premolars are slightiy higher crowned than corresponding upper teeth.

Lower molars of Nan. Westoni generally resemble those of Nan. fricki or Cor. ingenuum in morphology, with oval metaconids and metastylids separated by a " $V$ "-shaped linguaflexid and a deep ectoflexid that usually completely divides the isthmus. In early wear-stages however, and even in a few moderately worn molars le.g. UF 64504), the ectoflexid depth is reduced. As in the premolars, the protostylid is strong, attached to the protoconid, and observed on every available specimen (Figs. 13C-13D). Isthmus and para lophid 
plications are rare and limited to slightly worn specimens, as are pli caballinids. Unworn mech is about 42 or $43 \mathrm{~mm}$.

The dp2 is relatively short, with an unexpanded paraconid, a shallow ectoflexid, and a moderate pli caballinid. It thus greatly resembles the permanent $p 2$, except for its greater length, oval ectostylid, and rudimentary protostylid. In the dp34, both the protostylid and ectostylid are usually strong, the ectoflexid deeply penetrates the isthmus, and there is a weak pli caballinid in early wear-stages. The dp34 are less high crowned than those of Nan. minor, with an unworn mcch of about $19.5 \mathrm{~mm}$.

A number of medial metapodials from the Love Site are referred to $\underline{N a n}$. westoni as their size is similar to those of other species of Nannippus (Table 11). They display a mosaic of advanced Nannippus and primitive hipparionine features. Advanced characters include their length (Table 11), slenderness, large unciform facets on the MC III, and large cuboid and entocuneiform facets on the MT III. Primitively, the MC III has two distinct facets for articualtion with the unciform (Fig. 14; they merge in Nan. minor and Nan. peninsulatus), the proximal anteroposterior breadth is large relative to the proximal width (cf. Sondaar, 1968, p. 55), and the distal width measured across the tuberosities is usually greater (although often by less than $1 \mathrm{~mm}$ ) than the width measured across the dista 1 condyles. The MT III retains a moderate distal depression on the anterior face of the shaft above the condyles. It is further reduced in later species of Nannippus (Hussain, 1975). The distal width of 
Figure 14. Proximal (A-D) and anterior (E-G) views of medial metapodials of Nannippus from Florida. A. UF 57344, proxima 1 metacarpal III of Nan. minor, Palmetto Fauna, Bone Valley Region, Polk County. B, E. UF 34029, metacarpal I I I of Nan. westoni, Love Site, Alachua County. C, F. UF 69936, metacarpaTII of Nan. minor, Moss Acres Racetrack Site, Marion County. D, G. UF 69934, metatarsal III of Nan. minor, Moss Acres Racetrack Site, Marion County. 


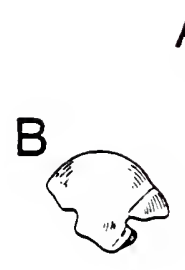

$A$

E

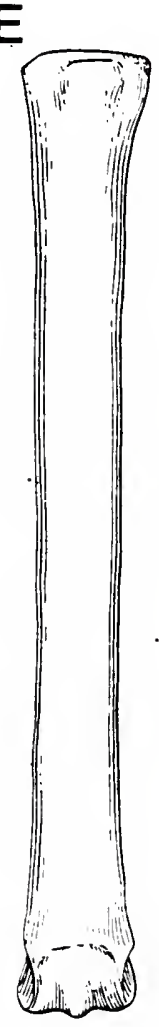

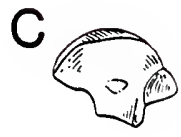

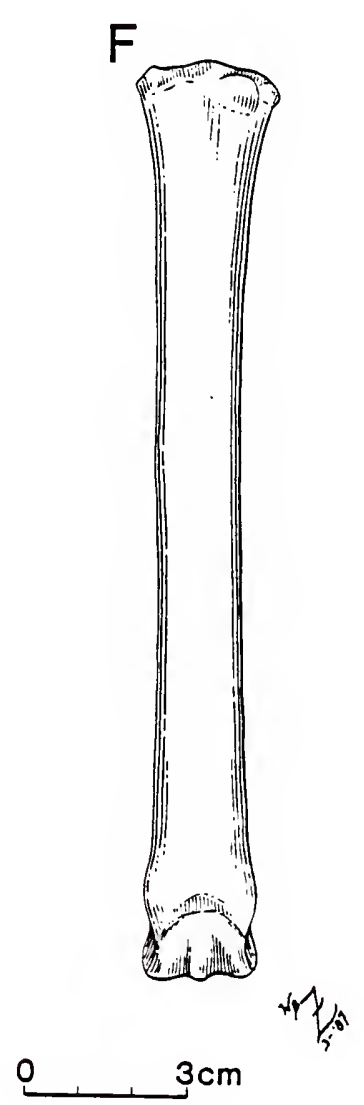

D

G

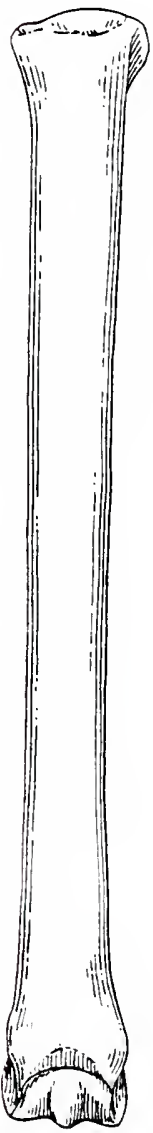




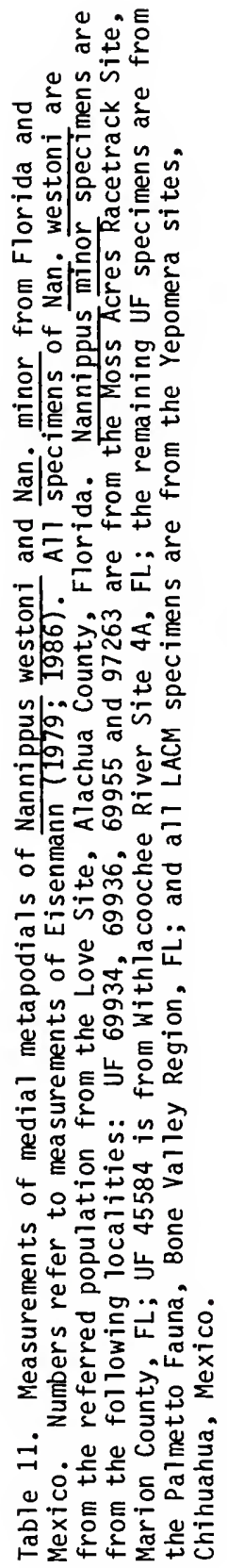

-

on

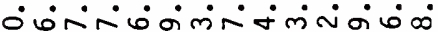

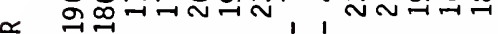
$7 \rightarrow 1,11$

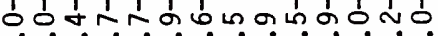

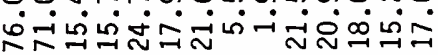

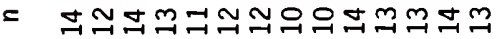

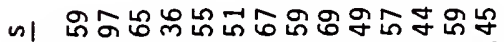
mí0ல்

$\infty 0 \omega \sim+\infty \infty m$ or $m$ \% $m \infty$

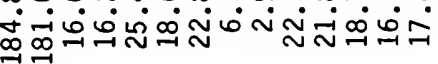

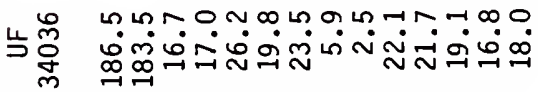

개

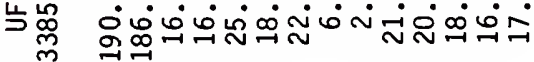

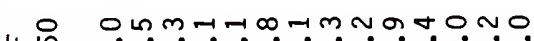
岁亚

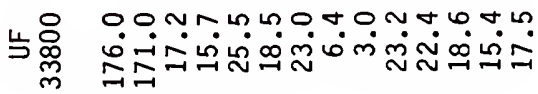

岁孚

岁每

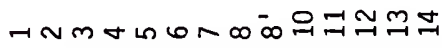




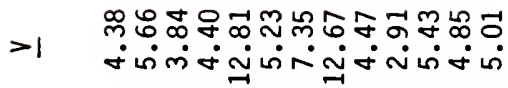

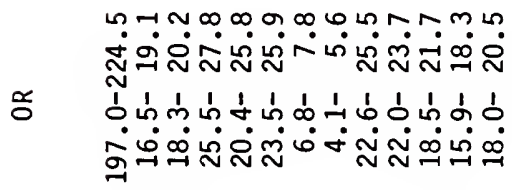

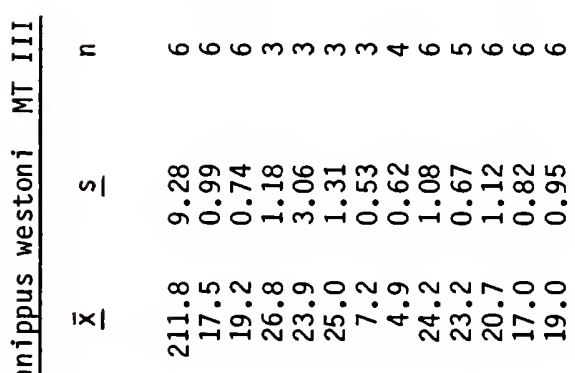

空|

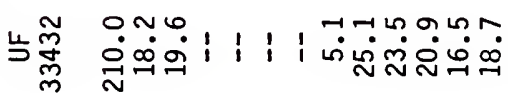

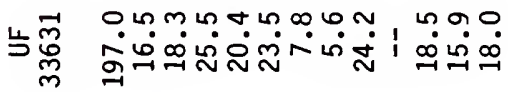

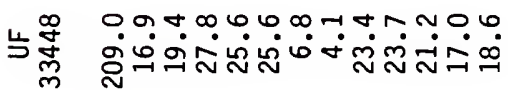

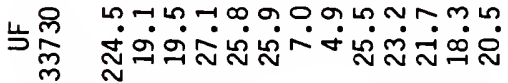

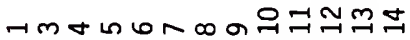


$>$ >

= $\theta+\theta+N N$.

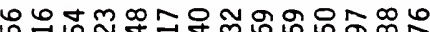
जा

| ம்

Е

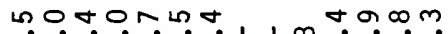

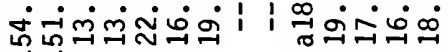

ร

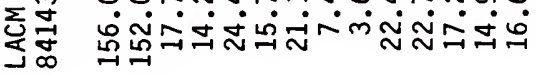

I $004+40,000 \infty+m \infty$ 造 过壳

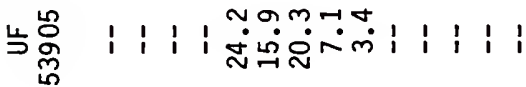
岁旋 | l i i

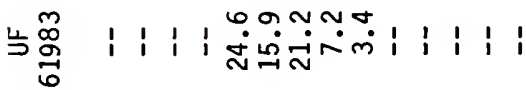

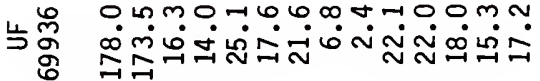

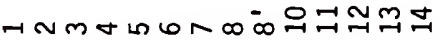




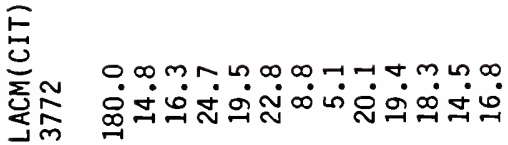

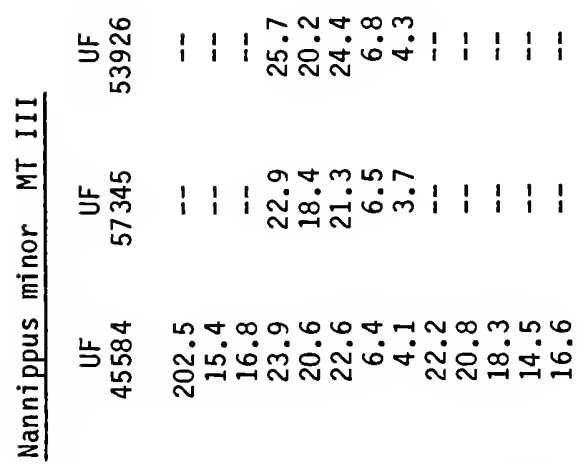

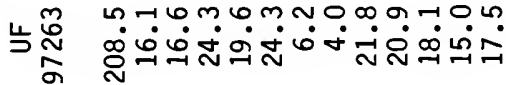

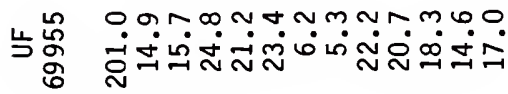

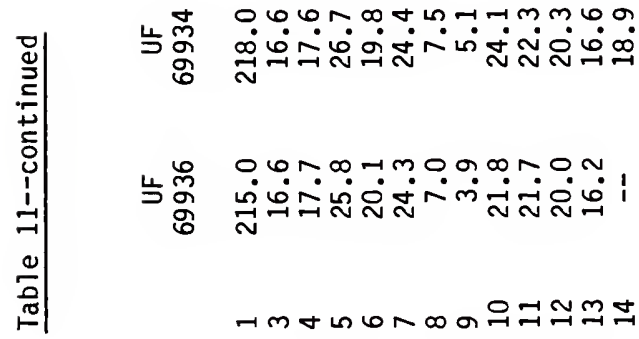


the MT III measured across the tuberosities is also greater than the distal condylar width (Table 11). Hussain (1975, p. 207) stated that the opposite is true for Nannippus, but most MT III of Nan. minor, $\underline{\text { Nan. }}$ lenticularis and Nan. peninsulatus I have measured are like those of the Love Site in this regard (Table 11).

Discussion. Simpson (1930) based Merychippus westoni on a maxillary fragment containing four heavily worn teeth (Fig. 12A). A1though the MSCH cannot be measured directly on any of the teeth (aS they are still housed in their alveoli), I estimate their crown heights to be about 12 to $16 \mathrm{~mm}$ maximum. Simpson (1930) interpreted the specimen's morphology to represent a primitive, low crowned species of Merychippus; it seems more plausable to now consider the type an old individual of a more advanced, hypsodont species. Except for details reflecting individual variation, heavily worn Love Site specimens perfectly match the type in size (Table 8) and all aspects of its enamel morphology (Figs. 12B-12C). The persistently open hypoconal groove and isolated protocone preclude assignment to Pseudhipparion or Calippus, and the simple nature of the fossettes stressed by Simpson (1930) is merely an artifact of the specimen's advanced age. As far as can be determined, no other vertebrate specimens were ever recovered from the type locality of Merychippus westoni, and thus the geologic age of the holotype can on ly be inferred from the specimen itself. The exact locality was never recorded, and was no doubt destoyed by mining operations.

Mining in the vicintiy of the town of Newberry continues to this day, although now the limestone itself is being quarried, rather than 
the phosphatic pockets. Vertebrate fossil-bearing sediments, either from filled sinkholes, or from channel deposits incised into the limestone, are common in this region. The Florida State Museum has collections from 41 separate localities (the Haile sites) from a limited region only about $9 \mathrm{~km}$ due east of the type locality of Merychippus westoni. Of these, six are early Hemphillian, one Blancan, six Irvingtonian, and 28 Rancholabrean. These, and a 11 other Miocene vertebrate sites in the vicinity are either too young to contain a primitive species of Merychippus (e.g. Love Site, McGehee Farm Site), or are too old (Thomas Farm, Buda, or SB-1A). In summary, there is neither good morphological or geological evidence for considering the holotype of $\underline{M}$. westoni a primitive, late Hemingfordian-grade merychippine as did Simpson (1930) and Stirton (1940). Rather, the more abundant referred material indicates a younger age and a referral to Nannippus.

Nan. westoni is principally known from isolated cheekteeth, the two major exceptions being the worn holotype and UF 32130, a fragmentary ramus with slightly worn teeth. Thus, none of the phylogenetically important cranial and rostral characters of Nannippus are known for this species, as well as the morphology of the lower incisors and the DP1. Generic features of Nannippus that are known for Nan. westoni are its small size (Tables 10, 11), oval-lenticular protocones isolated throughout most of the crown, open hypoconal grooves that do not form isolated hypoconal lakes as in Pseudhipparion, relatively persistent pli hypostyle, and poorly developed anterior regions on the $\mathrm{P} 2$ and $\mathrm{p} 2$. Other denta 1 characters, not usually considered typical of Nannippus (e.g. strong 
protostylids) are plesiomorphous, and cannot be used to exclude the species from the genus. Although crania are unknown, the relatively low crowned premolars suggest that Nan. westoni retained the anteriorly and ventrally positioned DPOF found in Nan. fricki. Metapodials of Nan. westoni al so demonstrate some derived Nannippus characters, such as large unciform and entocuneiform facets (see above).

Populations here considered referable to Nan. westoni were previously placed in Nan. minor (Waldrop, 1971; MacFadden and Waldrop, 1980; MacFadden, 1984a), although their more primitive nature (relative to the topotypic Upper Bone Valley sample) was realized. The rationale for this was the belief that Florida Nannippus populations formed a single, continually and gradually evolving lineage through the Hemphillian, with no obvious point of demarcation. A thorough study of the Love Site sample, by far the largest known for Nan. westoni, and new discoveries of relatively complete early Hemphillian Nan. minor (see below), suggest otherwise, at least for a set of characters that can be used to distinguish the two species.

Five localities ranging in age from very late Clarendonian to early Hemphillian (Fig. 1) contain referable specimens of Nan. westoni in addition to the type 10cality. Nan. westoni is rare at all these sites, with the exception of the Love Site, the rarest equid in each fauna. This is notable as Nan. minor is particularly common in later Hemphillian faunas in Florida, and is often the most abundantly represented equid species. Only a few records of Nannippus from the early Hemphillian of the Great Plains exist (e.g. 
F:AM 113744 from the J. Swayze Quarry, Kansas), and most often they consist of one or two isolated teeth inadequate for conclusive specific identification. Some are referable to Nan. lenticularis (MacFadden, 1984a; Winkler, 1985), while others might be either Nan. fricki, Nan. westoni, or an undescribed taxon.

Nannippus minor (Se11ards), 1916

Hipparion minor SELLARDS, 1916, p. 96.

Hipparion (Nannippus) minor Sellards, SIMPSON, 1930, p. 188;

MATTHEW and STIRTON, 1930, p. 354.

Hipparion (Nannippus) ingenuum (Leidy), SIMPSON, 1930, p. 187 (in part).

Nannippus minor (Sellards), STIRTON, 1940, p. 186; WEBB and TESSMAN, 1968, p. 807 (in part); VOORHIES, 1974, p. 110;

MACFADDEN and WALDROP, 1980, p. 31; MACFADDEN, 1984a, p. 123 (in part).

Nannippus cf. minor (Sellards), LANCE, 1950, p. 52. Nannippus aztecus MOOSER, 1968, p. 7; DALQUEST and MOOSER, 1980;

p. 13.

Hipparion ingenuum (Leidy), WEBB and TESSMAN, 1968, p. 807 (in part).

Type specimens. The holotype (UF/FGS 5867) and paratype (UF/FGS $1167)$ were lost in the 1920s. MacFadden and Waldrop (1980) selected UF 17570 as the neotype; it consists of an associated left P3-M3 and right M2-M3.

Neotype locality. Palmet to Mine, Polk County, Florida. 
Stratigraphic occurence and age of the neotype locality. Upper horizon of the Bone Valley Formation; very late Hemphillian (early Pliocene), about 4.5 to $5.0 \mathrm{ma}$.

Distribution. Early, but not earliest, Hemphillian of Florida; late Hemphillian of southern North America (nor thernmost records are from the Texas Panhandle).

Referred Florida specimens. Moss Acres Racetrack Site: UF 69933/69934 assoc. R P3, P4, M2, M3 and L P4, M2, M3; $R$ and $L$ mandibles with p2-m3; and post-cranial elements (Table 12); UF 69935/69936 assoc. $R$ maxilla with P2-M3; premaxillae with $R$ and $L$ I1-I3; L mandible with $\mathrm{p} 2-\mathrm{m} 3 ; \mathrm{R} \mathrm{p} 3$; and post-cranial elements (Table 12); 92994 L P34; 95409 assoc. $R$ m2-m3; 95404 L m12; 69955 assoc. $R$ and $L$ juvenile hindlimbs (Table 12); 97263 assoc. $R$ and L MT III and tarsal elements; 69954 L femur; 95465 L distal MC III; $95406 R$ distal tibia.

Dunnellon Phosphate Mines: UF/FGS V-1424 M12; -1492 p34; -1429 m12.

With 4A: UF $18311 \mathrm{~L}$ maxilla with P3-M2; 17202, 53522, 63645, 63646 P34s; 19618, 53520, 53521, 53523, 53546, 53547, 63649 M12s; 63647, 63650 M3s; 45512, 45513 DP34s; 17304, 95368 p2s; 95369-95373, 95375 p34s; 17307, 53488, $53489 \mathrm{~m} 12 \mathrm{~s} ; 45516 \mathrm{m3} ; 45584$ MT III.

Manatee Dam Site: UF 11929 P4(?); 11933 DP34; 11924-11926 p34s.

Lockwood Meadows Site: UF 61459, 64117 P34s; 61460, 61462, 61463 p34s; 61457, 61458, 61461 m12s; 61456, $61465 \mathrm{~m} 3 \mathrm{~s}$.

Palmetto Fauna, Bone Valley Region: UF 67000 Taterally crushed rear half of sku11 with R M2-M3 and L M3; 57576 partial L maxilla with L M1-M3; UF 17249, 19431-19433, 24701, 63626, 63959, 63960, 
67980, 68976, 91206 P2s; F:AM 113760, UF/FGS V-1426, UF 14988, 17250 , $17251,17276,19435,47368,55822,55891,57214,57312,58382,63628$, $63629,63965,63966,63978-63980,64156,64157,67982,91211,93224$, 93252, 93253 P34s; F:AM 113761, 113763-113765, UCMP 130132-130134, UF $10313,17252,17253,17264,17267,17279,17281,19434,47362$, 47364-47366, 47370-47372, 53843-53845, 53952, 53953, 55893, 55933, $57215,58296,58381,58409,61992,62030,63627,63630-63633$, $63961-63964,63967,63968,63977,64174,65796,67981,67983,90385$, 91210, 91207, 91208, 93222, 93225, 93232, 93240, 93241 M12s; UF $10300,12056,17183,17254,17290,19436,25710,32017,40082,47369$, $57216,57217,57394,58481,62014,63635,63969-63976,65717,65794$, 68994, 91209, 91212, 91214, 93209, 93233 M3s; UF 17255 DP34s; UF 65176 R mandible with p3-m3; UF 17273 R mandible with p4-m1; UF 69903 (cast of TRO 567) L mandible with p2-m3; UF $57213 \mathrm{~L}$ mandible with p2-p4; UF 97360 mandibular symphysis with $R$ and L i1-i3; UF 10310, $17629,53878,61486,61487,61489,65178,65179,65201$ p2s; UF 13219, $17270,17277,24710,28855,28856,52432,52433,53954,61304$, $61490-61495,65180,65182,65192-65198,65212,65223,65228-65230$, 68959-68962, 68978, 69911, 91213, 93226 p34s; UF/FGS V-6608, -6610, $-6611,-6615$, UF 10299, 10303, 12500, 17271, 17274, 17293, 21028, 24702, 24702, 24704, 24706, 24708, 24712, 28854, 52434, 53955, 57218, $58482,61496,62032,65183-65191,65202-65204,65210,65211$, $65214-65219,65227,68977,69912,93234,93235,93254 \mathrm{~m} 12 \mathrm{~s}$; UF 10313, $17272,17280,17394,18914,24698,24699,24703,24709,61497,62031$, 65205-65209, 65213, 65220-65222 m3s; UF 69905, $69906 \mathrm{dp} 2 \mathrm{~s}$; UF 17275, $53959,61488,61499,69649,69650,93255$ dp $34 \mathrm{~s}$; UF 53905, 53906, 
53964, 57344, 61983 proximal MC III; UF 53926, 57395 proximal MT III; UF 53931 distal MT III.

Revised diagnosis. Smallest species of Nannippus with trl of 82 to $95 \mathrm{~mm}$; mean M12 TRW $13.7 \mathrm{~mm}$; unworn M12 MSCH 51 to $53 \mathrm{~mm}$. Protostylids very reduced or absent on most permanent lower cheekteeth; if present not isolated from protoconid as in Nan. lenticularis. Ectostylids absent on dp2-dp4. Isthmus and paralophid plications frequent. Hypoconal groove shallow, usually remains open until late wear-stages, does not form isolated lake.

Description. The following dental description is based on the topotypic Bone Valley sample of Nan. minor. The Yepomera and El Ocote samples have been described by Lance (1950), Mooser (1968), Sondaar (1968), Dalquest and Mooser (1980), and MacFadden (1984a). The Mexican populations are similar to that from Florida (Tables 13, 14), and I follow Waldrop (1971) and MacFadden (1984a) in considering them conspecific. 01der, early Hemphillian samples (which include associated cranial and post-cranial material) referred to Nan. minor are described in a following section and compared to the late Hemphillian population. Originally described based on a single tooth (now lost), Nan. minor from the Bone Valley was poorly known through the first half of this century. Over the past 20 years, extensive field operations and generous donations by amateurs to the Florida State Museum have resulted in the recovery of over 200 specimens. Most of these are isolated cheekteeth, but a few more complete specimens are now known, including a partial skull (UF 67000) and one complete lower toothrow (UF 69903). Unfortunately, UF 67000 does not preserve any portion of the skull anterior to the orbits, and it has 


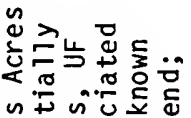

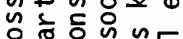

之艺出芯

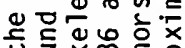
+ ㅌㄴ

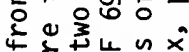

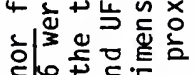

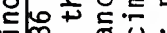
E祭 ง 을 둥 \% 임 응 용 등 등 元

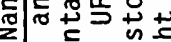
$2 \frac{5}{4}$ 的市 ○ ติ: ๙ n

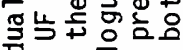
둥휴 중 드 동 的 은

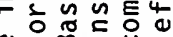
음도용

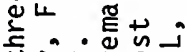

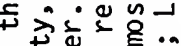
收紊的近 웅다. + ᄃ 등등ㄴㅇ 을요 웜

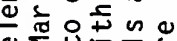
$0 \sum \frac{1}{2} \frac{1}{6}$

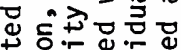

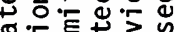

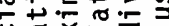
응 뚱므 은 잉드 든

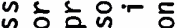
ه 낭 थ 운

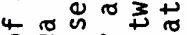
얼 음 >ㄴำ जै ปัำ = ำ

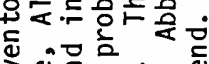

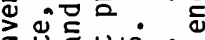
듀 ง 용 유 - 뻥

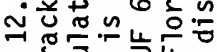

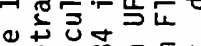

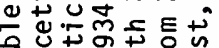
ฮิ

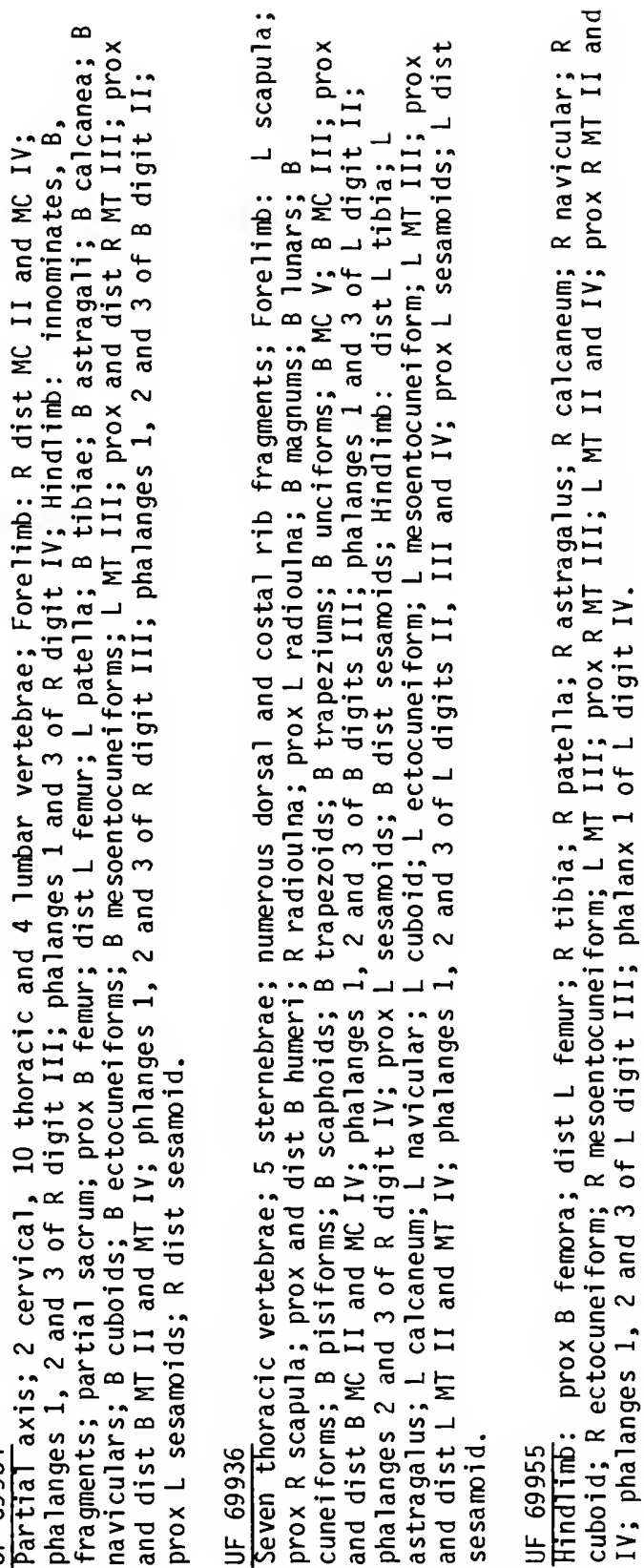


Table 13. Standard univariate statistics for upper cheekteeth of Nannippus minor. Format as in Table 2. Populations are W4A, Withlacoochee River Site 4A, Florida; UBV, Palmetto Fauna, Bone Valley Region, Florida; and YEP, Yepomera localities, Chihuahua, Mexico. No P2s are present in the Withlacoochee River 4A sample.

\begin{tabular}{|c|c|c|c|}
\hline \multirow{2}{*}{ FAUNA } & W4A & UBV & YEP \\
\hline & \multicolumn{3}{|c|}{ P2 } \\
\hline APL & ---- & $\begin{array}{l}16.8,1.29,9 \\
15.0-18.9,7.69\end{array}$ & $\begin{array}{l}16.1,0.92,13 \\
14.9-18.1,5.68\end{array}$ \\
\hline BAPL & ---- & $\begin{array}{l}13.6,0.69,6 \\
12.7-14.5,5.05\end{array}$ & $\begin{array}{l}13.2,0.63,12 \\
12.4-14.4,4.73\end{array}$ \\
\hline TRW & ---- & $\begin{array}{l}13.4,0.80,9 \\
12.3-14.6,5.94\end{array}$ & $\begin{array}{l}14.8,0.64,13 \\
13.7-15.8,4.29\end{array}$ \\
\hline PRL & ---- & $\begin{array}{l}4.3,0.34,9 \\
3.8-4.9,7.90\end{array}$ & $\begin{array}{l}4.4,0.46,13 \\
3.6-5.3,10.37\end{array}$ \\
\hline \multirow[t]{2}{*}{ PRW } & --- & $\begin{array}{l}3.1,0.29,9 \\
2.8-3.6,9.41\end{array}$ & $\begin{array}{l}3.6,0.21,13 \\
3.3-3.9,5.65\end{array}$ \\
\hline & \multicolumn{3}{|c|}{ P34 } \\
\hline APL & $\begin{array}{l}13.9,1.49 .6 \\
12.0-16.0,10.73\end{array}$ & $\begin{array}{l}14.9,1.22,25 \\
11.6-17.3,8.22\end{array}$ & $\begin{array}{l}14.7,1.01,35 \\
13.1-16.8,6.86\end{array}$ \\
\hline BAPL & $\begin{array}{l}11.7,1.31,4 \\
9.8-12.8,11.27\end{array}$ & $\begin{array}{l}11.6,0.90,20 \\
10.1-13.4,7.74\end{array}$ & $\begin{array}{l}11.8,0.41,32 \\
10.9-12.7,3.51\end{array}$ \\
\hline TRW & $\begin{array}{l}14.2,1.42,6 \\
12.3-15.5,10.02\end{array}$ & $\begin{array}{l}14.5,0.82,25 \\
12.7-15.9,5.62\end{array}$ & $\begin{array}{l}15.2,0.67,34 \\
13.8-16.5,4.37\end{array}$ \\
\hline PRL & $\begin{array}{l}5.0,0.92,6 \\
4.2-6.3,18.45\end{array}$ & $\begin{array}{l}4.4,0.50,28 \\
3.6-5.5,11.44\end{array}$ & $\begin{array}{l}5.4,0.48,35 \\
4.6-6.4,8.96\end{array}$ \\
\hline PRW & $\begin{array}{l}2.9,0.41,6 \\
2.4-3.4,13.92\end{array}$ & $\begin{array}{l}3.0,0.30,26 \\
2.5-3.8,9.99\end{array}$ & $\begin{array}{l}3.7,0.24,35 \\
2.7-3.9,6.41\end{array}$ \\
\hline
\end{tabular}


Table 13--continued

\begin{tabular}{clll}
\multicolumn{4}{c}{$M 12$} \\
APL & $13.9,2.01,10$ & $14.7,0.94,45$ & $14.2,1.09,39$ \\
& $11.7-17.8,14.48$ & $12.6-16.7,6.39$ & $12.1-17.0,7.71$ \\
BAPL & $10.8,1.31,6$ & $11.3,1.30,26$ & $11.2,0.43,35$ \\
& $8.7-12.3,12.10$ & $9.6-14.0,10.38$ & $10.3-12.1,3.84$ \\
TRW & $12.9,1.37,9$ & $13.7,1.10,43$ & $14.3,0.52,39$ \\
& $11.3-15.5,10.63$ & $11.2-16.1,8.06$ & $13.5-15.7,3.64$ \\
PRL & $5.0,0.82,9$ & $4.7,0.51,46$ & $5.5,0.50,39$ \\
& $4.2-6.6,16.32$ & $3.6-5.6,10.91$ & $4.6-6.8,9.13$ \\
PRW & $2.6,0.33,10$ & $2.9,0.26,48$ & $3.5,0.17,39$ \\
& $2.1-3.2,12.57$ & $2.4-3.5,9.14$ & $3.0-3.8,4.69$
\end{tabular}


A

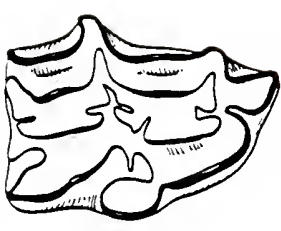

$\mathrm{D}$

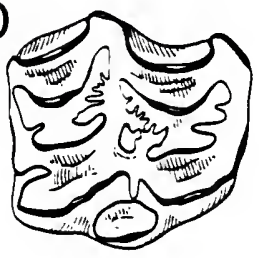

$\mathrm{G}$

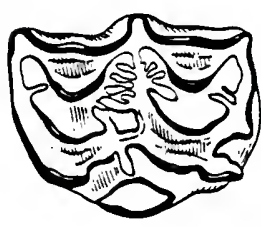

$\mathrm{B}$

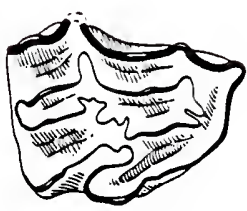

$E$

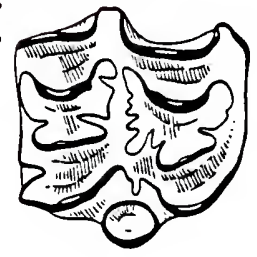

$\mathrm{H}$

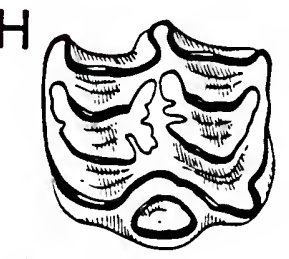

$1 \mathrm{~cm}$
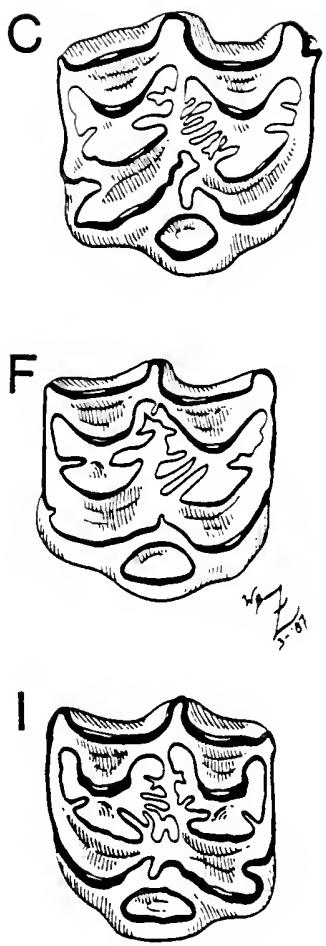

Figure 15. Occlusal views of upper cheekteeth of Nannippus minor from the Palmetto Fauna (latest Hemphillian), Bone Valley Region, Polk County, Florida. A. UF 63626, R P2, early wear-stage. B. UF 67980 , R P2, late wear-stage. C. UF 63628 , R P34, early moderate wear-stage. D. UF $17250, \mathrm{R}$ P34, moderate wear-stage. E. UF 63978, R P34, late moderate wear-stage. F. UF 67981, R M12, early moderate wear-stage. G. UF $47362, \mathrm{~L} \mathrm{M12}$, early moderate wear-stage. H. UF 67983, L M12, late moderate wear-stage. I. UF 90385, L M12, late moderate wear-stage. 


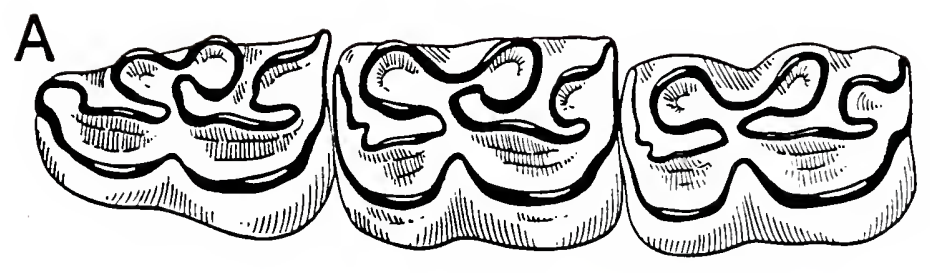

$B$
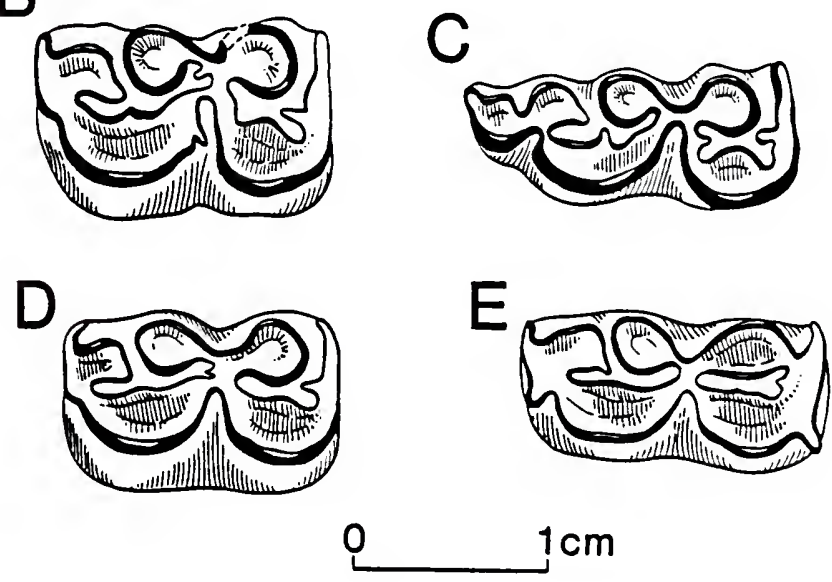

Figure 16. Occlusal views of lower cheekteeth of Nannippus minor from the Palmetto Fauna (latest Hemphillian), Bone Valley Region, Polk County, Florida. A. UF 57213, associated L p2-p4, moderate wear-stage. B. UF 53954, R p34, moderate wear-stage. C. UF 93235, $\mathrm{R} \mathrm{m} 12$, early wear-stage. D. UF $65192, R \mathrm{ml2}$, moderate wear-stage. E. UF 17275, R dp34, late wear-stage. 
been laterally crushed and deformed. No measurements taken on the specimen would realistically conform to its original dimensions.

The P2s of Nan. minor (Fig. 15; Table 13) have very poorly developed anterostyles and have relatively short APLs and BAPLS. The pseudoparastyle is prominent. The oval protocone connects to the protoselene during very early wear-stages (Fig. 15A); the connection remains tightly constricted by the pre- and postprotoconal grooves until the tooth is heavily worn. The pli caballin is long, narrow, and usually single. Fossette complexity is moderate to high, but most plications are shallow and not bifurcated. Unworn MSCH is about $34 \mathrm{~mm}$.

The P3 and P4 are characterized by round (Figs. 15C, 15E) to slightly oval (Fig. 15D) protocones that lack spurs and remain isolated until MSCHs of $14 \mathrm{~mm}$ or less; strong, grooved parastyles; better developed metastyles than Nan. Westoni; usually single, well developed pli caballins; open, usually shallow hypoconal grooves; and moderate to very complicated fossettes (Figs. 15C-15E). A single pli protoloph and pli hypostyle are usually retained until MSCHs of less than $20 \mathrm{~mm}$, and the anterior half of the prefossette may also bear one or two additional plications in early wear. The posterior half of the prefossette generally has three to six plications (eight maximum) in early to moderate wear-stages, one or two in heavily worn teeth. The anterior half of the postfossette has two to four plications. Unworn P34 MSCH is about 45 to $47 \mathrm{~mm}$. The DP34 have sma11, oval protocones; strong, bifurcated parastyles; and moderately complex fossettes. 
The M1 and M2 are only slightly smaller than the P34 (Table 13), with relatively longer protocones, smaller hypocones, pli caballins often reduced or absent, and weaker metastyles (Figs. 15F-15I). Fossette complexity varies greatly; some molars resemble the P34 and are complex (Figs. 15G, 15I), others are noticably simpler at comparable crown heights (Figs 15F, 15H). The pli protoloph and pli hypostyle are often present but are absent more frequently than in the P34. Protocones begin connecting to the protoselene at MSCHs of about $10 \mathrm{~mm}$. Unworn M12 MSCH of this species does exceed $50 \mathrm{~mm}$ (contra MacFadden and WaIdrop, 1980 and MacFadden, 1984a), but complete specimens are rare (due to breakage). The tallest measurable Bone Valley specimens are UF $93240(\mathrm{MSCH}=45.7 \mathrm{~mm})$ and $\mathrm{F}: \mathrm{AM}$ $113762(48.1 \mathrm{~mm})$; both are worn with fully formed postfossettes, implying that unworn molars would be at least 3 to $5 \mathrm{~mm}$ taller. Two specimens with wear from Yepomera, LACM (CIT) 3759 and 3784, each have MSCHs exceeding $50 \mathrm{~mm}$.

The only known specimen from the Bone Valley Region that preserves the mandibular symphysis and lower incisors is UF 97360. Collected in 1983 in association with typical Upper Bone Valley Fauna elements, it is referred to Nan. minor because of its small size. The maximum transverse width across the $i 3 s$ is $43.1 \mathrm{~mm}$. At its early wear-stage, the infundibula are large and completely formed on the $i 1$ and $i 2$. Those of the $i 3$ are incomplete ("half infundibulum" of Bennett, 1980). The incisors plesiomorphically resemble those of other hipparionines (e.g. Cormohipparion) rather than the extremely procumbent lower incisors of Nan. peninsulatus and Nan. beckensis (Dalquest and Donovan, 1973; MacFadden and Waldrop, 1980). 
Table 14. Standard univariate statistics for lower cheekteeth of Nannippus minor. Format as in Table 2. Populations are UBV, Palmetto Fauna, Bone Valley Region, Florida; and YEP, Yepomera localities, Chihuahua, Mexico, both of latest Hemphillian age.

FAUNA

apl

bap1

atw

ptw

$\mathrm{mm}]$

ent 1

apl

bapl

atw

ptw

$\mathrm{mml}$

ent 1
UBV

YEP
$14.9,1.05,7$

$13.1-16.3,7.08$

$11.8,0.23,3$

$11.7-12.1,1.95$

$6.2,0.41,7$

$5.5-6.7,6.60$

$7.7,0.21,8$

$7.3-7.9,2.80$

$7.0,0.55,10$

$5.9-7.6,7.95$

$7.3,0.78,10$

$5.9-8.7,10.70$

p34

p2

$14.8,0.57,11$

$13.6-15.4,3.87$

$11.8,0.38,10$

$11.3-12.6,3.25$

$7.0,0.39,11$

$6.7-8.0,5.51$

$8.5,0.37,11$

8.0-9.2,4.33

$7.7,0.46,11$

$7.0-8.4,5.96$

$6.2,1.02,11$

$4.0-7.2,16.45$

$14.4,1.21,35$

$12.6-17.1,8.38$

$15.4,0.87,10$

$14.6-17.3,5.62$

$11.3,0.74,20$

$11.7,0.78,6$

$10.0-12.7,6.51$

$10.6-12.9,6.66$

$8.1,0.70,32$

9.3,0.84, 9

$6.5-9.5,8.67$

$8.0-10.3,9.10$

$7.9,1.24,32$

$6.8-13.9,15.7$

$9.0,0.39,10$

$8.6-9.8,4.33$

$8.9,0.63,36$

$7.2-10.4,7.04$

$10.2,0.50,10$

$9.6-11.0,4.90$

$6.7,0.99,36$

$3.5-8.1,14.74$

$6.4,1.00,10$

$4.5-7.6,15.74$ 
Table 14--continued

ap 1

bap1

atw

ptw

$\mathrm{mm} 1$

ent 1 $\mathrm{m} 12$

$15.1,1.57,40$

$12.3-18.4,10.44$

$14.7,1.63,14$

$12.9-18.5,11.09$

$10.8,0.73,15$

$9.4-12.0,6.71$

$11.0,0.58,13$

$9.9-11.9,5.23$

$6.9,0.47,36$

$5.6-7.9,6.76$

$8.1,0.66,15$

$6.6-9.2,8.18$

$6.4,0.48,39$

$5.5-7.7,7.60$

$7.3,0.56,15$

$6.2-8.5,7.56$

$8.6,0.52,42$

$7.8-9.8,5.99$

9.3,0.47,15

$8.4-10.1,5.06$

$5.5,0.79,42$

$4.2-7.6,14.24$

$4.7,1.36,15$

$3.2-8.3,29.09$ 
Lower cheekteeth of Nan. minor have large, oval, expanded metaconids and metastylids (Table 14); shallow, broadly " $V$ "-shaped (occasionally "U"-shaped) linguaflexids; rounded labial borders; and relatively simple enamel (Fig. 16). Pli caballinids are limited to slightly worn teeth, and are much less prominent than in Neo. eurystyle or Cor. emsliei from the same fauna. Isthmus plications are less common than in these two species, but are more frequent than in Nan. westoni. However, most lowers (e.g. 32 of $36 \mathrm{p} 34 \mathrm{~s}$ ) have a plicated paralophid. The ectoflexid is shallow in premolars and very slightly worn molars; usually the ectoflexid of the molars rapidly penetrates the entire isthmus, but in some it remains shallow (Fig. 160). The entoconid is smaller relative to the metastylid than in Nan. westoni. The protostylid is variably expressed in the Bone Valley sample, with three morphs observed: 1) those with relatively strong protostylids running most of the length of the crown; 2) those with very rudimentary protostylids restricted to near the base of the crown; and 3) those with no trace of a protostylid. Of 33 Bone Valley $p 3$ and p4s, morph 2 is most common $(n=21)$, while 11 are of morph 3, and only one specimen (UF 61492) shows morph 1. A combined sample of lower molars (m1-m3, $n=56)$ has 5 with morph 1,18 with morph 2, and 33 with morph 3. Unworn mech are similar to those of the upper cheekteeth. For example, UF 65203, a slightly worn $\mathrm{ml}$ has a mcch of $50.9 \mathrm{~mm}$, and UF 12500, a worn $\mathrm{m} 2$, has a mcch of $50.7 \mathrm{~mm}$.

The Bone Valley sample includes a number of lower deciduous premolars (Fig. 16E). They are very high crowned, with unworn mcchs of about $24 \mathrm{~mm}$ for the $\mathrm{dp} 34$. The $\mathrm{dp} 2 \mathrm{~s}$ have shorter ap1 and bap1 than 
the dp34, and bear strong pli caballinids. No pli caballinids are observed on the dp34s. The metaconid-metastylid complex is very elongated, and the ectoflexid is typically shallow. A protostylid is present on all dp34s, but it is reduced and rises to variable heights on the crown ( 10 to $18 \mathrm{~mm}$ ). None of the specimens bears an ectostylid.

Post-cranial elements of Nan. minor are poorly represented from the Bone Valley, and only a few broken metapodials are confidently referred to the species. Four relatively complete metacarpals and a metatarsal are known from the Yepomera Fauna. These elements are 20 to $30 \mathrm{~mm}$ shorter than those of $\mathrm{Nan}$. westoni (Table 11), but have similar proximal, midshaft and distal widths. The two unciform facets of the MC III are merged to form one continuous surface (Fig. 14A). Description of Early Hemphillian Nan. minor from Florida. The sample of Nannippus from Moss Acres is intermediate in size and crown height between Nan. westoni and the Bone Valley sample of Nan. minor (Table 8; Figs. 14C-14D, 14F-14G, 17, 18). The approximate UTRL of UF 69935 is $95 \mathrm{~mm}$. The slightly worn P4, M2, p4 and m2 of UF 69933 indicate that the unworn crown heights for this population would have been about $40 \mathrm{~mm}$ for premolars and $45 \mathrm{~mm}$ for molars. UF 69933 and 69935 are referred to Nan. minor (rather than Nan. westoni) because they display the following characters: very reduced P2 anterostyle; lack of protoconal spur in slightly worn premolars; relatively complex fossettes; protostylid absent or very rudimentary; and we 11 developed isthmus and paralophid plications. The maxillary fragment of UF 69935 preserves some of the preorbital facial region (Fig. 17), although it is crushed and fragmented. The IOF is small and located 


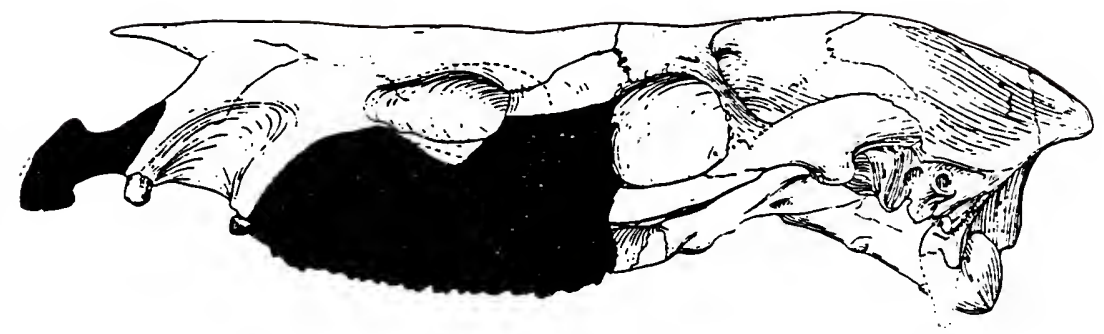

Figure 17. Schematic lateral view showing the area of the facial region preserved (darkened area) on UF 69935, Nannippus minor from the Moss Acres Racetrack Site, Marion County, FTorida. The specimen is too poorly preserved to be illustrated, but does indicate the presence of a well developed DPOF in this species. See Figure 18A and $18 \mathrm{~F}$ for occlusal views of the cheekteeth of this individual. 


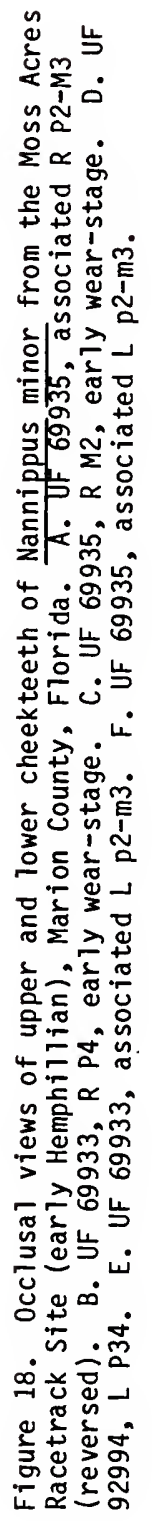




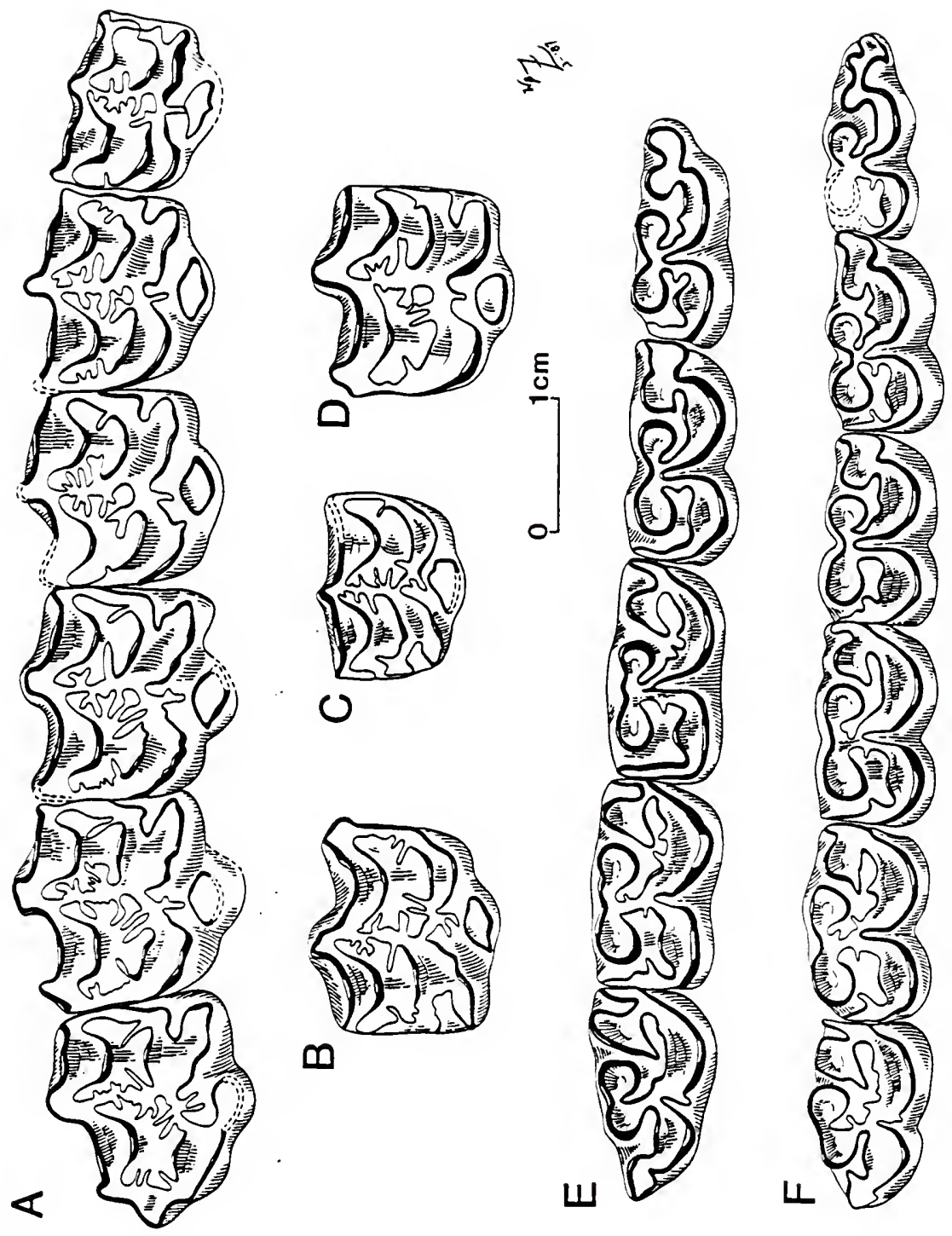


posteriorly, dorsal to the P4 parastyle, about $27 \mathrm{~mm}$ above the alveolar margin. There is no trace of a DPOF immediately dorsal to the IOF (as in Nan. fricki). However, part of the posteroventral margin of the DPOF is present located about $40 \mathrm{~mm}$ anterior of the orbit. It is difficult to discern how for dorsally the DPOF is above the toothrow (because of the crushing), but it was probably located much higher on the face than in Nan. fricki. It is impossible to judge its exact dimensions, but it was undoubtedly smaller than in Nan. fricki.

The Moss Acres sample of Nan. minor includes three partial associated skeletons (Table 12), and several isolated post-cranial elements. Two of the skeletons (UF 69934 and 69936) were directly associated with the dental and cranial elements described above, and are therefore readily identifiable. The other specimens were referred to Nan. minor because of morphologic similarity to the se two individuals. A comprehensive descriptive osteology of these specimens is beyond the scope of this review, and only a few points of importance are noted. Just as the teeth are intermediate in size between Nan. westoni and late Hemphillian samples of Nan. minor, so too are the metapodials (Table 11). The MC III morphologically resemble the latter in their small proximal breadth relative to proximal width (Fig. 14C; Table 11). The two unciform facets are partially fused into one, especially on the right MC III. The entocuneiform and cuboid facets are well developed on the MT III, and the distal depression on the anterior face of the shaft is very shallow. UF 69936 includes the wrist bones of both sides, and each 
has a rudimentary fifth metacarpal (MC V) and trapezium. The trapezium is an irregular, fusiform bone about $8.4 \mathrm{~mm} 10 \mathrm{~g}$, with an articular surface bearing two facets of unequal size at the proximal end. The larger facet, which is slightly convex, articulates with a posterior depression on the trapezoid. The smaller facet is for articulation with a similarly sized area on the distal face of the scaphoid. The $M C V$ is also fusiform, $11.1 \mathrm{~mm} 10 \mathrm{ng}$, and bears a single, small $(2.9 \mathrm{~mm}$ in diameter) facet for articulation with the $M C$ IV. Articulation of the MC $V$ with the MC IV (instead of with the unciform) in Nannippus resembles the condition described by Sondaar (1968, p. 53) for Neohipparion, and differs from Dinohippus. The absence of a MC V and trapezium have long been considered "generic characters" of Nannippus (Matthew, 1926; Sondaar, 1968), although these observations are based on relatively few specimens. Both elements can be variably expressed in quarry samples of advanced equids (Sondaar, 1968, Table 6).

The slightly younger With 4A sample of Nan. minor consists primarily of isolated teeth. The maxilla (UF 18311) is from a very old individual, similar to the type of Nan. westoni. Its teeth are much smaller in occlusal dimensions than UF/FGS V-4088 (Table 13), and the P3-M2 length is $51.5 \mathrm{~mm}$. That of UF/FGS V-4088 is $58.5 \mathrm{~mm}$. The APL, TRW and BAPL of the with $4 A$ sample have extremely high $\underline{V}$ (Table 13). These are not just due to the small sample sizes, but truely reflect the variability of the sample. Some specimens (e.g. UF 19619) are larger than any observed in the Bone Valley sample, others (e.g. UF 53523) are smaller. Specimens smaller in occlusal dimensions than average Bone Valley individuals are more abundant, 
thus the entire sample has smaller mean values. The only major differnce in enamel morphology between the With $4 \mathrm{~A}$ and Bone Valley samples is that some lower premolars have relatively strong $p l i$ caballinids that persist until moderate wear-stages (e.g. UF 95368 , 95371). Others (e.g. UF 95370) do not have pli caballinids, and match those from Moss Acres and the Bone Valley. A heavily worn dp2, UF 45514 , is of appropriate size to represent Nan. minor. It has a shallow ectoflexid and lacks an ectostylid. Most (10 of 12) lower cheekteeth of the With 4 A sample either lack a protostylid, or only have a very reduced one.

Discussion. As noted by MacFadden (1984a), Nan. minor is referable to Nannippus based on its small size, hypsodont cheekteeth, poorly developed $\mathrm{P} 2$ anterostyle and p2 paraconid, and slender metapodials. Lower cheekteeth of Nan. minor generally either lack protostylids, or have rudimentary ones at the base of the crown. In this they resemble Nan. peninsulatus and Nan. beckensis, as well as in the lack of an ectostylid on the lower deciduous premolars. The distribution of Nan. minor is concentrated in the southern half of North America (MacFadden, 1984a), with its northern-most records in the Texas Panhandle, where it is exceedingly rare. Its distribution is approximately parapatric with that of Nan. lenticularis, the typical Nannippus of the Great Plains.

Genus Cormohipparion Skinner and MacFadden, 1977

Cormohipparion SKINNER AND MACFADDEN, 1977, p. 917. 
Type species. Cormohipparion occidentale (Leidy), 1856.

Included North American species. Cor. sphenodus (Cope), 1889 ;

Cor. plicatile (Leidy), 1887, n. comb.; Cor. ingenuum (Leidy), 1885, n. comb.; and Cor. emsliei n. sp.

Revised diagnosis. Medium to large-sized hipparionines with prominent, oval or tear-drop shaped, generally deep DPOFs with well developed, usually continuous anterior rims; other margins also well defined; positioned far anteriorly from orbit. Advanced lineages in both 0ld and New World independently reduce DPOF. Upper cheekteeth generally with large DP1 retained with adult dentition; protocone isolated (except P2) until very late wear, usually oval or elongate-oval in shape; P2 anterostyle well developed and P2 much longer than other cheekteeth. In advanced species (excluding "Cor." goorisi), pli caballin prominent, usually bifurcated, multiple, or both; fossettes moderately to very complicated, with persistent plis protoloph and hypostyle, and well developed prefossette loop; styles strong, parastyle frequently grooved. Lower cheekteeth have large, well separated, oval or angular metaconids and metastylids; usually well developed protostylids (absent on p2) and plicated isthmuses; pli caballinids variably developed, become more prominent and persistent in younger species. Paraconid of p2 relatively expanded. Ectostylids prominent on dp2-dp4. [Modified after MacFadden, 1984a.] Discussion. Skinner and MacFadden (1977) described Cormohipparion as a new genus of hipparionine equid, and assigned both New and 01d World species to their new taxon. This led to renewed, sometimes spirited discussions on the phylogenetic relationships of 0ld and New World hipparionines that are still ongoing (e.g. MacFadden 1980; 
1987; MacFadden and Skinner, 1981; 1982; MacFadden and Woodburne, 1982; Woodburne and Bernor, 1980; Eisenmann, 1981; Woodburne et al., 1981; Woodburne and MacFadden, 1983; For sten, 1982; 1983; 1984; Bernor and Hussain, 1985; Eisenmann et al., 1987). Several conclusions can be drawn from these works. 1) While there is no genera 1 concensus on how many genera of hipparionines there are in the 01d World Copinions range from one to at least three and possibly many more), there probably are several monophyletic supraspecific groups. Opinions also vary as to whether each of these represents independent immigration events from North America, or if some genera evolved in the old World from in situ ancestors. 2) Opinions on the number of immigration events from the New World vary from one (Bernor and Hussain, 1985) to two (MacFadden, 1980; 1984a) to three (Woodburne and MacFadden, 1983). 3) The oldest 0ld World hipparionines (Group 1 of Woodburne and Bernor, 1980 and other authors) are probably closely related to New World species now placed in Cormohipparion. Finally, 4) there has yet to be a cladistic analysis of 01d World species, preventing recognition of natural monophyletic taxa. For these reasons some workers prefer not to use generic names with certain species, as future revisions may show that they used incorrect binomial combinations. Bernor and Hussain (1985) placed Hippotherium primigenium (von Meyer) among the Group 1 hipparionines. Earlier, Woodburne and Bernor (1980) had cautioned against refering this old name to any group because no cranial material is known from its type locality. Bernor and Hussain (1985), however, applied the name to cranial material from Howenegg, Germany. They noted the possibility that Cormohipparion might be a junior 
synonym of Hippotherium Kaup, although more study was needed before such a synonymy could be formally proposed. One would prefer that before such a step were taken, that topotypic material of $\underline{H}$. primigenium would be illustrated, it should be shown that the species name is valid (i.e. the holotype is valid for comparative purposes), and that cranial material can be confidently referred to the species. I propose to use Cormohipparion (at least for New World species) until a thorough phylogenetic (i.e. cladistic) appraisal of 01d World taxa is presented. Only then can generic and subgeneric names be rigorously delineated. "Cor." goorisi, however, must be excluded from Cormohipparion, as it is the sister-taxon to both Nannippus and Cormohipparion (see Chapter 6). Ironically, Forsten (1984) has taken the opposite approach, and redefined Cormohipparion to include on ly its merychippine grade elements (i.e. "Cor." goorisi), and excluded those that are of hipparionine grade. This of course is invalid under the rules of zoological nomenclature, as it excludes the type species from its genus (Cor. occidentale in this case).

\section{Cormohipparion sphenodus (Cope), 1889}

Hippotherium sphenodus COPE, 1889, pp. 449-450.

Merychippus sphenodus (Cope), GIDLEY, 1907, p. 908; OSBORN, 1918, pp. 112-114; STIRTON, 1940, p. 181; GALBREATH, 1953, p. 105.

Cormohipparion sphenodus (Cope), WOODBURNE et a1., 1981, pp. 503-514; MACFADDEN, 1984a, pp. 156-162. 
Type specimens. Lectotype, AMNH 8281, a R P2; a L P34 (a Tso AMNH 8281 ) is the paratype (see discussion in Woodburne et al., 1981). Type locality. Pawnee Buttes, Logan or Weld County, Colorado. Stratigraphic occurrence and age of the type locality. Pawnee Creek Formation; late Barstovian (about 13 to $14 \mathrm{ma}$ ).

Distribution. Late Barstovian through early Clarendonian (about 11 to $15 \mathrm{ma}$ ) of California, New Mexico, Colorado, South Dakota, Nebraska, Texas and south-central Florida (revised after MacFadden, 1984a).

Referred Florida Gulf Coastal Plain specimens. Agricola Fauna, Bone Valley Region. Red Zone, Phosphoria Mine: UF 28432, $284332 \mathrm{R}$ M12; 28434 L M12; 28435 L M3; 28436 L P34; 28459 L p2; 28448, 284582 R p34; 28460, 28475, $284763 \mathrm{~L} \mathrm{p34;28453} \mathrm{R} \mathrm{m12;} \mathrm{28446,} 284472$ R m3; Gray Zone, Phosphoria Mine: UF 28683 L P2; 28556 R P34; 28555 L P34; 28557 R M3; 28558 R M1(?); 28567 L p34; 28568, 28569 2 R m12; 28583 R dp34; and Silver City Mine: UF 65706 L P34.

Revised diagnosis. Medium-sized, moderately hypsodont hipparionine with a TRL of about $126 \mathrm{~mm}$. Unworn MSCH of P2 about 30 to 35 $\mathrm{mm}$. DPOF moderately pocketed. Protocones oval with poorly developed anterior spur in early wear-stages. Fossettes complex, but relatively simple for the genus, especially the opposing borders of the prefossette and postfossette. P1i caballinids moderately developed in premolars and poorly developed or absent in molars. [Slightly modified after MacFadden (1984a, p. 156); note that his "MIMSTHT" should read "P2MSTHT."]

Description and discussion. Both the Red and Gray Zones from the Phosphoria Mine produced a medium-sized hipparionine referable to the 
widely distributed Cor. sphenodus. As the sample is too limited for statistical analysis, Table 15 presents measurements taken on selected specimens. They compare favorably in occlusal dimensions and crown height with data presented by Woodburne et al. (1981) for Cor. sphenodus. Additionally, the Phosphoria Mine samples correspond in almost every detail of enamel morphology of Cor. sphenodus as described and illustrated by Woodburne et al. (1981) and MacFadden (1984a). The protocone is oval or elongate-oval with a rudimentary spur in early wear; it is isolated from the protoselene in all specimens (Figs. 19A, 19C, 190). The hypocone is oriented posterolingually and has a constricted connection to the metaloph. The posterior half of the prefossette and the anterior half of the postfossette are moderately complex, but less so than typical younger samples of Cormohipparion from Florida. In early wear-stages, the lower premolars have moderately developed pli caballinids, shallow ectoflexids, and numerous enamel plications. In later wear-stages (e.g. UF 28460), the ectoflexid penetrates the isthmus past the level of the base of the entoflexid. The protostylid, which comes into wear about $10 \mathrm{~mm}$ below the unworn occlusal surface, is at first isolated (Fig. 19B), but later connects with the protoconid and is a prominent feature. This is also typical for all younger species of Cormohipparion. The well worn deciduous lower premolar (UF 28583) is notable for its large protostylid, ectostylid and hypostylid. Although comparisons are limited by the small sample sizes, Cor. sphenodus from the overlying Gray Zone is slightly more hypsodont, complex and larger than Red Zone specimens (Table 15). Similar observations were made by Woodburne et a1. (1981) concerning 

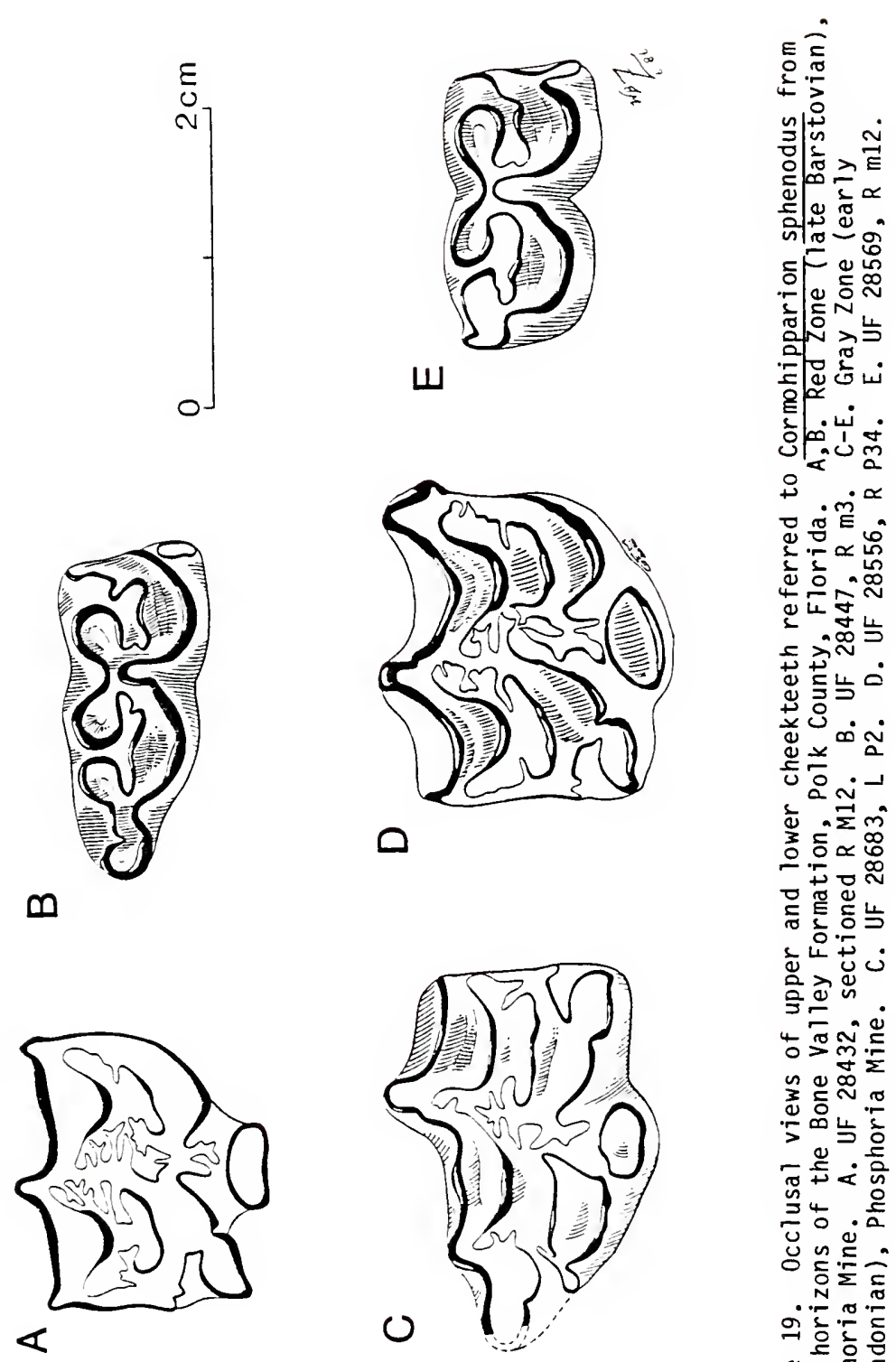

$+$

$\dot{m}^{\alpha}$

몬

此舟

ษ은ㅁำ

닌

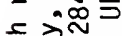

형

路与

这

$\stackrel{\square}{-}$

둥ㄱ-

ఫे

층 ธิ㇒ $\propto$

†

它漚岂

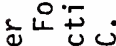

ن

윽 훠

世

$0>m$.

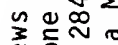

齐告

б市这完

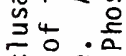

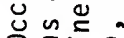

O

. N⿴囗十

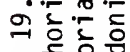

ه 등

ไั่ 的

프느응원 


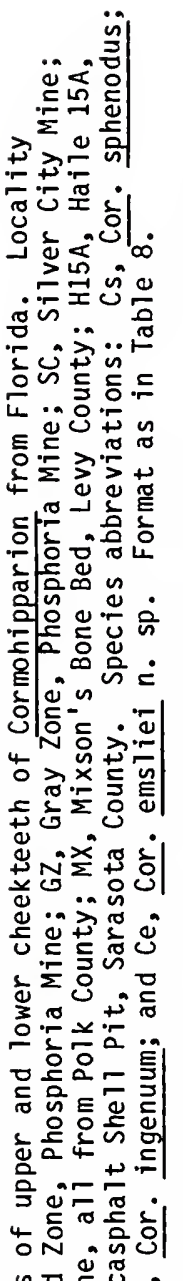

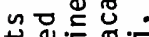

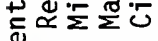

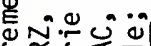

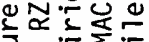

ज...

U i

은 농

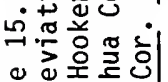

인소닌

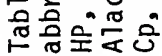

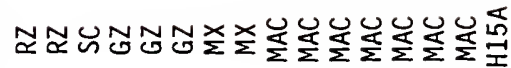

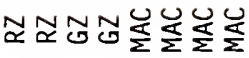

ำ

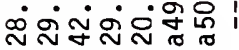

兄 m

등 ํ:

迹

i

$m \infty m \omega$ n $N \infty \infty$ تं $\dot{0} \dot{0} \dot{0} \dot{\circ}$

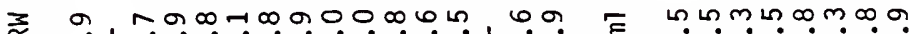
ம |

व

3 茪

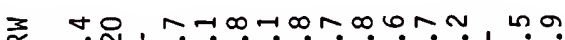

吕 $\quad \infty$ i

录

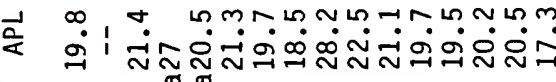

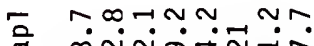
$\pi \pi$

$\infty \underset{\sim}{N} \underset{\sim}{\mathbb{N}} \mathbb{N} \widetilde{N}$

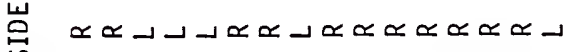

$-\propto \simeq \simeq \propto-\longrightarrow-$ I

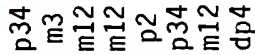

く

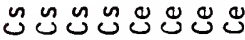

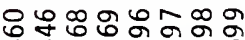
4 ᄂ

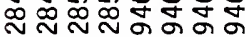

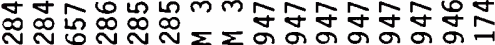

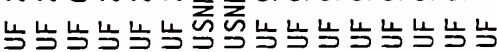


stratigraphically superposed populations of Cor. sphenodus from the Valentine Formation in Nebraska.

Cormohipparion occidenta le (Leidy), 1856

Hipparion occidentale LEIDY, 1856, p. 59 ; OSBORN, 1918 , p. 176. Hippotherium occidenta le (Leidy), COPE, 1886, P. 359 ; COPE, 1889, p. 434 (in part).

Neohipparion occidenta 1e (Leidy), GIDLEY, 1907, p. 877; STIRTON, 1940, p. 182; FORSTEN, 1975, p. 65 (in part).

Cormohipparion occidentale (Leidy), SKINNER and MACFADDEN, 1977, p. 917 ; MACFADDEN, $1984 a$, p. 162.

Type species. ANSP 11287, four $R$ and one $L$ associated upper cheekteeth.

Type locality. Exact locality unknown, Little White River Region, South Dakota, see discussion in Skinner and Taylor (1967).

Stratigraphic occurrence and age of type locality. Probably Ogallala Group; middle Clarendonian, about $10 \mathrm{ma}$.

Distribution. Latest Barstovian to early Hemphillian in the Great Plains, Clarendonian of the Texas Gulf Coastal Plain, Great Basin and California.

Referred Gulf Coastal specimens. Lapara Creek Fauna, Farish Ranch Site, Bee Co., TX: TMM 31081-844 crushed sku11 with R \& L P2-M3. Other specimens as listed by Forsten (1975, pp. 66-67), except those referred to Neo. affine (see above). 
Diagnosis. Largest North American species of Cormohipparion, with toothrow lengths of 130 to $150 \mathrm{~mm}$. Deep, continuously well rimmed, keyhole-shaped DPOF. More higher crowned cheekteeth than Cor. sphenodus. More complexly plicated fossettes than Cor. sphenodus, Cor. plicatile and Cor. ingenuum (on average, at comparable wearstages). Ectostylids on dp34 oval and larger than those of other North American species.

Description. TMM 31081-844 is notable as the only cranial material of Cormohipparion known from the Gulf Coastal Plain preserving the entire pre-orbital region. The DPOF (on the better preserved right side) is teardrop-shaped, about $60 \mathrm{~mm} 10 \mathrm{ng}$, and has a maximum dorsoventral height of about $30 \mathrm{~mm}$. The anterior border is located above the $P 3$, and the posterior border is above the M1-M2 contact. The pocketed, well rimmed fossa is located well anterior to the orbit with a preorbital bar length of about $57 \mathrm{~mm}$ (due to crushing and reconstruction with plaster this measurement is a rough estimate). For all important features, the facial region of TMM 31081-844 falls within the range of variation expressed by the large Hans Johnson Quarry sample of Cor. occidentale from the late Clarendonian of Nebraska (Skinner and MacFadden, 1977). The size and complexity of the cheekteeth of TMM 31081-844 are equivalent to the dental features of the Lapara Creek sample of Cor. occidentale described in detail by Forsten (1975). MacFadden (1984a, Fig. 134) was the first to illustrate a specimen of Cor. occidentale from the fauna, a right maxillary fragment with P2-M1.

In the upper cheekteeth, Cor. occidentale from Lapara Creek display the following important features that reflect their close 
relationship with other referred samples of the species (notably those from the Clarendon and Xmas-Kat Faunas). Premolars are slightly longer and much wider than the molars, with well developed styles. In early wear, the parastyles of the P34 are slightly grooved. The fossettes are richly plicated; typically in premolars the anterior half of the prefossette has a deep, persistent, generally unbranched pli protoloph and zero to three smaller, less persistent accessory plications. The posterior half of the prefossette and the anterior half of the postfossette are of approximately equal complexity, with numerous (usually four or five, up to eight) plications apiece, several of which are usually deep and bifurcated. The pli hypostyle is usually deep, unbranched, and persistent; it is often (33\% of examined specimens) accompanied by one or two additional small plications. In the M12, the fossettes are typically only slightly less complex, but the folds are not as deep and have fewer bifurcations. Both the pli protoloph and pli hypostyle are well developed, persistent, and have occassional accessory plications. Pli caballins are prominent, often multiple $(60 \%$ of specimens examined) in P34, generally single in P2 and M1-M3. Protocones are elongate-oval, usually slightly longer than twice their width, very rarely with spur, except on P2. Protocones are isolated until very late wear-stages, again except for the P2 which generaliy connects the protocone during the moderate-stage. When compared with the Clarendon and Xmas-Kat populations of Cor. occidentale, the Lapara Creek sample shows slight differences in size, hypsodonty (unworn M12 MSCH is about 50-54 mm in the Lapara Creek sample, about $60 \mathrm{~mm}$ in the two younger samples), and plication frequency. The 
Xmas-Kat sample is significantly more complicated than either of the two Texas populations. For example, pli caballins are multiple or bifurcated in $88 \%$ of the P34S $(n=66)$ and $55 \%$ of the M12s $(n=75)$. In complexity of fossette plications, the Xmas-Kat Quarries population of Cormohipparion is exceeded among North American hipparionines on ty by the late Hemphillian sample of Cor. emsliei $n$. sp.

In the lower cheekteeth, the Lapara Creek sample is characterized by rounded to slightly flattened labial protoconid and hypoconid borders (but not to the degree of Neo. affine); large, oval, subequal metaconids and metastylids; and relatively large protostylids that are ofen isolated from the protoconid during early wear. Pli caballinids are variably developed on the p2-p4; prominent in early wear-stages, retreating with wear until disappearing during late middle wear-stages. They are at best rudimentary on the $m 1-m 3$, and then only appearing in very early wear-stages. Lower cheekteeth are frequently plicated (Table 17); these are best expressed during early and early moderate wear-stages. The ectoflexids on the premolars generally penetrate to a level about equal to the base of the metaflexid, al though there are some with deeper and some with shallower ectoflexids. In the molars, ectoflexids are deep and completely divide the isthmus. Deciduous lower premolars have wider and deeper ectoflexids than permanent premolars, rudimentary pli caballinids, and relatively large, tall ectostylids that soon appear on the occlusal surface after the onset of wear (e.g. TMM 31081-456, 31081-7).

Discussion. Leidy described this species on five associated upper cheekteeth. Although of uncertain stratigraphic provenience 


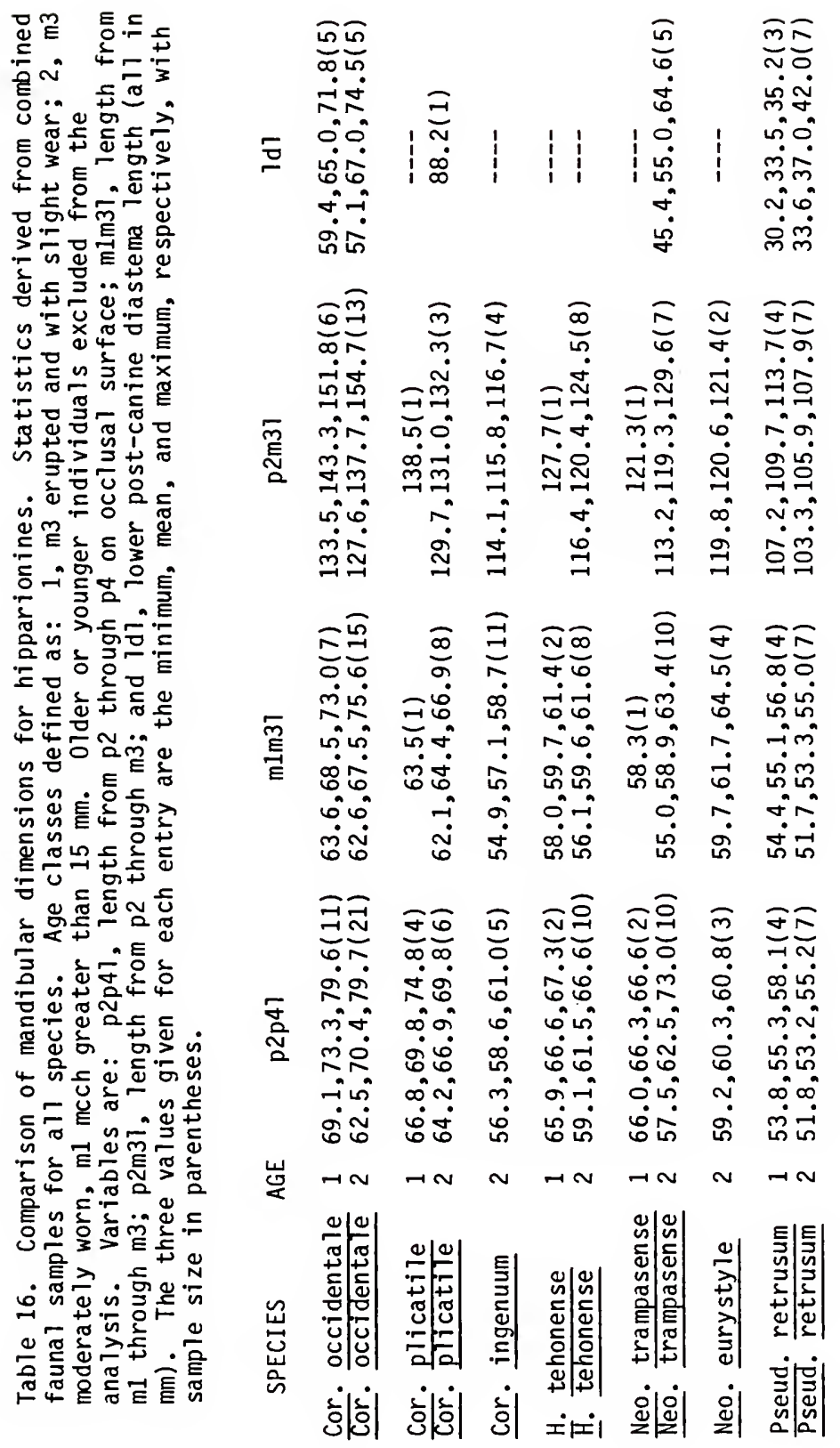


Table 17. Frequency of occurrence (in $\%$ ) of different ename 1 plications in the lower cheekteeth of various populations of Cormohipparion. Samples are: 1, Cor. occidentale, Lapara Creek Fauna; 2, Cor. occidentale, Clarendon Fauna; 3, Cor. occidentale, Xmas-Kat Quarries Fauna; 4, C. plicatile, Love Site; 5, Cor plicatile, combined early Hemphīilian sample of Florida localities; 6 , Cor. ingenuum, Love Site; 7 , Cor. emsliej n. sp., Upper Bone Val Tey Fauna. PARA, posterior pTication on paralophid; ANTI, plication on antisthmus or anterior side of isthmus; PSTI, plication on postisthmus or posterior half of isthmus; PLCB, pli caballinid.

\begin{tabular}{crrrrr} 
SAMPLE & $n$ & PARA & ANTI & PSTI & PLCB \\
\multicolumn{5}{c}{ p3 and p4 combined } \\
1 & 24 & 49 & 33 & 50 & 58 \\
2 & 17 & 26 & 35 & 65 & 59 \\
3 & 29 & 66 & 62 & 59 & 62 \\
4 & 48 & 48 & 71 & 47 & 45 \\
5 & 9 & 56 & 67 & 44 & 44 \\
6 & 35 & 63 & 63 & 46 & 49 \\
7 & 7 & 71 & 86 & 57 & 100
\end{tabular}

$\mathrm{m} 1$ and $\mathrm{m} 2$ combined

$\begin{array}{cccccc}1 & 16 & 30 & 63 & 38 & 12 \\ 2 & 18 & 0 & 28 & 17 & 0 \\ 3 & 30 & 27 & 63 & 30 & 3 \\ 4 & 68 & 16 & 76 & 19 & 4 \\ 5 & 16 & 13 & 56 & 25 & 13 \\ 6 & 44 & 32 & 70 & 23 & 0 \\ 7 & 16 & 25 & 69 & 50 & 31\end{array}$


Figure 20. Scatter diagram of standardized scores for principal components $I$ and II of $A$ ) individual $P 3$ and $P 4 S$ and $B$ ) individual $M I$ and M2s of Cormohipparion occidentale and Neohipparion affine. Seven characters were used in the analysis, APL, TRW, PRL, PRW (see Figure 1); width from the mesostyle to the pli caballin (MacFadden, 1984a); the sum of the plications from the posterior half of the prefossette and the anterior half of the postfossette; and the sum of the plications the anterior half of the prefossette and the posterior half of the postfossette. See discussion in text. 


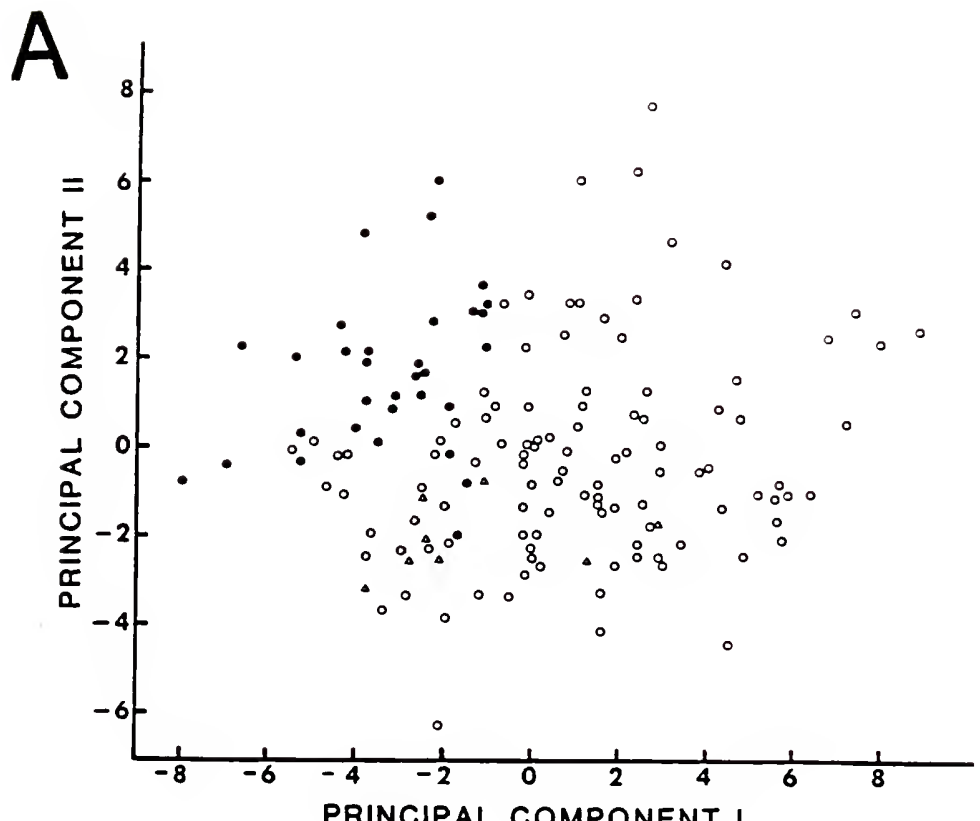

PRINCIPAL COMPONENT I

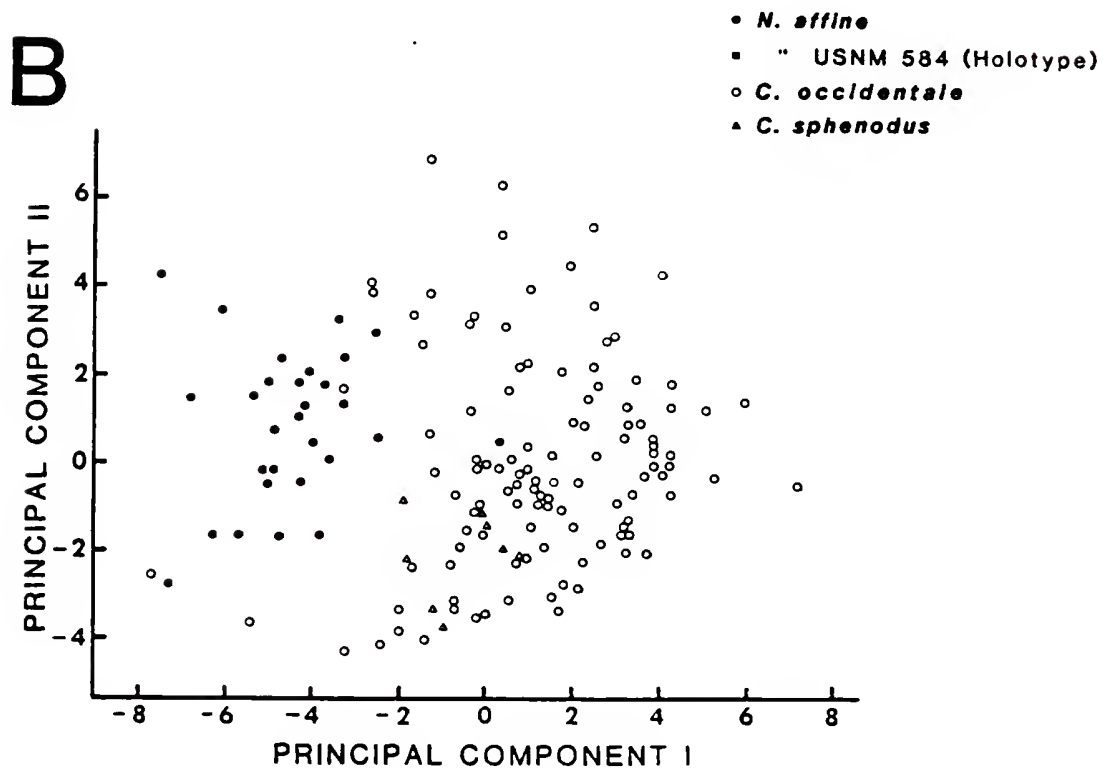


(Skinner and Taylor, 1967), the holotype displays a number of characters than unites it with referred populations from the Lapara Creek, Clarendon, and Xmas-Kat Faunas (and others 1 isted by MacFadden, $1984 a$, p. 163). These include size (relatively large), elongated protocones without spurs, well developed pli caballins that tend toward branching on the premolars, and complex fossette plications. However, Woodburne (pers. comm.) observed two or more cranial morphologies among the specimens combined here into a single species. This may indicate either the presence of more than one species with the distinctive "Cor. occidentale" dentition in the Clarendonian of the Great Plains, or that the species in polymorphic for certain cranial characters. If the former is correct, then Leidy's type material may not be complete enough to confidently assign it to one of the species, and the name may not be valid.

Prior to the naming of Cormohipparion by Skinner and MacFadden (1977), the species occidentale was routinely referred to the genus Neohipparion (e.g. Stirton, 1940). While there are similarities between Cor. occidentale and Neo. affine, especially in protocone shape and overall size, there are major differences in DPOF depth and degree of rimming, relative position of the DPOF and lacrimal bone, fossette complexity, shape of the labial borders of the protoconid and hypoconid, and the development of the ectostylid in deciduous premolars (Skinner and MacFadden, 1977; Skinner et al., 1977; MacFadden, 1984a). These serve not on ly to distingiush the two as distinct species, but support a phylogenetic hypothesis that they represent separate genera (see Chapter 6). 
Principal component analyses of upper cheekteeth (P34s and M12s analyzed separately; Fig. 20) generally segregated specimens of Cor. occidentale from Neo. affine, although there was some overlap. The first principal component (PC I) accounted for about $50 \%$ of the total variance in both analyses. The PC I in Figure $20 \mathrm{~B}$ contrasted molars with longer protocones and simpler fossettes with those having shorter protocones and more complex fossettes. In the analysis of the P34s (Fig. 20A), PC I had large, positive coefficients for both size and fossette variables; small (probably insignificant), negative coefficients for PRL and PRW. This tended to place specimens of Neo. affine, Cor. sphenodus, and moderate to heavily-worn individuals of Cor. occidentale to the left of the graph, lesser worn individuals of Cor. occidentale to the right. The PC II in Figure 20A had high, positive loadings on APL, TRW, PRL and a large negative coefficient for the number of internal plications. This separated the smaller, more complex Cor. sphenodus and worn Cor. occidentale individuals from those of the larger, less complex Neo. affine. The multivariate analyses corroborated the evidence from cranial morphology that the se populations represent two distinct species.

Although wide-spread and common throughout the western half of the United States during the Clarendonian, Cor. occidentale is not yet recognized from Florida. Instead, Cor. sphenodus seems to have persisted longer in the Southeast, and was then followed by Cor. plicatile and Cor. ingenuum, species not observed in the Great Plains (see below). 
Cormohipparion plicatile (Leidy), 1887 new combination

Hippotherium plicatile LEIDY, 1887, p. 310; COPE, 1889, p. 444; LEIDY and LUCAS, 1896, p. 50; MACFADDEN, 1984a, pp. 170-174 (in part).

Hipparion plicatile (Leidy), HAY, 1902, p. 620; GIDLEY, 1907, p. 905; HAY, 1916, pp. 41-42; OSBORN, 1918, p. 192; SIMPSON, 1930, pp. 187-188 (in part); HI RSCHFELD and WEBB, 1968, p. 249; WEBB and PERRIG0, 1984, pp. 243-245 (in part). Hipparion sp., SIMPSON, 1930, p. 176. ?Hipparion plicatile (Leidy), STIRTON, 1940, p. 184.

Type specimen. USNM 3292, a R upper cheektooth, probably a P4. Type locality. Mixson's Bone Bed, Levy County, Florida. Stratigraphic occurrence and age of the type locality. Alachua Formation; early Hemphillian, about $8 \mathrm{ma}$.

Topotypic sample. UF/FGS V-1428 R P2; F:AM 111730 assoc. R P2-M2 and L P3-M3; 107876 badly crushed sku11 with R and L DP2-M1; 113620 assoc. L P2-M2 and R M1; 113621 assoc. R P2-P3,M2-M3 and L P3,M2-M3; 113625-113629, 1136386 upper cheekteeth; 107874 assoc. $R$ and $L$ mandibles with $i 3, c 1, p 2-p 3, d p 4, m 1-m 2$ and $R$ (on 1y) i2; 113630 assoc. $R$ p2-p3 and L p2; 113634 assoc. L m2-m3; USNM 3309 R p2; F:AM 113640 L p2; 113636 R p34; 113631, 1136322 L p34; 113633, 1136352 L m12. Distribution.--Very late Clarendonian through early Hemphillian (about 6.0 to $9.0 \mathrm{ma}$ ) of peninsular Florida.

Referred specimens. Moss Acres Racetrack Site: UF 93000 assoc. juvenile crushed sku11 with $R$ and $L$ DP2-M1, $R$ and $L$ mandibles with 
dp2-m1, and various post-cranial elements; 69968 R M12; 96386 assoc. $R$ M2-M3 and L M3; 69967 assoc. $R$ and $L$ mandibles with $i 1-i 3, c, p 2-m 3$. Dunnellon Phosphate Company mine, Marion Co., FL: USNM 8265 R maxilla with P2-P4 (Hay, 1916, Plate 2.8).

Dunnellon Phosphate Company, Plant No. 5, near Hernando, Citrus Co., FL: UF/FGS V-1400 R M12.

Archer Fauna, Bone Valley Region. Nichols Mine: UF 24638 R P2; 23986 R P4; 24626, 24650, 246553 R dp34; 24631 R p34; 24625 R m12; $24642 \mathrm{~L} \mathrm{m12}$. Fort Green Mine: UF $53924 \mathrm{R}$ p34. Unknown mine near Mulberry, Polk Co., FL: AMNH 22482 mandible with p3-m3.

Peace River, near Gardner, Hardee Co., FL: UF/FGS V-4889, UF 559482 R M12; UF/FGS V-1482 L p34; UF 55951 R m12; UF 55952 L m12.

McGehee Farm: UF 17121 L P2; 17099, 17124, 17208, 17210, 19237, 456166 R P34; 17206, 17212, 45614, 535484 L P34; 9605, 9611, 17213, 456154 R M12; 17090, 17207, 17214, 456124 L M12; 7234 assoc. R mandible with $p 2-m 2$ and $L$ mandible with $p 2-p 4 ; 9541$ assoc. $R$ dp2-dp3; 12050 R dp2; 7240 L dp34; 45619, 45620 2 R p2; 17167, 45627, 534543 R p34; 17196, 17197, 45623, $534524 \mathrm{~L}$ p34; 7243, 9606, 16837, 17140, $17173,17192,18707,45623,534529 \mathrm{R} \mathrm{m12} ; 17169,17172,17175$, 17192B, 17193, 17195, $456188 \mathrm{~L} \mathrm{~m} 12 ; 45631 \mathrm{R} \mathrm{m} 3$.

Haile 5B, Alachua Co., FL: UF 17226 L P34.

Haile 19A, Alachua Co., FL: UF 47319 R M12.

Cummer Mine No. 8, Alachua Co., FL: UF/FGS V-1408 L p34.

Cofrin Creek, A7achua Co., FL: UF 17178 R p34; 55522 R m12.

Love Site: UF 32257 partial skul1 with $R$ and $L I 2-I 3, P 3$ and $R$ P4; 32260 assoc. $R$ maxilla with P4-M2 and L maxilla with P4-M3; $32250 \mathrm{R}$ maxilla with P4-M3; 32255 L maxilla with Dp2-M1; 35891 L maxilla with 
P4-M1; 32267 assoc. R DP2-DP4; 27993, 32262, 322633 assoc. $R$ and $L$ P2-M3; 32283 assoc. R P2,P4-M1 and L M1-M2; 32270 assoc. R P2-M1,M3 and L M1-M3; 32265 assoc. $R$ and L P2-M2; 32264 assoc. R P3-P4,M2-M3 and L P4-M3; 27316 assoc. R P2-M3; 36289 assoc. R M1-M2 and L P4; 32276, 322952 assoc. L DP2-DP4; 32285 assoc. L DP2-M1; 32266 assoc. L P2-M2; 53284 assoc. L P3-P4; 35967, 35970, 35976-35978, 35984$35985,35988-35989,35994,36000-36002,36005-36006,36008,36010$, $36015,36031-36035,36037,36040,36044,36047,36051,36063,36068-$ $36071,36263,36266,3626937$ R P2; 36143, 36147, 36151, 36153, $36156,36158-36159,36162,36165-36166,36169,36171,36177,36181-$ $36182,36184-36186,36188,36190,36193-36194,36201,36205,36209$, $36211-36212,36218-36219,36223,36225-36227,36237,36243-36244$, $36247,36250,36253,3625541$ L P2; 50641, 50643-50644, 53287-53289, 53291-53294, 53296, 53298-53299, 53301, 53423-53424, 62326-62350, $62438,62447,6981044 \mathrm{R}$ P34; 53302-53328, 53373, 53422, 62306-62324, 62381, 62384, 69809 50 L P34; 50642, 50645, 50647-50648, 53329-53332, $53334-53340,53344-53349,53351-53353,53416,53417,62351-62365$, 6981142 R M12; 53154-53156, 53354-53360, 53362-53367, 53369-53371, $53374,53377-53379,53418-53421,62367-62376$, 62378-62380, 62382$62383,62385-62389,6240848$ L M12; 32119 R mandible with dp2-dp3; 32157 assoc. $R$ and $L$ mandibles with p2-p3,dp4,m1-m2; 32180 assoc. mandibles with $\mathrm{R} \mathrm{m} 2-\mathrm{m} 3$ and $\mathrm{L} p 3-\mathrm{m} 3 ; 27317 \mathrm{R}$ mandible with $\mathrm{p} 2-\mathrm{m} 3$; 32104, $321742 \mathrm{R}$ mandibles with p2-m2; $32212 \mathrm{R}$ mandible with $\mathrm{p} 2-\mathrm{m} 1$; $32116 \mathrm{R}$ mandible with $\mathrm{p} 2, \mathrm{p4}-\mathrm{m} 3 ; 32190 \mathrm{R}$ mandible with $\mathrm{p} 3-\mathrm{m} 3 ; 32144$, $358932 \mathrm{R}$ mandibles with $\mathrm{p4}-\mathrm{m} 3 ; 32107,321992 \mathrm{~L}$ mandibles with p2-m3; 32111, 32118, 32160 $3 \mathrm{~L}$ mandibles with dp2-dp4; 32123, 321632 $\mathrm{L}$ mandibles with p2-m2; 32113, $321512 \mathrm{~L}$ mandibles with p2-m1; 32198, 
$322452 \mathrm{~L}$ mandibles with p3-m3; $32165 \mathrm{~L}$ mandible with p4-m3; 32182, $32105,36282,32134,36285,362806$ partial R mandibles; 32197 , $32195,32137,36287,35892,321026$ partial L mandibles; UF 35895 assoc. R dp2-dp4 and L dp3-dp4;32286, 901542 assoc. R dp2-dp4; 90160 assoc. R dp2-dp3; 90155, 901562 assoc. R dp3-dp4; 32196 assoc. $R$ p2-m3 and $L p 2-m 2 ; 32293$ assoc. $L p 4, m 2-m 3$ and $R$ p3-p4; 32146 assoc. R p2-m3; 32225 assoc. R p2-p4; 32239 assoc. R p3-m3; 32203, 322292 assoc. R p4-m3; 32181, 322232 assoc. R m1-m3; 32232, 322212 assoc. R m2-m3; 90158 assoc. $R d p 3$ and $L d p 2-d p 4 ; 90159$ assoc. $L$ dp2-dp3; 32227 assoc. L m1-m2 and R m2; 65167 assoc. L m1-m3; 901629017918 R dp2; 69813, 69814, 90121-90159 41 R dp34; 90180-90186, 90188-90197 17 L dp2; 90071-90120 50 L dp34; 50355, 50356, 50358$50362,50364,50365,50369,64926-64927,64929-64931,64934-6493619$ R p2; 50370, 50372, 50374-50379, 64937, 64940-64943, 64466 14 L p2; $50461-50479,50538,50544,50635,50639,64981-6502770$ R p34; 50447$50455,50460,50458,50640,32226,64944-64946,64948-64980,6516650$ L p34; 50420-50445, 65076-65109, 65028-65050, 69816 84 R m12; 50400$54019,65112-65165,69818,9026276 \mathrm{~L} \mathrm{m12;} 50380-5038910 \mathrm{R} \mathrm{m3}$; 50390-50399 $10 \mathrm{~L} \mathrm{m3}$; and many more catalogued and uncatalogued cranial fragments, isolated teeth, and post-cranial elements. Revised diagnosis. Medium-sized hipparionine with toothrow lengths of 125 to $140 \mathrm{~mm}$ in middle wear-stages. Unworn MSCH of P2 about $40 \mathrm{~mm}$ and $M 12$ about $58 \mathrm{~mm}$. On average, smaller than Cor. occidentale, generally with less complicated fossettes and less elongate protocones. More hypsodont and more complex enamel plications than Cor. sphenodus. Larger and higher crowned than Cor. 
ingenuum, larger than Cor. emsliei with weaker pli caballinids. Very elongated post-canine diastema.

Description. All cranial material referable to Cor. plicatile lacks uncrushed or complete pre-orbital regions. Four specimens (UF $32257,32255,35891,32250$ ) from the Love Site and UF 93000 from Moss Acres preserve parts of the facial region, but none contain the entire DPOF. The specimen with the most complete DPOF, UF 32250 , is an uncrushed, partial maxilla with well worn but diagnostic P3-M2 (Fig. 21). It contains the ventral base and rim of a deep (at least $15 \mathrm{~mm}$ ) DPOF located $46 \mathrm{~mm}$ dorsal to the toothrow (Fig. 21A). The three other Love Site specimens also preserve small portions of a fossa. These crania differ considerably from Love Site specimens assigned to Neo. trampasense, in which the DPOF is reduced to a slight depression (MacFadden, 1984a, and p. 60 above). The badly crushed skull of UF 93000 preserves only the dorsal portion of both DPOFs. It was evidently more poorly rimmed dorsally than those of Cor. occidentale, and probably shallower. Another extremely crushed skull of Cor. plicatile, F:AM 107876 from Mixson's Bone Bed, was noted by MacFadden (1984a) as not possessing a deep DPOF. F:AM 107876 is crushed and fragmented to such a degree that not even the orbits are discernible. Until discovery of uncrushed, more complete cranial material, the facial region of Cor. plicatile and the exact morphology of its DPOF must remain poorly documented. The Love Site and Moss Acres Racetrack Site specimens strongly suggest the presence of a moderate to deep DPOF.

The following dental descriptions are based primarily on the abundant Love Site sample, with added comparisons from other 
localities. Statistics of cheektooth dimensions of Cor. plicatile are presented in Tables 18 and 19. Upper cheekteeth of Cor. plicatile are characterized by oval protocones with convex lingual borders, richly plicated internal fossette borders (especially in early wear), moderately deep hypoconal grooves open to near the base of the crown, and strong styles. The $P 2$ has a well developed anterostyle, and is by far the longest tooth in the toothrow (Figs. $22 A, 22 B)$. The oval protocone of the $P 2$ generally remains isolated from the protoselene until mid-wear. Many P2s with MSCHs of 20 to 25 $\mathrm{mm}$ retain isolated protocones. Unworn $\mathrm{MSCH}$ of the $\mathrm{P} 2$ is about 38 to $42 \mathrm{~mm}$. Fossette plications resemble those of the P34, except that the anterior half of the prefossette usually has two or three small folds. The pli caballin is generally single, although often bifurcated. The P34 (Figs. 21B, 22, 23B) are much larger in occlusal area than the M12, with larger and more widely opened parastyles and mesostyles. The parastyles are often slightly grooved, and metastyles are occasionally developed, but not as prominently as in Cor. emsliei or Neohipparion eurystyle. In very early wear, the protocone of the P34 is elongate, often with a spur, but with wear the spur vanishes and the protocone rapidly becomes more oval. This change is produced by an increase in protocone width, as protocone length is uncorrelated with crown height $(\underline{r}=0.05, n=132)$, while protocone width has a significant negative correlation with crown height $(\underline{r}=-0.64$, $n=130, \underline{p}<0.001)$. Protocone length is generally less than twice its width, a feature useful in distinguishing Cor. plicatile from its slightly smaller contemporary, Neohipparion trampasense. The main axis of the protocone runs in a more direct anterior-posterior 
Table 18. Standard univariate statistics for upper cheekteeth of Cormohipparion plicatile from Florida. Format as in Table 2. Fauna abbreviations: Lov, Love Site, Alachua County, late Clarendonian; HE, combined sample from various early Hemphillian localities including McGehee Farm, Mixson's Bone Bed, Moss Acres Racetrack Site.

FAUNA LOV HE

P2

$\begin{array}{lll}\text { APL } & 26.7,1.26,55 & 27.1,1.36,4 \\ & 23.5-30.6,4.73 & 25.6-29.3,5.03 \\ \text { BAPL } & 21.8,0.79,54 & 22.0,0.40,5 \\ & 20.4-24.0,3.59 & 21.4-22.4,1.84 \\ \text { TRW } & 19.6,0.94,57 & 20.6,1.17,6 \\ & 17.3-21.5,4.79 & 19.7-22.8,5.70 \\ \text { PRL } & 6.1,0.53,58 & \\ & 5.0-7.2,8.66 & 5.5,0.68,6 \\ & & \\ \text { PRW } & 4.1,0.52,57 & 4.0,0.30,10.60 \\ & 3.4-5.6,12.76 & 3.7-4.5,7.59\end{array}$


Table 18--continued

P34

$\begin{array}{lll}\text { APL } & 21.8,1.19,112 & 22.1,1.08,18 \\ & 19.4-25.3,5.46 & 19.7-23.9,4.88 \\ \text { BAPL } & 17.6,0.98,107 & 17.6,0.72,14 \\ & 15.9-20.0,5.56 & 16.6-18.8,4.09 \\ \text { TRW } & 21.0,0.99,112 & 21.5,0.96,19 \\ & 18.6-24.1,4.70 & 19.8-23.4,4.46 \\ \text { PRL } & 7.4,0.80,116 & 6.9,0.70,19 \\ & 5.9-9.2,10.80 & 6.1-8.5,10.04 \\ \text { PRW } & 4.1,0.47,114 & 3.9,0.36,19 \\ & 3.0-5.2,11.41 & 3.4-4.9,9.23\end{array}$

M12

$\begin{array}{lll}\text { APL } & 20.5,1.36,115 & 20.5,1.51,18 \\ & 18.2-25.4,6.61 & 17.6-23.9,7.38 \\ \text { BAPL } & 16.4,0.69,108 & 16.5,0.69,11 \\ & 15.1-18.2,4.20 & 15.4-17.7,4.20 \\ \text { TRW } & 19.4,1.22,113 & 19.4,0.94,18 \\ & 15.4-22.0,6.29 & 17.1-20.8,4.82 \\ & & \\ \text { PRL } & 6.9,0.62,121 & 6.7,0.68,18 \\ & 5.7-8.3,8.99 & 5.6-8.4,6.26 \\ \text { PRW } & 3.8,0.56,120 & 3.6,0.41,18 \\ & 2.6-5.2,14.76 & 2.8-4.9,11.37\end{array}$



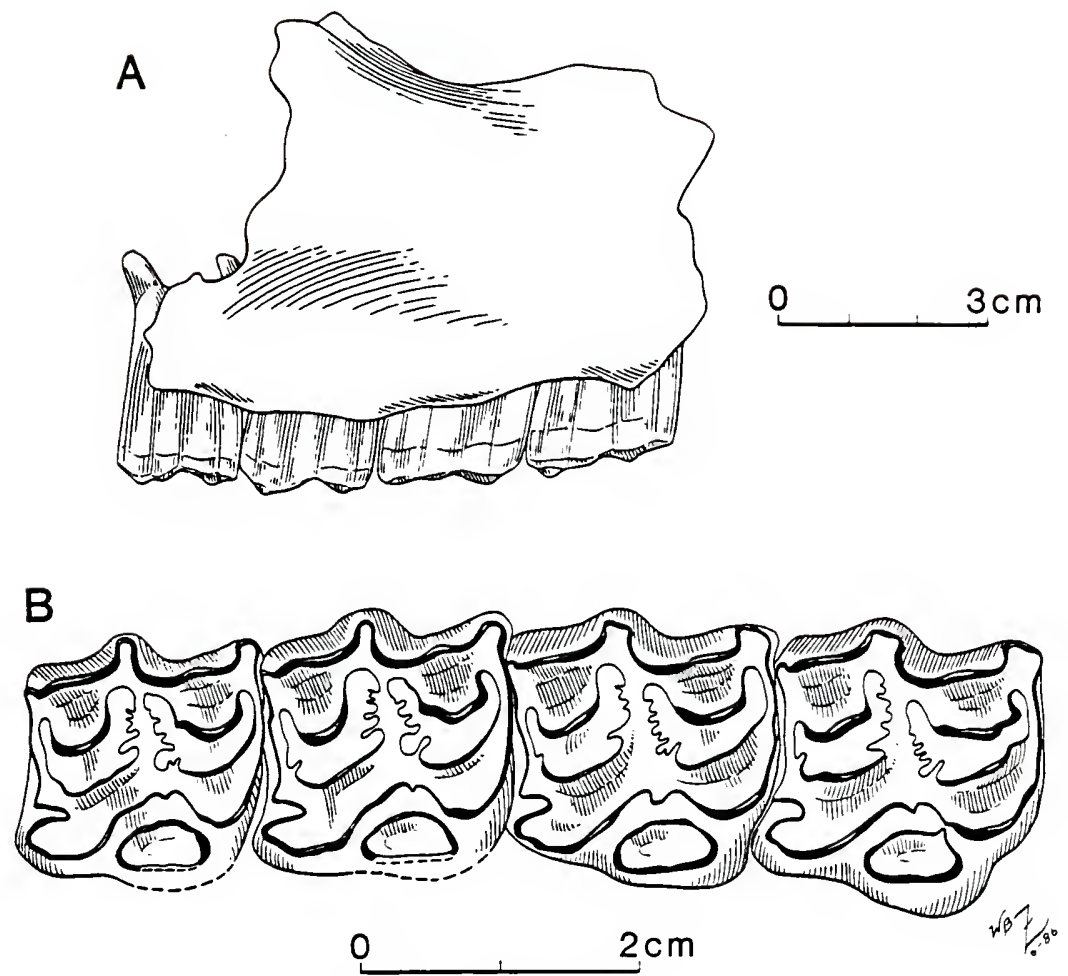

Figure 21. Lateral (A) and occlusal (B) views of UF 32250 , Cormohipparion plicatile, Love Site (late Clarendonian), Alachua County, FTorida. Occlusal pattern of R P3-M2 represents the late wear-stage for this species. 


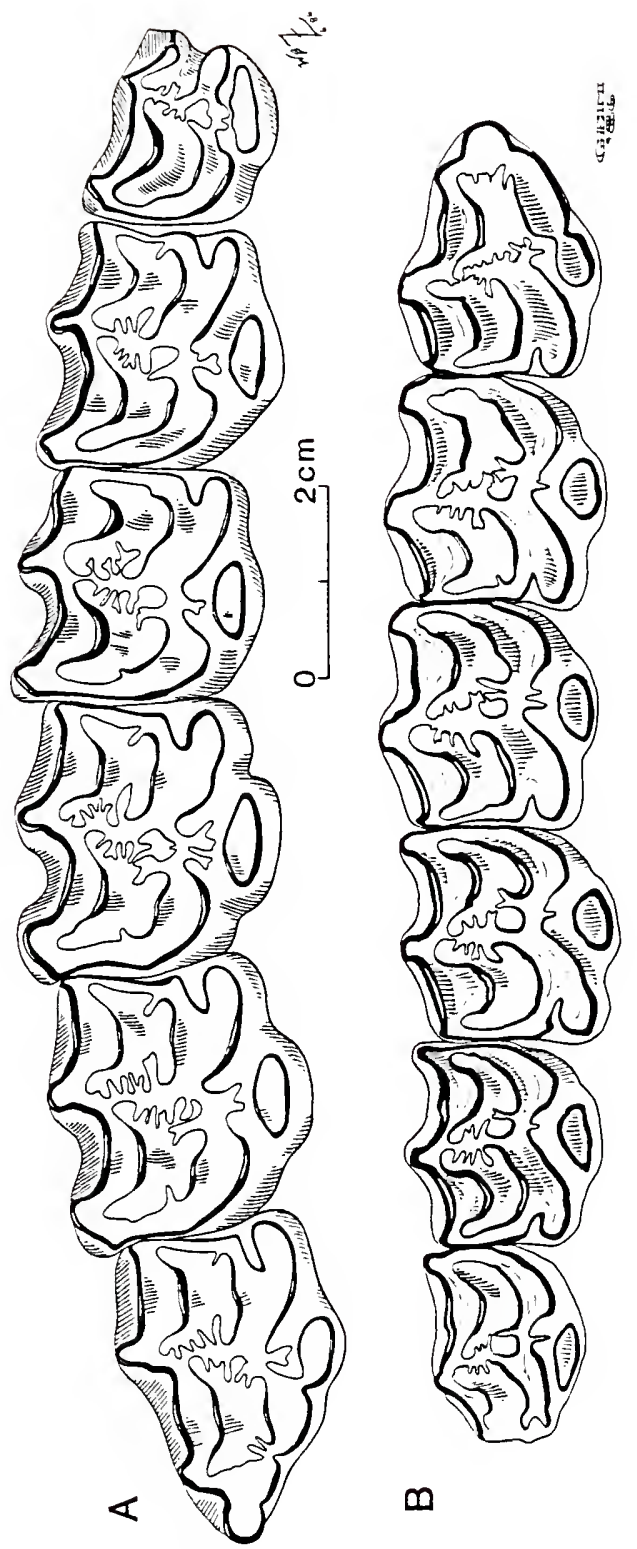

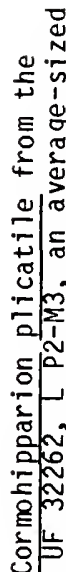

岤

n

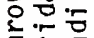

동드.

단-

$\therefore \rightarrow \frac{8}{5}$

ه

윽 동 궁

凹

雨

언

$+\approx$

区

जै.

을

น衣

4 등 즘

등 $\simeq$

บㄴ.

중ㅇ

$>0 \approx$

च

哇向告

就

过

홍

๑ 的.

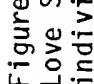




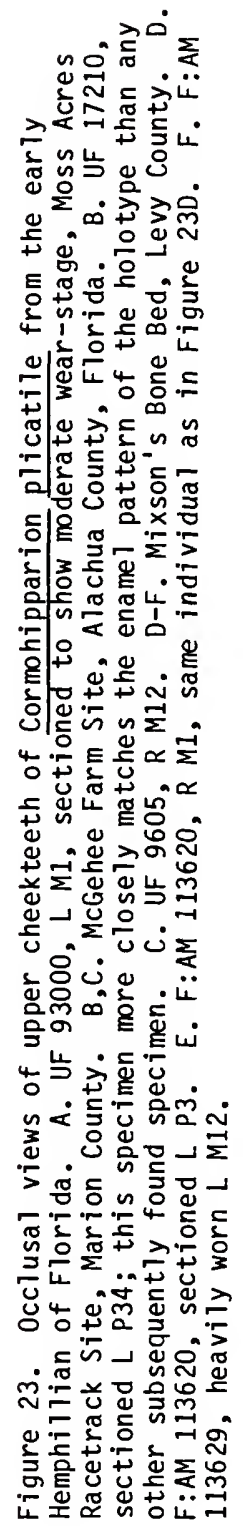



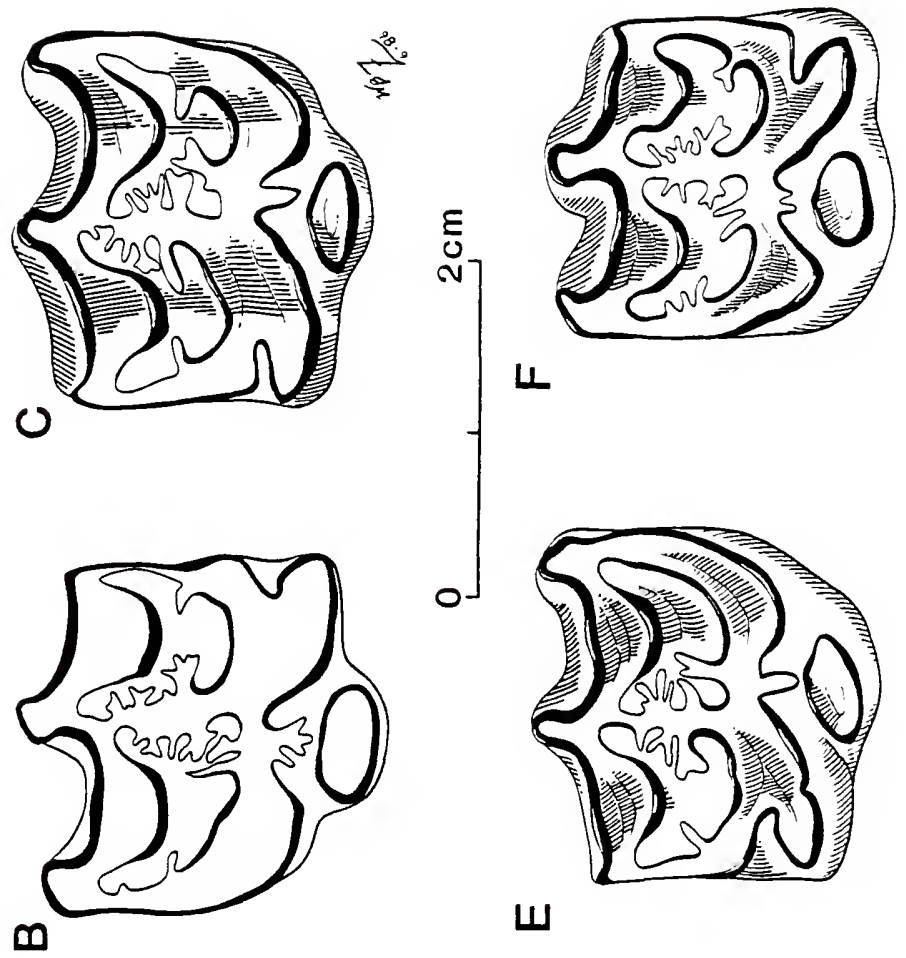

ע
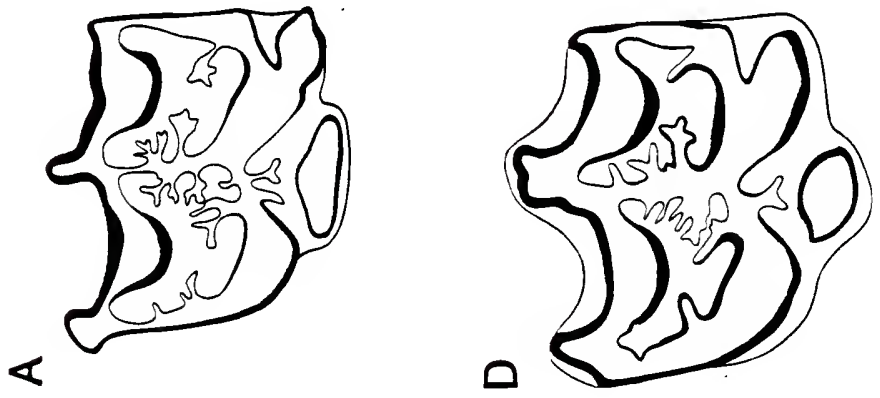
direction than that of Nan. trampasense. The protocone of the P34 does not connect to the protoselene until very late wear-stages (MSCH of $15 \mathrm{~mm}$ or less). Fossette and pli caballin complexity also vary considerably with crown height. In early wear, the well developed pli caballin is usually multiple, branched, or both (Fig. 22A). With wear, it decreases in length and complexity, usually becoming single by late mid-wear (MSCH of 15 to $30 \mathrm{~mm}$ ), and lost or rudimentary on $7 \mathrm{y}$ in very late wear (Fig. 21B). In the Love Site sample, the anterior half of the P34 prefossette most often is not plicated $160 \%$ of examined specimens, $n=112$ ), or has a single, small pli protoloph (32\%; Figs. 22A, 22B). The latter condition occurs most frequently in the less worn teeth. The posterior half of the prefossette in early to moderate wear is richly plicated, with four to nine folds, of which several are often deep and bifurcating. The anterior half of the postfossette is only slightly less complex, generally with a deep, often branched pli postfossette and two to five accessory plications. In moderate to late wear-stages, these internal fossette plications become shallower and less numerous (e.g. Fig. 21B), a) though even very heavily worn teeth usually retain at least two or three folds. The posterior half of the postfossette has a single (59\%, $n=110)$, relatively shallow and small pli hypostyle, or lacks all plications (39\% of observed specimens). Early Hemphillian samples of P34s of Cor. plicatile, while of similar proportions as the Love Site sample (Table 18), are on average more complexly plicated (Figs. 23B, 23D). For example, of 16 observed P34s, seven (44\%) had a single pli protoloph, eight (50\%) had a pli protoloph 
plus one or two accessory plications, and only one lacked a 11 plications on the anterior half of the prefossette (the character state found in the majority of the Love Site sample). Unworn P34 MSCH varies from 50 to $55 \mathrm{~mm}$.

In mid-wear, M12 of Cor. plicatile have nearly square occlusal surfaces, with length slightly exceeding width on average (Table 18). However, since length is positively correlated with crown height $(\underline{r}=0.77, n=124)$, and width is negatively correlated with crown height $(\underline{r}=-0.50, n=123)$, the ratio of length to width changes greatly through ontogeny. The M12 protocone is slightly smaller than that of the P34 (Table 18), but similar in morphology and degree of isolation from the protoselene. The pli caballin is only rarely double (6\% of observed Love Site specimens, $n=121$ ), but it persists unti 1 late wear, when it gradually disappears in extremely worn teeth (almost always after MSCH is less than $20 \mathrm{~mm}$ ). In the Love Site sample, the anterior half of the prefossette of the M12 generally lack plications (81\%, $n=120)$. A single, relatively shallow pli protoloph is occasionally found in early wear-stages, and it rarely has accessory plications. The posterior half of the prefossette most often has from three to five, rarely bifurcated plications, and a well developed prefossette loop. The anterior half of the postfossette generally has between two and four plications $186 \%$ of Love Site sample, $n=121$ ), usually consisting of a relatively deep, unbifurcated pli postfossette and several labial accessory plications. The posterior half of the postfossette in early wear often has a single pli hypostyle; it is usually lost by mid-wear. As with the P34, M12 of Cor. plicatile from the early Hemphillian localities (Mixson's, 
McGehee, Moss Acres) are on average more complicated than the Love Site population (Figs. 23A, 23C), although of the same general size (Table 18) and degree of hypsodonty. For example, a third of the pooled sample of M12 from the younger sites have multiple pli caballins (Figs. 23A, 23F). Also, fossette plications are more numerous and tend to persist longer throughout wear. Unworn MSCH of M12 are about 56 to $59 \mathrm{~mm}$.

Deciduous upper premolars of Cor. plicatile have very large parastyles, generally multiple pli caballins, and oval protocones. The degree of fossette complexity is intermediate between that of the P34 and the M12. Protoconal spurs are not uncommon, and the hypoconal groove frequently has a pli dihypostyle. No specimens are available to indicate the relative size of the DP1, but it was apparently lost in some mature individuals (e.g. USNM 8265).

The referred Love Site sample includes numerous associated lower dentitions and partial mandibles of Cor. plicatile (as well as several hundred isolated lower cheekteeth), but none are complete; i.e. there are no mandibles that include symphysial regions, and on ly one with an ascending ramus. However, UF 69967 , from Moss Acres, has a relatively complete symphysis (Fig. 24 ). In this adult male individual ( $\mathrm{m} 1 \mathrm{mcch}=35.3 \mathrm{~mm})$, the incisors form a normal rounded equine arcade about $55 \mathrm{~mm}$ in width (across the i3s) and are slightly procumbent. The ils have only small traces of the infundibula remaining, and the i3s do not have enclosed infundibula. The symphysial region is extremely elongated, with a $1 \mathrm{~d} 1$ of about $88 \mathrm{~mm}$ (Fig. 24). Another relatively complete symphysis is found on F:AM 107874 from Mixson's Bone Bed (MacFadden, 1984a, Fig. 143). This 
immature specimen has a $1 \mathrm{dl}$ of only about $66 \mathrm{~mm}$. Whether the

difference in diastema length between F:AM 107874 and UF 69967 is due to ontogeny, or if they just represent the extremes in a normal distribution, can on ly be judged with further samples.

Adequate samples of associated lower dentitions of Cor. plicatile are available to allow comparisons with other Miocene hipparionines (Table 16). While smaller than Cor. occidentale, Cor. plicatile was the largest hipparionine present at the Love, McGehee and Mixson's localities. The lower premolars of Cor. plicatile are very wide relative to length, as contrasted with the molars, or with the premolars of Neo. trampasense. The p2-p4 have large, oval metaconids, metastylids and entoconids (Figs. 25, 26B, 260). In very early wear-stages, the ectoflexid is very shallow, the isthmus is often plicated, and a pli caballinid is variably developed (Fig. 26B). If present, the pli caballinid reduces in size with wear until it gradually vanishes, usually by moderate wear-stages. Plications from the isthmus and paralophid are common (Table 17), and generally persist until at least mid-wear. The protostylid first comes into wear after the first 12 to $15 \mathrm{~mm}$ of the crown are worn away, and is at first isolated from the protoconid (e.g. the p3 in Figs. 25A, 25B). It quick7y becomes attached, and is a prominent feature. The labial borders of the protoconid and hypoconid are rounded or only very slightly flattened. Ectoflexid depth varies, but most commonly only penetrates the isthmus to about the level of the base of the entoflexid, or slightly deeper, even in heavily worn teeth (Fig. 260). Unworn mech of $\mathrm{p} 2$ is about $40 \mathrm{~mm}$, and 51 to $54 \mathrm{~mm}$ for the p34. 

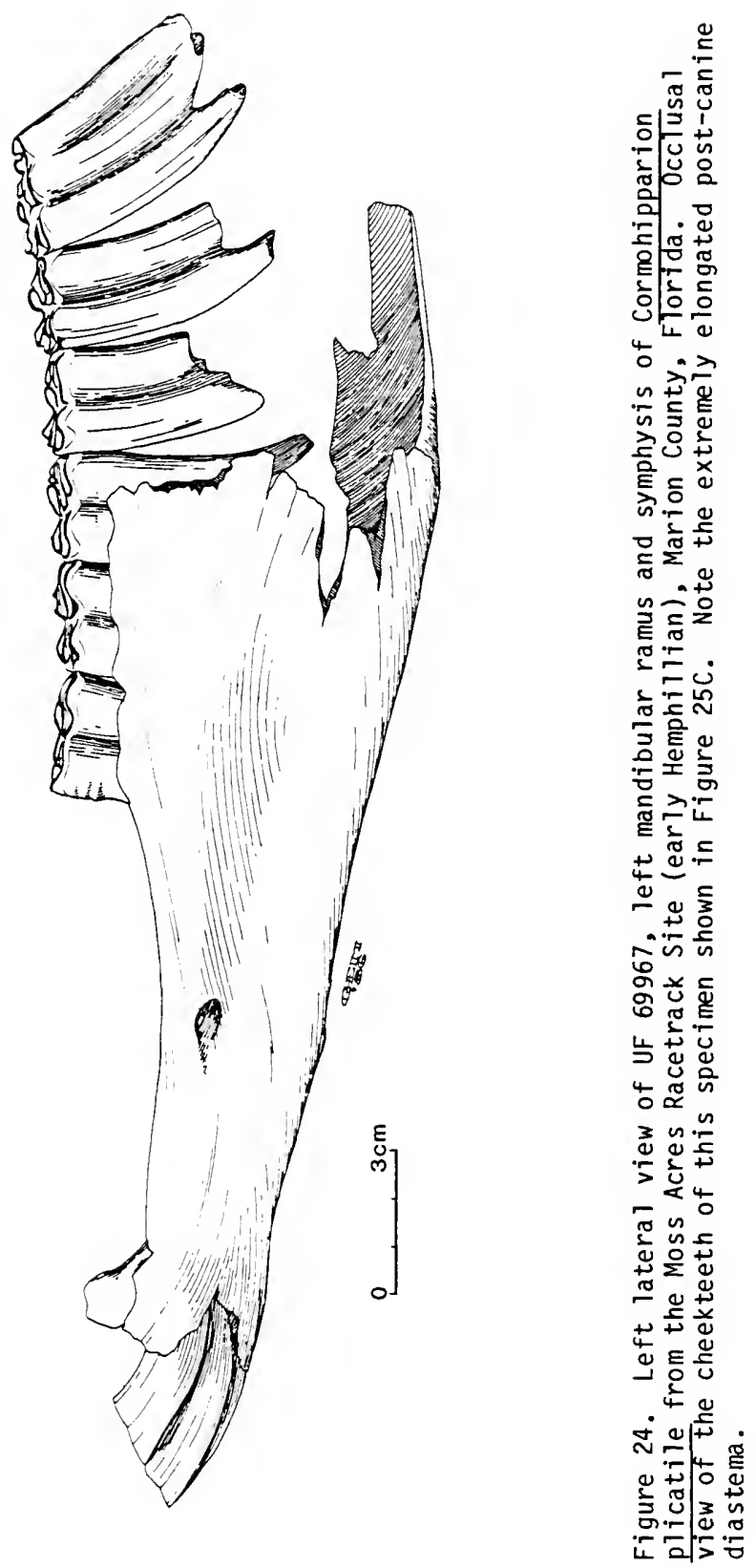

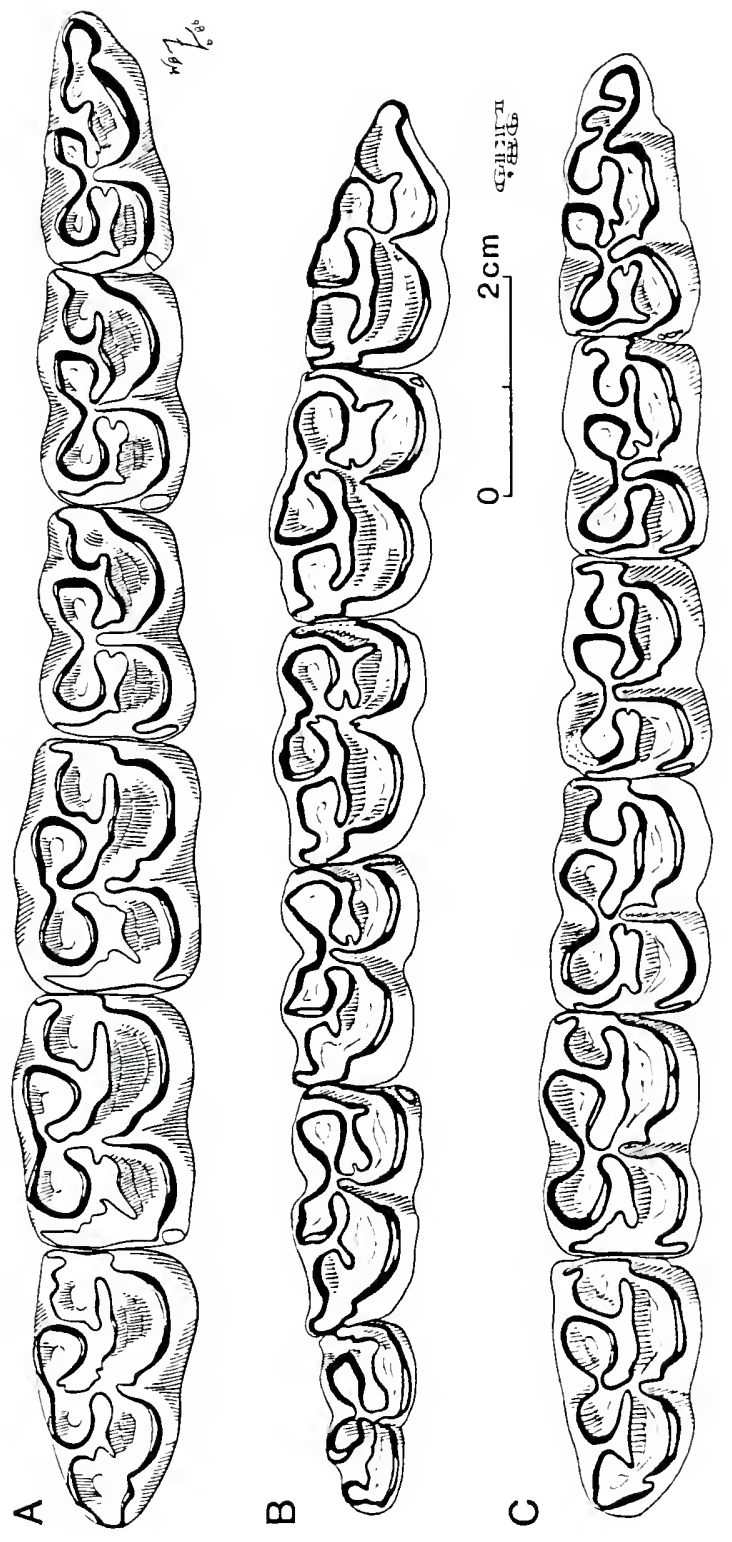

害管

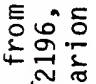

बांगे

ז

ชูำ

등

하흥

힝ㅎㅇ

아

월

읜ㄷㅀ

就。

4

ต

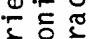

ㅎํㅇㅎํ

ऽ

웅

눤

东

는

일

을

$4+$

is 1

जा

>용

꼻ㅇํㅇ

옹

ن

ํํ요

的

岁。

严这 

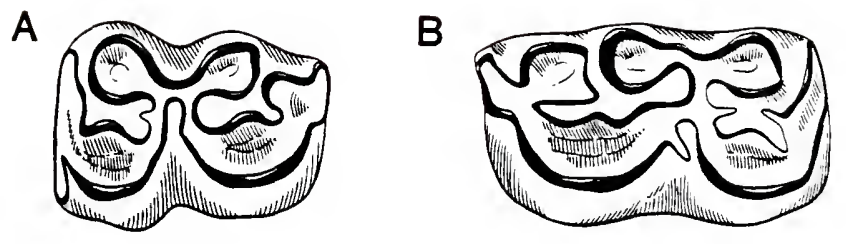

\section{C}
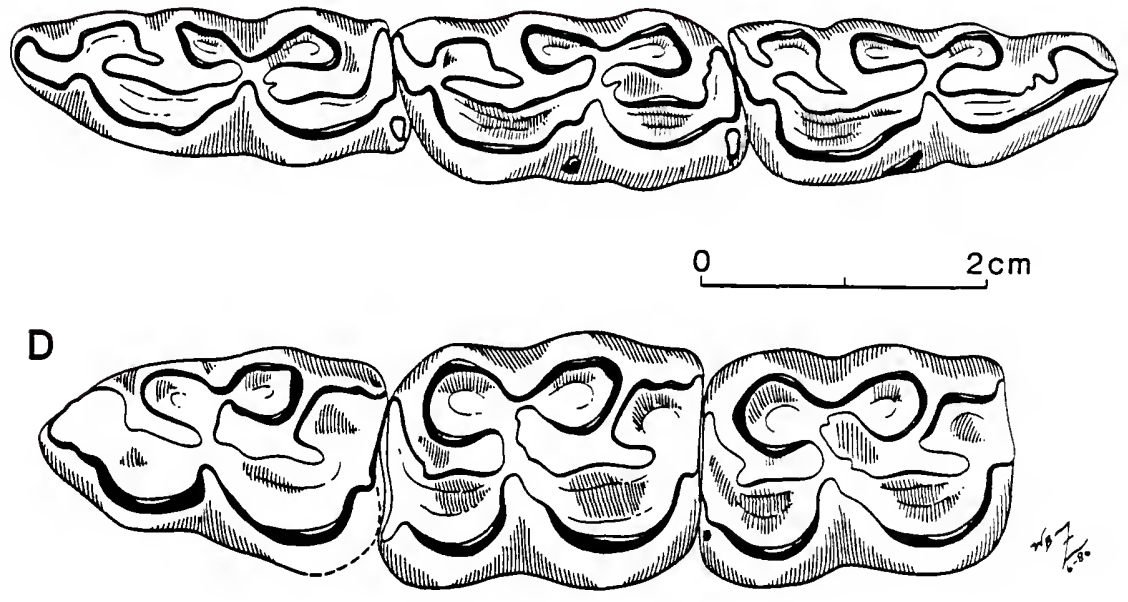

Figure 26. 0cclusal views of lower cheekteeth of Cormohipparion plicatile from Florida. A. F: AM $113635, \mathrm{~L}$ m12, Mixson's Bone Bed (early Hemphillian), Levy County. B,C. Love Site (late Clarendonian), A7achua County. B. UF 50639, slight7y worn p34. C. IJF 90154 , s7ight7y worn assoc. $R$ dp2-dp4. D. IJF 7234, heavily worn assoc. L p2-p4, McGehee Farm Site (very early Hemphitilian), Alachua County. 
Table 19. Standard univariate statistics for lower cheekteeth of Cormohipparion plicatile (CP) and Cor. ingenuum (CI) from Florida. Format as in Table 2. Populations as in Tables 18 and 22.

\begin{tabular}{|c|c|c|c|c|}
\hline TAXON & $C P$ & $C P$ & CI & CI \\
\hline FAUNA & LOV & HE & LOV & HE \\
\hline \multicolumn{5}{|c|}{ p2 } \\
\hline ap1 & $\begin{array}{l}23.7,1.14,39 \\
22.0-27.1,4.83\end{array}$ & $\begin{array}{l}23.8,1.11,4 \\
22.7-24.9,4.67\end{array}$ & $\begin{array}{l}21.5,0.96,19 \\
20.2-24.1,4.48\end{array}$ & $22.0,--, 1$ \\
\hline bapl & $\begin{array}{l}19.9,0.92,37 \\
18.0-21.3,4.62\end{array}$ & $19.3,--, 1$ & $\begin{array}{l}18.0,0.65,19 \\
16.9-19.6,3.64\end{array}$ & - \\
\hline atw & $\begin{array}{l}9.3,0.74,39 \\
7.5-10.4,7.97\end{array}$ & $\begin{array}{l}8.8,0.52,4 \\
8.5-9.6,5.88\end{array}$ & $\begin{array}{l}8.6,0.66,21 \\
7.7-9.9,7.70\end{array}$ & $8.4,--, 1$ \\
\hline ptw & $\begin{array}{c}11.5,0.91,41 \\
9.6-13.3,7.91\end{array}$ & $\begin{array}{l}11.5,1.03,4 \\
10.3-12.5,8.95\end{array}$ & $\begin{array}{c}10.6,0.86,21 \\
9.0-12.6,8.13\end{array}$ & $9.6,--, 1$ \\
\hline $\mathrm{mml}$ & $\begin{array}{l}10.2,1.13,41 \\
7.0-12.5,11.03\end{array}$ & $\begin{array}{l}10.2,0.74,4 \\
9.2-10.8,7.20\end{array}$ & $\begin{array}{l}9.1,0.99,21 \\
7.5-11.7,10.87\end{array}$ & $8.0,--, 1$ \\
\hline$n t]$ & $\begin{array}{l}9.8,1.34,41 \\
6.1-12.0,13.62\end{array}$ & $\begin{array}{l}9.8,1.63,4 \\
7.6-11.5,16.64\end{array}$ & $\begin{array}{l}8.7,1.37,21 \\
5.5-10.6,15.85\end{array}$ & $10.1,--, 1$ \\
\hline
\end{tabular}


Table 19--continued

p34

$\begin{array}{lllll}\text { ap1 } & 22.8,1.34,48 & 21.4,1.34,9 & 19.5,1.13,35 & 19.7,0.76,3 \\ & 19.2-25.6,5.87 & 19.4-24.1,6.28 & 17.6-22.1,5.81 & 19.2-20.6,3.84 \\ \text { bap1 } & 18.7,0.71,49 & 17.8,0.37,4 & 16.1,0.74,32 & 16.2,0.71,2 \\ & 17.0-20.6,3.82 & 17.3-18.2,2.08 & 14.4-17.8,4.60 & 15.7-16.7,4.36 \\ \text { atw } & 12.0,0.98,48 & 12.3,0.74,8 & 10.9,0.82,34 & 11.1,0.21,3 \\ & 8.4-14.0,8.14 & 11.1-13.4,5.97 & 9.5-12.5,7.50 & 10.9-11.3,1.88 \\ \text { ptw } & 12.0,1.01,48 & 12.0,0.78,8 & 10.6,0.61,35 & 11.2,0.46,3 \\ & 9.1-14.2,8.45 & 10.9-13.5,6.53 & 8.9-11.8,5.77 & 10.8-11.7,4.09 \\ \text { mm1 } & 13.1,1.07,48 & 12.9,0.68,9 & 11.3,0.59,35 & 12.1,0.85,3 \\ & 9.9-15.3,8.14 & 11.9-14.0,5.24 & 10.0-12.6,5.23 & 11.5-13.1,7.03 \\ \text { ent1 } & 10.4,1.02,48 & 10.1,0.95,9 & 9.1,1.03,35 & 9.1,1.50,3 \\ & 6.1-12.1,9.88 & 8.0-11.2,9.35 & 6.1-10.8,11.35 & 7.6-10.6,16.5 \\ & & & & \\ & & & & \\ \text { ap1 } & 22.2,2.03,68 & 21.3,1.90,15 & 19.5,1.63,43 & 18.2,1.82,4 \\ & 18.6-26.3,9.15 & 18.4-24.4,8.91 & 17.0-23.5,8.39 & 16.2-20.4,10.0 \\ \text { bap1 } & 17.4,0.90,64 & 17.8,0.88,8 & 15.3,0.89,41 & 15.6,--, 1 \\ & 15.4-20.2,5.15 & 16.9-19.4,4.94 & 13.2-17.1,5.79 & \\ \text { atw } & 10.2,1.08,68 & 10.7,1.72,16 & 9.1,1.07,44 & 9.9,0.70,5 \\ & 8.1-12.6,10.52 & 8.1-13.4,16.14 & 6.2-11.9,11.81 & 9.4-11.1,7.03 \\ \text { ptw } & 9.3,1.07,68 & 9.5,1.50,16 & 8.4,0.84,44 & 9.0,0.42,5 \\ & 6.4-11.4,11.49 & 7.1-12.1,15.78 & 6.5-10.0,9.96 & 8.6-9.7,4.65 \\ \text { mm1 } & 12.2,0.83,68 & 12.1,1.34,16 & 10.7,0.65,44 & 11.1,0.69,5 \\ & 10.5-14.3,6.78 & 10.1-14.2,11.10 & 9.0-12.1,6.03 & 10.3-11.8,6.18 \\ \text { ent1 } & 8.0,1.21,68 & 7.4,1.21,16 & 6.8,1.08,44 & 6.5,1.62,5 \\ & 5.5-10.1,14.08 & 5.5-9.8,16.29 & 4.5-9.0,15.80 & 4.3-7.2,24.97\end{array}$


The lower molars of Cor. plicatile (Figs. 25, 26A, Table 19), although smaller, closely resemble those of Cor. occidentale in overall enamel morphology. Although initially shallow, the ectoflexid deepens rapidly with wear, so that even molars with crown heights exceeding $50 \mathrm{~mm}$ have completely divided isthmuses. The metaconid and metastylid are well separated from each other by the deep ectoflexid and a broad, 'U'-shaped linguaflexid. The metaconid is generally oval, while the metastylid is typically more angular (Figs. 25B, 25C). The bases of the metaflexids and entoflexids are not flat, due to rounded lingual projections from the protoconid and hypoconid. Pli caballinids are rare in molars, always small, and confined to very early wear-stages (e.g. the m2 of F:AM 107874). Rudimentary thickenings of the enamel at the position in the ectoflexid from where pli caballinids would originate are not infrequent in early and moderate wear-stages, however. The antisthmus generally has a single plication in early wear-stages (Fig. 25), but plications are less common from the paralophid and postisthmus than in the premolars (Table 17). Slightly worn to unworn mech of m12 varies between 56 and $60 \mathrm{~mm}$, while that of the $\mathrm{m} 3$ is about 53 to $56 \mathrm{~mm}$. Lower deciduous premolars of Cor. plicatile (Fig. 26C) have more elongated metaconids and metastylids than do the p2-p4, large protostylids on the dp34, and somewhat variable ectoflexid depths. The ectoflexids may be shallow, especially in early wear-stages, and sometimes do not penetrate the isthmus; but generally they deepen with wear on the dp34. The dp2 ectoflexid tends to remain shallow. As is typical for the genus, ectostylids are well developed, 
especially on the dp3. This structure extends 8 to $17 \mathrm{~mm}$ above the base of the tooth, producing an isolated, dentine-filled lake on the occlusal surface when the tooth is sufficiently worn (Fig. 26C). Pli caballinids are either absent, or, in early wear-stages, rudimentary. Metaconid crown height of unworn dp34s is about $26 \mathrm{~mm}$.

Discussion. Leidy (1887, p. 309) noted that the holotype of Cor. plicatile (USNM 3292; see MacFadden 1984a, Fig. 140) was found at the same locality (i.e. Mixson's Bone Bed) as other fossils sent to him by local collectors. It is clear from his earlier writings (Leidy, 1884 ; 1885 ; 1887) that he considered the type locality of "Hippotherium" ingenuum, "H. "Auchenia" major, and other newly described taxa all to be Mixson's Bone Bed. It was later revealed that some specimens sent to him had been collected at additional localities in the vicinity of the town of Archer (Leidy and Lucas, 1896, pp. ix and $x i$ ). However, there is no evidence that Mixson's is not the type locality of both Cor. plicatile and Cor. ingenuum (e.g. based on preservation), and additional specimens referable to both were collected there by Frick field crews in the $1930 \mathrm{~s}$ and $1940 \mathrm{~s}$.

Ever since its initial description, USNM 3292 has been described as a "molar" (Leidy, 1887, 310; 0sborn, 1918, p. 192; MacFadden, $1984 a$, p. 170). Leidy, however, used the term to refer to both true molars and premolars. Leidy and Lucas (1896, p. 50) described USNM 3292 as a molar, "...probably the third...", apparently a reference to a P4. There are several features of the specimen that indicate that it is indeed a premolar, and not a molar. These include the relatively large and widely-open parastyle and mesostyle, and the 
complex pli caballin. Most importantly, the mesostyle angles anteriorly in labial view when the occlusal surface is face down, a distinguishing characteristic of P34s and not M12s (Bode, 1931).

That the holotype of Cor. plicatile is a premolar is important, because (as will be detailed below) the only feature that clearly distinguishes worn upper cheekteeth of Cor. plicatile from those of Cor. ingenuum is size. Is the size difference between the holotypes of Cor. plicatile and Cor. ingenuum merely a reflection of the typical significant size differences between P34s and M12s of Cormohipparion? For both Cor. plicatile and Cor. ingenuum to be valid, distinct species, it is necessary to show: 1) that two different sized populations of Cormohipparion exist at Mixson's Bone Bed and other nearby localities; 2) that the holotype of Cor. plicatile matches upper premolars of the larger-sized population in size and morphology; and 3) that the holotype of Cor. ingenuum matches upper molars of the smaller-sized population. If any of the se conditions is not met, then Cor. plicatile must be considered a junior

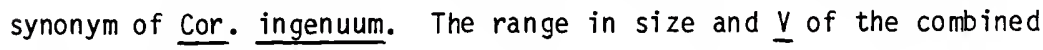
sample are greater than that observed in other single-species quarry or faunal populations (Table 20), indicating the presence of more than a single species. Frequency distributions of occlusal and basal crown dimensions (Figs. 27,28 ) are bimoda1, but do indicate appreciable overlap between the two populations. The apparent greater overlap in APL is lessened when the data are adjusted for crown height. The holotype of Cor. ingenuum clearly clusters with the molars of the smaller-sized population both in univariate and multivariate analyses (Tables 15 and 22; Figs. 27-29), indicating that the 


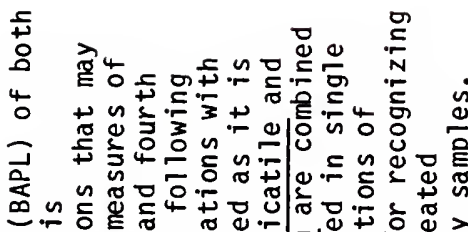

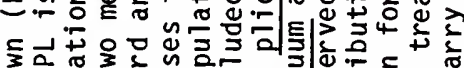

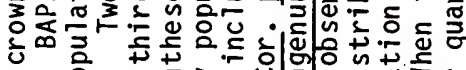

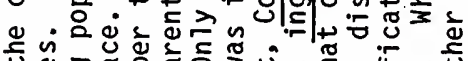

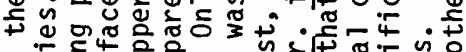

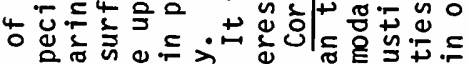

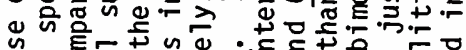

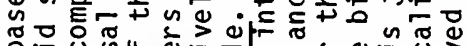

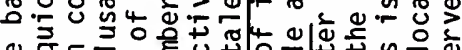

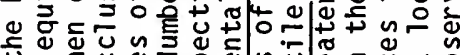
†

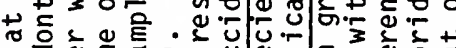

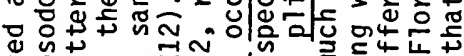

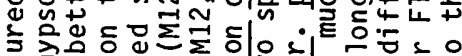

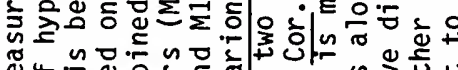

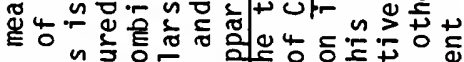

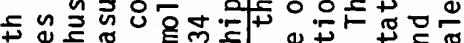

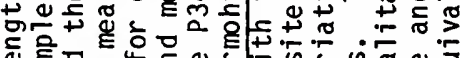

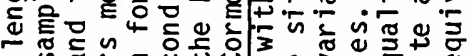

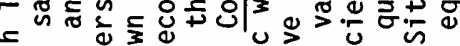

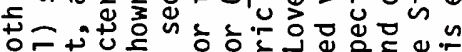

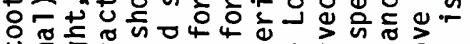

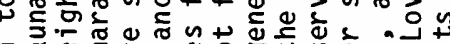
ᄃ

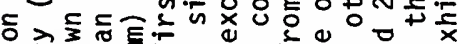

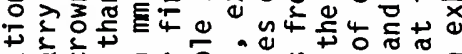

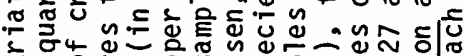

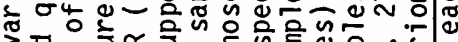

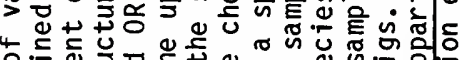
응은 혼

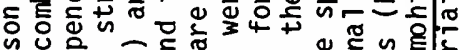

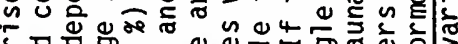

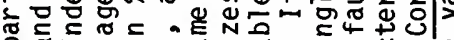

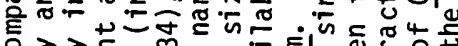

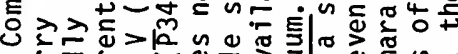

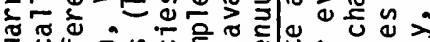

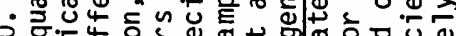

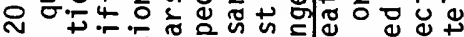
$0 \stackrel{0}{n}$ 舟 山元市

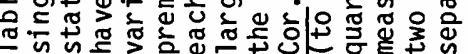

\begin{tabular}{|c|c|c|}
\hline 똥 & $\ddot{\sigma}$ & 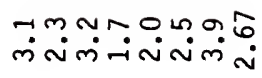 \\
\hline$>1$ & $\ddot{0}$ & 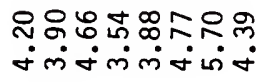 \\
\hline 号 & $\ddot{0}$ & تñ் \\
\hline$>1$ & $\stackrel{\pi}{n}$ & 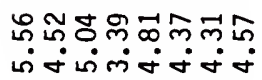 \\
\hline
\end{tabular}

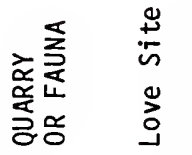

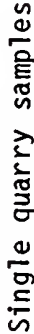

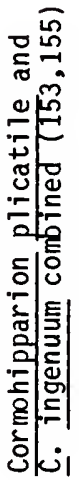

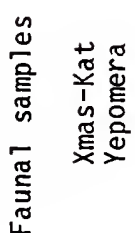

6 ตำ

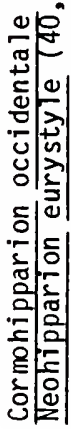




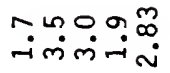

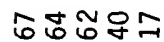

ن்

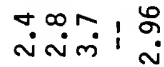

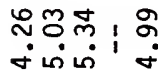

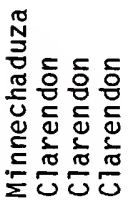

을

กิ

응

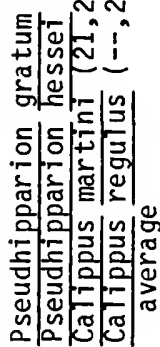


Figure 27. Histograms of the distribution of occlusal anteroposterior length (APL), transverse width (TRW), and basal crown length (BAPL) for combined Florida samples of upper third and fourth premolars (P34) of Cormohipparion ingenuum ( $A, C$ and $E$ ) and Cor. plicatile ( $B, D$ and $F)$. Analyzed samples exclude very slightTy worn and very heavily worn individuals. A,B. P34 APL; $n=53$ for Cor. ingenuum, $n=121$ for Cor. plicatile (similarly, the first value given in the following for sample size is that of Cor. ingenuum, the second Cor. plicatile). C,D. P34 TRW; $n=53,123$. E,F. P 34 BAPL; $n=48,121$. Distributions are interpreted as being primarily bimodal with varying degrees of overlap between the two species. All measurements in mm. 

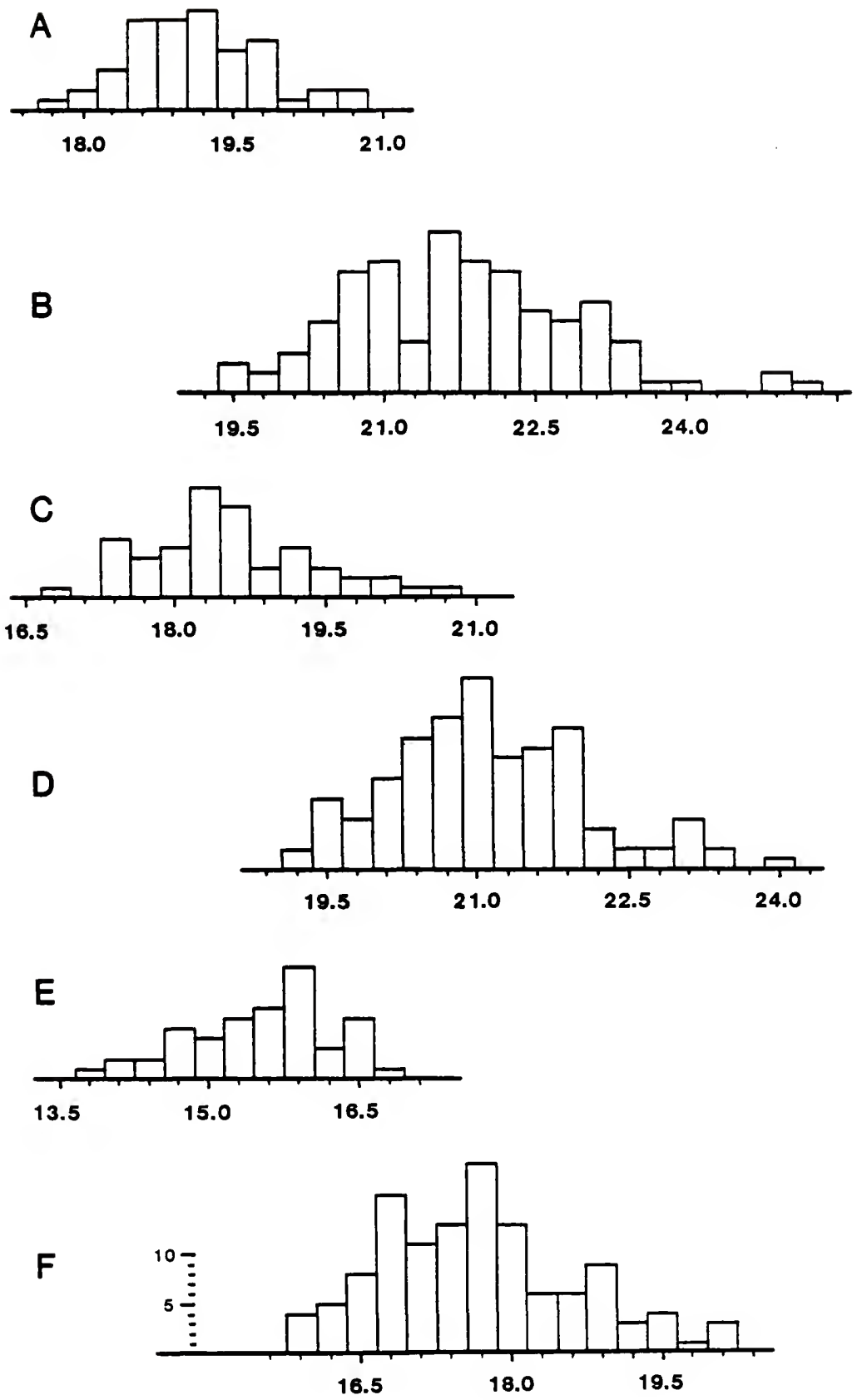
Figure 28. Histograms of the distribution of occlusal anteroposterior length (APL), transverse width (TRW), and basal crown length (BAPL) for combined Florida samples of first and second molars (M12) of Cormohipparion ingenuum ( $A, C$ and $E$ ) and Cor. plicatile ( $B$, $D$ and $F$ ). Analyzed sampTes excTude very slightly worn and very heavily worn individuals. A,B. M12 APL; $n=52,110$. C,D. M12 TRW; $n=53,105$. E,F. M12 BAPL; $n=56,120$. Distributions are interpreted as being primarily bimodal with varying degrees of overlap between the two species. All measurements in $\mathrm{mm}$. 


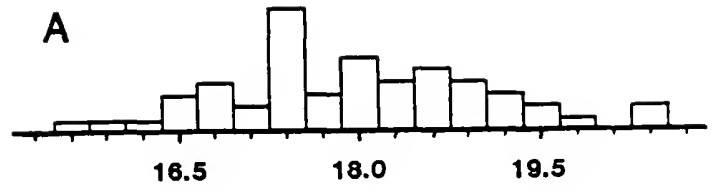

B
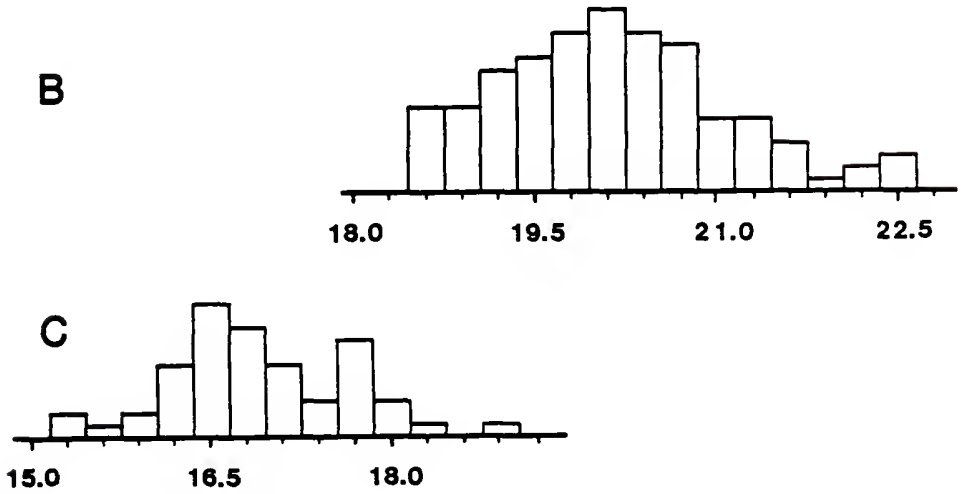

D

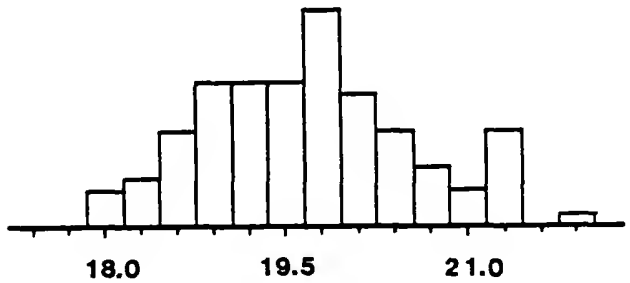

E

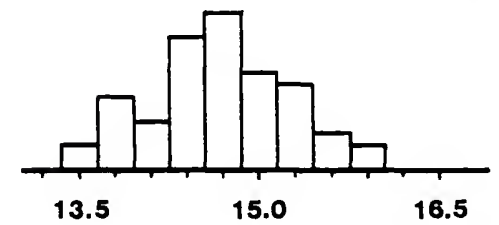

F

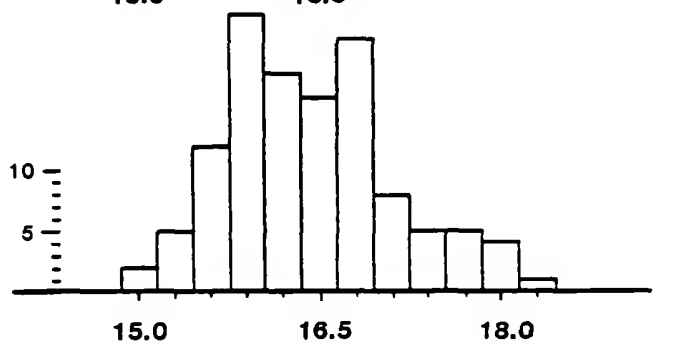




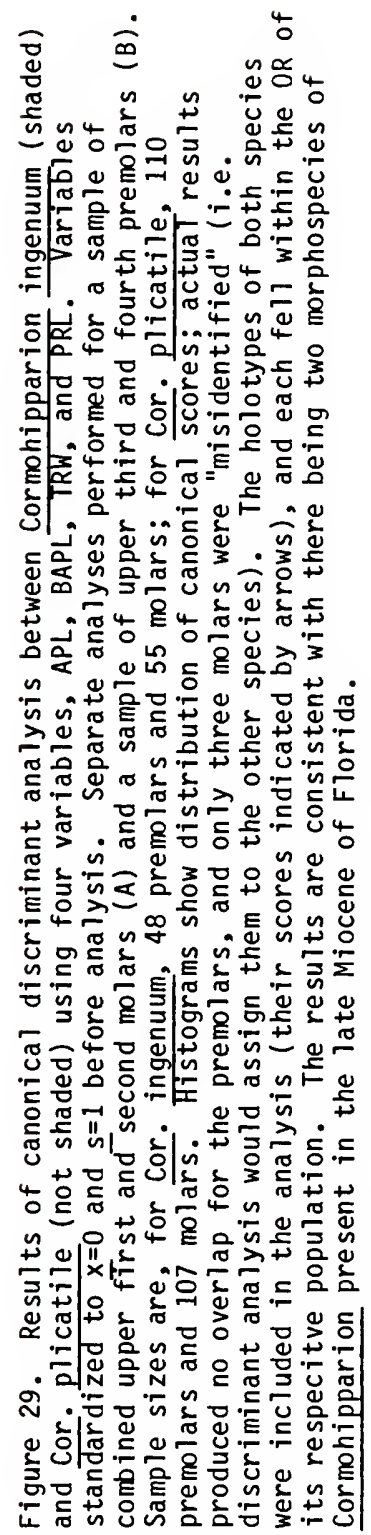




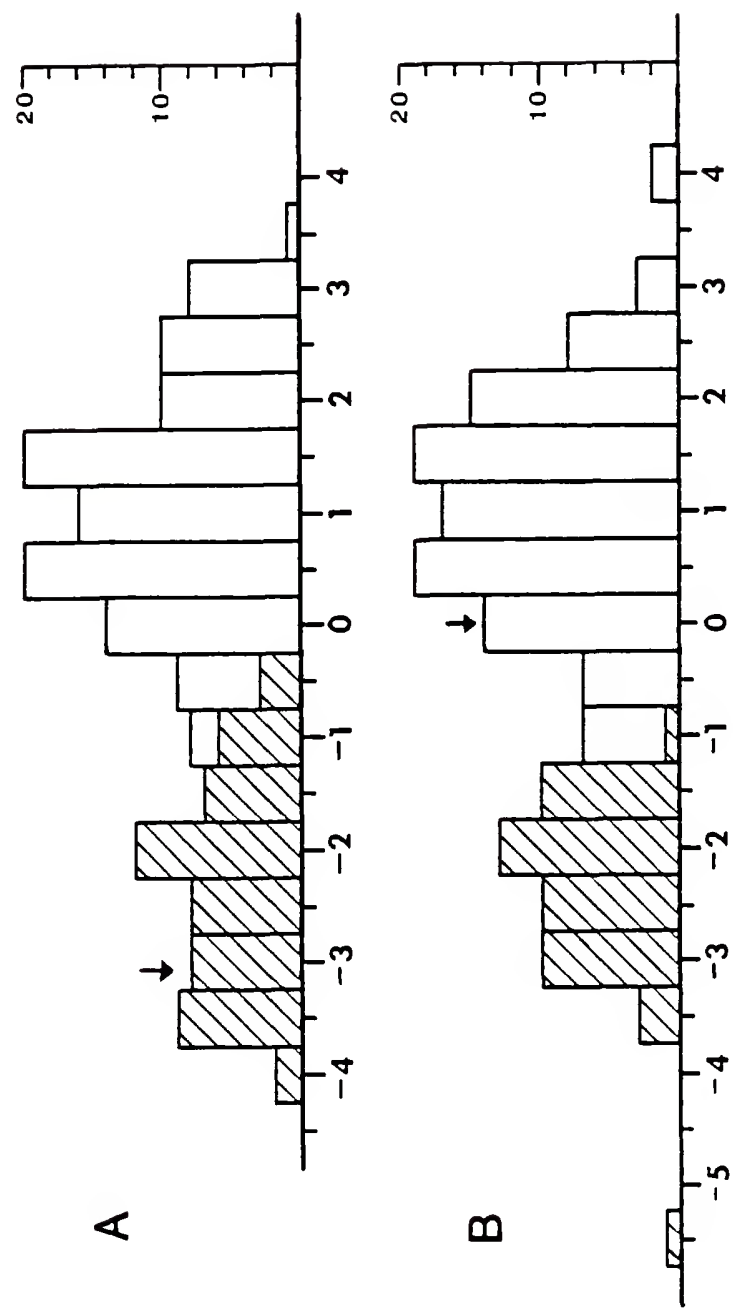


smaller sample should be referred to by the older name. The holotype of Cor. plicatile, while only within the range of the larger-sized population for TRW and BAPL (Table 15; Figs. 27D and 27F), has a relatively small APL $(19.7 \mathrm{~mm})$ that is within the observed range of both populations (Tables 15, 18, 22; Fig. 27B). Linear discriminant analysis separates the two with very little overlap, and places USNM 3292 with the larger sample (Fig. 29). Thus, the link between USNM 3292 and the larger-sized population, while somewhat more uncertain than that of the type of Cor. ingenuum and the smaller-sized population, is reasonable. The best matches for the peculiar fossette morphology of USNM 3292 are found in the larger-sized population (e.g. UF 17210, Fig. 23B). The Mahalanobis distances between the two populations are significantly different (at $\underline{p}<0.01$ ) for both of the separately analyzed samples of P34 and M12. That the two do in fact represent distinct species is further emphasized by the differences in the DPOF, the p2 morphology (described below), and in unworn crown height. The conditions for validation of both Cor. plicatile and Cor. ingenuum set forth above are thus apparently met, although the holotype of Cor. plicatile is atypical for certain characters relative to the majority of specimens referred to the species. These are judged to reflect individual variation rather than species-leve 1 differences.

Leidy's (1887), and later Cope's (1889), referral of plicatile to the genus Hippotherium reflected no particular phylogenetic significance. At this period, al1 hipparionine and many merychippine species were placed in Hippotherium, a name then considered valid for 
all Eurasian and North American forms previously recognized as Hipparion. Starting about 1900, Hipparion replaced Hippotherium as the commonly used genus for hipparionine equids, and plicatile was routinely transferred to Hipparion during this period (e.g. Hay, 1902). Gidley's (1907) use of "Hipparion" plicatile did have phylogenetic significance, however, as he felt that "H." plicatile (along with "ㅂ. ." ingenuum and $\underline{H}$. venustum) "...belong to an American branch of the Hipparion group of the 01d World" (Gidley, 1907, p. 906). Gidley's separation of hipparionines into two genera, Neohipparion (for New World species) and Hipparion (primarily for 0ld World species), was not accepted by his contemporaries Matthew and 0sborn (see e.g. Osborn, 1918, p. 173), who continued to refer all hipparionines to a single genus. Matthew (1924) concluded that the Miocene hipparionines from Florida and South Carolina (including "H." plicatile) were not especially related to 01d World species, a view a) so endorsed by Simpson (1930). Stirton (1940) separated North American Hipparion s.1. into three genera, Hipparion s.s., Nannippus and Neohipparion, and, by his assignment of "?Hipparion plicatile", again raised the possibility that it was more closely related to $01 d$ World taxa than most North American hipparionines (which he assigned to either Neohipparion or Nannippus). More recently, "H." plicatile has appeared in some faunal lists (e.g. Hirschfeld and Webb, 1968; Webb and Perrigo, 1984), but it was not again analyzed phylogenetically until MacFadden (1984a). MacFadden (1984a, pp. 170-174) concluded that the species, while valid, was generically indeterminant. The major problem with all prior studies of the generic affinities of "Hippotherium" plicatile was the limited amount 
of available topotypic and referable material. This obstacle has been eliminated by the samples from McGehee Farm, Moss Acres, and especially the Love Site.

Quantitative and qualitative analyses of the dental material listed above indicate that "H. " plicatile is more closely related to Cor. sphenodus and Cor. occidentale than to any other hipparionine taxa from North America, and that it can be referred to Cormohipparion sen su MacFadden (1984a). Cormohipparion plicatile shares the following features with Cor. sphenodus and Cor. occidentale which in combination serve to distinguish them from other North American hipparionine genera: high, well developed ectostylids on deciduous lower premolars; lower permanent premolars with moderately reduced ectoflexid depth and moderate pli caballinids in early wear-stages; high frequency of plicated isthmuses; p2 and P2 much longer than p34 and P34 with expanded paraconids and anterostyles, respectively; oval or elongate-oval protocones isolated until late wear-stages; and highly complex and intricately plicated fossettes and pli caballins until at least middle wear-stages. While some of these character states evolved independently in other hipparionine genera, in combination they support the referral of plicatile to Cormohipparion. This assignment can be tested with the discovery of more complete material, especially well preserved skulls. This referral to Cormohipparion in part vindicates the theories of Gidley (1907), Osborn (1918, p. 192) and Stirton (1940) concerning possible relationships with 01d World taxa. However, both Cor. plicatile and Cor. ingenuum are too young to be directly ancestral to old World hipparionines. 
Leidy's name "plicatile" suggested that the species had exceptionally complex fossette borders (as indeed is shown by the somewhat atypical holotype). This has been further emphasized by MacFadden (1984a, pp. 170-171). However, these observations were based on small sample sizes, and, in some cases, included specimens I would

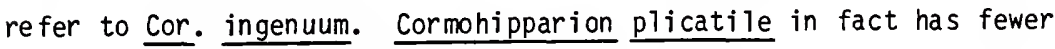
fossette plications on average than any other advanced species of North American Cormohipparion (Table 21; Figs. 30, 31). It might also be noted that the complexity of the holotype of Cor. plicatile results more from extreme bifurcating of plications, and a not unusually high number of total plications (12) for the species. Although the median differences (Table 21) are slight, Figures 30 and 31 reveal a quite different pattern of fossette plications between Cor. plicatile and Cor. occidentale. The multimodal distribution for Cor. occidentale is not the result of combining samples from different localities. Similar multimodal distributions were produced using a sample drawn from a restricted geographic and chronologic population (Fig. 32). Much of the difference between Cor. plicatile and $\underline{\text { Cor }}$. occidentale results from variation of plications on the anterior half of the prefossette. Slightly worn uppers of Cor. occidentale typically have four to sixplications on the anterior half of the prefossette. More moderately worn teeth most often have only one or two. The decrease does not proceed linearly with wear, but tends to follow a step-wise pattern. This, combined with a perhaps more linear decrease in plications on other regions of the fossettes, produces the multimodal distributions in Figures $30 \mathrm{~A}, 31 \mathrm{~A}$ and 32. There are three distinct peaks in fossette complexity within 


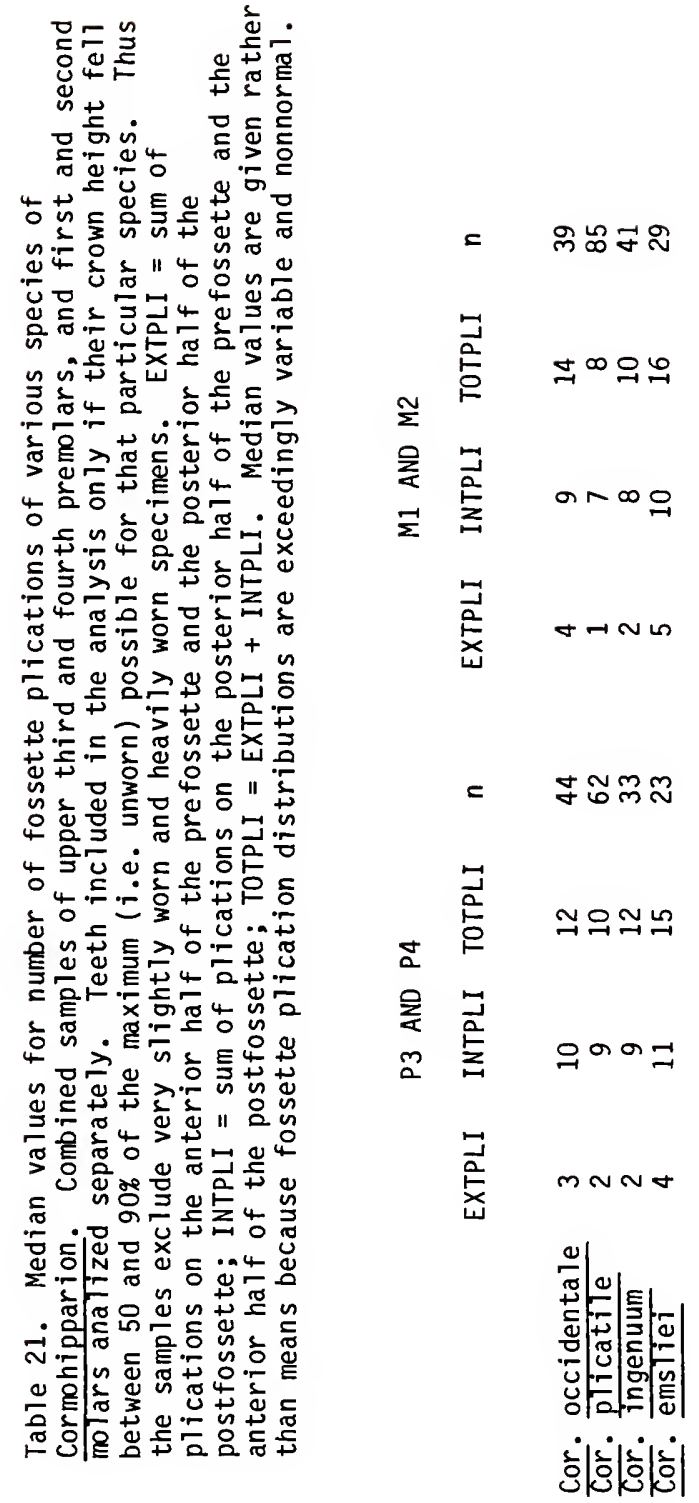


Figure 30. Histograms of total number of fossette plications on the P3 and P4 of four species of Cormohipparion. A. Cor. occidentale, combined sample from Clarendonian and earTy HemphiTTian of Texas and Nebraska, $n=44$. B. Cor. plicatile, combined sample from Florida sites, $n=62$. C. Cor ingenuum, combined sample from Florida sites, $n=33$. D. Cor. emstiei, combined sample from Bone Valley and Macasphait Shei 1 Pit sites, $n=23$. Samples include only specimens with MSCH between 50 and $90 \%$ of unworn crown height for each particular species. 
A CORMOHIPPARION P3 AND P4
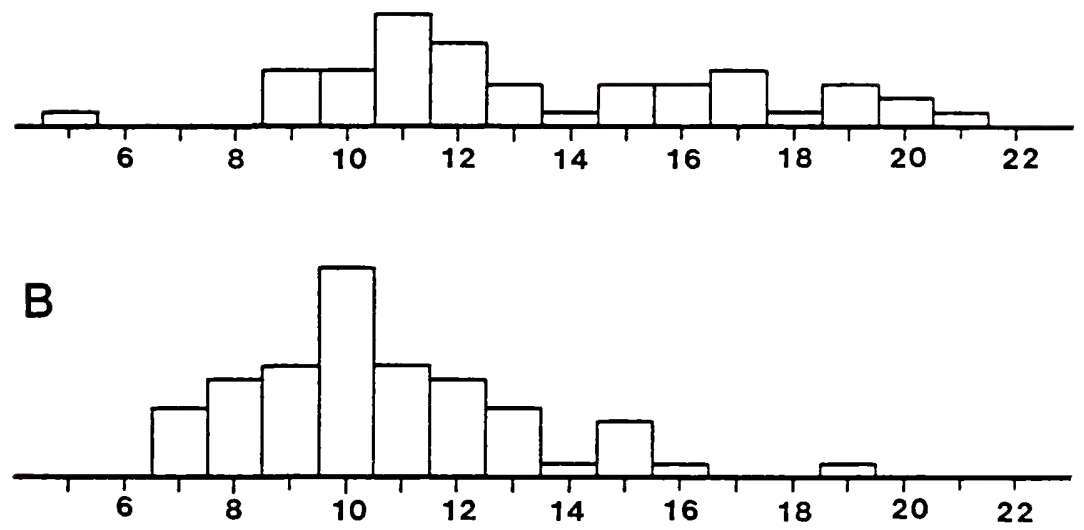

C

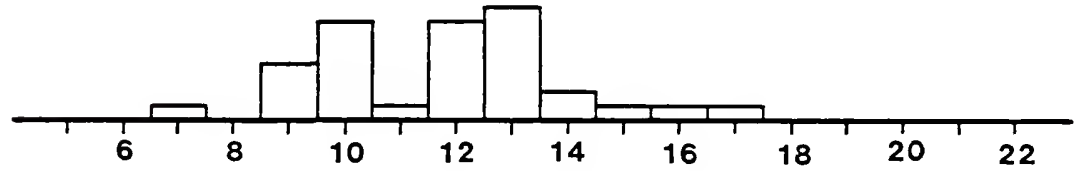

D

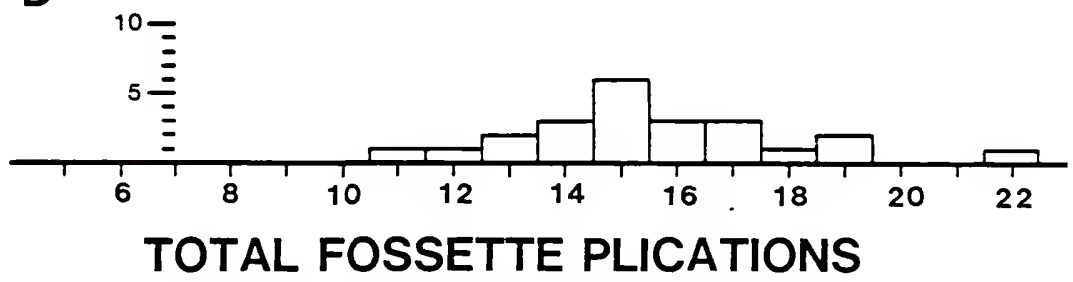


Figure 31. Histograms of total number of fossette plications on the M1 and M2 of four species of Cormohipparion. A. Cor. occidentale, combined sample from Clarendonian and earty HemphiTTian of Texas and Nebraska, $n=39$. B. Cor. plicatile, combined sample from Florida sites, $n=85$. C. Cor. ingenuum, combined sample from Florida sites, $n=41$. D. Cor. emstiei, combined sample from Bone Valley and Macasphalt Sheil Pit sites, $n=29$. Samples include on ly specimens with MSCH between 50 and $90 \%$ of unworn crown height for each particular species. 


\section{A CORMOHIPPARION M1 AND M2}
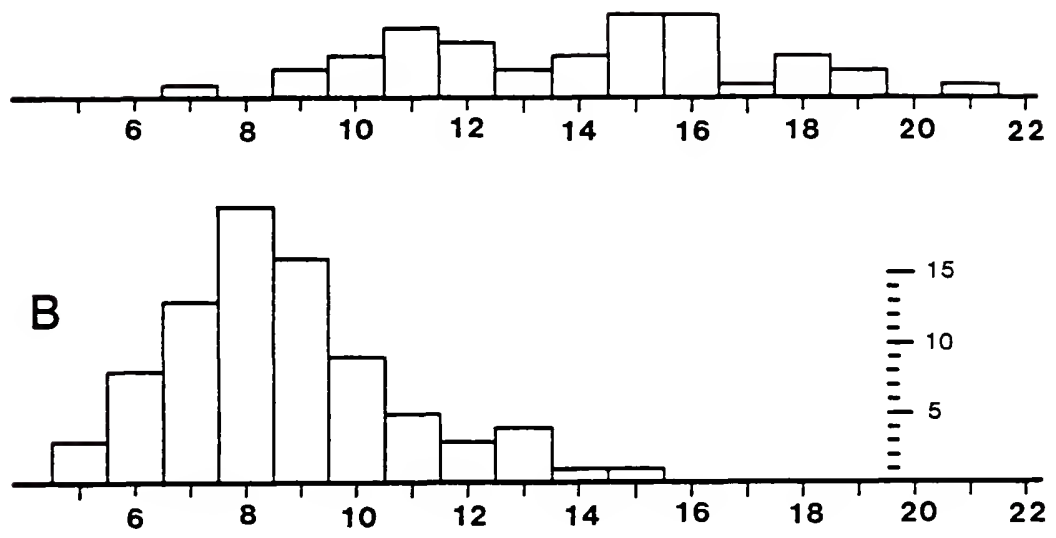

C

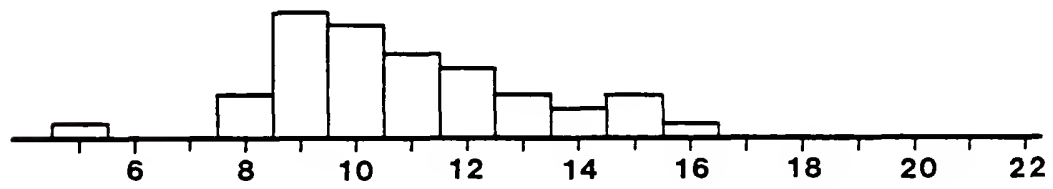

D

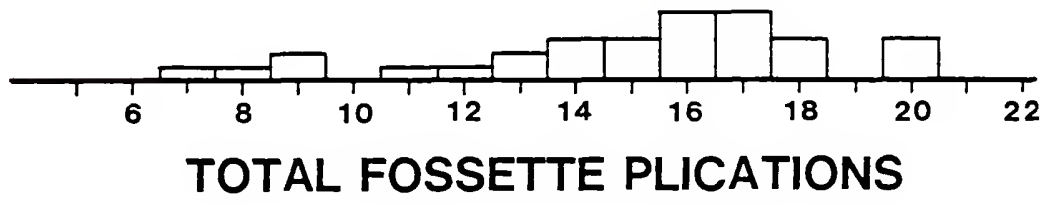




\section{TOTAL FOSSETTE PLICATIONS \\ Cormohipparion occidentale}
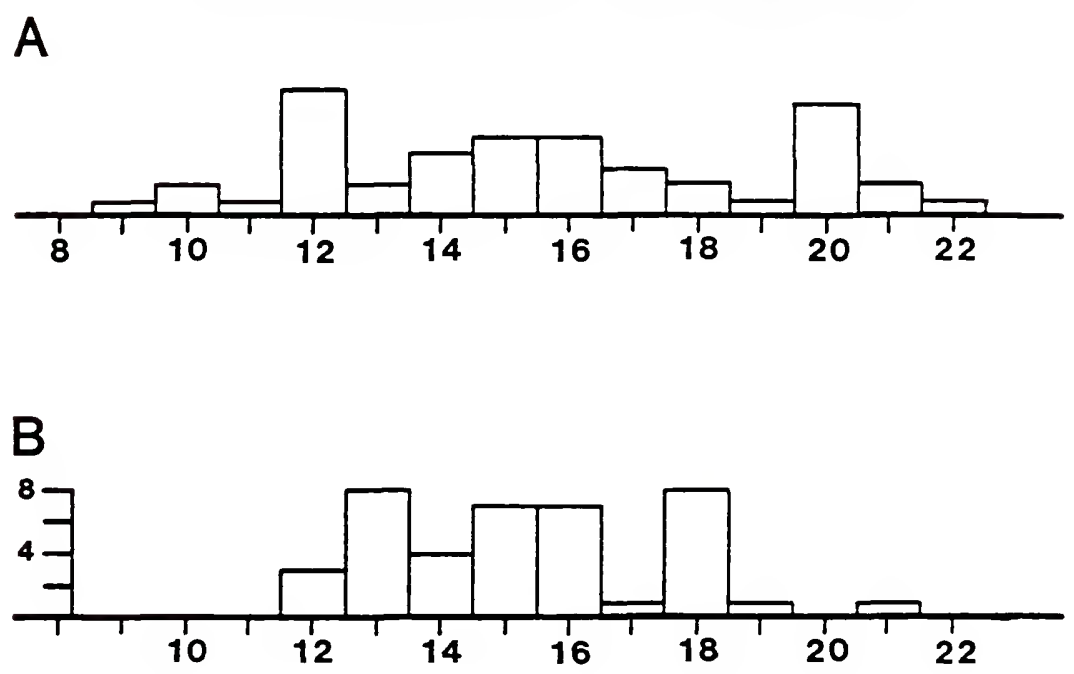

Figure 32. Histograms of total number of fossette plications of $A$, the P3 and P4 $(n=43)$; and $B$, the $M 1$ and $M 2 \quad(n=40)$ of Cormohipparion occidentale from the Xmas-Kat Quarries Fauna, Cherry County, Nebraska (Tate Clarendonian). Sample analyzed as those in Figures 30 and 31 , but the Xmas-Kat sample consists primarily of skulls. Therefore, crown height cannot be directly measured on most of these specimens. To make the sample comparable to those in Figures 30 and 31 , values of APL were used to exclude slightly worn or excessively worn specimens. The Xmas-Kat specimens, although slightly more complex on average, display the same multimodal pattern as the combined sample of Cor. occidentale in Figures 30 and 31. 
the wear-stages under consideration. These are an early phase with a mode of 18, 19 or 20 (here termed fossette-group A); an intermediate group (B) with a mode of 15 to 17; and a final group (C) with a mode of 11 to 13. In Cor. plicatile, three important differences are observed: 1) the number of plications on the anterior half of the prefossette is much less variable, being almost always 0,1 , or more rarely 2; 2) the modal values are less (by 2 or 3 ); and 3 ) group $C$ is reached much earlier in ontogeny, such that groups $A$ and $B$ are either not observed (group A for molars, Fig. 31B) or are very rare. Genera11y, the first two fossette-groups are ephemerally expressed during earliest wear-stages, in the first $10 \%$ of the crown. The result is a distribution that appears more normal than that of Cor. occidentale, and only slightly skewed to the left. The pattern in Cor. plicatile is judged to represent the primitive condition, as the general trend in the genus is to increase plication number and duration, and because Cor. sphenodus appears to have a similar pattern (although limited available sample sizes prevent further analysis of that species). The fossette border morphology of Cor. occidentale could have evolved from an ancestor with Cor. plicatilelike fossettes by slightly increasing the median plication number (per fosette-group), and, more importantly, substantially delaying the average crown height at which fossette-group $A$ transforms into $B$, and likewise $B$ into $C$.

Cormohipparion plicatile is known from at least thirteen localities in Florida (see referred specimens list and Fig. 2) that range in age from latest Clarendonian (Love Site, about $9.0 \mathrm{ma}$ ) 
through the later part of the early Hemphillian (about $6.0 \mathrm{ma}$ ). The youngest specimens referred to Cor. plicatile are probably those derived from the Dunnellon phosphate-mining region. In this area, Cor. plicatile is found together with Cor. ingenuum, Nan. minor and Neo. eurystyle. The period of overlap between these four is the late early Hemphillian (about 6.0 to $7.0 \mathrm{ma}$; Tedford et al., in press). The otherwise best represented fauna of this interval in Florida, the With 4A site (Webb, 1969b; Becker, 1985a), lacks Cor. plicatile, however. Anagenetic microevolution is observed when younger and older samples are compared, especially in terms of plication complexity. Another relatively young referred sample is that from the Moss Acres Racetrack Site (Figs. 23A, 24, 25C). The upper molars from Moss Acres (UF 69968, 93000 and 96386) are much more complex than average Love Site specimens, with multiple pli protolophs and pli caballins. The lower molars of UF 69967 and UF 93000 have stronger and more persistent pli caballinids than any specimen from the numerous Love Site sample. The Moss Acres sample does not appear to differ from older populations in terms of size or hypsodonty. The observed magnitude of intraspecific evolution is similar to that found in other equid chronospecies over similar intervals of time (e.g. Neohipparion trampasense).

Equid populations from outside of Florida have only occasionally been referred to Cor. plicatile. Webb (1969a) listed "H." plicatile in the Clarendon Fauna, but gave no references or specimen numbers. Apparently he was referring to the same population later placed by MacFadden $(1980 ; 1984 \mathrm{a})$ in $\underline{\mathrm{H}}$. tehonense. Webb and Perrigo (1984) recently referred to " $\underline{H}$. " plicatile a sample of about 50 cheekteeth 
from the Gracias Formation of Honduras. While morphologically similar to Cor. plicatile, the smaller occlusal dimensions of this sample clearly indicate a referral to Cor. ingenuum, and they will be more fully discussed with that taxon. Examination of equid specimens from the following major faunas or localities (in the F:AM, AMNH, UNSM and UCMP collections) of late Clarendonian or early Hemphillian age has failed to indicate the presence of Cor. plicatile in western North America: Xmas-Kat Channels, Cole Highway Pit, Pratt Pit I, J. Swayze Quarry, Port of Entry Pit, Box T Quarry, Higgins Fauna and the Cambridge Fauna. Most of the se instead contain a large, advanced form of Cor. occidentale. Thus, at the present time, there are no known referable samples of Cor. plicatile outside of central Florida.

\section{Cormohipparion ingenuum (Leidy), 1885 new combination}

Hippotherium ingenuum LEIDY, 1885, p. 33. Hippotherium gratum (Leidy), COPE, 1889, p. 445 (in part); LEIDY and LUCAS, 1896, pp. 49-50 (in part).

Hipparion ingenuum (Leidy), GIDLEY, 1907, p. 902; SELLARDS, 1916, pp. 94, 97 (in part); OSBORN, 1918, p. 191.

Hipparion (Nannippus) ingenuum (Leidy), SIMPSON, 1930, pp. $187-188$ (in part).

Nannippus ingenuus (Leidy), STIRTON, 1940, p. 186; QUINN, 1955, p. 75 (in part); MACFADDEN, 1984a, pp. 126-133 (in part). Hipparion plicatile (Leidy), SIMPSON, 1930, pp. 187-188 (in part); WEBB and PERRIGO, 1984, pp. 243-245 (in part). "Hippotherium" plicatile (Leidy), MACFADDEN, 1984a, pp. 170-174 
(in part).

Cormohipparion n. Sp., BECKER, 1985a, p. 30.

Not Nannippus cf. Nan. ingenuum (Leidy), FORSTEN, 1975, pp. 61-65.

Not Hipparion ingenuum (Leidy), WEBB and TESSMAN, 1968, p. 807.

Type specimen. USNM 3306, a L upper molar, probably a M1 (Osborn, 1918, Fig. 154 or MacFadden, 1984a, Fig. 97).

Type locality. Mixson's Bone Bed, Levy County, Florida.

Stratigraphic occurrence and age of type locality. Alachua Formation; early Hemphillian, about $8 \mathrm{ma}$.

Topotypic sample. USNM 3305 L M3; F:AM 107875 assoc. R P2,P4-M3 and L P2-M3; F:AM 113623, 113624, 1136383 L M12; F:AM 104870 L p34. Distribution. Very late Clarendonian through early Hemphillian (about 6.0 to $9.0 \mathrm{ma}$ ) of central Florida. Early Hemphillian of Honduras.

Referred Gulf Coastal Plain specimens. McGehee Farm: UF $17209 \mathrm{R}$ P34; 7246, 172152 L P34; 9557, 456132 L M12; 17219, 535492 R M3; 11825 L dp34; 17165 L p2; 19482 R p34; 17194, 456262 R m12; 9775, $171012 \mathrm{~L} \mathrm{~m} 12$.

Haile 19A: UF 65727 L M12; $47323 R$ p2; 64751 R p34. Cofrin Creek, Alachua Co., FL: UF $57107 \mathrm{R} \mathrm{m12;} 17223 \mathrm{R} \mathrm{m} 3$. VA Hospital Site, Alachua Co., FL: UF 17224 L M12; 53562 R M12; With 4A: UF 17204 L maxilla with P2-M3; 45517, 53518, $535193 \mathrm{~L}$ P2; 17200, 53516 R P34; 45530 R M12; 19622, 53512 2 L M3; 53459, 53482, 534923 L p34.

With 4X: UF 18329 L P34. 
Moss Acres Racetrack Site: UF 97259 female $R$ and $L$ mandibles with $i 1-i 3, p 2-m 3$.

Dunnellon Phosphate Mining Region, Marion Co., FL: UF/FGS V-1479 R M12; -1483, -1485 2 L M12.

Archer Fauna, Nichols Mine: UF 24624 L M2; 24632 L p2.

Peace River, near Gardner, Hardee Co., FL: UF 55950 R m12.

Love Site: UF 32300 partial skull with L I3, R and L C,P2-M3; 32254 assoc. $R$ maxilla with P2,P4-M3 and L maxilla with P2-M3; 53409 assoc. $R$ and $L M 2 ; 53410$ assoc. $R$ and $L M 1 ; 35966,35971-35973$, $35975,35979-35980,35990,35996,36011,36017-36023,36026-36027$, $36029-36030,36039,36042-36043,36045-36046,36050,36052,36055$, $36058,36061-36062,36067,36261-36262,36264-36265,36267-36268$, 6039639 R P2; 36138-36142, 36148, 36150, 36154, 36160-36161, 36163$36164,36167,36170,36172,36175,36178-36179,36187,36191,36196-$ $36198,36203-36204,36207-36208,36215-36216,36224,36230-36231$, $36234,36240,36242,36245-36246,36252,36259,36271,6980843$ L P2; $53350,53392,53393,53397,53399-53404,62433-62437,62439-62446$, $62418,62426,6229726 \mathrm{R} P 34$; 53176, 53406-53408, 62325, 62377, $62449-62453,62455,62457-62459,62461-62464,62466-6247024$ L P34; $53333,53341,53343,53386-53391,53394-53396,53426,62304,62414-$ $62417,62419-62425,62427-6243231$ R M12; 53375, 53380-53385, 6239062407, 62409-62413 30 L M12; 32120, 321332 R mandibles with dp2-dp4; $32150 \mathrm{~L}$ mandible with $\mathrm{dp} 2-\mathrm{dp} 4 ; 32191$ assoc. $R$ mandible with $\mathrm{p} 2-\mathrm{m} 3$ and $L$ mandible with $\mathrm{p} 3-\mathrm{m} 3 ; 32172,362862 \mathrm{R}$ mandibles with $\mathrm{p} 2-\mathrm{m} 3 ; 32169 \mathrm{R}$ mandible with $\mathrm{p} 2-\mathrm{m} 2 ; 32155,321892 \mathrm{R}$ mandibles with $\mathrm{p} 3-\mathrm{m} 3 ; 32101$, $32154,322973 \mathrm{~L}$ mandibles with $\mathrm{p} 2-\mathrm{m} 3$; $32198 \mathrm{~L}$ mandible with $\mathrm{p} 3-\mathrm{m} 3$; $32171,32132,60395,32124,32241,32138,36284,32289,32181,36280$, 
3211711 partial $\mathrm{R}$ mandibles; 32103, 32112, 32128, 32115, 321585 partial L mandibles; 90199, 902002 assoc. R dp2-dp3; 90198 assoc. L dp2-dp3; 32294 assoc. L dp2-dp4; 32200, 362862 assoc. R p2-m3; 35894 assoc. R m1-m3; 90201-90209 $9 \mathrm{R} \mathrm{dp2;} \mathrm{90210-90214} 5 \mathrm{~L} \mathrm{dp2;90236-90261}$ 26 R dp34; 90215-90235 21 L dp34; 50357, 50363, 50366, 50367, 64807$64842,64923-64925,64932,64933,9296816 \mathrm{R} \mathrm{p} 2 ; 50371,64800,64801$, $64803-64806,64922,64938,64939,69817,9296712 \mathrm{~L} \mathrm{p} 2 ; 50542,64752-$ $6477828 \mathrm{R} \mathrm{p} 34 ; 50457,50459,50519,50526,64779-6479925 \mathrm{~L} \mathrm{p} 34$; $64814-64859,65174,6517548 \mathrm{R} \mathrm{m} 12 ; 64860-64901,65169-6517347 \mathrm{~L}$ m12; and many more catalogued and uncata logued isolated teeth and post-cranial elements.

Revised diagnosis. Medium-sized hipparionine with toothrow lengths of 112 to $120 \mathrm{~mm}$ in middle wear-stages. Unworn MSCH of P2 about $37 \mathrm{~mm}$ and $M 12$ about $49 \mathrm{~mm}$. Smaller than Cor. sphenodus, Cor. occidentale or Cor. plicatile. Less unworn crown height than Cor. occidentale, Cor. plicatile, or Cor. emsliei. Ventral border of DPOF less distinctly rimmed than Cor. occidentale or Cor. plicatile, but fossa better developed than in Cor. emsliei. Lower permanent and deciduous second premolars with an enamel fold projecting from the metaconid (or less frequently the paraconid) that in late wear-stages usualiy closes off the metaflexid into an isolated fossettid.

Description. Cranial material completely exhibiting the gener-

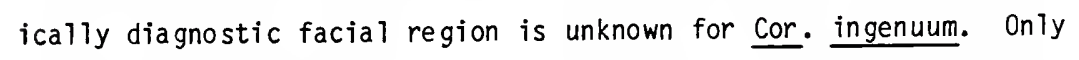
two referable specimens (UF 32300 from the Love Site and UF 17204 from the With 4A locality) preserve portions of the face, each including only the ventral-most part of the DPOF. On the more complete specimen (UF 17204, Fig. 33A), the ventral portion of the 
DPOF consists of a moderately deep impression (at least $11 \mathrm{~mm}$ ) with an unrimmed, sloping ventral border located about $33 \mathrm{~mm}$ above the alveolar border of the P4. The border is located just posterior to the infraorbital foramen. On UF 32300, the ventra1-most part of the DPOF is located about $37 \mathrm{~mm}$ dorsal to the alveolar border of the P3. Summary statistics of measurements on upper and lower cheekteeth are listed in Tables 19 and 22. As is typical for Cormohipparion, the P2 is the longest upper cheektooth, with a well developed anterostyle (Fig. 34A). Upper premolars are characterized by elongate-oval protocones, often with straight or concave lingual borders, that are isolated until late wear (except P2), grooved parastyles for the upper third of the crown, well developed pli caballins and complex fossette borders (Figs. 33B, 34A, 34B). In the Love Site sample, half (26 of 52 observed specimens) of a 11 P34s contain bifurcated or multiple pli caballins; this includes almost all specimens in early and moderate wear-stages. Most (75\%, n=51) of the P34s have a single, deep, unbranched pli protoloph on the anterior half of the prefossette; the remainder have an additional one to three smaller plications labial to it. The pli protoloph is lost only in very late wear-stages. The posterior half of the prefossette is richly plicated, the large prefossette loop is secondarily plicated with deep folds in early wear, and there are usually four to six total infoldings of varying depth and complexity. The anterior half of the postfossette is somewhat less complex, generally with between two and five folds $196 \%$ of observed specimens); the pli postfossette is usually bifurcated, as are one or two of the other plications in early wear-stages. A single, 
Table 22. Standard univariate statistics for upper cheekteeth of Cormohipparion ingenuum from Florida. Format as in Table 2. Faunat abbreviations: LOV, Love Site, Alachua County, late Clarendonian; HE, combined sample from various early Hemphillian localities including McGehee Farm, Mixson's Bone Bed, and Withlacoochee River $4 A$ and $4 X$.

FAUNA LOV HE

P2

$\begin{array}{lll}\text { APL } & 24.5,1.24,43 & 25.2,0.42,2 \\ & 22.1-26.9,5.06 & 24.9-25.5,1.68 \\ \text { BAPL } & \begin{array}{l}19.8,0.91,42 \\ 18.0-21.2,4.60\end{array} & 20.6,--, 1 \\ & & \\ \text { TRW } & 17.3,0.74,44 & 17.8,0.44,3 \\ & 14.9-18.8,4.27 & 17.5-18.3,2.45 \\ \text { PRL } & 5.9,0.55,43 & 6.9,0.61,3 \\ & 4.6-7.5,9.37 & 6.4-7.6,8.81 \\ \text { PRW } & 3.6,0.32,42 & 3.4,0.23,3 \\ & 3.0-4.8,8.87 & 3.3-3.7,6.73\end{array}$


Table 22--continued

P34

$\begin{array}{lll}\text { APL } & 19.2,0.73,49 & 18.8,1.58,9 \\ & 17.8-21.5,3.82 & 15.0-20.5,8.44 \\ \text { BAPL } & 15.5,0.70,46 & 15.8,1.12,4 \\ & 13.9-16.6,4.52 & 14.2-16.7,7.07 \\ \text { TRW } & 18.5,0.85,49 & 17.4,2.02,9 \\ & 16.9-20.7,4.58 & 14.0-19.5,11.6 \\ \text { PRL } & 6.7,0.69,50 & 6.4,0.92,9 \\ & 5.0-8.7,10.24 & 4.8-7.5,14.49 \\ \text { PRW } & 3.6,0.37,49 & 3.5,0.30,9 \\ & 3.1-4.7,10.17 & 2.9-3.8,8.53 \\ & & \\ & & \\ \text { APL } & 18.3,1.28,54 & 18.6,1.27,12 \\ & 15.6-20.8,7.00 & 16.8-21.1,6.85 \\ \text { BAPL } & 14.6,0.57,47 & 14.9,0.70,8 \\ & 13.5-15.8,3.90 & 14.1-15.9,4.67 \\ \text { TRW } & 16.7,0.94,54 & 17.0,0.86,12 \\ & 13.8-18.9,5.65 & 15.6-18.1,5.03 \\ \text { PRL } & 6.5,0.58,55 & 6.3,0.83,12 \\ & 5.2-7.5,8.84 & 4.7-7.4,13.33 \\ \text { PRW } & 3.4,0.39,54 & 3.3,0.27,12 \\ & 2.3-4.3,11.45 & 2.9-3.7,8.11\end{array}$



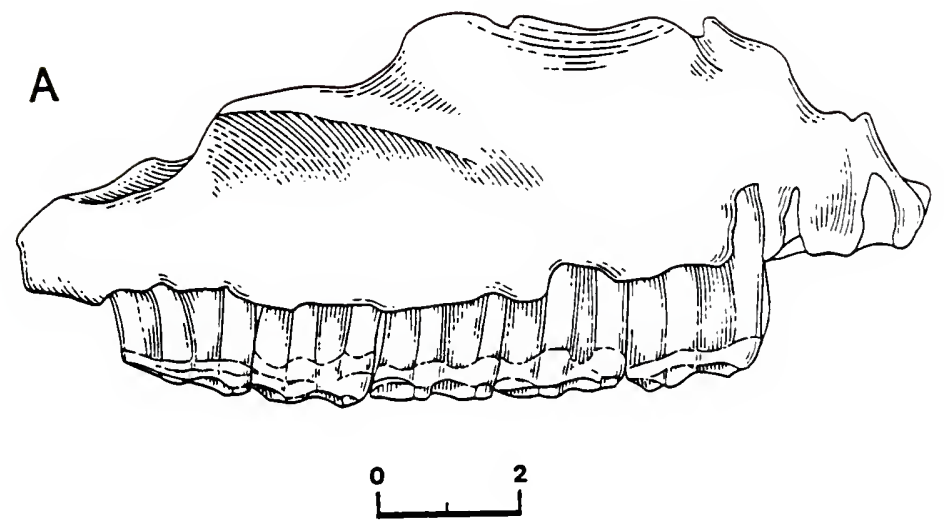

B

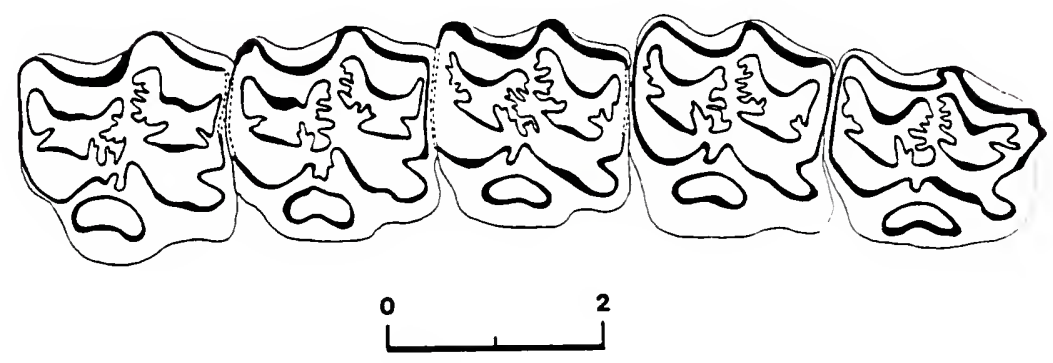

Figure 33. Lateral and occlusal views of Cormohipparion ingenuum from the Withlacoochee River Site 4A (late early HemphiTlian), Marion-Citrus county line, Florida. A. UF 17204, lateral view of right maxilla showing poorly defined anterior ventral margin of dorsal preorbital fossa. B. UF 17204, occlusal view of R P3-M3 (reversed). 

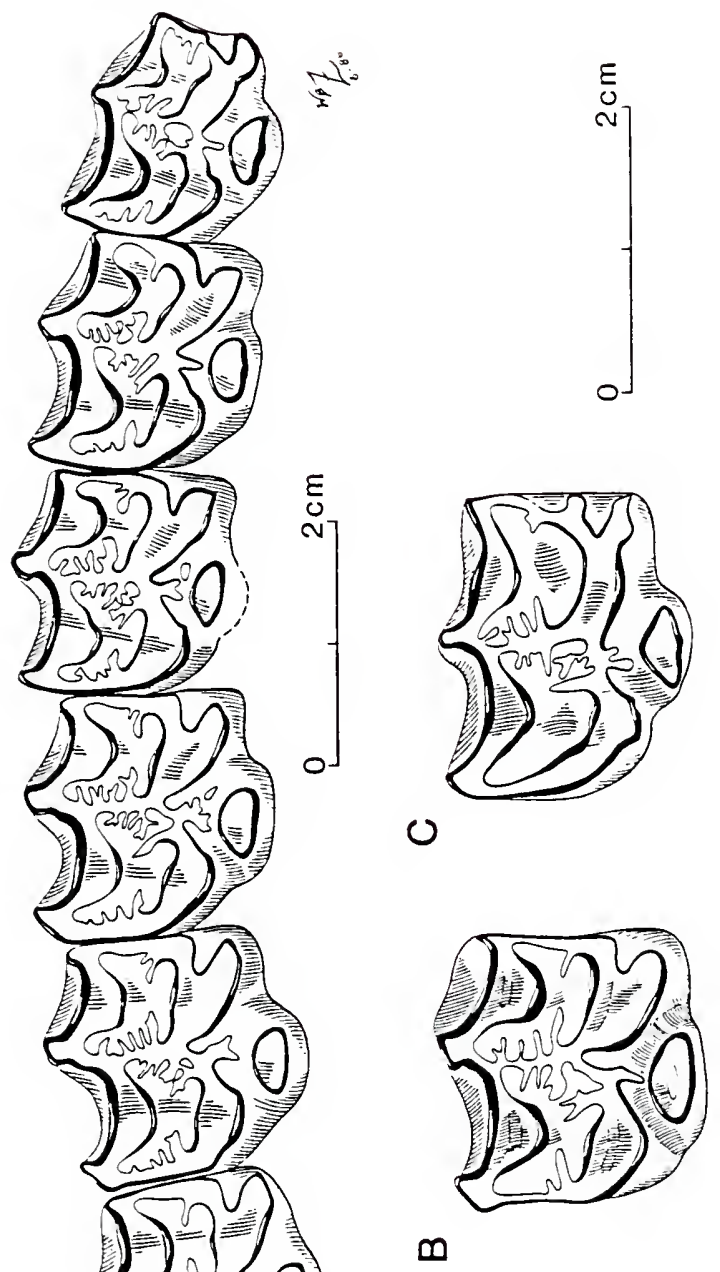

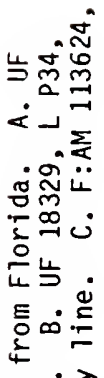

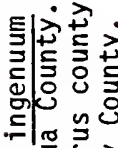

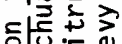

어

就

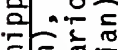

을 흔

흐응 등

나을 흘

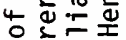

든든

岃出

$+\underset{0}{+}$

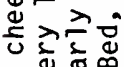

- \ه

웜웡

4云二心

잉

竎过

>

$\sum_{i}^{m}$

蹒㐫

可山我

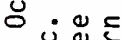

원옹 $\dot{\sim}$ in 学告员 ㄴㅇㅇㅁำ 킁요도.

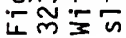




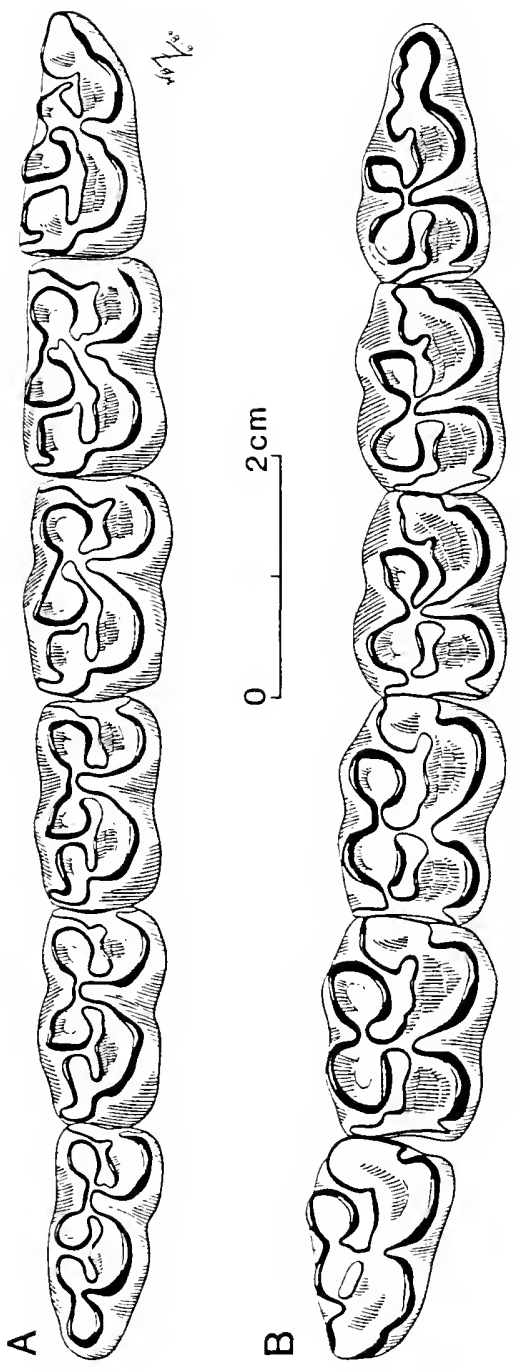

$+$

的

崩

导 $\underset{E}{E}$

통

$4 \div$

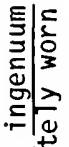

디웡

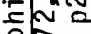

통

ᄒ़्ग

范告总

n< 0

.

离

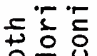

은

总崖

洁吉

过

호올운

4

《

3ํำ

$>$ 車

.

꽁 을 훙

过要

芦茟

离 


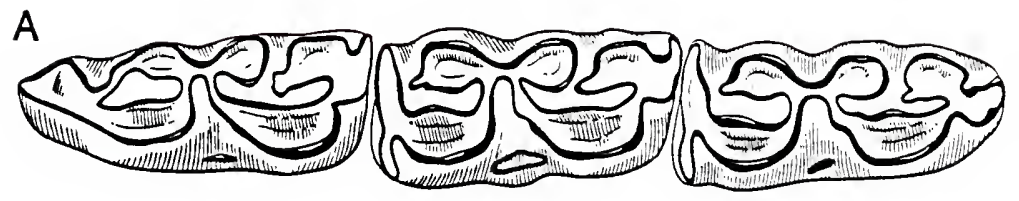

B

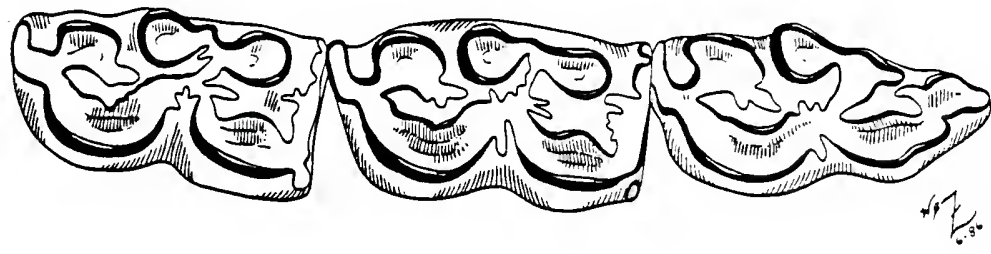

C
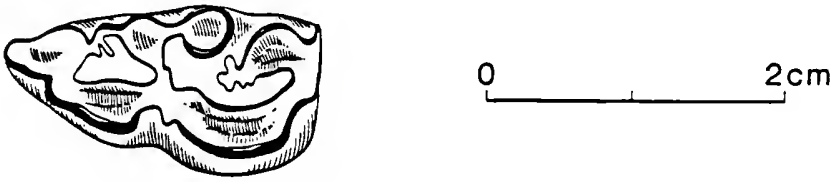

Figure 36. Occlusal views of lower cheekteeth of Cormohipparion ingenuum from Florida. A, B. Love Site (late Clarendonian), Alachua County. A. UF 32294, moderately worn as soc. L dp2-dp4. B. UF 32171, slightly worn as soc. R p2-p4. C. JJF 24632, L p2, Nichols Mine (late Clarendonian or early Hemphillian), Polk County. 
unbranched pli hypostyle is found on most of the P34 $(92 \%, n=50)$; it is rarely absent or with accessory folds. The hypoconal groove remains open throughout wear. Unworn or slightly worn MSCH of P2S range from 36 to $38 \mathrm{~mm}$; examples of unworn or slightly worn P34s are rare, but their MSCHs are about $45 \mathrm{~mm}$.

Upper molars are noticeably smaller in occlusal area than P34 (Table 22), with less well developed styles and generally with shorter, more oval protocones (Fig. 34A). The lingual border of the protocone is usually convex; occasionally concave or straight, especially in early wear-stages. Pli caballins, while well developed, are more likely to be single ( $76 \%, n=55$, Love Site sample) than branched or multiple (18\%), but are retained until very late wear-stages. The anterior half of the prefossette most often has a single pli protoloph (56\%, $n=55)$, while $27 \%$ al so have small accessory plications. The posterior half of the prefossette consists of only a moderately developed (relative to that of the P34) prefossette loop and generally four to six plications. These are smaller and shallower than their counterparts on the P34, and have a greater tendency to disappear with wear. The anterior half of the postfossette most often has between three and five plications, and the pli postfossette is often bifurcated in early and moderate wear. The posterior half of the postfossette generally $(84 \%, n=50)$ has a single, shallow pli hypostyle. Unworn MSCH of M12 is about 47 to 51 $\mathrm{mm}$.

Lower cheekteeth of Cor. ingenuum are principally known on ly from the Love Site, and demonstrate many phylogenetically important 
features. They generally resemble lower dentitions of other species of Cormohipparion, except for their smaller size (Tables 16, 17, 19). The lower premolars are characterized by: rounded labial borders; large metaconids and metastylids equal in size and well separated from each other, especially by an anterolingual extension of the entoflexid (Figs. 35, 36B); ectoflexids that generally partially penetrate the isthmus; and well developed protostylids. In early wear-stages (Fig. 36B), isthmus and paralophid plications are common, and a small pli caballinid is usually present (Table 17). With wear, the ectoflexid deepens, and the plications and pli caballinid fade (Fig. 35B). Protostylids are slightly less prominent than in Cor. plicatile. As is usual in Cormohipparion, they first appear as isolated structures, but quickly connect to the protoconid. On most $\mathrm{p} 2 \mathrm{~s}$ (and $\mathrm{dp} 2 \mathrm{~s}$ ), there is an anterolabial plication that emanates from the metaconid (Fig. 35A). Infrequently, the plication originates instead from the paraconid, and projects posteriorly, or both plications can be present (e.g. Fig. 36B). The plication first appears on the occlusal surface during early to middle wear-stages, although the crown height at which it becomes exposed varies. In later wear-stages, it commonly connects the metaconid and paraconid, isolating a portion of the metaflexid as a fossettid (Figs. 35B, 36A, 36C). While similar plications are occasionally found on p2s of other species of Cormohipparion and other genera, in no other sample is its appearance so frequent (except for Cor. emsliei). Unworn mcch of p2 is about $35 \mathrm{~mm}$, and 43 to $47 \mathrm{~mm}$ for the p34.

The lower molars of Cor. ingenuum are similar in morphology to those previously described for Cor. plicatile, but have shorter 
unworn crown heights and are much smaller (Table 19; Fig. 35). Pli caballinids are very rare in the Love Site sample, and if present occur only in slightly worn individuals. The Moss Acres specimen (UF 97259) retains small but distinct pli caballins on its deeply worn molars. Plications on the isthmus and paralophid are common (Table 17), especially in slightly worn teeth. Unworn or slightly worn m12 mech is about $50 \mathrm{~mm}$.

Lower deciduous premolars of Cor. ingenuum have relatively shallow ectoflexids, elongated metaconids, metastylids and entoconids, and moderately developed pli caballinids in early wear. With wear, however, the ectoflexids deepen, the metaconids and metastylids become more oval, and the pli caballinids are lost or become rudimentary. In late wear-stages, sma11, generally elongate-oval ectostylids appear on the occlusal surface (Fig. 36A). They are not as prominent as in Cor. emsliei, Cor. occidentale or Cor. plicatile, and are especially rudimentary on the dp2. Unworn dp34 mcch is about 21 to $23 \mathrm{~mm}$.

Discussion. To an even greater degree than Cor. plicatile, the generic affinities of "Hippotherium" ingenuum have remained enigmatic due to the paucity of topotypic material. This has led to a number of equid populations from the western United States being incorrectly considered conspecific with it. The numerous Love Site sample for the first time gives an accurate representation of the size and variation of its upper and lower cheekteeth, and at least a partial indication of its facial morphology. These combine to suggest a new generic assignment for "H." ingenuum and to falsify all previous hypotheses. 
As was shown in the discussion section of Cor. plicatile, late Clarendonian and early Hemphillian faunas of central Florida contain two very similar equid populations distinguished primarily on the basis of size and hypsodonty. The smaller of these two populations agrees with the holotype of "‥ " ingenuum both in size (Figs. 28, 29) and enamel morphology, and can confidently be referred to that species. It is this population that has been described in the preceeding section. Two important questions remain to be discussed:

1) are any equid populations or species other than those from north-central florida so similar in hypsodonty, dental and crania 1 morphology, and size that they can be referred to "…" ingenuum (or, if based on an older name, is "ㅌ.. " ingenuum a junior synonym of another species)? and 2) with what species is "H.." ingenuum most closely related, i.e. in what genus does it belong?

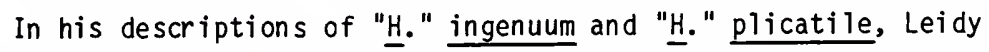
(1885; 1887) made no attempt to compare them with other taxa, except for "․․" venustum, an inadequately known species from South Carolina. The holotype of the latter is lost and it is a nomen dubium (MacFadden, 1984a, p. 126). Cope (1889) synonymized "ㅁ․ " ingenuum with "…" gratum without comment, and Lucas (in Leidy and Lucas, 1896) followed this synonymy. Pseudhipparion gratum is now known to differ greatly from "ㅌ. " ingenuum in size, facial morphology, and enamel pattern (Webb, 1969a; Webb and Hulbert, 1986). Later workers (e.g. Gidley, 1907) resurrected Leidy's species, and it has subsequently been considered valid. Stirton (1940) listed it with Nannippus, but did not state any reasons for his referral. Quinn (1955, p. 73) listed both Nan. tehonensis and Nan. ingenuum as occurring in 
the Lapara Creek Fauna. Forsten (1975) referred the entire sample of medium-sized hipparionines from both the Lapara Creek and Clarendon Faunas to Nannippus cf. ingenuum. She gave no specific reasons for her referral, and presented no comparisons with material from Florida. MacFadden $(1980 ; 1984 a)$ later referred the same population from the Clarendon Fauna to $\underline{H}$. tehonense, and a portion of the Lapara Creek sample is also referable to this species of Hipparion, and not to "Nan." ingenuum. Other specimens from the Lapara Creek Fauna included in "Nannippus cf. ingenuum" by Forsten (1975) are referable to Nannippus sp., cf. Nan. fricki (see pp. 112-117).

More recently, MacFadden (1984a, p. 132) synonymized "Nannippus" ingenuus and Nan. lenticularis (a late Hemphillian species particularly well known from the Coffee Ranch, Edson, and Uptegrove localities of the Great Plains) "...based on overall similarity in size, crown height, and dental pattern...". Examination of large numbers of individuals of both taxa fails to substantiate the validity of MacFadden's synonymy. While of similar size ("H.." ingenuum is slightly larger on average, but observed ranges of tooth length and width overlap), there are numerous important differences between the two. In Nan. lenticularis, the posterior cheek region does not contain a fossa, but there is a small fossa located anterior to the infraorbital foramen. This observation of MacFadden (1984a, p. 130) is based on a single specimen, F:AM 113731. I believe that this feature may be an artifact of, or greatly accentuated by, the preservation and/or preparation of this particular specimen. In "H.." ingenuum, a moderately developed DPOF is located posterior to the 
infraorbital foramen. Significant dental differences between the two taxa are:

1. Unworn crown height of upper and lower third and fourth premolars of "H." ingenuum is about $45 \mathrm{~mm}$, of first and second molars about $50 \mathrm{~mm}$. In Nan. lenticularis, unworn premolar crown height is about $50 \mathrm{~mm}$, and $57 \mathrm{~mm}$ for molars.

2. In "H." ingenuum, the P2 and P2 are much longer than the other premolars, with well developed anterostyles and paraconids, respectively. In Nan. lenticularis, they are relatively short, with poorly developed anterostyles and paraconids. The former is characteristic of Cormohipparion and Neohipparion, the latter condition is found in Nannippus and $\underline{H}$. tehonense. As shown in Chapter 6, a reduced anterostyle is a derived character state for hipparionines.

3. In "ㅂ. " ingenuum, pli caballins are well developed, frequently bifurcated or multiple, and persistent throughout wear. In Nan. lenticularis, pli caballins are at best moderately developed, not branched or multiple, and are often absent or lost with wear (e.g. F:AM 111731, MacFadden, 1984a, Fig. 98D).

4. In "H. " ingenuum, fossette plications are very complex, often deep and bifurcating. In Nan. lenticularis, fossette plications are shallow and usually simple, with a much greater tendency for the pli hypostyle to be absent.

5. In "H." ingenuum, the lingual border of the protocone is often straight or concave, especially in premolars. In Nan. lenticularis, it is nearly always convex. The protocone also 
tends to connect to the protoselene much earlier in the premolars of Nan. lenticularis, at $\mathrm{MSCHs}$ as high as $25 \mathrm{~mm}$. 6. In "ㅂ. " ingenuum, the protostylid is prominent and is isolated from the protoconid only for a short period of wear. In Nan. lenticularis, the protostylid is small, remains isolated from the protoconid until very late wear-stages, and is occasionally absent (see also Dalquest, 1983).

7. In "ㅂ. " ingenuum, the metaconid of the $p 2$ and dp2 have an anterolabial plication that closes off the metaflexid. In samples of Nan. lenticularis, such structures are absent or very rare.

There are additional, more minor, differences between the cheekteeth of the two taxa, but the seven listed above (plus the differing facial morphologies) suffice to prove that two separate species and genera are represented by these populations. The differences are greater than those observed between early and late populations of other equid species with long, well documented chronologic ranges (e.g. chronoclinal variation observed in Neo. trampasense or Cor. occidentale). Typically in those cases, the younger population shows advanced features that are observed in more rudimentary form in the older population. Samples of intermediate age are of intermediate grade. With regards to "므." ingenuum and Nan. lenticularis, some of the features of the younger taxon (those numbered $3,4,5$ and 7 ) are more primitive than those of the older. Others (2 and 6), which are derived in the younger population, are not observed in any rudimentary or incipient form in the older samples. Nan. lenticularis is best considered a distinct, valid 
species. Although its inclusion in Nannippus has been questioned (Sondaar, 1968), it shares a number of derived features with other species of Nannippus and should be retained in that genus.

Leidy's (1885) "H. " ingenuum can be referred to Cormohipparion based on the same suite of characters previously used (p. 217) with Cor. plicatile. As is the case with the latter species, recovery of well preserved cranial material will test this phylogenetic hypothesis.

Fossette plications in Cor. ingenuum more resemble those of $\underline{\text { Cor }}$. plicatile than Cor. occidentale in frequency distributions (Figs. 30 , 31), although it has slightly more fossette plications on average than does Cor. plicatile (Table 21). The distribution of tota 1 fossette plications for the $\mathrm{P} 3$ and $\mathrm{P} 4$ (Fig. $30 \mathrm{C}$ ) is obscured by the small sample size, and no obvious modal value for fossette-group $C$ (see p. 216) is apparent. It could be either 10,12, or 13. However, the distribution of fossette plications of the M1 and M2 is more revealing (Fig. 31C). Two modes are apparent, that of group $C$ at 9, and group B at 15. Like Cor. plicatile, Cor. ingenuum represents the primitive Cormohipparion pattern for ontogenetic variation in fossette complexity (see p. 216 for further discussion). Webb and Perrigo (1984) referred a sample of teeth from the Gracias Formation of Honduras to "Hipparion" plicatile. As they noted, in many respects this sample does compare favorably with Cor. plicatile as defined in this study. However, the size of the specimens, as listed by Webb and Perrigo (1984, p. 244), clearly indicates a referral to the smaller cor. ingenuum. The north-central Florida and Central American samples are remarkably similar, 
considering the geographic distance separating them. The major difference is a better developed pli cabaliinid in the Honduran sample. It is more persistent on the p2-p4 than in the Love Site sample, and even occurs on some molars. It is not so well developed as in Cor. emsliei, however, nor does the Honduran sample have the extreme fossette complexity observed in the Pliocene species. The relatively advanced nature of the Honduran sample of Cor. ingenuum emphasizes Webb and Perrigo's (1984) conclusion that the age of the Gracias Fauna is early Hemphillian rather than late Clarendonian.

As noted by Simpson (1930), Cor. ingenuum is commonly found in Florida, however typically it is less abundant than its congener, Cor. plicatile. Its biostratigraphic range in Florida as here recognized extends from the latest Clarendonian (Love Site) to the late early Hemphillian (With $4 A$ and Dunnellon sites). Simpson (1930, Fig. 20C) illustrated a molar of Nannippus minor as Cor. ingenuum (UF/FGS V-1426). The specimen is actually less complete than represented in the figure, and slightly smaller. The slightly worn molar he figured as Cor. plicatile (Simpson, 1930, Fig. 20B) is referable to Cor. ingenuum, instead. Diagnostic features of this specimen (UF/FGS V-1485) are its narrow protocone with a flattened lingual border and its small TRW. Cormohipparion ingenuum has often been recognized from the Bone Valley Formation (Sellards, 1916; Simpson, 1930; Webb and Tessman, 1968; Webb, 1969b), either as "Hipparion" ingenuum or "Nan." ingenuus. Most of these records are referable to the more advanced species, Cor. emsliei. Others, particularly those from the Manatee Dam Site (Webb and Tessman, 1968), are either generically indeterminant or referable to Nan. 
minor. Both Cor. plicatile and Cor. ingenuum are recognized from the Bone Valley Formation (especially from the Nichols Mine, see referred specimens listing and Figure $36 \mathrm{C}$ ), but are interpreted as being derived from an older horizon than that which produces $\underline{\text { Cor. emsliei. }}$. Based on the joint occurrence with Pseud. skinneri (Webb and Hulbert, 1986), these records are either late Clarendonian or early Hemphilian.

Cormohipparion ems liei new species

Hipparion ingenuum (Leidy), SELLARDS, 1916, p. 97 (in part); not WEBB and TESSMAN, 1968, p. 807 , Figure 5.

Hipparion (Nannippus) ingenuum (Leidy), SIMPSON, 1930, pp. 187-188 (in part, not Figure 20C).

Hipparion plicatile (Leidy), SIMPSON, 1930, pp. 187-188 (in part).

Nannippus phlegon (Hay), ROBERTSON, 1976, pp. 158-159 (in part), Figure 15; MACFADDEN and WALDROP, 1980, p. 7 (in part). "Hippotherium" plicatile-7ike form, MACFADDEN, 1986, p.471.

Type specimen. The holotype is UF 94700, a partial skull consisting of most of the right maxilla with OP1, P2-M3; right and left premaxillae with I1-I3; and an edentulous fragment of the left maxilla with alveoli for the DP1 and P2. The premaxillae were collected about $15 \mathrm{~cm}$ from the maxillae, and there is no direct contact between them. They are judged to belong to the same individual based on their close association in the field, similar stages 
of tooth wear, identical preservation, and on the overa 11 rarity of mammalian remains at the type locality. Collected 13 June 1986. Type locality. Macasphalt Shell Pit, $3 \mathrm{~km}$ north of Fruitville, Sarasota County, Florida.

Stratigraphic occurrence and age of the type locality. Unit 4 lof Petuch, 1982), Pinecrest Member, Tamiami Formation. Age based the associated mammalian fauna is Upper Pliocene (late Blancan), about 2.0 to $3.0 \mathrm{ma}$.

Topotypic sample. UF 94634, R M12; 94696, R p2; 94697, L p34; 94698, L m12; 94699, L dp4; 94635, R metatarsal III; 94636, R ectocuneiform; 94637, proximal phalanx of lateral digit.

Etymology. For Steven D. Emslie, Department of Zoology, University of Florida, who collected the holotype and several of the topotypes, and in recognition of his contributions to vertebrate paleontology of the Pliocene and Pleistocene of Florida.

Distribution. Known only from the Pliocene (about 5.0 to 2.0 ) of peninsular Florida.

Referred specimens. Palmetto Fauna, Bone Valley Region. Palmetto Mine: UF 17184, 63636, $639833 \mathrm{R}$ P2; $63640 \mathrm{R}$ P34; 12503, 17185-17186, 63637-63639, 63956 7 L P34; 17187, 63641-63642, 639524 R M12; 63643, 63951, 63955 3 L M12; 17189, 63952, 63957 3 R M3; 10306 L DP34; 17163 R partial mandible with dp2-dp3 and partial dp4; 53493 $L$ mandibular fragment with dp2 (possibly same individual as UF 17163); $17190 \mathrm{R}$ partial mandible with m1-m2; $69909 \mathrm{R} \mathrm{dp} 34$; $93497 \mathrm{~L}$ dp4; 17152, 699082 R p2; 17153, 53495, 69910 3 R p34; 19438-19439, 53494, 53498, 53501, $636446 \mathrm{R} \mathrm{m12;} \mathrm{19437,} \mathrm{53502,} 535053 \mathrm{~L} \mathrm{m12.}$ North Palmetto Mine: UF 63982 R M12; 63981 R M3. TRO Quarry, Payne 
Creek Mine: UF 24705 R P34; 24713 R M12; 24865 L partial mandible with dp2-dp4. Payne Creek Mine: UF 53983, L M12. Fort Green Mine: UF 55821, 572192 R P2; 61981, 55901, 52431, 584104 R P34; 23995, 57220,656653 L M12; 55823 R M3; 58380, 584112 L M3; 58396 L p34. Nichols Mine: UF 24637 R P34; 28836 L P34; 53563 L mandible with m1m3; 24631 R p34. Phosphoria Mine: UF 53557 R M12; 93215 L M12; $53555 \mathrm{R} \mathrm{m12;} 53556 \mathrm{~L} \mathrm{~m} 3$. Kingsford Mine: UF $53891 \mathrm{~L} \mathrm{P34;13215R}$ P34; 17227 L m12. Gardinier Mine: UF 58295 R P2; 67976 L P34. C. F. Industries Mine: UF $40083 \mathrm{~L}$ P2. Chicora Mine: UF $65226 \mathrm{R} \mathrm{m} 12$. Brewster Mine: UF 93213 R M3. Agrico Pierce Mine: UF/FGS V-5503 L p34. Amax Mine: UF $93236 \mathrm{Lm}$ 12. Specific mine or locality unknown: UF/FGS V-6614, UF 53841-53842 3 L P2; 53551, 53853, 58333, 559004 L P34; 53533 R M12; 47384, 53552 2 L M12; 61476 R p2; 61484 L p2; 53846, 61480-61481, 64158 $4 \mathrm{R}$ p34; 61482-61483 $2 \mathrm{~L} p 34 ; 61474 \mathrm{R}$ $\mathrm{m} 12 ; 61477-614793 \mathrm{~L} \mathrm{m12} ; 61485 \mathrm{R} \mathrm{m} 3$.

Haile 15A, Alachua Co., FL: UF 17484 L P34.

Diagnosis. Medium-sized (mean M12 APL=19.2 mm, BAPL=15.7 mm) species of Cormohipparion, differs from "Mer." goorisi by greater size and much greater unworn crown height; from Cor. occidentale and Cor. plicatile by smaller size (by about $10 \%$ and $5 \%$ on average, respecitively); and from all North American species of Cormohipparion by its extremely complex fossette plications and better developed, more persistent pli caballinids. $M S C H$ of unworn molars about $57 \mathrm{~mm}$, 15\% taller than those of Cor. ingenuum. Metaconid and metastylid of $d p 2-d p 4$ and p2-p4 with unique lingual groove in early wear-stages. DPOF reduced anteriorly. Grooved incisors. 
Description. The only known cranial material of Cor. emsliei is the holotype, UF 94700, a young but mature individual (Figs. 37A, 37B, 37C). The preserved portion of the facial region (Fig. 37A) reveals a very prominent malar crest that extends anteriorly to above the mesostyle of the P4. The infraorbital foramen (IOF) is located about $58 \mathrm{~mm}$ dorsal to the alveolar margin, midway between the parastyle and mesostyle of the P3 (Fig. 37A). The region immediately dorsal and posterior to the IOF is preserved; it does not contain the usual Cormohipparion DPOF (e.g. MacFadden, 1984a, Fig. 8A), but rather a moderate depression whose long axis of maximum depth (ca. 5 $\mathrm{mm}$ ) runs posterodorsal-anteroventrally at about a $45^{\circ}$ angle from the occlusal surface of the toothrow. Whether or not this depression deepened posteriorly and was rimmed can not be determined from the holotype. Portions of the typical equine buccinator fossa are located anterior to the P2.

The incisors of UF 94700 form a semicircle (Fig. 37C) with a diameter of $65.1 \mathrm{~mm}$ (maximum width measured at the occlusal surface of the I3s). The I1s have a single, broad, labial groove; the I2s have two shallower labial grooves, giving the enamel surface a slightly undulatory appearance (Fig. 37C). Both the II and I2 have elongate, completely enclosed infundibula, and the outer enamel has pinched-off, horn-like structures on the sides. These would have persisted until about an additional $9 \mathrm{~mm}$ of crown had worn away. The I3s are slightly worn, and their infundibula are open posteriorly. The I3 labial surface has many shallow grooves and an irregular texture. The dimensions of the incisors of UF 94700 (maximum occlusal length $\times$ width, in $\mathrm{mm}$ ) are: $\mathrm{I} 1,16.8 \times 9.4 ; 12,19.0 \times 8.7$; 


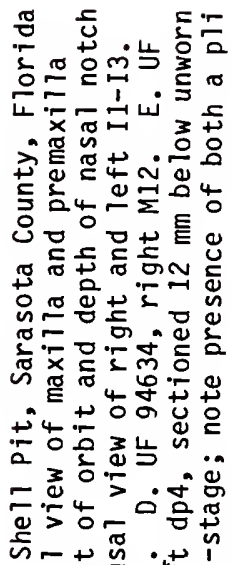

+ क ष 舟 শ

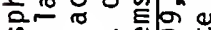
ज次

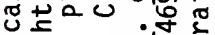

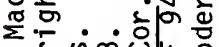

次

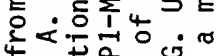
- 的市 용을웡

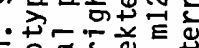
ᄃ워

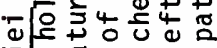
$\because$ 它 30

ต

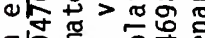

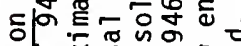
- $x$ 品两

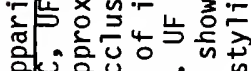
产委 .

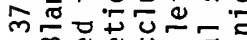

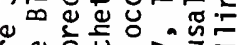
唔

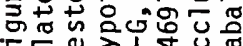
픈치 

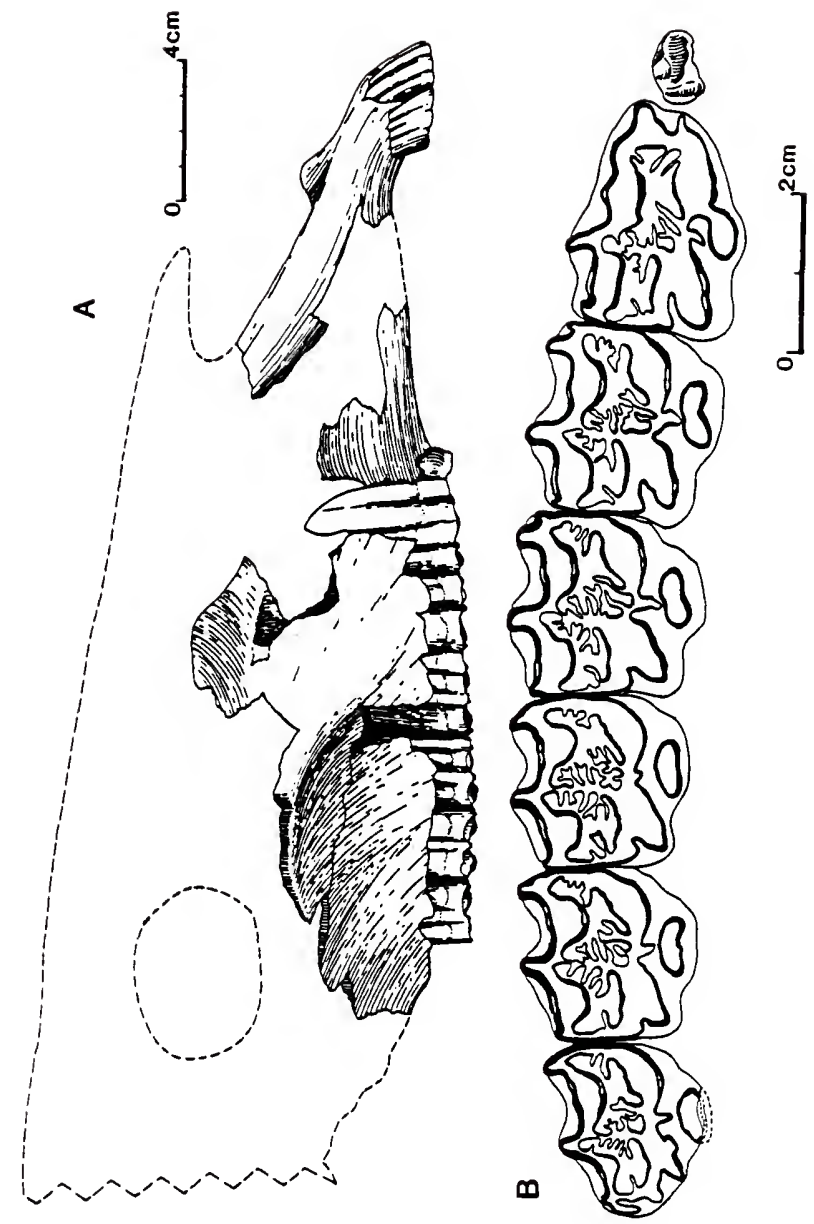

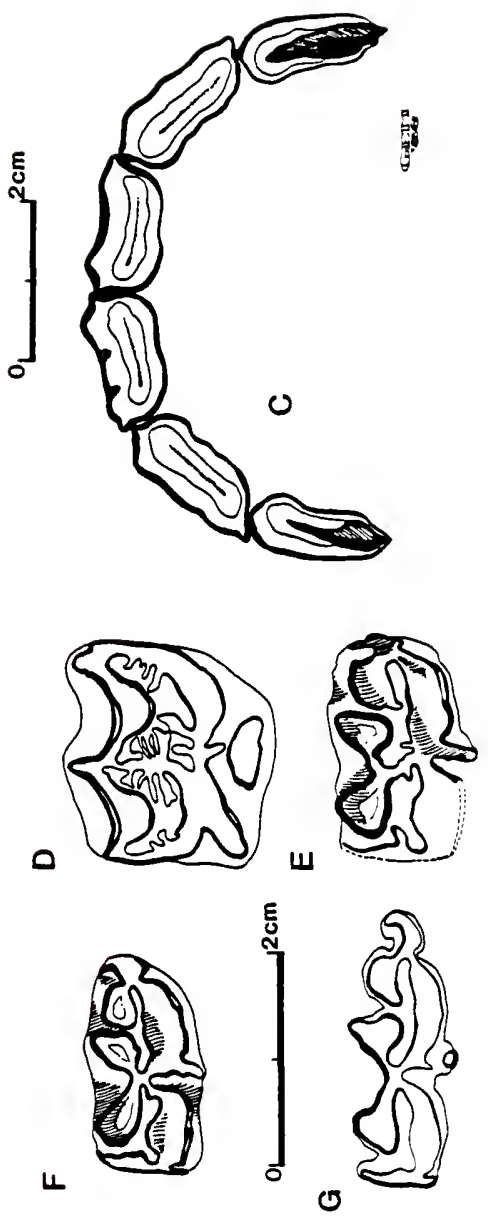

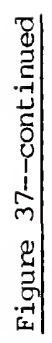




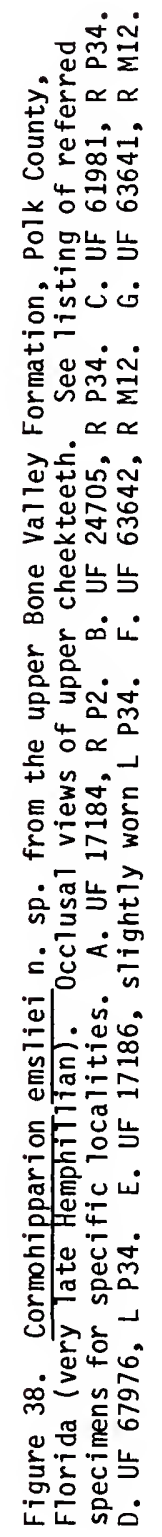




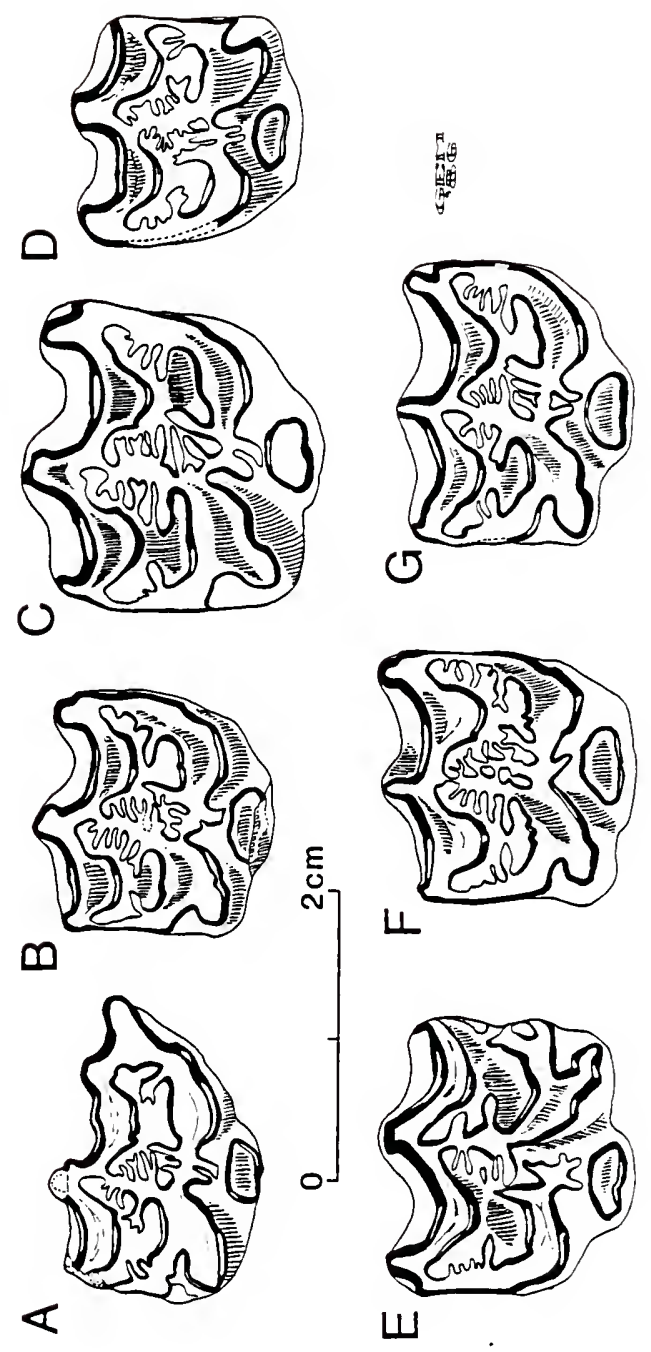




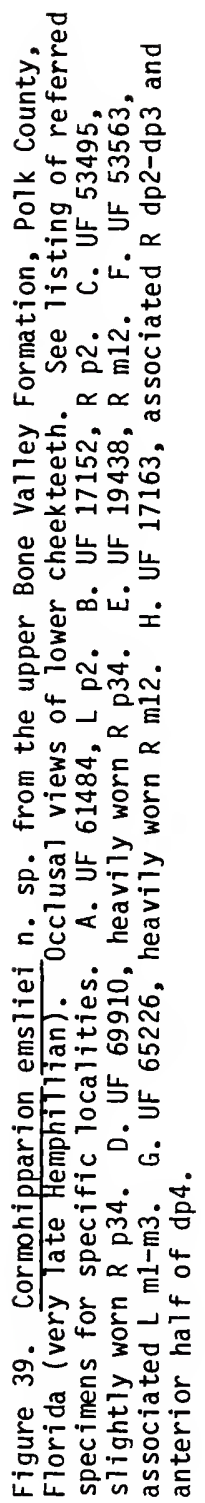



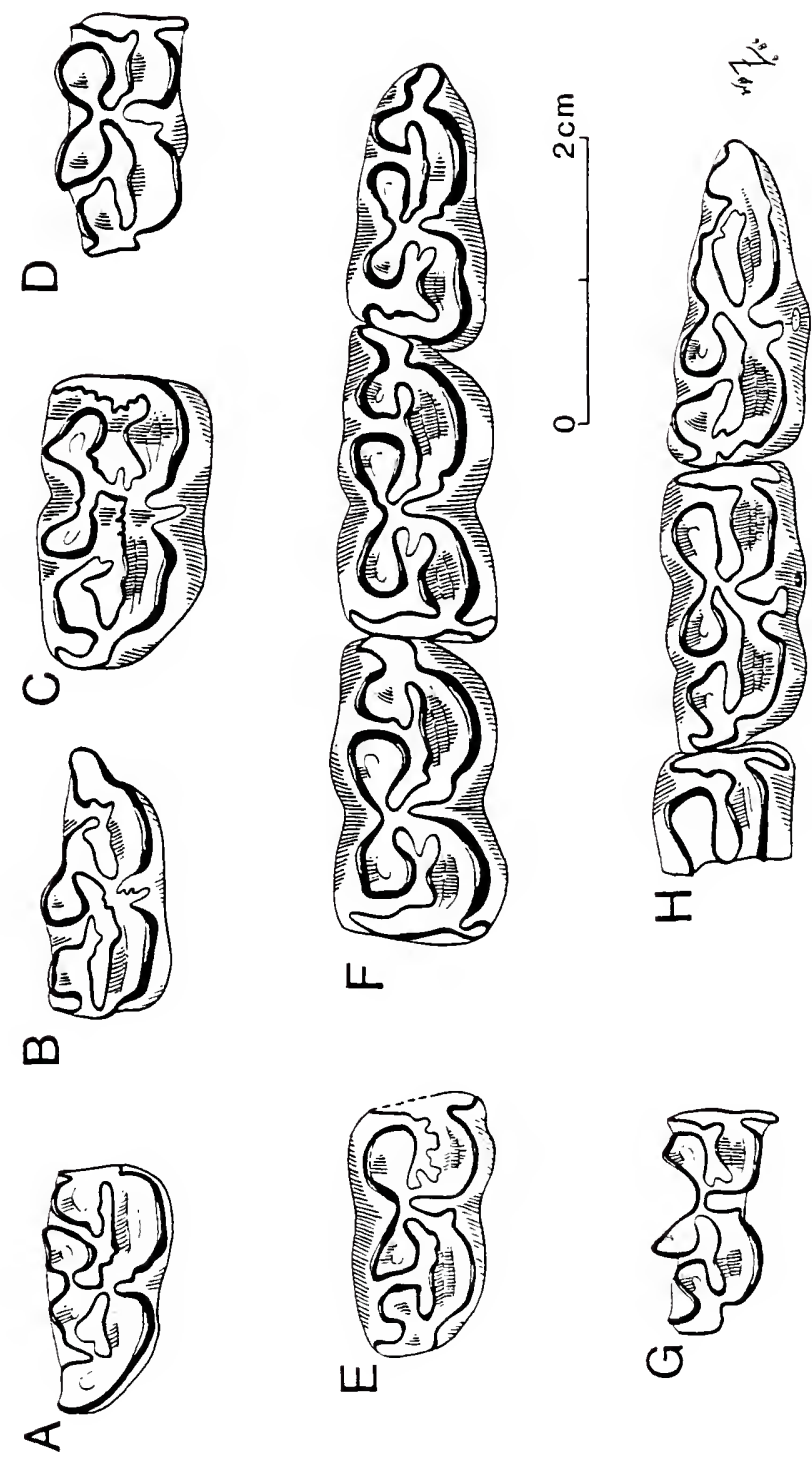
Table 23. Standard univariate statistics of upper cheekteeth of Cormohipparion emsliei n. sp. from the Palmet to Fauna, Bone Valley Region, Polk and adjacent counties, Florida. Format as in Table 2.

P2

P34

M12

APL

$23.7,2.14,5$

$21.8-27.3,9.00$

$18.9,1.40,23$

$17.0-22.1,7.39$

$19.2,1.09,24$

$20.2,2.21,4$

$15.5,1.01,15$

$17.6-22.7,10.95$

$14.2-17.9,6.53$

$15.7,1.01,17$

BAPL

$18.1,1.39,8$

TRW

$$
16.5-19.8,7.70
$$

$18.2,1.29,24$

$16.2-20.9,7.06$

$13.9-17.1,6.41$

PRL

$5.7,0.55,11$
$4.9-6.5,9.71$

$6.0,0.80,24$

$4.8-8.8,13.33$

$17.2,1.18,22$

$15.3-20.1,6.87$

PRW

$3.3,0.32,10$
$2.8-3.7,9.83$

3. $3,0.29,22$

2. $8-3.9,8.73$

$6.4,0.64,23$

$5.2-7.5,9.96$

$3.2,0.31,23$

2. 4-3.7,9.72 
Table 24. Standard univariate statistics for lower cheekteeth of Cormohipparion emsliei n. sp. from the Palmetto Fauna, Bone Valley Region, Polk and adjacent counties, Florida. Format as in Table 2.

p2

ap1

$19.4,1.46,3$ $18.1-21.0,7.55$

bapl

$16.2,0.57,2$ $15.8-16.6,3.49$

atw

$7.7,0.78,2$

$7.1-8.2,10.10$

ptw

$\mathrm{mm} 1$

ent1

$$
9.2,0.57,2
$$$$
8.8-9.6,6.15
$$

$$
8.6,0.32,3
$$$$
8.4-9.0,3.72
$$

$$
8.8,1.54,3
$$$$
7.0-9.8,17.54
$$

p34

$19.3,1.36,9$ $17.5-21.4,7.08$

$16.1,1.07,5$ $14.9-17.3,6.69$

$$
9.9,0.74,9
$$$$
8.6-11.1,7.50
$$

$9.5,0.76,10$

$8.6-10.9,8.00$

$10.7,0.95,10$

$9.2-11.5,8.92$

9.3,0.77,10

$8.1-10.6,8.23$ m12

$19.1,1.62,18$

$15.9-22.0,8.50$

$15.5,1.04,8$

$14.1-16.5,6.71$

8.3,0.65, 19

7. $3-9.5,7.80$

$8.1,0.81,18$

$6.7-9.5,10.01$

$10.4,1.04,19$

$8.7-12.0,9.92$

$7.4,0.89,18$

$5.8-8.4,12.04$ 
13, $17.6 \times 7.3$. The lengths would decrease substantially with attritiona 1 wear.

Upper cheekteeth characterized by: grooved parastyle in the upper portion of the crown in both premolars and molars (Figs. 37B, 38C, $38 G$ ); strong mesostyles that are occasionally also grooved;

metastyles present and often relatively strong (but not to the degree of Neohipparion eurystyle); P2 with well developed, large anterostyle (Fig. 38A). The relatively large (in UF 94700 , length $=9.2 \mathrm{~mm}$ ), single rooted DP1 is located almost completely anterior to the P2, and is readily visible in lateral view (Fig. 37A). It bears wear facets from occlusion with the $p 2$ paraconid. The protocone of the P3-M3 is relatively sma11, elongate-oval, with a variably shaped lingual border. In early to moderate wear it is usually concave (Fig. 37B) or straight; becoming more rounded (convex) with heavy wear. The P2 protocone is shorter, more oval, and of all the cheekteeth, the only one with a tendency to connect with the protoselene prior to extremely late wear-stages. Compared to other species of Cormohipparion, however, the P2 protocone is much more frequently isolated in Cor. emsliei at comparable wear-stages. For example, the percentage of isolated protocones in moderately worn P2s (MSCH between 20 and $30 \mathrm{~mm}$ ) is $63 \%$ for Cor. plicatile $(n=24), 61 \%$ for Cor. ingenuum $(n=28)$ and $100 \%$ for cor. emsliei $(n=5)$. The hypocona 1 groove of all cheekteeth is widely opened until very late wearstages, but shallow when heavily worn (Figs. 38B, 38F). Pli caballins are strong, persistent, and frequently double in both premolars and molars (Figs. 38C, 38D, 38G). A very diagnostic feature of Cor. 
emsliei upper cheekteeth is their extremely complex fossette plications (Figs. 37B, 37D, 38). Premolars are, on average, slightly more complex than molars. The anterior half of the prefossette of P2-P4 always has at least one, to a maximum of five, plications. The pli protoloph is always deep and occasionally bifurcated; accessory labial plications are also present on 21 of 33 examined specimens. The posterior half of the prefossette generally ( $91 \%$ of observed P34; $n=23$ ) has from six to eight plications, several of which are branched and deep. The prefossette loop has several secondary folds; these not infrequently merge to isolate portions of the distal section of the loop from the prefossette (Figs. 38D, 38F). The anterior half of the postfossette is less complex, generally with three to five plications. The pli hypostyle is deep, never absent, and often accompanied by one or two accessory plications. The fossette plications of the M1-M3 are only slightly less complex and persistent (Figs. 37B, 37D, 38F, 38G). The anterior half of the prefossette in early wear-stages also has a deep pli protoloph and numerous (usually two or three, up to five) smaller plications. In later wear-stages, the accessory plications are lost or become rudimentary, and the pli protoloph is much shallower. The posterior half of the prefossette and the anterior half of the postfossette have (in general) four to eight and three to five plications, respectively. Those of the prefossette have a greater tendency to bifurcate. The pli hypostyle is again deep and often ( $40 \%$ of observed M12, $n=20$ ) accompanied by one or two accessory plications. The on ly known upper deciduous premolar (UF 10306) resembles its permanent counterparts with its sma11, oval protocone, double pli caballin, complex fossettes, and 
grooved parastyle. Unworn to slightly worn MSCHs for P34 are estimated to be about 48 to $53 \mathrm{~mm}$, and about 56 to $58 \mathrm{~mm}$ for the $\mathrm{M} 12$.

Lower cheekteeth exhibit the basic Cormohipparion pattern, but with a greater tendency to flatten the labial borders of the protoconid and hypoconid, and better developed pli caballinids (Figs. $37 \mathrm{E}, 37 \mathrm{~F}, 37 \mathrm{G}, 39)$. Lower second premolars have large paraconids, and in early wear-stages, a prominent anterior extension of the entoconid that projects labial to the metastylid (Fig. 39B). As in Cor. ingenuum, there is a plication from either the metaconid or the paraconid that eventually connects with the opposing structure, isolating the metaflexid as a fossettid (Fig. 39A). The ectoflexid is shallow in all known p2s, not penetrating the isthmus, even in relatively late wear-stages (e.g., UF 61484, mcch=13.4 mm). Lower third and fourth premolars are al so characterized by reduced ectoflexid depth. In early wear-stages, a long pli caballinid extends labially past the borders of the hypoconid (Figs. 37E, 39B, 39c). The isthmus, paralophid and entoconid are frequently plicated, and the metaconid and metastylid have angular lingual borders. A strong protostylid appears on the occlusal surface after the upper-most 10 to $15 \mathrm{~mm}$ of the crown wears off on the p34; it is sometimes recurved as in Neo. eurystyle. The plications and pli caballinids are reduced in later wear-stages, but are usually still evident. In early wear-stages of the p34 and the dp2-dp4, the metaconid and metastylid have prominent lingual grooves; the se persist until moderate wear on the metastylid of the dps (Fig. 37G), but are rapidly worn off the permanent teeth. Unworn to very 
slightly worn molars also have nonpersistent lingual grooves, usually just on the metaconid (e.g. UF 93236).

The enamel morphology of the lower molars is variable. Some patterns are nearly identical to those of Cor. ingenuum (e.g. UF 53563, Fig. 39F), but most are more advanced, with moderately developed pli caballinids and angular metastylids (Figs. 37F, 39E, 39G). Labial borders of the hypoconid and protoconid are flattened in early wear-stages, rounded in later ones. The ectoflexids often on ly partially penetrate the isthmus (Fig. 37F) in early wear-stages; but in later stages they typically penetrate very deeply (Fig. 39G). Estimated unworn mech are about $35 \mathrm{~mm}$ for the p2, about 52 for the p34, and about 57 for the $\mathrm{m} 12$.

Lower deciduous premolars of Cor. emsliei are unusual among hipparionines in having both well developed pli caballinids and ectostylids (Figs. $37 \mathrm{G}, 39 \mathrm{H}$ ). The dp34 also have large protostylids. The metaflexid of the dp2 is isolated into a fossettid in moderate wear-stages by a plication between the metaconid and paraconid. Unworn mcch of the dp34 is about $27 \mathrm{~mm}$.

UF 94635 , a right MT III, is referred to Cor. emsliei based on its moderate size, intermediate between that of Nannippus and Equus simplicidens (Table 25), and morphology (Fig. 40). A7though on ly slightly longer than those of average-sized individuals of Nan. peninsulatus or Nan. beckensis, it is notably more massive. The cuboid and mesoentocuneiform facets on the proximal articular surface are relatively small (Fig. 40A; Table 25); while the facets for articulation with MT II and IV are robust. The opposite is true of Nannippus metatarsals. The posterior (plantar) surface (Fig. 40C) 
Figure 40. Proximal (A), anterior (B) and posterior (C) views of UF 94635 , right metatarsal III of Cormohipparion emsliei $n$. sp. from Macasphalt She 11 Pit, Sarasota County, FTorida Tlate BTancan). 


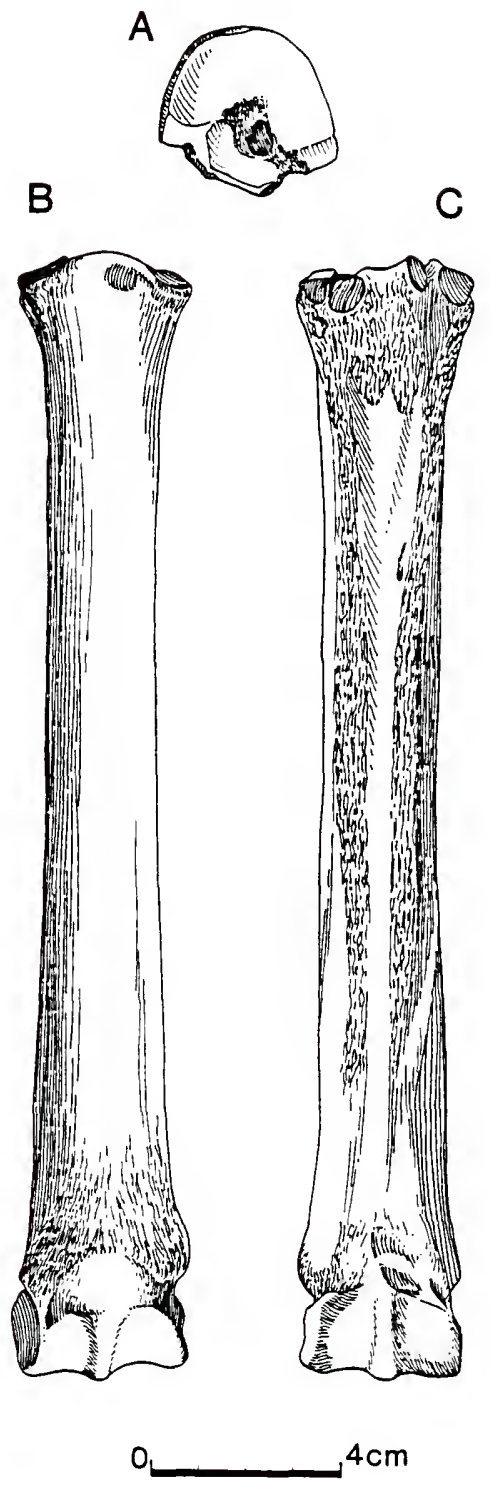




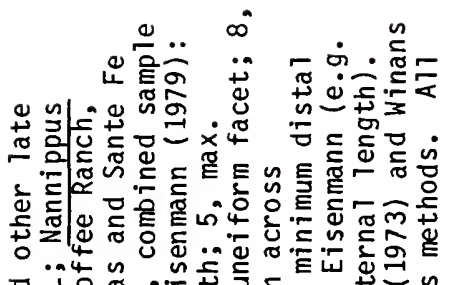

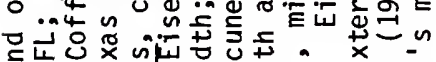

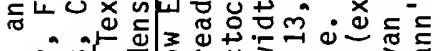

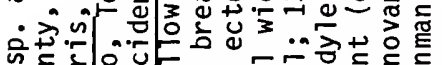

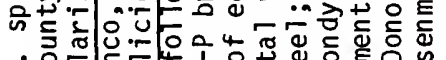
¿ テ气

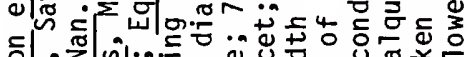
至| 造 플

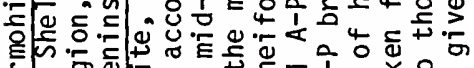

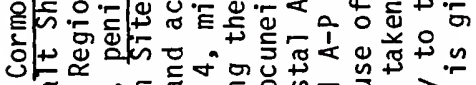

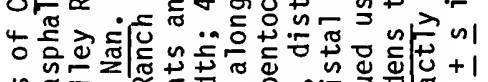
을 శึ

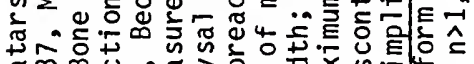

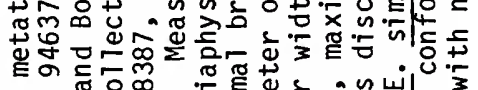
б

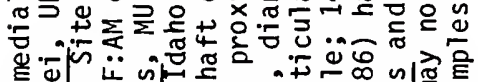
借

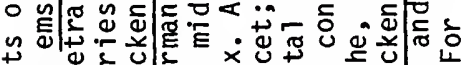
言 غ 乡... थ

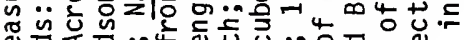

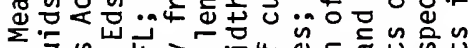

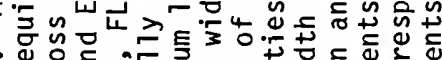
- U을 둥 ฟ

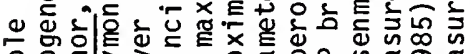

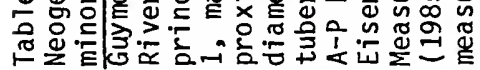

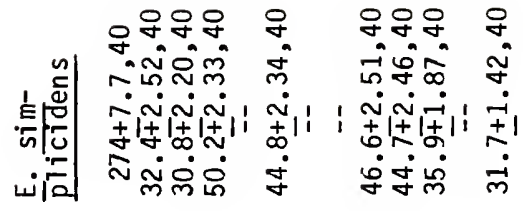

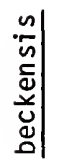

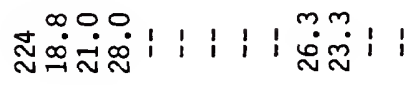
zi

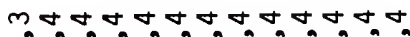

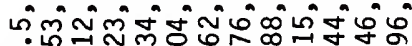

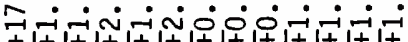

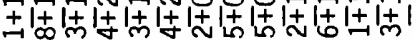
N $-10 \dot{0} \dot{0} \dot{0}$ 금츄ำ

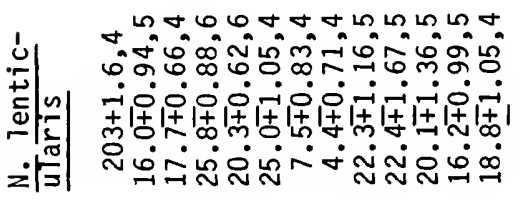

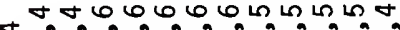
+ம் \%

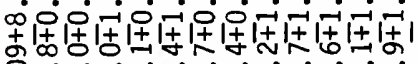

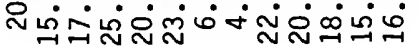

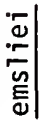
m 录的迥山ம் i 
Table 26. Comparisons of unworn mesostyle crown height (MSCH) and relative hypsodonty of first and second molars of late Miocene and Pliocene hipparionine equids. Unworn crown height is estimated from unworn and very slightly worn upper molars for each species; basal crown length (BAPL) is a mean value, either of a single sample, or a combination of populations. Hypsodonty index (HI) is calculated as the ratio of unworn crown height to mean BAPL. The grade of hypsodonty of Cormohipparion emsliei is more like that of Clarendonian equids, is much less than its Tate HemphillianBlancan contemporaries, and reflects relative stasis in this character compared to contemporary equid genera.

FAUNA(S) MSCH BAPL $(n) \quad H$

Clarendonian-early Hemphillian equids

Cormohipparion occidentale

XMAS-KAT,

60

$17.3(13)$

LAPARA CREEK

Cormohipparion plicatile

LOVE

59

$16.4(108)$

3.6

Cormohipparion ingenuum

LOVE

50

$14.6(47) \quad 3.4$

Hipparion tehonense

CLARENDON

50

$15.4(9)$

3.2

Pseudhipparion hessei

CLARENDON

48

$13.1(53)$

3.7

Neohipparion trampasense

LOVE

60

$15.2(138)$

3.9

Nannippus weston $\mathbf{i}$

LOVE

43

$12.7(24)$

3.4

Late Hemphillian-Blancan equids

Cormohipparion emsiiei n. sp.

BONE VALLEY 57

Neohipparion eurystyle

YEPOMERA

57

$15.7(17) \quad 3.6$

Nannippus lenticularis

COFFEE RANCH

73

$16.2(33)$

4.5

Nannippus minor

BONE VALLEY

57

13.1(29)

4.3

Pseudhipparion simpsoni

BONE VALLEY

51

$11.5(26)$

4.6

Nannippus peninsulatus

MT. BLANCO, 75
SAN PEDRO VALLEY

110

$8.1(8)$

13.6

$75 \quad 12.5(15)$

6.0 


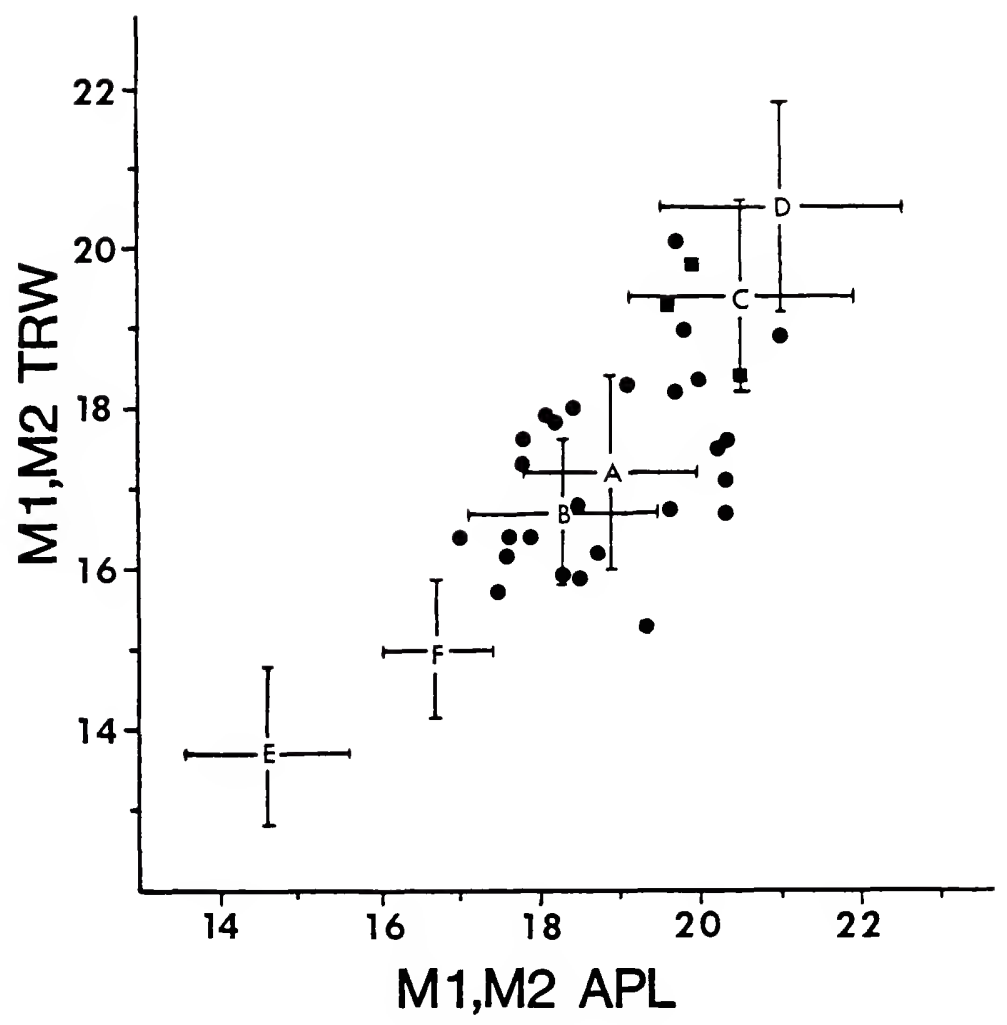

Figure 41. Bivariate plot of occlusal anteroposterior length (APL) versus transverse width (TRW) of upper first and second molars. A-F represent species means, with lines indicating plus and minus one standard deviation from the mean. A, Cormohipparion emsliei n. sp., upper Bone Valley sample on ly $(n=27) ; \bar{B}$, Cor. ingenuum, Love Site, Alachua County, Florida $(n=54) ; C$, Cor. plicatile, Love Site, Alachua County, Florida $(n=113)$; $D$, Cor. Occidenta Te, Xmas-Kat Quarries Fauna, Cherry County, Nebraska $(n=75) ; E$, Nannippus minor, upper Bone Valley Fauna, Polk County, Florida $(n = 2 8 \longdiv { ; F , ~ N a n n i p p u s }$ peninsulatus, combined sample from Florida, Texas, and New Mexico $(n=15)$. Circles represent individuals of Cor. emsliei from the Bone Valley; squares individuals from Macasphalt She 11 Pit. The latter appear to resemble more those of Cor. plicatile, but they are in eariy wear-stages and overlap simitarly worn Bone Valley specimens. slightly worn Cor. plicatile molars are much larger, on average. 
bears two highly roughened areas for the attachment of the interosseus lateral metatarsal ligaments; the se extend down about $70 \%$ of the length of the shaft. Posterior to the large distal supraarticular tuberosities on the lateral and medial surfaces of the shaft are additional roughened areas for ligament attachment. On the anterior (dorsal) surface between the tuberosities is a moderate depression; a feature characteristic of tridactyl equids (Hussain, 1975). There is a deep groove for passage of the great metatarsal artery on the posterolateral side of UF 94635 , another feature of tridactyl equids (Webb, 1969a, p. 125). The median sagittal ridge (keel) that separates the distal articular condyles runs along the entire length of the articular surface. It is notably less well developed (lower and less sharp) on the anterior surface than it is posteriorly. The lower part of the shaft is curved slightly posteriorly, more so than in Nannippus. Similar-sized metapodials (e.g. UF 58397) have been recovered from the Bone Valley Region, but as that fauna contains several medium-sized equids, they are not yet conclusively referred to Cor. emsliei. Increased sample sizes of Bone valley equid post-cranial elements are needed for rigorous biometrical analysis and comparisons with the numerous late Miocene specimens from Florida (e.g. the Love Site sample).

Two other post-cranial elements from Macasphalt appear to represent Cor. emsliei, an ectocuneiform and a lateral phalanx. The proportions of the ectocuneiform conform to those of the proximal articular surface of the MT III. The two bones articulate reasonabiy we11, although they evidently are from different individuals, as the 
fit is not perfect. The proximal surface of the ectocuneiform is composed mainly of the navicular facet, with limited area for nonarticular regions for attachment of intertarsal ligaments. The ectocuneiform more nearly resembles that of Hipparion figured by Hussain (1975, Fig. 8C) than that of Equus simplicidens (Hussain, 1975, Fig. 8B). The proximal phalanx of the lateral digit is long and slender. Its maximum length is $36.1 \mathrm{~mm}$. The concave proximal articular surface is $14.6 \mathrm{~mm}$ (A-P depth) by $10.1 \mathrm{~mm}$ (transverse width). Its large size indicates an animal with functional lateral digits, as do many characters of the MT III.

Discussion. The only population of Cor. emsliei well enough represented to allow statistical evaluation is that from the late Hemphillian Bone Valley Region (Tables 23 and 24). Cheekteeth in this sample have very similar occlusal dimensions to those of Cor. ingenuum (Fig. 41), and are larger than those of Nannippus. The topotypic sample from the Macasphalt She 11 Pit has mean dimensions slightly larger than those of the older population, and more elongated protocones (Tables 15, 23, 24; Fig. 41). Much of the apparent size difference, however, is due to the relatively early wear-stages of the Macasphait teeth. For example, UF 94634, which just falls within the $O R$ of the Bone Valley sample in occlusal length and width (Table 23), would have a length of only about $18 \mathrm{~mm}$ when worn to a MSCH of $25 \mathrm{~mm}$. The upper premolars of the type specimen appear especially large due to their early wear-stages, as almost all of the premolars from the Bone valley are from individuals with moderate to heavily worn teeth. The only very slightly worn P34, UF 58333, has an APL of $22.1 \mathrm{~mm}$, which is similar to those of type. The ename 1 
patterns of the teeth from Macasphalt, except for the relatively more elongated protocones, are identical to those from the Bone Valley.

The third occurrence of Cor. emsliei is a very heavily worn P4 (?) from Haile 15A, UF 17484 (Robertson, 1976, Fig. 5). Its MSCH is on $1 y$ about $9 \mathrm{~mm}$; even so it retains a large, elongated, isolated protocone. Previously this specimen was referred to Nan. "phlegon" (Robertson, 1976; MacFadden and Waldrop, 1980), but it is too large for that species (Table 15). A P34 of Nan. peninsulatus in the same very late wear-stage as UF 17484, UF 22634, has an APL of on ly 13.8 $\mathrm{mm}, \mathrm{a}$ TRW of $15.2 \mathrm{~mm}$, and a connected protocone. The occlusal dimensions of UF 17484 fall within the OR of the Bone Valley sample of Cor. emsliei, and its occlusal area (APL $\times$ TRW) is $50 \%$ greater than that of UF 22634. Thus, despite its late wear-stage, UF 17484 is confidently referred to cor. emsliei. The remainder of the material listed by Robertson (1976, p. 158) does appear to represent Nan. peninsulatus.

Genus Hipparion de Christol, 1832

Type species. Hipparion prostylum Gervais, 1849.

Included Nor th American species. H. shirleyi MacFadden, 1984; $\underline{H}$. tehonense (Merriam), 1916; $\underline{H}$. forcei Richey, 1948.

Chronologic and geographic distribution in North America. Late Barstovian through early Hemphillian in the Gulf Coastal Plain; Clarendonian through early Hemphillian in the Great Plains; Clarendonian of the West Coast. 
Diagnosis. Small to medium-sized hipparionine with relatively deep nasal notch. Moderately deep OPOF located well forward of orbit, usually anterior to lacrimal; poorly defined anteriorly, well defined posteriorly with continuous rim and variably developed pocket. Cheekteeth moderately complex for a hipparionine; protocone often connects relatively early in ontogeny; hypoconal groove open to near base of crown. Protostylid moderate to poorly developed, weaker than in Cormohipparion. [Modified after MacFadden, 1980.]

Discussion. North American Hipparion sensu MacFadden (1980; 1984a) consists of three species, making it the least diverse group of hipparionines on the continent. Their cheektooth morphology is not very distinctive for hipparionines, but the facial and cranial morphology suggests phylogenetic alliance with 01d World Hipparion s.s. Bernor and Hussain (1985) argued that this is a product of parallelism. However, in this study, I continue to follow the hypothesis of MacFadden (1980) that the resemblance is not coincidental.

\section{Hipparion shirleyi MacFadden, 1984}

Type specimen. F:AM 73950, a nearly complete female individual consisting of the skull, mandibles and post-cranial elements.

Type locality. Wright Farm, Polk County, Texas.

Stratigraphic occurience and age of type locality. Fleming Formation, Cold Spring Fauna; late Barstovian, about $13 \mathrm{ma}$.

Distribution. Known on $1 y$ from the Cold Spring Fauna of the Texas Gulf Coastal Plain. 
Referred specimens. In addition to those listed by MacFadden (1984a) from the Wright Farm and McMurry Pit sites, the following specimens from Cold Spring Fauna sites appear to be referable to $\underline{H}$. shirleyi. Noble Farm 1.f., Grimes Co., TX: TAMU 3035 R M12; 3036 R p2; 3037 L dp34. Goodrich 1.f., Polk Co., TX: TMM 31183-11 L maxilla with P4-M1; -22 L mandible with p3-m3. Cold Spring 1.f., San Jacinto Co., TX: TAMU 3031 L maxilla with M1-M2; TMM 31219-145 L maxilla with DP1-P4; $-67,-1332$ R P2; $-342,-3882$ L P2; $-24,-343$, -345, TAMU 30334 R P34; TMM 31219-346, -347 2 L P34; -350-353 $4 R$ M12; $-28,-243,-354,-3554$ L M12; $-356,-357$, TAMU $30323 \mathrm{R}$ M3; TMM 31219-176, -358-362 6 L M3; $-363,-3642 R$ p34; -365 L p34; $-9,-366$, $-3673 R m 12 ;-32,-3682 L m 12 ;-82,-369,-3703 R m 3 ;-371 R$ mandible with $\mathrm{p} 3-\mathrm{m} 3$.

Diagnosis. Smal1, low crowned species of Hipparion, with toothrow lengths of about 100-105 mm, and unworn molar crown heights of 30-35 $\mathrm{mm}$. Protocone oval or elongate-oval with large spur; deep hypoconal groove; hypocone elongate, with constricted connection to metaloph; fossettes moderately complex; pli hypostyle deep and usually directed labially, not anteriorly.

Description and discussion. Forsten (1975) described as the most common equid species in the cold Spring Fauna a sample she called "Merychippus sp. nr. Hipparion." My examination of this material indicates that she included at least two and probably three species in this taxon. A portion are clearly referable to $\underline{H}$. shirleyi MacFadden, based on their small size, distinctive fossette morphology, deep premolar ectoflexids, and relatively poorly expanded metaconids and metastylids. In most uppers, the pli hypostyle does 
not project anteriorly in the postfossette (as is typical in advanced equids), but instead deeply penetrates the fossette labially (see MacFadden, 1984a, Figs. 28 and 31). This appears to be the primitive hipparionine condition, and it is also found in "Cormohipparion" goorisi and "Merychippus insignis" (MacFadden, 1984a; Skinner and Taylor, 1967). Neither of the two partial skulls described by Forsten (1975, p. 39) are referable to $\underline{H}$. shirleyi. TMM 31219-224 has a very shallowly retracted nasal notch and a shallow, indistinct DPOF. Its dentition is worn beyond generic or specific recognition. TMM 31219-189 has less worn teeth, but on $7 y$ the ventral part of the face is preserved. It does not have the fossette pattern typical of H. shirleyi. The generic affinities of these two specimens are unclear. A third hipparionine in the fauna, represented by slightly larger and on average more complex cheekteeth than $\underline{H}$. shirleyi, belongs in either Cormohipparion or Nannippus.

Hipparion tehonense (Merriam), 1916

Neohipparion gratum tehonense MERRIAM, 1916, p. 119. Hipparion gratum tehonense (Merriam), OSBORN, 1918, p. 189. Nannippus tehonensis (Merriam), STIRTON, 1939, p. 347; STIRTON, 1940, p. 186; QUINN, 1955, p. 73; WEBB, 1969a, p. 130. Nannippus cf. $\underline{N}$. ingenuum (Leidy), FORSTEN, 1975, p. 61 (in part).

Hipparion tehonense (Merriam), MACFADDEN, 1980, p. 623. 
Type specimen. UCMP 21780, R M12.

Type locality. Exact locality unknown, South Tejon Hills, southern end of San Joaquin Valley, California.

Statigraphic occurrence and age of type locality. Chanac Formation; early Clarendonian, about $11 \mathrm{ma}$.

Distribution. Clarendonian of California, Great Basin, Great Plains, and Texas Gulf Coastal Plain. Possibly Clarendonian and early Hemphillian of Florida (see below).

Referred Texas Gulf Coastal Plain specimens. Lapara Creek Fauna. Buckner Ranch Site, Bee Co., TX: TMM 30896-537 assoc. R P4,M3 \& L M1-M3. Farish Ranch Site, Bee Co., TX: TMM 31081-162 R maxilla with OP3-DP4,M1; -705, -1440, -1482 3 L P2; -822, -1397 B 2 R P34; -1033, -1159 A 2 L P34; -823, -952, -1463, -1240, -1375A, -1397A 6 R M12; $-50,-341 B,-1375 B,-1397 C,-1421 C 5$ L M12; $-627,-12222$ R M3; $-168 \mathrm{~A},-862,-9173 \mathrm{R}$ dp34; -168 assoc. R p3-m1; -1072 R p2; $-397 \mathrm{~L}$ p2; -95 R p34; $-643,-10712$ L p34; -1117 R m12. Medio Creek, Site No. 19, Bee Co., TX: TMM 31170-92A, -9OG, 2 R P34; -9OF L P34; -90E, $-92 E,-92 H 3 R$ M12; -92M, -920, -90A, -111C 4 L M12; -92G, -92F 2 L M3; -49 R mandible with dp2-dp4. Bridge Estate Site, Bee Co., TX: TMM 31132-22A,C assoc. L M1-M2; -307B, -94A 2 R P2; -169 L P2; -22B L P34; -440A, -440B 2 L M12; -266A R p2; -386 L dp2; -287B L p34; -192 $L \mathrm{~m} 12$. Of the specimens Forsten (1975) referred to Nannippus cf.

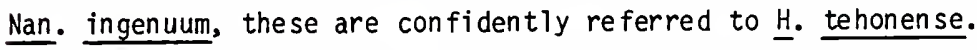
Others are referred instead to Nannippus cf. Nan. fricki, while the remainder are indeterminant.

Diagnosis. Medium-sized hipparionine with toothrow lengths between 110 and $130 \mathrm{~mm}$. OPOF well developed posteriorly, poorly 
defined anteriorly, located well anterior of the orbit. Nasal notch usually retracted dorsal to P2. Estimated unworn M12 MSCH about 45 mm. Differs from $\underline{H}$. forcei in smaller size, and more poorly developed P2 anterostyle. Isthmus plications rare; ectoflexids generally deep. [Modified after MacFadden, 1984a.]

Description and discussion. MacFadden (1980; 1984a) described the cranial and dental morphology of this medium-sized hipparionine, and discussed $i$ ts systematic relationships. Forsten (1975) described the Lapara Creek sample of $\underline{H}$. tehonense as Nannippus cf. Nan. ingenuum, but noted its resemblance to "Nan." tehonesis (p. 64). Comparisons of the populations of $\underline{H}$. tehonense from Tejon Hills, California, the Clarendon Fauna of northern Texas, and the Lapara Creek Fauna indicate close resemblances in size (Table 27) and enamel morphology. In particular, the Lapara Creek sample has rounded to oval protocones that connect to the protoselene at about the start of the late wearstage, and that have well developed spurs in early wear-stages. Pli caballins are well developed but rarely complex. Fossettes are moderately complex, with nonbifurcating plications. Lower cheekteeth have deep ectoflexids and few isthmus plications. These all suggest referral to $\underline{H}$. tehonense.

Hipparion sp., cf. H. tehonense (Merriam), 1916

Referred specimens.--Hookers Prairie Mine, Polk Co, FL: UF 93203 R p34.

Love Site: UF 53405 R P34; 53375, 621652 L P34; 32108, 32125, $321703 \mathrm{~L}$ mandibles; $96526 \mathrm{R}$ p34; 64917, 64918 $2 \mathrm{R} \mathrm{m12} ; 96527 \mathrm{~L} \mathrm{~m} 3$. 
Table 27. Standard univariate statistics for upper cheekteeth of Hipparion from Texas and California. Populations are TJH, tehonense from the Tejon Hills, San Joaquin Valley, Califorñia (topotypic sample); CLAR, H. tehonense from the Clarendon Fauna, Donley County, Texas; and BHR, H. forcei from the Black Hawk Ranch 1.f., Contra Costa County, California (topotypic sample). Format as in Table 2.

FAUNA

BHR

P2

APL

$$
22.3,0.14,2
$$

22. 2-22.4,0.63

$24.9,1.20,14$

$22.9-27.0,4.80$

$29.5,2.23,5$

BAPL

$20.8,1.04,4$

$19.3-21.6,5.01$

$23.0,1.22,5$

TRW

$18.3,0.42,2$

$18.0-18.6,2.32$

$19.0,1.25,14$

$17.1-21.3,6.59$

$19.7,0.99,6$

$18.7-21.1,5.03$

PRL

$$
\begin{aligned}
& 6.2,0.21,2 \\
& 6.0-6.3,3.45
\end{aligned}
$$

$$
5.6,0.50,14
$$

$5.0-6.8,8.83$

$5.8,0.35,6$

PRW

$$
\begin{aligned}
& 4.2,0.14,2 \\
& 4.1-4.3,3.37
\end{aligned}
$$

$$
\begin{aligned}
& 4.0,0.39,14 \\
& 3.5-4.7,9.71
\end{aligned}
$$

$4.1,0.53,6$

$3.2-4.7,12.86$

\section{P34}

$\begin{array}{llll}\text { APL } & 19.1,0.74,5 & 20.7,1.06,27 & 22.7,1.82,11 \\ & 18.1-19.9,3.89 & 18.5-23.2,5.11 & 19.7-25.5,8.03 \\ \text { BAPL } & --- & 17.1,0.97,6 & 19.0,0.05,7 \\ & & 15.3-18.1,5.70 & 17.2-20.5,5.52 \\ \text { TRW } & 19.0,0.85,5 & 21.2,1.39,27 & 21.6,1.23,11 \\ & 17.9-19.9,4.45 & 17.9-24.1,6.55 & 20.5-23.9,5.68 \\ & & & \\ \text { PRL } & 6.7,0.37,5 & 6.7,0.69,27 & 6.4,0.45,11 \\ & 6.4-7.3,5.54 & 5.5-8.0,10.31 & 5.7-7.1,7.07 \\ \text { PRW } & 3.8,0.17,5 & 3.7,0.26,27 & 4.1,0.27,11 \\ & 3.7-4.1,4.36 & 3.4-4.3,7.04 & 3.5-4.6,6.55\end{array}$


Table 27--continued

M12

$\begin{array}{llll}\text { APL } & 18.6,2.27,8 & 19.3,1.40,32 & 21.6,1.92,5 \\ & 16.2-22.4,12.22 & 16.8-22.3,7.25 & 19.7-24.6,8.87 \\ \text { BAPL } & 16.0,--, 1 & 15.4,1.31,9 & 17.7,0.74,5 \\ & & 14.0-17.1,8.47 & 16.9-18.8,4.18 \\ \text { TRW } & 17.9,0.95,8 & 19.2,0.99,32 & 20.1,0.95,6 \\ & 16.5-19.5,5.32 & 17.7-21.7,5.13 & 18.9-21.7,4.72 \\ \text { PRL } & 6.2,0.37,8 & 6.4,0.85,32 & \\ & 5.8-6.9,6.00 & 4.9-7.9,13.21 & 5.3,0.52,5 \\ & & & \\ \text { PRW } & 3.6,0.28,8 & 3.4,0.25,31 & 3.9,0.47 \\ & 3.1-3.9,7.66 & 3.0-4.1,7.23 & 3.5-4.6,6.55\end{array}$




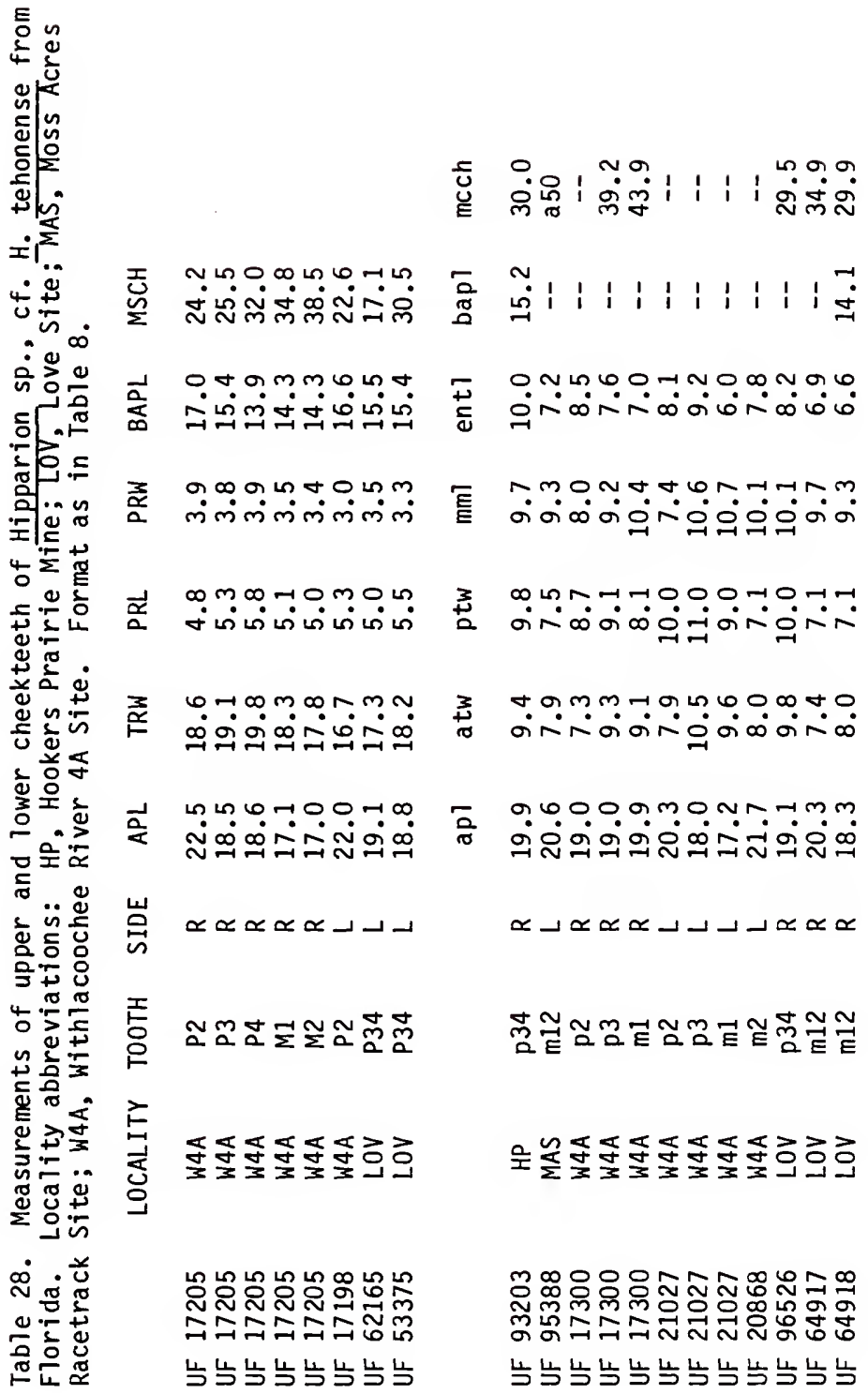


Figure 42. Hipparion sp., cf. H. tehonense from Florida. A. UF 93203, R p34, Hookers Prairie Mine (?earTy Clarendonian), Polk County. B-E. Withlacoochee River Site 4A (late early Hemphillian), Marion-Citrus county line, Florida. B. UF 17205, left maxilla in lateral view. C. UF 17205, occlusal view of $L$ P2-M1 and assoc. $R$ (reversed) M2-M3. D. UF 21027, occlusal view of $L p 2-m 3$. E. UF 21027, lateral view of $L$ mandible. UF 17205 and 21027 probably represent a single individual. 
A
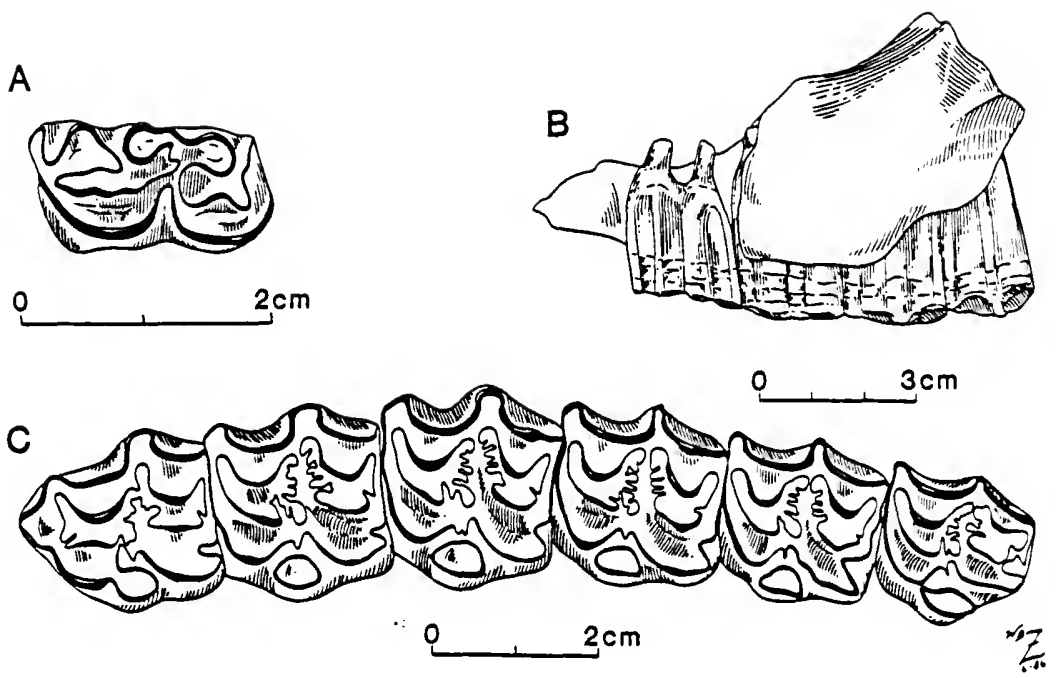

D
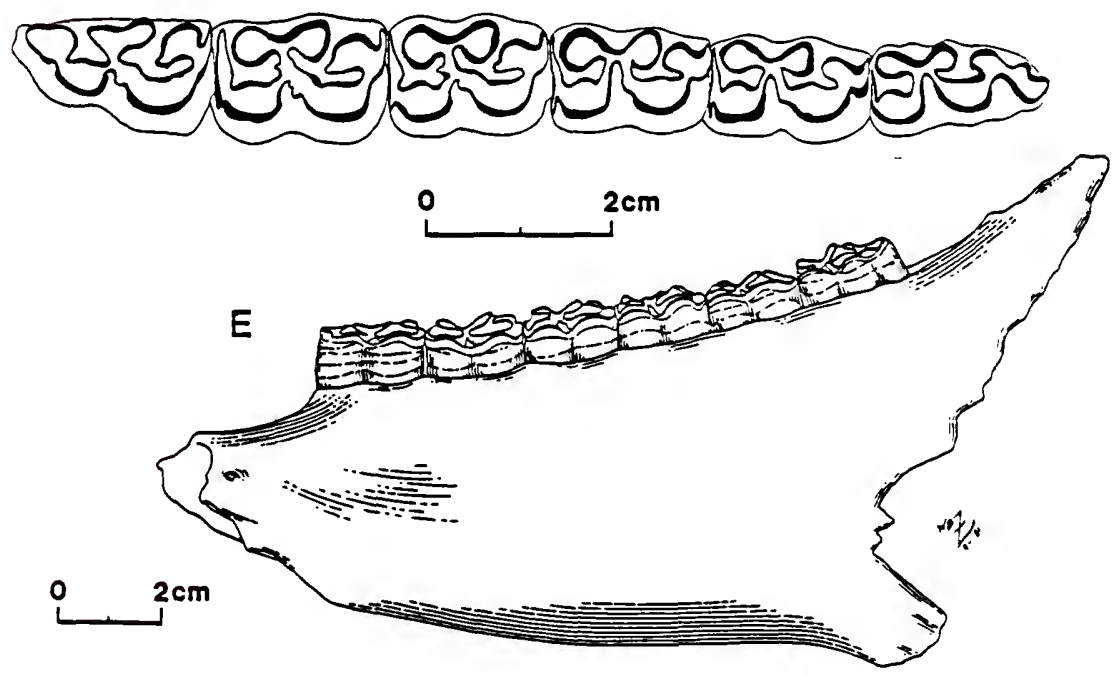
Moss Acres Racetrack Site: UF 95388 L m12; 95396 R M3.

With 4A: UF 17205 assoc. L maxilla with P2-M1 and R P2-M3; 53414 as soc. L P3-P4; 53517 R P2; 17198 L P2; 53510, 535152 R M12; 17201, 196202 L M12; 17203, 535112 R M3; 19621, 535132 L M3; 17300 assoc. $R$ and $L$ mandibles with $p 2-m 3 ; 20868 L$ mandible with $p 2-m 3 ; 21027 \mathrm{~L}$ mandible with p2-m3 (probably same individual as UF 17205); $17305 \mathrm{R}$ p2; 53464, 53484-53486 4 R p34; 53483 L p34; 53470-53472, 534744 R m12; 53466-53469 4 L m12; 53475 R m3.

Description and discussion. UF 93203 (Fig. 42A) is referred to Hipparion rather than Cormohipparion based on its poorly developed protostylid, lack of isthmus or paralophid plications and pli caballinid, and moderate size. Its size (Table 28) is within the OR for $\underline{H}$. tehonense lower premolars, and it closely resembles referred specimens of that taxon (e.g. MacFadden, 1984a, Figs. 38-39). UF 93203 was recovered from mining spoil piles, and thus its original stratigraphic position is unknown. Terrestrial vertebrates older than late Hemphillian are relatively common in phosphatic sediments being processed in the region of the Hookers Prairie Mine and adjacent mines, including the early Clarendonian Gray Zone fauna from the Phosphoria Mine. This is the most likely source for UF 93203. If this specimen has been correctly identified, the absence of Hipparion from deposits in the Phosphoria Mine, that have produced about 75 early Clarendonian equid teeth, is puzzling.

The With $4 A$ sample is referred to Hipparion based on the presence of a moderately deep DPOF (Fig. 42B); upper cheekteeth with rounded to slightly oval protocones with anterior spurs in early wear-stages 
and that connect to the protoselene relatively early in ontogeny, fossettes with relatively simple and shallow plications, relatively poorly developed pli caballins (especially on molars), hypoconal grooves open to the base of the crown, and broad, unconstricted connections of the hypocone and the metaloph (Fig. 42C); and lower cheekteeth with relatively deep ectoflexids, poorly developed protostylids, and weak plications (Fig. 42D). This combination of dental and facial characters exciudes the population from all hipparionine genera except Hipparion.

When compared to the two recognized advanced species of Hipparion, $\underline{H}$. tehonense and $\underline{H}$. forcei (MacFadden, 1984a), the With 4A sample compares more favorably in size with $\underline{H}$. tehonense (Tables 27,28 ). On average, $\underline{H}$. forcei, is about $15 \%$ larger than $\underline{H}$. tehonense, including the early Hemphillian populations referred to by MacFadden (1984a). The With 4 A sample also compares favorably with $\underline{H}$. tehonense in the location and depth of the DPOF, and in many dental features. For example, the anterostyle of the $P 2$ is poorly developed and not well separated from the rest of the tooth (Fig. 42C). The major differences are that the with $4 \mathrm{~A}$ sample is slightly smaller, lacks retention of the DP1 with the permanent dentition, has on average more complex and persistent fossette plications, has slightly higher unworn crown heights (by about 5 to $7 \mathrm{~mm}$ ), and, on average, better developed plications on the lower cheekteeth. These are not considered sufficient to designate a new species. Rather, they are trends typically observed in evolving equid chronospecies. Early Hemphillian $\underline{H}$. forcei from Nebraska shows several of the same differences when compared with Clarendonian populations from 
California, and the magnitude of change is comparable to that in other species with long chronologic ranges (e.g. Cor. occidentale). Therefore, the With $4 \mathrm{~A}$ sample is tentatively referred to $\underline{H}$. tehonense.

The lower molar from Moss Acres is very similar to slightly worn molars from With $4 A$, especially the $\mathrm{m} 2$ of UF 20868 . The protostylid is weak and the metaconid-metastylid complex is poorly expanded, much less so than in contemporary populations of Cormohipparion. Therefore, it too is referred to Hipparion sp., cf. $\underline{H}$. tehonense.

A limited sample of mandibles and isolated teeth from the Love Site is also tentatively referred to $\underline{H}$. tehonense. Observed differences with the more common and similarly sized Cor. ingenuum are much simpler fossettes, shorter protocones, weaker protostylids, fewer and less persistent isthmus plications, and a shorter diastema.

These records greatly extend the known geographic range of Hipparion in North America. The With $4 A$ and Moss Acres populations are significantly younger than others with $\underline{H}$. tehonense (MacFadden, 1984a, Table 12). If correctly indentified from these two sites, $\underline{H}$. tehonense would become one of only a few equid species known to have ranged entirely across North America. 
Tribe Equini Quinn, 1955

Equini QUINN, 1955, p. 43 (in part).

Calippini QUINN, 1955, p. 27 (in part).

Protohippini QUINN, 1955, p. 13 (in part).

Type genus. Equus Linnaeus, 1758.

Included subtribes. Protohippina Quinn, 1955 new rank; Equina new subtribe.

Revised diagnosis. Advanced tridactyl or monodactyl equids with well cemented, subhypsodont or hypsodont cheekteeth and well formed fossettes. Differ from hipparionines by have more poorly separated metaconids and metastylids on the lower cheekteeth (Equus and some other progressive species of equines independently acquire this trait in the late Miocene); lower molars have the metaconid placed notably more linguad than the metastylid; protocone usually connected to the protoselene in moderate and early wear-stages; fossette plications relatively simple, or absent altogether (except advanced Equus which can have complex fossettes).

Discussion. The earliest recognized member of the Equini is "Merychippus" carrizoensis, which is well known from the late Hemingfordian of California (Dougherty, 1940; Munthe, 1979; Quinn, 1984).

Thus the tribe's first appearance in the fossil record coincides with that of its sister-taxon, the Hipparionini. Two monophyletic subtribes comprise the Equini, the Protohippina and the Equina. 
Subtribe Protohippina Quinn, 1955 new rank

Protohippini QUINN, 1955, p. 13 (in part).

Calippini QUINN, 1955, p. 27 (in part).

Type genus. Protohippus Leidy, 1958.

Included genus. Calippus Matthew and Stirton, 1930.

Revised diagnosis. Advanced nonhipparionine equids that differ

from equine genera by their relatively short diastemae and relatively broad muzzles. Ectoflexid depth of the lower premolars shallow. Malar fossa absent; DPOF depth shallow. Lateral digits with no tendency towards reduction.

Discussion. Protohippus and Calippus are hypothesized to form a monophyletic group based on the common possession of shortened diastemae and broad muzzles. They both have more elongated protocones and metaconid-metastylid complexes than primitive equines, but these were independently acquired in many equid lineages through the Miocene. Protohippus and Calippus are both restricted to faunas east of the continental divide, but species of each range widely through the Great Plains to the Gulf Coastal Plain. Protohippine diversity was at a maximum during the Clarendonian, and both genera went extinct at the end of the early Hemphillian.

Genus Calippus Matthew and Stirton, 1930

Protohippus (Calippus) MATTHEW and STIRTON, 1930, p. 354. Callipus Matthew and Stirton, STIRTON, 1940, p. 188. 
Type species. Cal. (Calippus) placidus (Leidy), 1858.

Included subgenera. Cal. (Calippus) Matthew and Stirton, 1930;

Cal. (Grammohippus) n. subgen.

Revised diagnosis. Very small to medium-sized, tridactyl equids, with toothrow lengths less than $140 \mathrm{~mm}$; DPOF long, relatively shallow, not pocketed; or absent; MF absent; muzzle region greatly expanded (width $45 \%$ or greater than UTRL), with relatively large I12/i12; first and second incisors positioned in a straight row of four teeth, with the $13 / i 3$ angled sharply posteriorly; postcanine diastema relatively short. Cheekteeth moderate to extremely hypsodont. Upper cheekteeth with elongate or oval protocones broadly connected to protoselene (very rarely isolated in early wear); simple fossettes with plications absent or limited to early wear-stages; single, unbranched pli caballins that fade with wear and are typically much stronger on premolars than molars. Lower cheekteeth typically with relatively nonpersistent lingual flexids; shallow premolar ectoflexids; lacking plications (except for pli entoflexids in early wear-stages) including pli caballinids. Deciduous lower premolars lack ectostylids.

Chronologic and geographic distribution. Early late Barstovian through late early Hemphillian (about 14.5 to $6.0 \mathrm{ma}$ ), al though most abundant and diverse during the Clarendonian. Widespread in North America east of the Rocky Mountains, ranging from Florida to Texas, 
nor th through the Great Plains to South Dakota, and south to Honduras.

Discussion. The genus Calippus is here recognized by its unique, highly derived muzzle morphology (Fig. 43, see also Fig. 49), which along with other cranial and dental characters distinguish it from all other equid genera. The failure of prior studies (e.g. Stirton, 1940) to recognize this can be attributed to the rarity of complete specimens, i.e. associated premaxillae and maxillae, or mandibles with symphyses. Only the Frick Collection contains a sufficient number of relatively complete crania of most of the species of Calippus to allow recognition of the systematic importance of the anterior skull region.

Two monophyletic species-groups of Calippus are recognized; the smaller-sized taxa that traditionally comprise the genus, and a number of medium-sized species classically referred to Astrohippus or Pliohippus. Both groups lack malar fossae, a derived feature present in Pliohippus (MacFadden, 1984b, pp. 275-277), Astrohippus (Mat thew and Stirton, 1930, p. 361; MacFadden, 1984b, p. 277), and primitive equines like "Merychippus" stylodontus (Quinn, 1984). These taxa have normal (i.e. primitive) equid diastema lengths, incisor morphologies, and muzzle widths relative to their body size (Fig. 43). The two species groups of Calippus are here formally recognized as subgenera, $\underline{\mathrm{Cal}}$. (Calippus) and $\underline{\mathrm{Cal}}$. (Grammohippus) new subgenus. 
Figure 43. Relationship between upper toothrow length and muzzle width for various equid species. A-0 are taxa judged to have normal (i.e. unexpanded) muzzles and are plotted to indicate baseline values for muzzle width relative to body size (here represented by toothrow length). A, Mesohippus barbouri; B, "Merychippus" primus; C, Merychippus insignis; D, Cormohipparion sphenodus; E, Cor. occidentale; F, "Merychippus "republicanus; $G$, Neohipparion affine; $H$, Pseudhipparion retrusum; 1, Pseud. gratum; J, "Merychippus" isonesus; K, PTiohippus mirabilis; L, PTio. pernix; M, Dinohippus Teidyanus; N, D. interpolatus; 0 . Equus grevyi. The least squares regression line fitted to these 15 points has an equation of $y=0.362 x+0.457$, with a correlation coefficient of 0.967 . The remaining eight points (1-8) are of taxa with relatively expanded muzzles: 1, Protohippus perditus; 2, Protohippus supremus; 3, Calippus (Grammohippus) martini; 4, Cal. (G.) maccartyi (muzzle width estimated from mandibular symphysis); 5, Cal. (G.) sp. from the Hemphillian of the Great Plains; 6, Cal. (Cal.Tproplacidus; 7, Cal. (Cal.) placidus; and 8 , Cal. (Cal.TreguTus. of these, the most primitive is Pro. perditus whose muzze width falls within the observed range of normal equids. However, it is relatively expanded when compared to contemporary equines such as Pliohippus mirabilis $(K)$. All points are mean values for each species, taken on mature (but not extremely heavily worn) individuals, and when available on equal numbers of each sex. Muzzle width measured across I3s, toothrow length from P2 to M3. 


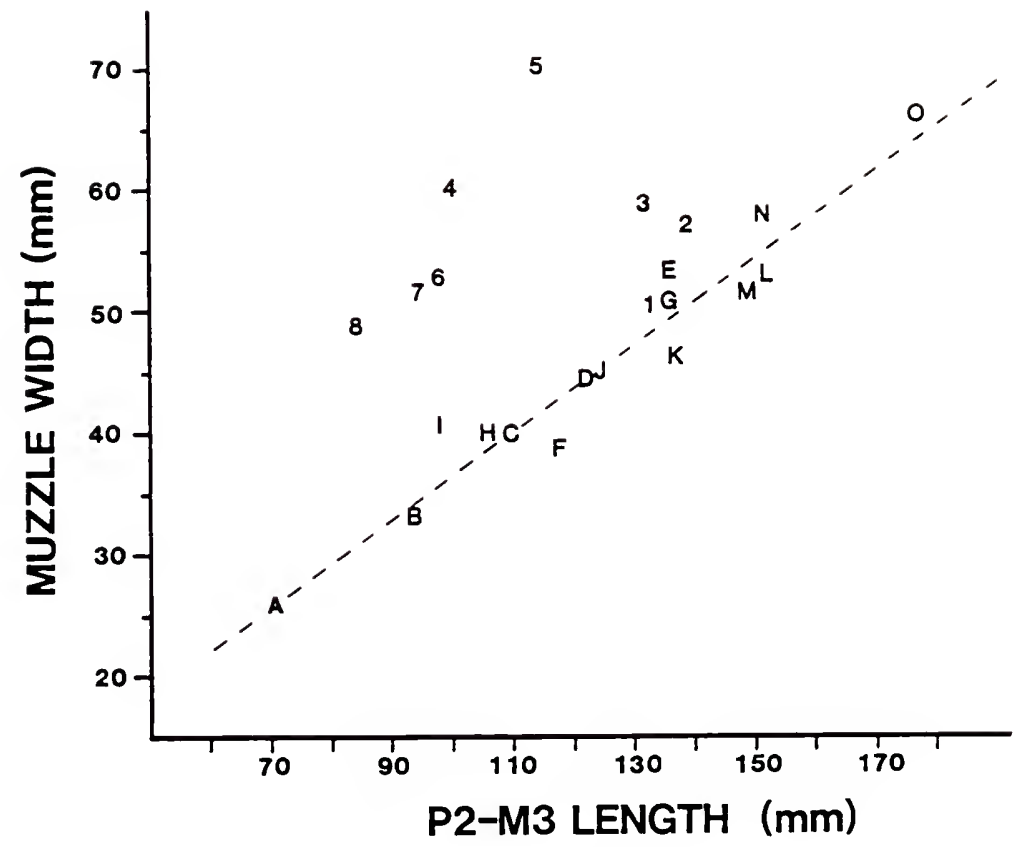


Subgenus Calippus Matthew and Stirton, 1930

Type species. Calippus (Cal.) placidus (Leidy), 1858.

Included species. Cal. (Cal.) proplacidus (Osborn), 1918, $\mathrm{n}$. comb.; Cal. (Cal.) regulus Johnston, 1937; Cal. (Cal.) elachistus $n$. sp.

Revised diagnosis. Relatively very small, hypsodont equids with UTRL and $1 \mathrm{tr} 1$ less than $105 \mathrm{~mm}$. Elongated, elliptical protocones that connect immediately to the protoselene at on set of wear. P1i caballin single, relatively small or absent; absent or only present in very early wear-stages of molars; usually present through middle wear-stages of premolars. Upper cheekteeth relatively straight, with reduced styles. Hypoconal groove shallow, closed by a hypostylar fold in early or middle wear-stages; lost or persists as an isolated fossette in advanced wear-stages. Protostylids present on $p 3-m 3$ and dp3-dp4. Muzzle width relatively very broad, exceeds $50 \%$ of UTRL. Discussion. Cal. (Calippus) includes all species traditionally placed in Calippus (e.g. Stirton, 1940; Quinn, 1955; Webb, 1969a). They are among the smallest of advanced, hypsodont equids; being matched in size only by some species of Pseudhipparion (Webb and Hulbert, 1986) and smaller individuals of Nan. minor. The phylogeny of this group is therefore of interest, as decreases in body size are uncommon among equid lineages (Romer, 1949; MacFadden, 1987). In addition to size, members of Cal. (Calippus) generally differ from those of Cal. (Grammohippus) n. subgen. in their straighter upper cheekteeth, generally simpler fossettes, pli caballins and styles, 
and the presence of well developed protostylids on lower cheekteeth (except p2).

Ca1. (Calippus) proplacidus (Osborn) 1918, new combination

Protohippus proplacidus OSBORN, 1918, pp. 139-141 (in part).

Merychippus francisi HAY, 1924, p. 9; STIRTON, 1940, p. 181;

HESSE, 1943, pp. 168-169, 171.

Merychippus proplacidus (Osborn), STIRTON, 1940, p. 182;

GALBREATH, 1953, p. 105.

Calippus francisi (Hay), QUINN, 1955, pp. 27-30; WEBB, 1969a, p. 82; FORSTEN, 1975, pp. 41-44.

Type specimen. AMNH 91158, palate with L DP1-DP2 and R DP1-DP4, $M 1$ (unerupted) and associated $L$ and $R$ rami with dp2-dp4 (Osborn, 1918, Fig. 112).

Type locality. Sand Canyon Fauna, Logan Co., Colorado. Stratigraphic occurrence and age of type locality. Upper Pawnee Creek Formation; late Barstovian, about 12 to $13 \mathrm{ma}$.

Topotypic sample. AMNH 9038, dp3 (one of three paratypes listed by Osborn, $1918, p .140)$.

Revised distribution. Late Barstovian of northeastern Colorado, Nebraska, and the Gulf Coastal Plain of Texas and Florida.

Referred specimens. Devils Gulch Hor se Quarry, Brown Co., NB (Skinner and Johnson, 1984, p. 282): F:AM 60443, 60439, 604373 skulls; 60438 assoc. skull and mandible; 60442, 60444, 60445, 604464 maxillae; 114088 assoc. $R$ and $L$ mandibles with deciduous dentition. 
Cold Spring Fauna. Noble Farm 1.f., Grimes Co., TX: TAMU 3013 R DP34; 3014-3015 2 L P34; 2390 (holotype, Cal. francisi), 3016-30173 L M12; 3018 L M3. Cold Spring 1.f., San Jacinto Co., TX: TMM 31219-143, -165 2 R P2; -307, -308 2 R P34; -309-313 5 L P34; -25, $-314-3186$ R M12; $-53,-67,-91,-319-3238$ L M12; $-324,-3252$ L M3; $-286 \mathrm{R}$ mandible with $\mathrm{m} 1-\mathrm{m} 3 ;-240 \mathrm{~L}$ mandible with $\mathrm{p} 4-\mathrm{m} 3 ;-10 \mathrm{~L}$ mandible with p3,dp4,m1; -110 assoc. $\mathrm{R}$ m2-m3; TAMU $3005 \mathrm{R}$ dp2; TMM 31219-290, -291 2 R p2; -283, -292-294 4 L p2; -202, -296 2 R p34; -52, -295, TAMU 30043 L p34; TMM 31219-11, -63, -95, -297-2996R $m 12 ;-122,-162,-300-3025 \mathrm{~L} m 12 ;-114,-196,-305,-3064 \mathrm{R} m 3$; $-106,-303,-3043 \mathrm{~L} \mathrm{m3}$. Sam Houston 1.f., San Jacinto Co., TX: TMM 31191-12, -29 2 L M12. Goodrich 1.f., Polk Co., TX: TMM 31183-63 and -49 assoc. palate with $R$ and $L D P 1-M 3$ and $R$ mandible with $p 2-m 3$. Chapel Hill Site, Washington Co., TX: TMM 31272-35 R M12.

Agricola Fauna, Bone Valley Region. Red Zone, Phosphoria Mine: UF $28442,28443,28467,28469-28471,284742$ deciduous and 5 permanent upper cheekteeth; $28452 \mathrm{~L} \mathrm{m12.} \mathrm{TRO} \mathrm{locality} \mathrm{F7201,}$ Kingsford Mine: UF 55938 L P34.

Ashville Site: UF/FGS V-6101, -61252 L P34; -6064 R M12; -6117 L M12; -6061 L m12.

Revised diagnosis. Small equid with toothrow lengths of about 95 to $102 \mathrm{~mm}$ and unworn molar crown heights about $40 \mathrm{~mm}$. Larger than Cal. regulus or $\underline{\mathrm{Cal}}$. elachistus, and with better developed styles and fossette plications. Less hypsodont, shallower linguaflexids, and less elongated metaconids and metastylids than Cal. placidus. 
Description. Calippus proplacidus has many distinctive characters that it shares with other members of the subgenus, including relatively small size (Figs. 44, 46, 47; Tables 29-31), weak pli caballin, simple fossettes, lack of a MF, protostylids on lower cheekteeth, and ectostylids absent on dp2-dp4. The maximum length of the unworn DPI of AMNH $9115 \mathrm{~B}$ is $8.0 \mathrm{~mm}$. Three specimens from the Devil's Gulch Horse Quarry have DP1 lengths of $8.1,8.2$ and $9.0 \mathrm{~mm}$ (F:AM 60439, 60443 and 60442, respectively), and a Cold Spring specimen (TMM 31183-63) has a DP1 length of $8.8 \mathrm{~mm}$. The lower toothrow length (dp2-dp4) of the holotype is $59.8 \mathrm{~mm}$. F:AM 114088, from the Devil's Gulch Horse Quarry, that is in the same very early wear-stage as AMNH 9115B, has a length of $59.1 \mathrm{~mm}$. Toothrow lengths of juvenile rami of Cal. regulus are smaller; F:AM 114178 and $F: A M$ 60428 from MacAdams Quarry, Clarendon Fauna, measure 52.3 and 52.9 mm, and F:AM 60495 and F:AM 60496, from Lucht Quarry, Burge Fauna, 55.9 and $56.1 \mathrm{~mm}$.

The series of skulls from the Devil's Gulch Hor se Quarry allows description of the facial morphology of Cal. proplacidus. The DPOF is usually large and shallow, with a moderate posterior rim. The fossa blends into the surrounding facial region anteriorly and ventrally. The preorbital bar is relatively narrow. The ventral portion of the face lacks a MF. F:AM 60437 has a shallower DPOF located more anteriorly than other members of the population, but is similar in size and dental morphology.

The cheekteeth of Cal. proplacidus (Tables 29-31; Fig. 44) were previously described by Quinn (1955) and Forsten (1975, pp. 42-43) 
Table 29. Standard univariate statistics for upper cheekteeth of Calippus proplacidus from the Devil's Gulch Member, Valentine Formation, Brown County Nebraska (late Barstovian) and from the Cold Spring Fauna, Fleming Formation, San Jacinto and Grimes Counties, Texas (late Barstovian), and for Cal. placidus from the Minnechaduza Fauna, Ash Hol low Formation, Brown and Cherry Counties, Nebraska and Todd County, South Dakota (Clarendonian) and from the Clarendon Fauna, Don ley County, Texas (middle Clarendonian). Format as in Table 2.

$\begin{array}{llll}\text { TAXON proplacidus } & \text { proplacidus } & \text { placidus } & \text { placidus } \\ \text { FAUNA DEVIL'S GULCH } & \text { COLD SPRING } & \text { MINNECHADUZA } & \text { CLARENDON }\end{array}$

P2

\begin{tabular}{lllll} 
APL & $19.8,0.35,4$ & $18.4,0.64,2$ & $20.5,1.34,11$ & $20.3,1.18,4$ \\
& $19.4-20.2,1.77$ & $17.9-18.8,3.47$ & $17.6-22.7,6.56$ & $18.7-21.3,5.83$ \\
BAPL & $15.8,--, 1$ & \multicolumn{1}{c}{----} & $16.2,1.12,5$ & -1 \\
& & & $15.2-18.1,6.92$ & \\
TRW & $15.9,1.27,4$ & $14.7,0.42,2$ & $16.2,1.23,12$ & $16.5,1.32,4$ \\
& $14.1-17.0,7.98$ & $14.4-15.0,2.89$ & $14.1-18.1,7.57$ & $14.9-18.1,7.98$ \\
PRL & $4.7,0.47,4$ & $4.9,0.28,2$ & $5.2,0.62,12$ & $5.1,0.36,4$ \\
& $4.2-5.3,9.94$ & $4.7-5.1,5.77$ & $4.4-6.4,11.83$ & $4.8-5.6,7.01$ \\
PRW & $3.6,0.38,4$ & $2.9,0.14,2$ & $3.6,0.30,12$ & $3.6,0.27,4$ \\
& $3.1-4.0,10.41$ & $2.8-3.0,4.88$ & $3.1-4.0,8.16$ & $3.4-4.0,7.52$
\end{tabular}

\begin{tabular}{|c|c|c|c|c|}
\hline APL & $\begin{array}{l}17.5,1.17,15 \\
16.0-19.4,6.72\end{array}$ & $\begin{array}{l}16.4,0.67,9 \\
15.4-17.5,4.08\end{array}$ & $\begin{array}{l}17.1,1.06,18 \\
15.3-19.0,6.21\end{array}$ & $\begin{array}{l}16.7,0.57,10 \\
15.9-17.8,3.42\end{array}$ \\
\hline BAPL & $14.3,--, 1$ & $\begin{array}{l}13.1,0.49,6 \\
12.3-13.7,3.75\end{array}$ & $\begin{array}{l}12.4,1.12,4 \\
10.9-13.6,9.00\end{array}$ & ----- \\
\hline TRW & $\begin{array}{l}17.9,0.67,15 \\
16.3-18.7,3.73\end{array}$ & $\begin{array}{l}16.6,0.74,9 \\
15.0-17.8,4.47\end{array}$ & $\begin{array}{l}17.8,0.87,18 \\
16.5-19.8,4.89\end{array}$ & $\begin{array}{l}18.2,1.22,9 \\
16.7-19.9,6.73\end{array}$ \\
\hline PRL & $\begin{array}{l}6.0,0.84,15 \\
4.8-7.7,13.99\end{array}$ & $\begin{array}{l}6.1,0.75,9 \\
5.2-7.1,12.31\end{array}$ & $\begin{array}{l}6.2,0.54,18 \\
5.1-7.2,8.74\end{array}$ & $\begin{array}{l}6.3,0.65,10 \\
5.5-7.5,10.36\end{array}$ \\
\hline PRW & $\begin{array}{l}3.5,0.34,15 \\
3.1-4.1,9.84\end{array}$ & $\begin{array}{l}3.3,0 \cdot 30,9 \\
3.0-4 \cdot 0,9 \cdot 12\end{array}$ & $\begin{array}{l}3.9,0.40,18 \\
3.4-4.8,10.21\end{array}$ & $\begin{array}{l}3.8,0.30,10 \\
3.2-4.1,7.91\end{array}$ \\
\hline
\end{tabular}


Table 29--continued

M12

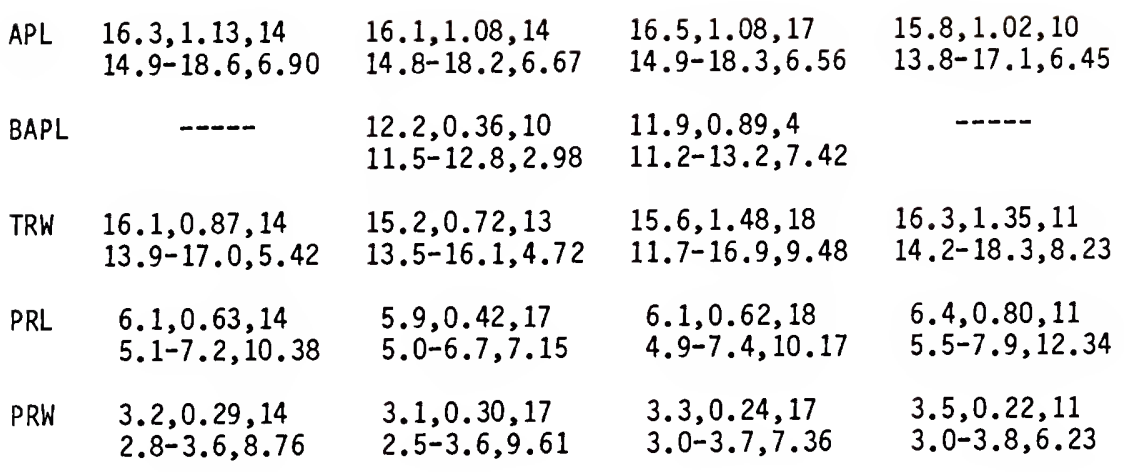


Table 30. Standard univariate statistics for lower cheekteeth of Calippus proplacidus from the Devil's Gulch Member, Valentine Formation, Brown County, Nebraska (late Barstovian) and from the Cold Spring Fauna, Fleming Formation, Grimes and San Jacinto Counties, Texas (late Barstovian), and for Cal. placidus from the Clarendon Fauna, Don ley County, Texas (middTe clarendonian). Format as in Table 2.

\begin{tabular}{|c|c|c|c|}
\hline SPECIES & proplacidus & proplacidus & placidus \\
\hline \multirow[t]{2}{*}{ FAUNA } & DEVIL'S GULCH & COLD SPRING & CLARENDON \\
\hline & & p2 & \\
\hline apl & $\begin{array}{l}17.2,0.34,4 \\
16.7-17.5,1.98\end{array}$ & $\begin{array}{l}16 \cdot 2,1.16,6 \\
14.5-17.6,7.19\end{array}$ & $\begin{array}{l}16.8,1.15,5 \\
14.9-17.9,6.84\end{array}$ \\
\hline bapl & ---- & $\begin{array}{l}13.3,0.87,4 \\
12.4-14.4,6.54\end{array}$ & ---- \\
\hline atw & $\begin{array}{l}7.3,0.17,4 \\
7.1-7.5,2.39\end{array}$ & $\begin{array}{l}6.2,0.29,6 \\
5.7-6.5,4.72\end{array}$ & $\begin{array}{l}7.3,0.54,5 \\
6.5-7.8,7.36\end{array}$ \\
\hline ptw & $\begin{array}{l}9.5,0.34,5 \\
9.1-10.0,3.57\end{array}$ & $\begin{array}{l}8.4,0.33,5 \\
8.0-8.6,3.93\end{array}$ & $\begin{array}{l}9.1,0.66,5 \\
8.0-9.6,7.28\end{array}$ \\
\hline $\mathrm{mml}$ & $\begin{array}{l}5.1,0.62,4 \\
4.4-5.9,12.07\end{array}$ & $\begin{array}{l}4.4,0.76,6 \\
4.0-5.7,17.23\end{array}$ & $\begin{array}{l}6.1,0.34,5 \\
5.7-6.4,5.59\end{array}$ \\
\hline \multirow[t]{2}{*}{ entr } & $\begin{array}{l}6.8,0.96,5 \\
5.3-7.8,13.97\end{array}$ & $\begin{array}{l}5.6,0.78,6 \\
4.8-6.7,13.97\end{array}$ & $\begin{array}{l}8.0,0.60,5 \\
7.4-8.8,7.54\end{array}$ \\
\hline & & p34 & \\
\hline apl & $\begin{array}{l}17.3,1.31,12 \\
15.7-19.6,7.56\end{array}$ & $\begin{array}{l}16.7,0.45,7 \\
16.1-17.3,2.71\end{array}$ & $\begin{array}{l}17.4,0.90,9 \\
15.4-18.8,5.20\end{array}$ \\
\hline bapt & ---- & $\begin{array}{l}13.9,0.50,4 \\
13.3-14.5,3.61\end{array}$ & ---- \\
\hline atw & $\begin{array}{c}10.0,0.68,12 \\
9.3-11.1,6.79\end{array}$ & $\begin{array}{l}8.8,0.63,7 \\
8.1-9.9,7.12\end{array}$ & $\begin{array}{l}9.6,1.26,9 \\
7.7-1 i .1,13.16\end{array}$ \\
\hline ptw & $\begin{array}{c}10.1,0.70,12 \\
8.7-11.0,6.96\end{array}$ & $\begin{array}{l}9.3,0.93,7 \\
8.0-10.3,9.98\end{array}$ & $\begin{array}{l}9.3,0.83,9 \\
8.1-10.6,8.91\end{array}$ \\
\hline $\mathrm{mml}$ & $\begin{array}{l}8.6,0.68,12 \\
7.6-9.7,7.91\end{array}$ & $\begin{array}{l}7.8,0.45,7 \\
7.1-8.5,5.71\end{array}$ & $\begin{array}{l}8.7,0.39,9 \\
8.0-9.2,4.47\end{array}$ \\
\hline ent 1 & $\begin{array}{l}6.7,0.87,12 \\
5.2-7.9,12.97\end{array}$ & $\begin{array}{l}7.0,0.31,7 \\
6.5-7.4,4.40\end{array}$ & $\begin{array}{l}8 \cdot 0,0.75,9 \\
6.3-9.0,9 \cdot 47\end{array}$ \\
\hline
\end{tabular}


Table 30--continued

m12

\begin{tabular}{|c|c|c|c|}
\hline apl & $\begin{array}{l}16.7,1.53,14 \\
14.7-19.9,9.16\end{array}$ & $\begin{array}{l}16.2,1.43,10 \\
14.3-18.4,8.79\end{array}$ & $\begin{array}{l}16.7,1.34,10 \\
14.7-18.7,8.03\end{array}$ \\
\hline bap1 & --- & $\begin{array}{l}12.6,0.61,7 \\
11.5-13.3,4.81\end{array}$ & ---- \\
\hline atw & $\begin{array}{l}8.1,0.34,14 \\
7.5-8.6,4.18\end{array}$ & $\begin{array}{l}7.0,0.52,10 \\
6.0-7.6,7.41\end{array}$ & $\begin{array}{l}8.6,0.62,10 \\
7.7-9.5,7.19\end{array}$ \\
\hline ptw & $\begin{array}{l}6.6,0.35,14 \\
6.2-7.4,5.34\end{array}$ & $\begin{array}{l}6.2,0.23,11 \\
5.7-6.5,3.63\end{array}$ & $\begin{array}{l}7.2,0.60,10 \\
6.3-8.0,8.29\end{array}$ \\
\hline $\mathrm{mm} 1$ & $\begin{array}{l}7.3,0.42,14 \\
6.5-7.9,5.72\end{array}$ & $\begin{array}{l}6.7,0.49,10 \\
6.2-7.4,7.38\end{array}$ & $\begin{array}{l}7.5,0.65,10 \\
6.7-8.6,8.65\end{array}$ \\
\hline t & $\begin{array}{l}4.2,1.16,14 \\
2.2-6.4,27.42\end{array}$ & $\begin{array}{l}4.0,0.73,11 \\
2.8-4.8,18.24\end{array}$ & $\begin{array}{l}6.8,1.33,10 \\
4.1-8.2,19.40\end{array}$ \\
\hline
\end{tabular}


Table 31. Measurements of specimens of Calippus proplacidus from lower horizons of the Bone Valley Formation, PoTk County, FTorida. An "a" before a value indicates that it is an approximation from a broken or waterworn specimen.

\begin{tabular}{|c|c|c|c|c|c|c|c|c|c|}
\hline \multirow{3}{*}{$\begin{array}{l}\text { UF } 28469 \\
\text { UF } 55938 \\
\text { UF } 28442 \\
\text { UF } 28471\end{array}$} & \multicolumn{2}{|c|}{ ToothSide } & APL & TRW & PRL & PRW & BAPL & $\mathrm{MSCH}$ & \\
\hline & $\begin{array}{l}\text { P34 } \\
\text { P34 } \\
\text { M12 } \\
\text { M12 }\end{array}$ & $\begin{array}{l}R \\
L \\
R \\
R\end{array}$ & $\begin{array}{l}15.0 \\
14.6 \\
15.4 \\
15.4\end{array}$ & $\begin{array}{l}14.9 \\
13.9 \\
14.8 \\
12.9\end{array}$ & $\begin{array}{l}4.9 \\
4.6 \\
5.8 \\
5.6\end{array}$ & $\begin{array}{l}3.1 \\
3.4 \\
3.1 \\
3.1\end{array}$ & $\begin{array}{l}10.8 \\
10.5 \\
11.4 \\
10.1\end{array}$ & $\begin{array}{l}32.4 \\
\text { a } 31 \\
33.0 \\
\text { a } 33\end{array}$ & \\
\hline & & & apl & atw & ptw & $\mathrm{mml}$ & ent 1 & bapl & mech \\
\hline JF 28452 & $\mathrm{~m} 12$ & $L$ & 16.0 & 6.9 & 6.4 & 6.9 & 6.0 & -- & 32.3 \\
\hline
\end{tabular}


A

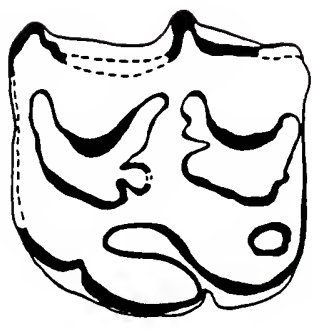

0

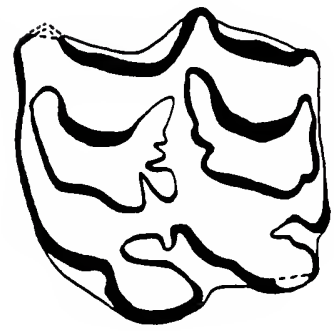

$D$

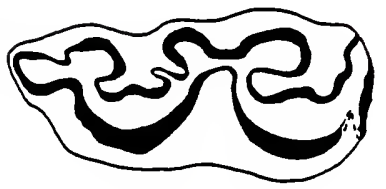

B

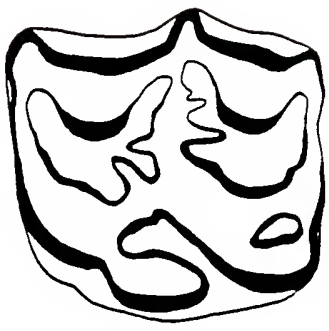

$2 \mathrm{~cm}$

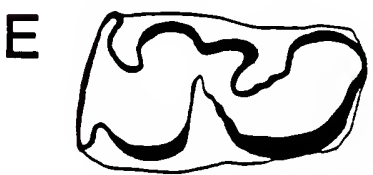

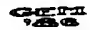

Figure 44. Occlusal views of cheekteeth of Cal. (Calippus) proplacidus from the Cold Spring Fauna, Texas (late Barstovian). $\overline{A-B}$. Noble Farm Site, Grimes County. A. TAMU 2390, L M12, holotype of Cal. francisi (Hay). B. TAMU 3016, L M12. C-E. Cold Spring local fauna, San Jacinto County. C. TMM 31219-309, L P34. D. TMM 31219-95, R m12. E. TMM 31219-302, L m12. 
A

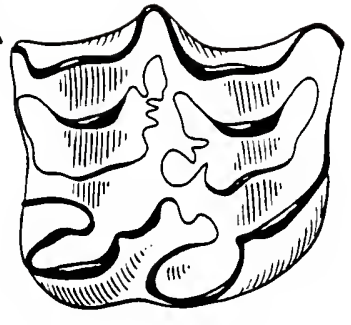

Q
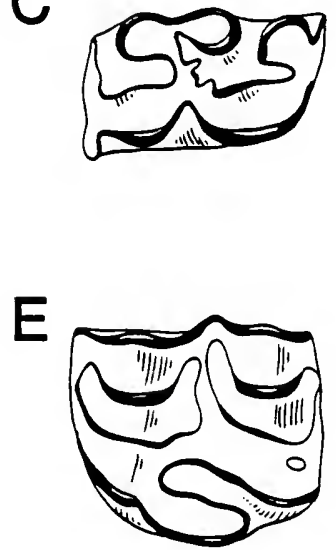

0
B

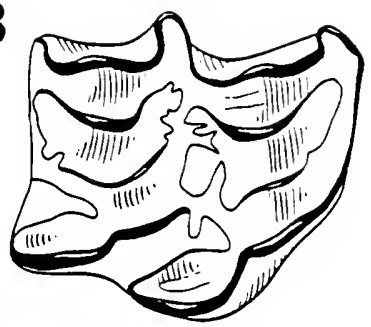

D

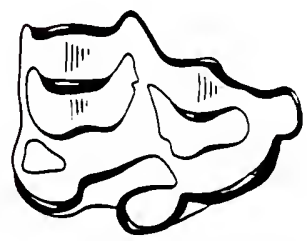

5

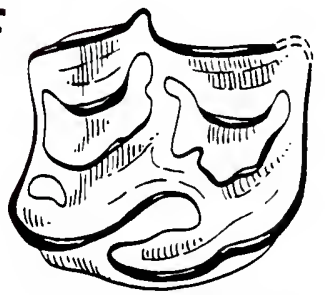

$2 \mathrm{~cm}$

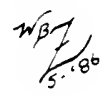

Figure 45. Occlusal views pf cheekteeth of Cal $1 \mathrm{l}$ (Calippus) from A-B. Cal. proplacidus, Red Zone, Phosphoria Mine. A. UF $28469, R$ P34. B. UF 28442, RM12. C-F. Calippus sp. C. IJF 61343, L p34, Kingsford Mine. D. UF 28421, R P2, Red Zone, Phosphoria Mine. E. UF 28680, L M12, Gray Zone, Phosphoria Mine. F. UF 93201, R P34, Gray Zone, Phosphoria Mine. 


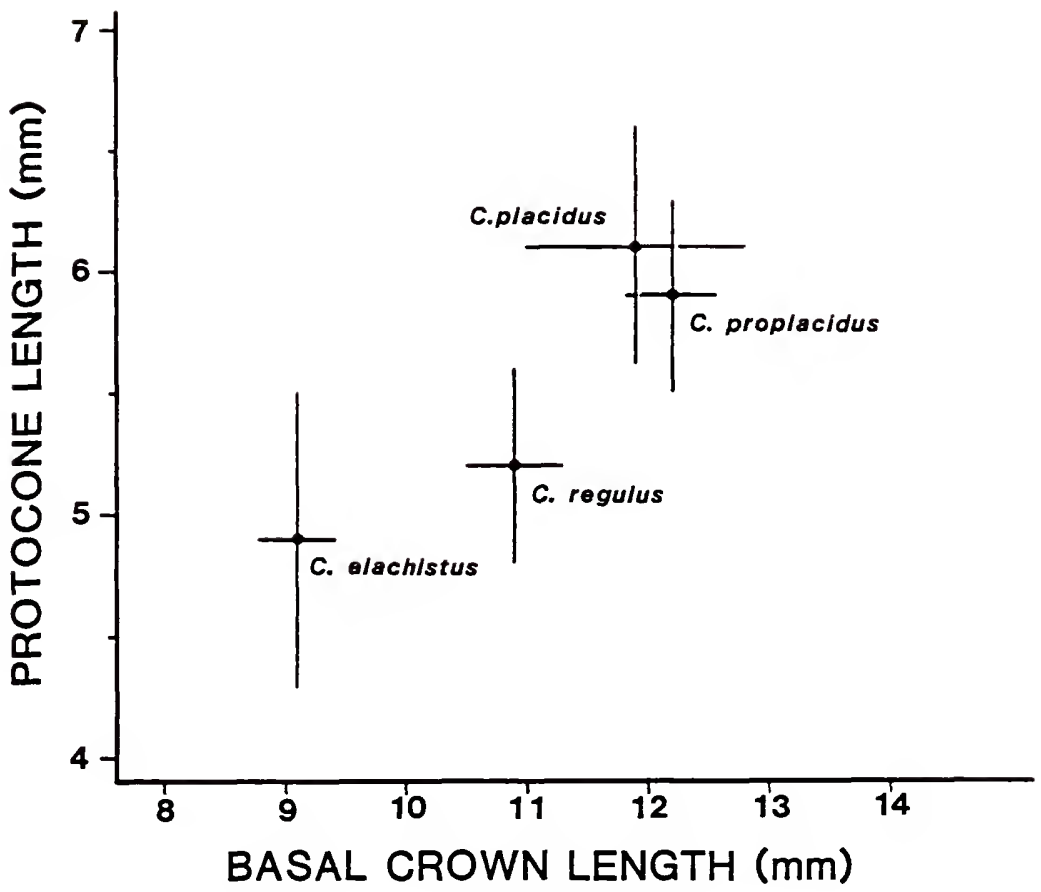

Figure 46. Bivariate plot of basal crown length (BAPL) versus protocone length (PRL) of combined samples of M1s and M2s for four species of Cal. (Calippus). One standard deviation is plotted on both sides of the mean value for the following populations: Cal. proplacidus, Cold Spring Fauna; Cal. placidus, Minnechaduza Fauna; Cal. reguTus, Clarendon Fauna; CaT. elachistus, Archer Fauna Tprimarily the Love Site). 


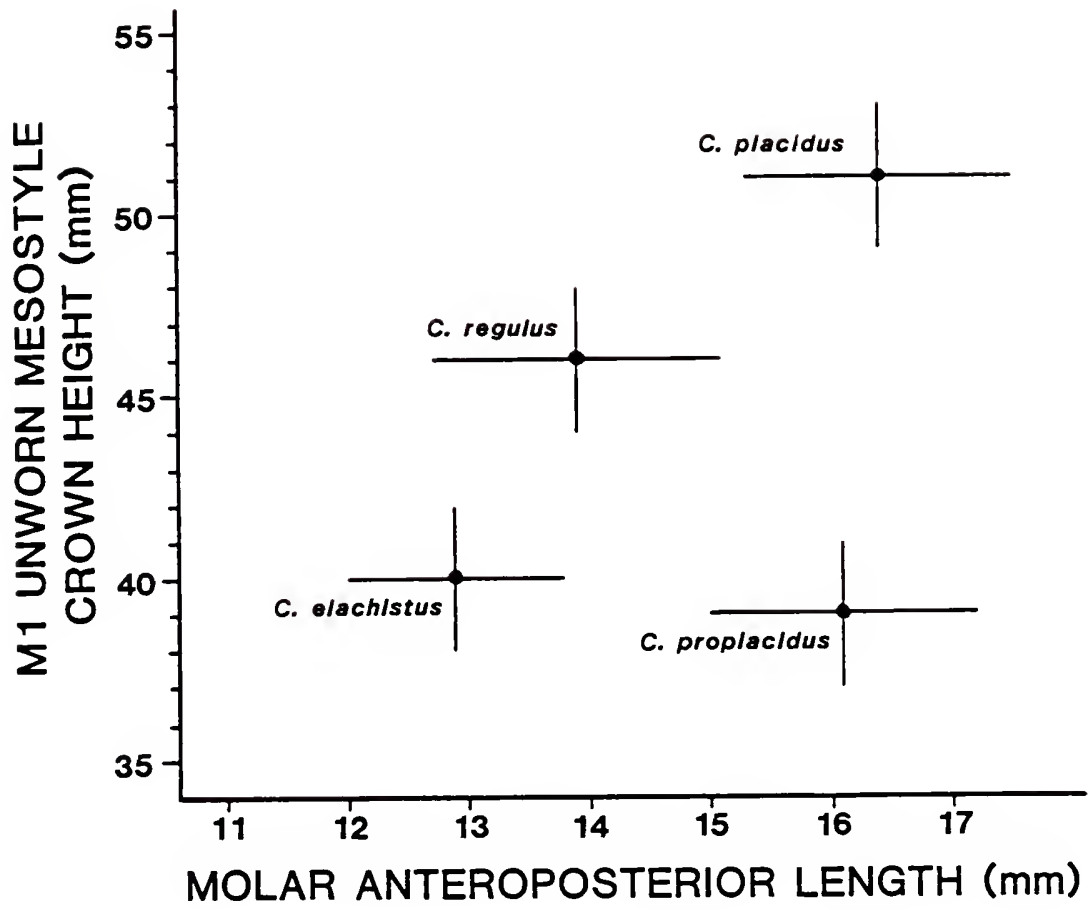

Figure 47. Bivariate plot of the occlusal anteroposterior length (APL) of $M 1 \mathrm{~s}$ and $M 2 \mathrm{~s}$ versus the estimated unworn molar crown height for the same four populations as in Figure 46 . One standard deviation is plotted to the right and left of the mean for APL, while the unworn crown height is plotted plus and minus $2 \mathrm{~mm}$ to estimate the observed range of variation of this character. 
as Cal. francisi for the Cold Spring sample. Specimens from Florida (Figs. 45A, 45B) and Nebraska generally conform to their observations. However, Forsten (1975, p. 43) noted that her sample included teeth with up to 14 fossette plications, about twice the maximum I observed. Probably her sample was heterogeneous and included specimens of the similarly sized, but more complex, Hipparion shirleyi. Based on F:AM 60442, TMM 31183-63 and 31183-91, unworn or slightly worn MSCHs of Cal. proplacidus are about $29 \mathrm{~mm}$ for $P 2$ and 35 to $40 \mathrm{~mm}$ for P3-M2. Cal. proplacidus is significantly much larger in occlusal dimensions than $\mathrm{Cal}$. regulus or Cal. elachistus, but about the same size as Cal. placidus (Figs. 46, 47; Tables 29-30). Upper cheekteeth are characterized by relatively strong (for the subgenus) styles, including small metastyles on some individuals (Figs. 44B, 44C, 45A, 45B). The protocone is usually connected to the protoselene at the on set of wear, although very slightly worn P34s may have isolated protocones with large spurs (e.g. UF 28443, $F: A M$ 60445). The long axis of the protocone is slightly anterolabial-posterolingually orientated. The protocone occasionally connects to the hypocone in well worn molars. As described by Forsten (1975), the hypoconal groove is closed by a hypostylar fold, generally in the upper quarter of the crown, but may remain as an isolated lake until late wear before disappearing (Figs. 44A, 44B). A few specimens (e.g. UF 28469) retain the primitive condition of an open hypoconal groove until moderate to late wear-stages. Fossette plications are relatively complex for a Calippus, with a single, small pli protoloph (that rapidly disappears with wear) and a 
somewhat more persistent single pli hypostyle. The internal fossette margins usually have one or two shallow plications that disappear by middle wear-stages.

Lower cheekteeth of Cal. proplacidus (Table 30) generally resemble others of the subgenus. The lingual flexids, especially the linguaflexid, are more poorly developed and less persistent than those of Cal. placidus, but somewhat more advanced than those of Cal. regulus (Figs. 44D, 44E; Quinn, 1955, Plate 4, Fig. 6). A strong pli entoflexid is observed in early wear-stages. Protostylids appear on the occlusal surface shortly after the onset of wear on the p3-m3. Discussion. Osborn (1918) based "M." proplacidus on a nearly unworn, associated upper and lower juvenile dentition, and listed it as a member of his Sand Canyon Fauna. Galbreath (1953) and Tedford et al. (in press) have discussed the biostratigraphy of Miocene deposits in northeastern Colorado. Tedford et al. (in press) concluded that the Sand Canyon Fauna includes both the Vim-Peetz and Kennesaw local faunas of Galbreath (1953), and that it dates from about 13 to $12 \mathrm{ma}$. They list among its chronologic equivalents local faunas in the Crookston Bridge and Devil's Gulch Members of the Valentine Formation in Nebraska, and the Cold Spring Fauna of southeastern Texas. As noted by Galbreath (1953), Stirton (1940, p. 182) proposed that $\mathrm{Cal}$. proplacidus was a member of an older fauna in the Pawnee Creek Formation. Referral of morphologic equivalents from the Crookston Bridge Member (Webb, 1969a, p. 82), Devil's Gulch Member and the cold Spring Fauna to $\underline{\text { Cal }}$ proplacidus would appear to invalidate Stirton's suggestion. Osborn (1918, p. 140) listed three 
paratypes for "M.." proplacidus, AMNH 9036, 9037 and 9038, and gave their locality data as "...also probably from Sand Canyon...". of the three, only AMNH 9038 probably belongs with Cal. proplacidus. It is an unworn dp34 of similar size $(\mathrm{apl}=21.6 \mathrm{~mm})$ and morphology as the holotype (e.g. lacks an ectostylid, strong protostylid). AMNH 9036 is a partial associated, heavily worn upper and lower dentition that is referable to Pseudhipparion, cf. Pseud. retrusum, because despite the late wear-stage the specimen retains traces of $\mathrm{pli}$ caballins, the fossettes still bear some plications, and the linguaflexids are still moderately deep. AMNH 9037, an assemblage of seven associated right and left lower cheekteeth (plus incisors and fragments), while referable to Calippus, is too small to be included in Cal. proplacidus, but resembles primitive, late Barstovian representatives of Cal. regulus from the Burge Fauna in size and morphology.

Merychippus francisi was described from an isolated upper molar (TAMU 2390, Fig. 44A) by Hay (1924) and subsequent7y referred to Calippus by Quinn (1955). The fauna from the type locality (Noble Farm, Grimes Co., Texas) includes Gomphotherium (Hesse, 1943); thus its age is no older than late Barstovian (Tedford et al., in press). Other specimens referred and figured by Hay (1924) as M. francisi, including a P2 and a $\mathrm{m} 3$, probably do not represent the same species as the type. Hesse (1943), Quinn (1955), and Forsten (1975) described additional material of Cal. francisi from other sites in the Cold Spring Fauna, including some relatively complete dentitions. The cold Spring population is morphologically indistinguishable from 
Great Plains samples of Cal. proplacidus, but on average slightly smaller (Tables 29,30 ). Thus, Cal. proplacidus must be regarded as the senior synonym of Cal. francisi. Forsten (1975, pp. 41-42) also referred a few isolated teeth from older (early late Barstovian) sites in the Texas Gulf Coastal Plains sequence to $\mathrm{Cal}$. proplacidus. These are more primitive than referred Cold Spring or Devil's Gulch specimens; e.g. a slightly worn M1 (TMM 40070-26) has a MSCH of on $1 y$ $32.4 \mathrm{~mm}$. The older material is inadequate to document specific identity with Cal. proplacidus, but is referable to Cal. (Calippus) and indicates that the two subgenera of Calippus had diverged at least by $14 \mathrm{ma}$.

Specimens from Florida referable to Cal. proplacidus (Figs. 45A, 45B; Table 31) have been collected in situ from the Red Zone of the Agricola Fauna in the Phosphoria Mine. The dimensions of the Red Zone specimens (Table 31) are similar to, or slightly smaller than, those from the cold Spring Fauna, but are otherwise indistinguishable. A few isolated teeth from the Ashville local fauna (01sen, 1964) are also apparently referable to Cal. proplacidus. Although poorly preserved, they appear to have better developed styles and are larger than Cal. regulus.

Cal. (Calippus) placidus (Leidy), 1869

Protohippus placidus LEIDY, 1869, pp. 277-279 (in part); GIDLEY, 1906a, pp. 140-142 (in part); GIDLEY, 1907, p. 887 (in part); OSBORN, 1918, pp. 133-136. 
Protohippus (Calippus) placidus Leidy, MATTHEW and STIRTON, 1930, p. 354 .

Calippus placidus (Leidy), STIRTON, 1940, p. 188; QUINN, 1955, pp. 39-40; WEBB, 1969a, pp. 79-82 (in part).

Calippus optimus QUINN, 1955, pp.35-38.

Astrohippus curtivallis QUINN, 1955, pp. 40-42 (in part).

Pliohippus (Astrohippus) martini (Hesse), GREEN, 1956, p. 161

(in part).

Calippus anatinus Quinn, WEBB, 1969a, p. 82 (in part).

Lectotype specimen. USNM 621, L P2 (0sborn, 1918, Fig. 106).

Selected from the type series by Gidley (1907).

Type locality. Exact locality unknown, collected from deposits a long "the Niobrara River" (Leidy, 1869, p. 277).

Stratigraphic occurrence and age of the type locality. Presumably Minnechaduza Fauna (Ash Hollow Formation) of northern Nebraska (see Webb, 1969a and below).

Distribution. Clarendonian (about 11.5 to $9.5 \mathrm{ma}$ ) of the northern and southern Great Plains, and Texas Gulf Coastal Plain.

Referred Gulf Coastal Plain specimens. Lapara Creek Fauna. Buckner Ranch Site, Bee Co., TX: TMM 30896-528, -530 assoc. palate with $R$ and $L P 2-M 3$ and $R$ mandible with $p 3-m 3$ (type, Cal. optimus Quinn); -200 assoc. R P4-M2; -187 DP2-M1; -479 R mandible with dp2-m1; -419 assoc. R DP2-DP4. George West Site, Live Oak Co., TX: TMM 30936-160 L P34; -353 L P34; -80 R P34. Bridge Estate Site, Bee Co., TX: TMM 31132-105 assoc. L P3-M2; -617 R M12. Farish Ranch Site, Bee Co., TX: TMM 31081-75 R P2; -1375 R M12; -1139 R M3. 
Revised diagnosis. Small equid with toothrow lengths of about 95 to $105 \mathrm{~mm}$; unworn M12 MSCH about $51 \mathrm{~mm}$; DPOF long, oval and relatively deep (for Calippus). Higher crowned teeth than Cal. proplacidus. Larger than $\mathrm{Cal}$. regulus and $\underline{\mathrm{Cal}}$. elachistus, with more complex fossettes, deeper linguaflexids, and a larger, moderate-sized DP 1 .

Description. Cal. placidus lacks a true MF, as do all members of the genus, although a shallow depression on the malar bone is occasionally observed. Incisor morphology is typical for the genus, I12 and $i 12$ in straight rows across a broad, squared-off muzzle. The width of the muzzle (measured across the I3s) is about $55 \%$ of the UTRL (Fig. 43).

Upper cheekteeth of Cal. placidus (Table 29) have, in early wear-stages, relatively large pli caballins on the premolars, but they are absent or small on the molars. Protocones are elongate, and connected to the protoselene (Fig. 48). The hypoconal groove remains open, or is present as an isolated lake through at least two-thirds of the total crown height. Fossette plications are shallow and primarily restricted to the posterior half of the prefossette (one to three) and the anterior half of the postfossette (one or two). 0lder individuals tend to lack all plications. Unworn $\mathrm{MSCH}$ is about $33 \mathrm{~mm}$ for P2s, $47 \mathrm{~mm}$ for P34s and $51 \mathrm{~mm}$ for M12s. Deciduous premolars have elongate, obliquely oriented protocones broadly connected to protoselene; open hypoconal grooves until late wear; simple fossettes; and small or absent pli caballins. The anterostyle of the DP2 is not large and is broadly connected to the rest of the tooth. 

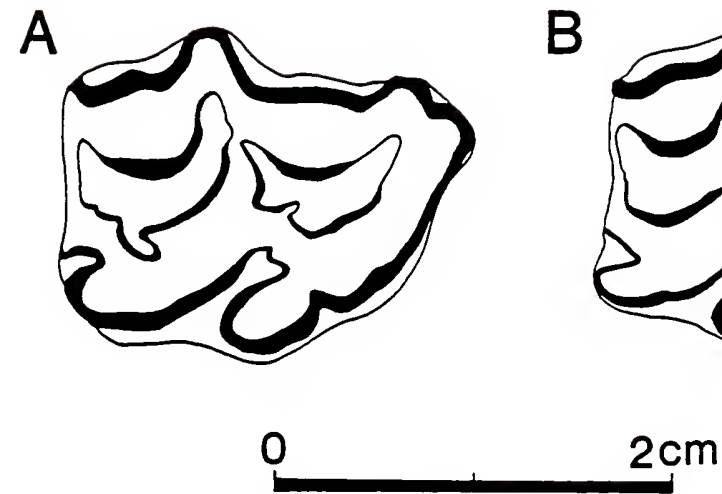

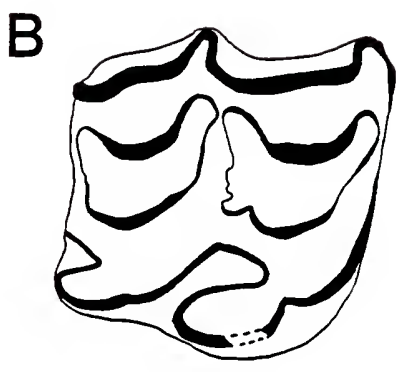

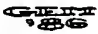

Figure 48. Occlusal views of upper cheekteeth of Cal. (Calippus) placidus from the Lapara Creek Fauna, Bee County, Texas Tearly Clarendonian). A. TMM 31081-75, R P2, Farish Ranch Site. B. TMM 31132-617, R M12, Bridge Estate Site. 
Lower cheekteeth of Cal. placidus (Table 30) show notable advancement from the primitive Calippus-grade, with relatively elongated metaconids and metastylids, increased depth and persistence of the lingual flexids, some flattening of the labial borders, and a minor reduction in depth of the ectoflexid in slightly worn molars. No enamel plications except the protostylid are present in moderately worn teeth (pli entoflexid having disappeared). Lower deciduous premolars (e.g. TMM 30896-479; Quinn, 1955, Plate 6.3) also have moderately elongated, well separated metaconids and metastylids, and lack ectostylids.

Discussion. Calippus placidus has had a very tortuous taxonomic history, due in part to an inadequate lectotype and no knowledge as to the stratigraphic horizon of the type series. Moderate to heavily-worn teeth of Cal. placidus are not easily differentiated from equaliy worn specimens of Pseud. gratum (Cope, 1892; Quinn, 1955; Webb, 1969a; Webb and Hulbert, 1986), a similar sized equid with which $\mathrm{Cal}$. placidus coexisted in the Clarendonian of Nebraska and South Dakota. Leidy's (1869) type series of ten isolated teeth includes specimens referable to both taxa (e.g. Leidy, 1869, Plate 18, Figs. 40,43 , and 44 are Cal. placidus; Figs. $39,41,47$ and 48 are Pseud. gratum), and others which are indeterminant. Leidy (1869, p. 279) himself recognized that some of the specimens listed above could represent Pseud. gratum. Gidley (1906a; 1907) attempted to better characterize Cal. placidus by referring specimens to it from Big Springs Canyon, South Dakota as "neotypes." Unfortunately, as noted by Webb (1969a), all of Gidley's material is referable to 
Pseudhipparion, not Calippus. When Matthew and Stirton (1930) named Calippus, with Proto. placidus as the subgenotypic species, they referred to it as a Valentinian species. Quinn (1955), while correctly recognizing its presence in the Clarendon and Lapara Creek Faunas, also stated that Cal. placidus was from the Valentinian of Nebraska. Webb (1969a), however, concluded that the type series was not Valentinian, but Clarendonian (from his Minnechaduza Fauna), and referred five specimens from the Ash Hol low Formation to Cal. placidus. The evidence for this derives from the type series including Pseud. gratum, an Ash Hollow Formation taxon, rather than Pseud. retrusum, the corresponding Valentine Formation species (Webb, 1969a; Webb and Hulbert, 1986). I agree with Webb (1969a) that Cal. placidus occurs in the Cap Rock and the lower part of the Merritt Dam Members of the Ash Hollow Formation of Nebraska. There it is found with Pseud. gratum, Cor. occidenta le, Neo. affine, Hipparion tehonense, Nan. fricki, Cal. martini, Pro. supremus and Plio. pernix; a typical, diverse middle Clarendonian equid assemblage. Webb (1969a, Fig. 20b) also referred specimens from the upper Merritt Dam Member (Xmas-Kat Quarry Zone) to Cal. placidus. These specimens are referable to Pseud. skinneri (Webb and Hulbert, 1986). The subgenus Cal. (Calippus) is apparently absent from the Xmas-Kat Fauna, and all younger faunas of the Great Plains.

Quinn (1955) recognized four small protohippine species in the Lapara Creek Fauna: Cal. anatinus; Cal. optimus; Cal. cf. placidus; and Astrohippus curtivallis. Webb (1969a) later referred all four to a single taxon (Cal. anatinus). Following forsten (1975), Cal. 
anatinus is here recognized as a junior synonym of Cal. regulus (see below). She noted that the remaining three taxa are distinctly larger than $\mathrm{Cal}$. regulus, and suggested that they were referable to Pseudhipparion. Webb and Hulbert (1986) concluded that the holotype of A. curtivallis (TMM 30896-196) is indeed referable to Pseudhipparion, and it thus became the type of the Lapara Creek sample of Pseudhipparion (i.e. Pseud. curtivallum). However, specimens recognized by Quinn (1955) as Cal. optimus, Cal. cf. $\underline{\text { placidus }}$ and the figured upper premolars of $\underline{A}$. curtivallis are not referable to Pseudhipparion, but to Cal. placidus (Fig. 48). The numerous referred specimens now known from Nebraska indicate that the cheekteeth of $\mathrm{Cal}$. placidus do resemble those of hipparionines in some features (e.g. its expanded metaconid-metastylid complex), thus perpetuating the confusion between it and Pseudhipparion. The two can be distinguished by the more rapidly connected protocone, the greater tendency in worn teeth for lost pli caballins and hypoconal grooves, and simpler fossettes in Cal. placidus. Cranially, the two are quite distinct, with Calippus having a much better developed DPOF, shorter diastema, and widened, squared-off muzzle.

Cal. (Calippus) regulus Johnston, 1937

Protohippus proplacidus OSBORN, 1918, pp. 139-141 (in part). Calippus sp., HESSE, 1936 , p. 65. 
Calippus regulus JOHNSTON, 1937, pp. 905-907; STIRTON, 1940, p. 188; QUINN, 1955, p. 27; WEBB, 1969a, p. 81; FORSTEN, 1975, pp. 44-48.

Calippus anatinus QUINN, 1955, pp. 30-35; WEBB, 1969a, p. 82 (in part).

Type specimen. WT 878, $R$ maxilla with P2-M3.

Type locality. Clarendon Fauna, Grant Lease Site, Donley Co., Texas (see Schultz, 1977, Fig. 6).

Stratigraphic occurrence and age of type locality. Ogallala

Formation or Group; middle Clarendonian, about $10.5 \mathrm{ma}$.

Distribution. Late Barstovian of northern Great Plains; early and middle Clarendonian of southern Great Plains; early Clarendonian of Texas Gulf Coastal Plain.

Referred specimens. Pawnee Creek Formation, Logan Co., Colorado: AMNH 9037 assoc. R p2,p34,m1-m3 \& L m1-m2, and 5 incisors.

Burge Fauna, Brown Co., NB. June Quarry: F:AM 60441 palate with L P2-M3 \& R P3-M3; Quinn Mastodon Quarry: F:AM 60486 L M12. Lucht Quarry: F:AM 60458A L P2; 60458B L M12; 60466 R M12; $60494 R$ mandible with $p 3-m 3 ; 60495,604962$ mandibles with dp2-dp4.

Clarendon Fauna, Don ley Co., TX. MacAdams Quarry: F:AM 60414, $60416,60430,60467$ skulls with adult dentitions; 60415 skul1 with $R$ \& L DP2-M2; 60419, 60422, 60434, 60490, $4 \mathrm{R}$ maxillae with P2-M3;

$60423 \mathrm{R}$ maxilla with P2-M2; 60417, 60418, 60469, $1141744 \mathrm{~L}$ maxillae with P2-M3; 114175 L maxilla with P2-M2; 60412 L maxi11a with P3-M1; 60427 L maxilla with P3-M2; 60429 assoc. $R$ maxilla with P2-M3, $R$ mandible with $p 3-m 2$, and $L$ mandible with $i 1, p 2-m 3 ; 114177$ R mandible 
with $\mathrm{p3-m2;} 114178 \mathrm{R}$ mandible with $\mathrm{dp2}-\mathrm{dp} 4 ; 60433 \mathrm{~L}$ mandible with $\mathrm{p} 2-$ $\mathrm{m} 3 ; 60432 \mathrm{~L}$ mandible with dp2-m1. The F:AM, PPM, UCMP, TMM and other institutions have additional samples of $\mathrm{Cal}$. regulus from the Clarendon Fauna.

Lapara Creek Fauna. See Forsten (1975, pp. 44, 46).

Revised Diagnosis. Very small, hypsodont equid with toothrow lengths generally between 75 and $85 \mathrm{~mm}$; unworn M12 MSCH about $46 \mathrm{~mm}$; very short, broad rostrum; DPOF long, shallow, unrimmed and runs anteriorly to connect with buccinator fossa. Cheektooth enamel morphology more simple than Cal. placidus or Cal. proplacidus. Metaconid of p2 very reduced or absent. Linguaflexid very shallow, metaconid and metastylid broadly confluent on molars after slight wear.

Description. The facial region of $\underline{\mathrm{Cal}}$. regulus is well preserved on a few specimens from the type region (e.g. F:AM 60430, F:AM 60417). The DPOF is a long, narrow, shallow depression (Fig. 49); it is shallower and less distinctly rimmed than in Cal. placidus. The DPOF runs anterodorsally to the IOF to become confluent with the buccinator fossa (Fig. 49). The two are separated only by a low ridge dorsal and just anterior to the P2. The nasal notch is not retracted further than the anterior portion of the P2. The postcanine diastema is very short (about $27 \mathrm{~mm}, \mathrm{Fig}$. 49). The muzzle (measured across the $13 \mathrm{~s}$ ) is relatively broader than in any other known species of the subgenus, about $60 \%$ of the UTRL. In the topotypic sample, the DP1 is vestigial or absent in adults. 
The cheekteeth of $\underline{\mathrm{Cal}}$. regulus are easily distinguished from Cal. proplacidus and Cal. placidus both on the basis of smaller size (Tables 32, 33) and morphology. Dental differences with Cal. elachistus n. sp. are outlined below. As noted by Johnston (1937), the upper cheekteeth have extremely simple fossettes, generally lacking all plications, except in early wear-stages, when several very shallow folds may be present. The pli caballin is usually absent on molars, small or absent on premolars. The elongated protocone becomes broadly connected with the protoselene after relatively little wear; as noted by forsten (1975) it is oriented anterolabial-posterolingually on both molars and premolars, and does not connect with the hypocone. The hypoconal groove closes to form a lake and subsequently disappears with wear more rapidly than in Cal. placidus. The styles are relatively very delicate, especially on molars, and the metastyle is usually absent. Unworn or slightly worn MSCHs are slightly less than in Cal. placidus, about $31 \mathrm{~mm}$ for P2s, $42 \mathrm{~mm}$ for P34s, and $46 \mathrm{~mm}$ for M12s. Upper deciduous premolars as described by Quinn (1955, p. 31).

Lower cheekteeth of Cal. regulus (Table 33, Fig. 490), as is typical in Calippus, undergo drastic enamel morphology changes through ontogeny. In early wear-stages, the metastylids are relatively large and elongated, the linguaflexids moderately well developed, the ectoflexids shallow, and one or two pli entoflexids are generally present (these are better developed and more persistent in premolars). The protostylid is small but distictive. With wear, the metastylid shortens, the linguaflexid becomes very shallow 
Figure 49. Cal. (Calippus) regulus from MacAdams Quarry, Donley County, Texas (Clarendon Fauna). A. F:AM 60430, left lateral view of sku17. B. F:AM 114176, lateral view of left mandible and symphysis. C. F:AM 60430, occlusal view of left P2-M3. D. F:AM 114176, occlusal view of right and left i1-13, $c$ and left p2-m3. 

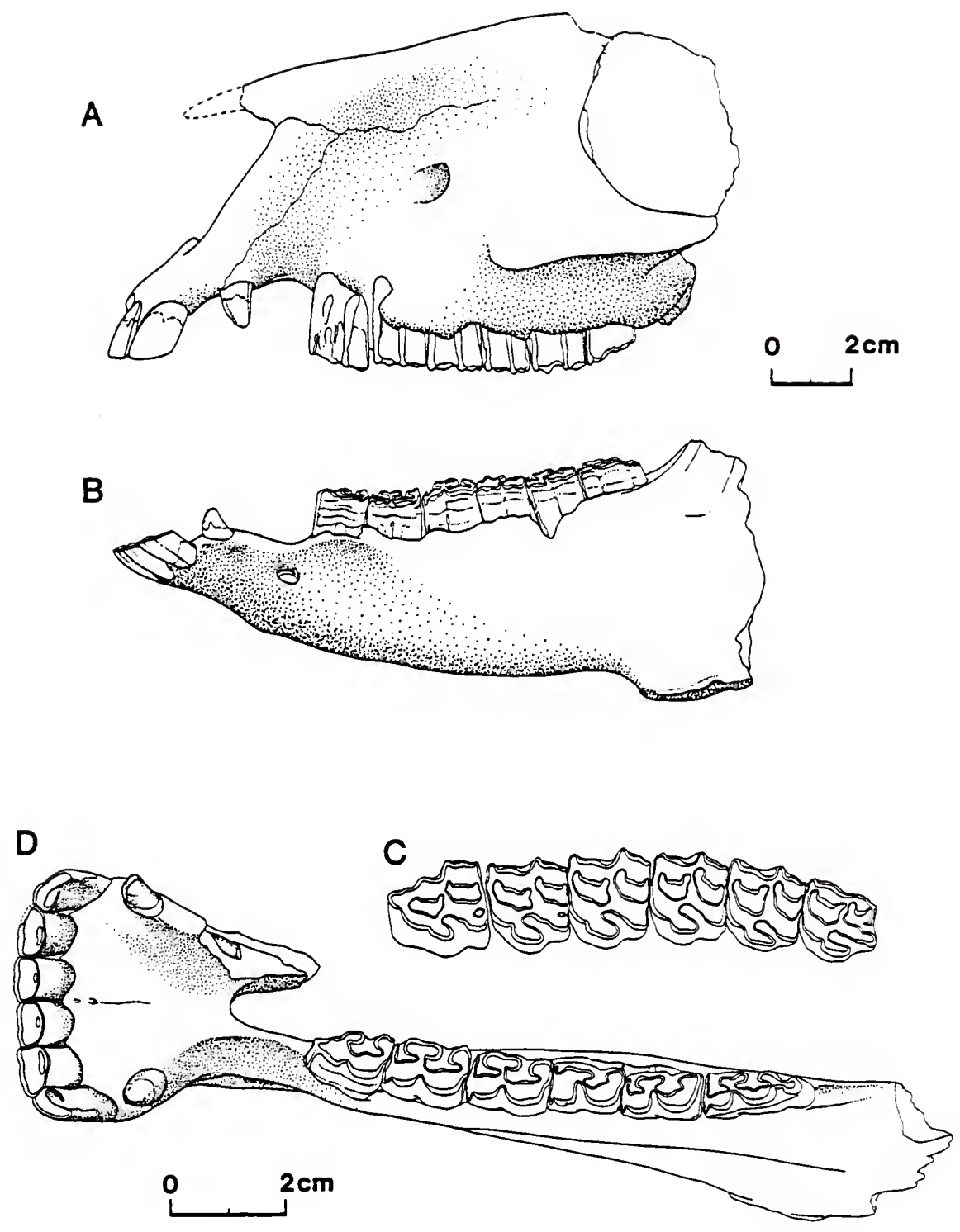
Table 32. Standard univariate statistics for upper cheekteeth of Calippus regulus from the Clarendon Fauna, Donley County Texas (middle cTarendonian) and from the Lapara Creek Fauna, Bee and Live oak Counties, Texas (early Clarendonian), and of Calippus elachistus n. sp. from the Archer Fauna, Alachua County, Florida Tlatest clarendonian - early Hemphilitian). Format as in Table 2.

\begin{tabular}{|c|c|c|c|}
\hline SPECIES & C. regulus & c. regulus & C. elachistus \\
\hline \multirow[t]{2}{*}{ FAUNA } & CLARENDON & LAPARA CREEK & ARCHER \\
\hline & \multicolumn{3}{|c|}{ P2 } \\
\hline APL & $\begin{array}{l}17.1,0.75,25 \\
15.8-18.7,4.38\end{array}$ & $\begin{array}{l}16.1,1.08,5 \\
14.5-17.4,6.67\end{array}$ & $\begin{array}{l}14.5,1.12,4 \\
13.1-15.8,7.70\end{array}$ \\
\hline BAPL & $\begin{array}{l}14.6,0.83,9 \\
12.9-15.7,5.72\end{array}$ & $\begin{array}{l}14.1,0.85,5 \\
12.8-14.8,6.00\end{array}$ & $\begin{array}{l}10.9,0.36,4 \\
10.1-11.5,6.73\end{array}$ \\
\hline TRW & $\begin{array}{l}13.1,0.52,25 \\
12.2-14.3,4.00\end{array}$ & $\begin{array}{l}12.6,0.59,5 \\
11.9-13.5,4.70\end{array}$ & $\begin{array}{l}13.1,0.36,4 \\
12.7-13.7,2.77\end{array}$ \\
\hline PRL & $\begin{array}{l}3.9,0.44,25 \\
3.3-4.8,11.19\end{array}$ & $\begin{array}{l}3.8,0.37,5 \\
3.2-4.1,9.70\end{array}$ & $\begin{array}{l}3.9,0.47,4 \\
3.4-4.5,11.88\end{array}$ \\
\hline \multirow[t]{2}{*}{ PRW } & $\begin{array}{l}3.2,0.33,25 \\
2.6-3.9,10.37\end{array}$ & $\begin{array}{l}3.1,0.30,5 \\
2.9-3.6,9.45\end{array}$ & $\begin{array}{l}2.9,0.29,4 \\
2.5-3.3,9.80\end{array}$ \\
\hline & \multicolumn{3}{|c|}{ P34 } \\
\hline APL & $\begin{array}{l}14.7,0.99,44 \\
12.6-16.7,6.58\end{array}$ & $\begin{array}{l}13.3,0.39,6 \\
12.8-13.8,2.91\end{array}$ & $\begin{array}{l}13.4,0.31,6 \\
13.0-13.8,2.28\end{array}$ \\
\hline BAPL & $\begin{array}{l}12.3,0.48,7 \\
11.6-12.8,3.85\end{array}$ & $\begin{array}{l}11.8,0.92,6 \\
10.7-13.1,7.80\end{array}$ & $\begin{array}{l}9.9,0.43,5 \\
9.3-10.5,4.38\end{array}$ \\
\hline TRW & $\begin{array}{l}14.7,0.84,43 \\
12.0-16.1,5.72\end{array}$ & $\begin{array}{l}14.4,0.55,7 \\
13.8-15.4,3.83\end{array}$ & $\begin{array}{l}14.3,0.48,6 \\
13.7-14.9,3.32\end{array}$ \\
\hline PRL & $\begin{array}{l}5.3,0.42,45 \\
4.1-6.5,7.94\end{array}$ & $\begin{array}{l}5.0,0.29,7 \\
4.5-5.4,5.89\end{array}$ & $\begin{array}{l}4.9,0.60,6 \\
4.1-5.7,12.24\end{array}$ \\
\hline PRW & $\begin{array}{l}3.3,0.26,44 \\
2.6-3.7,7.99\end{array}$ & $\begin{array}{l}3.2,0.13,7 \\
3.0-3.4,4.03\end{array}$ & $\begin{array}{l}3.2,0.27,6 \\
2.8-3.5,8.63\end{array}$ \\
\hline
\end{tabular}


Table 32--continued

\begin{tabular}{cccc}
\multicolumn{3}{c}{$M 12$} \\
APL & $13.9,1.21,64$ & $14.2,1.46,21$ & $12.9,0.89,7$ \\
& $11.1-16.3,8.69$ & $11.7-16.9,10.28$ & $11.8-14.0,6.91$ \\
BAPL & $10.9,0.48,26$ & $10.9,0.42,21$ & $9.1,0.30,7$ \\
& $9.9-11.8,4.40$ & $9.8-11.8,3.88$ & $8.7-9.5,3.33$ \\
TRW & $13.6,0.88,64$ & $12.8,0.65,22$ & $12.2,0.89,8$ \\
& $10.6-15.5,6.44$ & $11.3-14.1,5.06$ & $11.1-13.9,7.28$ \\
PRL & $5.5,0.42,64$ & $5.2,0.40,22$ & $4.9,0.61,6$ \\
& $4.6-6.3,7.61$ & $4.2-5.8,7.62$ & $3.9-5.6,12.58$ \\
\multirow{2}{*}{ PRW } & $3.1,0.28,64$ & $2.9,0.29,22$ & $2.7,0.21,6$ \\
& $2.4-3.7,9.18$ & $2.5-3.4,10.28$ & $2.4-2.9,7.83$
\end{tabular}


Table 33. Standard univariate statistics for lower cheekteeth of Calippus regulus from the Clarendon Fauna, Donley County, Texas (middle (Tarendonian) and from the Lapara Creek Fauna, Bee and Live Oak Counties, Texas (early Clarendonian), and of Calippus elachistus n. sp. from the Archer Fauna, Alachua and Polk Counties, FTorida (latest Clarendonian - early Hemphillian). Format as in Table 2.

\begin{tabular}{|c|c|c|c|}
\hline SPECIES & c. regulus & c. regulus & c. elachistus \\
\hline \multirow[t]{2}{*}{ FAUNA } & CLARENDON & LAPARA CREEK & ARCHER \\
\hline & & p2 & \\
\hline apl & $\begin{array}{l}14.1,0.61,10 \\
13.2-14.8,4.35\end{array}$ & $\begin{array}{l}13.8,0.47,10 \\
12.8-14.2,3.39\end{array}$ & $\begin{array}{l}13.5,0.83,4 \\
12.6-14.5,6.14\end{array}$ \\
\hline bapl & $\begin{array}{l}11.9,0.21,3 \\
11.7-12.1,1.75\end{array}$ & $\begin{array}{l}11.7,0.66,6 \\
10.7-12.4,5.66\end{array}$ & $\begin{array}{l}9.7,0.81,4 \\
9.2-10.9,8.29\end{array}$ \\
\hline atw & $\begin{array}{l}6.3,0.45,10 \\
5.6-6.9,7.19\end{array}$ & $\begin{array}{l}6.0,0.14,10 \\
5.8-6.3,2.28\end{array}$ & $\begin{array}{l}6.2,0.54,4 \\
5.8-7.0,8.74\end{array}$ \\
\hline ptw & $\begin{array}{l}8.1,0.51,10 \\
7.5-9.2,6.27\end{array}$ & $\begin{array}{l}7.6,0.34,10 \\
7.2-8.1,4.44\end{array}$ & $\begin{array}{l}7.7,0.21,4 \\
7.5-8.0,2.67\end{array}$ \\
\hline $\mathrm{mml}$ & $\begin{array}{l}4.5,0.53,10 \\
3.3-5.1,11.71\end{array}$ & $\begin{array}{l}4.2,0.71,10 \\
3.4-5.6,16.89\end{array}$ & $\begin{array}{l}5.8,0.08,4 \\
5.7-5.9,1.41\end{array}$ \\
\hline \multirow[t]{2}{*}{ ent 1} & $\begin{array}{l}6.4,0.56,10 \\
5.1-7.3,8.89\end{array}$ & $\begin{array}{l}6.0,0.49,10 \\
5.0-6.7,8.13\end{array}$ & $\begin{array}{l}6.3,0.36,4 \\
6.0-6.8,5.73\end{array}$ \\
\hline & & p34 & \\
\hline apl & $\begin{array}{l}14.9,0.86,25 \\
12.9-16.7,5.89\end{array}$ & $\begin{array}{l}14.3,0.74,16 \\
12.9-15.4,5.18\end{array}$ & $\begin{array}{l}13.9,1.08,16 \\
11.7-15.6,7.81\end{array}$ \\
\hline bapl & $\begin{array}{l}12.0,0.55,10 \\
11.0-12.7,4.56\end{array}$ & $\begin{array}{l}11.6,0.62,10 \\
10.5-12.4,5.30\end{array}$ & $\begin{array}{l}9.9,0.43,13 \\
8.9-10.5,4.33\end{array}$ \\
\hline atw & $\begin{array}{l}8.5,0.62,25 \\
7.2-10.2,7.31\end{array}$ & $\begin{array}{l}8.2,0.70,17 \\
7.0-9.3,8.57\end{array}$ & $\begin{array}{l}8.3,0.47,16 \\
7.4-9.2,5.70\end{array}$ \\
\hline ptw & $\begin{array}{l}8.6,0.70,25 \\
7.2-9.5,8.20\end{array}$ & $\begin{array}{l}8.4,0.68,17 \\
7.0-9.5,8.09\end{array}$ & $\begin{array}{l}8.4,0.36,16 \\
7.5-8.9,4.26\end{array}$ \\
\hline $\mathrm{mml}$ & $\begin{array}{l}6.8,0.42,25 \\
5.8-7.6,6.09\end{array}$ & $\begin{array}{l}6.6,0.48,17 \\
5.7-7.4,7.23\end{array}$ & $\begin{array}{l}7.4,0.45,16 \\
6.5-8.0,6.15\end{array}$ \\
\hline entr & $\begin{array}{l}6.6,0.57,25 \\
5.1-7.8,8.61\end{array}$ & $\begin{array}{l}6.4,0.81,17 \\
4.9-7.6,12.58\end{array}$ & $\begin{array}{l}7.1,0.65,16 \\
5.8-8.3,9.15\end{array}$ \\
\hline
\end{tabular}


Table 33--continued

$$
\text { m12 }
$$

$\begin{array}{llll}\text { ap1 } & 14.5,1.30,21 & 14.1,1.41,20 & 13.5,1.26,13 \\ & 12.0-17.2,8.97 & 11.1-16.1,9.97 & 11.5-15.0,9.37 \\ \text { bap1 } & 11.4,0.67,5 & 11.2,0.58,14 & 9.2,0.50,10 \\ & 10.7-12.4,5.85 & 10.1-12.5,5.15 & 8.4-10.3,5.45 \\ \text { atw } & 6.9,0.48,21 & 6.9,0.73,20 & 7.1,0.45,13 \\ & 5.9-7.8,6.91 & 6.0-9.5,10.47 & 6.5-7.7,6.27 \\ \text { ptw } & 5.9,0.43,21 & 6.1,0.75,20 & 6.7,0.46,13 \\ & 5.1-6.7,7.19 & 5.1-8.6,12.25 & 6.2-7.6,6.88 \\ \text { mm1 } & 5.8,0.53,21 & 5.7,0.52,20 & 6.1,0.51,14 \\ & 5.2-7.3,9.11 & 4.9-6.6,9.12 & 5.2-7.1,8.33 \\ \text { ent1 } & 4.9,0.81,21 & 4.9,1.05,20 & 6.0,0.96,13 \\ & 4.0-6.5,16.45 & 2.5-7.1,21.38 & 3.9-7.1,15.82\end{array}$


allowing the metaconid and metastylid to become broadly confluent, and the metaflexid quickly retreats. The se changes occur very rapidly, so that a tooth takes on the appearance of what in other protohippines is present in late wear-stages, but after on ly a third of the original crown is worn off. The metaconid of the p2 is very reduced or absent (Fig. 49D). Lower deciduous premolars have larger protostylids, and persistently larger metastylids that are about equal in size to the metaconids on the dp34. The dp2, un1ike the $p 2$, has a well developed metaconid that is only slightly smaller than the metastylid. The ectoflexid is shallow on the dp2, not penetrating the isthmus; but is deeper on the dp34. This, coupled with a deep linguaflexid, keep the metaconid and metastylid well separated (e.g. F:AM 60432).

Discussion. Ever since Johnston's (1937) description, Cal. regulus has generally been used as the model when comparing other genera with Calippus (e.g. Webb, 1969a, p. 134). This naturally resulted from it being well represented in many museum collections, and the continuing confusion surrounding the genotypic species Cal. placidus. Calippus regulus, however, displays a combination of primitive and derived features that are not representitive of the genus or subgenus as a whole. These include its ultrasimple enamel morphology, reduced styles, poorly developed lingual flexids and extremely small size.

The earliest records of $\underline{\mathrm{Cal}}$. regulus are from the late Barstovian of Colorado and Nebraska. A similar, but notably even smaller population is recognized from the late Barstovian and early 
Clarendonian of Florida, and is described below as Calippus sp. The early, northern Great Plains populations are slightly larger than the topotypic sample, and retain some more primitive features (e.g. a larger DP1). Calippus regulus was evidently very rare in the northern Great Plains during the late Barstovian. Of the nineteen quarries listed by Skinner and Johnson (1984) from the Burge Member, specimens referable to $\mathrm{Cal}$. regulus were found in only three, and in relatively few numbers. During the early half of the Clarendonian, Cal. regulus is common in the southern Great Plains (Beaver and Clarendon Faunas), and the Texas Gulf Coastal Plain, but is no longer present in more northern faunas. Previous biogeographic interpretations considered $\underline{\mathrm{Cal}} \underline{\mathrm{placidus}}$ and $\underline{\mathrm{Cal}}$. regulus as northern and southern counterparts, and for them to have been allopatric. Webb (1969a) even discussed the possibility that they were clinal variants of a single species. However, the recognition of Cal. placidus in the Clarendon and Lapara Creek Faunas disproves this hypothesis. The interval during which $\mathrm{Cal}$. regulus is recognized (about 13 to $10 \mathrm{ma}$ ) was for most equid genera a period of speciation and relatively rapid morphological evolution. Calippus regulus instead generally displays morphologic stasis through this period. In part, this can be attributed to its already having attained a relatively high degree of hypsodonty $(H I=4.2)$ in the early Clarendonian, well in advance of its larger contemporaries (Table 26).

Calippus regulus from the Texas Gulf Coastal Plain was described by Quinn (1955) as a new species, Cal. anatinus. I follow Forsten 
Figure 50. Histograms of basal crown lengths (BAPL) of combined samples of $P 3 S$ and $P 4 S(A-D)$, and of M1S and M2S (E-H) for four populations of Cal. (Calippus). A, E. Cal. regulus, Lapara Creek Fauna, Texas GuTf Coastal PTain. B, F. Cal. regulus, Clarendon Fauna, Texas Panhandle. C, G. Calippus sp., Tower Bone Valley Formation, Central Florida. D, H. CaT. elachistus n. sp., Love Site, Central Florida. The two Texas poputations of CaT. regulus are of approximately the same size, but are much larger than the samples from Florida. Each square represents one individual. 
H $\mathrm{H}$ 月且
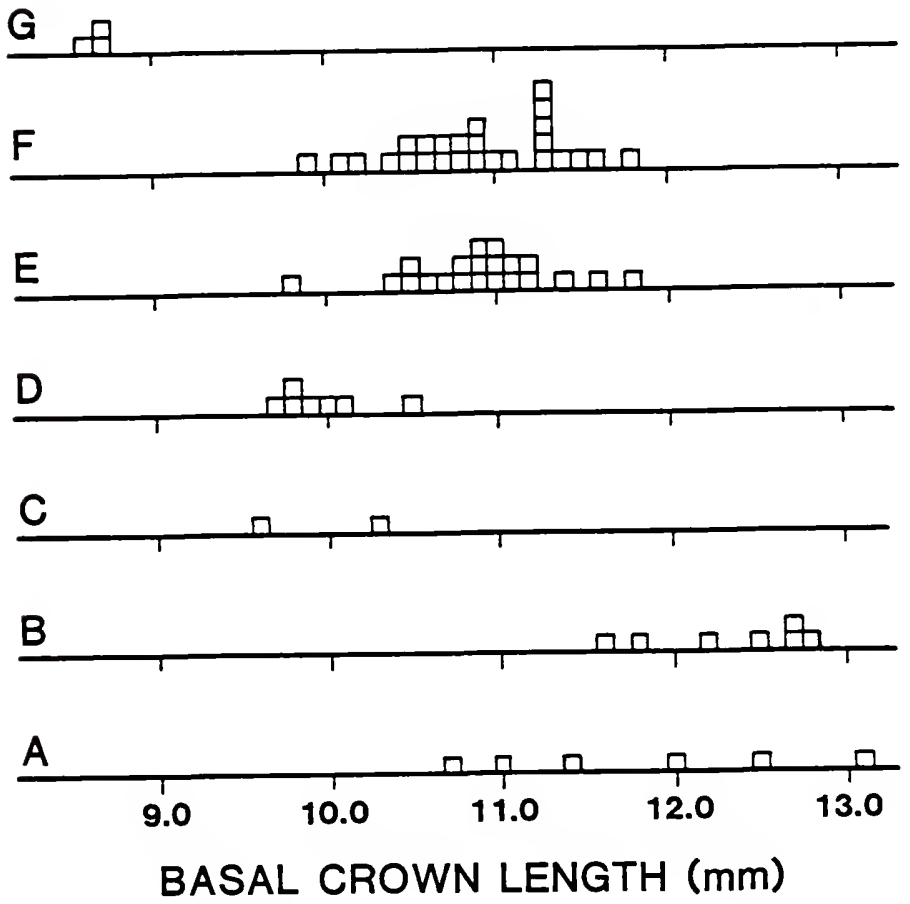
Table 34. Measurements of upper and lower cheekteeth of Calippus sp. from lower horizons of the Bone Valley Formation, Polk and Hillsborough Counties, Florida. Specimens from three superposed faunas: A, Bradley Fauna, late Barstovian; B, lower Agricola Fauna, latest Barstovian; and $C$, upper Agricola Fauna, early Clarendonian. Format as in Table 31.

TOOTHSIDEFAUNA APL TRW PRL PRW BAPL MSCH

$\begin{array}{lcllrrrrrl}\text { UF } 23979 & \text { P34 } & \text { R } & \text { A } & 12.8 & 13.4 & 4.3 & 3.0 & 9.6 & 20.3 \\ \text { UF } 61324 & \text { M12 } & \text { L } & \text { A } & 9.8 & -- & 4.3 & 2.5 & -- & --- \\ \text { UF 23983 } & \text { M12 } & \text { L } & \text { A } & 13.0 & -- & 5.0 & 2.5 & -- & \text { a 30 } \\ \text { UF 50756 } & \text { M12 } & \text { L } & \text { A } & 11.9 & 11.9 & 4.9 & 2.7 & 8.6 & 25.0 \\ \text { UF 61323 } & \text { M3 } & \text { R } & \text { A } & 11.2 & 9.2 & 4.3 & 2.2 & 10.8 & 19.6 \\ \text { UF 28421 } & \text { P2 } & \text { R } & \text { B } & 14.3 & 11.1 & 3.7 & 2.7 & 12.9 & 17.1 \\ \text { UF 28549 } & \text { P2 } & \text { L } & \text { C } & 16.0 & 13.6 & 4.1 & 3.4 & 13.4 & 17.2 \\ \text { UF 93201 } & \text { P34 } & \text { R } & \text { C } & 14.0 & 13.9 & 5.4 & 3.0 & 10.3 & 23.2 \\ \text { UF 28542 } & \text { M12 } & \text { L } & \text { C } & 10.1 & 11.0 & 4.2 & 2.8 & 8.6 & 10.4 \\ \text { UF 28680 } & \text { M12 } & \text { L } & \text { C } & 12.4 & 11.7 & 5.5 & 2.5 & 8.2 & 29.3 \\ \text { UF 93202 } & \text { M3 } & \text { R } & \text { C } & 12.1 & 10.3 & 5.0 & 2.0 & 12.8 & 22.3 \\ \text { UF 68993 } & \text { M12 } & \text { L } & ? & -- & 10.5 & 4.5 & 2.2 & -- & \text { a 18 }\end{array}$

apl atw ptw mmi entr bapl mech

$\begin{array}{llllllllllc}\text { UF } 93210 & \text { p2 } & \text { R } & \text { A? } & 12.9 & 5.9 & 7.8 & 5.4 & 6.3 & 9.8 & 17.2 \\ \text { UF } 61325 & \text { p34 } & \text { L } & \text { A } & 13.1 & 7.4 & 7.8 & 5.6 & 6.3 & -- & -- \\ \text { UF } 61343 & \text { p34 } & \text { L } & \text { A } & 12.6 & 7.0 & 7.3 & 6.2 & 6.3 & -- & -- \\ \text { UF } 23955 & \text { m12 } & \text { L } & \text { A } & 13.9 & 5.9 & 6.1 & 5.7 & 6.4 & -- & -- \\ \text { UF } 61505 & \text { p34 } & \text { L } & \text { C? } & 12.5 & 7.4 & 7.6 & 6.0 & 6.8 & 9.9 & 26.2\end{array}$


(1975) in considering Cal. anatinus a junior synonym of Cal. regulus. The differences in size (Fig. 50; Tables 32, 33) and morphology of the Lapara Creek and Clarendon samples of this tiny horse are inconsequential. No available specimens from Florida appear to be referable to this species. Instead, there are at least two different varieties of very small Calippus from Florida, as described below.

$$
\text { Ca1. (Calippus) sp. }
$$

Referred specimens. Bradley Fauna, Bone Valley Region. Kingsford Mine: UF 61323 R M3; 61324 L M12; 61325, 61343 2 L p34. Nichols Mine: UF 23960, 23983, 507563 M12; 23979 R P34.

Lower Bone Valley Formation (? Bradley Fauna), Four Corners Mine: UF 93210 R p2.

Agrico Fauna, Bone Valley Region. Red Zone, Phosphoria Mine: UF 28421 R P2; 28419, 284202 L M12; 28422 R M3; 28477 L p34. Gray Zone, Phosphoria Mine: UF 28549 L P2; 28542, 286802 L M12; 28540 R M3; 28541 L M3; 28543, 285442 L m12. Hookers Prairie Mine, Polk Co., FL: UF 93201 R P34; 93202 R M3.

Ashville Site: UF/FGS V-60086 R M12; -6087 R M3; -6110 L M12; $-6111 L M 3$.

Description and discussion. A limited sample of isolated teeth from the Bradley and Agricola Faunas (Waldrop and Webb, in prep; Webb and Hulbert, 1986) of the lower Bone Valley Formation are clearly referable to $\underline{\mathrm{Cal}}$. (Calippus). In enamel morphology they are extremely similar to $\underline{\mathrm{Cal}}$. regulus, in particular the very simple 
fossettes, reduced styles, and persistently isolated hypoconal lake in upper cheekteeth (Figs. 45D-45F), and well developed protostylids, large pli entoflexids in early wear-stages, relatively deep ectoflexids and shallow linguaflexids in lower cheekteeth (Fig. 45C). They differ from Cal. regulus in their smaller size (Table 34; Fig. 50), relatively well developed p2 metaconid (UF 93210), and probably shorter unworn crown heights. Maximum unworn M12 MSCH for these specimens is estimated to have been no more than $40 \mathrm{~mm}$, although the limited number of unworn or slightly worn teeth does not allow this parameter to be accurately predicted. Cal. (Calippus) sp. is of similar size as younger samples from Florida (Cal. elachistus, Table 34 and Fig. 50), but differs considerably from them in ename 1 mor phology.

\section{Cal. (Calippus) elachistus new species}

Calippus cf. regulus, WEBB et a1., 1981, p. 527.

Type specimens. Holotype, UF 32139, $R$ mandibular fragment with m2-m3. Paratypes, UF 53431 R P2; 53448 L M2; 53585 R p34. A11 collected by FSM personnel between 1974 and 1981. Type locality. Love Site, $1.5 \mathrm{~km} \mathrm{~N}$ of Archer, Alachua Co., Florida.

Stratigraphic occurrence and age of type locality. Fluvial sediments of the Alachua Formation; very late Clarendonian, about 9.0 ma. 
Topotypic sample. UF 53618-53620 3 R DP2; 68839 R DP34; $96323 \mathrm{~L}$ DP34; 53430 R P2; 53432-53434 3 L P2; 53435-53436, 53578, 535804 R P34; 53437-53441, 53598 6 L P34; 53576-53577, 535793 R M12;

$53442-53445,53447,535996$ L M12; 53450, 53616-53617, 535754 L M3;

53601 assoc. L m1-m2; 59161, 92951-92952 3 R dp34; 92953 L dp34;

53581-53584, 969795 R p2; 64527, 965652 L p2; 53586-53591, 68951-68952 8 R p34; 53593-53597, 59163-59164, 68954-68955 9 L p34; $53603-53610,59166,68953,6895612$ R m12; 59172, $689582 \mathrm{~L}$ m12; 53611-53614 4 R m3.

Etymology. elachistos, Greek for smallest or least. Distribution. Very late Clarendonian through early Hemphillian (about 6.2 to $9.0 \mathrm{ma}$ ) of central Florida.

Referred specimens. Haile 19A: UF 47320 R M12; $47325 \mathrm{~L} \mathrm{~m} 3$. McGehee Farm: UF 45640 R M12; 45641 L M3; 18471 R p34; 17313 R $\mathrm{m} 12 ; 7238 \mathrm{R} \mathrm{m} 3$.

Nichols Mine: UF 92999 L M3; 23957 L m12.

Manatee Dam Site: UF 11932 L M3; 95366 L m12.

Diagnosis. 0cclusal dimensions of cheekteeth much smaller than all other species of Calippus, but Cal. regulus; slightly smaller in early to middle wear-stages and significantly smaller basal crown lengths than $\mathrm{Cal}$. regulus. Protostylid reduced on $\mathrm{p} 3-\mathrm{m} 3$. Metaflexid and linguaflexid better developed and more persistent with wear than in Cal. regulus. Metastylid and hypoconulid not extremely elongated in early wear-stages on m1-m3. Ectoflexid reduced in depth on permanent and deciduous cheekteeth, generally not penetrating isthmus, except in heavily worn molars. Pli entoflexid absent on 
molars. Fossettes simple, without plications except in earliest wear-stages. Styles weak, but slightly stronger than those of $\mathrm{Cal}$. regulus. Pli caballin absent or vestigial. Hypoconal groove closed with onset of wear, persists as a lake until middle wear-stages on premolars; disappears in very early wear-stages of molars.

Description. The known sample of Cal. elachistus is almost exclusively isolated cheekteeth, and its facial and incisor morphology are therefore unknown. The holotype, UF 32139, consists of a mandibular fragment with a moderately worn $\mathrm{m} 2$ and slightly worn $\mathrm{m} 3$ (Figs. 51K, 52; Table 35). No distinctive portion of the ramus, e.g. its ventral border, remains with the specimen. As lower dental morphology changes so drastically with wear in Calippus, the holotype is best compared with similarly worn specimens of other species (e.g. F:AM 114176, Cal. reguluS). In UF 32139, the ectoflexid does not penetrate the isthmus on either the $\mathrm{m} 2$ or $\mathrm{m} 3$ (as it does in F:AM 114176). The rounded metastylids are well separated from the metaconids, however, by relatively deep, V-shaped 1 inguaflexids and anterolingual projections of the entoflexid (Fig. 51K). The labial borders of the metaflexid and entoflexid are relatively flat, with little or no tendency to be curved. The protostylids are small, and do not extend labially beyond the protoconid.

Based on the topotypic sample, the upper cheekteeth of Cal. elachistus resemble those of Cal. regulus in their small size (Figs. 46, 47, 50; Table 32) and simple fossettes. Upper premolars have moderately well developed parastyles and mesostyles, and some have 


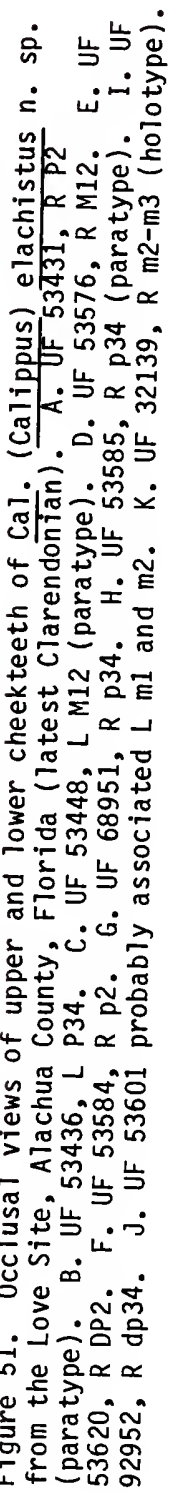



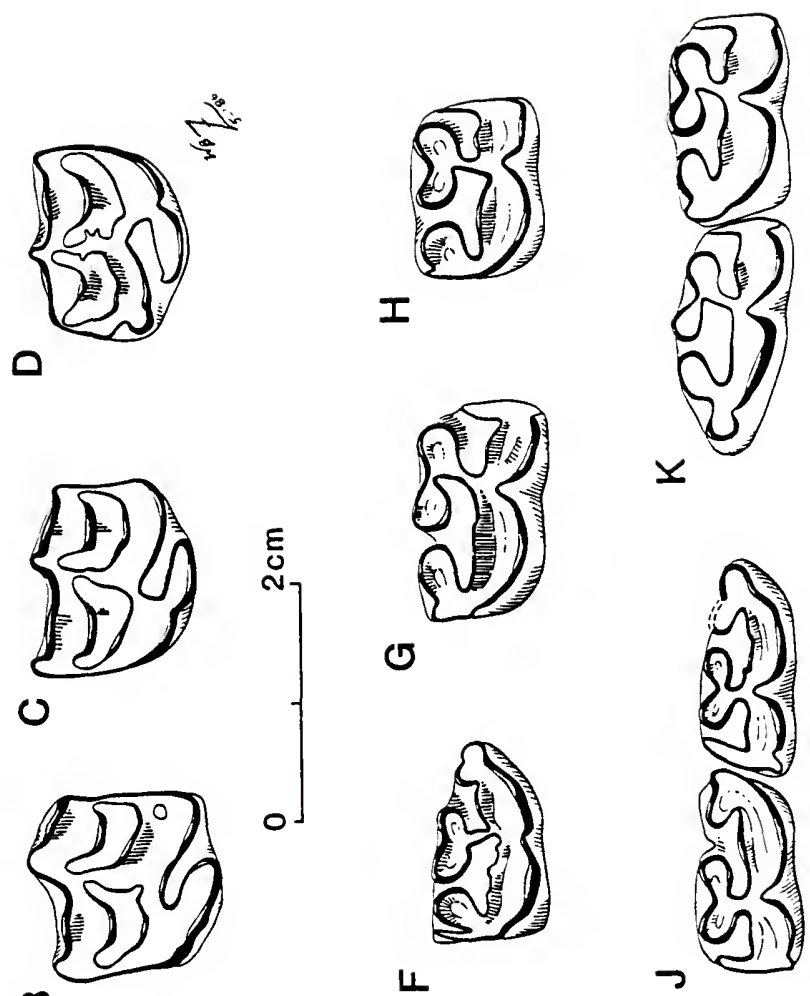
m
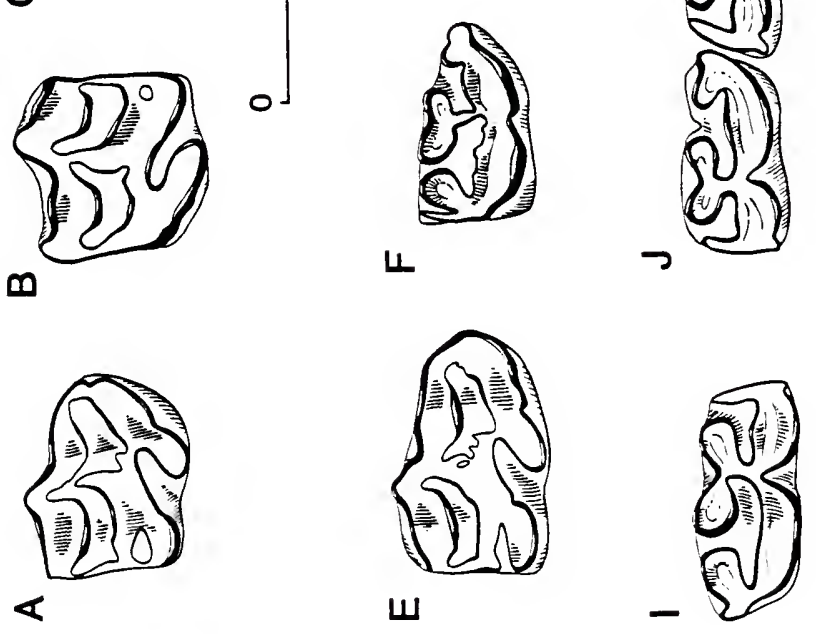


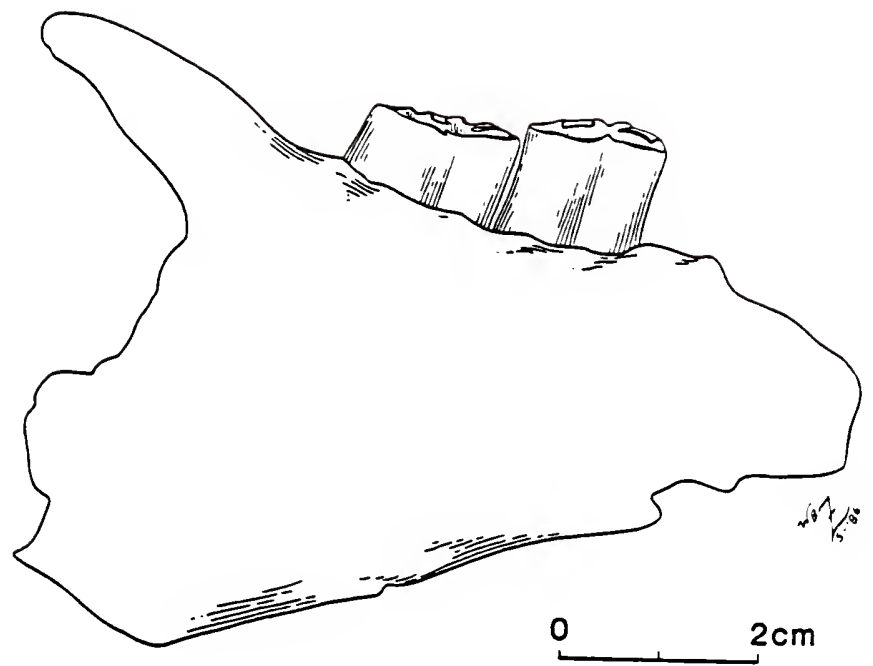

Figure 52. Lateral view of UF 32139, right mandibular fragment. Holotype of Cal. (Calippus) elachistus n. sp.; from the Love Site, Alachua County, Florida. See Fig. 5IK for occlusal view of m2-m3. 
A

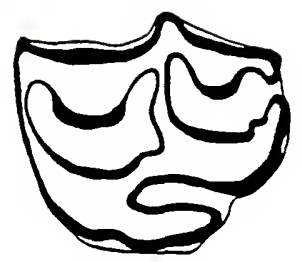

B

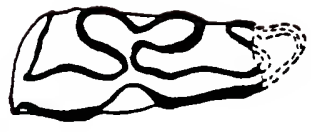

$2 \mathrm{~cm}$

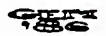

Figure 53. Occlusal views of cheekteeth of Cal. (Calippus) elachistus $n$. sp. from the Manatee County Dam Site, Florida (late early Hemphilitian, see Webb and Tessman, 1968). A. UF 11932, L M3, sectioned about $10 \mathrm{~mm}$ below unworn occlusal surface. B. UF 95366, partial $L \mathrm{~m} 12$. These are the youngest known specimens of the subgenus Cal. (Calippus). 


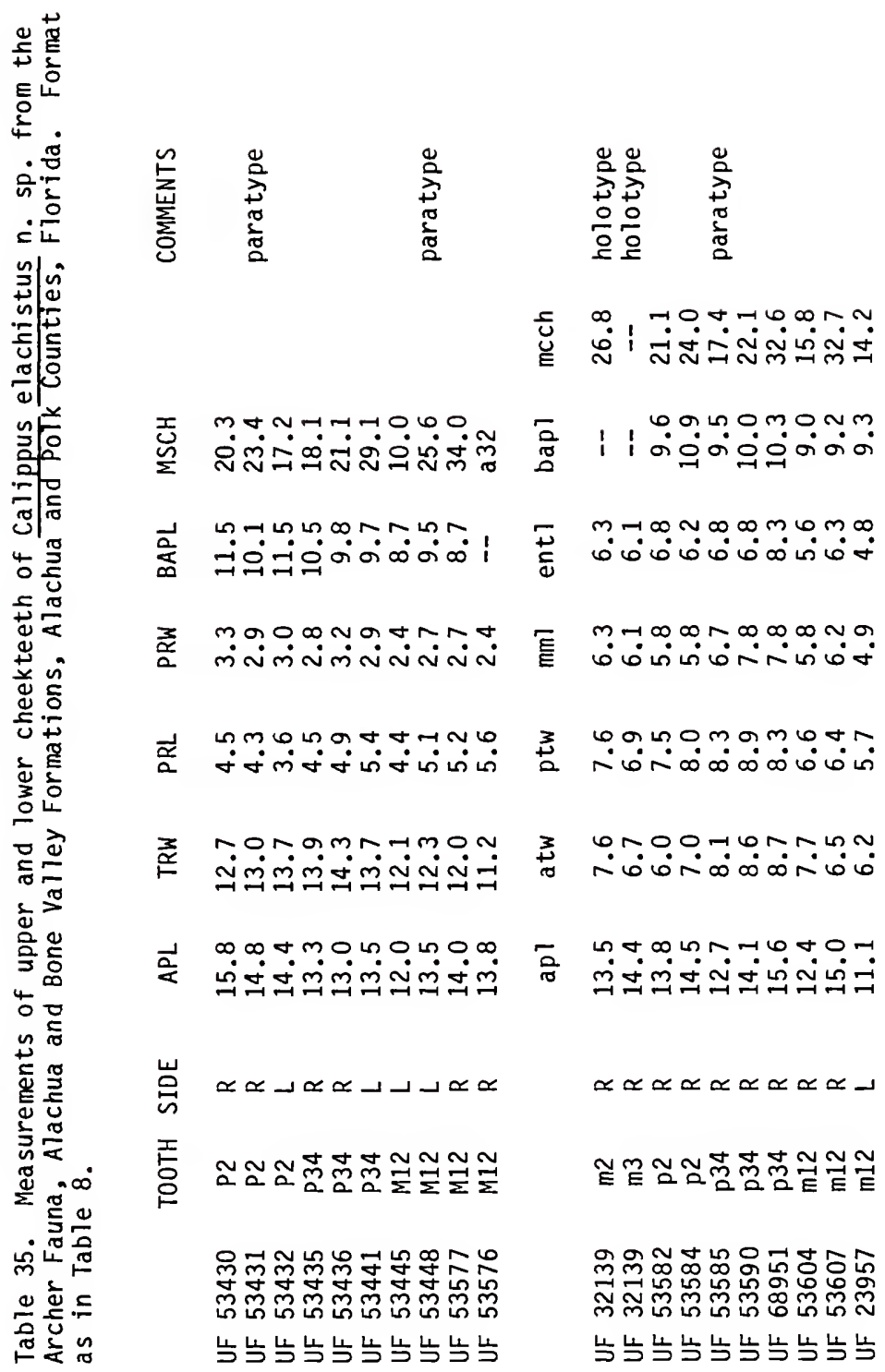


very slight metastyles. In this, they more closely resemble Cal. placidus than Cal. regulus. A weak pli caballin may be present, but only in early wear-stages. The protocone varies in shape from oval to very elongated (Figs. 51A-51D, 53A), and is broadly connected to the protoselene. The preprotoconal groove is shallow or absent. The hypoconal groove is open in earliest wear-stages, usually becomes an isolated lake rather quickly, and disappears during late wear-stages. For example, UF 53441 retains an open hypoconal groove with a MSCH of about $29 \mathrm{~mm}$, the heavily worn UF 53435 (MSCH=17.9 mm) still retains its hypoconal lake, al though UF 53439 (MSCH=19.0 mm) does not. Neither a pli protoloph nor pli hypostyle are observed in even the least worn P34. In early wear-stages, the posterior half of the prefossette may have one to three shallow plications, and a moderately developed prefossette loop can be present. The anterior half of the postfossette bears at most a single, shallow plication. With moderate wear (i.e. MSCH of $25 \mathrm{~mm}$ or less), a11 plications are obliterated. In the $P 2$, the anterostyle is generally not well separated from the ectoloph, and is not well developed. Three DP2s from the Love site are referred to Cal. elachistus rather than the similarly sized Pseud. skinneri (Webb and Hulbert, 1986). These DP2s have poorly developed anterostyles (Fig. 51E), while a DP2 referred to Pseud. skinneri (UF 90263) has a well developed anterostyle. The DP2 fossette borders are more complexly plicated than their permanent counterparts (Fig. 51E), and the hypoconal groove persists as a lake until late wear. A11 three DP2s have appresion facets for a DP1, as does UF 53433, a P2. 
Upper molars are slightly smaller than the premolars (Tables 32, 35), with more delicate styles, pli caballin absent, simpler fossettes, and more elongate protocone. The hypoconal groove is generally very shallow and disappears with relatively little wear (Fig. 51C). Occasionally, as in UF 53443, the hypoconal groove is as deep as in premolars. In very early wear (e.g. UF 53576 or UF 53577), the internal fossette margins may bear several very shallow plications; they are shallower than those on comparably worn premolars and are lost with wear more rapidly. Unworn or slightly worn MSCH for the M12 is about $40 \mathrm{~mm}$.

The p2 is represented by nine specimens from the Love Site. Their metaconids are stronger than in Cal. regulus (contrast Fig. $51 \mathrm{~F}$ with 49D), although they vary from a small angular structure projecting anteriorly from the metastylid, to rounded and almost equal to that of the metastylid. The ectoflexid is very shallow and does not penetrate the isthmus (Fig. 51F). The hypoconulid is well separated from the entoconid by a deep, U-shaped flexid until middle wear. The other lingual flexids are deep and well developed. In early wear a small pli entoflexid and pli caballinid may be present. The p34 are well represented in the topotypic sample. The metastylid is rounded to slightiy elongate-oval, subequal in size to the rounded metaconid (Figs. 51G, 51H). The two are well separated throughout most of the crown by the deep lingual flexids. The linguaflexid is broadly $\mathrm{U}$-shaped, and much better developed than in Cal. regulus. The ectoflexid is shallow and never penetrates the isthmus. The protostylid is smal1, much less prominent than in other members of 
the subgenus. Pli entoflexids are not observed, but the sample does not include any very slightly worn p34s. Several dp34s are referred to Cal. elachistus. Compared to those of Cal. regulus, they have shallower ectoflexids that just barely penetrate the isthmus, and shallower, broader $V$-shaped linguaflexids. The entoflexid is especially elongated, but unplicated (Fig. 51I). The protostylids are reduced, but stronger than in the p34. Lower molars are especially notable for their reduced ectoflexids, which on ly occasionally penetrate the isthmus, and persistent lingual flexids (Figs. 51J, 51K, 53B). The metaflexid, which is rapidly reduced with wear in Cal. regulus (e.g. the $\mathrm{ml}$ in Fig. 49D, note that F:AM 114176 is a relatively young adult), is retained in Cal. elachistus and not markedly retracted in depth until crown height is less than $15 \mathrm{~mm}$. The linguaflexid is also much better developed than in the molars of Cal. regulus, and persists throughout the entire crown. The metaconid and metastylid are of approximately the same size, and are oval. The metastylid and hypoconulid are not extremely elongated in very early wear, as is characteristic of Cal. regulus and Cal. placidus. This is reflected in the maximum apl observed in slightly worn molars; for Cal. elachistus this is about $16.5 \mathrm{~mm}$, for Cal. regulus it exceeds $17.0 \mathrm{~mm}$. The protostylid is present, but reduced or vestigial. Unworn or slightly worn mcchs are about $30 \mathrm{~mm}$ for the p2 (UF 96979), $35 \mathrm{~mm}$ for the p34, and $40 \mathrm{~mm}$ for the m12 (UF 59166). Discussion. Calippus elachistus is known from five localities in central florida. The majority of known specimens are from the Love Site, the type locality, and are latest Clarendonian (Webb et al., 
1981). Two nearby and slightly younger (early Hemphillian)

localities also contain specimens referable to Cal. elachistus, McGehee Farm and Haile 19A. Similar-aged taxa are rarely recovered from the Bone Valley Formation, most terrestrial specimens are either older or younger. However, a well worn lower molar from the Bone Valley, UF 23957, is definitely referable to Cal. elachistus rather than the older sample described above as Cal. (Calippus) sp. Especially notable in this specimen are its persistent entoflexid and linguaflexid, and the relatively shallow ectoflexid; all derived character states found in Cal. elachistus.

Cal. elachistus is the youngest known member of the subgenus Cal. (Calippus). Although based on on ly a few specimens, Cal. elachistus apparently persisted into the late early Hemphillian of Florida (Fig. 53) without significant morphological change. This is evidenced by its presence at the Manatee County Dam Site.

\section{Subgenus Grammohippus new subgenus}

Type species. Calippus (Grammohippus) martini Hesse, 1936. Included species. ?Cal. (?G.) circulus (Quinn), 1955, n. comb.; Cal. (G.) cerasinus n. sp., Cal. (G.) hondurensis (0ison and McGrew), 1941, n. comb.; Cal. (G.) maccartyi n. sp.

Etymology. grammodes, Greek for linear and hippos, Greek for hor se. In reference to the linearly arranged incisors of the genus. Diagnosis. Small to medium-sized equids with toothrow lengths between 100 and $135 \mathrm{~mm}$. Protocone oval or elongate-oval, connected 
to protoselene (only rarely isolated in very early wear-stages). Pli caballin single, large in premolars, variable in molars. Relatively simple fossettes, with moderately developed plications limited to the upper half of the crown. Hypoconal groove generally remains open longer than in Cal. (Calippus); variably persistent and occasionally forms a lake; usually completely lost in latter wear-stages; lost earlier with wear in premolars than molars. Large parastyles and mesostyles; moderately well developed metastyles often present. Upper cheekteeth moderately curved, more so than in Cal. (Calippus), although less than in Pliohippus. Protostylids relatively poorly developed or absent on permanent lower cheekteeth; if present moderately developed only on the lower third (or less) of the crown. DPOF long, narrow, shallow, unpocketed, poorly rimmed posteriorly; probably absent in some younger species. Rostrum short, relatively broad; muzzle width varies from $45 \%$ to greater than $60 \%$ of the UTRL.

Discussion. Members of the subgenus Grammohippus are easily distinguished from those of Cal. (Calippus) by their greater size, stronger styles, more curved upper cheekteeth, and rudimentary or absent protostylids. Specimens here assigned to Grammohippus have been variously placed in Pliohippus, Astrohippus or Protohippus. While these four taxa can be easily differentiated by their facial fossae morphology, and Grammohippus has the unique Calippus incisor arrangement, isolated cheekteeth and some toothrow series cannot a)ways be unequivocally assigned to a genus. In general, Pliohippus upper cheekteeth differ from those of Grammohippus by being larger, more curved, having more rapid closure and loss of the hypoconal 
groove, simpler fossettes, and much more frequent connection between the protocone and hypocone. Protohippus upper cheekteeth tend to be larger, have better developed pli caballins and prefossette loops, and often have isolated protocones in early wear-stages. Astrohippus upper cheekteeth are less curved, have simpler fossettes, more rudimentary pli caballins, and more rapid loss of the hypoconal groove. The lower cheekteeth of all four share many plesiomorphous characters. Discrimination among genera is further complicated by frequent parallel evolution of certain characters, especially those related to the elongation of the metaconid-metastylid complex and greater development of the lingual flexids.

Five species are referred to Grammohippus, ranging in age from late Barstovian to early Hemphillian. While this subgenus evidently diverged from Cal. (Calippus) sometime in the early Barstovian, no records exist prior to the late Barstovian (Cold Spring Fauna). However, it is unlikely that early specimens of Grammohippus would be readily distinguished from Protohippus or Pliohippus, unless very complete cranial material was available. "Pro." castilli was described by Cope (1885) from the Tehuichila Fauna, Hildalgo, Mexico, possibly of late Hemphillian age (based on supposed co-occurence with Agriotherium; Miller and Carranza-Casteneda, 1984). The occlusal dimensions of the holotype (AMNH 8344) fall well outside the observed range of $\mathrm{Cal}$. (G.) hondurensis, but it otherwise resembles that species in its enamel morphology, especially the relatively small protocone. "Pro." castilli thus may represent a late surviving member of Cal. (Grammohippus). However, a sample of five upper and 
three lower cheekteeth from the Corinto Fauna, El Salvador (Webb and Perrigo, 1984, Fig. 12B) compare favorably with the type of "Pro." castilli in size as well as morphology. Their large size and deep ectoflexids suggest referral instead to a equine genus (1arger samples are needed for a more precise identification). That the morphology of AMNH 8344 compares so very favorably with both protohippines and equines emphasizes that isolated cheekteeth are unreliable indicators of phylogenetic relationships among these equids. Additionally, there are several late early Hemphillian records of Calippus from the Great Plains mentioned by Tedford et al. (in press). These are currently under study by $M$. R. Voorhies and $M$. F. Skinner, and probably are also referable to Cal. (Grammohippus).

?Ca1. (?Grammohippus) circulus (Quinn), 1955 new combination

Merychippus perditus (Leidy), HESSE, 1943, p. 171 (in part). Pliohippus circulus QUINN, 1955, pp. 22-24 (in part). Merychippus circulus (Quinn), FORSTEN, 1975, pp. 32-35 (in part).

Type specimen. TMM 31191-10, assoc. R p4-m3.

Type locality. Sam Houston Local Fauna (Hesse, 1943, p. 171), San Jacinto County, Texas.

Stratigraphic occurrence and age of type localtiy. Fleming Formation, Cold Spring Fauna; late Barstovian, about $13.0 \mathrm{ma}$.

Distribution. Known on ly from the middle late Barstovian (about 13.5 to $12.5 \mathrm{ma}$ ) of the eastern Texas Gulf Coastal Plain. 
Referred specimens. Cold Spring Fauna. Cold Spring 1.f., San Jacinto Co., TX: TMM 31219-327 R P2; -160 R P34; TAMU 3027 R M12; TMM 31219-326 L m3. Noble Farm 1.f., TAMU locality No. 19, Grimes Co., TX: TAMU 3019, 30202 L M12; 3021 R M3; 3022 R m12; 3023-3024 2 L m12; 3025 R m3; 3026 L m3.

Revised diagnosis. Cheekteeth with least unworn crown height of known species of the subgenus; unworn molar MSCH about $40 \mathrm{~mm}$. Smaller than Cal. martini, with less complex fossettes, poorly developed pli caballins on premolars, and variable, often strong protostylids.

Description. ?Calippus circulus is at present known on $7 y$ from a few isolated teeth; its generic referral is thus somewhat problematic until more complete material is discovered. The P2, TMM 31219-327, is moderately worn (Fig. 54A; Table 36) and the anterior third is broken off. The well connected protocone is round to slightly oval with a small preprotoconal groove (Fig. 54A). The fossettes are very simple with only a trace of a pli prefossette, and there is neither a pli caballin nor hypoconal groove remaining at this wear-stage. The moderately worn P34, TMM 31219-160, is very typically calippine, with a connected, elongate-oval protocone, small pli caballin, simple fossettes, well developed parastyle, and a slight metastyle (Fig. 54B, Table 36). The tooth is moderately curved $(R O C=40 \mathrm{~mm})$. Upper molars are represented by three specimens. The barely worn TAMU 3027 has a MSCH of only $38 \mathrm{~mm}$. The other two specimens are heavily worn. The protocone is elongate-oval, broadly connected to the protoselene, and with a shallow but persistent preprotoconal groove. Fossettes 
are simple; the pli caballin is vestigial, and the hypoconal grooves close without forming a lake.

The associated lower series that constitutes the holotype was illustrated and exhaustively described by Quinn (1955, pp. 23-24). The referred lowers match the type in size and general enamel morphology, although many of the molars have stronger protostylids. They can be well developed on the lower third of the crown and present to near the top of the unworn crown. On others, including the type series and most of the referred $\mathrm{m} 3 \mathrm{~s}$, the protostylid is much weaker, and is at best moderately developed only near the base of the crown. Smaller and less high crowned than Cal. martini, the lowers otherwise resemble that better known taxon. The metaconid-metastylid complex is relatively unexpanded, and the lingual flexids shallow, short and nonpersistent.

Discussion. Quinn (1955) described ?Cal. circulus as a primitive member of Pliohippus based on two specimens, the type lower series and a juvenile upper dentition (TMM 31219-165). The latter includes the right and 1eft DP2-DP4, the right M1-M2 (Quinn, 1955, Plate 3, Figs. 5-7), and the left M2-M3. The upper molars of TMM 31219-165 have strong pli caballins, moderately complex fossettes, and isolated protocones in early wear-stages, all of which suggest a referral to Protohippus rather than Pliohippus or Calippus. They are also larger than other upper cheekteeth from the Cold Spring Fauna which appear to be those of a primitive, moderate-sized member of Cal. (Grammohippus). The latter are judged to better correspond with the 
A

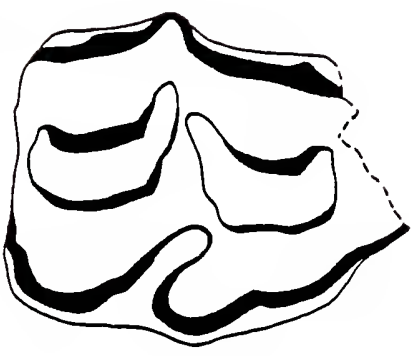

$2 \mathrm{~cm}$

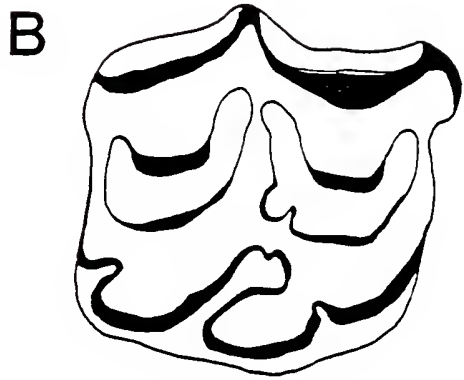

\section{표표}

Figure 54. Occlusal views of upper cheekteeth of ?Calippus (?Grammohippus) circulus from the cold Spring local fauna, San Jacinto County, Texas (Tate Barstovian). A. TMM 31219-327, R P2. B. TMM 31219-160, R P34. 
冚

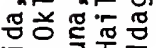

‘.

는ㅎㅇㅇㅛ.

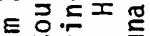

엉언.. 독

ᄂㅎํ유

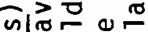

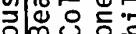

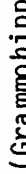

¿n un

일

。링

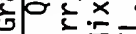

도인

ง|ซ்

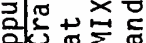

- $\simeq \ldots$

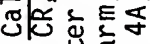

䒘.. 交市

동워웜

+․ㅇㅁ웡

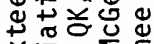

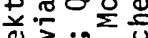

ه

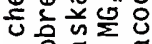

<

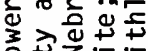

으문

등 Ð

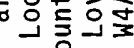

ঠे. S >

윽 웅

다..n

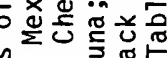

行

등 준

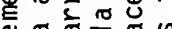

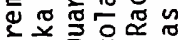

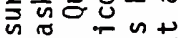

ज

造过志它选这

2 U⿺⿻一𠃋火

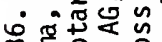

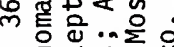

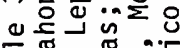

둥

음웜월

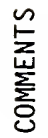

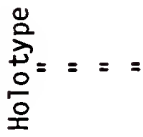

$\frac{\stackrel{0}{2}}{\frac{0}{0}}==$

坖

l 1 i

? $, \infty, \infty+0, \varphi$ స |

迹 $\quad i$

i 1 i i i

i i i

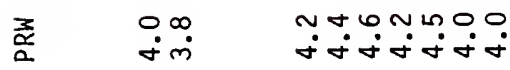

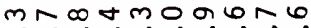
$\dot{m} \dot{m} \dot{m} \dot{m} \dot{\dot{m}} \dot{m} \dot{m} \dot{m}$

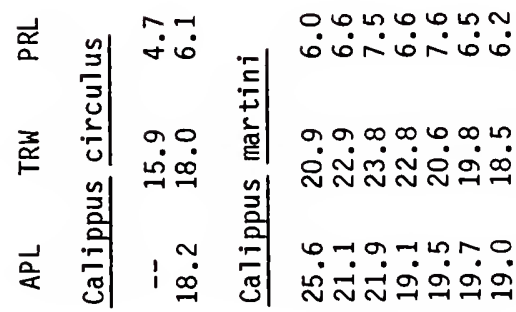

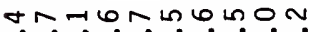
ن

Nตת

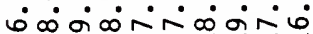

N $\infty$ n $\infty \simeq \infty 0$

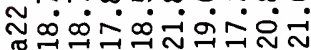

- :

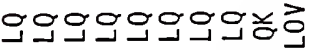

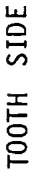

\lrcorner$-\neg-\neg \propto-$

$\longrightarrow-\longrightarrow--\longrightarrow \propto-\longrightarrow-$

$\propto \propto$

$\sim \stackrel{+}{2}$

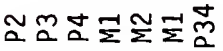

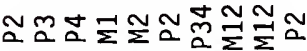

ㄲํำ

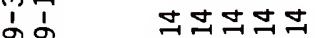

की

N N N N

लॉल

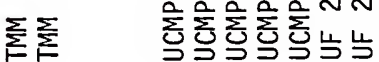

ㅇㅇㅇㅊำ 일

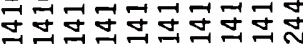
吉吉吉吉吉吉吉吉

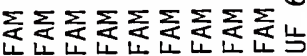

$\infty \sim 0-1$ 


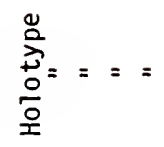

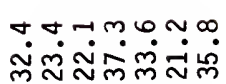

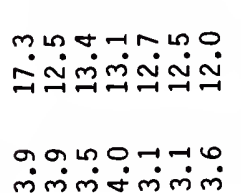

manongm

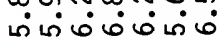

\% ம்

$\infty$ Now \% إ $\dot{\sim} \dot{0} \infty \dot{0} \dot{0} \dot{0}$ 너엄

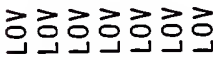

$-\lrcorner-\propto \sim \propto \propto$

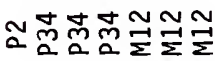

웅하영웡츄 ธิ๊

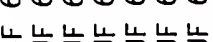
$\stackrel{\circ}{\sim} \underset{\sim}{\sim} \underset{0}{\infty} \stackrel{0}{\sim}$

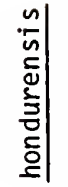

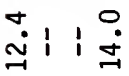

|ீंற்

๘)

ثே

in

in

형

ஸ்பீ口卄

กิำ

$0+-6$

$\dot{0} \dot{0} \dot{0} 0$

言

톨톨옾

$\propto \propto\lrcorner \propto$

熍灾灾

$\leftarrow \infty$

(5)

ะNำ

녕ㄷ⽊워

告的告光
NNM $m$

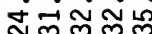

تִ90

n̊n:

लंखिए

n) $-2 \rightarrow n$ in जi

NmR N

$\dot{\infty} \dot{\infty} \dot{0} \dot{\infty}$

$\rightarrow-\rightarrow-1$

$0 \infty 10$.

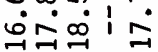

肴希希希出

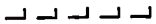

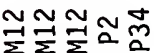

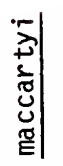

号

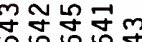
论论热 雨 $\sum_{<} \sum_{1} \sum_{i} \sum_{i} \sum_{i}$ $\dot{0} \dot{0} \dot{0}=\dot{0}$

พ ت்

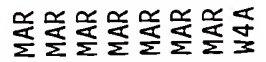
$\simeq\lrcorner\lrcorner\lrcorner\lrcorner\lrcorner \simeq \simeq$

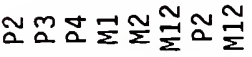

Nก \% , 6

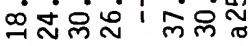

过1 1 1

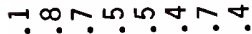
लिंलिलंलंजिं

mดन N MmL ช N

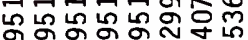

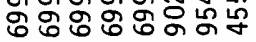
当当岁当当岁岁当 
$\sum_{\substack{\sum \\ j}}^{n}$

它

\%

ก $6 \sim$

的年

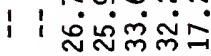

$\underset{n}{m}$

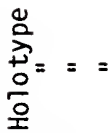

ฮั

I 1 min்

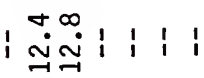

=

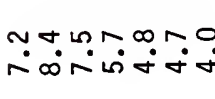

ह

Nmunam

\begin{tabular}{l|l}
$n$ & $m$ \\
$\frac{n}{c}$ & $m$ \\
$\frac{1}{5}$ & \\
$\frac{5}{0}$ & \\
$\frac{5}{5}$ & 0
\end{tabular}

$\infty \sigma \infty$,

$\dot{0} \dot{0} \dot{0} \dot{0}$

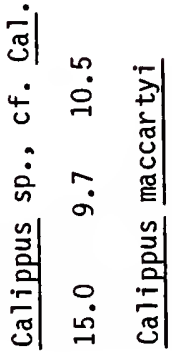

$\underset{3}{3}$

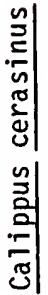

n.

சं어요

a以d $\mathrm{NO}, \mathrm{m}$

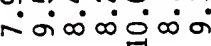

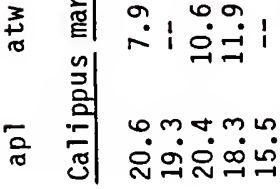

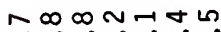

Noن

$\infty$ \% $\infty$ ?

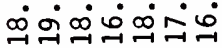

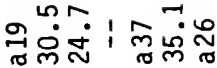

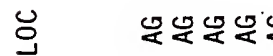

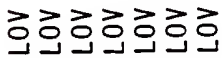

空

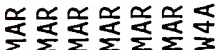

㟔号 $-⿻-\propto$

\lrcorner$--\propto-\propto-$

$\simeq$

\lrcorner$-\lrcorner-\propto \propto \propto$

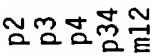

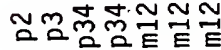

$\stackrel{\sim}{n}$

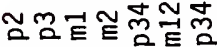

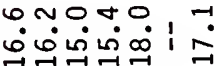
$\infty$ i

○ మ กิ

늉ㅇㅇ N

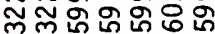

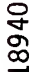

岇岇䒓岇岇岇

告告告告岁

드네엥ㅇㅇ ๙ু ুু 岇岇岁岁岁告 
type lowers of ?Cal. circulus. The total sample is quite limited, and more complete specimens are needed to confirm the association of upper and lower teeth proposed here. In the absence of cranial material, the provisional referral to Calippus rather than Pliohippus is based on the moderate size (contemporary populations of Plio. mirabilis in Nebraska are much larger), the strong styles, and the moderately developed protostylids of the cold Spring sample. Forsten (1975) grouped Quinn's (1955) Plio. circulus and Eoequus wilsoni into a single taxon (Merychippus circulus). Most of the larger specimens from the cold Spring Fauna do pertain to a single species, although I follow Hesse (1943) in referring them to Protohippus perditus (see below). The few specimens here referred to ?Cal. circulus differ from those of Pro. perditus by being smaller, much shorter crowned, having simpler fossettes, rapidly connected protocones, less elongate lingual flexids and weaker protostylids. ?Calippus circulus is at present recognized on ly from the Texas Gulf Coastal Plain.

\section{Ca1. (Grammohippus) martini Hesse, 1936}

Protohippus perditus Leidy, GIDLEY, 1906a, pp. 136-139 (in part); GIDLEY, 1907, pp. 882-883 (in part); QUINN, 1955, pp. 19-20 (in part).

Callippus martini HESSE, 1936, pp. 52-54.

Priohippus (Astrohippus) martini (Hesse), STIRTON, 1940, pp. 190, 192; FORSTEN, 1975, pp. 48-53 (in part).

Pliohippus sp., GREGORY, 1942, pp. 412-413. 
Protohippus martini (Hesse), QUINN, 1955, pp. 21-22.

Equus laparensis QUINN, 1955, pp. 58-61 (in part).

Equus sp., QUINN, 1955, pp. 61-62.

Astrohippus martini (Hesse), WEBB, 1969a, pp. 95-96; SCHULTZ, 1977, p. 48.

Astrohippus sellardsi (Quinn), WEBB, 1969a, p. 96 (in part).

Type specimen. UCMP 32814, as sociated L P2-M3.

Type locality. Cragin Quarry (UCMP V-3516), Beaver County,

OkTahoma.

Stratigraphic occurrence and age of type locality. Ogallala Group; middle Clarendonian, about 10.0 to $11.5 \mathrm{ma}$.

Distribution.-Early to middle Clarendonian of the northern and southern Great Plains; early Clarendonian of the Gulf Coastal Plain of Texas and Florida.

Referred specimens. Clarendon Fauna, Donley Co., TX. Chamberlain's Quarry No., 7: F:AM 114163 assoc. R \& L mandibles. MacAdams Quarry: F:AM 114165-114168, 1141735 sku11s; 114169-114172, 1170365 maxillae; 117038-117040 3 mandibles. C. Risley Ranch Site: TMM 255-34 L mandible with p2-m3; -35 L mandible with p2-p4; -31 L M12. Noble Ranch Site: JWT 1498A R maxilla with P2-M3; JWT 1498B L maxilla with P4-M3. Grant Lease Site: JWT 880A R mandible with P2m2; WT $941 \mathrm{R}$ maxillae with P4-M2. Many additional specimens, including isolated teeth measured in this study are known from this fauna, and are housed in the F:AM, PPM, UCMP and TMM collections.

Minnechaduza Fauna. Gallup Gulch Quarry, Cherry Co., NB: F:AM 114156 R maxil1ae with P4-M1; 114157 R P2; 117018 L P2; 117023 , 
117024, 1170293 R P34; 117019, 117021, 1170223 L P34; 117020, 1170282 L M12; 117026 R M1; 117027 R M2; 114159 assoc. R \& L mandibles with $p 2-m 3 ; 114160$ assoc. $R$ \& $L$ mandibles with $c, p 2, d p 3-$ dp4,m1-m2; $114161 \mathrm{~L}$ mandible with dp2-m2; 117034, $1170352 \mathrm{~m} 12$. Mensinger Quarry, Cherry Co., NB: F:AM 117031 L P34; 117032 assoc. R \& L mandibles with dp2-m1. Big Spring Canyon, Bennett Co., South Dakota: AMNH 10838 juvenile skull (Gidley, 1906a, Figs. 3-5). Hol low Horn Bear Quarry, Todd Co., South Dakota: F:AM 117008 premaxillae with R \& L I1-I3; 117009 L maxilla with M1-M2; 117010 R P34; 114148, 114149, 117011, 1170124 R M12; 114135-114147, 11701311701718 mandibles. Dawson Locality No. 3 (SDSM locality V-553), Todd Co., South Dakota: SDSM 55154 assoc. sku11, mandibles and postcranial elements of immature male individual. Additional specimens from this fauna in the UCMP collection are listed in Webb (1969a). Lapara Creek Fauna. Buckner Ranch Site, Bee Co., TX: TMM 30896-127 assoc. R P2-M3; -195 assoc. L P2-P4; -188 palate with $R$ DP2-DP 4 and L DP2-M1; -569 crushed sku11 with R P4-M3; -418 assoc. $R$ P4-M1; -533 L p2; -545 assoc. $R$ p2-p4 and $L p 2-m 3 ;-207 R$ mandible

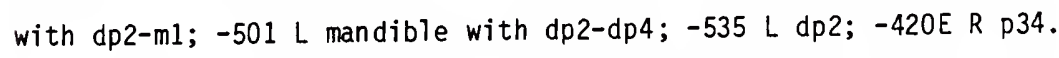
Farish Ranch Site, Bee Co., TX: TMM 31081-169 R M12; -1244 L M12; -1253B L p 34. Bridge Estate Site, Bee Co., TX: TMM 31132-190C, $-366 B 2 R$ P34; -190B L P34; -169, -334B, -366A 3 R M12; -430 assoc. $R$ p3-p4; -343 assoc. L p4-m3; -357 L dp34; -445 L dp2; -445B R dp34; $-498 \mathrm{R}$ p34; $-13 \mathrm{~A},-285 \mathrm{~A},-400,-5694 \mathrm{~L} \mathrm{~m} 12$. Medio Creek, Site No. 19, Bee Co., TX: TMM 31170-73 R P34; -74B R dp34; -74A R m12; -13A L m12. 
Agricola Fauna, Bone Valley Region. Gray Zone, Phosphoria Mine: UF 28552, 933262 L P34; 28551 R M12; 28579 L m3; 55886 assoc. L p2-m1. Brewster Haynsworth Mine: UF 24375 R M3 (Berta and Galiano, 1984, Fig. 2). Fort Green Mine: UF 57358 R p34; 55888 L p34; 52409 R m12.

Revised diagnosis. Largest described species of Calippus, with toothrow lengths of 125 to $140 \mathrm{~mm}$ and unworn molar crown height of about $57 \mathrm{~mm}$. Metastylid poorly separated from metaconid by relatively shallow and rapidly retracting linguaflexid and entoflexid. Muzzle width about $45 \%$ of toothrow length.

Description. Subsequent to its original description, relationships between $\underline{\mathrm{Cal}}$. martini and other taxa have been based almost exclusively on characters of the upper cheekteeth (e.g. Stirton, 1940). This is the first documentation of the facial and incisor morphology of the species, although Gidley (1906a) figured and described as the "hypotype" of Pro. perditus a skull here referred to Cal. martini. The topotypic sample and that from the nearby Beaver Quarry are limited to cheekteeth and mandibular fragments. Crania from various quarries of the Clarendon Fauna reveal the facial characters of Cal. martini. Upper cheekteeth of Cal. martini are abundant in collections of the Clarendon Fauna, and they do not differ in size or morphology from the holotype (Tables $36,37)$. The medium-sized protohippine from the Clarendon Fauna has long been recognized as being conspecific with Hesse's (1936) species. The following cranial features are based on skulls whose dentitions also match those of the type. Although all are crushed or 
distorted to varying degrees, their facial morphology is consistent. The malar region lacks any fossa of the Pliohippus-type. There occasionally is a small, shallow depression, which is often accentuated by crushing. Similar shallow depressions are variably observed in "Merychippus," Pseudhipparion, Neohipparion, and other species of Calippus (Skinner and Taylor, 1967; MacFadden, 1984a; Webb and Hutbert, 1986). The DPOF (best preserved on F:AM 114173 and 117036; see also Gidley, 1906a, Fig. 3) is located high on the face, dorsal to the M3 to $P 3$, about $60 \mathrm{~mm}$ above the alveolar tooth margin. It is long (about 75 to $85 \mathrm{~mm}$ ), relatively narrow when compared to that of Protohippus, and with a less distinct posterior margin. The ventral, anterior, and dorsal margins all blend into the surrounding facial region without rims. The preorbital bar is moderately narrow, like that of Protohippus, with a length of about $17 \mathrm{~mm}$. The lacrimal bone is included in the posterior region of the DPOF. The nasal notch does not extend over the $P 2$. The rostrum is relatively short compared to Protohippus, and especially to pliohippus. The premaxillae and mandibular symphyses are expanded as in Cal. (Calippus), with the enlarged first and second incisors arranged linearly or nearly linearly to form a broad, straight biting surface. The muzzle width is about $45 \%$ of the UTRL. This is somewhat less than in more advanced species of Calippus (Fig. 43), but relatively wider than similarly sized equids.

Upper cheekteeth of Cal. martini (Tables 36, 37; Fig. 55B) have large parastyles and mesostyles. Protocones are oval (elongate-oval in early wear), have rounded or pointed posterior ends, and are of 


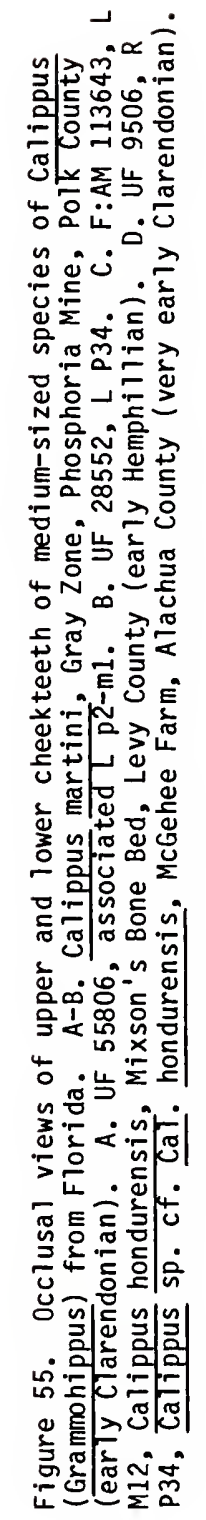




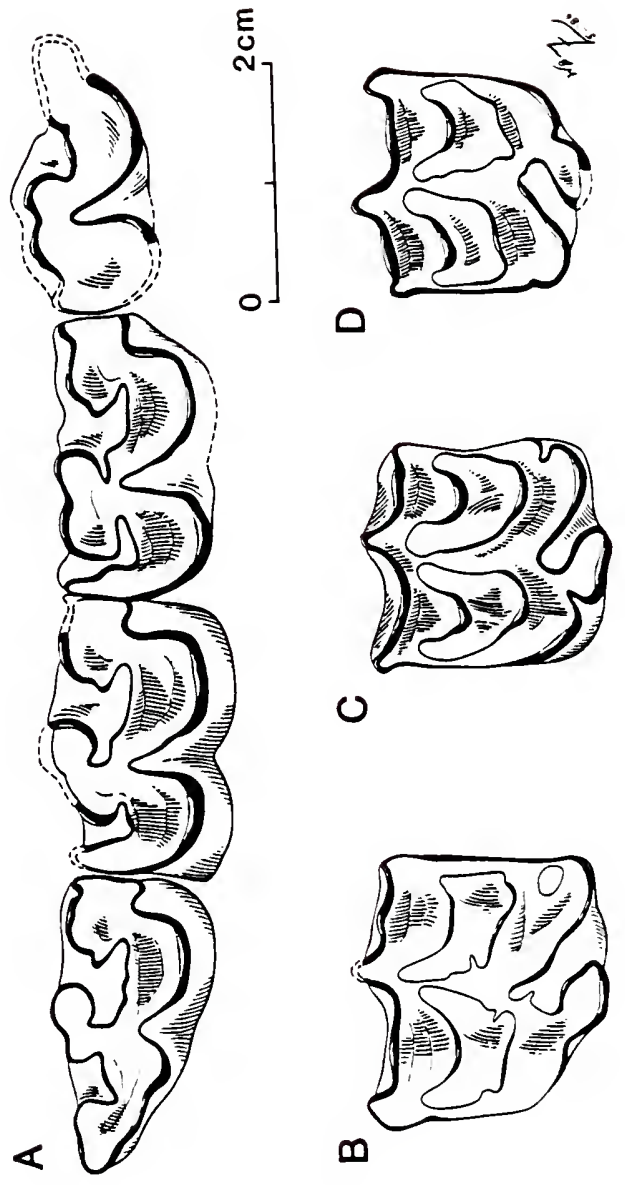


Table 37. Standard univariate statistics for upper cheekteeth of Calippus martini from the Clarendon Fauna, Don ley County, Texas (middle CTarendonian), from the Minnechaduza Fauna, Brown and Cherry Counties, Nebraska and Todd County, South Dakota (middle Clarendonian), and from the Lapara Creek Fauna, Bee and Live Oak Counties, Texas (early Clarendonian). Format as in Table 2.

FAUNA CLARENDON

APL

$$
25.4,1.17,19
$$$$
23.6-27.6,4.60
$$

BAPL

$$
21.3,1.57,12
$$$$
17.5-22.8,7.41
$$

TRW

$$
19.9,1.07,18
$$$$
17.7-22.1,5.40
$$

PRL

PRW

$$
\begin{aligned}
& 5.9,0.41,19 \\
& 5.3-6.9,7.03
\end{aligned}
$$

$$
4.5,0.48,19
$$$$
3.1-5.2,10.68
$$

MINNECHADUZA

LAPARA CREEK

P2

$24.5,1.10,3$

$23.4-25.6,3.66$

$21.3,0.78,2$

$20.7-21.8,3.66$

$19.3,1.40,3$

$18.3-20.9,7.25$

$$
\begin{aligned}
& 5.6,0.40,3 \\
& 5.2-6.0,7.14
\end{aligned}
$$

$$
4.3,0.10,3
$$$$
4.2-4.4,2.33
$$

P34

APL

$$
21.9,1.47,37
$$

$18.6-24.6,6.71$

BAPL $\quad 16.4,0.87,21$

$15.2-18.9,5.34$

TRW

$$
22.1,1.22,37
$$$$
20.1-24.5,5.51
$$

PRL

$$
\begin{aligned}
& 7.5,0.91,37 \\
& 6.1-9.4,12.10
\end{aligned}
$$

PRW
$21.5,0.65,11$

20.4-22.5,3.01

$16.2,0.58,7$

$15.2-16.9,3.60$

$21.7,1.15,10$

20.0-23.8,5.29

$6.9,0.51,10$

$6.1-7.5,7.35$

$4.4,0.38,10$

$3.9-5.0,8.66$
$24.7,0.62,3$

$24.2-25.4,2.53$

$20.2,--, 1$

$18.8,0.35,3$

$18.5-19.2,1.87$

$5.7,0.28,2$

5.5-5.9, 4.96

$3.8,0.12,3$

$3.7-3.9,3.04$
$20.9,0.66,5$

$20.2-22.0,3.17$

$16.1,0.52,3$

$15.5-16.4,3.23$

$21.1,1.19,6$

$19.0-22.4,5.66$

$7.2,0.59,7$

$6.1-7.8,7.75$

$4.0,0.20,7$
$4.4,0.38,37$

$3.7-4.3,5.11$ 
Table 37--continued

M12

$\begin{array}{llll}\text { APL } & 21.2,1.58,42 & 20.6,1.28,13 & 20.1,0.64,5 \\ & 17.5-23.6,7.42 & 18.9-23.0,6.22 & 19.4-21.0,3.17 \\ \text { BAPL } & 16.2,0.91,23 & 15.3,0.50,8 & 15.7,1.67,4 \\ & 15.0-18.0,5.62 & 14.7-15.9,3.28 & 13.5-17.3,10.64 \\ \text { TRW } & 20.5,1.82,44 & 20.7,1.45,13 & 19.5,1.79,5 \\ & 15.8-24.1,8.89 & 17.4-22.8,7.01 & 16.6-21.2,9.17 \\ \text { PRL } & 8.0,0.80,44 & 7.6,0.82,13 & 7.1,0.49,5 \\ & 5.6-10.0,10.01 & 5.7-8.5,10.74 & 6.3-7.6,6.86 \\ & & & \\ \text { PRW } & 4.0,0.41,44 & 4.1,0.33,13 & 3.7,0.31,5 \\ & 3.3-5.0,10.15 & 3.5-4.5,8.05 & 3.2-4.0,8.46\end{array}$


Table 38. Standard univariate statistics for lower cheekteeth of Calippus martini from the Clarendon Fauna, Donley County, Texas (middle (Tarendonian), from the Minnechaduza Fauna, Brown and Cherry Counties, Nebraska and Todd County, South Dakota (middle Clarendonian), and from the Lapara Creek Fauna, Bee and Live Oak Counties, Texas (early Clarendonian). Format as in Table 2.

FAUNA CLARENDON

ap1

$$
\begin{aligned}
& 21.0,0.71,10 \\
& 19.8-21.8,3.36
\end{aligned}
$$

bapl

$17.4,0.73,10$ $16.7-19.1,4.18$

atw

$8.6,0.85,10$ 7.5-10.1,9.89

ptw

$11.2,0.65,10$ $10.1-12.1,5.82$

$\mathrm{mm} 1$

ent 1

$7.2,0.87,10$

$5.7-8.7,12.14$

$$
\begin{aligned}
& 8.5,0.54,10 \\
& 7.5-9.2,6.40
\end{aligned}
$$

ap 1

$$
21.8,0.90,17
$$$$
20.2-23.7,4.12
$$

bapl

$$
16.6,0.58,15
$$$$
15.7-18.0,3.49
$$

atw

$$
11.4,0.80,17
$$$$
10.2-13.0,7.05
$$

$11.6,0.92,9$ $10.1-12.5,7.93$

$8.4,0.45,7$

$7.8-9.1,5.33$

$10.8,0.28,7$

$10.3-11.1,2.61$

7. $3,0.72,7$

$6.2-8.1,9.83$

$5.7,1.78,7$

$3.3-8.1,31.50$

p34

$19.1,1.55,9$

$16.9-21.0,8.08$

$19.2,0.32,3$

$19.0-19.6,1.67$

$16.4,0.99,2$

$15.7-17.1,6.04$

$11.3,1.32,3$

9.9-12.5,11.66

ptw

$12.1,1.00,16$

$10.4-13.9,8.23$

$11.5,0.59,9$

$10.8-12.4,5.09$

$11.9,0.38,3$

$11.5-12.2,3.18$

$\mathrm{mm} 1$

$$
\begin{aligned}
& 9.7,0.63,17 \\
& 8.6-11.2,6.48
\end{aligned}
$$

$8.4,0.58,9$

$7.3-9.0,6.86$

$9.4,1.65,3$

$8.3-11.3,17.58$

ent

$$
\begin{aligned}
& 8.8,0.85,17 \\
& 7.2-10.2,9.69
\end{aligned}
$$

$7.3,1.32,3$

$6.1-8.7,18.09$ 
Table 38--continued

$$
\text { m12 }
$$

$\begin{array}{llll}\text { ap1 } & 22.3,1.95,29 & 18.0,2.39,11 & 21.4,1.80,5 \\ & 18.4-27.3,8.73 & 15.5-21.6,13.27 & 18.9-23.7,8.39 \\ \text { bap1 } & \begin{array}{l}16.3,0.79,29 \\ 15.2-17.9,4.85\end{array} & -\cdots & 16.6,1.38,5 \\ & & & 15.6-18.9,8.29 \\ \text { atw } & 9.4,0.78,28 & 9.3,0.99,11 & 9.1,0.77,5 \\ & 8.1-11.5,8.29 & 7.8-11.3,10.56 & 8.4-10.0,8.50 \\ \text { ptw } & 8.9,1.00,29 & 7.7,0.51,11 & 8.6,0.65,5 \\ & 7.3-12.6,11.25 & 6.8-8.4,6.57 & 7.8-9.6,7.58 \\ \text { mm1 } & 8.5,0.70,29 & 6.7,1.08,11 & 8.9,1.28,5 \\ & 7.3-10.0,8.25 & 4.3-8.2,15.95 & 7.8-11.1,14.37 \\ \text { ent1 } & 5.9,0.95,29 & 4.1,1.72,11 & 6.2,2.02,5 \\ & 4.3-8.1,15.95 & 1.2-6.2,42.20 & 4.2-9.6,32.52\end{array}$




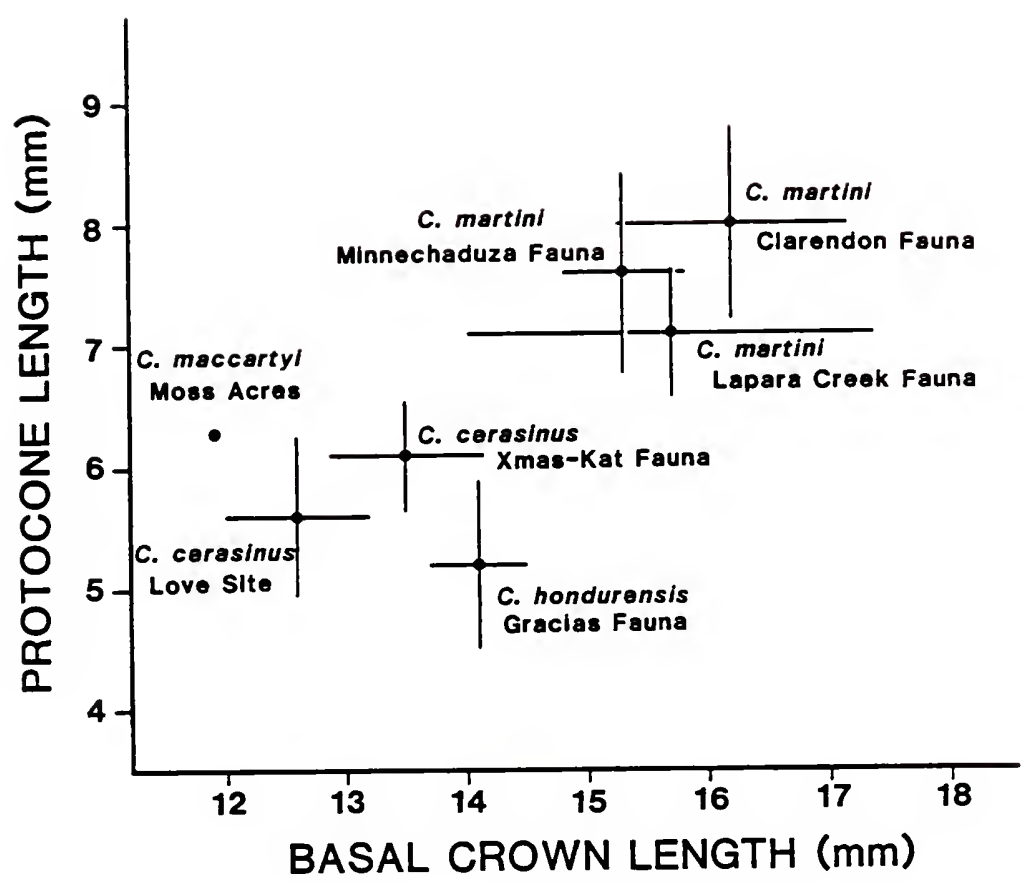

Figure 56. Bivariate plot of basal crown length (BAPL) versus protocone length (PRL) of combined samples of M1s and M2s for four species of Calippus (Grammohippus). One standard deviation is plotted on both sides of the mean value for the following populations: Cal. martini, Minnechaduza, Lapara Creek and Clarendon Faunas; Cal. cerasinus, Love Site and Xmas-Kat Faunas; Cal. hondurensis, Gracias Fauna. Also plotted are the values for UF 90299, a molar of Cal. maccartyi from the Moss Acres Racetrack Site. 
moderate length relative to tooth size. The protoconal connection is narrow and constricted by a deep preprotoconal groove in early wear-stages; it is more open in later wear-stages. The protocone is oriented in an oblique, anterolabial-posterolingual direction, more so in premolars than molars. A long, single pli caballin is evident in moderate to slightly worn premolars; smaller or absent with greater wear. Pli caballins are typically small or absent on molars, and infrequently well developed. Fossette plications are usually simple and shallow, but better developed than those of Cal.

(Calippus). Premolars in early wear-stages usually have two to four plications on each of the internal fossette borders, sometimes

bifurcated, and with moderate development of a prefossette loop. Pli protoloph and pli hypostyle are either single and shallow, or, more frequent1y, absent. A P34 with a MSCH of $18 \mathrm{~mm}$ or less typically has lost all plications. The fossettes of the molars are even simpler, and most plications are lost very early in ontogeny. The hypoconal groove closes to form a lake about in middle wear-stages, but the crown height at which this occurs varies. Well worn molars (i.e. those with less than half of their original crown height) generally lack all fossette plications, pli caballins and a hypoconal groove. The protocone rarely connects to the hypocone, and then on ly in very heavily worn molars. Deciduous premolars are similar in fossette complexity and pli caballin development as the permanent premolars. The hypoconal groove, however, remains open longer, until late wear-stages. A moderate-sized OP1 (about $10 \mathrm{~mm}$ long) is present and 
remains with the permanent dentition. Unworn or slightly worn MSCHS are about $45 \mathrm{~mm}$ for the P2, $52 \mathrm{~mm}$ for the P34 and $57 \mathrm{~mm}$ for the $M 12$.

The lower cheekteeth of Cal. martini display the primitive protohippine pattern (Fig. 55A). The premolars have smaller, more lingually situated metastylids than metaconids. Therefore, posterior width is typically greater than atw (Table 38), although the difference is much less in older individuals. In early wear-stages, the linguaflexid and a well developed anterolingual extension of the entoflexid "pinch off" the metastylid from the metaconid (Fig. 55A). With wear, both contract, thus broadening the connection between them. The metaflexid rapidly retreats with wear, creating a broad confluence between the protoconid, metaconid and protolophid (Fig. 55A). The ectoflexid is relatively shallow on the $p 2$, not penetrating the isthmus. In the $\mathrm{p} 34$, its depth is variable; in early wear-stages it generally slightiy penetrates the isthmus, to a point deeper than the level of the base of the entoflexid. In later wear-stages, it may retreat. Molars are much narrower than premolars, with relatively short metaconid-metastylid complexes (Table 38), and with the isthmus completely divided by the deep ectoflexid. The lingual flexids are shallow and rapidly contract with wear. Plications are uncommon; a small pli caballinid is rarely observed in slightly worn premolars, and a pli entoflexid is somewhat more common in both slightly worn molars and premolars. Usually a weakly developed protostylid is present only on the lower 15 to $25 \mathrm{~mm}$ of the crown of the $p 3-m 3$, thus reaching the occlusal surface only in older individuals. Lower deciduous premolars in early wear resemble 
the permanent premolars with shallow ectoflexids and lingually placed metastylids. The dp2 has a well developed paraconid and an angular metaconid that is relatively large for a protohippine. With wear, the ectoflexids deepen and the dp2-dp4 take on a more molariform appearance, although with more expanded metaconids and metastylids. Protostylids are moderately developed on the lower two-thirds of the crown (e.g. TMM 30896-207; see also Hesse, 1936, Fig. 2). Ectostylids are absent. A small, vestigial dpl may be present with the juvenile dentition, but it is lost with the eruption of the p2, and its alveolus is reabsorbed.

Discussion. As can be judged from the synopsis of usage, the nomenclatural history of Cal. martini is complex. Some of the confusion originated with Hesse's (1936) description. He failed to list any measurements taken on the holotype, and the type figure (Hesse, 1936, Fig. 1) is not natural size as stated in the caption, but reduced by about $20 \%$. This created a misconception in some that the species is considerably smaller than it really is. Measurements of the type are listed in Table 36. The Lapara Creek sample of Cal. martini closely agrees with other referred populations in size (Fig. 56, Tables 37, 38) and morphology. The remainder of the confusion can be traced to Stirton's (1940) transfer of Cal. martini to Plio. (Astrohippus).

Stirton (1940) described Astrohippus as a new subgenus of Pliohippus, with "Pro." ansae as the subgenotype. Stirton (1940) hypothesized that $\underline{A}$. ansae was ancestral to Equus, and that "…" martini was ancestral to $\underline{A}$. ansae. "A. " martini was in turn thought 
to be descended from "Merychippus" perditus. While subsequent work has documented that Dinohippus, and not Astrohippus, is the sistergroup of Equus (Lance, 1950; Bennett, 1980; MacFadden, 1984b; a7so see Chapter 6), most authors have followed Stirton (1940) in considering martini as a member of Astrohippus. Quinn (1955) is a notable exception, as his systematic approach was vertical rather than the horizontal definitions of Stirton (1940). Almost all the characters of the cheekteeth that Stirton (1940) used to unite Cal. martini and A. ansae are either primitive for the Equini, or are judged to have evolved in parallel (see Chapter 6). He needed a late Miocene link between Merychippus s.1. and $\underline{A}$. ansae, so that there would be a complete North American phylogenetic sequence of species from Hyracotherium to Equus. Calippus martini was inserted into this sequence based on its moderate size, appropriate age, and suitable upper cheektooth morphology. However, the derived Calippus muzzle morphology prevents $\underline{C a l}$. martini from being ancestral to $\underline{A}$. ansae or Equus. Furthermore, the well-developed MF of Astrohippus llacking in Cal. martini) is a shared derived character of equines.

Gidley (1906a) described and figured a skull (AMNH 10838) from the Little White River Region of South Dakota as Protohippus perditus. Osborn (1918) and Tabrum (1981) have both suggested that AMNH 10838 does not represent that same taxon as Pro. perditus. Examination of the specimen reveals some descrepancies with Gidley's (1906a) description, confirms that it is not referable to Pro. perditus (especially as redefined below), and demonstrates instead a referral to Cal. martini. Dental characters that suggest this are $i$ ts very 
high crowned MI (Gidley, 1906a, Fig. 4), lack of a pli caballin, simpler enamel pattern, smaller DP1, and slightly smaller size than Pro. perditus. Its facial morphology also resembles those described above from the Clarendon Fauna (rather than skulls referred to Pro. perditus below). In particular are the absence of a MF, narrow preorbital bar, and narrow DPOF with poorly defined margins and no posterior pocket. AMNH 10838 is slightly dor soventrally crushed, especially along the naso-maxillary suture, deforming and to some extent deepening the DPOF. The impressions on the dorsal roof of the skull discussed by Gidley (1906a) also resulted from postmortem distortion. Unfortunately, the anterior portion of the skull has been broken off, and is no longer associated with the specimen. Judging by Gidley's (1906a) illustrations and descriptions, however, AMNH 10838 had an expanded, Calippus-type muzzle. The postcanine diastema was short. The width across the incisive border was listed by Gidley as $48 \mathrm{~mm}$. As the specimen was a young juvenile, that still retained the DI 2 and DI3, the muzzle width would no doubt have grown to match those of adult individuals of Cal. martini (to about 55 to $60 \mathrm{~mm})$.

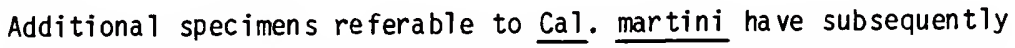
been recovered from a number of Clarendonian localities in South Dakota (Gregory, 1942; Tabrum, 1981; see also referred specimens listing), including an additional immature sku1l, SDSM 55154. The latter is associated with a mandible, the on ly known definitely associated upper and lower dentitions for the species. It resembles AMNH 10838 in all its facial characters, has a short, broad muzzle, 
and its dp4 lacks an ectostylid. This absence is a derived character state of Calippus, and not characteristic of Protohippus. Stirton (1940, p. 190) questioned whether the juvenile mandible Hesse (1936, Fig. 2) illustrated belonged to the same taxon as the type upper dentition. The referred juvenile rami, including that of SDSM 55154 , indicate that Hesse's referral was correct.

About $45 \mathrm{~km}$ to the south, in north-central Nebraska, and in stratigraphically equivalent horizons (Skinner and Johnson, 1984), Cal. martini is an uncommon member of the Minnechaduza Fauna. Quinn (1955, p. 21) referred to this population in a general way, and a small sample was listed by Webb (1969a). The combined Nebraska and South Dakota sample is slightly smaller than the Clarendon population (Tables 37,38 ), but the two are indistinguishable in dental and facial morphology. For example, the length of the protocone relative to the APL averages $34 \%$ and $38 \%$ in Clarendon premolars (P34s) and molars (M12s), respectively. In the northern plains samples, the values are $32 \%$ and $37 \%$.

Quinn (1955) recognized a total of eight medium to large-sized protohippines and equines in the Lapara Creek Fauna (Pro. perditus, Equus sp., E. laparensis, Hippotigris sellardsi, $\underline{H}$. parastylus, Plio. supremus, Dinohippus subvenus, and Asinus sp.). Webb (1969a) recognized the first four as a single taxon, which he referred to as Astrohippus sellardsi, and the other four as Pliohippus supremus. Forsten (1975) also recognized just two taxa, but in a different combination. She referred to Pliohippus (Astrohippus) martini the first six listed taxa, and only the latter two to Plio. (Pliohippus) 
cf. Plio. supremus. Based on relatively complete skulls and mandibles, contemporary faunas from the Great Plains (e.g. Clarendon and Minnechaduza) contain at least three medium to large-sized equines and protohippines: Cal. martini, Pro. supremus and Plio. pernix. Dinohippus may also be present, as Tedford (pers. comm.) recognizes it as early as the late Barstovian, but it is not yet clearly documented in Clarendonian faunas. As previously indicated, Calippus, Protohippus and Pliohippus are often difficult, or even impossible, to distinguish on the basis of isolated cheekteeth, which make up the bulk of the Lapara Creek sample. However, some of the more complete specimens from this fauna can be relatively confidently referred to each of the three taxa found in the more northern faunas.

Forsten (1975, p. 52) noted that her sample of "plio." martini varied considerably in morphology, and that two morphs could be distinguished: a smaller population with hypoconal lakes, weaker (often absent) pli caballins, poorer styles, and weak or absent protostylids; and a larger population with stronger styles, pli caballin persistent and large in premolars and present in molars, and large, well developed protostylids. She also noted that some of the deciduous lower premolars lacked ectostylids (protostylids of her terminology) and others had them (Forsten, 1975, p. 51). She included these two populations in a single species because their range in size greatly overlapped and they had other characters in common. Samples from the Clarendon and Minnechaduza Faunas indicate that these are among the consistent dental differences that distinguish $\underline{\mathrm{Cal}}$. martini and Pro. supremus, respectively. While the 
two are clearly distinct based on muzzle and facial characters, they are of about the same size, and overall their cheekteeth greatly resemble one another.

A limited sample from a lower horizon in the Bone Valley Formation of south-central Florida is referable to Cal. martini. Its morphology and size (Table 36 ; Figs. 55A, 55B) agree with the other referred samples. They are larger than younger populations of Cal. (Grammohippus) from the same region. Calippus martini is an important biochronologic indicator in the Bone Valley. Its presence in the Gray Zone (late Agricola Fauna) of Phosphoria Mine indicates a Clarendonian age for this fauna. An M3 of Cal. martini (UF 24375) suggests that the type of Pliocyon robustus Berta and Galiano (1984) is Clarendonian, as the two specimens were found in close proximity in undisturbed sediments.

\section{Ca1. (Grammohippus) cerasinus new species}

Astrohippus martini (Hesse), WEBB et a1., 1981, p. 527.

Type specimen. F:AM 114100, partial adult skull containing left maxilla with P2-M3, and portions of the left facial region, orbit and braincase.

Type locality. Leptarctus Quarry (NE 1/4, NE 1/4 sec. 28, T34N, R25W, Sparks Quad.), Cherry Co., Nebraska

Stratigraphic occurrence and age of type locality. Upper Merritt Dam Member, Ash Hol low Formation, Ogallala Group. From channel deposits incised into the Cap Rock Member (Skinner and Johnson, 
1984). Xmas-Kat Faunal Zone, very late Clarendonian, about 9.5 to $10.0 \mathrm{ma}$.

Topotypic sample. F:AM 114124 L P2; 114125-114126 2 R P34; 114127

L P34; 114128 R M12; 114129-114132, 1142415 L M12; 114133 L M3;

114134 R p34.

Etymology. cerasinus, Greek meaning of or related to cherries.

In reference to the county which produced the holotype and thousands of other vertebrate fossils.

Distribution. Very late Clarendonian (about 9.0 to $10.0 \mathrm{ma}$ ) of Nebraska and Florida.

Referred specimens. Xmas-Kat Quarries Fauna, Cherry Co., NB. Xmas Quarry: F:AM 114096 R mandible with i2,c,p2-m2; $114097 \mathrm{~L}$ male mandible and symphysis with $L i 3, c, p 2-m 3$ and $R i 2-i 3, c ; 114099$ assoc. $\mathrm{R}$ mandible with $\mathrm{p} 2-\mathrm{m} 2$ and $\mathrm{L}$ mandible with $\mathrm{p} 2-\mathrm{ml}$; West Line Kat Quarry: F:AM 114117 L P2; 114242 R P34; 1141021141182 R M12; 114103-114104 2 L M12; 114101 L mandible with p2-m3; 114119 R p34; 114120 R m12; Quarter Kat Quarry: F:AM 114122 R M12; 114240 L M12; $114238 \mathrm{R}$ m12; Kat Quarry: F:AM $114115 \mathrm{~L}$ mandible with p2-m1; Connection Kat Quarry: F:AM $114123 \mathrm{~L}$ m12; East Kat Quarry: F:AM 114105 L P34; 114121 L p34; Wade Quarry: F:AM 114160 R mandible with m1-m3. Precise locality and stratigraphic data for these sites are in Skinner and Johnson (1984).

Love Site: UF 32268 assoc. R P4-M3 and L M1-M3; 32281 assoc. R M1-M2; 32286 assoc. R DP2-DP4; 60315 assoc. R and L M1; 65238-65239, 902663 R DP2; 65240-65241 2 L DP2; 65242, 929932 L DP34; 35974, 60251-60267 18 R P2; 36144, 60234-60246, 60248-60250 16 L P2; 
$60268-60275,60277-60287,60314,60328,60351-6035223 R$ P34;

60288-60291, 60293-60294, 60297-60300, 60302-60306, 60308-60313, 6035922 L P34; 60276, 60316-60327, 60329-60350, 9295736 R M12;

$60292,60296,60301,60307,60353-60358,60360-6036820$ L M12; 603806039415 R M3; 60369-60379 11 L M3; 32143 R mandibular fragment with p3; $32141 \mathrm{R}$ mandible with dp2-dp3; $32194 \mathrm{R}$ mandible with $\mathrm{p} 3-\mathrm{m} 2 ; 32201$ $R$ mandible with $\mathrm{p} 3-\mathrm{m} 3 ; 32206 \mathrm{~L}$ mandible with $\mathrm{p} 3-\mathrm{m} 3 ; 32215 \mathrm{~L}$ mandible with p2-p3; 96548 R dp2; 96549-96454 6 L dp2; 65246-65247, 92956 , 965474 R dp34; 65243-65245, 92954-9 2955, 96545-96546, 96977-96978 9 L dp34; 59178-59184, 64528, 65248, 69804, 96557-96559 13 R p2; 59176$59177,64508,96555-96556,969766 \mathrm{~L} \mathrm{p} 2 ; 59185-59200,6878617 \mathrm{R} \mathrm{p} 34$; 59951-59956, 59958-59969 18 L p34; 59990-59999, 60207-60218 22 R m12; 59970-59989 20 L m12; 60219-60225, 68784-68785 9 R m3; 60226-60233 8 L m3.

Archer Fauna, Bone Valley Region. Nichols Mine: UF 24648 R m12; $24634 \mathrm{R}$ m3. Swift Mine: UF $18922 \mathrm{~L} M 1$.

Diagnosis. Smaller than Cal. martini and with less high-crowned cheekteeth. Unworn M12 MSCH about $50 \mathrm{~mm}$; toothrow lengths of 105 to $110 \mathrm{~mm}$ in moderate wear. Moderately curved upper cheekteeth with strong styles; anterolabial-posterolingually oriented, elongate-oval protocones with rounded lingual borders and shallow preprotoconal grooves; hypoconal groove variable in depth, persistently open in molars, closed to form lake and then lost with wear in premolars; pli caballin vestigial in premolars, absent in molars. Protocone relatively and absolutely longer than that of $\mathrm{Cal}$. hondurensis. Lower cheekteeth with small metastyles relative to metaconids, 
generally with deeper ectoflexids than Cal. hondurensis, and with more poorly developed protostylids.

Description. The holotype, F:AM 114100 (Figs. 57 A, 58A; Table 36), is a partial skull of a young adult. The $M 3$ is in the process of erupting and its posterior half is as yet unworn. The ventral half of the facial region is slightly crushed, but nearly complete. The malar region lacks a distinct fossa, but contains a slight oval depression equidistant between the anterior margin of the orbit and the IOF. This depression resembles those sometimes found in crania of Cal. martini, and may have been caused or accentuated by the crushing. The malar crest is not expanded (as it is in Pseudhipparion), and extends anteriorly just dorsal to the M1 mesostyle. The IOF is located about $43 \mathrm{~mm}$ anterior from the orbit, and $38 \mathrm{~mm}$ dorsal to the alveolar border above the M1 parastyle. F:AM 114100 is broken dorsally $5 \mathrm{~mm}$ above the IOF, so the condition of the DPOF is unknown. The anterior-most point of the lacrimal is present (about $32.5 \mathrm{~mm}$ in front of the orbit), and does not form part of the DPOF (Fig. 57A).

The upper cheekteeth are moderately curved, with ROC of P34s between 45 and $50 \mathrm{~mm}$, and for M12s, between 38 and $45 \mathrm{~mm}$. The styles are moderately strong, and the P3 through M2 generally have a moderate metastyle (Figs. 58A-58E). The protocone is elongate-oval with a pointed posterior end. The protocone connects to the protoselene at the onset of wear, and, in early wear-stages, the connection is constricted by a moderate preprotoconal groove and the postprotoconal valley. By mid-wear (e.g. the Ml of the holotype), 
离

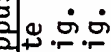
T几

$>\approx$

这包

에인

ता

히응

는오

评㐫

列

- 形害过

4

58 눙

들 권

过芭艺

ठㄴ웡

․․

के

둥ㅇㅇ

$\rightarrow$ 过

등 的

क以

这芹

ㅎํ은

으움ㅇ.

옹요

4 $<$ 잉

。 矛要

ज行

उ

5 है

>

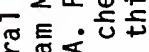

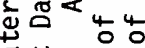

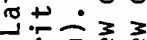

둥

- 包尔分

的

눙

的的气

可的证

元 


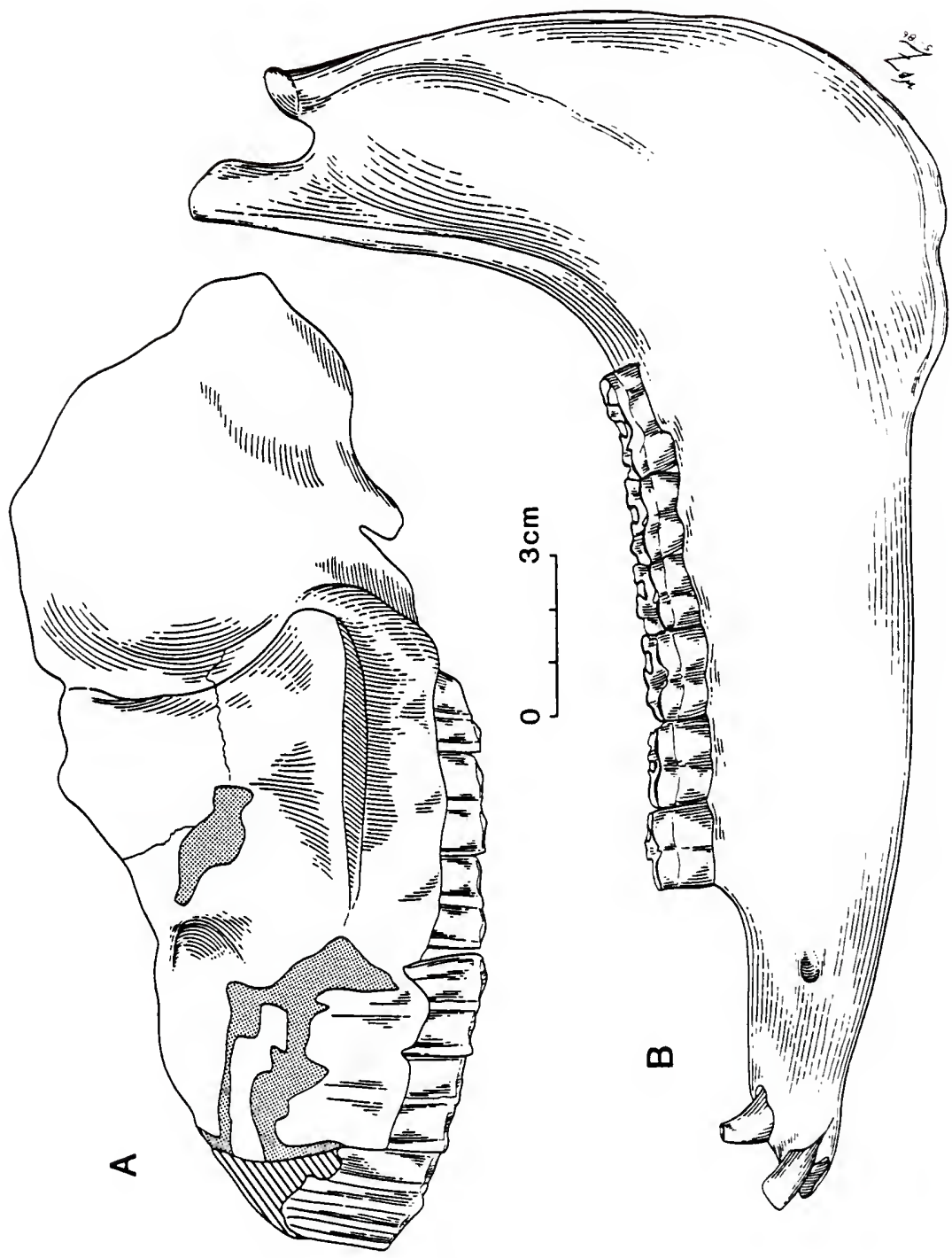




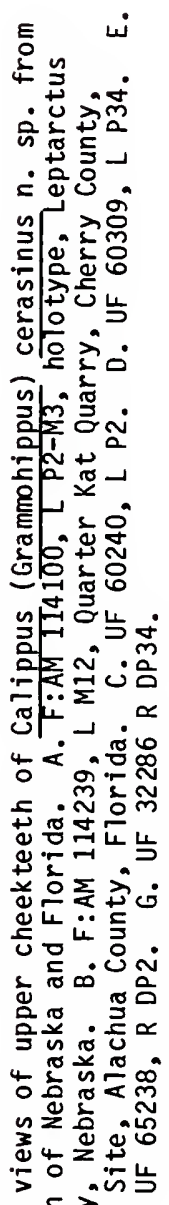

б

ํㅗㄱ동ㅇㅇㅇ

응 엄

ن ئ

ฮั

هن

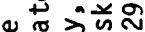

는 용

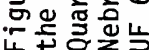




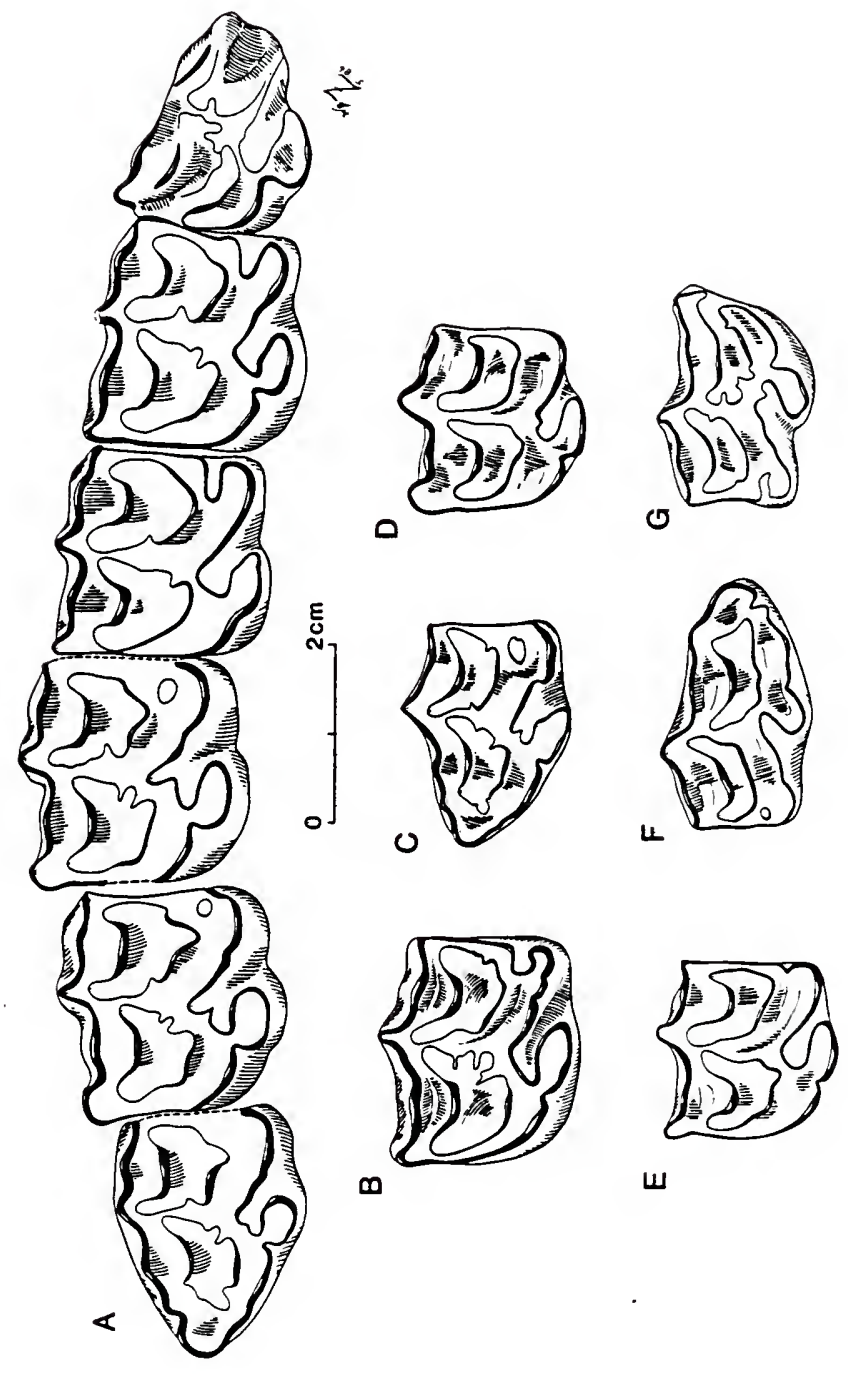




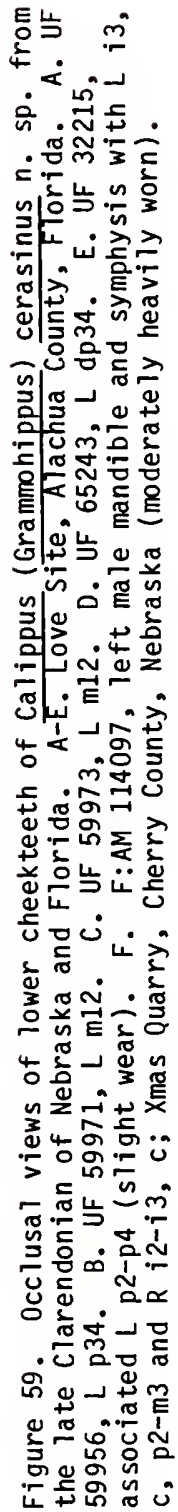



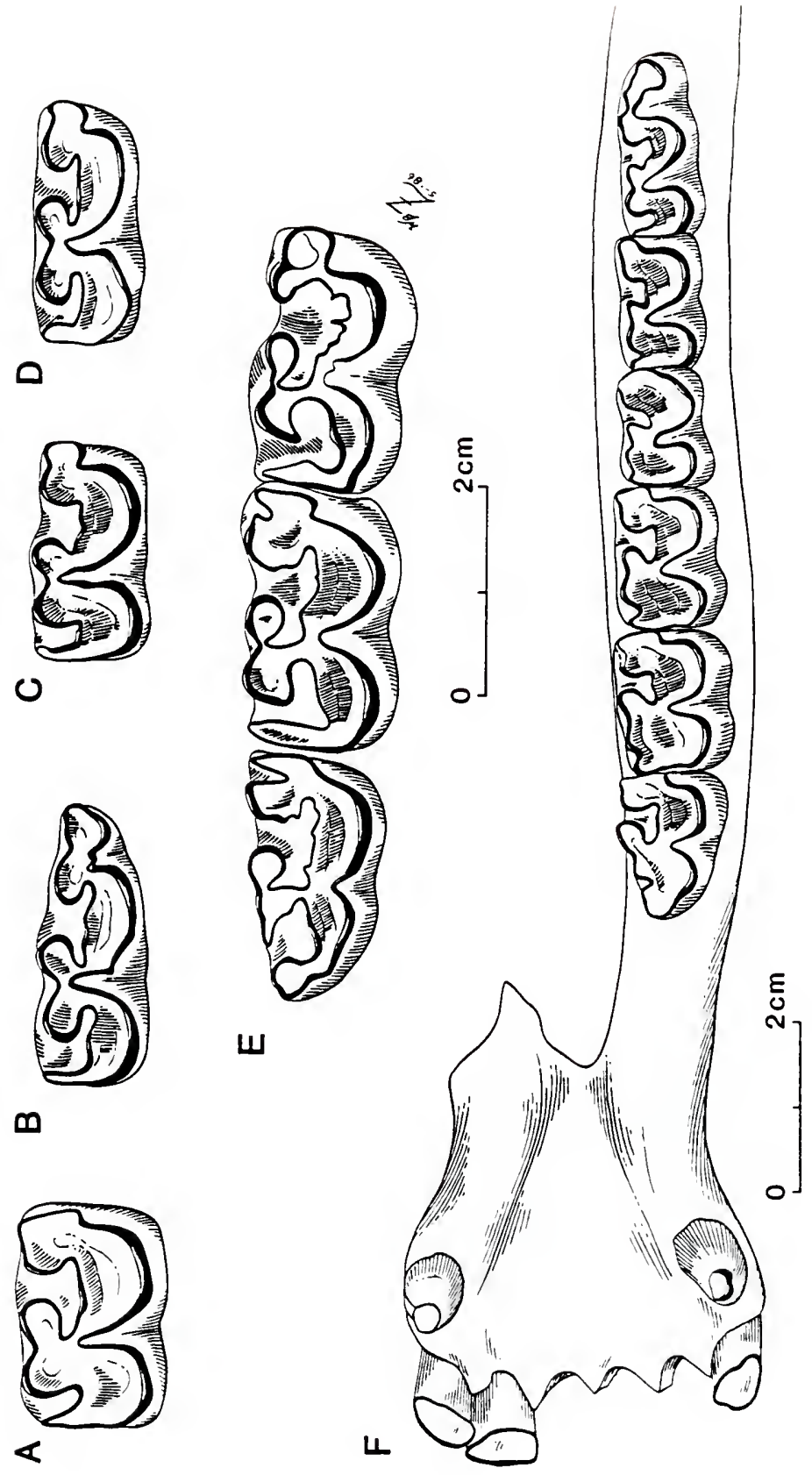
Table 39. Standard univariate statistics for upper cheekteeth of Calippus cerasinus $n$. sp. from the Xmas-Kat Fauna, upper Merritt Dam Member, Ash Hollow Formation, Cherry County, Nebraska (latest Clarendonian) and from the Love Site, Alachua Formation, Alachua County, Florida (latest Clarendonian), and of Calippus hondurensis from the Gracias Fauna, Department of Lempira, Honduras. Format as in Table 2.

\begin{tabular}{|c|c|c|c|}
\hline SPECIES & C. cerasinus & C. cerasinus & C. hondurensis \\
\hline \multirow[t]{2}{*}{ FAUNA } & XMAS-KAT & LOVE & GRACIAS \\
\hline & & P2 & \\
\hline APL & $\begin{array}{l}23.1,1.78,2 \\
21.8-24.3,7.65\end{array}$ & $\begin{array}{l}20.0,1.52,26 \\
17.8-22.9,7.60\end{array}$ & $\begin{array}{l}22.2,0.75,3 \\
21.5-23.0,3.38\end{array}$ \\
\hline BAPL & $\begin{array}{l}18.3,0.35,2 \\
18.0-18.5,1.94\end{array}$ & $\begin{array}{l}16.3,0.80,25 \\
14.5-18.1,4.91\end{array}$ & $18.8,--, 1$ \\
\hline TRW & $\begin{array}{l}16.7,0.76,3 \\
16.2-17.6,4.53\end{array}$ & $\begin{array}{l}16.4,0.78,28 \\
14.7-17.9,4.79\end{array}$ & $\begin{array}{l}16.0,0.42,3 \\
15.7-16.5,2.60\end{array}$ \\
\hline PRL & $\begin{array}{l}4.4,0.15,3 \\
4.2-4.5,3.50\end{array}$ & $\begin{array}{l}4.5,0.39,26 \\
3.9-5.8,8.62\end{array}$ & $\begin{array}{l}4.3,0.12,3 \\
4.2-4.4,2.71\end{array}$ \\
\hline \multirow[t]{2}{*}{ PRW } & $\begin{array}{l}3.6,0.35,3 \\
3.3-4.0,9.76\end{array}$ & $\begin{array}{l}3.6,0.27,25 \\
3.1-4.1,7.32\end{array}$ & $\begin{array}{l}3.7,0.10,3 \\
3.6-3.8,2.70\end{array}$ \\
\hline & & P34 & \\
\hline APL & $\begin{array}{l}18.8,0.64,6 \\
17.8-19.6,3.41\end{array}$ & $\begin{array}{l}17.1,1.07,35 \\
14.7-19.1,6.27\end{array}$ & $\begin{array}{l}17.9,0.75,10 \\
16.6-19.2,4.18\end{array}$ \\
\hline BAPL & $\begin{array}{l}13.8,0.80,3 \\
13.0-14.6,5.81\end{array}$ & $\begin{array}{l}12.7,0.56,29 \\
11.7-14.4,4.37\end{array}$ & $\begin{array}{l}14.9,0.40,6 \\
14.2-15.3,2.69\end{array}$ \\
\hline TRW & $\begin{array}{l}18.8,0.52,6 \\
18.0-19.5,2.77\end{array}$ & $\begin{array}{l}18.2,0.89,34 \\
16.6-19.8,4.90\end{array}$ & $\begin{array}{l}18.5,0.89,12 \\
16.1-19.3,4.81\end{array}$ \\
\hline PRL & $\begin{array}{l}6.5,0.86,6 \\
5.7-7.6,13.40\end{array}$ & $\begin{array}{l}5.7,0.68,33 \\
4.4-7.3,11.84\end{array}$ & $\begin{array}{l}4.7,0.34,12 \\
4.2-5.5,7.20\end{array}$ \\
\hline PRW & $\begin{array}{l}3.9,0.18,6 \\
3.7-4.2,4.53\end{array}$ & $\begin{array}{l}3.6,0.27,32 \\
3.0-4.2,7.53\end{array}$ & $\begin{array}{l}3.7,0.38,12 \\
2.9-4.4,10.18\end{array}$ \\
\hline
\end{tabular}


Table 39--continued

\begin{tabular}{|c|c|c|c|}
\hline \multirow[b]{2}{*}{ APL } & \multicolumn{3}{|c|}{ M12 } \\
\hline & $\begin{array}{l}19.0,0.94,13 \\
17.2-20.8,4.96\end{array}$ & $\begin{array}{l}16.4,1.23,46 \\
13.8-19.4,7.50\end{array}$ & $\begin{array}{l}16.9,0.73,7 \\
15.9-17.9,4.32\end{array}$ \\
\hline BAPL & $\begin{array}{l}13.5,0.63,10 \\
12.5-14.0,4.70\end{array}$ & $\begin{array}{l}12.6,0.60,45 \\
11.6-14.1,4.77\end{array}$ & $\begin{array}{l}14.1,0.40,3 \\
13.7-14.5,2.84\end{array}$ \\
\hline TRW & $\begin{array}{l}17.4,1.41,13 \\
14.0-19.1,8.11\end{array}$ & $\begin{array}{l}17.2,1.05,48 \\
13.3-19.3,6.07\end{array}$ & $\begin{array}{l}17.5,1.02,7 \\
16.0-18.5,5.84\end{array}$ \\
\hline PRL & $\begin{array}{l}6.1,0.44,12 \\
5.5-6.8,7.18\end{array}$ & $\begin{array}{l}5.6,0.67,47 \\
4.3-7.7,11.80\end{array}$ & $\begin{array}{l}5.2,0.69,7 \\
4.2-6.0,13.17\end{array}$ \\
\hline PRW & $\begin{array}{l}3.6,0.27,12 \\
3.1-4.1,7.63\end{array}$ & $\begin{array}{l}3.5,0.34,47 \\
3.0-4.7,9.89\end{array}$ & $\begin{array}{l}3.5,0.41,7 \\
3.2-4.3,11.51\end{array}$ \\
\hline
\end{tabular}


Table 40. Standard univariate statistics for lower cheekteeth of Calippus cerasinus $n$. sp. from the Xmas-Kat Fauna, upper Merritt Dam Member, Ash Hollow Formation, Cherry County, Nebraska (1atest Clarendonian) and from the Love Site, Alachua Formation, Alachua County, Florida (latest Clarendonian), and of Calippus hondurensis from the Gracias Fauna, Department of Lempira, Honduras. Format as in Table 2 .

\begin{tabular}{|c|c|c|c|}
\hline SPECIES & C. cerasinus & C. cerasinus & C. hondurensis \\
\hline FAUNA & XMAS-KAT & LOVE & GRACIAS \\
\hline & \multicolumn{3}{|c|}{ p2 } \\
\hline apl & $\begin{array}{l}18.3,0.60,5 \\
17.5-18.9,3.28\end{array}$ & $\begin{array}{l}16.8,0.92,8 \\
15.8-18.7,5.45\end{array}$ & $\begin{array}{l}20.5,0.85,3 \\
19.6-21.3,4.17\end{array}$ \\
\hline bapl & $-\cdots--$ & $\begin{array}{l}13.2,0.17,4 \\
13.0-13.3,1.32\end{array}$ & $\begin{array}{l}15.5,0.07,2 \\
15.4-15.5,0.46\end{array}$ \\
\hline atw & $\begin{array}{l}7.5,0.85,5 \\
6.2-8.4,11.40\end{array}$ & $\begin{array}{l}7.8,0.35,8 \\
7.2-8.3,4.47\end{array}$ & $\begin{array}{l}7.6,0.25,3 \\
7.3-7.8,3.33\end{array}$ \\
\hline ptw & $\begin{array}{l}10.0,1.08,5 \\
8.5-11.2,10.73\end{array}$ & $\begin{array}{l}10.2,0.46,7 \\
9.5-10.7,4.48\end{array}$ & $\begin{array}{l}10.5,0.12,3 \\
10.4-10.6,1.10\end{array}$ \\
\hline $\mathrm{mml}$ & $\begin{array}{l}6.6,0.71,5 \\
5.4-7.3,10.81\end{array}$ & $\begin{array}{l}6.8,0.59,8 \\
5.8-7.8,8.72\end{array}$ & $\begin{array}{l}7.8,0.36,3 \\
7.4-8.1,4.62\end{array}$ \\
\hline \multirow[t]{2}{*}{ entl } & $\begin{array}{l}6.1,1.80,5 \\
3.5-7.8,29.55\end{array}$ & $\begin{array}{l}5.7,1.06,8 \\
3.9-7.3,18.55\end{array}$ & $\begin{array}{l}7.7,0.32,3 \\
7.3-7.9,4.19\end{array}$ \\
\hline & \multicolumn{3}{|c|}{ p34 } \\
\hline ap 1 & $\begin{array}{l}18.7,1.25,9 \\
16.6-19.9,6.69\end{array}$ & $\begin{array}{l}17.3,1.35,35 \\
15.0-19.8,7.80\end{array}$ & $\begin{array}{l}17.8,0.82,11 \\
16.6-19.1,4.60\end{array}$ \\
\hline bap1 & ---- & $\begin{array}{l}13.4,0.35,22 \\
12.7-14.2,2.63\end{array}$ & $\begin{array}{l}14.5,0.94,5 \\
13.6-16.0,6.52\end{array}$ \\
\hline atw & $\begin{array}{r}10.2,0.97,9 \\
8.9-11.4,9.44\end{array}$ & $\begin{array}{l}10.5,0.72,36 \\
8.7-11.6,6.82\end{array}$ & $\begin{array}{l}10.4,0.89,11 \\
8.1-11.1,8.53\end{array}$ \\
\hline ptw & $\begin{array}{r}10.9,0.80,9 \\
9.8-11.7,7.36\end{array}$ & $\begin{array}{l}10.6,0.84,37 \\
7.8-11.8,7.91\end{array}$ & $\begin{array}{l}10.8,1.00,11 \\
8.3-11.8,9.32\end{array}$ \\
\hline $\mathrm{mm} 1$ & $\begin{array}{l}8.5,0.71,9 \\
7.5-9.4,8.31\end{array}$ & $\begin{array}{l}7.8,0.68,36 \\
6.6-9.2,8.66\end{array}$ & $\begin{array}{l}8.9,0.43,11 \\
8.0-9.6,4.80\end{array}$ \\
\hline nt1 & $\begin{array}{l}7.3,1.61,9 \\
4.3-9.3,21.89\end{array}$ & $\begin{array}{l}6.4,1.39,36 \\
3.9-8.9,21.62\end{array}$ & $\begin{array}{l}6.3,1.29,10 \\
3.9-8.0,20.45\end{array}$ \\
\hline
\end{tabular}


Table 40--continued

\begin{tabular}{llll} 
& \multicolumn{3}{c}{$\mathrm{m} 12$} \\
ap1 & $17.3,2.01,10$ & $17.2,2.24,35$ & $15.7,1.40,12$ \\
& $13.7-20.5,11.61$ & $14.2-22.4,12.97$ & $14.3-19.3,8.92$ \\
bap1 & $13.4,0.35,2$ & $12.6,0.59,27$ & $13.0,0.21,5$ \\
& $13.1-13.6,2.65$ & $11.5-13.8,4.69$ & $12.8-13.3,1.59$ \\
atw & $8.5,0.99,11$ & $8.3,0.66,38$ & $8.5,0.32,12$ \\
& $7.1-10.5,11.60$ & $7.0-9.9,7.89$ & $8.0-9.1,3.82$ \\
ptw & $7.5,0.51,11$ & $7.8,0.60,38$ & $7.3,0.51,12$ \\
& $6.6-8.1,6.75$ & $6.7-9.0,7.65$ & $6.6-8.2,7.04$ \\
mm1 & $6.9,0.58,11$ & $6.7,0.86,36$ & $6.6,0.73,12$ \\
& $5.6-7.5,8.31$ & $4.9-8.5,12.72$ & $5.8-8.3,11.12$ \\
ent1 & $4.1,0.72,11$ & $4.5,0.94,38$ & $3.3,0.47,11$ \\
& $2.7-5.0,17.66$ & $2.8-6.7,20.92$ & $2.6-4.3,14.23$
\end{tabular}


the preprotoconal groove becomes shallow and the protoconal connection widens; further wear accentuates this. The PRL is relatively similar to that of Cal. martini, averaging about 33 to $35 \%$ of APL in P3-M2, and the protocone is similarly oriented in an oblique, anterolabial-posterolingual direction (Fig. 58B). The pli caballin is small and nonpersistent in the premolars, and absent in molars. Fossette plications are also similar in number as those of Cal. martini, but are slightly less persistent with wear, as in Cal. hondurensis. Single, shallow pli protolophs and pli hypostyles are variable in early wear-stages, on ly rarely observed in older individuals. In premolars, the posterior half of the prefossette is the most complex, with from one to four shallow plications in early wear-stages (Fig. 58A); generally zero or one by mid-wear; and unplicated in later wear-stages (Fig. 58D). The anterior half of the postfossette bears at most two shallow plications in early wear (more commonly one or none), these are lost by middle wear-stages. In molars, the pli protoloph and pli hypostyle are rarer, and, if present, less persistent. The inner borders of the fossettes generally have one plication each in early wear-stages; the se are shallow and nonpersistent. The hypoconal groove closes almost at the onset of wear on the P2-P4, forming a lake that persists for about the upper third of the crown, and is then lost at MSCHs of about 30 $\mathrm{mm}$. The M12 of the Xmas-Kat Fauna sample generally retain open hypoconal grooves until late wear-stages. Two individuals (F:AM 114102 and 114130), however, have lost the hypoconal groove at crown heights of 40.0 and $31.0 \mathrm{~mm}$, respectively. The $M 12 \mathrm{~s}$ of the Love Site 
sample tend to lose the hypoconal groove much earlier on average, generally at MSCHs of 32 to $35 \mathrm{~mm}$, although in some it may persist to a MSCH of $26 \mathrm{~mm}$ or less (e.g. UF 60344). In both faunas, the groove of the M12 rarely forms an isolated hypoconal lake (on ly one example from the Love Site sample of about $50 \mathrm{molars}$ ); the structure just becomes increasingly shallow until it disappears. Unworn or slightly worn MSCHs are about $36 \mathrm{~mm}$ for the P2, $47 \mathrm{~mm}$ for the P34 and $50 \mathrm{~mm}$ for the M12.

Deciduous upper premolars (Figs. 58F, 58G) have rudimentary pli cabalions in early wear, that are soon lost. Protocone shape and orientation, styles, and fossette complexity resembles that of permanent premolars. The hypoconal groove is open in very early wear-stages, closes to form a lake, and is lost in late wear-stages. Lower cheekteeth (Table 40; Fig. 59) are smaller than those of Cal. martini, but similar in morphology. The premolars in early wear have the metastylid well separated from the metaconid by the linguaflexid and an anterolingual projection of the entoflexid (Fig. $59 E)$. The metastylid is notably smaller than the metaconid, and it is generally positioned more lingually. The ectoflexid on the p2 is shallow and does not penetrate the isthmus; on the p34, it generally partially penetrates the isthmus, deeper than the labial borders of the metaflexid and entoflexid. With wear, the flexids retract, broadening the dentine confluence of the conids. By latest wear-stages (Fig. 59F, p3), the metaflexid and linguaflexid are particularly shallow. The molars in earliest wear-stages have relatively more expanded metaconids and metastylids than in Cal. 
martini. The lingual flexids are shallower and less well developed than those of the premolars, particularly the entoflexid. The isthmus is completely divided by a deep ectoflexid, that, until it begins to retract in late wear, separates the metaconid and metastylid. Typical of Calippus, the lingual flexids retreat with wear (contrast Figs. 59B, 59C, and $\mathrm{ml}$ of 59F). Protostylids, if present, are restricted to the lower part of the crown and are weak. In the Love site sample, more than $90 \%$ of the $p 3-m 3$ bear not even the slightest trace of a protostylid. Plications are rare, and generally limited to minor pli entoflexids in early wear-stages. The dp2 has a persistently shallow ectoflexid, lacks a pli caballinid or isthmus plications, and has a well developed metaconid. The dp34 differ from those of Cal. martini by having deep ectoflexids and linguaflexids in early wear-stages. Protostylids are more vestigial than in Cal. martini, and ectostylids are absent. Unworn or slightly worn mech are about $30 \mathrm{~mm}$ for p2s, $45 \mathrm{~mm}$ for $\mathrm{p} 34$, and $48 \mathrm{~mm}$ for $\mathrm{m} 12$.

The incisors and muzzle region of Cal. cerasinus are at present best known from mandibular symphyses (e.g. F:AM 114097, Figs. 57B, $59 F)$. They are very similar to those of Cal. martini and Cal. hondurensis. The occlusal surface of the $R$ and $L i 12$ form a straight line, the $i 12$ are large relative to other equids, and the male lower canines are especially massive and conical. The muzzle width appears to be at least $50 \%$ of the UTRL.

$$
\text { Discussion. Calippus cerasinus is closely related to } \underline{\mathrm{Cal}} \text {. }
$$

hondurensis. The two are inseparable on the basis of size (Fig. 56; Tables 39,40 ), and differ on ly in details of cheektooth morphology 
and crown height. The most important of these are length, morphology and orientation of the protocone, the formation of a hypoconal lake on the P34, the strength of the pli caballin, the depth of the ectoflexid on $p 3-m 3$, and the relative size and separation of the metaconid and metastylid on p34. The unworn crown height of Cal. hondurensis cheekteeth are about $10 \%$ greater than those of Cal. cerasinus.

Calippus cerasinus is at present recognized from two faunas that are quite separated from one another geographically, but that seem very close biochronologically (see also Webb et al., 1981; Webb and Hulbert, 1986; Tedford et al., in press). Much of the apparent size differences between the two populations (Fig. 56; Tables 39, 40) are related to differences in age distributions. The Xmas-Kat sample (especially the uppers) includes a greater proportion of younger individuals, which accounts for its greater means for many of the characters. The basal lengths of molars and premolars indicate that individuals from the Xmas-Kat population averaged only about 5 to $8 \%$ larger than those from the Love site. This minor size difference is not considered sufficient to separate the two as distinct species.

\section{$\frac{\text { Cal. (Grammohippus) hon durensis (01 son and McGrew), } 1941}{\text { new combination }}$}

Pliohippus sp., FRICK, 1933, p. 528.

Pliohippus hondurensis $O L S O N$ and MCGREW, 1941, pp. 1232-1235;

WEBB and PERRIGO, 1984, pp. 245, 247-249 (in part). 
Type specimen. WM 1769, palate with R P2-M3 and L P2-P4.

Type locality. Rancho Lobo, $6 \mathrm{~km} \mathrm{NW}$ of Gracias, Department of Lempira, Honduras.

Stratigraphic occurrence and age of type locality. Gracias Formation; early Hemphillian, about 7 to 9 ma.

Topotypic sample. In addition to those 1isted by 01 son and McGrew (1941): F:AM 27029 L maxilla with P2-M3; 27028 L maxilla with P2-M2; 27021 assoc. R and L DP2-DP4; 27030-27032, 270404 mandibutar fragments with teeth; UF 17754 assoc. R P3-M1; UF 17755 assoc. L M1M3; UF 92339 L P2; 92340, 923442 R P34; 92341 R M3; $92342-923432$ L M3; 92326 assoc. R p2-m3; 17758 R p2; 92327-92333 7 R p34; 92347$923482 \mathrm{~L}$ p34; 92334, 92345-92346 $3 \mathrm{R} \mathrm{m12;} \mathrm{17782,} 923382 \mathrm{~L} \mathrm{m12;}$ 92335-92337 $3 \mathrm{~L} \mathrm{m3;} 92349 \mathrm{~L}$ mandibular fragment with $\mathrm{m} 3$. The F:AM sample also includes a number of isolated teeth and post-cranial elements.

Distribution. Early Hemphillian (about 7.0 to $9.0 \mathrm{ma}$ ) of Honduras and Florida. Late (?) Hemphillian of Mexico.

Referred specimens.-Gracias Fauna, Saddle Locality, Honduras (see Webb and Perrigo, 1984, Fig. 3 for location of UF sites in the Gracias Formation of Honduras): UF $92351 \mathrm{~L} \mathrm{M12;} 92350 \mathrm{R} \mathrm{p} 34 ; 17745 \mathrm{~L}$ m12; New Year Locality, Honduras: UF 17774, 92358-92360 4 R P34; 92355-92357 3 L P34; 92361-92364 4 R M12; 92365-92366 2 R M3; 9235292354, 923674 L M3; 92370 R p2; 92372 L p2; 92368-92369 2 R p34; 92373-92374 2 L p34; 92371 R m12; 92375 L m12; El Carrizal Locality, Honduras: UF 92376-92377 2 L P34; 92378-92379 2 R P34; 18017 L m12. Tehuichila Fauna, Hildalgo, Mexico: AMNH 8343 L P34. 
Mixson's Bone Bed, Levy Co., FL: F:AM 113641 L P2; 113642-443643, 1136453 L M12; 113646 R P4; 113648 R M3.

Revised diagnosis. Smaller than Cal. martini or "Pro." castilli, with moderately worn toothrow lengths of about 101 to $112 \mathrm{~mm}$. Unworn M12 MSCH about $55 \mathrm{~mm}$. Protocone smal1, oval, with persistent preprotoconal groove and flattened 1 ingual border. Hypoconal groove shallow; persistently open until late wear-stages in molars; closed earlier in premolars, without hypoconal lakes on P34. Molars with pli caballins in early wear. Ectoflexid generally shallower than in Cal. cerasinus, rarely penetrating isthmus in p2-p4. Large metastylid on p34. Protostylids variably developed.

Description. The facial region of Cal. hondurensis is unknown. The most complete cranial material includes the holotype and $F: A M$ 27029 , both of which preserve on ly the ventral-most portion of the face. The anterior portion of the malar crest is well preserved on F:AM 27029. As in Cal. cerasinus, it is uninflated. Its anterior-most part is directly dorsal to the M1 parastyle.

The cheekteeth of Cal. hondurensis were admirably described by 01 son and McGrew (1941). Of particular note was their attention to ontogenetic variation in enamel morphology. A slight drawback was their failure to distinguish between molars and premolars in their discussion of upper cheekteeth, as they did with the lowers. The following discussion will highlight those features of Cal. hondurensis that differ from those of other members of Cal. (Grammohippus), that allow Florida specimens to be referred to this 
Central American taxon, and that allow it to be placed in Calippus rather than Pliohippus.

As noted by 01 son and McGrew (1941) in their diagnosis, a characteristic feature of Cal. hondurensis is its relatively short protocones (Table 39; Fig. 55C). For the Honduras sample, the P34 protocone length averages $26 \%$ of the APL; the MI protocone, $31 \%$. Those of the premolars in particular are much smaller than those of Cal. martini or Cal. cerasinus, that average between 32 to $36 \%$ of the APL. Other important features are the persistently deep preprotoconal groove and the flattened lingual border of the protocone (Fig. 55C). The difference in the preprotoconal groove between $\mathrm{Cal}$. hondurensis and $\underline{\mathrm{Cal}}$. cerasinus is best judged comparing similarly worn teeth, e.g. Figs. 55C and 580. In Cal. hondurensis, the premolars in early wear-stages have moderately well developed pli caballins, and the molars have small ones; these along with the fossette plications are lost by middle wear-stages. A hypoconal lake is formed only on the $P 2$ in the available F:AM and UF samples. In the P34, the well developed hypoconal groove in early wear becomes progressively shallower with wear, and is generally lost at MSCHs of about $28 \mathrm{~mm}$. The hypoconal groove generally persists in the molars until late wear-stages, although it can be lost in teeth with MSCHs as great as $30 \mathrm{~mm}$. Unworn or slightly worn MSCHs for P34 are about $51 \mathrm{~mm}$ and about $55 \mathrm{~mm}$ for the M12.

Lower cheekteeth (Table 40) differ notably from those of Cal. cerasinus in the greater relative size of the metastylid (especially on slightly worn premolars), in the shallower ectoflexids, and in the 
deeper and more expanded linguaflexids at similar wear-stages.

Protostylids are variably developed, but are generally present on the p3-m3. They usually begin to be expressed on the occlusal surface when crown heights reach from 20 to $30 \mathrm{~mm}$, and can be moderately well developed (e.g. F:AM 27031), although not to the degree of Protohippus or Cal. (Calippus).

The incisor region is best preserved on WM 1771 (01son and McGrew, 1941, Plate 2B). The symphysial region is similar to, but relatively even more massive than, that of Cal. cerasinus (e.g. F:AM 114097), and the male canines are equally massive and conical. The enlarged symphysis and short diastema are characteristic of Calippus.

Discussion. 01 son and McGrew (1941) assigned their new species to the genus Pliohippus, but failed to note any distinctive (i.e. derived) characters that it shared with that taxon. In a brief section discussing relationships, they exclude Nannippus because of its isolated protocones, and "Pro." placidus because of its straighter upper cheekteeth and (supposed) less complex fossettes. Pliohippus upper cheekteeth differ from those of "plio." hondurensis in having rapidly closed hypoconal grooves, very frequent connection of the protocones and hypocones (Skinner et a1., 1977), and are more curved. Connected protocones and hypocones are very rarely observed in Cal. (Grammohippus) populations ( 1 to $2 \%$ of observed molars). Pliohippus lower cheekteeth lost the protostylid in the late Barstovian. "Plio." hondurensis dentally is very similar to Cal.

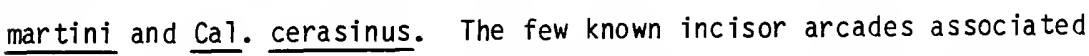
with cheekteeth of "Plio." hondurensis, especially WM 1771, appear to 
show Calippus-1ike features. "P1io." hondurensis is therefore transferred to Cal. (Grammohippus).

The topotypic sample of Cal. hondurensis was derived from fluvial sediments in Honduras. The first major collection was made by Blick in 1929, and later briefly mentioned by Frick (1933) in his description of the proboscideans. 01 son and McGrew (1941) and Webb and Perrigo (1984) reported the presence of $\mathrm{Cal}$. hondurensis not on ly at Rancho Lobo, but at a number of other localities within the Gracias Formation. As noted above, specimens from El Salvador referred to $\mathrm{Cal}$. hondurensis by Webb and Perrigo (1984) are much larger than that species, and have much deeper ectoflexids. They do not represent $\mathrm{Cal}$. hondurensis, but rather some member of the equine clade. Generic identification of the sample will require more complete specimens. A premolar from the Tehuichila Fauna, AMNH 8344, is indistinguishable from topotypes of Cal. hondurensis.

01 son and McGrew (1941) concluded that the age of the Gracias Fauna was Clarendonian, primarily based on the stage of evolution of the equids. McGrew (1944a) later adjusted the age upwards into the Hemphillian based on the presence of Osteoborus cynoides. Webb and Perrigo (1984) reviewed the Gracias Fauna, and confirmed its age as early Hemphillian. The other common equid in the Gracias Fauna is Cormohipparion ingenuum, that was originally described from Mixson's Bone Bed in Florida (see above).

A limited sample of six upper and two lower cheekteeth from Mixson's Bone Bed apparently represent a population of Cal. (Grammohippus) referable to $\mathrm{Cal}$. hondurensis rather than $\mathrm{Cal}$. 
cerasinus. Important features observed in the sample (Fig. 55C; Table 36) are short protocones with flattened labial borders; deep, persistent preprotoconal grooves; and strong pli caballins on premolars. The presence of $\mathrm{Cal}$. hondurensis at Mixson's would seem to confirm a Hemphillian age for the Gracias Fauna.

Cal. (Grammohippus) sp., cf. Cal. hondurensis

Referred specimens. McGehee Farm: UF 17259 L DP34; 9506, 17236A 2 R P34; 17236B L P34; 18323, 166242 L M12; 17237 L M3; 18940 R p34; 17242 R m12.

Haile 19A: UF 45948/47489 assoc. R P2-P4 and L P2-M3; 47322, 657332 partial upper cheekteeth

Discussion. This limited sample of cheekteeth is definitely referable to Cal. (Grammohippus), but is morphologically intermediate between $\mathrm{Cal}$. cerasinus and $\mathrm{Cal}$. hondurensis. Most of the specimens are either heavily worn or broken, thus hindering specific identification. UF 18323 (Fig. 55D) is one of the best preserved specimens, and of the sample it most resembles Cal. cerasinus in its protocone morphology. Others do have better developed and more persistent preprotoconal grooves, as is characteristic of Cal. hondurensis. The lingual border of the protocone varies from rounded as in UF 18323 to slightly flattened as in UF 17236 and UF 17259. The protocone orientation is less oblique than in Cal. cerasinus, but more than in Cal. hondurensis. On UF 52963, the metastylid is relatively large, as in Cal. hondurensis. This sample was referred 
to "Pliohippus" hondurensis by Waldrop (1971), who was the first to recognize the close relationship between the Central American and Florida samples. The McGehee and Haile 19A populations probably represent a slightly older sample within an evolving chronospecies than that of Mixson's, but larger, more complete samples are needed before they can be referred to a species with a high degree of confidence.

The three principal north-central Florida localities of the Archer Fauna (the Love Site, McGehee Farm and Mixson's Bone Bed) otherwise share a common equid fauna at the species level, except for some absences at Mixson's. While other mammalian taxa are similarly shared (e.g. camelids, dromomerycids), others differ (see Chapter 4). The degree of evolution of Cal. (Grammohippus) suggests the relative ages for the three sites are, from oldest to youngest, Love, McGehee and Mixson's.

\section{Cal. (Grammohippus) maccartyi new species}

Pliohippus cf. hondurensis 01 son and McGrew, BECKER, 1985a, p. 29.

Type specimen. UF 69951, badly crushed anterior half of skull of adult male with $R$ and L I1-I3, C, P2 and L P3-M3; assoc. mandibular symphysis and lower cheekteeth, $R$ and $L i 1-i 3, c, p 2$ and $L$ p4-m2. Sku11 and mandible were found in near occlusion and certainly represent a single individual. Collected by R. McCarty on 5 March 1985. 
Type locality. Moss Acres Racetrack Site, $5.8 \mathrm{~km}$ E of Morriston, Marion Co., Florida.

Stratigraphic occurrence and age of type locality. From a massive clay deposit, Alachua Formation; late(?) early Hemphillian, about 7 ma.

Topotypic sample. UF 65249 L DP34; 95407 R P2; 90299 L M12; 95397 R p34; 90287 R m12; 902983 lower cheektooth fragments.

Etymology. Named for Russell McCarty of the Florida State Museum, who collected and prepared the holotype and several of the topotypes. Formation of the species name follows Recommendation 21a of the International Code of Zoological Nomenclature (1964, p. 109). Distribution. Known only from the early, probably late early Hemphillian (about 6.0 to $7.5 \mathrm{ma}$ ) of north-central Florida.

Referred specimens. With 4A: UF $45537 \mathrm{~L} \mathrm{P2;} 17240 \mathrm{R}$ P34; $45540 \mathrm{~L}$ P34; 45535-45536 2 R M12; 45538 L M3; 53460, 534872 R p34; $53463 R$ m12; $61348 \mathrm{R} \mathrm{m3.}$

Diagnosis. Small species of Cal. (Grammohippus) with toothrow lengths of about $100 \mathrm{~mm}$. Preprotoconal groove deep, persistent. Protocones elongated, not short as in Cal. hondurensis; lingual borders rounded to slightly flattened; oriented slightly obliquely. Hypoconal groove open until mid-wear; forms lakes on P2-P4. P1i caballin small, single; fades with wear; vestigial or absent in molars. Plications simple but persistent, not lost until heavy wear. Upper cheekteeth not as curved as other species of Grammohippus. Lower cheekteeth with widely expanded metaconids and metastylids; lingual flexids more persistent than other species; variable 
protostylids; enamel plications in early wear-stages. Ectoflexid shallow on p2-p4, only moderately deep on m1-m3. Muzzle width about $60 \%$ of UTRL.

Description. Calippus maccartyi is as yet known on ly from a small number of specimens, but its dental morphology (especially the lowers) indicates the presence of a distinct species of Grammohippus. The holotype (UF 69951) is one of the five known Tertiary equid specimens from Florida with associated upper and lower dentitions. The other four (two individuals of Nannippus and two of Cormohipparion) are also from the newly discovered Moss Acres Racetrack Site. UF 69951 consists of the anterior (pre-orbital) half of a sku11, but it has been crushed laterally such that no facial characters can be recognized. The specimen does suggest that any fossa was shallow at best. The premaxillary region is the least damaged part of the cranium, but it is still cracked and distorted. The teeth that are present, however, are very we11 preserved, except for the left I3, which has the top $10 \mathrm{~mm}$ of its crown broken off. Much of the mandibular symphysis is preserved intact and undistorted. The incisors display the characteristic Calippus morphology (Fig. 61): i12 are aligned in a straight row; the $i 3$ was originally positioned at a sharp angle to them, but with wear its occlusal surface has become aligned with that of the $i 12$. The width across the $i 3 s$ of UF 69951 is $58.4 \mathrm{~mm}$. Due to the post-mortem crushing, this value is probably within $2 \mathrm{~mm}$ of the true width, and is probably too small (as the teeth are compressed laterally). The diastema between the $i 3$ and $c$ is short $(4.6 \mathrm{~mm})$. The left $c$ is $7.5 \mathrm{~mm}$ long and $6.1 \mathrm{~mm}$ wide. 


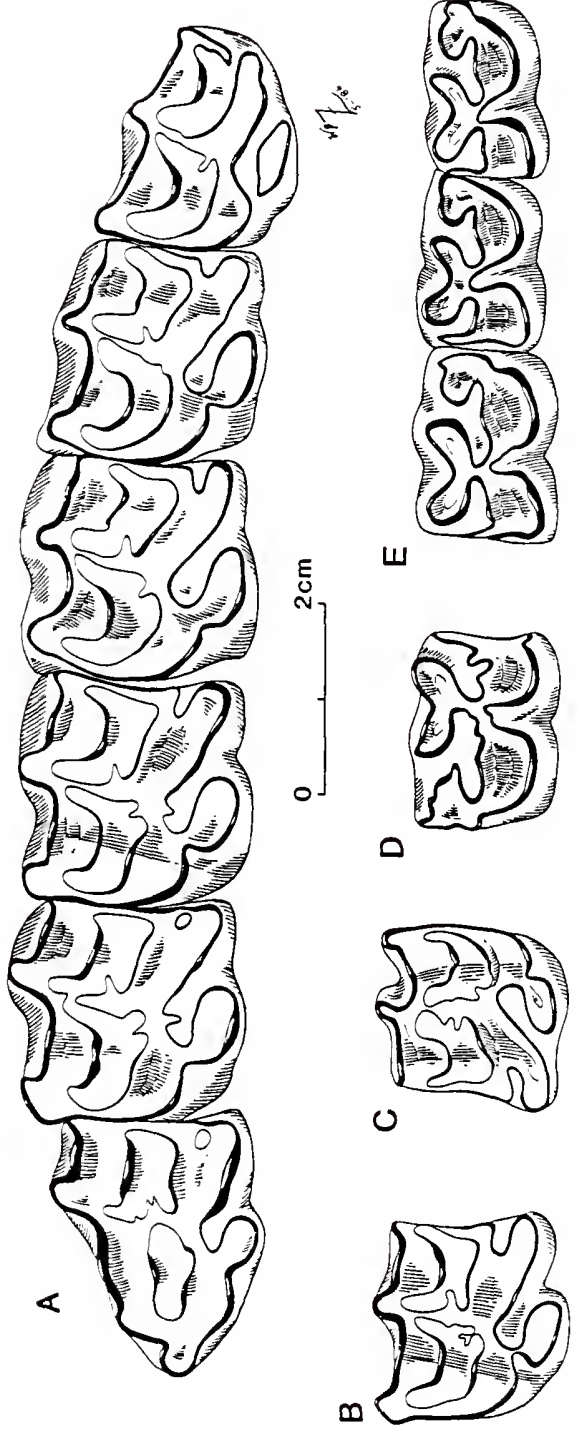

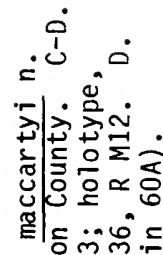

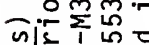

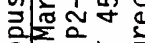
윰는

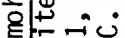
穿然 는 约吉出 잉 उ山 \& 4 는 운들

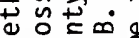
瑝 汹 $\dot{0}$ ฮㄷํㅇ 舟市至

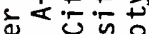

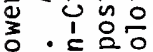
응ㅎㅇ응

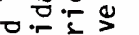

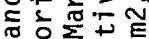
는 立这守它 낭항 윽으-1 4 。年步少 등 苋 을는

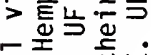

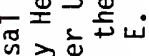

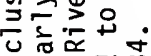

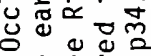

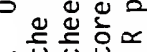

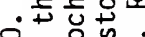
틍 ㄴ 4 닌워

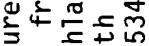
哥. 可高

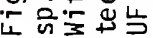




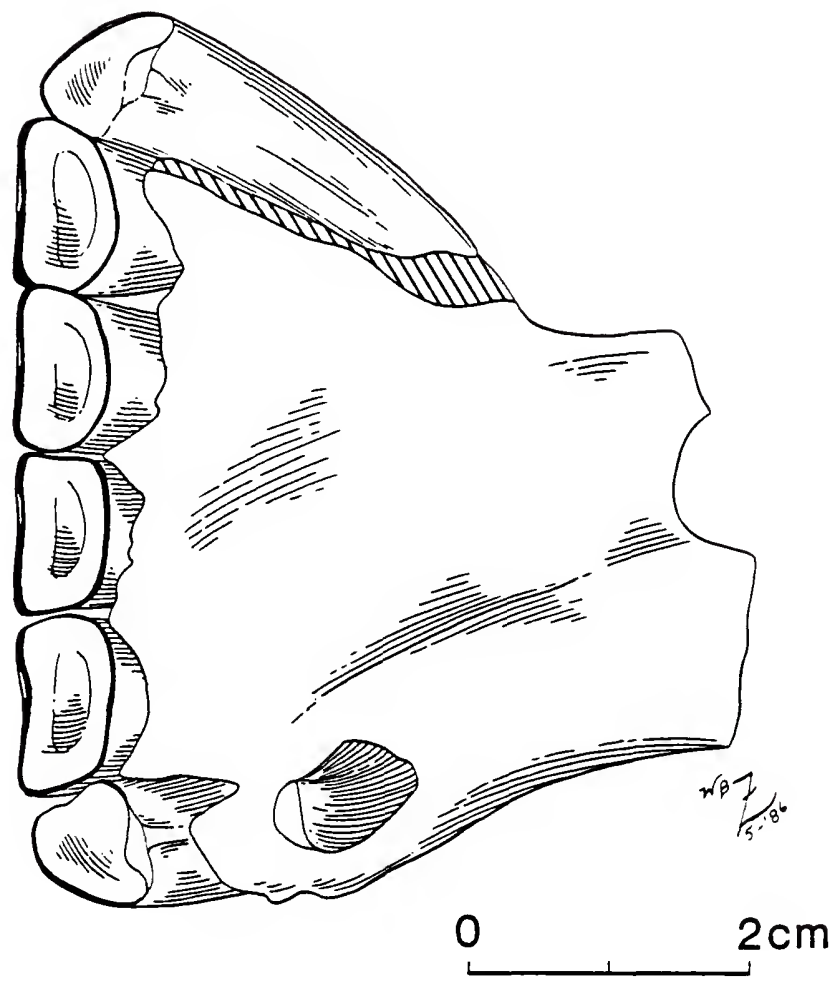

Figure 61. Occlusal view of mandibular symphysis of Calippus (Grammohippus) maccartyi n. sp.; UF 69951, holotype; from Moss Acres Racetrack Site, Marion County, Florida. Teeth present: R i1-i3; L $i 1-i 3, c ; R$ side of symphysis is broken and the $i 3$ has been restored to near its original position. 
Upper cheekteeth of Cal. maccartyi (Table 36; Figs. 60A-60C) are smaller than average-sized individuals of Cal. cerasinus or Cal. hondurensis, but fall within their observed ranges. UF 69951 is an adult, with the occlusal surface of the M3 fully worn, and a MI MSCH of about $27 \mathrm{~mm}$. The P2 of UF 69951 seems relatively more heavily worn, perhaps pathologically, when compared to the other teeth. The P2 protocone is short and rounded, with a broad connection to the protoselene. It has no pli caballin, and the hypoconal groove is a small lake on the left side, while the right side has lost all trace of it. Fossette plications are limited to a vestigial pli prefossette and a single, modest pli postfossette. The metastyle is still relatively prominent. On the less worn UF 95407, there is a small pli caballin, a deep hypoconal groove that is in the process of being closed off by a labial projection from the hypocone, and an oval, very obliquely oriented protocone. The fossettes are also simple, although the single pli prefossette and pli postfossette are deeper than in UF 69951. On the P3 and P4, the protocone is large, more elongate-oval in shape, oriented anterolabial-posterolingually, and with a slightly flattened lingual border (Fig. 60A). The preprotoconal groove is moderately deep, so that the protoconal connection is notably constricted. A single, small pli caballin is present on both the P3 and P4 of the type. The more heavily worn premolars from the referred With 4A sample lack pli caballins, but still have moderate preprotoconal grooves. The P4 of UF 69951 retains an open hypoconal groove, while the $\mathrm{P} 3$ has an isolated lake. The preprotoconal grooves of the M1 and M2 are shallower than those 
of the premolars, thus broadening the protoconal connection, and the protocone is less obliquely oriented (Fig. 60A). The type M1 and M2 both lack a pli caballin, but the less worn UF 90299 has a very small one. The hypoconal groove closes on molars variably during ontogeny; it would close on UF 90299 at a MSCH of about $20 \mathrm{~mm}$, but would be present until late wear on UF 45535. On both M3s the hypoconal groove opens directly into the postfossette, a not uncommon condition in Calippus M3s. The M3 of UF 69951 also has an isolated protocone, a feature not observed in a sample of 25 specimens of Cal. cerasinus from the Love Site. An isolated protocone is rarely observed in M3s of Cal. martini. Molars in early wear-stages (as exemplified by UF 90299) have very deep preprotoconal grooves.

The fossettes of the P3-M3 are similar. A pli hypostyle or pli protoloph are not observed, except during earliest wear-stages. The opposing inner fossette margins are closely appressed (Figs. 60A, $60 \mathrm{~B})$, more so than in other species of Grammohippus. Fossette plications are shallow, unbranching and not numerous, but are retained until the $\mathrm{MSCH}$ reaches about $20 \mathrm{~mm}$ or 1 ess. With the limited sample, unworn crown heights are not directly observable. The specimen with the greatest MSCH (UF 45535, $40.2 \mathrm{~mm}$ ) has formed roots and has a completely worn occlusal surface. Therefore, its unworn crown height would have been at least 5 to $10 \mathrm{~mm}$ greater. ROC of available specimens of Cal. maccartyi varies from 55 to $85 \mathrm{~mm}$, much greater than that of $\mathrm{Cal}$. cerasinus or $\mathrm{Cal}$. hondurensis (their $O R$ is $38-50 \mathrm{~mm})$. The crowns are not as straight as those of Cal. (Calippus), however. 
The lower cheekteeth of Cal. maccartyi (Table 36; Figs. 60D, 60E) are considerably advanced over other species of Grammohippus, with large, widely flairing metaconids and metastylids. They greatly resemble the basic enamel pattern observed in Astrohippus, as the metaconid, metastylid and unpenetrated isthmus form a "Y" (Fig. 60D). In premolars (Figs. 60D, 60E), the ectoflexid is shallow, the labial borders are rounded or only slightly flattened, and the lingual flexids are deep and persistent through much of the crown. The metaconid of the $\mathrm{p} 2$ is large and well developed. In earliest wear-stages, there may be plications extending posteriorly from the isthmus and/or protolophid on both premolars and molars. Molars resemble the premolars more than in any other species of Calippus, but do differ in their deeper ectoflexids and narrower occlusal surfaces. On p3 to $\mathrm{m} 3$, the protostylid is a variably developed ridge that extends to near the top of the unworn crown, and that often becomes more prominent with wear (Fig. 600). Even extremely worn molars (e.g. UF 53463) retain well developed lingual flexids. Discussion. Calippus maccartyi is recognized from only two early Hemphillian localities in north-central Florida. The combined presence of Indarctos and Machairodus at With $4 \mathrm{~A}$ indicate a late early Hemphillian age (Becker, 1985a; Tedford et al., in press). Nejther is present at Moss Acres, but its fauna (Table 1) indicates a similar but younger age than either the Mixson's or McGehee local faunas. Cal. maccartyi represents one of the youngest known species of Cal. (Grammohippus), and is the most dervived in terms of dental evolution. The lower cheekteeth of $\mathrm{Cal}$. maccartyi greatly resemble 
those of Astrohippus, however this is interpreted to represent parallelism and not an especially close phylogenetic relationship (see below). Pseud. simpsoni is a third equid lineage that evolved a similar morphology (Webb and Hulbert, 1986).

Genus Protohippus Leidy, 1858

Protohippus LEIDY, 1858, p. 26.

Type species. Pro. perditus (Leidy), 1858.

Included species. Pro. supremus Leidy, 1869; Pro. gidleyi n. sp. Chronologic and geographic distribution. Late Barstovian through early Hemphillian of Great Plains and Florida; late Barstovian and early Clarendonian of Texas Gulf Coastal Plain; possibly Clarendonian of California.

Revised diagnosis. Medium to large-sized, hypsodont, tridacty 1 equids with toothrow lengths generally between 125 and $145 \mathrm{~mm}$ in mature individuals. MF absent; DPOF large, teardrop-shaped, relatively shallow; distinctly rimmed dorsally and posteriorly in earlier populations, often with a small posterior pocket; less distinct in later populations, without a pocket. Lacrimal bone large, included in posterior region of DPOF. Diastema short; rostrum broad, but not to the degree of advanced species of Calippus; incisors form typical rounded equine arcade. Upper cheekteeth with large, elongate-oval protocones that are isolated from the protoselene to varying degrees during early wear-stages (most prevalent on P34 and M3); moderately large, single pli caballins on P34 (smaller 
and less persistent with wear on molars); simple but relatively persistent fossette plications; hypoconal groove generally remains open until at least middle wear; prominent parastyles on P34. Large protostylids on permanent and deciduous lower cheekteeth. Variabiy developed ectostylids on dp2-dp4.

Discussion. Leidy (1858) first named Protohippus as a subgenus of Equus, but later (e.g. Leidy, 1869) raised it to generic rank. Its wide-spread use in the latter half of the 19th Century is evidenced by Leidy, Marsh and Cope having described 11 species of Protohippus before 1900 (Gidley, 1907). However, many of the se were subsequent7y regarded as synonymous and/or belonging to other genera (Stirton, 1940; Webb, 1969a), and on ly three species of Protohippus are here recognized as valid. In a series of papers based on an increasing number of relatively complete specimens with more accurate locality data, Gidley $(1904 ; 1906 a ; 1907)$ was able to redefine Protohippus and clearly distinguish it from Pliohippus and Merychippus. Gidley's (1907) concepts of Pliohippus and Protohippus were essentially followed by Osborn (1918) and Matthew (1926). McGrew and Stirton (e.g. McGrew, 1938; McGrew and Meade, 1938; Stirton, 1940) proposed a horizontal reorganization of equid genera, in which a number of "primitive" species thought ancestral to a number of advanced genera were a11 transferred to a single genus, Merychippus. Pro. perditus (the genotype) was one of these, and Protohippus was subsumed within Merychippus as a subgenus. The chronologic distribution of species played a major role in determining generic assignments in their scheme. They considered the boundary between the Miocene and 
Pliocene to fall between the Devil's Gulch and Burge Faunas, and all late Miocene non-anchitheriine equids were considered to belong in Merychippus. The characters they used to define Merychippus are all primitive, and can no longer be considered valid reasons for taxonomic grouping. MacFadden and Skinner (e.g. MacFadden and Skinner, 1981; MacFadden, 1984a) have recognized pre-Burge equid populations with Merychippus-grade dentitions as members of advanced genera (Hipparion and Cormohipparion). A similar, vertical repartitioning of the taxa Stirton (1940) assigned to Merychippus (Protohippus) is therefore appropriate, and can be based on the stratigraphicallycontrolled Frick collection of crania and associated dentitions.

\section{Protohippus perditus (Leidy), 1858}

Equus (Protohippus) perditus LEIOY, 1858, pp. 26-27.

Protohippus perditus (Leidy), LEIDY, 1869, Pp. 275-277, GIDLEY, 1906a, pp. 136-139 (in part); GIDLEY, 1907, pp. 882-883 (in part); OSBORN, 1918, pp. 129-130; QUINN, 1955, pp. 19-21 (in part); EVANDER, 1978, p. 41.

Protohippus or Hippotherium profectus COPE, 1889, p. 447. Merychippus perditus (Leidy), COPE, 1892, p. 943; MCGREW and MEADE, 1938, pp. 200-202; STIRTON, 1940, p. 182; HESSE, 1943, pp. 168-169; FORSTEN, 1975, p. 31 . Eoequus wilsoni QUINN, 1955, pp. 54-58.

Merychippus circulus (Quinn), FORSTEN, 1975, pp. 32-35 (in part). 
Type specimen. USNM 619, a $R$ maxillary fragment with P4-M3.

Type locality. Exact locality unknown; from "the valley of the Niobrara River" (Leidy, 1858, p. 20), in Nebraska.

Stratigraphic occurrence and age of type locality. Unknown, but probably from the Valentine Formation (Devil's Gulch or Crookston Bridge Member?) or stratigraphic equivalent; late Barstovian, about $13 \mathrm{ma}$.

Distribution. Late, but not latest, Barstovian (about 12 to 14 ma) of the northern Great Plains and the Gulf Coastal Plain of Florida and Texas.

Referred specimens. Devil's Gulch Fauna, Devil's Gulch Horse Quarry, Brown Co., NB: F:AM 60350-60352, 60358, and 1140675 sku11s; F:AM 114091 mandible with dp2-m2. There are many additional, mostly uncatalogued, crania, mandibles and teeth in the F:AM collection from this fauna. Additional material from the slightly older Crookston Bridge (Evander, 1978) and Norden (Skinner and Johnson, 1984) Faunas is also referable to Pro. perditus, and is principally housed in the UNSM and F:AM collections.

Cold Spring Fauna. Cold Spring l.f., San Jacinto Co., TX: TMM 31219-165 assoc. R DP2-DP4,M1-M2 and L DP2-DP4,M2-M3; -230 partial sku11 with R DP3-DP4,M1-M2 and L DP1-DP4,M1-M2; -61, -328 2 L P2; -253 R P34; $-329,-3302$ L P34; -331, TAMU 30302 R M12; TMM 31219-332 L M12; -333 R M3; -5 L M3; -203 assoc. $R$ and $L$ mandibles with dp2-dp4 (probably same individual as 31219-165); $-43 \mathrm{R}$ mandible with dp2-m1 (probably same individual as 31219-230); -204 $R$ mandible with $\mathrm{p} 4-\mathrm{m} 3 ;-337 \mathrm{~L}$ mandible with $\mathrm{p} 2-\mathrm{m} 1 ;-138 \mathrm{~L}$ assoc. $\mathrm{p} 4-\mathrm{m} 3 ;-168$ 
assoc. (?) L p3-p4; TAMU 3027 R dp4; TMM 31219-334 R p2; -336 R p34; -335, TAMU 3028, $30293 \mathrm{~L}$ p34; TMM 31219-338-340 $3 \mathrm{~L} \mathrm{m12.} \mathrm{Noble} \mathrm{Farm}$ 1.f., Grimes Co., TX: TAMU 3031-3033 3 R P34; 3034 L M12; 3035 L mandible with dp2-m2; $3036 \mathrm{R}$ p34. Chapel Hi11, Washington Co., TX: TMM 31272-8 L M3; Goodrich 1.f., Polk Co., TX: TMM 31183-30, -37 and -66 assoc. skull with $R$ and $L P 2-M 3$ and $R$ and $L$ mandibles with $p 2-m 3$ (holotype, Eoequus wilsoni; Quinn, 1955, Plates 10-13).

Bradley Fauna, Bone Valley Region. Kingsford Mine (Paige No. 1 Dragline): UF 61344 L P4; 95902 R M3.

Revised diagnosis. Slightly smaller and less hypsodont than Pro. supremus, with toothrow lengths of about 120 to $135 \mathrm{~mm}$ and unworn M12 MSCH of about $47 \mathrm{~mm}$. Relatively short postcanine diastema and large DP1. Shorter, more oval protocones than other species of Protohippus; also shorter metaconid-metastylid complexes and entoflexid lengths.

Description. The holotype of Pro. perditus (Osborn, 1918, Fig. 102) lacks precise locality data, and was recovered from a region where vertebrate fossils have been found ranging from the early Miocene to the Pleistocene. A large sample of upper dentitions from the Devil's Gulch Horse Quarry (DGHQ) closely match USNM 619 in size and morphology, and are here referred to Pro. perditus following unpublished work by Morris Skinner. This sample also includes associated mandibles and crania, thus permitting a more complete description of one of the earliest named North American equid species.

The cranial morphology of Pro. perditus is well preserved on several sku11s from the DGHQ, especial1y F:AM 60350 and 60351 . No MF or 
depression is evident on the se specimens, as well as USNM 619 or TMM 31183-30 (Quinn, 1955, Plate 12). The DPOF is large, oval or teardrop-shaped, running from above the anterior half of the $M 3$ to the posterior half of the P3. Its greatest length is about $80 \mathrm{~mm}$; its maximum height measured perpendicular to the latter and just posterior to the IOF is about $45 \mathrm{~mm}$. The posterior and dorsal margins of the DPOF on the lacrimal and nasal bones are well rimmed, and there is a slight posterior pocket. The preorbital bar is narrow (about 13.5 to $15.5 \mathrm{~mm}$ ). The postcanine diastema is shorter than that of Pro. supremus, and the incisor region is only slightly expanded (Fig. 43; the muzzle width is about $38 \%$ of the UTRL). A relatively large DPI (12 to $13 \mathrm{~mm}$ long) is retained with the adult dentition, functionally occludes with the p2, contains several distinct cones and lophs, and resembles those of Pliohippus.

The upper cheekteeth of Pro. perditus (Table 41; Fig. 62A) are characterized by oval (elongate-oval in early wear) protocones that are isolated from the protoselene in very early wear-stages (Quinn, 1955, Plate 10.1 ), but which then rapidly connect. When isolated, the protocones have large anterolabial spurs. Protocones of the premolars are notably shorter than those of the molars. In heavily worn molars, the protocone not uncommonly connects with the hypocone. Fossette plications are relatively simple, and not as numerous as in Pro. supremus or Pro. gidleyi, nor is the prefossette loop so well formed. By moderate wear-stages, on ly a single pli prefossette and pli postfossette remain (Fig. 62A). The hypoconal groove remains open until moderate wear; it may simply fade with wear, or persist as 
an isolated lake. The pli caballin is generally less prominent than in Pro. supremus or Pro. gidleyi, and is frequently absent in moderately worn teeth. The upper cheekteeth are moderately curved, with ROC usualiy about 45 to $55 \mathrm{~mm}$. Examples of measurable slightly worn or unworn teeth are rare. MSCHs for the slightly worn P2 and P3 of TMM 31183-30 are about 36 and $42 \mathrm{~mm}$, respectively. The slightly worn M1 of TMM 31219-230 has a MSCH of $43.3 \mathrm{~mm}$. Two very slightly worn molars from the DGHQ have MSCHs of 42 and $45 \mathrm{~mm}$. Thus unworn MSCH of the M12 probably lies between 45 and $50 \mathrm{~mm}$. The DP2-DP4 resemble the permanent cheekteeth, but the protocone is relatively much shorter, and the fossette plications are more numerous and persistent in early wear-stages (e.g. TMM 31219-165). Small pli caballins are present and the hypoconal groove remains open even in heavily worn DPs.

Lower cheekteeth (Table 42) are typically protohippine, with large protostylids on $\mathrm{p} 3-\mathrm{m} 3$ and $\mathrm{dp} 34$. The metastylid is equal or subequal to the metaconid in size. Permanent premolars in early wear most often have a long isthmus that connects to the metaconid, and the metastylid buds off the metaconid posteriorly and lingually. In some, the ectoflexid can be deep, and penetrate the isthmus to varying depths (this morph is very common in the Cold Spring sample). In the majority of observed premolars from the DGHQ, the ectoflexid is shallow and does not, or only shallowly, penetrate the isthmus, however. The metaflexid contracts rapidly with wear (the primitive protohippine condition), as do the linguaflexid and entoflexid to a lesser degree. The $\mathrm{p} 2$ and dp2 have flattened anterior margins. 
Table 41. Standard univariate statistics for upper cheekteeth of three species of Protohippus: Pro. perditus from the Devil's Gulch Member, Valentine Formation, Brown County, Nebraska (1ate Barstovian); Pro. supremus, combined sample from the Burge Fauna, Valentine Formation and the Minnechaduza Fauna, Ash Hollow Formation, Brown and Cherry Counties, Nebraska (1atest Barstovian - middle Clarendonian); Pro. gidley n. sp. from the Archer Fauna, Alachua Formation, Alachua County, FTorida (latest Clarendonian - early Hemphil1ian); and Pro. gidleyi n. sp. from the Cambridge Fauna (UNSM 10c. Ft-40), Frontier county, Nebraska (late early Hemphillian). Format as in Table 2.

$\begin{array}{lllll}\text { TAXON } & \underline{P} \cdot \underline{\text { perditus }} & \underline{P} \cdot \underline{\text { supremus }} & \underline{P} \cdot \underline{\text { gidleyi }} & \frac{P}{\text { gidleyi }} \\ \text { FAUNA } & \text { DEVIL'S GULCH } & \text { BURGE/MINN. } & \text { ARCHER } & \text { CAMBRIDGE }\end{array}$

P2

\begin{tabular}{lllll} 
APL & $25.9,1.25,5$ & $27.5,1.02,13$ & $25.1,1.02,13$ & $27.3,0.64,2$ \\
& $23.9-27.2,4.82$ & $25.1-28.6,3.72$ & $23.5-27.0,4.05$ & $26.8-27.7,2.34$ \\
BAPL & $19.2,--, 1$ & $\begin{array}{l}22.4,0.83,4 \\
21.6-23.5,3.68\end{array}$ & $\begin{array}{l}20.3,1.07,13 \\
18.7-22.0,5.26\end{array}$ & $-\cdots$ \\
& & & & \\
TRW & $19.3,1.21,5$ & $21.7,1.06,13$ & $19.7,0.81,11$ & $22.2,1.41,2$ \\
& $17.9-20.8,6.27$ & $19.7-22.8,4.86$ & $18.2-20.7,4.10$ & $21.2-23.2,6.37$ \\
\multirow{2}{*}{ PRL } & $5.5,0.53,5$ & $6.0,0.44,13$ & $5.6,0.27,13$ & $6.3,0.42,2$ \\
& $4.9-6.3,9.71$ & $5.2-6.8,7.33$ & $5.1-6.0,4.73$ & $6.0-6.6,6.73$ \\
PRW & $4.7,0.53,5$ & $5.0,0.44,13$ & $4.1,0.23,11$ & $5.3,0.85,2$ \\
& $4.0-5.3,11.36$ & $4.3-6.1,8.88$ & $3.7-4.5,5.56$ & $4.7-5.9,16.01$
\end{tabular}

P34

\begin{tabular}{|c|c|c|c|c|}
\hline APL & $\begin{array}{l}21 \cdot 3,1.90,9 \\
18 \cdot 6-24.9,8.93\end{array}$ & $\begin{array}{l}23.7,1.32,33 \\
20.9-26.0,5.56\end{array}$ & $\begin{array}{l}22.4,1.50,37 \\
19.0-25.2,6.67\end{array}$ & $\begin{array}{l}22.2,2.24,5 \\
18.9-24.9,10.1\end{array}$ \\
\hline BAPI & ----- & $\begin{array}{l}19.2,1.02,12 \\
17.0-20.6,5.33\end{array}$ & $\begin{array}{l}16.3,0.70,36 \\
15.1-18.0,4.31\end{array}$ & $17.7,--, 1$ \\
\hline TRW & $\begin{array}{l}22.6,0.44,9 \\
22.1-23.2,1.95\end{array}$ & $\begin{array}{l}24.3,1.12, \\
20.8-25.9,\end{array}$ & $\begin{array}{l}22.3,0.98,37 \\
20.3-24.1,4.42\end{array}$ & $\begin{array}{l}23.3,1.07,5 \\
22.6-25.2,4.60\end{array}$ \\
\hline PRL & $\begin{array}{l}7.3,0.73,9 \\
6.0-8.5,10.04\end{array}$ & $\begin{array}{l}7.8,0.89,33 \\
6.3-10.7,11.42\end{array}$ & $\begin{array}{l}8.1,0.97,38 \\
6.4-9.9,12.02\end{array}$ & $\begin{array}{l}8.8,1.45,5 \\
7.0-10.2,16.5\end{array}$ \\
\hline 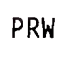 & $\begin{array}{l}4.6,0 . \\
3.6-5 .\end{array}$ & $\begin{array}{l}4.8,0.24,32 \\
4.5-5.4,5.03\end{array}$ & $\begin{array}{l}4.5,0.29,38 \\
3.9-5.4,6.40\end{array}$ & $\begin{array}{l}5.1,0.5 \\
4.5-6.0\end{array}$ \\
\hline
\end{tabular}


Table 41--continued

M12

APL $20.1,1.77,11 \quad 23.0,1.87,42$

$16.9-23.1,8.83 \quad 20.0-27.3,8.14$

$21.0,1.35,32 \quad 22.4,2.72,11$

$17.4-23.2,6.43$

$18.1-26.8,12.1$

BAPL 15.0,-- ,1

$18.5,0.70,16$

$17.3-19.9,3.79$

$15.5,0.88,30$

$13.9-17.8,5.70$

$18.4,0.74,6$

$17.8-19.7,4.02$

TRW

$\begin{array}{ll}21.5,0.80,11 & 22.5,1.46,44 \\ 19.9-22.8,3.72 & 18.0-24.7,6.50\end{array}$

$20.5,1.06,32$

$18.5-22.5,5.18$

$22.3,1.00,11$

$8.0,0.84,11$

PRL

$8.0,0.84,11$
$6.7-9.2,10.5$

$8.7,0.99,43$

$7.1-10.5,11.31$

$8.0,0.81,33$

$6.5-10.0,10.08$

$8.2,1.31,11$

$4.5,0.49,11$

$3.6-5.2,10.84$

$4.5,0.49,43$

$4.2,0.32,32$

$3.7-4.8,7.44$

$6.6-10.6,13.8$

PRW

$3.2-5.5,10.80$

$4.9,0.36,11$

4. 4-5.3,7.29 
Table 42. Standard univariate statistics for lower cheekteeth of three species of Protohippus. Same populations as in Table 41. Format as in Table 2 .

TAXON $\underline{P}$. perditus $\quad \underline{P}$. supremus $\quad \underline{P} \cdot \underline{\text { gidleyi }} \quad \underline{P} \cdot \underline{\text { gidleyj }}$

FAUNA DEVIL'S GULCH BURGE/MINN. ARCHER CAMBRIDGE

p2

\begin{tabular}{|c|c|c|c|c|}
\hline 1 & $\begin{array}{l}21.5,0.84,19 \\
19.9-22.9,3.92\end{array}$ & $\begin{array}{l}23.2,1.14,8 \\
21.8-24.7,4.93\end{array}$ & $\begin{array}{l}22.0,1.05,12 \\
20.7-24.4,4.79\end{array}$ & $\begin{array}{l}23.4,1.61,6 \\
20.7-25.5,6.87\end{array}$ \\
\hline apl & ---- & ----- & $\begin{array}{l}7,9 \\
4,4.79\end{array}$ & $\begin{array}{l}19.5,0.72,5 \\
18.7-20.6,3.68\end{array}$ \\
\hline$W$ & $\begin{array}{l}8.8,0.87,19 \\
6.9-10.4,9.94\end{array}$ & $\begin{array}{l}9.00 .79,8 \\
8.1-10.4,8.78\end{array}$ & $\begin{array}{l}9.2,0.46,11 \\
8.4-9.7,5.01\end{array}$ & $\begin{array}{l}9.8,0.19,6 \\
9.5-10.0,1.92\end{array}$ \\
\hline tw & $\begin{array}{l}11.3,0.91,19 \\
9.0-12.8,8.01\end{array}$ & $\begin{array}{l}11.8,0.49,8 \\
11.1-12.4,4.12\end{array}$ & $\begin{array}{l}11.8,0.77,12 \\
10.3-12.7,6.56\end{array}$ & $\begin{array}{l}12.5,0.60,6 \\
12.0-13.5,4.79\end{array}$ \\
\hline $\mathrm{ml}$ & $\begin{array}{l}6.1,0.90,19 \\
4.3-7.7,14.76\end{array}$ & $\begin{array}{l}6.9,0.91,8 \\
5.5-8.2,13.18\end{array}$ & $\begin{array}{l}8.4,0.62,12 \\
6.8-9.3,7.41\end{array}$ & $\begin{array}{l}9.6,1.18,6 \\
8.2-11.4,12.3\end{array}$ \\
\hline+ & $\begin{array}{l}6.9,1.45,19 \\
4.1-8.9,21.22\end{array}$ & $\begin{array}{l}8.2,1.56,8 \\
5.8-10.0,19.04\end{array}$ & $\begin{array}{l}9.2,1.26,12 \\
6.5-11.7,13.65\end{array}$ & $\begin{array}{r}10.2,1.86,6 \\
6.6-11.5,18.2\end{array}$ \\
\hline & \\
\hline 7 & $\begin{array}{l}22.1,1.06,31 \\
20.2-24.9,4.81\end{array}$ & $\begin{array}{l}23.6,1.41,25 \\
20.8-25.7,5.98\end{array}$ & $\begin{array}{l}21.5,1.19,47 \\
19.1-24.7,5.54\end{array}$ & $\begin{array}{l}23.3,0.77,9 \\
21.8-24.5,3.29\end{array}$ \\
\hline apl & ---- & $\begin{array}{l}19.5,0.52,9 \\
18.8-20.3,2.67\end{array}$ & $\begin{array}{l}16.7,0.70,30 \\
15.4-18.2,4.18\end{array}$ & $\begin{array}{l}19.2,1.13,7 \\
17.7-21.1,5.90\end{array}$ \\
\hline 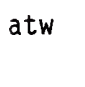 & $\begin{array}{l}12.0,1.12,31 \\
9.5-14.7,9.36\end{array}$ & $\begin{array}{l}12.5,0.92,25 \\
10.8-14.4,7.38\end{array}$ & $\begin{array}{l}12.6,0.63,47 \\
11.1-14.0,5.01\end{array}$ & $\begin{array}{l}13.2,0.61,9 \\
12.3-14.0,4.60\end{array}$ \\
\hline tw & $\begin{array}{l}12 \cdot 6,1.02,31 \\
10.2-14.4,8.10\end{array}$ & $\begin{array}{l}13.3,0.71,25 \\
12.2-14.9,5.38\end{array}$ & $\begin{array}{l}12.1,0.64,46 \\
10.8-13.8,5.28\end{array}$ & $\begin{array}{l}13.2,0.67,9 \\
12.0-13.9,5.12\end{array}$ \\
\hline $\mathrm{m} 7$ & $\begin{array}{l}10.1,0.47,31 \\
9.0-11.2,4.61\end{array}$ & $\begin{array}{l}10.7,0.55,25 \\
9.7-12.0,5.07\end{array}$ & $\begin{array}{l}11.1,0.55,47 \\
10.0-12.4,4.91\end{array}$ & $\begin{array}{l}12.5,0.65,9 \\
11.7-13.4,5.15\end{array}$ \\
\hline & $\begin{array}{l}7.7,1.68,31 \\
4.3-10.5,21.89\end{array}$ & $\begin{array}{l}9.4,1.78,25 \\
5.4-12.6,18.87\end{array}$ & $\begin{array}{l}8.5,1.17,47 \\
3.7-10.0,13.79\end{array}$ & $\begin{array}{l}10.6,0.28,9 \\
8.2-12.3,12\end{array}$ \\
\hline
\end{tabular}


Table 42--continued

m12

ap1 $20.8,1.90,38$

$23.0,2.23,23$

bapl $17.1-25.8,9.11$

$19.0-26.4,9.71$

$21.0,2.03,64$

$23.1,1.99,11$

$19.1,0.25,5$

$18.7-19.3,1.30$

$15.9,0.52,44$

$15.0-16.9,3.30$

$18.6,0.79,6$

$17.2-19.5,4.25$

atw $\quad \begin{aligned} & 10.0,1.00, 38 \\ & 7.9-12.4,9.96\end{aligned}$

$10.2,0.82,23$

$8.2-11.3,8.04$

$10.6,0.58,64$

$8.6-11.6,5.45$

$10.8,1.01,10$

$8.5,0.70,38$

$6.9-9.9,8.23$

$8.6,0.47,23$

$7.8-9.5,5.41$

$8.7,0.54,65$

$6.9-9.8,6.22$

$9.1-12.6,9.39$

ptw

$\begin{array}{ll}\mathrm{mm} 1 & 8.6,0.54,37 \\ & 7.7-10.5,6.26\end{array}$

$\begin{array}{ll}m m 7 & 8.6,0.54,37 \\ & 7.7-10.5,6.26\end{array}$

$9.4,0.63,23$

$8.2-10.6,6.65$

$9.3,0.79,66$

$7.8-11.7,8.50$

$9.0,0.59,10$

$8.0-9.9,6.54$

$5.5,1.22,23$

$\begin{array}{ll}\text { ent1 } & 4.4,1.27,38 \\ & 1.0-7.0,29.18\end{array}$

$3.5-8.3,22.18$

$6.4,1.25,65$

$2.2-9.7,19.47$

$10.5,0.84,11$

$9.0-11.7,8.01$

$3.5-8.3,22.18$

$7.8,1.31,11$

$5.2-9.4,16.77$ 
Figure 62. Occlusal views of upper cheekteeth of Protohippus from Florida. A. UF 61344, Pro. perditus, L P4, Kingsford Mine, Bradley Fauna (late Barstovian), Polk County. B. UF 28553, Pro. supremus, L P4, Grey Zone, Phosphoria Mine, Agricola Fauna (early Clarendonian), Polk County. C-F. Pro. gidleyi n. sp., Love Site, latest

Clarendonian, Alachüa County. C. UF 62482, L P2. D. UF 62497, R P34. E. UF 62500, R P34. F. UF 62540, R M12. 
A

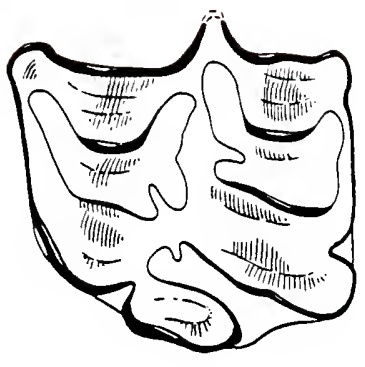

C

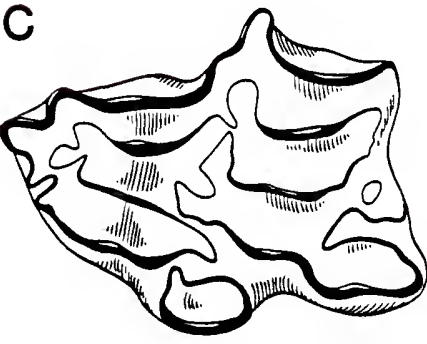

E

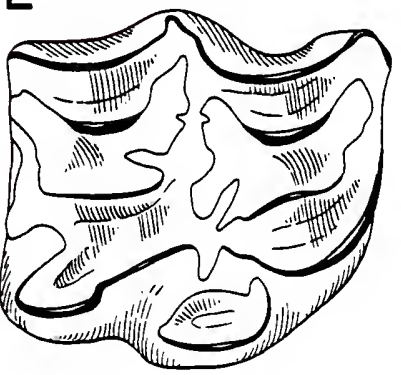

0
B
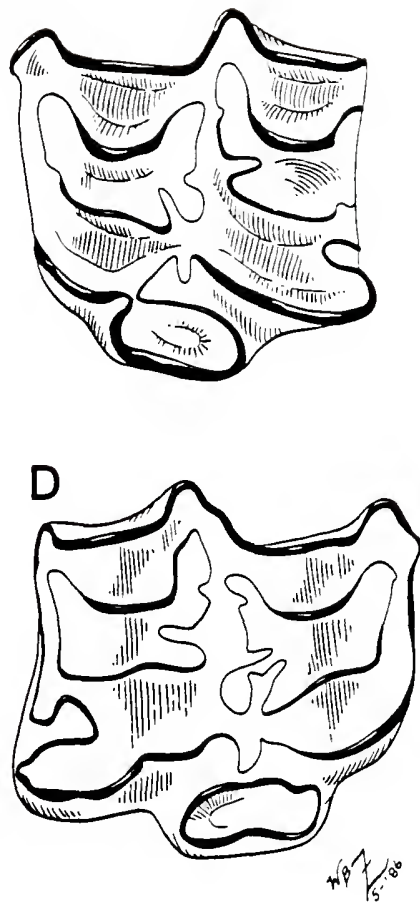

F

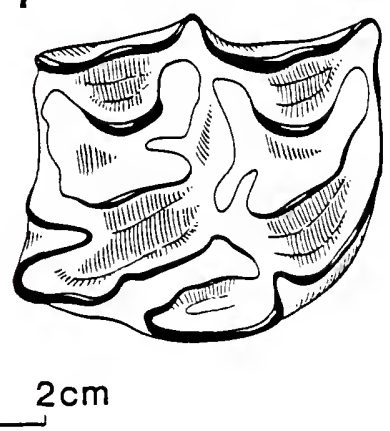




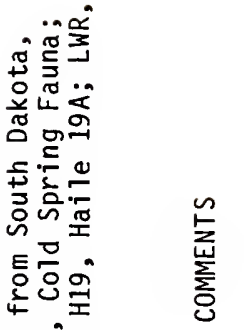

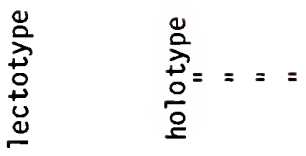

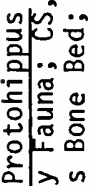

$4 \frac{1}{8}=$

ㅇํㅇㅇำ

$\therefore \frac{\pi}{\infty} \times \infty$

屯我

岃

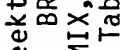

议

过

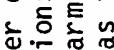

य地

음

권 동

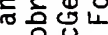

< के

远

I

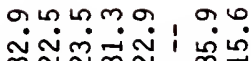

+\% mNNm m传 \&m

ஸ்

$\frac{1}{0}$

$m \pi n \infty \infty, n$

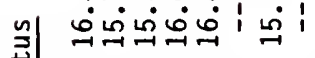

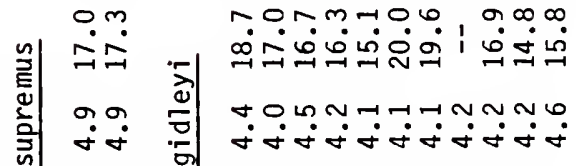

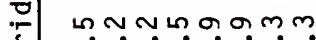

$\frac{3}{\alpha}$

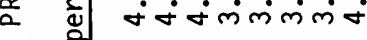

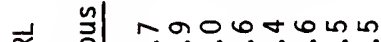

$\frac{\alpha}{\alpha}$

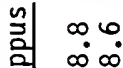

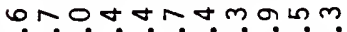

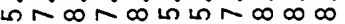

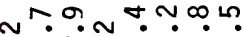
$\underset{\sim}{\sim} \sim \underset{\sim}{\sim} \dot{\sim} \dot{\sim} \dot{\sim} \dot{\sim}$

의

Nㅡ

- N $\dot{\sim} \underset{\sim}{\sim} \dot{\sim} \dot{\sim} \dot{\sim} \dot{\sim} \dot{\sim} \dot{\sim} \dot{\sim} \dot{\sim}$

$+2$ ณ ம

$\nabla$ 西学

$\frac{1}{2}$

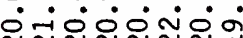

ن்

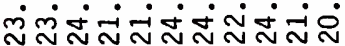

U $\nabla$ 두

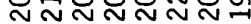

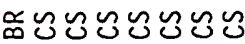

呂导

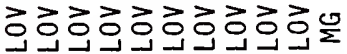

$4=$

0 \%

n

더넌

岳 楁

施要

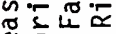

运迸宁

m 을 토

m $\frac{1}{\sigma}$

๑ $\sim \frac{0}{0}$

둥

$\stackrel{్}{0}$

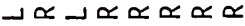

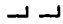

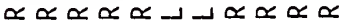

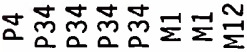

অ্

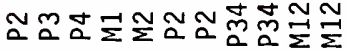

กึ: ó

ด्ञ

m

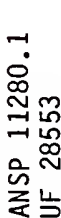

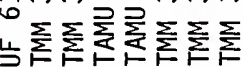

nmmmm

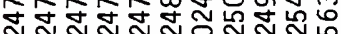
ฟิ

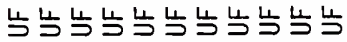




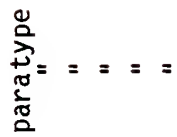

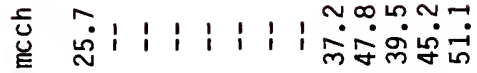

- $111111,1,150 \%$ 응 | | | | | | | | | | -

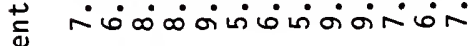
镸 z mषm\&nTm

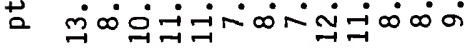
$3 \quad \infty 6 \infty m$ )

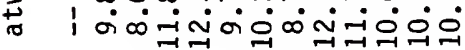

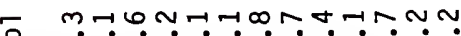

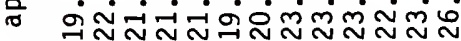

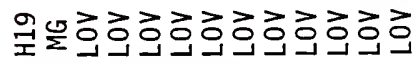
\lrcorner$\propto \propto \propto \propto \propto \propto \propto \propto \propto \propto \propto-$

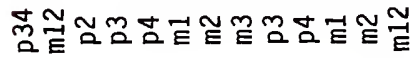

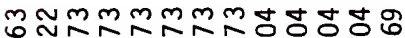

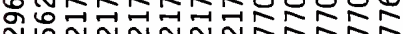
กี

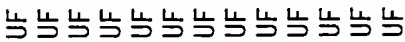


Table 44. Comparison of cranial character states of Protohippus and Pliohippus.

\begin{tabular}{|c|c|c|}
\hline CHARACTER & Pro. perditus & Pro. supremus \\
\hline Malar fossa & absent & absent \\
\hline DPOF & large, shallow & large, v. shallow \\
\hline Muzzle width & slightly enlarged & en larged \\
\hline $\begin{array}{l}\text { Protocone con- } \\
\text { nection }\end{array}$ & $\begin{array}{l}\text { occassionally isolated } \\
\text { in early wear }\end{array}$ & $\begin{array}{l}\text { often isolated } \\
\text { with spur }\end{array}$ \\
\hline Protocone shape & oval & $\begin{array}{l}\text { oval to elongate- } \\
\text { oval }\end{array}$ \\
\hline Fossette complexity & simple to moderate & $\begin{array}{l}\text { moderate, } \\
\text { persistent }\end{array}$ \\
\hline Pli caballin & moderate & strong \\
\hline Radius of curvature & $45-50 \mathrm{~mm}$ & $50-55 \mathrm{~mm}$ \\
\hline Hypoconal groove & closed with moderate wear & $\begin{array}{l}\text { closed after } \\
\text { heavy wear }\end{array}$ \\
\hline $\mathrm{M} 12 \mathrm{MSCH}$ & $45 \mathrm{~mm}$ & $55 \mathrm{~mm}$ \\
\hline protostylid (p3-m3) & well developed & well developed \\
\hline protostylid (dp34) & well developed & well developed \\
\hline ectostlid (dp2-dp4) & present & present \\
\hline $\begin{array}{l}\text { metastylid size } \\
\text { relative to } \\
\text { metaconid }\end{array}$ & slightly smaller & equal \\
\hline Referred samples & $\begin{array}{l}\text { Devil's Gulch, Crookston } \\
\text { Bridge, Norden, Cold Spring } \\
\text { and Bradley Faunas }\end{array}$ & $\begin{array}{l}\text { Burge, Minnecha } \\
\text { duza, Clarendon, } \\
\text { Lapara Creek and } \\
\text { Agricola Faunas }\end{array}$ \\
\hline
\end{tabular}


Plio. mirabalis

present, often pocketed

large, deep, well pocketed

norma 1

rarely isolated and only in ear liest wear-stages

rounded to oval

very simple

sma11, not persistent

$35-40 \mathrm{~mm}$

closed with slight wear

$53 \mathrm{~mm}$

rudimentary or absent

rudimentary

absent

smaller

Devil's Gulch and Crookston Bridge

Faunas
Plio. pernix

well developed

large, deep, pocketed

normal

very rapidly connected;

very rarely isolated

oval or elongate-oval

very simple

sma11, not persistent

$35-40 \mathrm{~mm}$

closed with slight wear

$58 \mathrm{~mm}$

generally absent

generally absent

absent

smaller

Burge, Minnechaduza, Big

Spring Canyon, Snake

creek, clarendon and

Lapara Creek Faunas 
Molars greatly resemble those of Cal. martini, except for the strong protostylids, slightly larger metastylids, and lesser mcch. The moderately well-cemented deciduous lower premolars are characterized by deep linguaflexids and ectoflexids that nearly divide the tooth. With wear, the linguaflexid retreats, along with the metaflexid leaving a broad area of confluence between the metastylid, metaconid and protoconid. Moderate wear exposes large ectostylids on the dp2-dp4, that rise about 5 to $6 \mathrm{~mm}$ above the base of the crown. Heavier wear reveals hypostylids that are especially well developed on the dp3.

Discussion. Protohippus perditus has long been recognized as a characteristic member of the fauna from lower units of the valentine Formation (McGrew and Meade, 1938). As noted above, Gidley's (1907) "neotype" of Pro. perditus (AMNH 10838) is instead referable to Cal. martini. The relatively complete referred material from the Valentine Formation allows a better understanding of Pro. perditus, and aids the generic diagnosis. The referred specimens from the Gulf Coastal Plain, including the type of "Eoequus" wilsoni and UF 61344, resemble those from the DGHQ and USNM 619 in size, hypsodonty, and general dental morphology (Table 43; Fig. 62A), and indicate that the species was wide-spread during the late Barstovian.

Protohippus profectus was recovered along with the type of Pseud. retrusum (Cope, 1889), which suggests a late Barstovian age. It is synonymized with Pro. perditus rather than Pro. supremus because of its smaller size, weak fossette plications, and less well developed pli caballins. In the lower units of the Valentine Formation, Pro. 
perditus is found with the slightly larger plio. mirabilis (Leidy, 1858). Pliohippus mirabilis differs from Pro. perditus in its very deep DPOF, its well developed MF, and a number of dental characters outlined in Table 44. The two cannot be synonymous, as was proposed by Stirton (1940, p. 182).

Protohippus supremus Leidy, 1869

Protohippus supremus LEIDY, 1869, p. 328 (in part). Protohippus simus GIDLEY, 1906a, pp. 139-140; GIDLEY, 1907, pp. 925-926; OSBORN, 1918, pp. 136-138.

Pliohippus supremus (Leidy), GIDLEY, 1907, pp. 889-890 (in part); OSBORN, 1918, pp. 150-151; STIRTON, 1940, p. 192; QUINN, 1955, pp. 24-26 (in part); WEBB, 1969a, pp. 83-95 (in part); FORSTEN, 1975, p. 53.

Pliohippus simus (Gidley), MCGREW and MEADE, 1938, p. 201; STIRTON, 1940, p. 192.

Hippotigris sellardsi QUINN, 1955, pp. 46-48.

Hippotigris clarendonensis QUINN, 1955, 49-50.

Hippotigris parastylus QUINN, 1955, pp. 50-51.

Pliohippus martini (Hesse), FORSTEN, 1975, pp.48-53 (in part).

Pliohippus (Pliohippus) cf. Plio. supremus (Leidy), FORSTEN, 1975, pp. 53-61 (in part).

Lectotype specimen. ANSP 11280.1, a slightly worn L P34.

Selected by Gidley (1907) from the syntypic series, he referred to it as a M1, but his measurements clearly indicate which specimen he 
chose as the lectotype, as later figured by 0sborn (1918, Fig. 118.2).

Type locality. Exact locality unknown, Little White River region, South Dakota.

\section{Stratigraphic occurrence and age of type localtiy. Probably}

Clarendonian deposits of the Ogallala Group; about 10 to $11 \mathrm{ma}$. Distribution. Latest Barstovian and Clarendonian of northern Great Plains (about 10.0 to $12.0 \mathrm{ma}$ ); Clarendonian of southern Great Plains, Gulf Coastal Plain of Florida and Texas.

Referred specimens. Little White River region, SD: AMNH 980 partial skull with R I3, R and L DP1-M3 (type, Pro. simus); AMNH 10871 L maxilla with P2-P4, M2-M3.

Burge Fauna, Cherry Co., NB. Burge Quarry: F:AM 60356 skul1 with $R$ and L DP 1-M3; 108187, 114058-114063 7 maxillae or palates; 60353, 603572 assoc skulls, R and L rami. Midway Quarry: F:AM 60354 assoc. sku11, $R$ and $L$ rami.

Clarendon Fauna, Don ley Co., TX. MacAdams Quarry: F:AM 111728 assoc. skull and rami. C. Risley Ranch Site: TMM 255-29 R mandible with p3-m3 (type, $\underline{H}$ clarendonensis); 255-17 L m12.

Lapara Creek Fauna. Bridge Estate Site, Bee Co., TX: TMM 31132-284D R P34; -541, -542 2 R M12; -459 L mandible with p2-m3 (type, ㅂ. parastylus); -335 assoc. p4,m2-m3; $-237 \mathrm{~L}$ m12. Buckner Ranch Site, Bee Co., TX: TMM 30896-503 assoc. R and L P2-M3 (type, H. sellardsi); -206 and -541 assoc. mandibles with $R$ p3-m3 and $L$ p2-m3; $-240,-4762$ R mandibles with dp2-m1; $-420 C, F$ assoc. L m2-m3; -447 R p34; -420G L p34. Farish Ranch Site, Bee Co., TX: TMM 
31081-1183 L p34; -664 R mandible with p2-m3; -168E, F assoc. p4-m1; -1210 L p2.

Agricola Fauna, Bone Valley Region. Gray Zone, Phosphoria Mine: UF 28553 L P34. Nichols Mine: UF 25125 R P4.

Revised diagnosis. Large Protohippus with toothrow lengths of about 130 to $145 \mathrm{~mm}$, and unworn molar crown heights of about $54 \mathrm{~mm}$. Larger and more hypsodont than Pro. perditus, with a broader muzzle, smaller (on average) DP1, more elongate protocone, and more complex fossette plications. Hypoconal groove present until late wearstages; forms lake on premolars. Protocones isolated from protoselene in early wear-stages of P3-M2, until moderate wear on M3; not as isolated as those of Pro. gidleyi. Metastylid large, well separated from metaconid by well developed, persistent lingual flexids.

Description. Based on AMNH 9820 (holotype, Pro. simus) and a number of crania from the Burge Member of the Valentine Formation, the facial region of Pro. supremus greatly resembles that of the genotypic species, Pro. perditus. No MF is present. The OPOF is approximately the same size and in the same position as in Pro. perditus, but it is notably shallower and less well-rimmed (Osborn, 1918, Plate 21.1). The Burge specimens retain a well defined posterior rim and a very slight pocket. Clarendonian specimens (e.g. AMNH 9820 and F:AM 111728) have an even shallower and less well defined DPOF without a posterior pocket, but are otherwise identical to the latest Barstovian population. As noted by Gidley (1906a) in his description of Pro. simus, the muzzle is very broad (about $45 \%$ of the UTRL), much greater than that of a similarly-sized, typical equid 
(Fig. 43). The first two incisors are not linearly arranged, as in Calippus, but are slightly arcuate.

The upper cheekteeth of Pro. supremus (Tables 41, 43; Figs. 62B, 63) have very strong styles, including a well developed metastyle. The P2 has a shorter, rounder protocone than the other teeth; it is connected to the protoselene in all known specimens. The fossettes of the P2 tend to be simpler, and the hypoconal grooves close earlier than in the P34. The P34 have large, widely-open parastyles and mesostyles, and small metastyles that are retained until late wearstages. The protocone of the P34 is elongate, with wear it becomes shorter and wider. In early wear-stages, the protocone is isolated from the protoselene, but has a large labially-directed spur. With wear, the spur connects with the protoselene (Fig. 63); this connection is at first greatiy constricted by a deep preprotoconal groove, this condition persists until until at least moderate wear-stages. The P34 protocone orientation is markedly oblique (Fig. $628)$, and in late wear-stages, the protocone does not connect with the hypocone. The P34 have a large, usually single, but occasionally branched, pli caballin that is reduced and lost at MSCHs of about 25 to $30 \mathrm{~mm}$. The hypoconal groove remains open at least until moderate wear-stages; it closes to form a lake and disappears at a greater crown height than in the molars. Fossette plications are relatively complex and persistent for a member of the Equini, as on ly very greatly worn P34 totally lack plications (Fig. 63). A pli protoloph and pli hypostyle are uncommon, but occasionally found on slightly worn teeth. The posterior half of the prefossette almost always has 


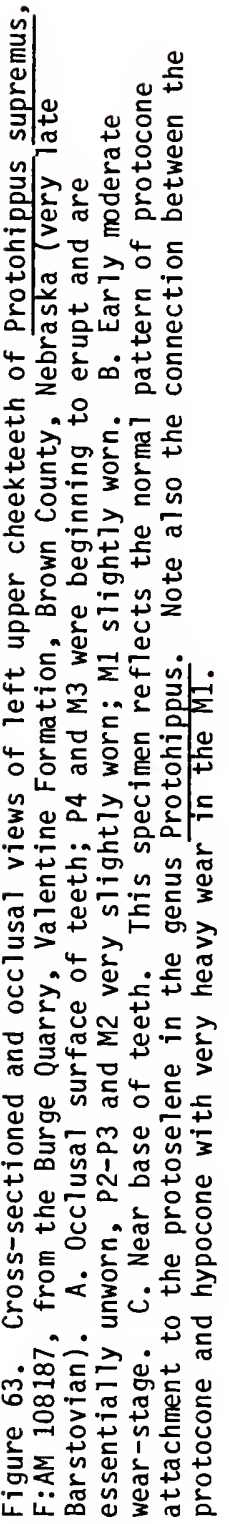



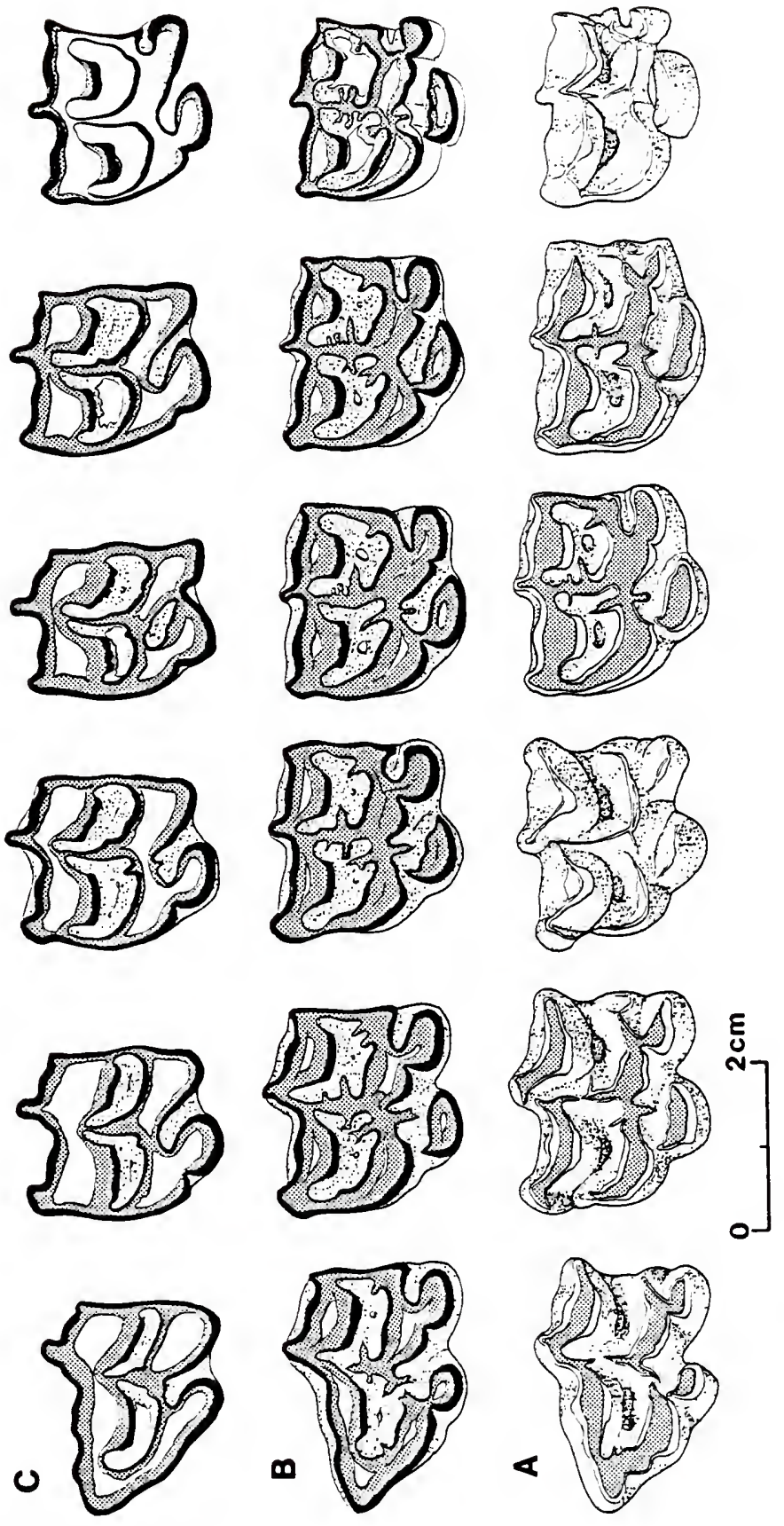
two deep plications surrounding a large prefossette loop in moderate to slightly worn teeth, with a third accessory plication possible. The opposing side of the postfossette has a deep pli postfossette and an accessory plication. At moderate wear-stages, the accessory plications are lost, and on ly the deep folds remain. The se are gradualiy lost only in very heavily worn P34s.

The molars exhibit basically the same pattern as the P34 (Fig. 63), although the pli caballin is smaller and lost earlier in wear, the hypoconal groove remains open until late wear-stages (and does not form a lake), and the protocone orientation is not as oblique. In late wear-stages, the protocone of the M12 may unite with the hypocone (Fig. 63 and F:AM 111728), isolating the postprotocona 1 valley as a fossette. This occurs less frequently and typically on ly in much more deeply worn teeth than in Pliohippus. In terms of degree of isolation of the protocone, the M3 ranks highest, fol lowed by the P34, then the M12, and finally the P2. Even moderately to heavily worn M3s can retain isolated protocones, for example the left M3 of AMNH 9820. This same pattern is observed, to an overall greater degree of isolation, in the younger species Pro. gidleyi. The deciduous premolars are similar to those of Pro. perditus, having more complex internal fossette borders than permanent teeth, persistent plications, and rounded protocones. The DP 1 is retained with the adult dentition, but is relatively (and usually absolutely) smaller than that of Pro. perditus $(\underline{x}=10.3 \mathrm{~mm} ; 0 R=9.2-11.1 \mathrm{~mm} ; n=5)$. P3-M2 are moderately curved, with ROC generally between 45 and $50 \mathrm{~mm}$. Unworn upper cheekteeth that can unambiguously be assigned to Pro. 
supremus are rare, thus unworn MSCHs are estimated from slightly worn teeth, and should be considered minimum values. These estimates are about $38 \mathrm{~mm}$ for the $\mathrm{P2}$ and about $55 \mathrm{~mm}$ for the P3-M2.

Lower cheekteeth of Pro. supremus (Table 42) are especially characterized by large protostylids that appear on the occlusal surface shortly after the onset of wear, and relatively large metastylids. In premolars, the metastylid is expanded equally with the metaconid. This, in conjunction with large, deep lingual flexids in early and moderate wear-stages gives the premolars a hipparionine-like appearance. The contraction of the lingual flexids is delayed relative to that observed in Pro. perditus and most species of Calippus. The ectoflexid of the premolars is quite variable in its depth of penetration of the isthmus, but is most often shallow. In general, the isthmus connects to the metaconid, or between the metaconid and metastylid, but occasionally to the metastylid as observed by Quinn (1955, Plate 9.5). The molars also have enlarged and expanded metaconids and metastylids, but are otherwise of typical protohippine morphology. Lower deciduous premolars are slightly larger, but similar to those of Pro. perditus, with low ectostylids and large protostylids on $\mathrm{dp} 34$. The $\mathrm{dp} 2$ has a flattened anterior border, and frequently a small protostylid. The anterior margin of the $p 2$ is often similarly truncated in later wear-stages.

Discussion. Leidy (1869) based Pro. supremus on three isolated upper cheekteeth from different individuals. He figured two of the specimens (Leidy, 1869, Plate 27.3 and 27.4), and described the third as unworn. Gidley $(1907$, p.889), acting as first revisor, selected 
one of the figured specimens (ANSP 11280.1) as the lectotype, the tooth Leidy (1869) described in most detail and figured in Plate 27.4 (re-illustrated by 0sborn, 1918, Fig. 118.2). Gidley's (1907) choice of a lectotype is critical, as the two principal syntypes apparently represent distinct species of different genera. The lectotype, here interpreted to represent Protohippus, is a premolar, and not a MI as was stated by Gidley (1907) and repeated by Osborn (1918). Quinn (1955, p. 24) also recognized that it is a P34, but failed to grasp its phylogentic significance. The specimen has the following characters that indicate that it is a premolar and not a molar: 1) parastyle open and very large (it is somewhat larger than indicated in the illustrations); 2) mesostyle widely open, not constricted; and 3) its angle of attrition is anterior (the method of Bode, 1931). This determination is important, as the dimensions of ANSP 11280.1 (Table 43), while matching those of referred P34s, are much larger than average for molars of Protohippus. The paratype (ANSP 11280.2) is a true molar (probably a M2), despite its much greater APL than the lectotype. Besides size, the lectotype has six characters that indicate its referral to Protohippus rather than Pliohippus: 1) protocone isolated from protoselene; 2) very strong pli caballin that nearly touches the protocone; 3 ) very long prefossette loop that extends lingually further than the main body of the prefossette; 4) deep hypoconal groove that would have remained open until late wear-stages; 5) large parastyle; and 6) radius of curvature of about $50 \mathrm{~mm}$. All of the se are characteristic of premolars from the referred sample of Protohippus supremus, and differ considerably from 
the conditions found in contemporary Clarendonian Pliohippus populations (Table 44; pers. obs. and Skinner et a1., 1977). The paratype is referable to Pliohippus based on its greater size, lower radius of curvature $(40 \mathrm{~mm})$, smaller prefossette loop, and the absence of a pli caballin. While Gidley (1907) did not clearly state which of the two he considered the type, the measurements he gives are those of the specimen that Osborn (1918) later stated was the lectotype. As his purpose was to place Leidy's species in Pliohippus, Gidley's (1907) choice of a lectotype was ironically incorrect, as his study was otherwise the first to clearly enumerate the differences between Protohippus and Pliohippus, and used characters that were ignored by later workers (e.g. Stirton, 1940).

The lectotype of Pro. supremus matches in size, curvature, and morphology a well represented sample from the very late Barstovian and Clarendonian of Nebraska and South Dakota. Although similar in many features, it is more advanced than, and clearly distinct from, Pro. perditus (as was first recognized in his description of Pro. simus by Gidley, 1906a). The important generic characters this referred sample shows are: lack of a MF; large, shallow DPOF; broadened muzzle; isolated protocones in early wear-stages; and well developed protostylids. The large series of associated dentitions in various wear-stages from the Burge Fauna indicate that the differences between the types of Pro. supremus and Pro. simus (both were collected from the Little White River region of South Dakota) result from differing degrees of wear, and that the two are not specifically distinct. Based on priority, the proper name is Pro. supremus. 
Protohippus and Pliohippus lived contemporaneously, and apparently sympatrically, in Texas and the Great Plains from the late Barstovian to the early Hemphillian. Gidley (1907), primarily using cranial characters, distinguished the two into basically the arrangement used here, and allied Calippus (his Protohippus placidus) with Protohippus. Later studies (e.g. McGrew and Meade, 1938; Stirton, 1940) emphasized the use of upper cheekteeth to determine relationships (at the expense of cranial and lower cheektooth features), and contemporary populations of the two genera were frequently lumped into one species. For example, Stirton (1940) proposed that Pro. perditus and Pliohippus mirabilis were synonyms, and Webb's (1969a) referred sample of "Pliohippus" supremus includes specimens of both Protohippus and Pliohippus. Table 44 contrasts the features of Protohippus and Pliohippus, and is based on the large series of associated skulls and mandibles in the Frick collection.

Webb (1969a) provided the most complete discussion of the relationships of Pliohippus s.1. (including Protohippus as recognized here) in what might be termed the post-Stirton (1940) period. Webb correctly concluded (in my opinion) that many of the previously named, large, Clarendonian species of Pliohippus were synonymous. Webb (1969a, p. 95) hypothesized that species of Pliohippus could be divided into two groups, one with a shallow "lacrimal" fossa and no MF, the other with deep malar and lacrimal fossae. He bemoaned the lack of an adequate sample of skulls with which to test this hypothesis. The Frick collection, then unavailable to Webb for study, contains such a sample. Another factor then creating confusion was 
the common conception that Pliohippus pachyops from the Clarendon Fauna displayed a "Protohippus"-type face and a "Pliohippus"-type dentition, suggesting that the two could not be separated. The pliohippine dental features of the type of Plio. pachyops include dp3 and dp4 with very reduced protostylids and no ectostylids, and the connected protocone on the slightly worn M1. Recently, the holotype of Plio. pachyops has been further prepared, and removal of matrix in the ventral preorbital region revealed the presence of a small MF similar to the one found on the type of Pliohippus fossulatus, also from the Clarendon Fauna (D. Winkler, pers. comm.). Pro. simus thus cannot be synonymized with PTio. pachyops, as Webb (1969a) suggested. The results of this study indicate that Webb's (1969a) preferred hypothesis about Clarendonian Pliohippus s.1. was correct in its essential point (i.e., there are two taxa clearly differentiated on the basis of facial fossae and other characters), but that the names he chose for the two (P7iohippus supremus and Pliohippus pachyops) were incorrect. Instead, the presence of two genera are indicated, Pliohippus s.s. and Protohippus. With the referral of Pro. supremus to Protohippus, the next available name for the large Clarendonian Pliohippus is Pliohippus pernix Marsh (1874), the genotypic species. A number of species and specimens from beyond the type region are referable to Pro. supremus. "Hippotigris" clarendonensis Quinn from the Clarendon Fauna resembles Pro. supremus rather than Cal. martini or Pro. pernix with its large metastylids, well developed 1 ingual flexids and protostylids, and reduced ectoflexid depth on m1-m3. F:AM 111728, which was illustrated by MacFadden (1984a, Figs. 66 and 
$69)$ as Neohipparion affine, is another Clarendon specimen of Pro. supremus. Based on examination of the F:AM, TMM and PPM collections, Pro. supremus is rare in the Clarendon Fauna, while $\underline{\mathrm{Cal}}$. martini and Plio. pernix are common. Similarly, it is rare in the Minnechaduza Fauna, although common in the Burge. As the decline coincided with the appearance of $\mathrm{Cal}$. martini, competition with that species may have played a role in its drastic reduction in abundance. Pro. supremus is also present, but again rare relative to $\underline{\mathrm{Cal}}$. martini and P1io. pernix, in the Lapara Creek Fauna. Quinn (1955) named two species of "Hippotigris" from the Lapara Creek Fauna, $\underline{H}$. Sellardsi and $\underline{H}$. parastylus, that are synonymized with Pro. supremus. The three figured upper teeth (Quinn, 1955, Plate 4.1-4.3) are also referable to Pro. supremus, although the lowers called "Pliohippus" supremus (Plate 4.4) are instead referable to Plio. pernix. Two specimens from Florida, UF 28553 (Fig. 22B; Table 16) and UF 24125 al so represent Pro. supremus. A7though moderately worn, UF 28553 still retains a well developed prefossette loop and a pli caballin, the hypoconal groove is open, and the protoconal connection is tightly constricted. The slightly worn UF $24125(\mathrm{MSCH}=48.5 \mathrm{~mm})$ has an isolated protocone with a large spur, and a large prefossette loop. It has a ROC of $65 \mathrm{~mm}$. 


\section{Protohippus gidleyi new species}

Dinohippus or PTiohippus sp., HIRSCHFELD and WEBB, 1968, pp. 247,249 .

cf. Pliohippus sp., WEBB et al., 1981, p. 527.

Type specimens. Holotype, UF 62473 , as sociated $R$ P2-M3 and $L$ P2-M1. Paratype, UF $32173, R$ mandible with $p 2-m 3$, missing symphysis and most of ascending ramus.

Type locality. Love Site, $1.5 \mathrm{~km} \mathrm{~N}$ of Archer, Alachua Co., Florida.

Stratigraphic occurrence and age of type locality. Fluvial sediments of the Alachua Formation; very late Clarendonian, about 9.0 ma.

Topotypic sample. UF $32261 \mathrm{R}$ maxilla with P2,P3-M3; 32298/32299 assoc. R P3-M3 and L P2-M3; 32269 assoc. R P2-P3,M1,M3 and L P4-M3; 67703 assoc. R M1-M3; 60875 assoc. R M1-M2; 32279 assoc. L P4-M3; 65237,698212 R OP2; 36044, 36095, 36101, 36123, 968825 L DP2; $65231-65232,68849-68850,92958-92959,96893-9690014$ R DP34; 65233$65236,92960,96883-9689215$ L DP34; 36031, 36057, 60245, 62471$62472,62474-624757$ R P2; 36146, 36225, 36236, 62476-62477, 6247962482, $9299210 \mathrm{~L} \mathrm{P2}$; 61350, 62493-62502, 62504-62510, $6253719 \mathrm{R}$ P34; 61349, 62483-62491, 62513-62521 19 L P34; 62536, 62539-62540, 62542-62550 12 R M12; 62522-62532, 62534-62535 13 L M12; 68822-68824, 68826-68831 9 R M3; 68832-68838 7 L M3; 32207 R mandible with $p 3-m 3$; 32167, $322092 \mathrm{~L}$ mandibles with $\mathrm{p} 3-\mathrm{m} 3$; $32242 \mathrm{~L}$ mandible with $\mathrm{p4}-\mathrm{m} 2$; 32205 assoc. R dp2-dp3; 64402 assoc. L dp2-dp4; 67704 assoc. R p3-m3; 67747 assoc. $R$ p4-m3; 32129, 32135, 32140, 32220, 32243, 32288 , 
$36279,67729,67746,68776,68782,6878712$ partial mandibles or assoc. lower dentitions; 69802, 90267, $965383 \mathrm{R} \mathrm{dp2;} \mathrm{90187,} \mathrm{90268,}$

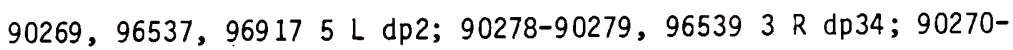
90277, 96540-96544 13 L dp34; 36290-36296, 96955-96957 9 R p2; 36297$36300,67701-67702,92961,96331,96950-9695110 \mathrm{~L} \mathrm{p2}$; 67705-6772319 R p34; 67724-67728, 67730-67745, 67748 22 L p34; 67779-67800, 68781 $23 \mathrm{R} \mathrm{m12}$; 67749-67778, $9296231 \mathrm{~L} \mathrm{m12;68770-68779,92991,9653312} \mathrm{R}$ m3; 68758-68769, 96523, $9653414 \mathrm{~L} \mathrm{m3}$.

Etymology. Named in honor of James W. Gidley, an outstanding scholar of mammalian systematics and evolution; especially for his contributions to the study of Protohippus.

Distribution. Very late Clarendonian to early Hemphillian of Florida (about 6.5 to $9.0 \mathrm{ma}$ ); early Hemphillian of Nebraska.

Referred specimens. McGehee Farm: UF 45634 R M12; 17138 R p2; 19238 R p34; 16633, $456222 \mathrm{R} \mathrm{m12;} 7239 \mathrm{~L} \mathrm{m12;} 45630 \mathrm{R} \mathrm{m} 3$.

Haile 19A: UF 52963 L p34.

Mixson's Bone Bed: F:AM 113639 assoc. R P4 and L P2-M3.

With 4A: UF 45521 assoc. R and L DP2-DP4,M1.

Cambridge Fauna, UNSM 10C. Ft-40, Frontier Co., NB: UNSM 90641 sku11; $2634 R$ maxi11a with P2-M3; 4024, 4072-4075, 4078-4079, 4082, $4251 \mathrm{~g}$ isolated upper cheekteeth; 2635 assoc. $R$ mandible with $p 2-m 2$ and $L$ mandible with p2-m3; 2951, 4046-4047, 4049-4050, 4052, 4054, 4056-4058, 4062-4065, 4067, 423716 isolated lower cheekteeth.

Diagnosis. Protohippus intermediate in size between Pro. perditus and Pro. supremus, with toothrow lengths of 125 to $135 \mathrm{~mm}$. Unworn M12 MSCH about $58 \mathrm{~mm}$. Protocones of P3 and P4 generally isolated for 
uppermost $20 \%$ of crown, then connected to protoselene at MSCHs of 30 to $40 \mathrm{~mm}$. M3 protocone also often isolated until moderate wearstages, but may connect earlier; protocones of P2, M1 and M2 generally isolated on $1 y$ in very early wear-stages; protocone of P3-M2 large, elongated. Anterostyle of P2 reduced. Lower cheekteeth similar to those of Pro. supremus but with more expanded metaconidmetastylid complexes, more persistent lingual flexids, and less prominent protostylids. Paraconid of $\mathrm{p} 2$ and dp2 less flattened anterioriy than in Pro. supremus. Ectostylid of dp2-dp4 rudimentary. Description. The holotype, UF 62473 (Fig. 64A; Table 43), consists of an associated assemblage of upper cheekteeth of a young adult. The M3 had only partially erupted, as its posterior half is not yet fully worn. The specimen evidently represents an individual whose remains were scattered by currents, as the teeth were recovered from several contiguous quadrants, and were not recognized as being associated in the field. That they represent a single individual is evidenced by similarity of preservation, their identical wear-stage, and the goodness of fit between them. The P2 (Fig. 64A) resembles other moderately worn individuals in the referred sample with its rounded protocone, well developed preprotoconal groove, lack of a $\mathrm{pli}$ caballin, deep hypoconal groove, simple fossettes, and relatively short anterostyle. The $\mathrm{P} 34$ have larger styles, moderate pli caballins, deep hypoconal grooves, and oval-elongate protocones with constricted protoconal connections and pointed posterior ends. The protocone of the right $P 4$ is still isolated (Fig. 64A), but its spur is within $1 \mathrm{~mm}$ of the protoselene, and it would no doubt have con- 
nected after slightly more wear. The M1 and M2 of UF 62473 differ from the P34 only slightly in size (Table 43), but do not have pli caballins, their protocones are more broadly connected and less obliquely orientated, have weaker styles, and smaller prefossette loops. The protocone of the $M 3$ is connected to the protoselene by a very narrow isthmus; most M3s of similar MSCH in the topotypic sample have isolated protocones.

Upper cheekteeth of Pro. gidleyi (Figs. 62C-62E, 64A, 64B; Tables 41, 43) resemble those of Pro. supremus in most regards. They are on ly moderately curved, with ROC of molars usually between 50 and 60 $\mathrm{mm}$. The P2 in early wear (Fig. 62C) has a rounded, isolated protocone with a spur, and the postprotoconal valley is often confluent with the prefossette (e.g. UF 62481,62482$)$. A strong metastyle is usually present, but it tends to fade with wear, as does the pseudoparastyle. The anterostyle is often weak, giving the P2 a more blunt appearance, rather than its its usual triangular form. The prefossette and postfossette are confluent in over half the sample of P2s from the Love Site, although they are separate in almost all of the heavily worn specimens (Fig. 64B). In early wear, the P2 can have well plicated fossettes (e.g. UF 62476), but these soon fade with wear, leaving at most a single pli prefossette and pli postfossette. Pli caballins are rarely present, and almost always weaker than those of the P34. With wear, the protoconal connection widens, the fossettes loose all plications and become more narrow, and with heavy wear, the hypoconal groove is 10st. The P34 (Figs. 62D, 62E) have strong styles, including metastyles, deep hypoconal grooves that 


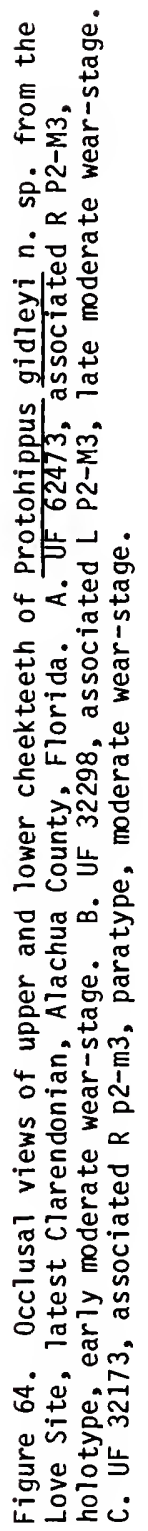




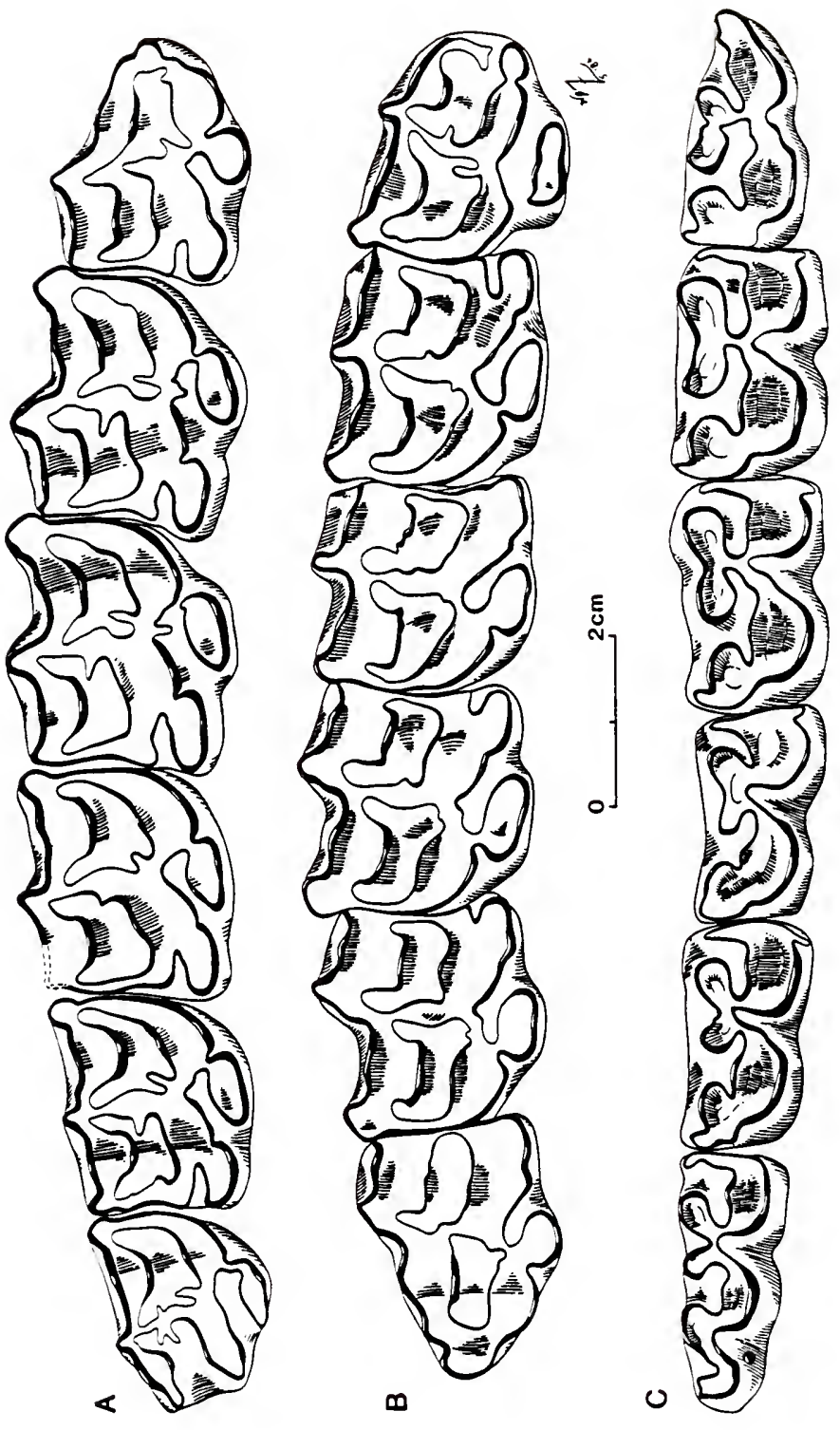



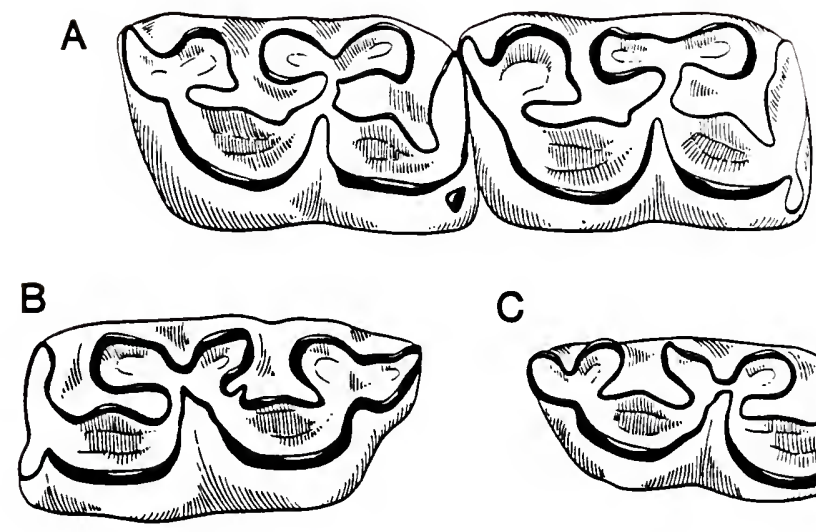

C
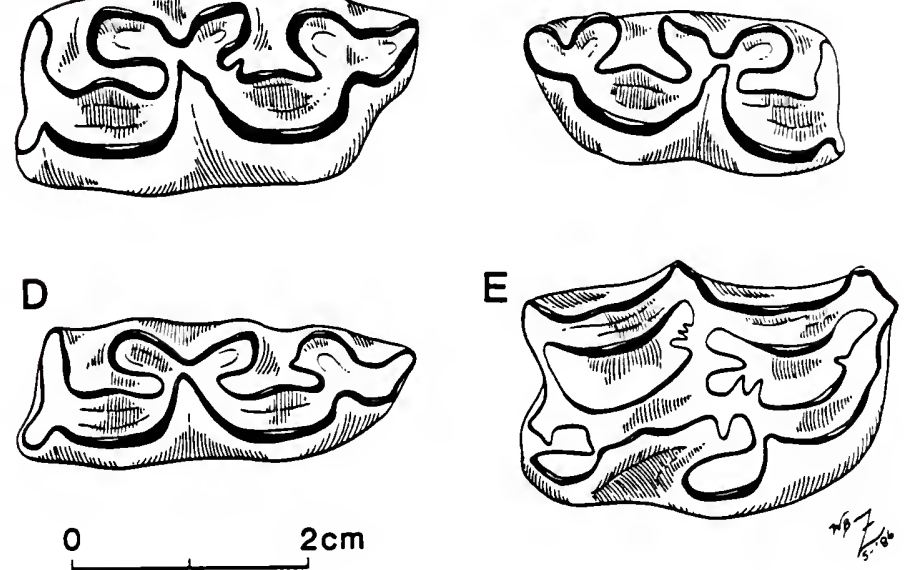

Figure 65. Occlusal views of upper and lower cheekteeth of Protohippus gidleyi n. sp. from the Love Site, latest Clarendonian, ATachua County, FTorida. A. UF 67704, associated R p3-p4, ear7y wear-stage. B. UF $67769, \mathrm{~L}$ m12, early wear-stage. C. UF $45622, R$ $\mathrm{m} 12$, early moderate wear-stage. D. UF 90274, L dp34. E. UF 65232, R DP34. 
Figure 66. Histograms indicating at what wear-stage the protocone connects to the protoselene, and the hypoconal groove becomes closed in upper third and fourth premolars of the Love Site population of Protohippus gidleyi n. sp. A. Percentage of specimens in each $5 \mathrm{~mm}$ wear-class with (shaded) and without (unshaded) connected protocones. All specimens with less than $50 \%$ of original crownheight have connected protocones. B. Percentage of specimens with open hypoconal grooves (unshaded) and those that have lost the hypoconal groove (shaded). Numbers above each wear-class indicate the sample size for each group. 

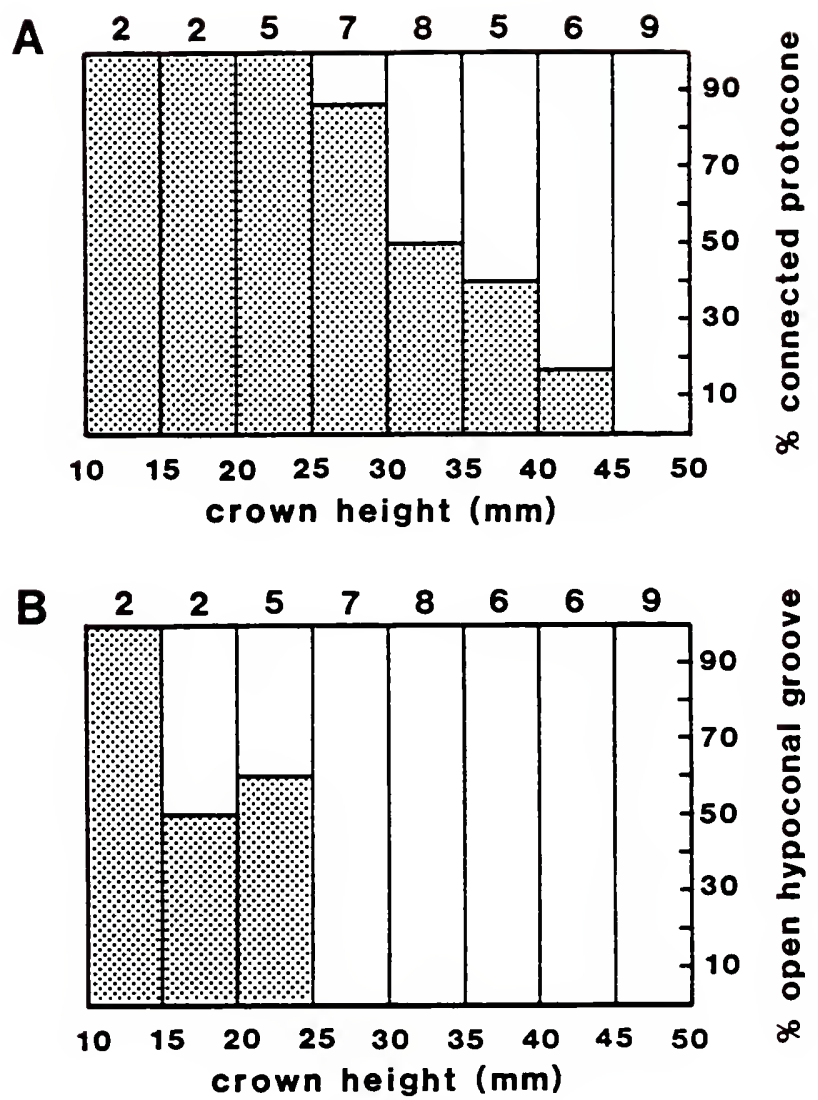
persist until about $45 \%$ of the crown is worn (Fig. 66), and moderately complex fossettes. The hypoconal grooves are almost always lost without forming a lake. A single, generally small pli protoloph or pli hypostyle is occasionally present in the upper quarter of the crown. In early wear-stages, the posterior half of the prefossette may have up to four (two or three are more common) plications, and the anterior half of the postfossette usually bears one or two. The prefossette loop is well developed, but is usually not as long as in Pro. supremus. Moderate to heavily worn P34s generally retain one or two plis prefossette and a single, deep pli postfossette. The se too tend to be lost as MSCHs reach $21 \mathrm{~mm}$ and 1ess. This is also the period when the pli caballin is usually lost. The protocones tend to be long, often with flattened to slightly concave lingual borders. The MSCH at which the protocone attaches to the protoselene is variable (Fig. 66), but usually between 30 and $40 \mathrm{~mm}$. Prior to connecting, the protocone bears a large, anterolabial spur (Fig. 62E). After the connection, the preprotoconal groove remains deep until latest wear-stages (Fig. 64B).

The M12 tend to be of about the same APL as the P34, but somewhat narrower (Tabie 41). As is typical for protohippines, the fossette plications are less numerous and are lost at earlier wear-stages than in the P34, and pli caballins are prominent on ly in earlier wearstages (Figs. 62F, 64A). The protocone is rapidly connected with wear, is oriented much less obliquely than in the P34, and becomes connected to the hypocone with heavy wear. The protoconal connection remains constricted throughout much of the crown, with a deep prepro- 
toconal groove. Metastyles are much less prominent than on the P34. The hypoconal groove remains open until the $M S C H$ reaches $20 \mathrm{~mm}$ or less. Unworn or slightly worn MSCHs are about $39 \mathrm{~mm}$ for P2, $50 \mathrm{~mm}$ for P34, and $58 \mathrm{~mm}$ for the M12.

Deciduous upper premolars are narrower counterparts to their permanent successors (Fig. 65E). The DP2 has a short protocone and a poor pli caballin. The DP34 have elongate protocones, generally strong pli caballins, well developed styles, and moderately simple fossettes. The hypoconal groove is deep and a pli dihypostyle is usually present.

Lower cheekteeth of Pro. gidleyi (Tables 42, 43; Figs. 64C, 65A-650) especially resemble those of Pro. supremus, the principal difference being that the younger species tends to exhibit advanced features, such as more elongated metaconids and metastylids, through a greater percentage of the crown. The paratype, UF 32173 , is a typical example of a moderately worn individual (Fig. 64C). Deep lingual flexids are retained on all but the $\mathrm{ml}$, which is starting to lose the metaflexid, and shorten the metastylid. The lower premolars retain expanded metaconids and metastylids, and relatively deep lingual flexids even at crown heights of less than $20 \mathrm{~mm}$. In very early wear-stages, the bases of the metaflexid and entoflexid may bear several plications (Fig. 65B), but the se are soon lost with wear. The p34 ectoflexid is a broad " $V$ ", generally penetrating into the isthmus to a depth about that of the base of the entoflexid (Fig. $65 \mathrm{~A})$. The ectoflexid of the $\mathrm{p} 2$ is shallower, not penetrating the isthmus, and its paraconid is usually angular in moderate to early 
wear-stages, becoming more blunt with heavy wear as in Pro. supremus. In the molars, the ectoflexid almost always separates the isthmus. In early wear-stages, the deep, "V"-shaped linguaflexid and the ectoflexid nearly completely separate the metaconid and metastylid, except for a narrow commissure (Fig. 65C). With wear, both retreat, so that there is greater dentine confluence between the metaconid and metastylid (Fig. 64C). In early to moderate wear-stages the metastylid is nearly as large as the metaconid, but tends to be angular while the latter is more rounded. Only in later wear-stages is the metastylid noticeably smaller and less lingually placed than the metaconid. Moderate protostylids appear on the occlusal surface shortly after the onset of wear on the p3-m3, and may at first be isolated from the protoconid (e.g. the m2 of UF 67704); they are stronger in $\mathrm{p} 34$ than $\mathrm{m} 1-\mathrm{m} 3$, but vary with age. The labial borders of the protoconid and hypoconid are rounded. Lower deciduous premolars are like those of Pro. supremus (Fig. 65D), but have more rudimentary ectostylids. The strong protostylids, however, serve to distinguish them from the dp2-dp4 of Pliohippus. As in the permanent teeth, the protostylid is often isolated from the protoconid in early wearstages (e.g. UF 64402).

Cranial features of Pro. gidleyi are known only from UNSM 9064, a nearly complete skull from the referred $\mathrm{Ft}-40$ population from Nebraska. The dentition of UNSM 9064 is extremely worn and nondiagnostic (except to indicate that it is a protohippine). The broadened muzzle and short diastema distinguish it from Dinohippus, the only large equine in the fauna. It is larger, and with a less 
broadened and robust muzzle than in advanced species of Cal. (Grammohippus). The facial region of UNSM 9064 has been distorted by crushing, and the depressions in the malar region are of post-depositional origin. The dorsal facial region of the somewhat better preserved right side indicates the presence of a faint DPOF located very anterior to the orbit, dorsal to the $M 2$ to $P 3$, and about $50 \mathrm{~mm}$ long. It is not distinctly rimmed or pocketed. Small alveoli indicate that a DP1 was retained with the permanent dentition.

Discussion. Protohippus gidleyi is the youngest and most derived species of Protohippus. Unworn crown heights of $i$ ts cheekteeth are about $5 \%$ greater than those of Pro. supremus. Its lower cheekteeth have the most expanded metaconids and metastylids of any protohippine, and elongated metaflexids and entoflexids remain deep until very late wear-stages. The most interesting trend evident in Pro. gidleyi is the tendency for increased isolation of the protocone from the protoselene. Possession of isolated protocones beyond early wear-stages is apparently a derived condition in advanced equids (Webb and Hulbert, 1986), but is generally considered structurally inferior to the connected condition (Stirton, 1941). The trend in Protohippus for increased protocone isolation, along with the successful radiation of the hipparionines, suggests that this hypothesis is incorrect.

The topotypic sample of Pro. gidleyi contains a number of upper and lower dentitions, along with many isolated cheekteeth, thus allowing a good estimate of individual and ontogenetic dental variation. Several early Hemphillian sites from Florida contain a few teeth that 
cannot be distinguished from the Love Site sample of Pro. gidleyi. UF 45521, a juvenile individual from the late early Hemphillian, is only provisionally referred to Pro. gidleyi. The protocone of the MI is relatively small and the fossettes are somewhat more plicated than in the topotypic population. The sample from the late early Hempnillian of Nebraska suggests that the latter feature may be a chronoclinal trend within Pro. gidleyi. This sample is important, as it includes the only known skull of Pro. gidleyj. It demonstrates notable differences in muzzle and fossae morphology from Dinohippus, Pliohippus and Calippus, and corroborates the dental evidence that the species belongs in Protohippus. The minor differences between the Love Site and Ft-40 populations are best explained by geographic variation and chronoclinal evolution. For example, the protocone of the M12 tends to be more isolated in the younger sample, surely a continuation of the trend observed throughout the entire genus.

\section{Subtribe Equina new subtribe}

Type genus. Equus Linnaeus, 1758.

Included taxa. "Merychippus" stylodontus Merriam, 1919; "M." Carrizoensis Dougherty, 1940; Pliohippus Marsh, 1874; Astrohippus Stirton, 1940; Dinohippus Quinn, 1955; Hippidion Owen, 1869 ; Onohippidium Moreno, 1891.

Diagnosis. Medium to large-sized equids with relatively elongated muzzle regions. Protocones connected to protoselene during earliest wear-stages; protostylids absent or very reduced on permanent 
cheekteeth; ectostylids absent on deciduous premolars. Well developed fossa in malar region; it and DPOF lost in some taxa. Lateral phalanges reduced in size or absent altogether.

Discussion. The Equina form the sister-taxon to the Protohippina. Early species are characterized by merychippine-grade dentitions and a variably developed MF. This structure is best developed in the well known Miocene genus Pliohippus. Excluding Pliohippus, equines have a poorly represented pre-Hemphillian fossil record. A possible explanation for this my lie in a predominantly West Coast distribution. There are many species names for Clarendonian West coast "Pliohippus," but these records are based on small samples of isolated teeth. The teeth referred to "Protohippus" or "Pliohippus" tehonensis by Merriam (1915b), Stock (1935), and Drescher (1941) from the early Clarendonian of California, and the specimen referred to Dinohippus sp. by Nelson et a1. (1984) from Utah both contain the proper mixture of primitive and derived character states to allow them to be the sister-taxa of some segment of the AstrohippusDinohippus-Hippidion clade. However, cranial material is essential for generic identification of equines, and is lacking in the se cases. Equines are especially poorly represented in Gulf Coastal Plain faunas. The Cold Spring and Lapara Creek Faunas contain Pliohippus, but it is uncommon, relative to hipparionines. In Florida, no unquestionable specimens are known until the early Hemphillian (Moss Acres). During the late Hemphillian, when various equines like Dinohippus, Astrohippus and Onohippidium numerically dominated all western and Great Plains equid faunas, hipparionines remained 
numerous and diverse in Florida. Even into the late Blancan, Cormohipparion and Nannippus are more numerous at some sites (e.g. Macasphalt She 11 Pit) than Equus. The reason for this difference is interpreted to be ecological. The Clarendonian Chronofauna must have evolved under relatively warm and mesic climatic conditions (contra Janis, 1984; see Webb, 1977). This is based on the northernly late Neogene distributions of Alligator and large Geochelone (Woodburne, 1959 ; Hibbard, 1960; Voorhies, 1971), and on the great diversity of the large mammalian fauna. Through the Hemphillian, progressive drying resulted in a less diverse fauna (Webb, 1977), and the monodactyl equids "took over." In may be inferred that mesic conditions continued to prevail in Florida, the most prominant exception to this trend. This allowed otherwise typical Miocene taxa like Cormohipparion, Pseudhipparion (Webb and Hulbert, 1986), and protoceratids (Webb, 1981) to flourish into the Pliocene. The same species of Dinohippus, Astrohippus, and Equus are known from the Pliocene of Florida as are found in western faunas (Robertson, 1976; MacFadden, 1986), but they are rare.

\section{Genus Pliohippus Marsh, 1874}

Type species. Pliohippus pernix Marsh, 1874.

Included species. Plio. mirabilis (Leidy), 1858 ; Plio. nobilis Osborn, 1918.

Chronologic and geographic distribution. Late Barstovian to early Hemphillian of the Great Plains; early Clarendonian and possibly late 
Barstovian of Gulf Coastal Plain. Numerous records and named species from the West Coast are at present generically indeterminant.

Diagnosis. Medium to large equine with very curved upper cheekteeth; shallow hypoconal groove that is lost early in wear; fossette plications simple or absent; molar protocone frequently connected to hypocone. Metaconid and metastylid poorly separated; relatively deep ectoflexids; protostylids very reduced or absent on deciduous and permanent cheekteeth; ectostylid absent on dps. Both DPOF and MF deep, wel1 rimmed posterior $1 y$, often pocketed. Moderate preorbital bar. Early populations tridactyl, later populations monodactyl. Discussion. Pliohippus is primarily known from the Great Plains where it is continuously represented from the middle Barstovian through the early Hemphillian (ca. 14.5 to $6.0 \mathrm{ma}$ ). Only scattered records are known from the Gulf Coastal Plain, and named West Coast taxa commonly referred to Pliohippus are either known on ly by dentitions and will require intensive study to determine their generic affinities (e.g. "․․" fairbanksi, "․․" tantalus), or seem to be more closely related to the Dinohippus-Hippidion clade (e.g. "P." spectans, "P." edensis). Barstovian species of Pliohippus are moderatesized (toothrow lengths of 130 to $140 \mathrm{~mm}$ ) and each lateral toe has three well formed but notably small phalanges. Clarendonian individuals (here included in a single species, the genotype $\underline{P}$. pernix) are about 10\% larger, while Hemphillian specimens ( $\underline{P}$. nobilis) are extremely large (toothrow lengths of up to $180 \mathrm{~mm}$ ) and monodactyl (based on the F:AM collection). Thus, in this genus, monodactyly evolved during the Clarendonian (Hussain, 1975). The DPOF is 
elongate-oval, deep, usually well pocketed and located about 15 to 20 $\mathrm{mm}$ in front of the orbit. Its ventral border is well rimmed and clearly separates the DPOF from the MF (Stirton and Chamberlain, 1939; MacFadden, 1984b). The variability of the MF is well documented in the F:AM samples from the Devil's Horse Gulch, Burge and MacAdams Quarries. It is invariably present, but can be almost as shallow as that of "Merychippus" sejunctus with only well defined posterior and ventral margins. The other extreme, represented by UCMP 33481 (Stirton and Chamberlain, 1939), is for a very deep, pocketed, multi-chambered MF with all of its margins well defined. Dentally, Pliohippus is characterized by very strongly curved upper cheekteeth, simple enamel patterns, shallow hypoconal grooves that are lost fairly early in ontogeny, and frequent connection between the protocone and hypocone in the molars. pliohippus was classically thought to be ancestral to the other monodactyl equids, Equus and/or the South American Hippidion-group. However, it is now clear "...that a chronocline of Pliohippus species with dual facial fossae and simple, highly curved teeth became a dead-end phylum during Early Hemphillian time..." (Skinner et a1., 1977, p. 359) and that monodactyly evolved at least twice within the Equidae.

cf. Pliohippus sp.

Referred specimens. Bradley Fauna, Bone Valley Region. Nichols Mine: UF 23977 R p34. Kingsford Mine: UF 61345 assoc. R p3-m2. 
Description and discussion. The two specimens listed above are nearly identical in morphology and very probably represent the same taxon. The following characters suggest referral to a Barstovian Pliohippus (e.g. Plio. mirabilis): protostylid very reduced to a thickened ridge of enamel on lower third of the crown; metastylid notably smaller than metaconid, while the two are unexpanded and poorly separated by shallow, nonpersistent lingual flexids; entoconid and hypoconulid poorly separated; and rounded labial borders. The size (Table 45) and overall morphology suggests a moderate-sized equine or protohippine. Protohippus is eliminated by the weak protostylid and the nonpersistent lingual flexids. The two specimens most likely represent either Pliohippus near Plio. mirabilis, or a primitive species of Calippus (Grammohippus), such as Cal. circulus. There are some similarities with the holotype of the latter species (TMM 31191-10), but these are mostly plesiomorphous for the Equini, except for the reduced protostylids in both. The molars of UF 61345 are much broader than those of TMM 31191-10, have shallower linguaflexids resulting in more confluence of the metaconid and metastylid, and lack any trace of a pli entoflexid. These characters suggest that the Florida specimens do not represent Cal. circulus, although the samples are so limited that this cannot be excluded. Pliohippus seems the more likely choice; if so these two specimens represent the sole sample of the genus known from Florida. Recovery of even a single upper cheektooth could confirm this assignment, as their morphology is often distinctive. UF 61345 is the specimen Webb and 


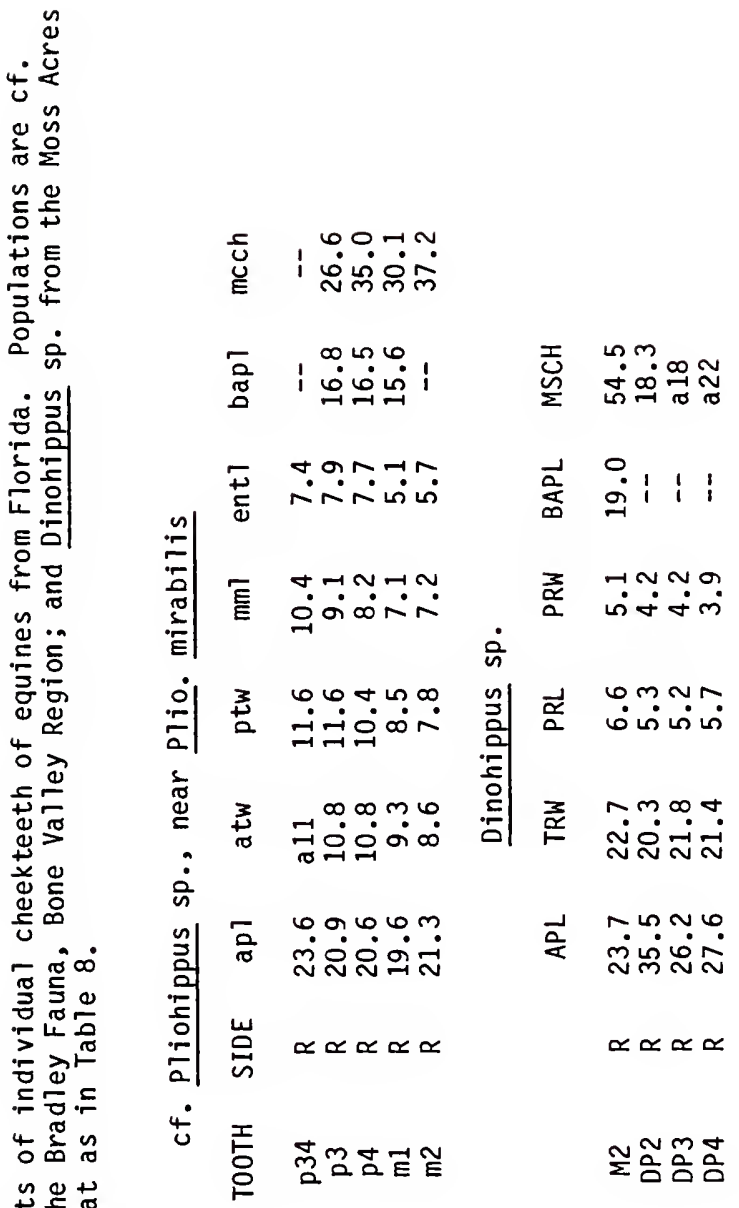
员岳总 틍한으 ปᄂ

هั

的新

品

守 혀ㅇㅝㅠ

0 동

$\div$ 용

은 元它

순

बेल ले

त6 666

告告当岇䒓

으으

न

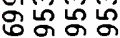

岇岇岁告 
Hulbert (1986, p. 261) used to include Plio. mirabilis in the Bradley Fauna.

Genus Astrohippus Stirton, 1940

Type species. Astrohippus ansae (Matthew and Stirton), 1930. Included species. A. stockii (Lance), 1950.

Chronologic and geographic distribution. Late Hemphillian of the Great Plains, Mexico, and Florida.

Diagnosis. Relatively small equine with very high crowned cheekteeth, very simple enamel patterns, and relatively straight upper cheekteeth. Moderately developed DPOF and MF, not distinctly separated. Preorbital bar length narrow. Probably monodactyl.

Discussion. MacFadden (1984b) described the facial morpholgy (as known) of this genus. Other characterics of Astrohippus are its moderate size (toothrow lengths of 115-135 mm), very hypsodont dentitions, simple fossettes, elongated protocones that do not connect with the hypocones, nonpersistent hypoconal grooves, widely expanded metaconids and metastylids, and shallow ectoflexids. The deciduous premolars retain relatively well developed protostylids. As Pliohippus has greatly reduced protostylids (or they are absent), a species of pliohippus s.s. is unlikely to be ancestral to either Dinohippus or Astrohippus, which retain them. 
Astrohippus stockii (Lance), 1950

MacFadden (1986) described the very limited $(n=3)$ sample of $\underline{A}$. stockii from the Palmetto Fauna of the Bone Valley Region of Florida. No additional specimens have been recovered subsequent to the completion of his study. A single specimen is also known from the Lockwood Meadows 1.f. (MacFadden, 1986).

\section{Genus Dinohippus Quinn, 1955}

Type species. Dinohippus leidyanus (Osborn), 1918.

Included species. D. mexicanus (Lance), 1950. Possibly also "Plio." interpolatus (Cope), 1893 and "Plio." spectans (Cope), 1880. Chronologic and geographic distribution. Hemphillian; widely distributed across North America.

Diagnosis. Large, monodactyl equines with moderately developed facial fossae; DPOF lies on maxillary and nasal bones with little or no contribution by the lacrimal; malar fossa very shallow or absent. Nasal notch deep, lies dorsal to the P2 or P3. Upper cheekteeth less curved than in Pliohippus, more so than in Equus. Hypoconal groove open to near base of crown; protocone does not unite with hypocone as in Pliohippus. Metapodials elongate, not shortened as in Hippidiongroup.

Discussion. Quinn (1955) erected Dinohippus for what he thought was a dead-end phylum related, but not ancestra 1, to Equus. His ancestor-descendant lineage leading to Equus at first glance seems 
entirely different than Stirton's (1940), but much of the difference is merely a matter of nomenclature. Quinn's (1955) Eoequus wilsoni is a junior synonym of Pro. perditus (see above), and his Equus laparensis is a junior synonym of Cal. martini. Protohippus perditus and Calippus martini were also main line segments in Stirton's phylogeny of Equus. The facial, dental and post-cranial features of Dinohippus have been described by Lance (1950), Sondaar (1968), Skinner et a1. (1977), Bennett (1980) and MacFadden (1984b; 1986). These studies a 11 suggested that Dinohippus was either "ancestral" to, or has a sister-group relationship with, Equus. Dinohippus first definitely appeared in the early Hemphillian, with records from Florida (see below) to California and Oregon. Complete cranial material and large sample sizes are unknown until the late Hemphillian, by which time it was perhaps the most common equid in North America (MacFadden, 1984b). Relative to Equus, Dinohippus appears to be a paraphyletic assemblage of populations, as it has no uniquely apomorphous characters. Through the Hemphillian, populations of Dinohippus show progressive shallowing of the facial fossae, increased persistence of the hypoconal groove, increased enamel complexity, retention of plications through a greater percentage of the crown, elongation of the protocone, increased crown height, and straighter upper cheekteeth. The final product of this morphocline was Equus. A strictly cladistic nomenclature would include "Dinohippus" within Equus. 
Dinohippus sp.

Referred specimens. Moss Acres Racetrack Site: UF 95399 crushed partial skuT1 with R DP2-DP4,M1 \& L DP1-DP4,M1; 92995 assoc. R \& L DI1-DI3, unerpted I1s, \& L DP1-DP2; 69952 R M12; 69953 partial mandibular symphysis with L I1-C.

Description. The juvenile cranium is dorsoventrally crushed but retains many important features. It is the oldest known skull definitely referable to the genus. A large, elongate-oval DPOF is located high on the face. The posterior margin is well defined but not pocketed. It is located $27 \mathrm{~mm}$ from the orbit on the better preserved right side. The dorsal margin is also well defined, but not strongly rimmed. The ventral margin is poorly defined, as is the anterior portion of the fossa. The anteriormost point of the fossa is located about $13 \mathrm{~mm}$ anterior to the IOF. The ventral border of the fossa is about 3 or $4 \mathrm{~mm}$ dorsal to the IOF. With the crushing, the greatest depth of the fossa cannot be determined, but it was probably not very deep. The total length of the fossa in this juvenile specimen is about $65 \mathrm{~mm}(+/-5 \mathrm{~mm}$ due to the distortion). The malar region is crushed on both sides of UF 95399, but there is no trace of a fossa in these regions. The specimen could not have had a deep, "Pliohippus"-style MF, although a shallow depression is possible (but not observed).

The dentition of UF 95399 is in the same wear-stage as UCMP 30202 (Matthew and Stirton, 1930, Plate 49.2), a maxilla of "Plio." interpolatus from the Coffee Ranch T.f. In both the postfossette of the 
DP4 had not yet fully formed. The M1 of UF 95399 had erupted through the maxilla, but had not yet begun to wear. The DP2-DP4 length of UF 95399 is $89 \mathrm{~mm}$, about 10\% less than UCMP 30202. Three slightly worn juveniles of $\underline{\mathrm{D}}$. mexicanus measure $94-95 \mathrm{~mm}$ (Lance, 1950, p. 43). The prefossette of the DP2 is confluent with the postprotoconal valley in both, although it is fully formed in the more heavily worn UF 92995. The fossettes are simple with very shallow, small plications. In both UF 95399 and UCMP 30202 the protocone of the DP2 and DP3 are rounded, while that of the DP4 is oval with a pointed posterior end. In UF 95399, the DP3 and DP4 both bear a moderate pli caballin, a structure not present on the Texas specimen. The DP1 is blade-Tike, with maximum basal dimensions of $18.4 \times 7.1 \mathrm{~mm}$ (UF 92995); that of UF 95399 is $15.5 \mathrm{~mm}$ long.

UF 69952 is a moderately worn ( $M S C H=54.5 \mathrm{~mm}$ ) upper molar, probably a M2. It has a low ROC of $45 \mathrm{~mm}$. The fossettes are simple, with a total of only two plications, both on the posterior half of the prefossette. The protocone is relatively short (Table 45), oval, with a pointed posterior end. The lingual protoconal border is convex. The parastyle is strong but ungrooved. The hypoconal groove is shallow and widely open. There is a very small pli caballin. Discussion. The morphology of this sample of Dinohippus appears to be relatively primitive. Thus, this population may be of importance in elucidating the origin of the genus. The preorbital bar length $(27 \mathrm{~mm})$ is not great, and intermediate between that observed in Pliohippus and younger Dinohippus (a)though the low value may in part be due to the specimen's juvenile age). Other, relatively 
primitive, character states observed in this sample are the short, rounded protocone, the convex 1 ingual border of the protocone, the very simple fossettes, and the moderate curvature of the $M 12$. Discovery of more specimens, especially lower cheekteeth, would greatly aid the phylogenetic interpretation of this population of Dinohippus sp.

\section{Dinohippus mexicanus (Lance), 1950}

A small number of isolated cheekteeth of this progressive species were recently described from the Upper Bone Valley Fauna by MacFadden (1986). Until further, more complete specimens are found in this region, little can be added to his descriptions. As he noted, the presence of $\underline{D}$. mexicanus provides additional evidence that the fauna is of latest Hemphillian age. Its rarity in the fauna (along with Astrohippus) is notable, and must reflect considerable ecological disparity with contemporary western faunas that are dominated by these two monodactyl equids (see above). 


\title{
CHAPTER 6 \\ PHYLOGENETIC ANALYSIS AND CLASSIFICATION
}

\section{Introduction and Historical Perspective}

\author{
Many problems of relationships and evolutionary \\ patterns within the perissodactyls still exist and \\ will continue to do so. Even for the very-well- \\ known horses there are problems at every level. \\ [E. C. 01son, 1971, p. 412]
}

It is no secret that the fossil record of perissodactyls, and especially horses, is relatively complete and abundant. This has resulted in a vast literature devoted to the study of fossil equids since they were first discovered in Europe in the 1820 s and North America in the 1850s. However, this has also led to the general conclusion that the phylogeny of the Equidae is especially well understood in contrast to that of other mammals. Most previous phylogenies of the family (especially those of Stirton and Simpson) were constructed within a theoretical framework currently termed "evolutionary taxonomy" (Mayr, 1969; Wiley, 1981), as opposed to those based on cladistics (phylogenetics) or phenetics. A basic difference between strict cladistic and evolutionary taxonomy is the acceptance of paraphyletic groups in the latter system. Traditionally, equid classification has employed a number of paraphyletic groups, e.g. the genera Merychippus, Parahippus and Pliohippus (Figs. 67A, 67B). Simpson's (1945) subfamilial divisions Hyracotheri inae and Anchitheriinae are also obviously paraphyletic assemblages. To 
some extent, the arbitrary nature of this arrangement of genera and subfamilies was realized; e.g. Simpson (1953, p. 260) noted that "...some of the groups named as genera represent structural stages rather than genera by a truly phylogenetic definition." It is now widely realized that phylogenetic analysis produces a more natural arrangement of taxa, one that reflects the true evolutionary history of a group (Wiley, 1981, and references therein).

The early phylogenies of the Equidae, as proposed by Huxley, Kovalevsky and Marsh in the late 1800s, were mere Ty series of structural grades placed in stratigraphic succession (e.g. Marsh, 1879). Gidley (1907) was probably the first person to address the problem of equid phylogeny in a modern sense. He divided the family into four subfamilies (Hyracotheriinae, Anchitheriinae, Protohippinae and Equinae), but noted (Gidley, 1907, p. 869) "... while phylogeny has by no means been ignored, ....[these]... subdivisions of the Equidae are founded on a basis of structural affinities rather than on phylogenetic relations." Presumabiy the reason for doing this was his belief that material available to him was inadequate to place the known genera in a truly phylogenetic arrangement (Gidley, 1907, p. 870). Two decades later, W. D. Matthew (1926) was able to propose a phylogenetic arrangement of equid genera. For Matthew, equid genera were still regarded as evolutionary stages, each of which could give rise to one or more successive genera. Matthew's (1926) arrangement made some important contributions to our understanding of equid phylogeny. Most important was the refutation of the concept that equids were a direct or thogenetic sequence of genera proceeding from 
Hyracotherium to Equus. He also recognized that advanced, hypsodont horses formed two distinct clades (Hipparionini and Equini as used here), and that North American hipparionines represented at least three distinct lineages. This last point was further elaborated by Matthew and Stirton (1930), although it was Stirton (e.g. 1940) who formally recognized them as distinct genera. Stirton's (1940) well known phylogeny of the Equidae is in large measure a derivation of Matthew's. Conceptually, the two are very similar, although Stirton formally recognized some later Tertiary groups (Calippus and Astrohippus) as distinct, explicitly noted the relative positions of some species in the phylogeny, and benefited from a better understanding of the Cenozoic timescale. The resemblances between the two are apparent in Figure 67, in which they have been converted into cladistic form. In doing so, species regarded as "ancestral" to certain groups (e.g. "Merychippus" jsonesus in Fig. 67B) by Stirton are given sister-group status. Stirton's phylogeny was an eclectic combination of horizontal and vertical classification. With respect to the Equinae, many of the "primitive" species were placed in a horizontal grade (Merychippus s.1.), from which descended five vertical clades. In this sense, Merychippus is an example of the familar "wastebasket" taxon widely employed by evolutionary taxonomists. Stirton's (1940) phylogeny was popularized by Simpson $(1944 ; 1951 ; 1953)$, who used it to examine various evolutionary mechanisms, and it has endured at the generic level to this day with little modification (e.g. MacFadden, 1985). The only substantive changes (other than those at the species level, e.g. by MacFadden 1984a; Webb and 


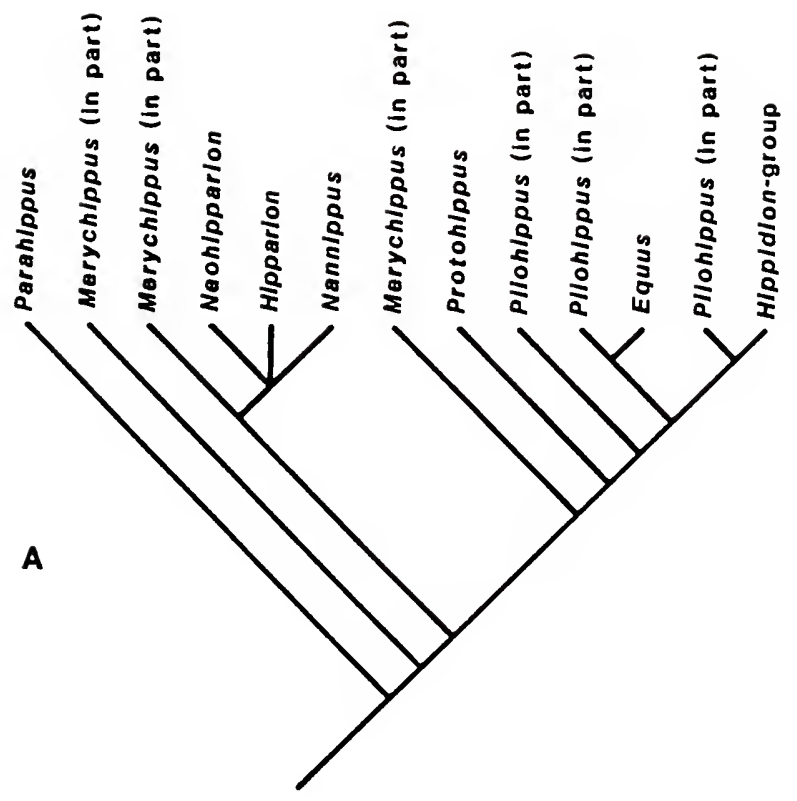

Figure 67. Previous phylogenetic hypotheses of advanced equids expressed in cladistic form. A. Matthew (1926). B. Stirton (1940). C. Quinn (1955). Matthew and Stirton expressiy used paraphyletic taxa in their classifications, e.g. the genera Merychippus and Pliohippus. Quinn did not use paraphyletic taxa, but his arrangement of equid genera differs considerably with both the traditional phylogenies of Matthew and Stirton, and the results of this study's cladistic analysis. 

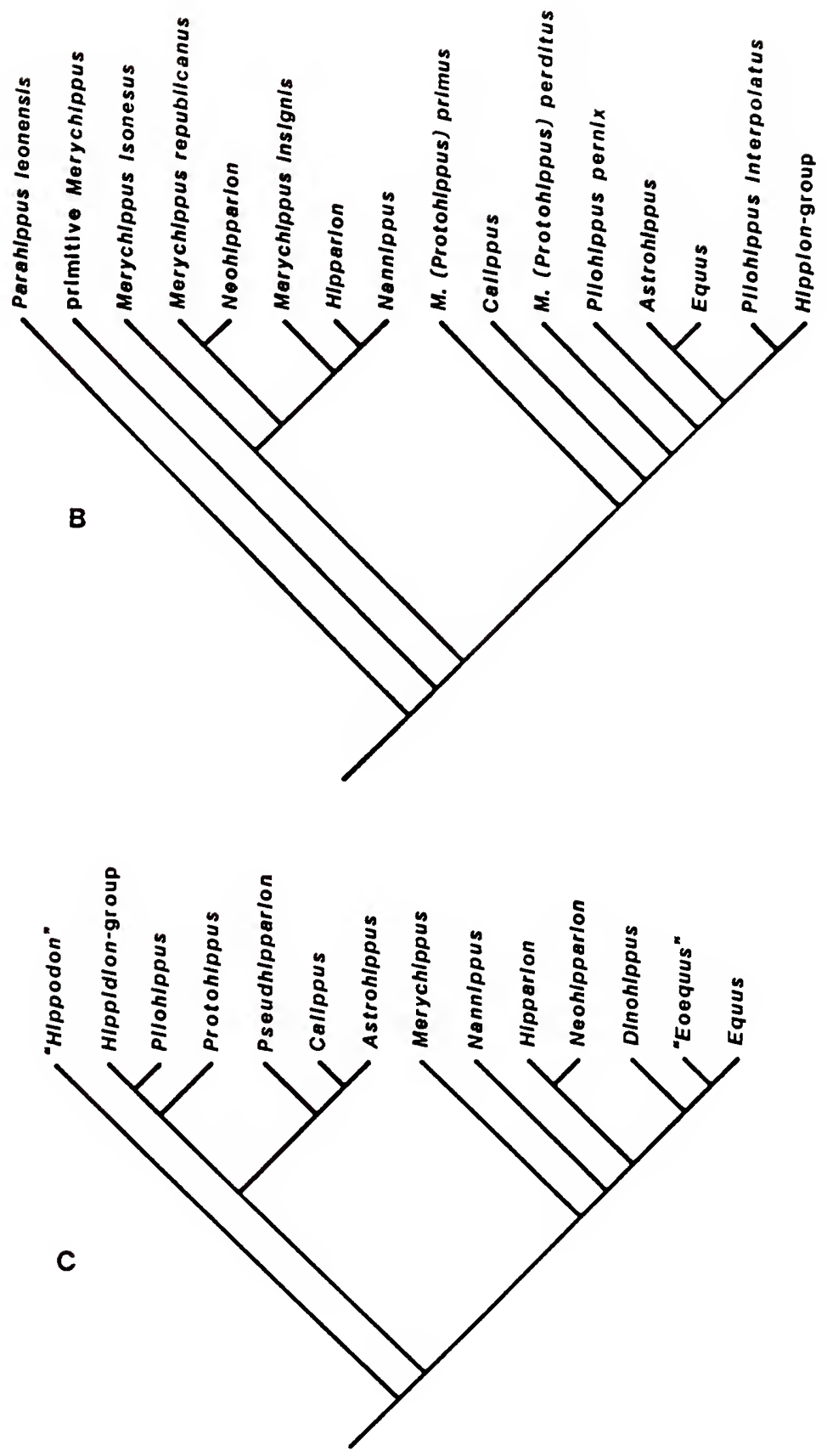

Figure $67--$ continued 


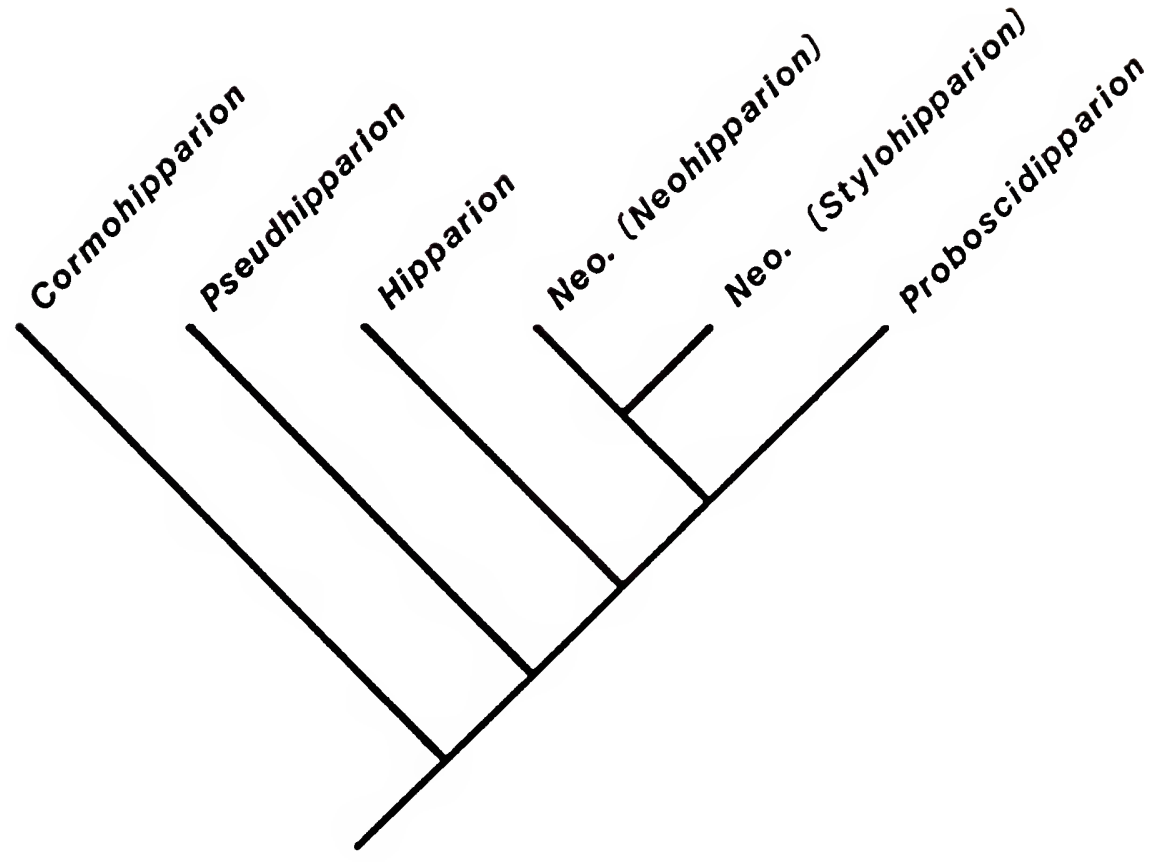

Figure 68. Forsten's (1984) cladogram expressing the interrelationships among the hipparionines. This arrangement is not supported by the results of this study (see Figures 73 and 74 ). 
Hulbert, 1986) have been the recognition of three more "advanced" genera (Dinohippus, Cormohipparion and Pseudhipparion), making a total of eight lineages independently rising out of Merychippus s.1.

Only one serious alternative to the phylogeny of Matthew and Stirton has been proposed, that of Quinn (1955). Quinn's arrangement (expressed cladistically in Fig. 67C), while strictly a vertical phylogeny, did not distinguish between primitive and derived characters, did not take into proper account ontogenetic and individual variation (thus badly oversplitting some taxa; Webb, 1969a; Forsten, 1975), and was based almost entirely on relatively incomplete Texas Gulf Coastal Plain specimens. The major difference between the phylogenies of Quinn and Stirton (Fig. 67) was that Quinn considered part of the equine clade (that containing Equus and closely related forms) as the sister-group of the hipparionines. Other, more minor differences, were 1) that Neohipparion was considered closer to Hipparion than was Nannippus, 2) Pseudhipparion was excluded from the hipparionines and considered related to Calippus and Astrohippus (Stirton, 1940;1947, considered Pseudhipparion to be a side branch within Nannippus), and 3) Protohippus and Calippus were not considered to be closely related. As noted previously $(p .445)$, a major difficulty in interpretting Quinn's phylogeny and comparing it to those of others, is understanding his specific and generic level taxonomy.

Forsten (1984) has recently proposed a cladistic phylogeny of the hipparionines, reproduced here as Figure 68 . As noted on p. 159, she improperly "redefined" Cormohipparion by excluding its hipparioninegrade species, although she did not specifically state which ones 
these are. Presumably this would have to exclude Cor. occidentale, the genotype species, as it undoubtedly has hipparionid lower cheekteeth. Forsten (1984) also included Nannippus in Hipparion, failed to state what characters unite Hipparion and Neohipparion, and united 01d and New World taxa in Neohipparion based on the presence of grooved incisors. Incisors associated with cheekteeth of NeO. leptode and Neo. eurystyle are not grooved, and the validity of this character is doubtful.

Cladistic analysis produces phylogenies in the form of testable hypotheses. Previous phylogenies of the Equidae were based on a limited number of characters. Some, especially that of Stirton (1940), almost exclusively used upper cheekteeth. With the current improved knowledge of cranial characters for many taxa (due in large measure to the Frick collection), a cladistic analysis of advanced equids is detailed below. The results are compared with previous phylogenies, and a new classification of these horses is proposed.

\section{Methods}

States for 60 characters and 57 taxa of advanced equids were compiled from Chapter 5 and from the literature (Table 46). These included all of the species described in Chapter 5, except for ?Cal. circulus which is currently too inadequately known. Only North American taxa were considered, as 01d World horses were beyond the scope of this study (since they were ultimately derived from North American species, a phylogenetic analysis of the latter is essential for interpreting their relationships, but not the converse). Also 
included were species not known from the Gulf Coastal Plain (e.g. Nan. lenticularis and Neo. leptode), and twelve late Hemingfordian to Barstovian species of "merychippine" grade. These were "Merychippus" gunteri, "M.." primus, "ㅍ.." isonesus, "M.." sejunctus, "M․" carrizoensis, "M." stylodontus, "Neo." coloradense, "Cor." goorisi, Hipparion shirleyi, Pro. vetus, Plio. mirabilis, and $\underline{M}$. insignis. Character states for the latter taxon were based on the Echo Quarry sample described by Skinner and Taylor (1967). Evander (1986) has questioned their referral of this material to that genus and species. Regardless of nomenclature, it is an important, we 11 represented sample. Parahippus leonensis was used as the out-group in all analyses, based on the well represented middle Hemingfordian Thomas Farm sample (Forsten, 1975; Hulbert, 1985). Para. leonensis (or its junior synonym Para. vellicans; synonymy follows Downs, 1956 and Forsten, 1975) has long been regarded as "ancestra $7 "$ to Merychippus s.1. (Schlaikjer, 1937; Stirton, 1940; Downs, 1956), making it the best candidate for an out-group.

Cladograms were constructed both "by hand" and by use of the computer program PAUP. PAUP computes most parsimonious tree(s) for taxa using a number of different methods and options (Swofford, 1985). Options used here were: rooting using the out-group method; weighing all characters equally regardless of the number of character states they contain (WEIGHTS SCALE option); optimizing the character states of hypothetical taxonomic intermediaries with the FARRIS option; and obtaining all equally most parsimonious trees with the SWAP=ALTERNATE method of branch-swapping in con junction with the 
MULPARS option. The number of taxa and characters being studied prevents the exact determination of the truly most parsimonious tree (i.e. through the use of PAUP's ALLTREES or BANDB options). The computer time required to calculate truly most parsimonious trees with PAUP becomes prohibitive (i.e. $>24$ hours on an IBM PC) when more than 12 to 16 taxa are analyzed together. Instead, the program must use a complex algorithm to obtain the heuristically best solution to the problem (Swofford, 1985). As a matter of convenience, trees obtained with this algorithm will be termed "most parsimonious" for the remainder of this study. Using the TOPOLOGY command, cladograms constructed "by hand" were analyzed by PAUP for comparison with the trees derived using the parsimony criterion.

of the 60 characters (Table 47), 13 are cranial features (of which six relate to the morphology and position of the facial fossae); three are characters taken from the incisors; 42 from the cheekteeth (22 uppers, 17 lowers, 3 genera 1); one postcranial character; and general size. Lack of associated post-cranial and cranial material for many species prevents a greater use of post-cranial characters in the study. However, the overall basic morpholgy of equid postcranial elements is relatively conservative among the advanced equids (Schlaijker, 1937) compared to other mammalian families. In species that demonstrate multiple character states for a particular feature, the one most commonly observed was assigned in Table 46. This did not happen very often, as the character states were selected and divided so as to avoid this. However, given the great intraspecific variation observed in equid cheektooth ename 1 patterns, some 


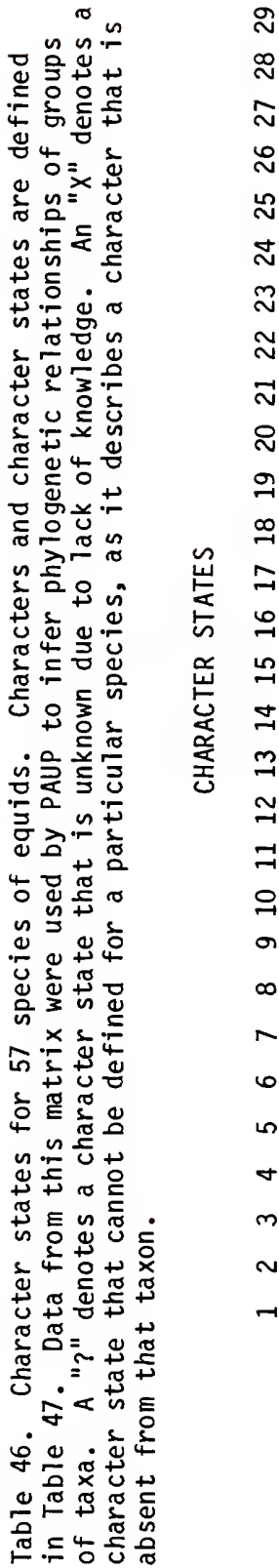

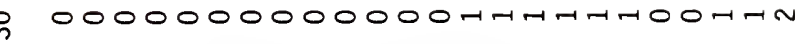

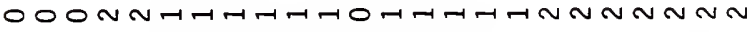
$\sqcap N-N \sim N N \sim N N \sim N N m m m m m \sim m m m m m$

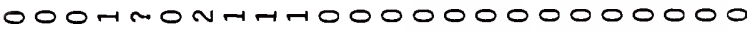
NM NMNG

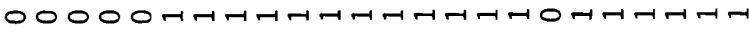
00000NNNNNNNMMMMMOHNNTNM $0000000000 \pi$ NNNMM0000000

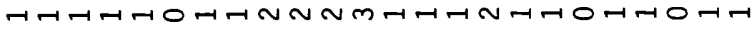
000HनNNNmmmmmm 000000000000000000070000 OOHA-INNNNNNNNNNNNOMNNONN 0000000000 HMNNNM000M000 0m0000000000000mro000000

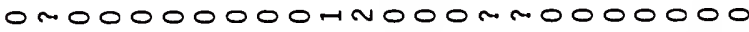
omo00000000m000mmo000000 oro00000000m000mmo000000 HM-

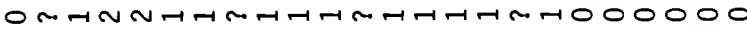

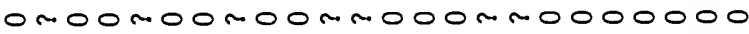

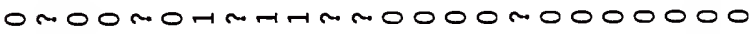

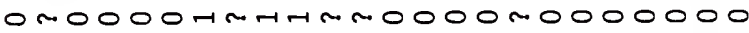

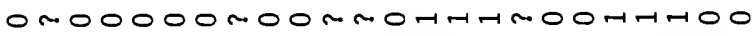
omoloolomolommonoxmo000000

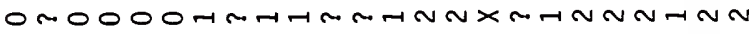

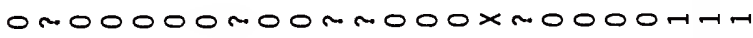

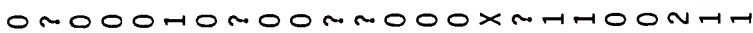
HMHANNHMHTMNHOOOMNNNNNmmm

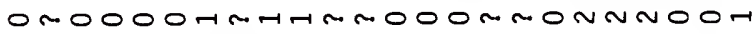

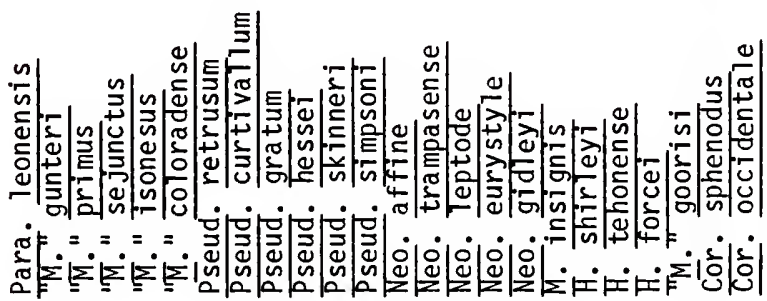


HHNH0H0H-1000000000000000000000000

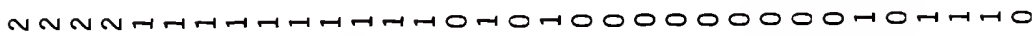
mmmm N N N

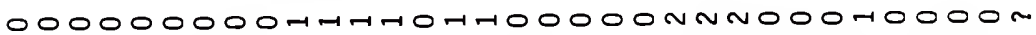

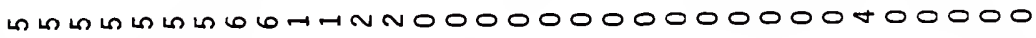
L HनHनHनHनH0000000000000000000000000 mmm-HMNMmH-HHD00000000000000000000

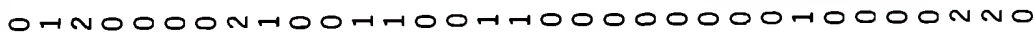

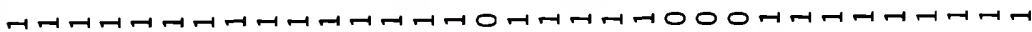
NN NNNN 000 NNNNNO0007000000000000000000000

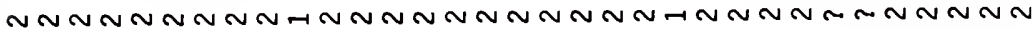

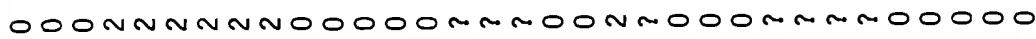
o00mmHomhmo0000000000m000000000000 $000000000 m 0000000000 m 000000000000$ 000000000 N000नHनHनHनM000000000000

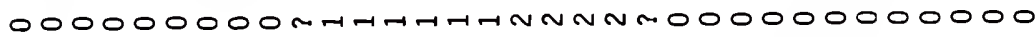
VNNmmnmm

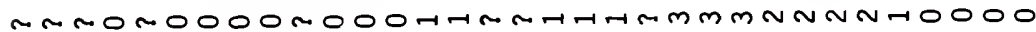

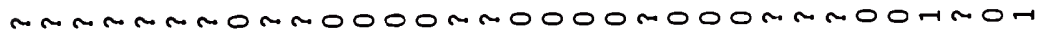

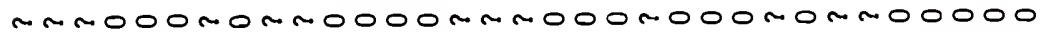

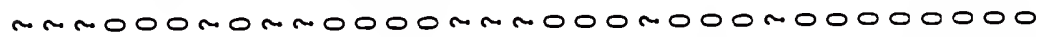

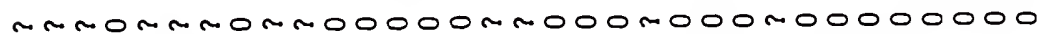

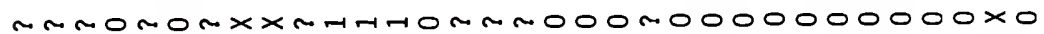

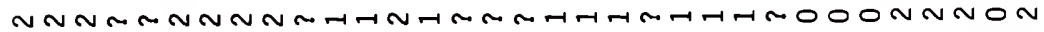

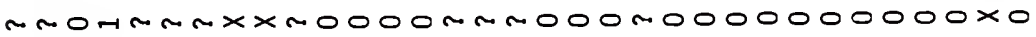

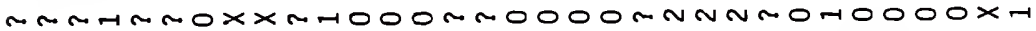

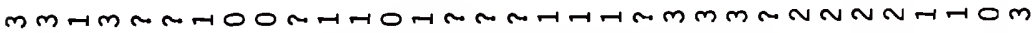

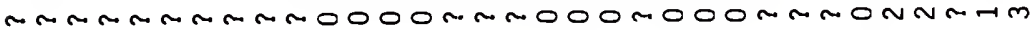

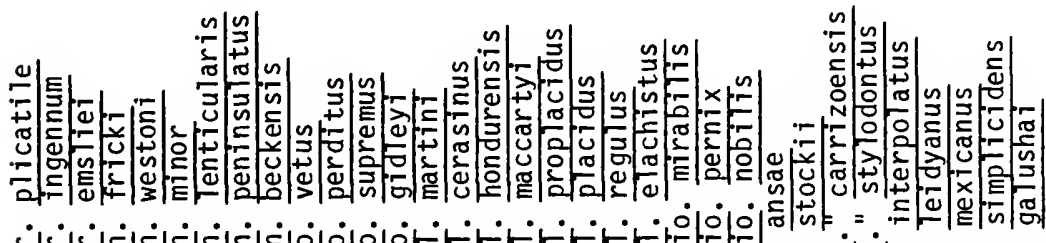

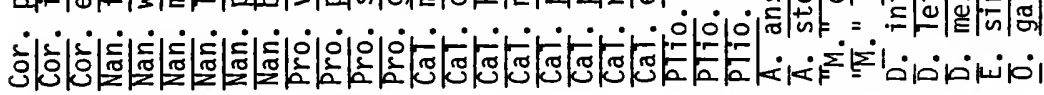


$00000000000 m 0000 m 0000000$ 0000000000000 rnmo00000r ortmmanan

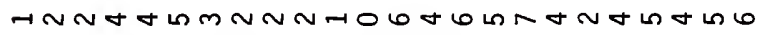
000000000000000000000000 $000000000000 \pi t 7-10000000$ $0000000-1000 m-n N m m 000000 \pi$ o 000 ONNNNNNNmmmmo0-n 000000000000 Tnmmmo00000-1 $000000000000 \pi N N m N 00000$ H $0000000000000 \pi n-100000 \pi-1$

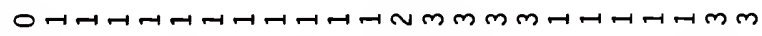
000000000000000000000000

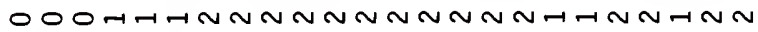

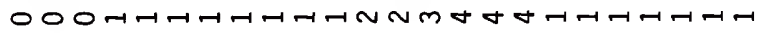
$00000000000000000000004 \pi$

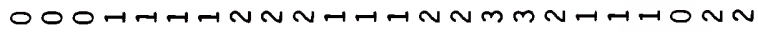
000000000000000000000000

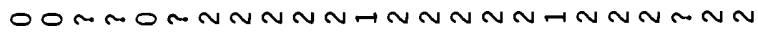
o0mnoropo0000000000000n00

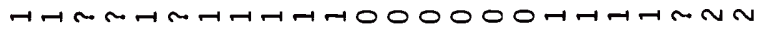

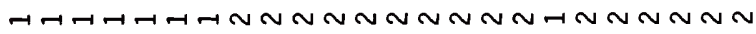
0000000000000 thth0000000 000000000000000000000000

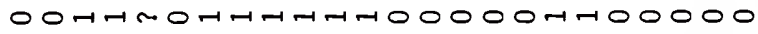
00नHAnNMmMm000000000000

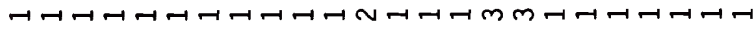

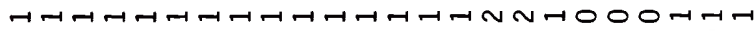

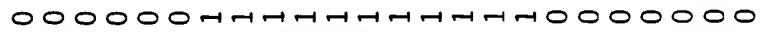
mmmmmmot 等 


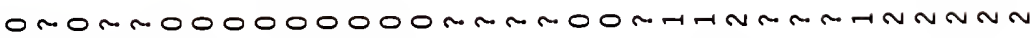

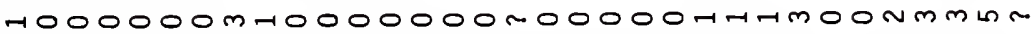
$\infty \omega$ ○ แ

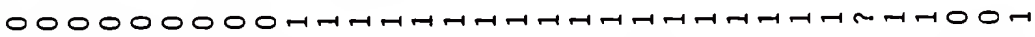
$00000007-10000000000000000-10000070$

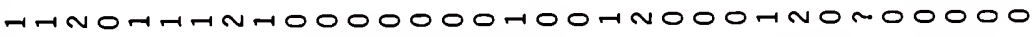

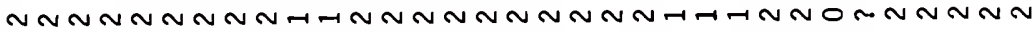
HTN0000000000000000000000000000

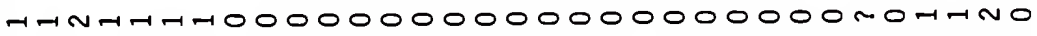

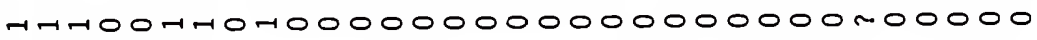

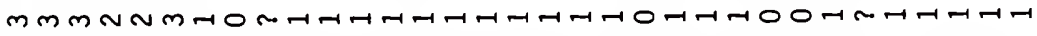
0 -1000000000000000000000000100000

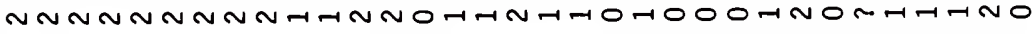

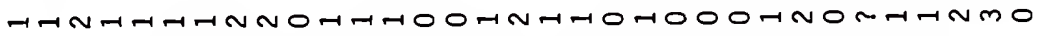

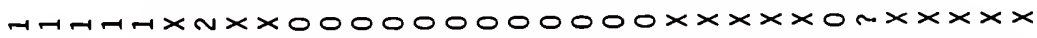
Nom $N$ N

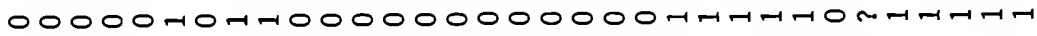
NNNNN- -

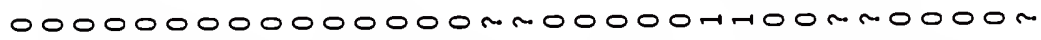

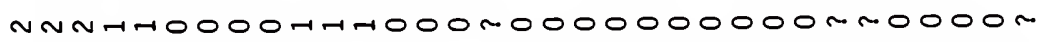

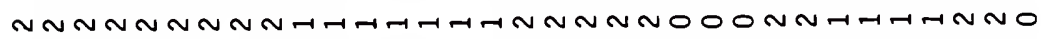
0000070 H. 000000000000000000000000

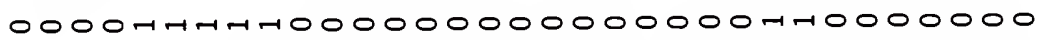

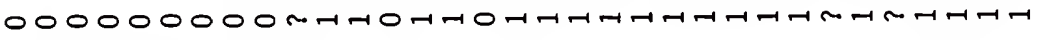

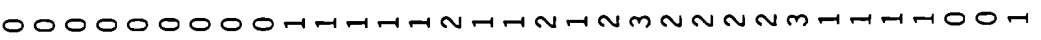

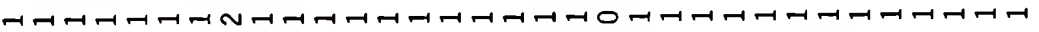

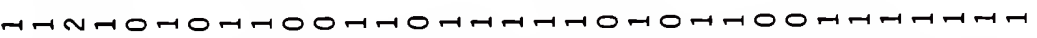

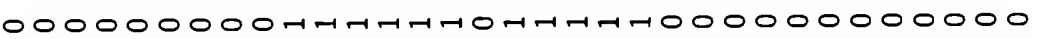
מ

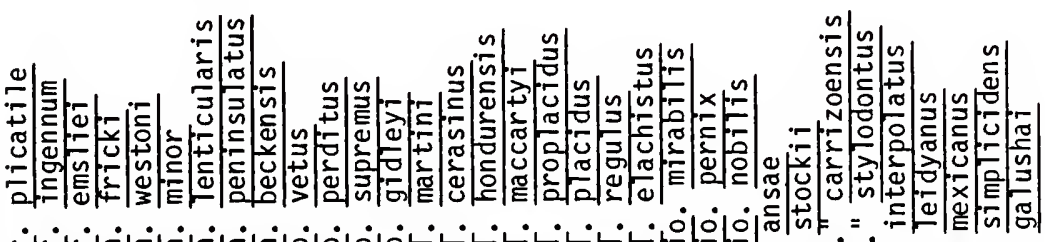

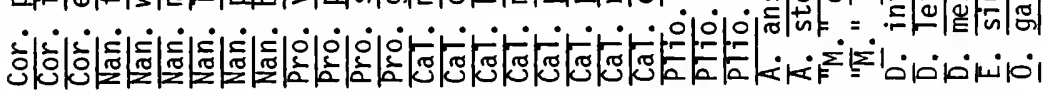


Table 47. Description of characters and character states used in the phylogenetic analyses. Characters with three or more states were considered to be transformationa 1 sequences (morphoclines).

CHARACTER

1. Depth of nasal notch

2. depth of DPOF

3. DPOF posterior pocket

4. DPOF anterior margin

5. preorbital bar length

6. DPOF shape

7. size of lacrimal bone

8. frontal bones

9. zygomatic arch buckle

10. long process of premaxilla extends past nasal notch

11. malar region

\section{CHARACTER STATES}

0 very shallow

1 deep, over anterior half of P2

2 deep, over posterior half of $P 2$

3 very deep, passed the P2

0 absent or rudimentary

1 shallow

2 moderate

3 deep

0 not present

1 slight pocketing

2 deeply pocketed

0 confluent with face

1 well defined or rimmed

0 narrow $(<5 \mathrm{~mm})$

1 moderate $(5-15 \mathrm{~mm})$

2 long (>15 mm)

0 elongate-oval

1 ova 1

0 relatively large

1 relatively smal1

0 not notably domed

1 notably domed

0 present

1 absent

0 yes

1 no

0 inflated, no fossa

1 variably shallow depression

2 moderate fossa

3 deep fossa 
Table 47--continued

12. relative muzzle length

0 very short

1 short

2 moderate

3 elongated

4 very elongated

13. relative muzzle width

0 normal

1 broadened

2 very broad

14. incisor arcade

0 arcuate

1 straight

15. incisors

0 norma 1, rooted

1 very hypsodont

2 ever-growing, rootless

16. Tower incisors

0 norma 1

1 very procumbent

17. relative size of DPI

0 large

1 small

2 very reduced or absent

18. deciduous premolars

0 mesodont, 1ittle or no cement

1 weakly cemented

2 subhypsodont, well cemented

19. P2/DP2 anterostyle

0 well developed

1 reduced

2 very reduced

20. protocone shape

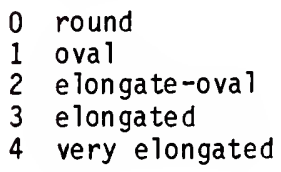

21. relative protocone size

$\begin{array}{ll}0 & \text { smal1 } \\ 1 & \text { moderate } \\ 2 & \text { large }\end{array}$

22. protocone lingual border

0 round or convex

1 straight

2 straight or concave

3 concave 
Table 47--continued

23. protocone spur

0 large, per sistent

1 large, on ly in early wear-stage

2 reduced, on ly in early wear

3 absent or very rare

24. protocone spur connects to protoselene

0 yes

1 no

25. timing of protocone connection to protoselene on P34

0 immediately after on set of wear

1 in very early wear-stage

2 in early wear-stage

3 in early moderate wear-stage

4 in late moderate wear-stage

5 in late wear-stage

6 isolated to base of crown

26. timing of protocone connection to protoselene on $\mathrm{M} 12$

0 immediately after on set of wear

1 in very early wear-stage

2 in early wear-stage

3 in early moderate wear-stage

4 in late moderate wear-stage

5 in late wear-stage

6 isolated to base of crown

27. protocone connection to hypocone

0 never

1 rarely, always in late wear

2 common ly

28. pli caballin on premolars

0 absent or very rare

1 weak or nonpersistent

2 strong, single

3 strong, often multiple

29. pli caballin on molars

0 absent or very rare

1 weak or nonpersistent

2 strong, single

3 strong, often multiple

30. external fossette plications

0 not plicated or very simple

1 persistently plicated

2 multiple pli protoloph common

31. internal fossette plications

0 absent or very rare

1 very simple

2 simple, nonpersistent

3 simple, persistent

4 moderate

5 complex to moderate

6 persistently very complex 
Table 47--continued

32. protocone orientation on P34

33. metastyle

34. mesostyle

35. hypoconal groove closure

36. hypoconal groove

37. depth of hypoconal groove

38. orientation of hypocone

39. ROC of upper cheekteeth

40. ectostylids on dp2-dp4

41. protostylids on $\mathrm{dp} 34$

42. strength of dp34 protostylids

43. protostylids on $p 3-m 3$
0 anteroposterior

1 markedly oblique

0 generally absent

1 often present, not strong

2 very well developed

0 relatively weak

1 moderate

2 strong

3 strong, notably constricted

0 open to base of crown

1 closed in moderate wear-stage

2 closed in early wear-stage

3 closed in very early wear-stage

0 does not form lake when closed

1 forms isolated lake

0 deep

1 shallow

0 anteroposterior

1 oblique

0 low (strongly curved)

1 moderate

2 high, teeth not curved

0 absent or rudimentary

1 moderate

2 very strong

0 present

1 absent

0 "Hippodon" grade
1 moderate
2 strong

0 present

1 absent 
Table 47--continued

44. strength of protostylids on $p 3-m 3$

0 "Hippodon" grade

1 moderate

2 strong

3 strong, recurved posterior $1 y$

45. protostylid attachment

0 attached to protoconid

1 isolated when it first appears

2 persistently isolated

46. metaconid-metasty 1 id complex

0 sma 11, unexpanded

1 expanded

2 elongated

3 very elongated

4 extremely elongated

47. metaconid-metastylid

0 poorly separated

1 well separated in early wearstage on $7 y$

2 persistentiy we11 separated

48. $p 2 / d p 2$ metaflexid

0 rarely closed

1 frequently closed by metaconid plication

49. isthmus plications

0 absent or very rare

1 pli entoflexid on ly

2 frequent, but nonpersistent

3 frequent, persistent

50. para lophid plication

0 absent or rare

1 frequent

51. pli caballinid on premolars

0 absent

1 small, on $1 y$ in early wear

2 we 11 developed, per sistent

3 as in 2, but often multiple

52. pli caballinid on molars

0 absent

1 smal1, on 1y in early wear

2 moderate, lasts until mid-wear

3 persistent, strong

53. ectoflexid depth on premolars

0 deeply penetrates isthmus

1 slightly penetrates isthmus

2 shallow, no penetration

3 very shallow 
Table 47--continued

54. ectoflexid depth on molars

0 completely penetrates isthmus

1 depth reduced in early wearstages, then as in 0

2 depth reduced until moderate wear-stages, then very deep

3 shallow, no penetration

55. labial borders of protoconid and hypoconid

0 rounded

1 flattened

56. position of metaconid rela- 0 the same tive to metastylid on molars 1 notably more linguad

57. genera) size (mean UTRL +/- $5 \mathrm{~mm}$ )

0 very sma $11,80 \mathrm{~mm}$

$1 \mathrm{sma} 11,90 \mathrm{~mm}$

$2100 \mathrm{~mm}$

$3110 \mathrm{~mm}$

$4120 \mathrm{~mm}$

$5130 \mathrm{~mm}$

$6 \quad 140 \mathrm{~mm}$

$7150 \mathrm{~mm}$

$8>155 \mathrm{~mm}$

58. unworn M1 MSCH or $\mathrm{m} 1 \mathrm{mcch},+/-2.5 \mathrm{~mm}$
$020 \mathrm{~mm}$
$125 \mathrm{~mm}$
$230 \mathrm{~mm}$
$335 \mathrm{~mm}$
$440 \mathrm{~mm}$
$545 \mathrm{~mm}$
$650 \mathrm{~mm}$
$755 \mathrm{~mm}$
$8>58 \mathrm{~mm}$

59. same as 58

$$
\begin{array}{ll}
0 & <58 \mathrm{~mm} \\
1 & 60 \mathrm{~mm} \\
2 & 65 \mathrm{~mm} \\
3 & 70 \mathrm{~mm} \\
4 & 75 \mathrm{~mm} \\
5 & 80 \mathrm{~mm} \\
6 & >83 \mathrm{~mm}
\end{array}
$$

60. lateral digits

0 present, relatively large

1 notably reduced

2 absent 
individuals will not match all the character states listed in Table 46 for any given taxon.

\section{Results and Classification}

Pre Timinary Ana Tyses

There were three primary goals of this phylogenetic analysis. The first was to determine the cladistic interrelationships of the species. The second was to use that information to delineate generic and other monophyletic supraspecific groups within the Equinae. The third was to examine the true phylogenetic relationships of merychippine-grade taxa with others traditionally assigned to more "advanced" genera. The results of the analyses are not completely conclusive, and further analysis with more characters should clarify some relationships. One potential source for additional characters is the basicranium. Webb (1969a) gave a detailed description of a skull of Pseud. retrusum, and noted severa 1 differences between its basicranium and those of Pliohippus and Equus. The large F:AM sample of skulls of Pseudhipparion, Cormohipparion, Calippus, Protohippus, Pliohippus and various merychippines should demonstrate the range of intraspecific variation of the se characters, and determine this region's potential value for equid systematics. Another potential source of additional characters is the post-cranial skeleton, especially the distal limb elements. Recent discoveries of associated individuals at Moss Acres and the Poison Ivy Quarry make this more feasible than before. 
In the first preliminary analysis, as many taxa as possible were examined simultaneously. The maximum number of taxa PAUP (Version 2.4) can analyze at once is 45 . Thus 12 taxa from the original data set had to be excluded. Those deleted had incomplete data, or were so similar to others that they added 7ittle information to the overall tree (e.g. Nan. beckensis, as it was obviously closely related to Nan. peninsulatus). Using a 1160 characters, three equally parsimonious trees were produced, of which one is shown in Figure 69. These differed only in the relative positions of Pseud. gratum, Pseud. hessei and Pseud. skinneri, so there is essentially but one most parsimonious arrangement of the 45 taxa. The tree shown in Figure 69 indicates that advanced equids consist of two major clades. If merychippine-grade species are not considered, four monophyletic hipparionine clades are recognized, Hipparion, Cormohipparion (plus Nan. fricki), Neohipparion and Nannippus. The other major clade contains the following monophyletic groups: Pseudhipparion, Protohippus, Calippus (excluding Grammohippus), Astrohippus and Pliohippus. Dinohippus and CaT. (Grammohippus) are paraphyletic. Many of the features (and problems) of this tree (and others produced with slightly different combinations of characters and taxa) are similar to those observed by Kirsch and Archer (1982) in a study of computer-generated cladograms of carnivorous marsupials. Comparisons between the two studies are appropriate because both have species as their terminal taxa (instead of, e.g. Novacek's [1986] analysis of mammals at the ordinal level), both use similar tree-generating programs with parsimony criteria, and in both, dental traits far 


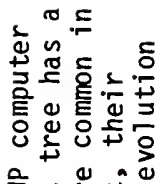

을

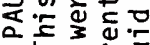

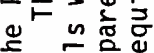

†

疋的告

ऽ

뒁

풍요

닉믄 는

र $=$ б

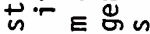

ᄃㅇㅇㅁㄷㄴ

웡뮤

ㅇNㅁ

元元它

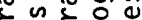

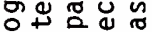

용

艺范。-

U.

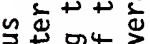

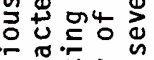

듄

을 옹 도

的贻

ชั

口东

$\rightarrow=4$ 옹

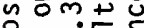

을엉드

\㟧

б웅

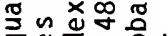

원용

떤드 음응

\& 次

的额的

†

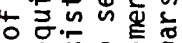

宁的。焉

능

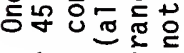

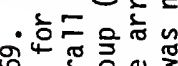

인 운

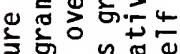

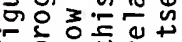

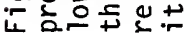




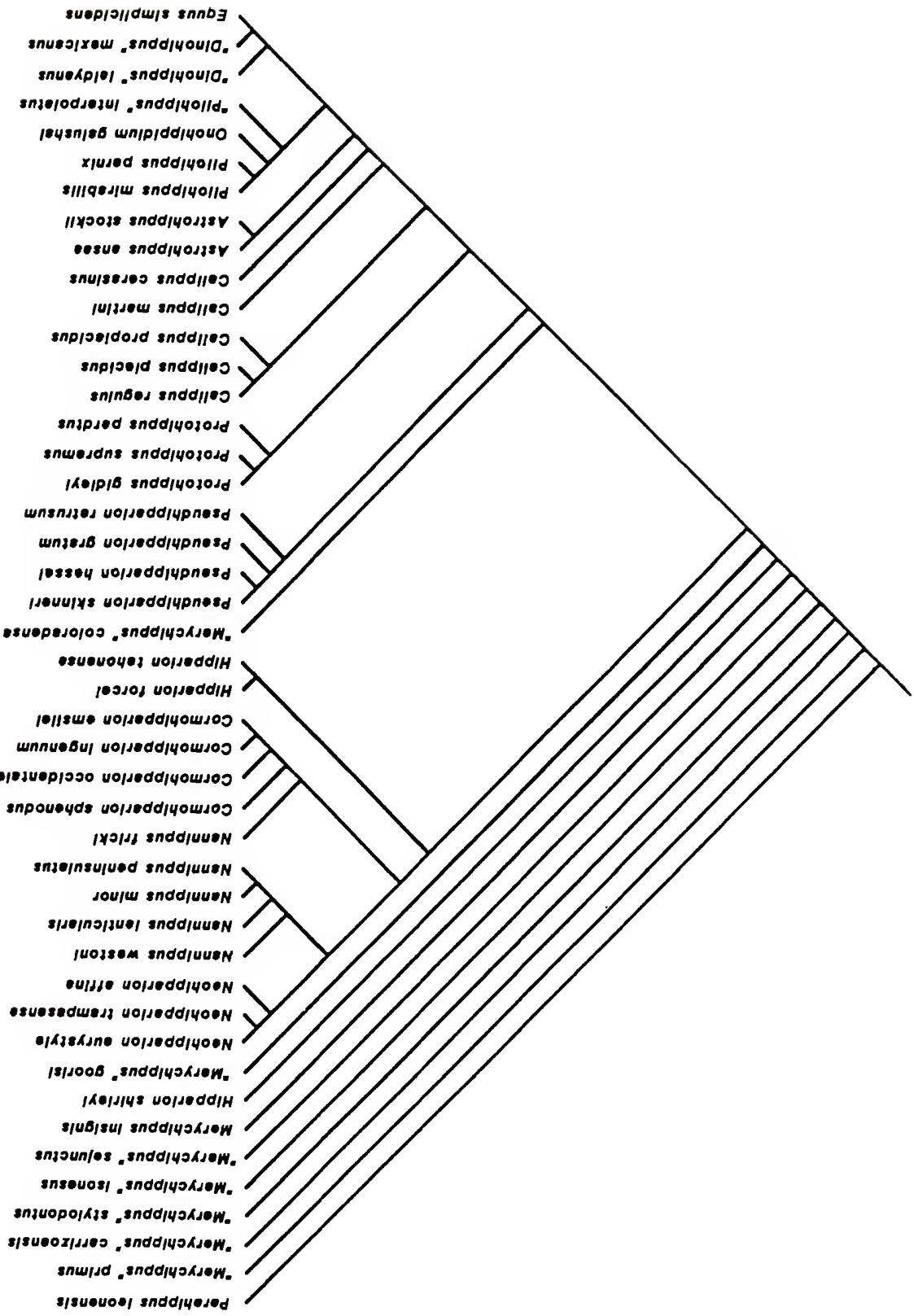




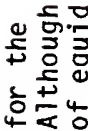

E 9

ธิ is

政

○。

눙

ఫั

늠

을ㄴ단

언 농

4

告运

ล ธะ

잉

峲

즈윹

뭉 ำ

$+$

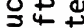

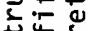

的文

등⿺ㅝㅇㅝㅝ

E $ح$.

ธั

ช。

음든

는

乌苛

อ

통ํํ

in

家

中比市

幽

을.둠ํำ

( ) 5

중

क क

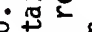

묻ㄷㅇ

눈

吉洁

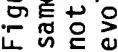




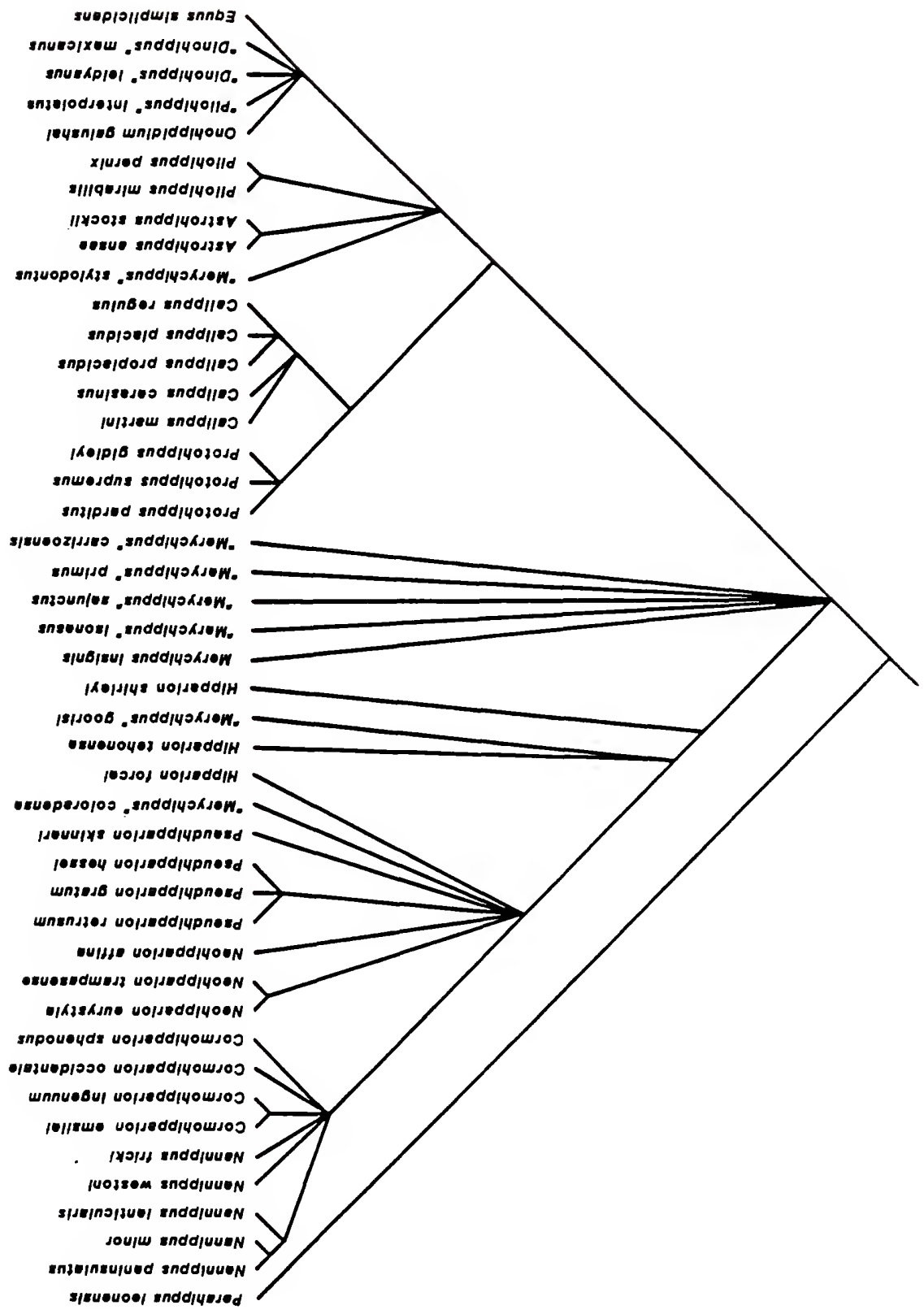




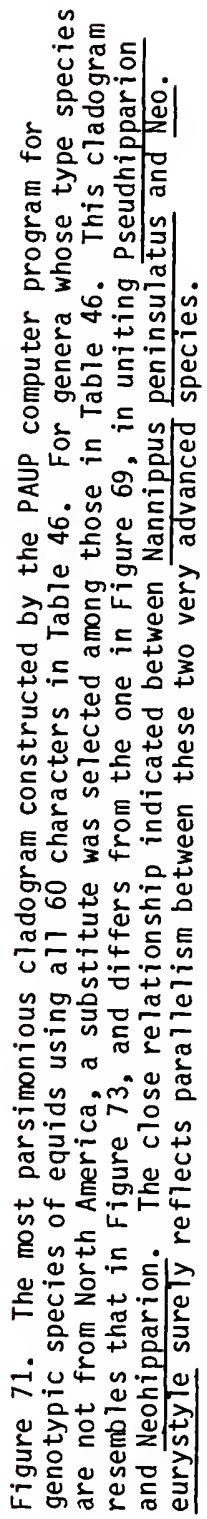




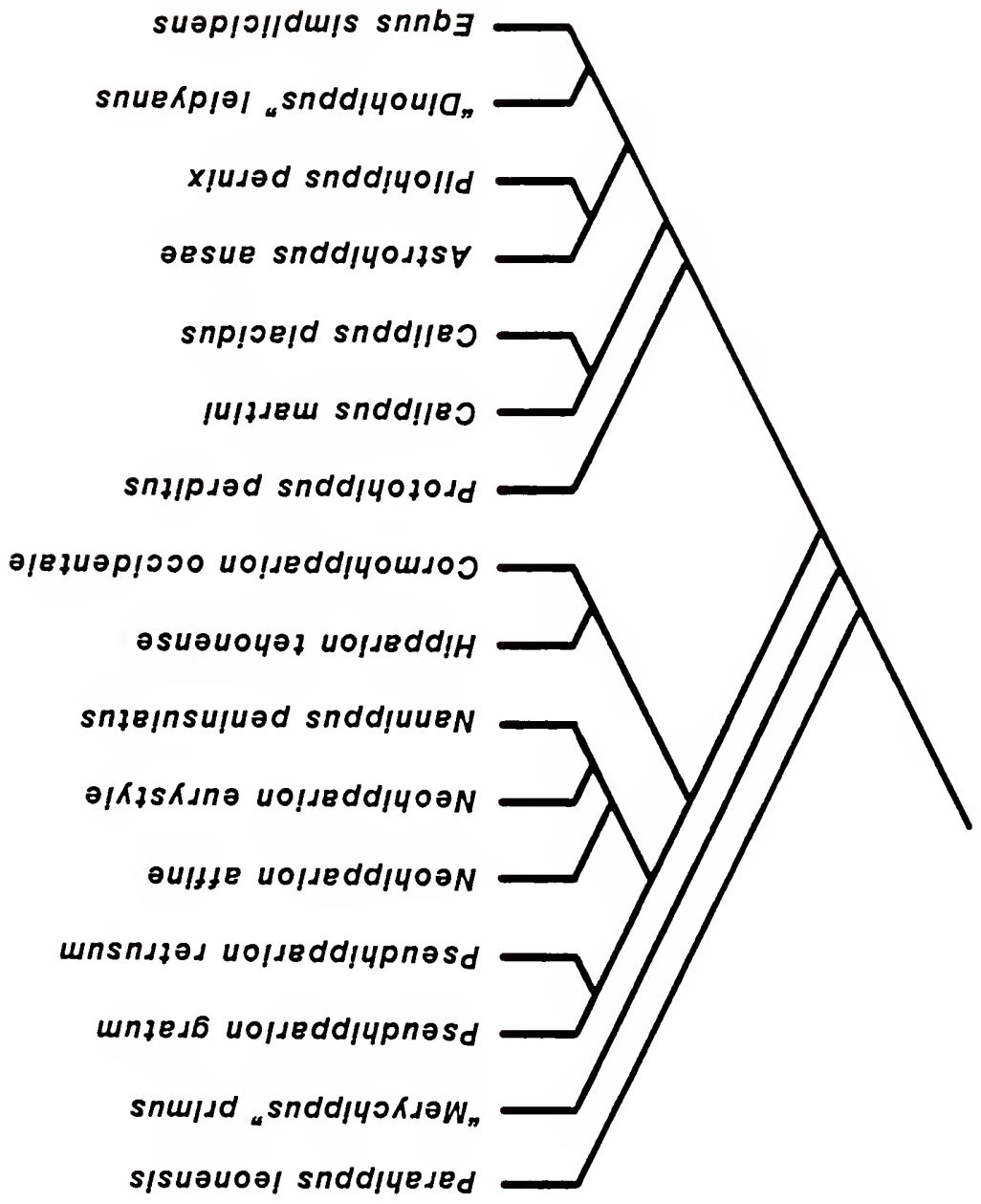




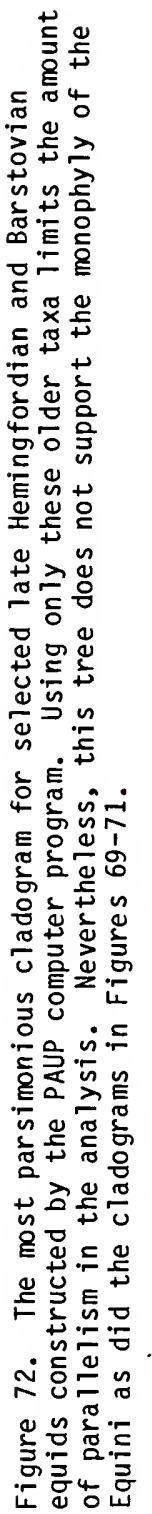




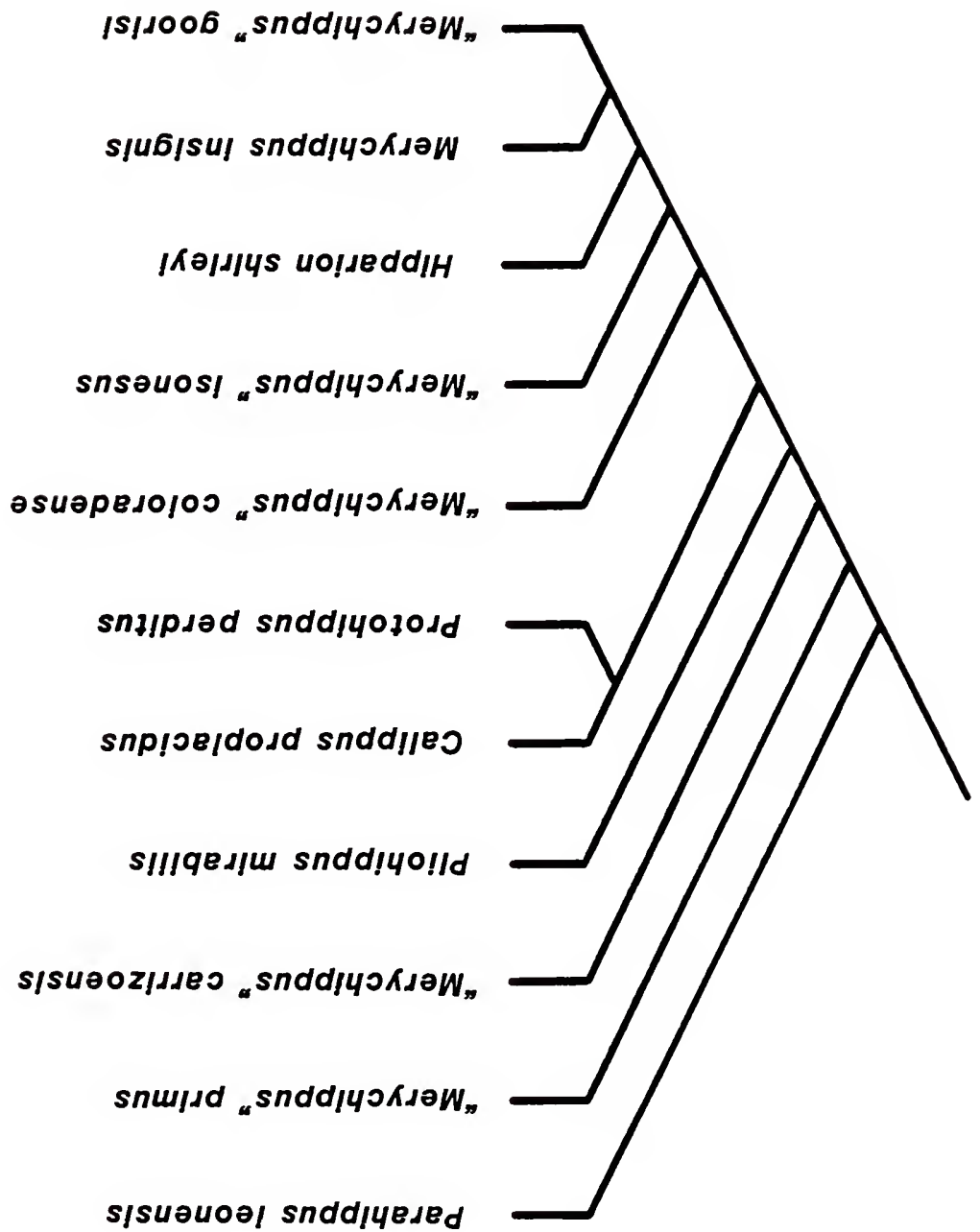


Table 48. Consistency indices (CIS) for individual characters in the cladogram depicted in Figure 69. The CI for a single character is the minimum possible number of changes over the entire tree divided by the actual number of changes for the character. A character that evolved only once over a given tree, and has no reversals, has the maximum possible CI, 1.00. Numbers for characters refer to those in Table 47.

\begin{tabular}{cccccc} 
CHARACTER & CI & CHARACTER & CI & CHARACTER & CI \\
\hline 1 & 0.25 & 21 & 0.40 & 41 & 1.00 \\
2 & 0.20 & 22 & 0.25 & 42 & 0.40 \\
3 & 0.20 & 23 & 0.33 & 43 & 0.50 \\
4 & 0.33 & 24 & 0.50 & 44 & 0.27 \\
5 & 0.22 & 25 & 0.43 & 45 & 0.67 \\
6 & 1.00 & 26 & 0.38 & 46 & 0.33 \\
7 & 0.33 & 27 & 0.22 & 47 & 0.22 \\
8 & 1.00 & 28 & 0.22 & 48 & 1.00 \\
9 & 1.00 & 29 & 0.29 & 49 & 0.33 \\
10 & 0.50 & 30 & 0.29 & 50 & 0.25 \\
11 & 0.25 & 31 & 0.26 & 51 & 0.43 \\
12 & 0.25 & 32 & 0.33 & 52 & 0.50 \\
13 & 0.67 & 33 & 0.18 & 53 & 0.50 \\
14 & 0.50 & 34 & 0.75 & 54 & 0.33 \\
15 & 1.00 & 35 & 0.25 & 55 & 0.25 \\
16 & 1.00 & 36 & 0.25 & 56 & 0.33 \\
17 & 0.25 & 37 & 0.50 & 57 & 0.22 \\
18 & 0.40 & 38 & 0.50 & 58 & 0.24 \\
19 & 0.40 & 39 & 0.29 & 59 & 0.31 \\
20 & 0.44 & 40 & 0.40 & 60 & 0.50
\end{tabular}


outnumber other types of characters. The amount of homoplasy is great. The overall consistency index (CI) is only 0.34 , while $83 \%$ of the characters had individual CIs equal to or less than 0.50 (Table 48). Groups were thus not delineated by sets of uniquely derived character states, but by different combinations of character sets (polythetic sensu Kirsch and Archer, 1982). To achieve maximum parsimony, in this and in many other trials, the algorithm often proceeds in directions that are very unlikely in an evolutionary sense. For example, there are many instances of decreasing crown height, deepening ectoflexids, and shortening protocones and metaconid-metastylid complexes. All of these, while not impossible, are extremely unlikely in equid evolution. Thus, the tree in Figure 69 would appear not to accurately reflect the true evolutionary history of the Equinae.

To further investigate the interrelationships of these taxa, three additional trees were computed. In one (Fig. 70), the same 45 taxa were used, but only those characters with CIs of 0.50 or greater in Table 48. The result is a highly consistent, but much less fully resolved tree, with numerous multichotomies. In the second (Fig. 71), all 60 characters were used, but on ly with genotypic species. The third tree (Fig. 72) also included all 60 characters, but on $1 y$ Barstovian or older taxa were analyzed. Comparisons of these trees, and with the one in Figure 69 , reveal both differences and similarities. The presence of "M." carrizoensis unduly affects character polarities, as PAUP invariably made it the sister-taxon to all more "advanced" equids (Figs. 69, 72), rather than just the sister-taxon 
to the Equini. This species has a combination of very primitive (e.g. low crown height, deep premolar ectoflexids) and very advanced (e.g. rapidly connected protocones, simple fossettes, malar fossa) characters (Munthe, 1979; Quinn, 1984). Other taxa, e.g. Calippus cerasinus, also appear to have certain combinations of advanced and primitive characters that force them into "unexpected" positions in the computer-generated tress. The problem is not so much where the computer places these taxa in the tree, but how that position affects judgements of character polarity in other OTUs.

The three trees (Figs. 70-72) all share with the one in Figure 69 a monophyletic hipparionine clade, although of differing composition. Pseudhipparion is included in this clade, rather than with the equines and protohippines. Calippus is the sister-taxon to other equines in Figures 69 and 71, while in the other analyses it and Protohippus are sister-groups. Contrasts between the trees in Figures 69 and 70 are especially instructive. One is based on on ly a few, but highly consistent characters (overall CI=0.79), the other on many characters, most of which are homoplasous (Table 48). Both reveal different aspects of equid evolution. The tree in Figure 70 probably represents the true major dichotomies within the advanced Equinae (i.e. the Equina, Protohippina and Hipparionini as defined in Chapter 5). The tree in Figure 69 emphasizes that parallelism and character reversal were extremely commonplace in equid evolution (as has long been noted), and that a strictly parsimonious approach is unlikely to correctly classify the group (cf. Felsenstein, 1978; Kirsch and Archer, 1982; Gosliner and Ghiselin, 1984). 
As justified by these preliminary results, the next two sections will discuss the results of analyses run separately for hipparionines and nonhipparionines (protohippines plus equines). To some extent, this limited the amount of observed parallelism, and allowed for more judicial generic assignments. In each case, the most parsimonious cladogram will be contrasted with a "hand-drawn" tree. The latter are only slightly less parsimonious, do not contain unlikely evolutionary events (e.g. decreasing crown height), and are more compatable with the fossil record.

Phylogenetic Analysis of Hipparionine Taxa

Figures 73 and 74 present two alternative phylogenetic hypotheses concerning 28 species of hipparionines. Figure 73 was generated by PAUP based on all sixty equally weighted characters discussed above (Table 46). It has a length of 116.8 steps, which converts to a CI of 0.45 . The cladogram in Figure 74 was generated "by hand" using the same set of characters. While parsimony was one criterion used in its construction, subjective judgements were also made as to which characters were more important (weighting), and which were thought to be more likely to have evolved in parallel in various genera (Gosliner and Ghiselin, 1984). It has a length of 119.5 steps (2.3\% longer than the other tree), and a CI of 0.44. As opposed to the situation described below for the Equini, there is actually very little difference between the two trees, on ly the relative positions of two taxa are different. In the most parsimonious tree (Fig. 73), Merychippus insignis (Echo Quarry population) and "M." coloradense 


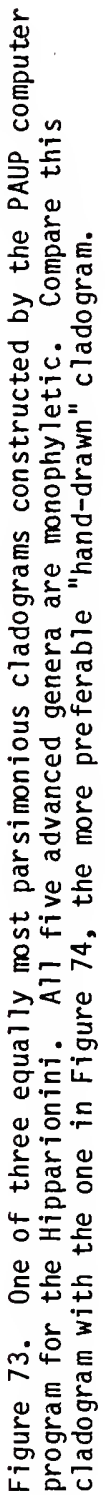




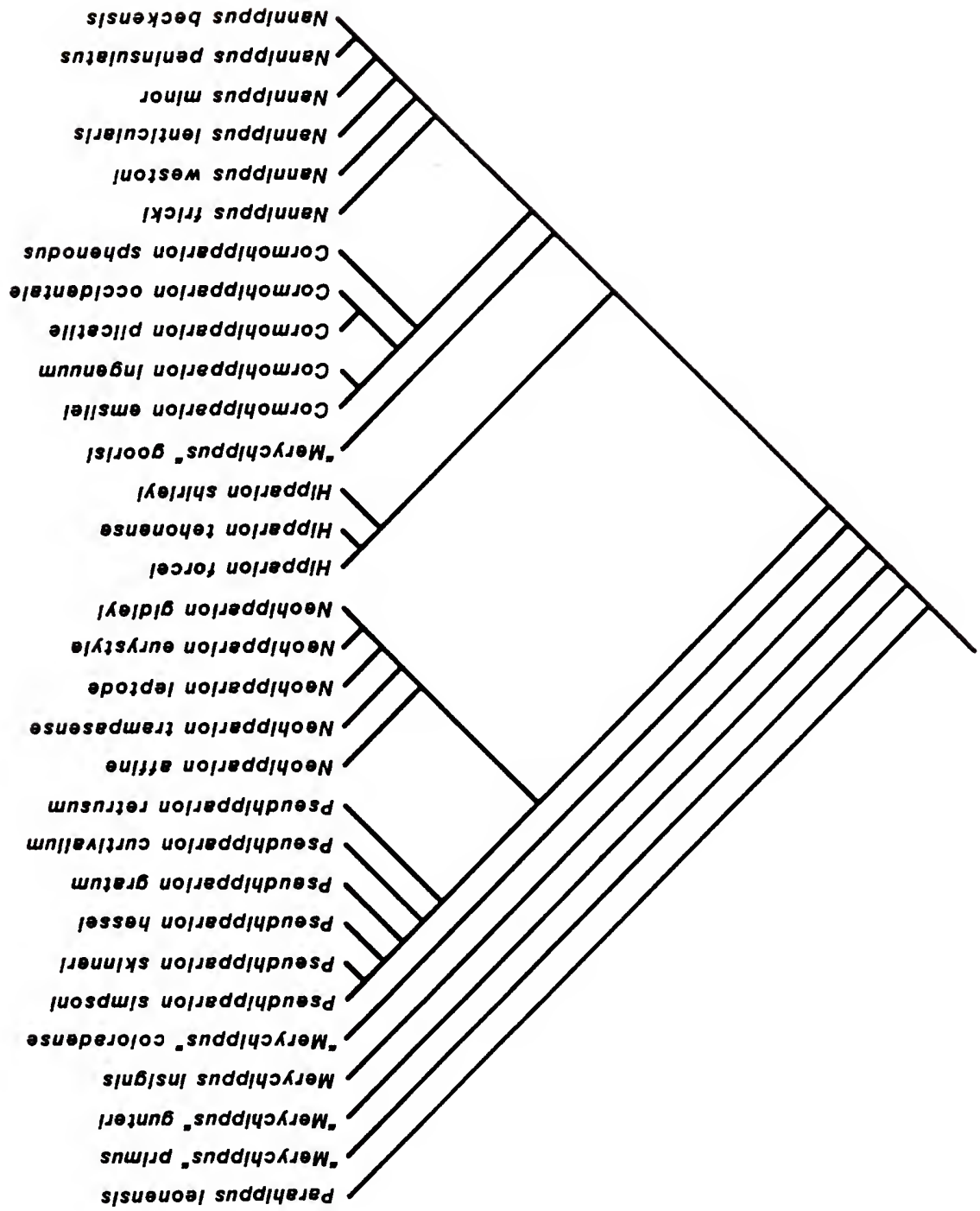


$\frac{7}{\frac{1}{2}}$

동

$=\frac{\mathscr{c}}{\square}$

든

3

웜

둔

듬

ธิ ข

故

응

응

음

둥

ज格

这是

শ্

号

하

के

음 올

함

닝

ㄷㅇㅇ

늘

है

过

ล

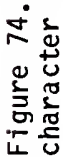




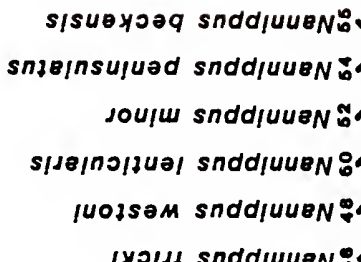

IYO/J snddIUUEN:

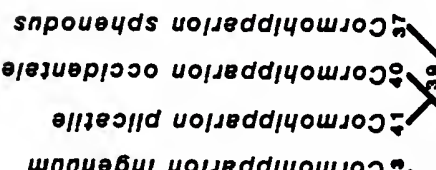
wnnuebul volsedd/40uso5 \$

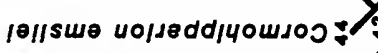

|s/1006 sndd/40KJOW,

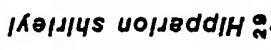

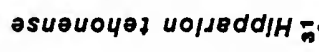
jeosos volsedd/H क्ष slub/sul sndd/YORJeW : esuepedoloo snddIUOKAOW,

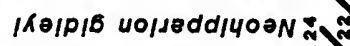

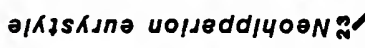

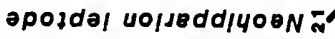

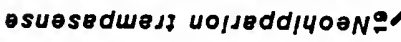
จU/H० UO/JEddIYOON= unsnjJed volseddiupnesd un/lea/tuno volsedd/upnosd o wnjes6 volseddlupnesd을 jessey voljeddjupnesd jeuulys voljedd/upnesd: luosdw/s voljeddiupnasd jajunB snddluOKJOW.

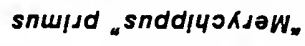
s/suavorl sndd/48jed

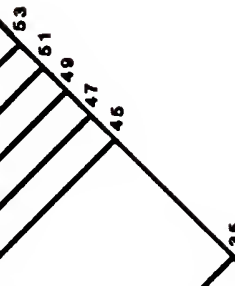


form successive sister-taxa to the remainder of the hipparionines. In the other tree (Fig. 74), M. insignis is considered to be the sister-taxon of only Hipparion, Cormohipparion and Nannippus, and "M." coloradense the sister-taxon of on ly Pseudhipparion and Neohipparion. In all other respects the two trees are identical. Based on Figure 74 , the cladistic relationships among hipparionines are determined by the following groups of derived characters: Node 1. The Hipparioni are united by:

a. moderately deep DPOF (secondarily shallow in several groups); b. DPOF with slight posterior pocket (secondarily lost in severa 1 groups);

c. oval protocones;

d. nonpersistent protoconal spur;

e. protocone not connected to protoselene until moderate wearstage;

f. molars with pli caballin;

g. moderately developed, persistent internal fossette plications;

h. strong protostylid on $\mathrm{dp} 34$;

i. moderately we 11 developed protostylid on p3-m3;

j. expanded metaconid-metastylid complex;

k. metaconid and metastylid well separated in early wear-stage;

1. unworn molar crown height $30 \mathrm{~mm}$ or more.

Node 2. "M." coloradense, Pseudhipparion and Neohipparion share:

a. elongate-oval protocone;

b. protoconal spur not very persistent, reduced; 
c. shallow premolar ectoflexid;

d. well cemented, subhypsodont deciduous premolars;

f. increased unworn molar crown height, $40 \mathrm{~mm}$ or more.

Node 3. "M." coloradense is primitive for all known characters relative to Pseudhipparion and Neohipparion.

Node 4. Pseudhipparion and Neohipparion share:

a. shallow DPOF, not well rimmed;

b. DPOF lacks posterior pocket;

c. moderate preorbital bar length;

d. markedly oblique premolar protocone orientation;

e. metaconid and metastylid persistently well separated.

Node 5. Pseudhipparion is derived relative to Neohipparion by:

a. deeper nasal notch;

b. frontals notably domed;

c. zygomatic arch lacks pronounced buckle (Webb, 1969a);

d. protocone connects to protoselene in early moderate wearstage;

e. protocone connects to hypocone in late wear-stage of molars;

f. hypoconal groove closed in early wear-stage;

g. hypoconal groove forms isolated lake after closing;

h. reduced size, UTRL about $110 \mathrm{~mm}$ or less.

Node 6 . Pseud. retrusum is derived relative to all other species of Pseudhipparion by:
a. rapid connection of molar protocone to hypocone;
b. increased unworn molar crown height, about $45 \mathrm{~mm}$. 
Node 7. Pseud. Curtivallum, Pseud. gratum, Pseud. hessei, Pseud. skinneri and Pseud. simpsoni share:

a. strong protostylid on $p 3-m 3$ (1ater reduced in some species);

b. stronger, more persistently open metaflexid;

c. increased ROC;

d. reduced size, UTRL about $100 \mathrm{~mm}$ or less.

Node 8. Pseud. curtivallum is derived relative to Pseud. gratum,

Pseud. hessei, Pseud. skinneri and Pseud. simpsoni by:

a. shallower molar ectoflexids in early wear-stage.

Node 9. Pseud. gratum, Pseud. hessei, Pseud. skinneri and Pseud. simpsoni share:

a. more elongated protocone;

b. protocone size large relative to tooth length;

c. hypoconal groove closed in early wear-stage;

d. increased unworn molar crown height, about $50 \mathrm{~mm}$.

Node 10. Pseud. gratum is derived relative to Pseud. hessei, Pseud. skinneri and Pseud. simpsoni by:

a. protocone isolated until late moderate wear-stage in P3-M2;

b. increased unworn molar crown height, about $54 \mathrm{~mm}$.

Node 11. Pseud. hessei, Pseud. Skinneri and Pseud. simpsoni share:

a. molar protocone connected to protoselene in early wear-stage. Node 12. Pseud. hessei is derived relative to Pseud. skinneri and Pseud. simpsoni by:

a. premolar protocone often connected to protoselene in early or very early wear-stage. 
Node 13. Pseud. skinneri and Pseud. simpsoni share:

a. very hypsodont incisors;

b. reduced DP 1 ;

c. protocone lingual border flattened;

d. molar protocone never connected to hypocone;

e. simpler, less persistent fossette plications;

f. earlier loss of hypoconal lake on P2-P4;

g. reduced protostylid on $\mathrm{p} 3-\mathrm{m} 3$;

h. reduced size, UTRL about $90 \mathrm{~mm}$.

Node 14 . Pseud. skinneri is derived relative to Pseud. simpsoni by:

a. very early loss of hypoconal lake on P2-M3.

Node 15. Pseud. simpsoni is derived relative to Pseud. skinneri by:

a. rootless, ever-growing incisors;

b. incipiently hypselodont cheekteeth;

c. lack of pli calallin;

d. simpler fossettes, fossettes absent in late wear-stage;

e. very strong mesostyle;

f. ectostylids absent on dp2-dp4;

g. protostylids reduced on $\mathrm{dp} 34$ and $\mathrm{p} 3-\mathrm{m} 3$, or absent;

h. widely expanded metaconid and metastylid;

i. very shallow ectoflexid on molars.

Node 16. Neohipparion is derived relative to Pseudhipparion by:

a. DP1 reduced in relative size;

b. more elongated protocone, without spur;

c. protocone lingual border straight or concave;

d. protocone isolated from protoselene to base of crown; 
e. ectostylid absent on dp2-dp4;

f. metaconid-metastylid complex elongated;

g. isthmus plications common;

h. pli caballinids developed on premolars and molars, at least in early wear-stages;

i. molar ectoflexid shallower in early wear-stage;

j. labial borders of protoconid and hypoconid flattened;

$k$. increased unworn molar crown height, at least $55 \mathrm{~mm}$.

Node 17 . Neo. affine is derived relative to other species of Neohipparion by:

a. persistently simple fossette placations;

b. large size, UTRL about $140 \mathrm{~mm}$.

Node 18. Neo. trampasense, Neo. leptode, Neo. eurystyle and Neo. gidleyi share:

a. DPOF absent or vestigial;

b. very long preorbital bar;

c. lacrimal bone reduced in size;

d. moderately elongated muzzle;

e. DP1 absent in adult and some juvenile dentitions;

f. premolar pli caballin often branched or multiple;

g. very strong protostylids on $p 3-m 3$ and $d p 34$;

h. metaconid-metastylid complex very elongated;

i. isthmus plications present on most teeth, usually persistent;

j. paralophid plicated;

k. premolar pli caballinid well developed and persistent;

1. molar pli caballinid at least moderately developed; 
m. premolar ectoflexid very shallow, never penetrates isthmus;

n. molar ectoflexid shallow in early and early moderate wearstages;

o. increased unworn molar crown height, about $60 \mathrm{~mm}$.

Node 19. Neo. trampasense is primitive for a 11 known characters

relative to Neo. leptode, Neo. eurystyle and Neo. gidleyi.

Node 20. Neo. leptode, Neo. eurystyle and Neo. gidleyi share:

a. very elongated protocone;

b. extremely elongated metaconid-metastylid complex, linguaflexid $U$-shaped persistentiy;

c. molar pli caballinid strong, persistent;

d. increased unworn molar crown height, about $65 \mathrm{~mm}$;

e. increased size, UTRL usually greater than $130 \mathrm{~mm}$.

Node 21. Neo. leptode is primitive for all known characters relative to Neo. eurystyle and Neo. gidleyi except for:

a. increased size, UTRL about $140 \mathrm{~mm}$.

Node 22. Neo. eurystyle and Neo. gidleyi share:

a. protocone lingual border usually concave;

b. very strong, anteriorly curved metastyle;

c. strong, constricted mesostyle;

d. posteriorly curved, deeply grooved or bifurcated parastyle;

e. protostylid curved posteriorly;

f. molar ectoflexid persistently shallow;

g. increased unworn molar crown height, about $70 \mathrm{~mm}$ or greater. 
Node 23. Neo. eurystyle is derived relative to Neo. gidleyi by:

a. larger protocone relative to tooth length;

b. premolar pli caballinid often branched or multiple.

Node 24 . Neo. gidleyi is primitive for a 11 known characters relative to Neo. eurystyle except:

a. increased size, UTRL about $150 \mathrm{~mm}$.

Node 25. … insignis, Hipparion, "M‥" goorisi, Cormohipparion and Nannippus share:

a. persistently strong, often multiple pli caballin on premolars;

b. persistently strong, usually single pli caballin on molars;

c. pli protoloph and pli hypostyle relatively persistent;

d. moderate to complex internal fossette plications.

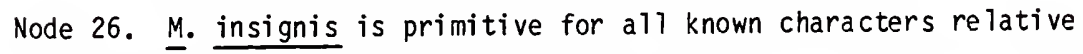
to Hipparion, Cormohipparion and Nannippus.

Node 27. Hipparion, "M.." goorisi, Cormohipparion and Nannippus share:

a. increased preorbital bar length;

b. inflated malar region, lacks depression or fossa;

c. moderate ly elongated muzzle;

d. large protoconal spur present on ly in early wear-stage.

e. increased ROC;

f. deciduous premolars weakly cemented.

Node 28. Hipparion is derived relative to "M." goorisi, Cormohipparion and Nannippus by:

a. deep nasal notch; 

b. less complex fossette plications;
c. metastyle absent or very reduced.

Node 29. H. shirleyi is primitive for a 11 known characters relative to $\underline{H}$. tehonense and $\underline{H}$. forcei except:

a. smal1 size, UTRL about $100 \mathrm{~mm}$.

Node 30 . $\underline{H}$. tehonense and $\underline{H}$. forcei share:

a. well cemented deciduous premolars;

b. DPOF not pocketed;

c. reduced lacrimal bone;

d. oval protocone;

e. reduced protoconal spur;

f. protocone isolated from protoselene until late wear-stage on P3-M3;

g. reduced fossette complexity, especially pli protoloph and pli hypostyle less persistent;

h. metaconid and metastylid persistently well separated;

i. increased unworn molar crown height, about $45 \mathrm{~mm}$.

Node 31. $\underline{H}$. tehonense is derived relative to $\underline{H}$. forcei by:

a. reduced P2 anterostyle.

Node 32. $\underline{H}$. forcei is derived relative to $\underline{H}$. tehonense by:
a. shallower p2 ectoflexid;
b. increased size, UTRL about $130 \mathrm{~mm}$;
c. increased unworn molar crown height, about $50 \mathrm{~mm}$.

Node 33. "M." goorisi, Cormohipparion and Nannippus share:

a. deep DPOF (secondarily shallow in some species);

b. anterior margin of DPOF well defined, often rimmed; 
c. shallower premolar ectoflexids that only partially penetrate the isthmus.

Node 34. "M." goorisi is derived relative to Cormohipparion and Nannippus by:

a. very deep posterior pocket on DPOF;

b. reduced lacrimal bone, does not touch DPOF;

c. because of b, malar bone forms part of DPOF;

d. relatively short muzzle;

e. very reduced protostylids;

Node 35. Cormohipparion and Nannippus share:

a. elongate-oval protocones;

b. protocone isolated from protoselene until late wear-stage on P3-M3;

c. prominent protostylid on $\mathrm{p} 3-\mathrm{m} 3$;

d. protostylid isolated from protoconid when it first appears on the occlusal surface;

e. metaconid-metastylid persistently well separated by deep lingual flexids;

f. frequent isthmus plications in early wear-stage;

g. weak pli caballinid on premolars in early wear-stage;

h. premolar ectoflexids shallow, usually do not penetrate isthmus;

i. well cemented, subhypsodont deciduous premolars;

j. increased unworn molar crown height, about $45 \mathrm{~mm}$ or more. Node 36. Cormohipparion is derived relative to Nannippus by:

a. protocone spur rudimentary or absent; 

b. very strong ectostylid on dp2-dp4;
c. persistent isthmus plications;
d. plicated paralophid
e. increased size, UTRL about $130 \mathrm{~mm}$ or more.

Node 37 . Cor. Sphenodus is primitive for all known characters relative to other species of Cormohipparion.

Node 38. Cor. occidentale, Cor. plicatile, Cor. ingenuum and Cor. emsliei share:
a. protocone spur absent;
b. pli caballinid on $\mathrm{ml}-\mathrm{m} 3$ in early wear-stage;
c. ectoflexid depth of $\mathrm{ml-m} 3$ reduced in early wear-stage;
d. elongated diastema;
e. increased unworn molar crown height, about $50 \mathrm{~mm}$ or more.

Node 39. Cor. occidentale and Cor. plicatile are derived relative to Cor. ingenuum and Cor. emsliei by:

a. increased unworn molar crown height, about $60 \mathrm{~mm}$.

Node 40 . Cor. occidentale is derived relative to Cor. plicatile by:
a. more elongated protocone;
b. multiple pli protoloph common;
c. increased average internal fossette complexity;
d. increased size, UTRL about $140 \mathrm{~mm}$.

Node 41 . Cor. plicatile is derived relative to Cor. occidentale by: a. very elongated muzzle.

Node 42. Cor. ingenuum and Cor. emsliei are derived relative to Cor. occidentale and Cor. plicatile by:

a. reduced depth and rimming of DPOF; 
b. lingual border of protocone often straight or concave;

c. metaflexid of $p 2$ and $d p 2$ closed to a fossettid in moderate wear-stage by plication from metaconid;

d. decreased size, UTRL about $120 \mathrm{~mm}$.

Node 43. Cor. ingenuum is primitive for all known characters relative to Cor. emsliei.

Node 44. Cor. emsliei is derived relative to Cor. ingenuum by:

a. very shallow DPOF;

b. persistently multiple pli protoloph;

c. extremely complex fossette margins;

d. very strong styles;

e. posteriorly curved protostylid;

f. elongated, angular metaconid-metastylid complex;

g. well developed pli caballinids on p2-p4, dp2-dp4, and most molars;

h. molar ectoflexid depth reduced until moderate wear-stage. Node 45. Nannippus is derived relative to Cormohipparion by:

a. elongated muzzle;

b. very reduced DP1, lacks hypocone or lophs, can be absent;

c. reduced $P 2$ and DP2 anterostyle;

d. p2 short relative to $\mathrm{p} 3 \mathrm{ap1}$;

e. reduced size, UTRL about $110 \mathrm{~mm}$ or less.

Node 46. Nan. fricki is primitive for all known characters relative to other species of Nannippus.

Node 47. Nan. westoni, Nan. lenticularis, Nan. minor, Nan. peninsulatus and Nan. beckensis share: 
a. P2 and DP2 anterostyle very reduced;

b. pli caballins relatively weak, rarely branched or multiple, very weak or absent on molars;

c. relatively shallow hypoconal grooves;

d. molar ectoflexid depth reduced in early wear-stage.

Node 48. Nan. westoni is derived relative to Nan. lenticularis, Nan. minor, Nan. peninsulatus and Nan. beckensis by:

a. relatively simple fossette plications;

b. metastyle absent.

Node 49. Nan. lenticularis, Nan. minor, Nan. peninsulatus and Nan. beckensis share:

a. reduced DPOF depth;

b. protocone spur rare, small or absent;

C. dp2-dp4 ectostylids absent;

d. reduced protostylids on $\mathrm{p} 3-\mathrm{m} 3$ and $\mathrm{dp} 34$;

e. increased unworn molar crown height, about $50 \mathrm{~mm}$, and a proportionally greater increase in premolar crown height.

Node. 50. Nan. lenticularis is derived relative to Nan. minor, Nan. peninsulatus and Nan. beckensis by:

a. isolated protocones on P2 until moderate wear-stage;

b. pli protoloph and pli hypostyle absent or nonpersistent;

c. protostylid usually isolated from protoconid for most of crown;

d. relatively short, broad metapodials. 
Node 51. Nan. minor, Nan. peninsulatus and Nan. beckensis share:

a. hypocone relatively small, long axis orientated obliquely;

b. protostylid generally very reduced or absent on p3-m3.

Node 52. Nan. minor is derived relative to Nan. peninsulatus and

Nan. beckensis by:

a. protocones often relatively small, variably rounded in premolars;

b. isthmus with persistent plications;

c. very small size, UTRL about $85 \mathrm{~mm}$.

Node 53. Nan. peninsulatus and Nan. beckensis share:

a. very procumbent, spatulate lower incisors;

b. DPOF vestigial or absent;

c. lingual border of protocone flattened;

d. protocone isolated from protoselene to base of crown;

e. relatively strong metastyles;

f. isthmus plications usually absent;

g. pli caballinids usually absent;

h. labial borders of protoconid and hypoconid flattened;

i. elongated metaconid-metastylid complex;

j. increased unworn molar crown height, about $60 \mathrm{~mm}$.

Node 54. Nan. peninsulatus is derived relative to Nan. beckensis by:

a. elongated protocones;

b. protocone lingual border straight or concave;

c. strong mesostyle, constricted on molars;

d. para lophid plications absent;

e. molar ectoflexid depth decreased until moderate wear-stage; 
f. increased unworn molar crown height, about $70 \mathrm{~mm}$.

g. decreased size, UTRL about $100 \mathrm{~mm}$.

Node 55. Nan. beckensis is derived relative to Nan. peninsulatus by:

a. very elongated muzzle;

b. robust metapodials.

The phylogenetic arrangement of hipparionine species in Figure 74 (or Fig. 73) indicates the presence of only six monophyletic genera, Pseudhipparion, Neohipparion, Merychippus s.s., Hipparion, Cormohipparion and Nannippus. Two additional genera have been named, Griphippus (Quinn, 1955; genotype Pseud. gratum) and Hesperohipparion (Dalquest, 1981; genotype Neo. floresi, recognized here and by MacFadden, 1984a, as a junior synonym of Neo. eurystyle). The cladogram indicates that use of either would result in the recognition of a paraphyletic genus, or a monotypic genus. Neither of these alternatives are justified based on the current understanding of hipparionine phylogeny. Merychippus s.s. should be limited to only those species which share derived character states with the genotype, $\underline{M}$. insignis. These may include species such as $\underline{M}$. brevidontus, $\underline{M}$. californicus and $\underline{M}$. calamarius, but these taxa will require further study to determine their exact relationships. Two species of hipparionines, "Neo." coloradense and "Cor." goorisi cannot be placed in any of the six recognized genera without making it paraphyletic. Two alternatives would be to erect monotypic genera for them, or to consider them as plesions. Plesion is a category of variable rank that substitutes for supraspecific categories in the Linnaean hierarchy (Wiley, 1981). It is useful when a species or a 
small monophyletic group of species forms the sister-group of a much more numerous clade. By using plesions, a phylogeneticist avoids having to erect numerous new monotypic taxa, a criticism made of early phylogenetic classifications (e.g., that of McKenna, 1975). If supporting evidence for the Neohipparion + Pseudhipparion versus Hipparion $+\underline{\text { Nannippus }}+$ Cormohipparion + Merychippus s.s. dichotomy within the Hipparionini is forthcoming, the two groups should be given formal (subtribal) designations. As the placement of Pseudhipparion in the Hipparionini is questioned by the parsimony criterion (Fig. 69), I refrain from formalizing this arrangement at this time.

Phylogenetic Ana Tysis of Protohippine and Equine Taxa

Twenty-four protohippine and equine species were analyzed in the same manner as the hipparionines. Figure 75 represents the output of the PAUP analysis. In this case, there is but a single most parsimonious tree with a length of 99.4 steps and a CI of 0.46 . Figure 76 presents the cladogram done "by hand." It has a length of 102.8 steps (3.4\% longer), and a CI of 0.45 . Although there are some similarities between the two, there are more differences than was the case with the hipparionine taxa. Some of this may be due to the absence of information concerning cranial characters for several species of Cal. (Grammohippus). The phylogenetic hypothesis as presented in Figure 76 is much more strongly supported by the chronological distributions of the taxa, and contains fewer "unlikely" evolutionary events (e.g. decreasing crown height). The following is a listing of the character states that support the 


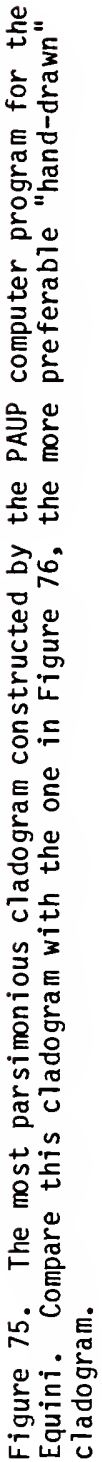




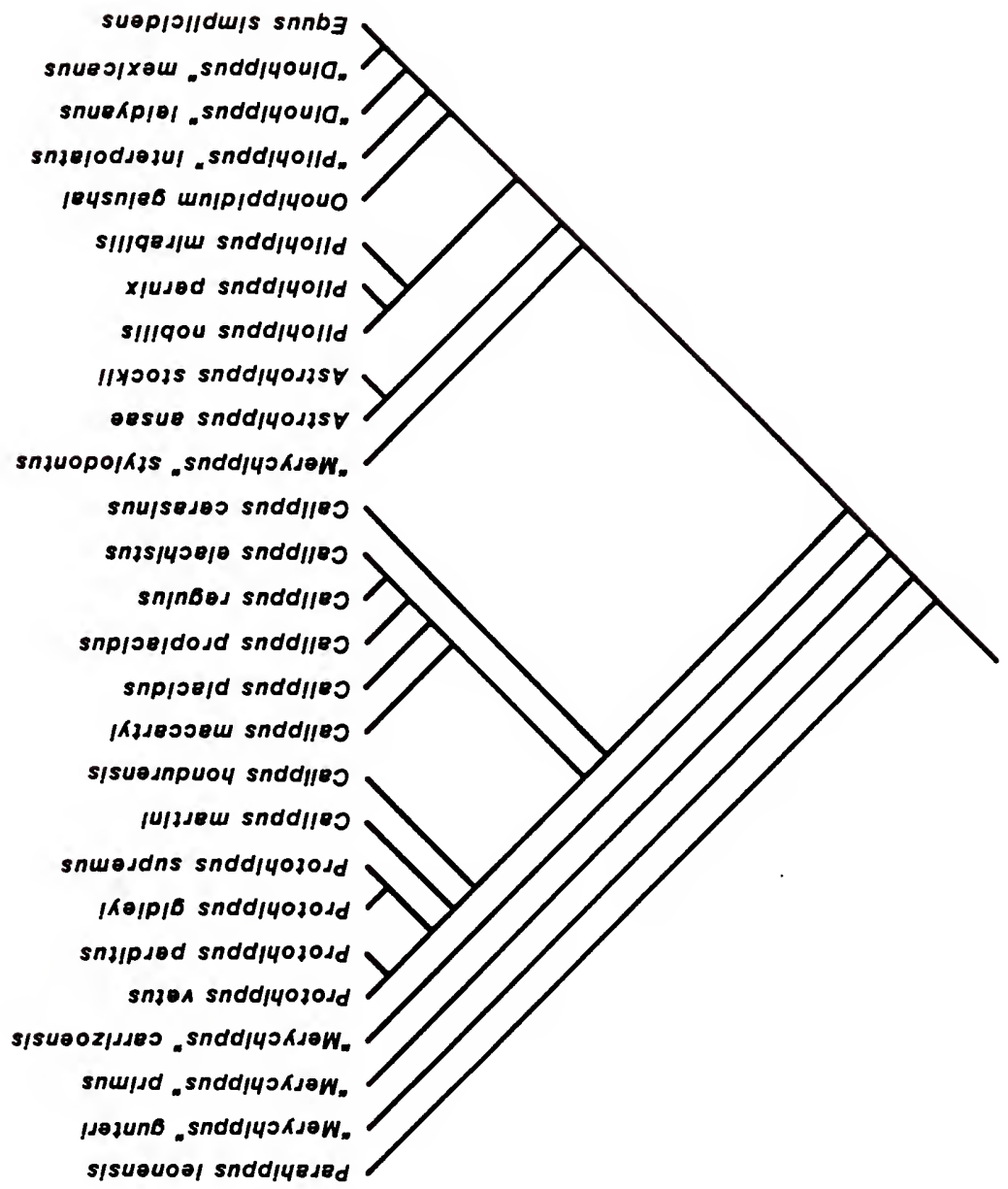




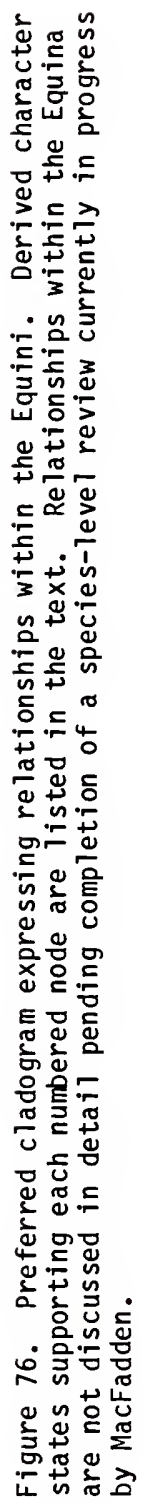




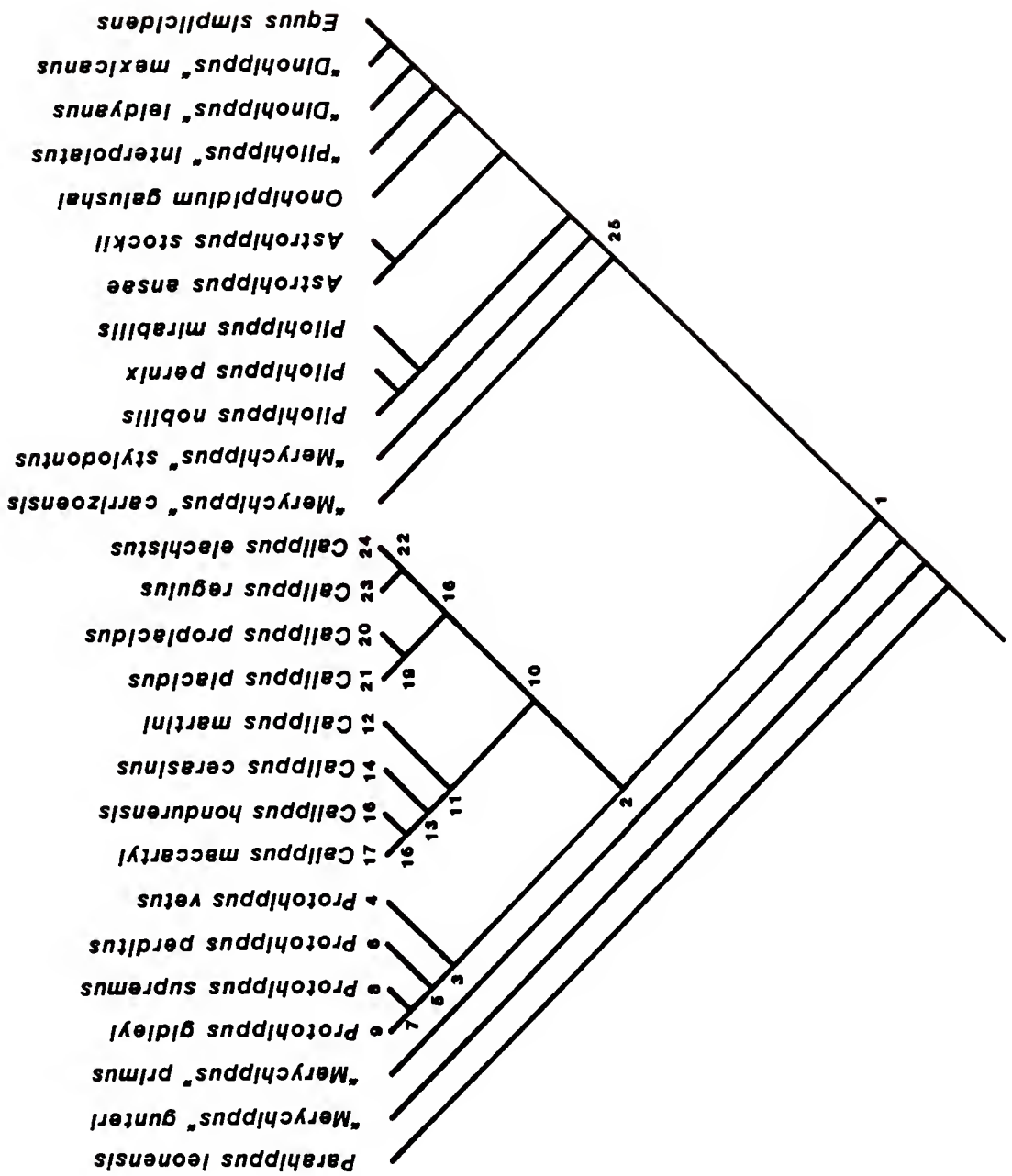


phylogeny in Figure 76. Equine species are not discussed in detail. They have not been extensively reviewed (as have the protohippines), and additional study will undoubtedly discover other characters to better judge their interrelationships. They are included here solely to demonstrate that Protohippus is not "ancestral" to either Pliohippus or Dinohippus, as is commonly stated in the literature (a concept that dates back to Marsh, 1879). Rather, with Calippus, it forms a sister-group to the clade containing Pliohippus, Astrohippus, Dinohippus, Equus and the Hippidion-group. To formally recognize these two monophyletic clades, the Equini is divided into the subtribes Protohippina and Equina.

Node 1 (Figure 76). The Equini share:
a. ova1 protocones;
b. protocone connected to protoselene in very early wear-stage;
C. simple internal fossette margins;
d. molar metaconid notably more linguad than the metastylid;
e. increased size, UTRL about $110 \mathrm{~mm}$.

[Character states a and e probably shared with hipparionines.]

Node 2. The Protohippina are derived relative to the Equina by:
a. moderate preorbital bar;
b. relatively broad muzzle;
c. cemented deciduous premolars;
d. elongate-oval protocones;
e. markedly oblique protocone orientation in premolars;
f. strong protostylid on $\mathrm{dp} 34$, moderate protostylid on $p 3-\mathrm{m} 3$;
g. metaconid and metastylid well separated in early wear-stage; 
h. decreased depth of premolar ectoflexid;

i. increased unworn molar crown height, about $35 \mathrm{~mm}$ or more. Node 3. Protohippus is derived relative to Calippus by:

a. large, very broad DPOF;

b. malar region inflated, lacks fossa or depression;

c. increased size, UTRL about $120 \mathrm{~mm}$ or more.

Node 4. Pro. vetus is primitive for a 11 known characters relative to other species of Protohippus.

Node 5. Pro. perditus, Pro. supremus and Pro. gidleyi share:

a. strong premolar pli caballin;

b. large protostylids on p3-m3;

C. en larged metastylid, subequal to metaconid;

d. increased unworn molar crown height, about $45 \mathrm{~mm}$;

e. increased size, UTRL about $130 \mathrm{~mm}$ or more.

Node 6. Pro. perditus is primitive for all known characters relative to Pro. supremus and Pro. gidleyi.

Node 7. Pro. supremus and Pro. gidleyi share:

a. protocone lingual border often flattened;

b. delayed connection of protocone to protoselene until early or early moderate wear-stage;

c. moderately persistent internal fossette plications;

d. metaconid and metastylid persistently well separated;

e. premolar ectoflexid very shallow, does not penetrate isthmus;

f. increased unworn molar crown height, about $55 \mathrm{~mm}$. 
Node 8. Pro. supremus is derived relative to Pro. gidleyi by:

a. larger, better developed prefossette loop;

b. increased size, UTRL about $140 \mathrm{~mm}$.

Node 9. Pro. gidleyi is derived relative to Pro. supremus by:

a. shallower DPOF, lacks posterior pocket;

b. very long preorbital bar;

C. reduced P2 anterostyle;

d. increased protocone isolation, not connected on P34 and M3 until moderate wear-stage;

e. hypoconal groove closes without forming a lake;

f. ectostylids on dp2-dp4 reduced;

g. increased unworn molar crown height, about $60 \mathrm{~mm}$.

Node 10. Calippus is derived relative to Protohippus by:

a. very short, very broad muzzle;

b. flattened, nonarcuate incisor margin;

c. relatively large incisors;

d. very shallow p2 ectoflexid;

e. loss of ectostylids on $d p 2-d p 4$;

f. protocone connects to protoselene immediately after onset of wear.

Node 11. Cal. (Grammohippus) is derived relative to Cal. (Calippus) by:

a. generaliy stronger metastyle;

b. deeper, more persistent preprotoconal groove;

c. protostylid of p3-m3 usualiy reduced, often limited to lower 
third of the crown or absent altogether;

d. increased unworn molar crown height, about $45 \mathrm{~mm}$ or more.

Node 12. Cal. martini is derived relative to $\mathrm{Cal}$. cerasinus, Cal. hondurensis and Cal. maccartyi by:

a. relatively strong pli caballins on P2-P4, weak but often present on M1-M3;

b. more persistently complex inner fossette margins;

c. increased unworn molar crown height, about $58 \mathrm{~mm}$;

d. increased size, UTRL about $135 \mathrm{~mm}$.

Node 13. Cal. cerasinus, Cal. hondurensis and Cal. maccartyi share:

a. relatively broader muzzle;

b. increased relative length of metaconid-metastylid complex.

Node 14. Cal. cerasinus is derived relative to $\mathrm{Cal}$. hondurensis and Cal. maccartyi by:
a. very reduced pli caballin;
b. rapidly closed hypoconal groove on P2-P4;
c. protostylids very reduced, often absent.

Node 15. Cal. hondurensis and $\mathrm{Cal}$. maccartyi share:
a. more persistent preprotoconal groove;
b. protocone lingual border flattened;
c. increased size of metastylid relative to metaconid;
d. shallower ectoflexids on premolars;

Node 16. Cal. hondurensis is derived relative to Cal. maccartyi by:

a. relatively very short protocone, especially on P2-P4;

b. premolar protocone orientation anteroposterior;

c. hypoconal groove closes on P2-P4 without forming a lake. 
Node 17. Cal. maccartyi is derived relative to Cal. hondurensis by:

a. fossettes persistently plicated, very closely apressed;

b. increased ROC of upper cheekteeth;

c. very expanded metaconids and metastylids;

d. shallow premolar and molar ectostylids;

e. decreased size, UTRL about $100 \mathrm{~mm}$.

Node 18. Cal. (Calippus) is derived relative to Cal. (Grammohippus)

by:

a. early closure of hypoconal groove;

b. increased ROC of upper cheekteeth;

c. strong protostylid on $p 3-m 3$;

d. expanded metaconid-metastylid complex;

e. decreased size, UTRL about $100 \mathrm{~mm}$ or less.

Node 19. Cal. proplacidus and Cal. placidus share:

a. strong premolar pli caballin;

b. relatively deeper and more persistent lingual flexids.

Node 20. Cal. proplacidus is primitive for all known characters relative to $\mathrm{Cal}$. placidus.

Node 21. Cal. placidus is derived relative to Cal. proplacidus by:

a. metaconid and metastylid enlarged, persistently well separated;

b. shallower ectoflexids;

c. increased unworn molar crown height, about $50 \mathrm{~mm}$.

Node 22. Cal. regulus and Cal. elachistus share:

a. DP 1 very reduced or absent;

b. very simple fossettes; 
c. very early closure of hypoconal groove;

d. decreased size, UTRL about $80 \mathrm{~mm}$ or Tess.

Node 23. Cal. regulus is derived relative to Cal. elachistus by:

a. poorly developed styles;

b. p2 metaconid very reduced or absent;

c. increased unworn molar crown height, about $45 \mathrm{~mm}$.

Node 24. Cal. elachistus is derived relative to Cal. regulus by:

a. hypoconal groove closed in very early wear-stage;

b. pli caballin vestigial or absent;

c. loss of pli entoflexid;

d. reduced protostylid;

e. shallower ectoflexids;

f. decreased basal crown lengths.

Node 25. The Equina are derived relative to the Protohippina by:

a. moderately deep DPOF (secondarily reduced in some species);

b. well developed malar fossa (secondarily reduced in some species);

c. elongated muzzles;

d. very simple internal fossette margins;

e. lateral phalanges reduced in size or absent.

Both Figures 75 and 76 support the monophyly of the Protohippina and Equina, of the genera Protohippus, Pliohippus and Astrohippus, and of the subgenus Cal. (Calippus). Only in Figure 76 (see also Figs. 70,71 ) is the entire genus Calippus (as recognized here) monophyletic, as are its two subgenera. 
Phylogenetic Classification

Table 49 presents a phylogenetic classification of the Hipparionini and Equini based on the cladograms depicted in Figures 74 and 76. In general, conventions 1-6 of Wiley (1981, pp. 205-213) are followed. Also, informal taxon names (Wiley, 1981, p. 199) are used to avoid proliferation of names, as is the plesion category. The latter is used only for species which form sister-groups to suprageneric groups (e.g. "ㅆ.." coloradense), and not for a 11 fossil groups as suggested by Wiley (1981; in this case almost every taxon would be a plesion). All merychippine-grade species not assigned to a recognized genus are uniformly designated as "Merychippus." These should not be confused with taxa assigned to the genus Merychippus, for which quotation marks are not used.

Only relatively minor changes to established equid nomenclature are suggested, despite the much greater information content of the phylogenetic classification. "Neohipparion" coloradense and "Cormohipparion" goorisi are removed from these genera, and placed as plesion sister-groups to combinations of genera, as noted above. More important is the use of Merychippus in a purely phylogenetic sense. Other species of merychippine-grade are relegated to their phylogenetically correct positions. "…" primus and "M.." gunteri cannot be assigned to either the Hipparionini or Equini, and appear to retain more primitive character states than either of the two advanced tribes. The systematic positions of these two species are currently under investigation (MacFadden and Hulbert, in prep.). 
Table 49. Phylogenetic hierarchical classification of the tribes Hipparioni and Equini based on the cladograms in Figures 74 and 76. Note that the subfamily contains other taxa in addition to the se two tribes (see Chapter 5). Pending a species-level review by MacFadden (in prep.), no species are listed for the genera in the Equina, and the relative positions of its constituents are left as a multichotomy. Sequencing conventions follow Wiley (1981).

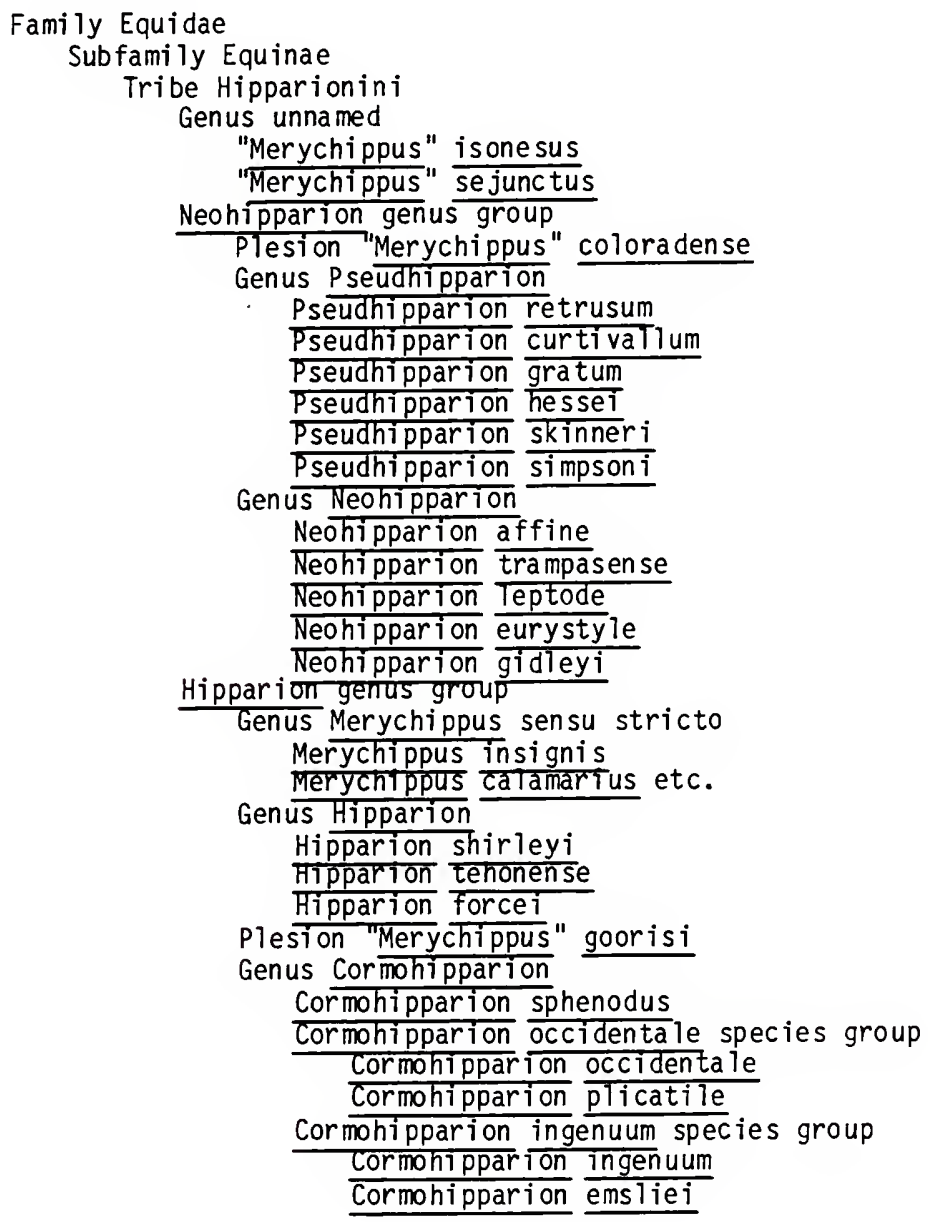


Table 49--continued

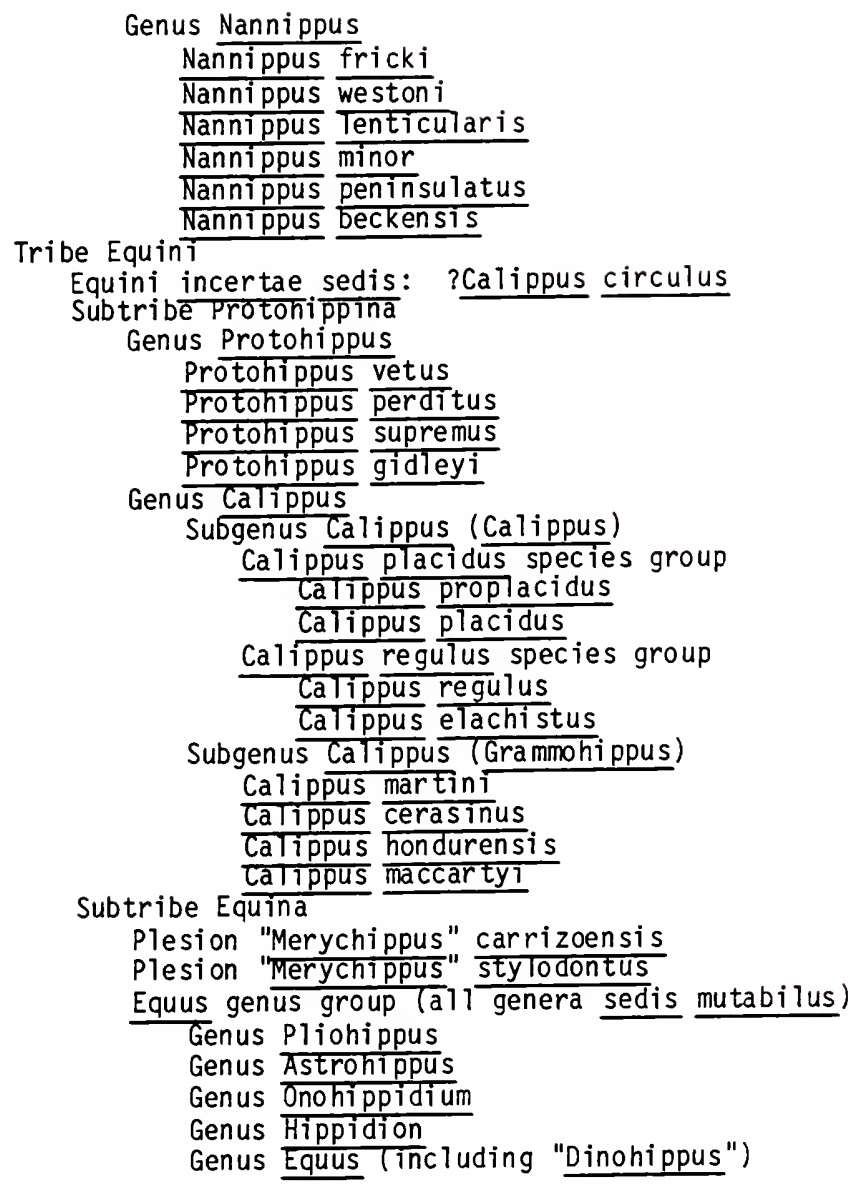


Comparisons with Previous Phylogenies

The hypothesized relationships of the Hipparionini (Fig. 74) and Equini (Fig. 76) presented here can be compared with the previous hypotheses of Matthew (1926, Fig. 67A), Stirton (1940, Fig. 67B), Quinn (1955, Fig. 67C), and Forsten (1984, Fig. 68). The results of the cladistic analysis are more similar to those of Matthew and Stirton. None of the changes proposed by Quinn (1955) are supported. The major differences between Stirton's traditional phylogeny and the cladistic arrangement proposed here are: 1) the sister-group relationship between Protohippus and Calippus was not recognized by Stirton (1940; although previous workers such as Gidley, 1907 , included them in the same genus); and 2) Stirton derived Equus from Astrohippus rather than "Dinohippus." The latter point has been repeatedly questioned in the literature, and current workers generally agree that most, if not all, of the subgenera of Equus are the sister-taxon of "D." mexicanus (Lance, 1950; Dalquest, 1978; Bennett, 1980; MacFadden, 1984b; MacFadden and Azzaroli, 1987). A11 of the cladograms produced by this study agreed with this interpretation.

The cladogram of Forsten (1984; see Fig. 68) is difficult to interpret because she did not state into what genus she was assigning certain North American taxa. The following comparison is based on the assumption that she regarded Cor. occidentale as a Hipparion, and not as a Neohipparion (as she has done previously, see e.g. Forsten, 1975). I assume this because she used the character states weak DPOF and caballoid lowers to diagnose Neohipparion (and Probosidipparion), 
neither of which are characteristic of Cor. occidentale. Forsten (1984) placed Cormohipparion as the primitive sister-group of all "true" hipparionines, which to her included on ly Pseudhipparion, Hipparion (with Nannippus), Neohipparion (with Stylohipparion) and Proboscidipparion. She listed five characters at the base of her cladogram to support this grouping (Forsten, 1984, Fig. 3), connected protocone, developed stylids, single preorbital fossa, "normal" nasals, and "normal" nasal openings. It is not clear whether she interpreted these as derived and uniting the five genera, or if she was only listing characteristic, but plesiomorphous, features of the group, as she did not give a specific out-group. Of these five, only developed stylids (i.e. a well developed protostylid; ectostylids are primitive) is a synapomorphy uniting these taxa. The others are either plesiomorphous for the Equini + Hipparionini, or too ambiguous. The protocone eventually connects to the protoselene at some stage of wear in virtually all equids, so its proper use as a character is only with regards to in what wear-stage it connects. Forsten (1984) specifically unites Pseudhipparion, Hipparion, Neohipparion and Proboscidipparion based on their subequally large, well separated metaconids and metastylids (the hipparionid pattern) and a mostiy disconnected protocone. The former is an important synapomorphy for the hipparionines (Fig. 74, Node 1), but I would argue that this pattern is observed in early wear-stages of "M." goorisi and $\underline{M}$. insignis, and so unites a 11 hipparionines and not just those listed by forsten (1984). There is no disagreement that Pseudhipparion diverged early from other hipparionines, but there are 
numerous apomorphies uniting it at this point with Neohipparion and "M." coloradense (Fig. 74, Nodes 2 and 4). Forsten (1984, Fig. 3) expressly presented no characters to justify uniting Hipparion, Neohipparion and Proboscidipparion, although it can be assumed that an isolated protocone to near the base of the crown is one. The cladistic analysis indicates that well isolated protocones evolved independently three times in North American hipparionines, at Nodes 16,30 and 35 in Figure 74.

Forsten (1984) grouped North American Neohipparion with the 01d World taxa Stylohipparion, Proboscidipparion, and Eurasian species putatively placed in Neohipparion. This was based on two characters, a weak or absent fossa, and caballoid lowers. There are several reasons for doubting this arrangement. First, the lower cheekteeth of the genotypic species of Neohipparion, Neo. affine (=Neo. whitneyi), are of hipparionid grade, with rounded borders of the metaconids and metastylids, and " $V$ "-shaped linguaflexids (Osborn, 1918, Fig. 144). Thus, even if this group was monophyletic, their relative arrangement cannot be as figured by Forsten (1984). Second, Forsten (1984) noted that transitiona 1, "incipiently" caballoid taxa first appear in the old World in the late Turolian. The transition from hipparionid to caballoid lowers in North American Neohipparion occurred in the late Clarendonian-early Hemphillian, with Neo. trampasense as a morphologic intermediary between Neo. affine and the fully caballoid Neo. eurystyle. This is approximately three million years prior to the appearance of incipiently caballoid hipparionines in the 01d World. All North American late Hemphillian Neohipparion 
are too derived to be ancestral to the Ruscinian radiation of caballoid hipparionines in Eurasia. The two must be independent lineages that evolved in parallel. Their putative synapomorphies were in fact acquired independently by many late Miocene/early Pliocene equid genera. For example, in North America alone, no less than five genera had caballoid lower cheekteeth to some degree: Neohipparion (e.g. Neo. eurystyle; Neo. gidleyi); Nannippus (e.g. Nan. peninsulatus, especially in deciduous premolars and in early wear-stages, see MacFadden, 1984a, Figs. 109 and 116); Cormohipparion (e.g. Cor. emsliei); Astrohippus (e.g. A. stockii); and the Dinohippus/Equus lineage. Of these five, four also have significantly reduced or lost the DPOF (a 11 except Astrohippus), indicating that caballoid lowers and a weak DPOF are not a systematically secure combination of apomorphies to unite otherwise dissimilar taxa. Rather, they are characteristic of an advanced grade of equid that evolved many times in various lineages under similar selection pressures with similar results (Gosliner and Ghiselin, 1984). Also characteristic of this grade are extremely hypsodont cheekteeth, and advanced metapodial and phalange morphology (Sondaar, 1968; Hussain, 1974 ; For sten, 1984; MacFadden, 1984a; 1986). 


\section{CHAPTER 7}

BIOCHRONOLOGY, BIOSTRATIGRAPHY, AND SPECIES DYNAMICS

The stratigraphic utility of equids has long been recognized by vertebrate biostratigraphers (e.g. Osborn, 1918; Stirton and McGrew, 1935; Stirton, 1952). Horses are well represented at most sites, and have experienced continual evolution throughout the Cenozoic, two of the criteria necessary for a stratigraphically useful taxon. The other primary criterion is ease of recognition, which has not always been the case with equids. Thus, much of their use has been limited to the generic level (or more often to grades like Merychippus). The recent species-level revisions of MacFadden (1984a), Webb and Hulbert (1986), and this study, along with work in progress by MacFadden, Woodburne, Hulbert, Evander, Prothero and others, should remedy this problem. Figure 77 illustrates the chronologic ranges of 60 equid taxa from the early Barstovian through the Blancan. These primarily reflect my personal observations and identifications of specimens in most of the major museum collections (as listed on pp. $x v-x v i$ ), and, to a much lesser degree, records taken from the literature. Some very poorly known Barstovian taxa were not included, and it must be re-emphasized that I have not studied equine species at nearly the detailed level as the protohippines and hipparionines. Even so, 
Figure 77. Chronologic distribution of equid species, with emphasis on taxa from the Great Plains and the Gulf Coastal Plain. Key to numbers: 1, Merychippus insignis and other members of Merychippus s.s.; 2, "Merychippus" coloradense; 3, "M." repubticanus; 4, Pseudhipparion retrusum; 5, Pseudhipparion sp. Tlower Bone valley); 6, Pseud. curtivalTum; 7 , Pseud. hessei ; 8 , Pseud. gratum; 9, Pseud. skinneri; 10, Pseud. simpson $i$;1, Neohipparion affine; 12, Neo. trampasen se; 13, Neo. Teptode; 14 , Neo. eurystyle; 15, Neo. gidleyi; 16, Hipparion shirTeyi; 17, H. tehonense; 18, H. forcei; 19, "M. " goorisi; 20, Nannippus fricki; 21, Nan. westonī; 22, Nan. lentīcularis; 23, Nan. minor; 24, Nan. beckensis; 25, Nan. peninsulatus; 26, Cormohi pparion sphenodus; 27 , Cor. ingenuum; 28 , cor. emstiei; 29 , Cor. plicatile; 30 , Cor. occidentale; 31, "M." carrizoensis; 32, "M." intermontanus; 33 , Protohippus vetus; 34 , Pro. perditus; 35, Pro supremus; 36 , Pro. gidleyi; 37, "M." proparvalus; 38, ?Calippus circulus; 39 , CaT. martini ; 40 , Cāi. cerasinus; 41 , Calippus $n$. sp. from $\mathrm{Ft}-40$ Tocality; 42, Cal. hondurensis; 43, Cal. maccartyi ; 44, Cal. proplacidus; 45, CaT. placidus; 46 , CaT. regulus; 47 , CaTippus sp. Tlower Bone valley); 48, Cal. elachistus; 49, "M. " sejunctus; 50 , "M." stylodontus; 51, Hippidion sp. (MacFadden and Skinner, 1979); $5 \overline{2}$, "Pliohippus" interpolatus; 53 , "Dinohippus" leidyanus; 54, "D. " mexicanus; 55, Equus s.1.; 56, Pliohippus mirabiTis; 57, Plio. pernix; 58, Plio. nobilis; 59, Astrohippus ansae; 60, A. Stockii. 
CHRONOLOGIC DISTRIBUTION OF EQUID TAXA

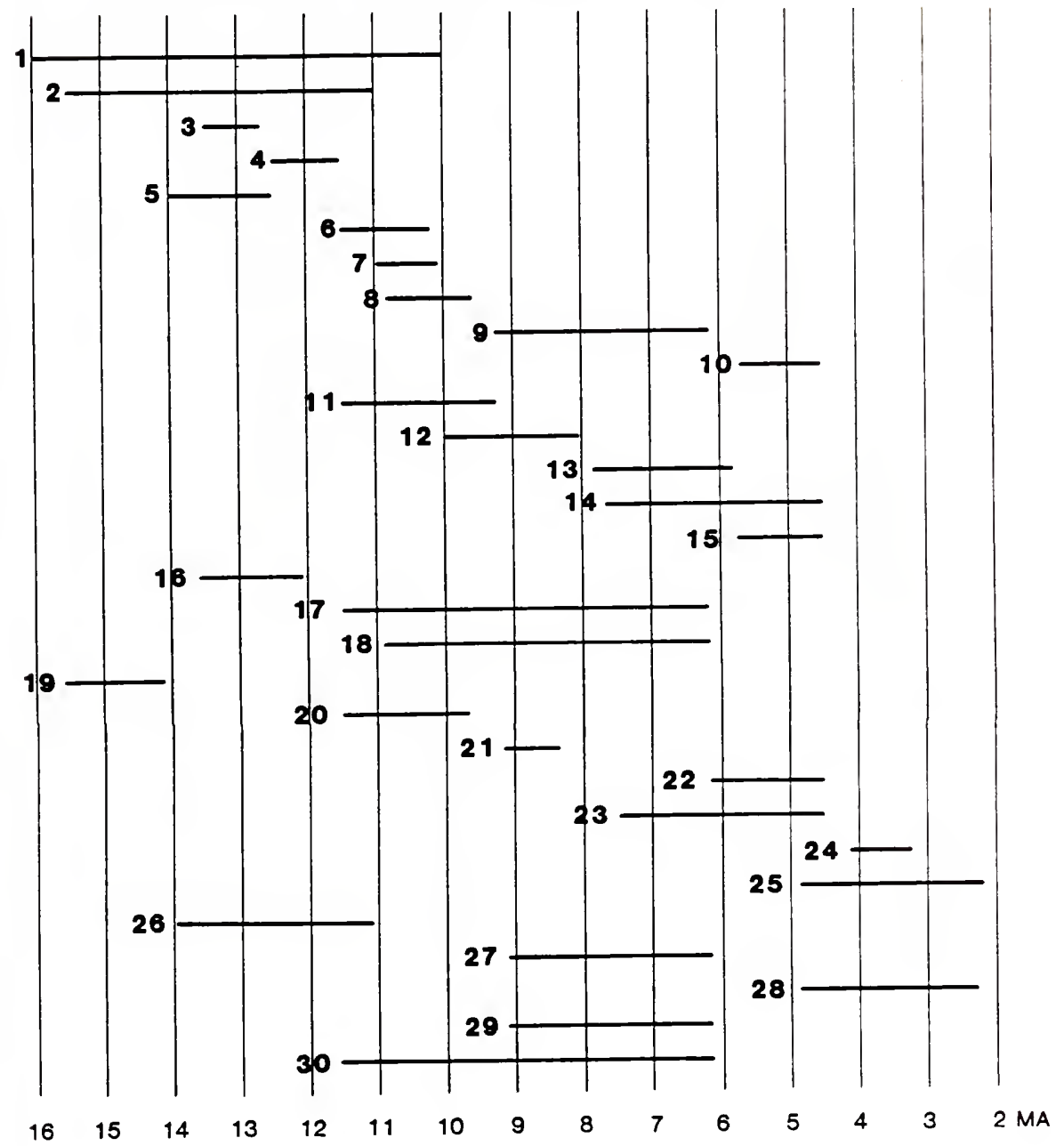




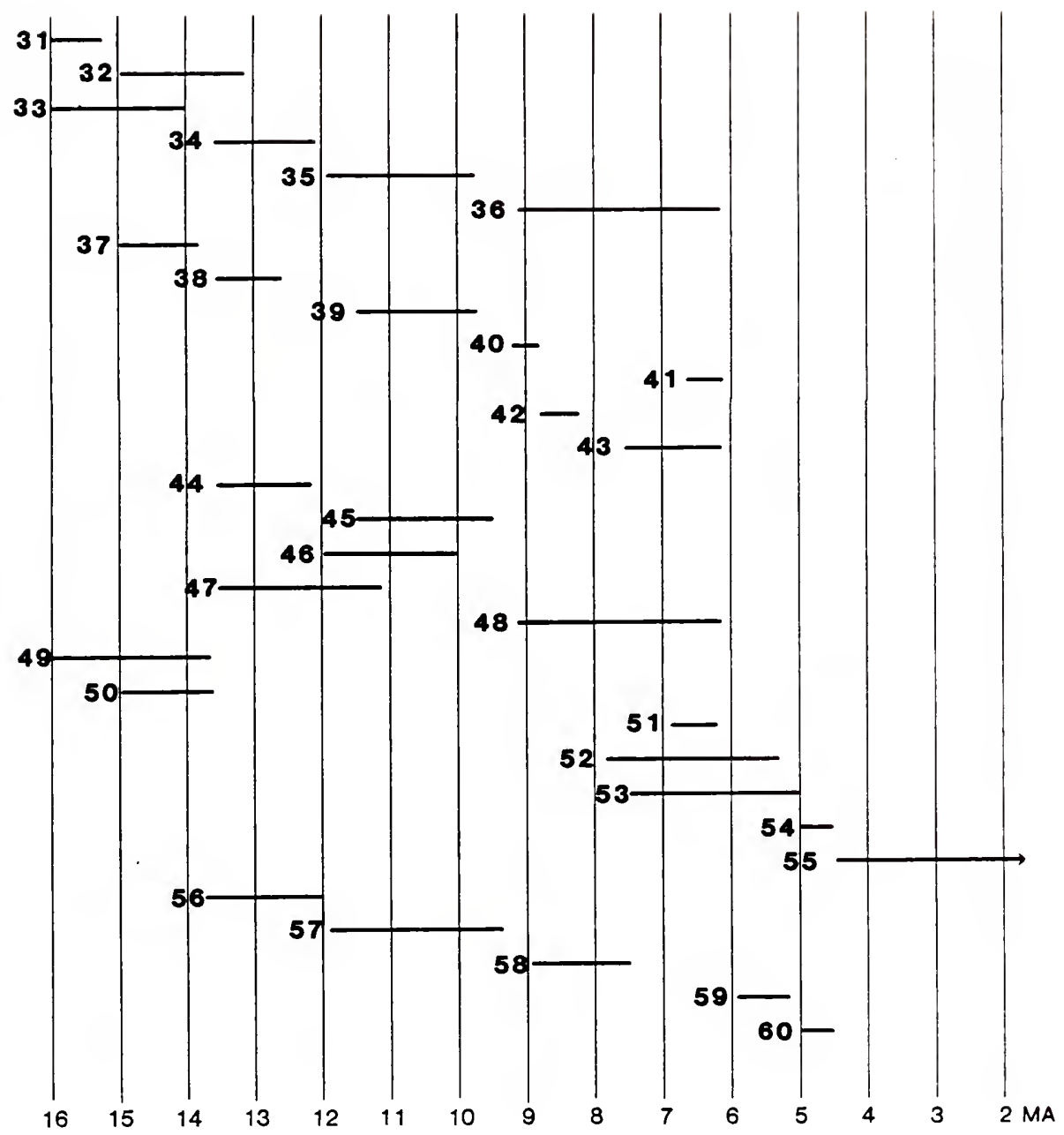


Figure 77 represents the most up-to-date, detailed data base from which to study equid biostratigraphy, diversity and extinction during the late Neogene.

\section{Biostratigraphy}

A detailed biostratigraphic zonation of Great Plains and Gulf Coastal plain faunas was constructed using the species ranges in Figure 77. The period from about 16 ma to 4.5 ma was subdivided into 9 biochrons varying in duration from 2.5 to 0.5 million years. Absolute ages are based on the summary of North American Miocene-early Pliocene biochronology of Tedford et al. (in press). Each biochron was defined by the concurrent range zone (CRZ) of two or three equid species. Those taxa selected were relatively common, and, if possible, had extensive geographic ranges in both the Great Plains and the Gulf Coastal Plain. Each biochron was also characterized by the first and last appearances of particular species. The ages of the boundaries of each biochron are given to the nearest $0.1 \mathrm{ma}$. In fact, the se are estimates based primarily on biostratigraphic corre1ation and interpolation, and are probably accurate to within \pm 0.2 ma. Current mammalian biostratigraphic practice emphasizes the use of first appearances of immigrant taxa from other continents to define the boundaries of land mammal ages and their subdivisions (Tedford and Hunter, 1984; Tedford et al., in press). While theoretically sound, this sometimes becomes difficult to apply in practice, because defining taxa can be rare or not widely distributed. I do not propose that an equid biochronology replace that 
based on immigrants, but suggest that chronologies of widely distributed, common autochthonous groups like canids, camelids and horses be used to supplement it.

Biochron 1 is the "Merychippus" coloradense - "M. " sejunctus CRZ, representing the interval between 16 and $13.5 \mathrm{ma}$. It is the longest and most poorly represented segment, with few taxa in common between the Great Plains and the Gulf Coastal Plain. Last appearances are by "M." sejunctus, "M." isonensus, "M.". goorisi, Pro. vetus; whi le Cor. sphenodus, Pseudhipparion sp., and Calippus sp. have their first appearances. $M$. insignis and related species are also typical of this biochron, as are derived species of Archaeohippus and "Parahippus." Faunas of this period include the Lower Snake Creek, Pawnee Creek, and the lower Burkeville faunas, as well as a recently discovered faunule in the lowermost Bone Valley Formation (MacFadden and Hulbert, in prep.).

Biochron 2 is the Protohippus perditus - Calippus proplacidus CRZ, representing the interval between 13.5 and $12.0 \mathrm{ma}$. Last appearances are by Plio. mirabilis, "M. " republicanus, ?Cal. circulus; first appearances are by Pseud. retrusum and ?Cal. circulus. Characteristic taxa include Hipparion shirleyi, Cor. sphenodus, and "Merychippus" s.1. Faunas of this interval include those of the lower Valentine Formation (Norden Bridge, Crookston Bridge and Devil's Guich), the upper Burkeville Fauna, the Cold Spring Fauna, the Bradley and lower Agricola Faunas of the Bone Valley, and the Ashville locality. 
Biochron 3 is the Protohippus supremus - Cormohipparion sphenodus $C R Z$, representing the interval between 12.0 and $11.3 \mathrm{ma}$. It includes the last appearance of Pseud. retrusum, and the first appearances of Plio. pernix, Call regulus, Pseud. Curtivallum, and probably Nannippus fricki. The Burge Fauna is the most important of the period, but it also includes the slightly younger upper Agricola Fauna of the Bone Valley.

Biochron 4 is the Cormohipparion occidentale - Pseudhipparion gratum - Calippus martini CRZ, representing the interval between 11.3 and $9.3 \mathrm{ma}$. Last appearances are by Merychippus s.s. and s.1, Pseud. curtivallum, Cal. regulus, Cal. placidus, Prot. supremus, Nan. fricki, and Plio. pernix; first appearances are by Cor. occidentale, Pseud. hessei, Neo. affine, and $\underline{H}$. tehonense. Faunas of this period include the extremely well known Clarendon, Minnechaduza, Upper Snake Creek, and Lapara Creek faunas.

Biochron 5 is the Neohipparion trampasense - Pseudhipparion skinneri CRZ, representing the interval between 9.3 and $8.5 \mathrm{ma}$. Neo. affine makes its last appearance during this period, while first appearances are by $\mathrm{Cal}$. cerasinus, $\mathrm{Cal}$. elachistus, Cor. ingenuum, Cor. plicatile, Plio. nobilis, Pro. gidleyi, and Nan. westoni. Cormohipparion occidentale persists in the Great Plains. Faunas of this period include the Xmas-Kat Quarries, J. Swayze Quarry, Arens Quarry, Love Site, and McGehee Farm.

Biochron 6 is the Calippus hondurensis - Pliohippus nobilis Neohipparion leptode CRZ, representing the interval between 8.5 and $7.5 \mathrm{ma}$. It includes the last appearance of Nan. westoni, and Cor. 
occidentale, Cor. plicatile, Cor. ingenuum and Pseudhipparion skinneri are characteristic taxa. Faunas of this period include Mixson's Bone Bed, Arnett, and Higgins.

Biochron 7 is the "Pliohippus" interpolatus - Calippus maccartyi Calippus n. sp. CRZ, representing the interval between 7.5 and 6.0 ma. It includes the last appearances of Pseud. skinneri, $\underline{H}$. forcei, H. tehonense, Cor. ingenuum, Cor. plicatile, Cor. occidentale, Pro. gidleyi, and Cal. elachistus, and the first appearances of Neo. eurystyle, Nan. lenticularis, Nan. minor, "ㅁ. " leidyanus, and the Hippidion-group. Faunas of this period include Ft-40, Box T, Aphelops Draw, Moss Acres, Manatee Dam, and Withlacoochee River 4A.

Biochron 8 is the Neohipparion eurystyle - Astrohippus ansae CRZ, representing the interval from 6.0 to $5.0 \mathrm{ma}$. It includes the last appearances of "Plio." interpolatus, "D.." leidyanus, and Neo. leptode, and the first appearances of Neo. gidleyi and Pseud simpsoni. Nannippus minor and Nan. lenticularis are characteristic taxa. Faunas of this period include Coffee Ranch, Optima, ZX Bar, Edson, and Uptegrove; note that the Gulf Coastal Plain is not represented at all in this interval.

Biochron 9 is the Dinohippus mexicanus - Astrohippus stockii CRZ, representing the interval from 5.0 to $4.5 \mathrm{ma}$. It includes the last appearances of Nan. minor, Nan. Ienticularis, Neo. eurystyle, Neo. gidleyi, and Pseud. simpsoni, and the first appearances of Cor. emsliei and Nan. peninsulatus. Faunas of this period include Axtell, Christian Ranch, Yepomera, Rancho El Ocote, and the Palmetto (Upper Bone Valley) faunas. 


\section{Diversity and Extinction Patterns}

Using the chronologic distributions from Figure 77, the observed number of taxa, number of originations (by cladogenesis or immigration on $1 y$, not by anagenic replacement), and number of extinctions (true extinction, not pseudoextinction or absence in the fossil record) were tallied for million year intervals (Table 50) and analyzed with the methods of Webb $(1969 \mathrm{C})$. The analysis was limited to species from faunas of the Great Plains and Gulf Coastal Plain. Although western and Mexican faunas share some species with them, they have quite different patterns of abundances and extinctions, they lack several characteristic eastern genera (Pseudhipparion, Calippus, Protohippus), and are not as well known. The Blancan radiation of Equus s.l. is poorly understood, so I have conservatively treated it as a single taxon. However, several Equus lineages are present at least by the late Blancan (Tedford, 1981).

The results of the analysis (Fig. 78) indicate that there was a period of rapid increase in diversity through the first two-thirds of the Barstovian. To some extent this may reflect the weakness in the data base for taxa of this age. The rate of increase leveled off at about 12 to $13 \mathrm{ma}$, after which there followed a six million year period of remarkable stability in both number of total taxa (Fig. 78A) and composition (Fig. 78B). This is in spite of a great deal of turnover at the species level through this interval (Fig. 77). This stable period from about 13 to 7 ma corresponds to the Clarendonian Chronofauna of Webb (1969a; 1977). 
4

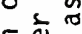

$\subseteq$ ○。

更

a

을

的

蛋

m.

政

요

4

54

ज०

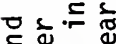

ชิ ปั ญ

을 웜

릉

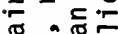

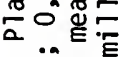

峄吴。

岕高

吃宁

든 둥

E匚这峁

인.二

㱒

बृ

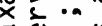

車宁

욜

D. =

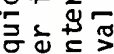

머월 중

뚷ํ

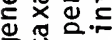

은

¿

>.

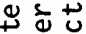

ه 距

-유워

4

ज०

U \&

हैं

空空出过

ㅇํㅇ वे

늩을

U.

号

با لسا

.

유룽요

뜬

흔호응 $\sum_{i=}$

L ᄂ $\dot{0} \dot{\sim} \dot{\sim} \dot{\sim} \dot{\sim} \dot{m} \dot{\infty} \dot{\oplus} \dot{\sim}$

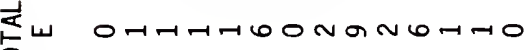

e

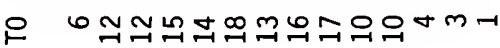

$\sum_{\propto}$

O n 00000 n 0 o n 000

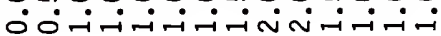

虫

岸山0000000नーनー000

o-100000NHA0000

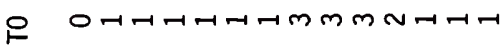

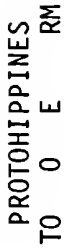

no 0 in 00 in 0000000

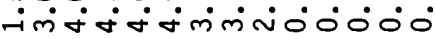

$00000 m 07000000$

HNOHOHHH000000

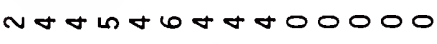

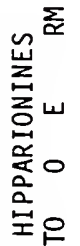

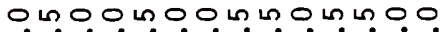
نं

OOHAOMOORHLHNO

OmनmmनOHHनNOOO

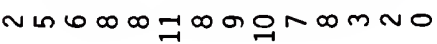

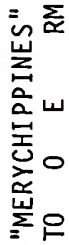

0 no 0 n 000000000

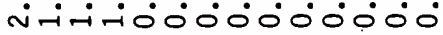

$0-100-1000000000$ 00000000000000 N NHA-1000000000

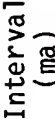

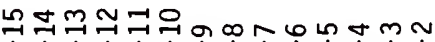

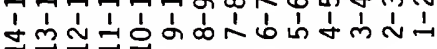


Figure 78. Equid species diversity pattern through the late Neogene, using the distributions in Figure 77, but on ly for taxa from the Great Plains and the Gulf Coastal Plain. See Table 50 for calculations. A. Running mean of equid species, divided into four taxonomic groups. B. Data of A expressed as a percentage of the total running mean. 


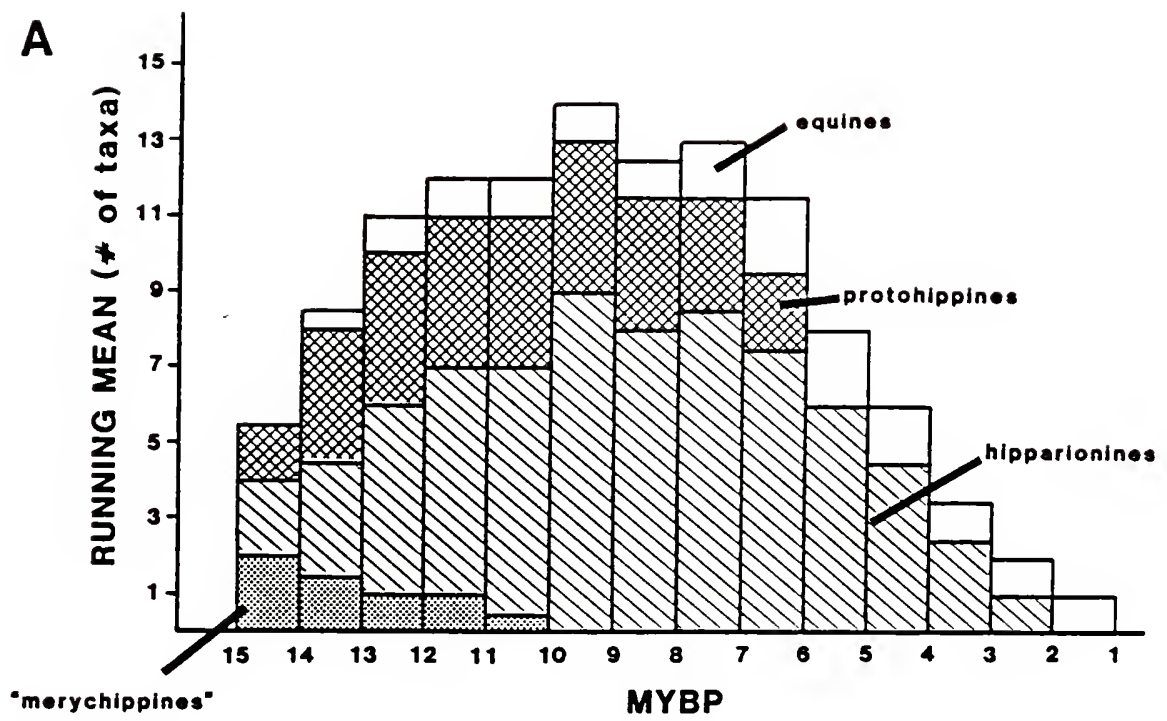

B

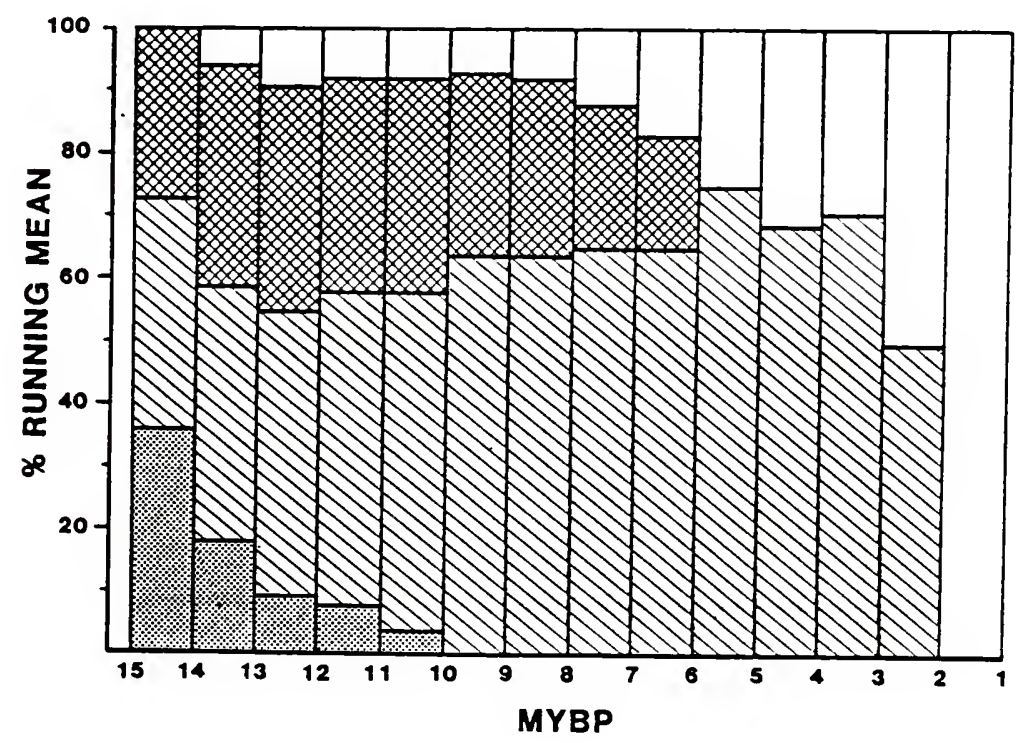


Starting at about $7 \mathrm{ma}$, the running mean for tota 1 number of taxa began to decline continually in each subsequent interval. There were two pulses of rapid (catastrophic?) major extinction within what was otherwise a period of gradual decline. Reasons for this decline are probably primarily climatic deterioration on a continental scale, with secondary effects from increased competition by grazing ruminants, such as camelids and antilocaprids (the latter experienced their maximum generic diversity in the Hemphillian, before declining themselves; Webb, 1984). The first episode of major extinction occurred at about $6.2 \mathrm{ma}$. All four lineages of the Protohippina went extinct at this point, as well as Pliohippus s.s., North American Hipparion, and many species of other hipparionines (Fig. 77). This also marked the turning point in relative diversity in Great Plains equid faunas, which from then on were numerically dominated by monodactyl equines (even though hipparionines remained more diverse taxonomically into the Blancan). The second episode of major extinction was at about $4.5 \mathrm{ma}$, and marked the last appearance of Neohipparion (two lineages), Pseudhipparion, Astrohippus, and two species of Nannippus. Over half of the observed taxa in this interval went extinct at this time, the greatest percentage for any of the million year periods (Table 50$)$. Webb $(1977 ; 1984)$ has previously noted the severity of this episode of extinction, which affected many more genera of mammals in North America than any other comparable period of extinction in the late Cenozoic. 
CHAPTER 8

SUMMARY AND CONCLUSIONS

Horses (Mammalia, Equidae) are a typical, oftentimes numerous, component of the Neogene large mammal community of North America. This study focused on the advanced equids (Subfamily Equinae) of the Gulf Coastal Plain of Florida and Texas from about 14.5 ma to about 4.5 ma (late Barstovian through Hemphillian), and their contemporaries from the Great Plains. The basic questions to be answered were: 1) how many species were present at each particular locality; 2) what species names should be applied to each population; and 3 ) how are these species related to one another? Cranial characters, particularly those of the facial fossae and muzzle region, were used, when known, in conjunction with traditional dental characters to answer these questions and infer systematic relationships. Morphology of post-cranial elements, particularly of the metapodials, was also used when specimens that courd be unambiguously associated with cranial/dental material were available (see MacFadden, 1984a). Unfortunately, this is exceedingly rare in Gulf Coastal Plain deposits.

At least twelve genera of advanced North American equids are probably valid (Table 49); of these six with Gulf Coastal Plain representatives are here described in detail (Neohipparion, 
Nannippus, Cormohipparion, Hipparion, Calippus and Protohippus). An additional common genus, Pseudhipparion, was recently reviewed by Webb and Hulbert (1986), so it is not treated here in detail, but is included in the phylogenetic analysis. Members of the subtribe Equina were much rarer in the Gulf Coastal Plain than these seven genera, and are only briefly described here (see also MacFadden, 1986). Merychippus, here restricted to a sma11, monophyletic group of species (cf. Evander, 1986), was also present in the Gulf Coastal Plain, but only in faunas older than $14.5 \mathrm{ma}$, and was therefore not studied in detail.

The tribe Hipparionini is found to be a monophyletic assemblage of six named genera: Neohipparion, Pseudhipparion, Merychippus s.s., Hipparion, Cormohipparion and Nannippus. Additional1y, "Merychippus" coloradense and "M." goorisi cannot be assigned to any particular genus, and are placed in the tribe as plesions with generic rank (Table 49). Hipparionines ranged widely in North America from the latest Hemingfordian (e.g. the Snake Creek Fauna, about $17 \mathrm{ma}$ ) to the late Blancan (about $2 \mathrm{ma}$ ), and are known from the Canadian plains to Honduras. The distribution of hipparionine taxa in Gulf Coastal and Great Plains faunas is summarized in Table 51.

Neohipparion forms a monophyletic group of five North American species, three of which are recognized in the Gulf Coastal Plain. Neo. affine is reported for the first time from the early Clarendonian Lapara Creek Fauna of southern Texas. Isolated teeth of Neo. affine can usually be distinguished from those of Cormohipparion occidentale by their simpler fossette patterns, longer protocones 


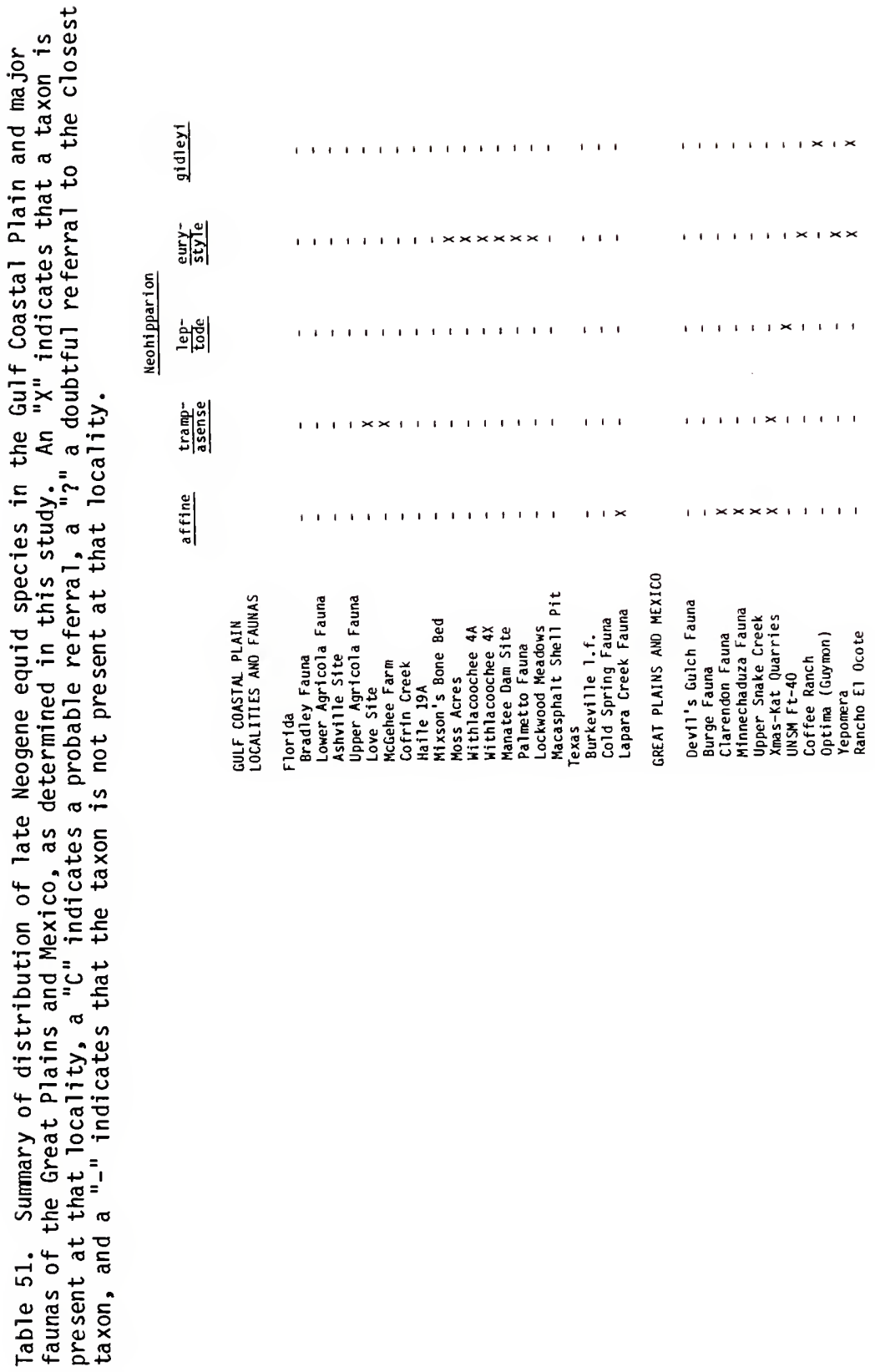




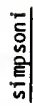

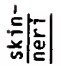

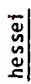

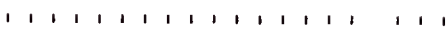

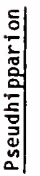

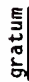

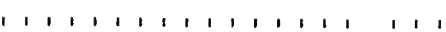

$1,1 \times x|1| 1,1$

紊年

官<smiles>[Mg][V]</smiles>

离|틴|
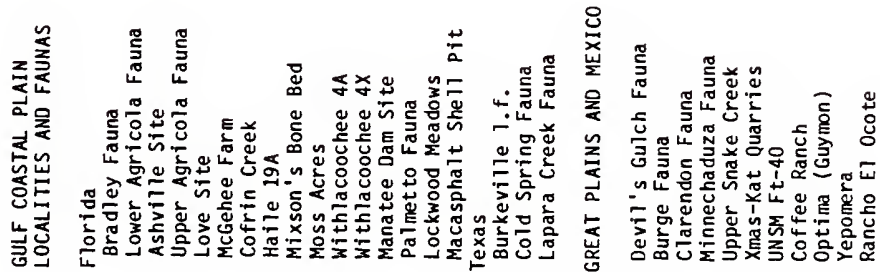


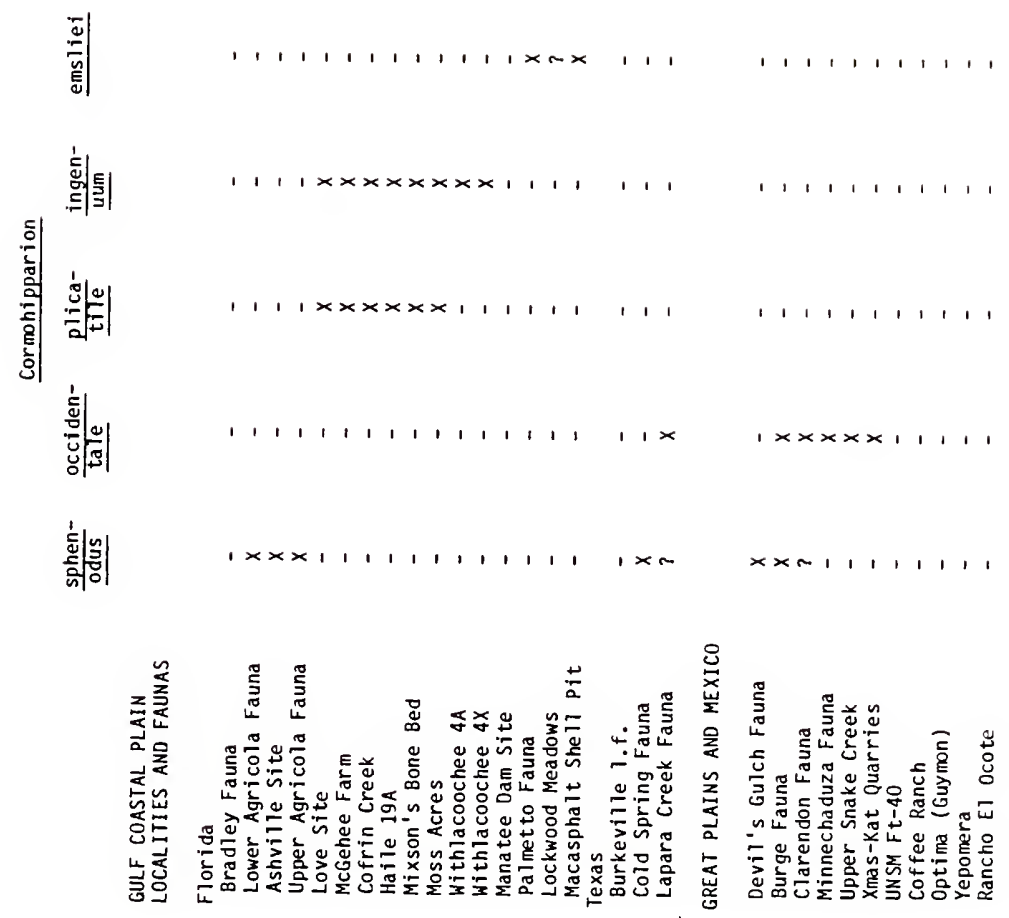

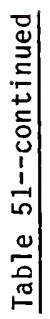


站|

힐

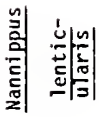

\begin{tabular}{l}
-5 \\
0 \\
0 \\
0 \\
\hdashline
\end{tabular}

$\frac{-5}{5}$

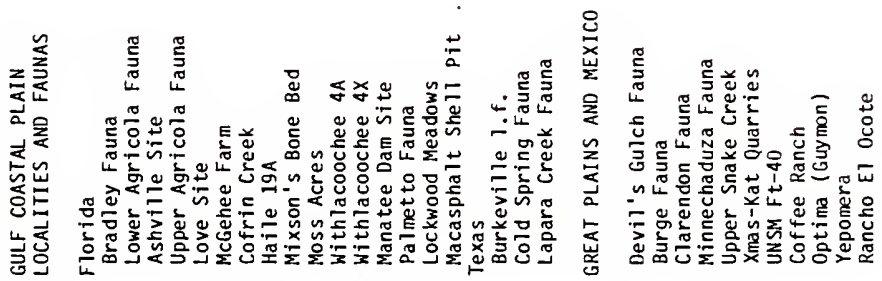




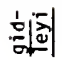

II

밈임

힌

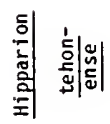

다민

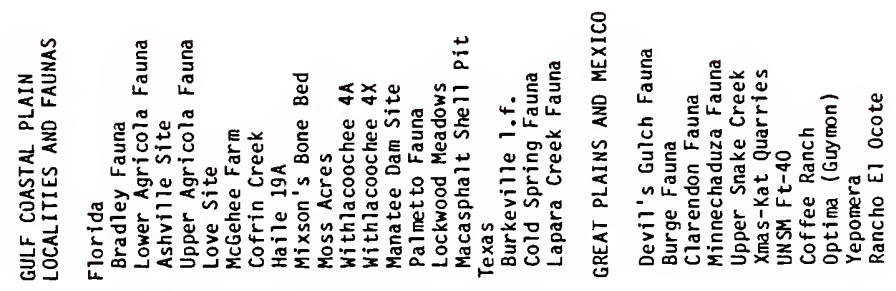




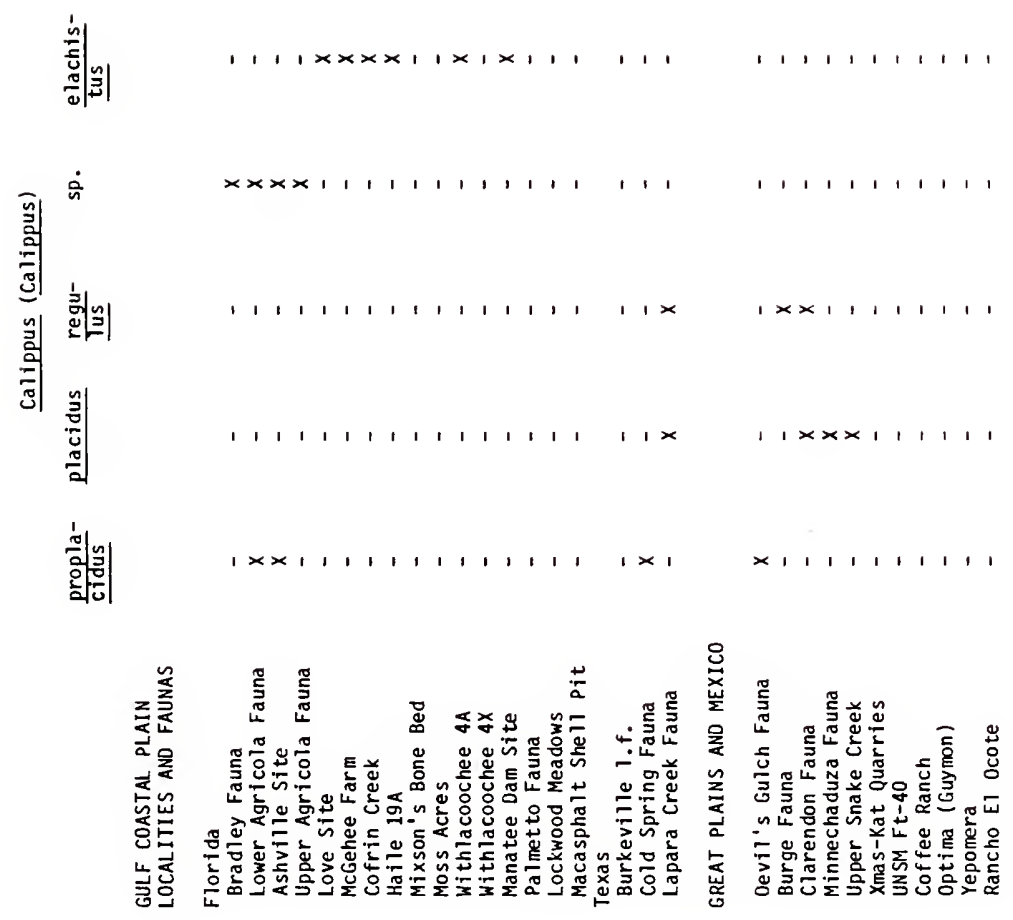




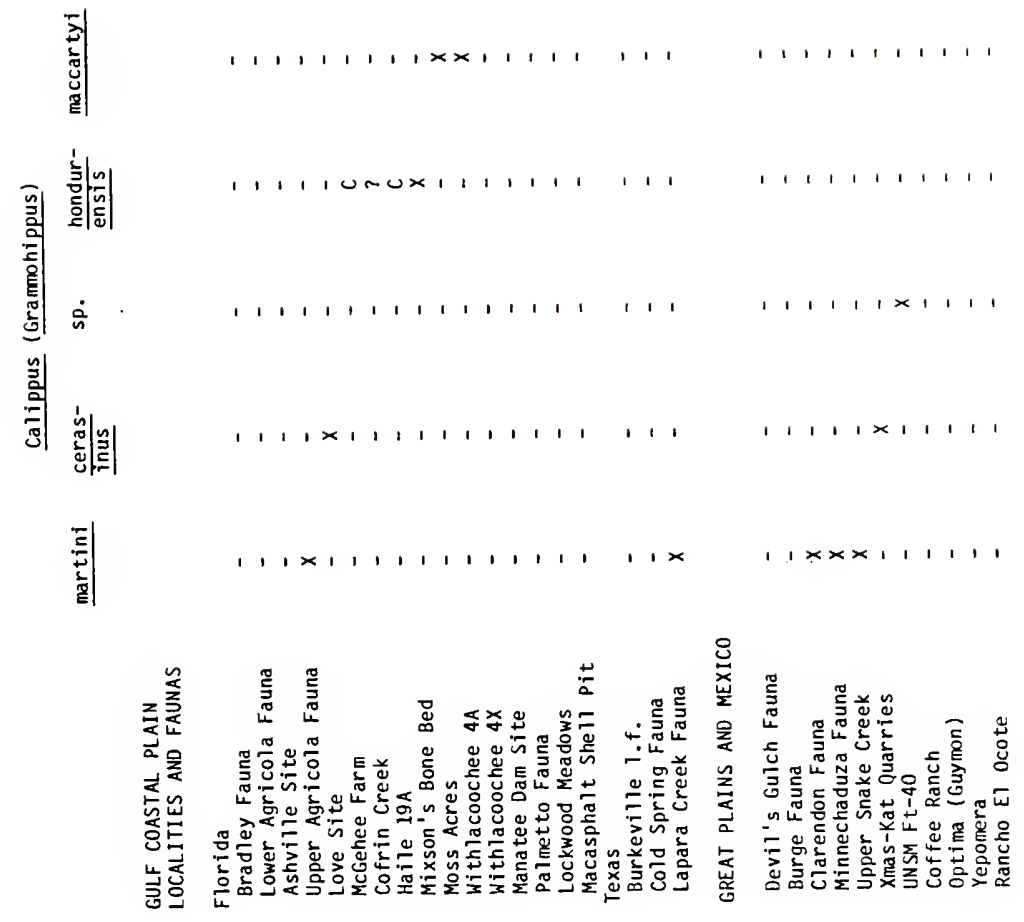



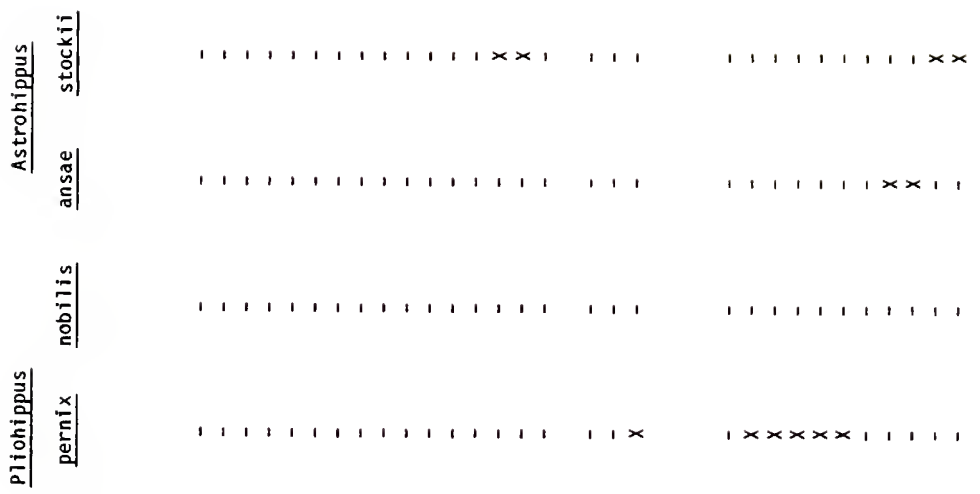

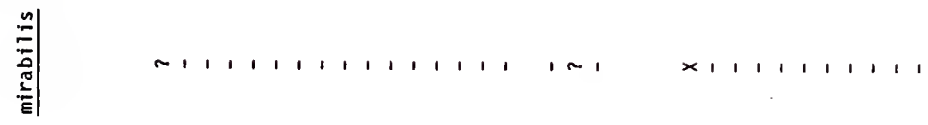

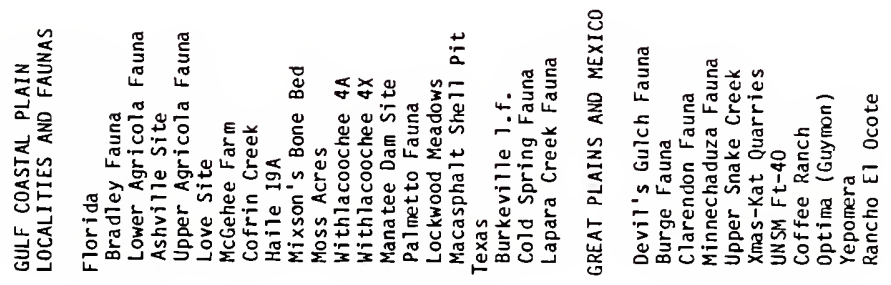


矛 号

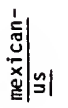

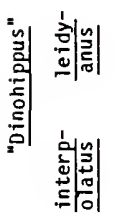

के

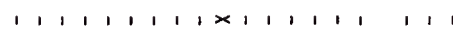

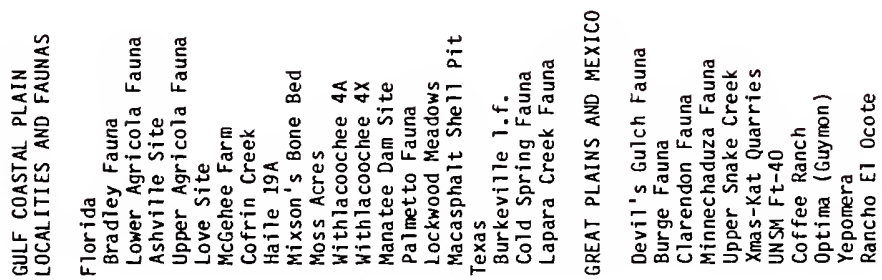


relative to tooth size, well developed pli caballinids in very early wear-stages of lower premolars, and reduced ectostylids in deciduous lower cheekteeth. Neo. trampasense, the probable direct ancestor of Neo. leptode and Neo. eurystyle, is described from late Clarendonian and early Hemphillian skulls, jaws and teeth from Florida, Kansas, and Nebraska. Pli caballinids in the lower molars (in early wearstages) are a critical diagnostic feature of this species, as are a very reduced DPOF, elongated protocones, and shallow ectoflexids in the lower premolars. Neo. eurystyle, a very advanced and hypsodont equid, continues many of the trends first observed in Neo. trampasense, especially in the "premolarizing" of the lower molars. The newly discovered Moss Acres Racetrack is the oldest and most primitive population referable to this species. The population from the very late Hemphillian (early Pliocene) Bone Valley Region of Florida, described by Simpson (1930) as Neo. phosphorum, falls within the observed range of variation in size, hypsodonty, and enamel morphology of Neo. eurystyle, as exemplified by large samples from the Coffee Ranch and Yepomera faunas, thus corroborating MacFadden's (1984a) synonymy of the two species.

Nannippus is a monophyletic assemblage of six species, four of which are recognized in the Gulf Coastal Plain. The oldest populations referred to Nannippus are from the Lapara Creek and upper Agricola faunas (very early Clarendonian). They are tentatively referred to Nan. fricki n. sp., which is typified by a slightly younger sample from north-central Nebraska. Nan. fricki is relatively much more abundant in the southernly Florida and Texas 
samples, a pattern that continued throughout the Neogene for the genus. Nan. fricki possessed a deep, pocketed DPOF that had a we 11 defined anterior margin. This along dental synapomorphies suggests a sister-group relationship between Nannippus and Cormohipparion. Later species of Nannippus reduced and eventially lost the DPOF, as did many other late Neogene equid 1ineages. Simpson (1930) described Merychippus westoni on a single specimen, a heavily worn maxilla of uncertain stratigraphic provenience. Stirton (1940) considered it a relatively old and primitive species of Merychippus, despite the poor quality and isolated nature of the type. When heavily worn, upper cheekteeth of Nannippus from the late Clarendonian Love Site match the type of "M." westoni in every detail of size and morphology, and Simpson's species is transferred to that genus. Nan. westoni ranged from the latest Clarendonian through the early Hemphillian of Florida, and like its contemporary Neo. trampasense, provides a morphological link between Clarendonian and late Hemphillian members of its genus. The Moss Acres Racetrack Site has produced the oldest (about $7.5 \mathrm{ma}$ ) and most complete specimens of Nan. minor known. They resemble younger populations on Nan. minor in their relatively hypsodont premolars, very reduced P2 anterostyle, complex fossettes, rounded premolar protocone, and very reduced (usually absent) protostylid. However, in size and crown height they plesiomorphically resemble Nan. westoni. By about $6.5 \mathrm{ma}$, very sma 11 individuals of Nan. minor first appear in the Florida record (at the Withlacoochee River $4 \mathrm{~A}$ and Manatee Dam localities), but relatively large individuals remained common. The type late Hemphillian labout 
5.0 to $4.5 \mathrm{ma}$ ) Bone Valley population is comprised primarily of only smal1 individuals. Nannippus persisted into the Blancan, represented in the Gulf Coastal Plain by Nan. peninsulatus (=Nan. phlegon;

Florida record reviewed by MacFadden and Waldrop, 1980).

Five North American species of Cormohipparion are recognized, and all are recorded in the Guif Coastal Plain region. The ubiquitous late Barstovian-early Clarendonian Cor. sphenodus is recognized for the first time in eastern North America. Limited, but diagnostic samples of isolated teeth of this species are found in the Agricola Fauna of the Bone Valley Region. Cor. occidentale, well known from the Clarendonian and early Hemphillian of the Great Plains, is not recognized in Florida, but did range as far as southern Texas, where it is a member of the Lapara Creek Fauna. In Florida, two previously enigmatic species described a century ago by Joseph Leidy from Mixson's Bone Bed can now both be referred to Cormohipparion. This is based on newly recovered and more complete material from the Love Site and the Moss Acres Racetrack Site. The referred material ranges in age from very late Clarendonian to late early Hemphillian, and demonstrates moderate amounts of chronoclinal microevolution, especially in increasing enamel complexity. Cor. plicatile is not recognized as yet from localities outside of peninsular florida. Cor. ingenuum is judged to not be the senior synonym of Nannippus lenticularis (Cope), as was proposed by MacFadden (1984a). The population referred to Cor. plicatile by Webb and Perrigo (1984) from Honduras is placed in Cor. ingenuum instead. This is based on the smaller size of the population, the principal difference between the 
two species. Cormohipparion has been thought to have become extinct at the end of the early Hemphillian (Webb, 1984), and is absent from all known late Hemphillian western faunas. However, the genus survived in Florida until near the end of the Blancan, based on the range of Cor. emsliei n. sp. Cor. emsliei, on average the most complexly plicated North American equid, apparently is descended from the similarly sized Cor. ingenuum.

Only three North American species of Hipparion are recognized, of which two are found in the Gulf Coastal Plain. ${ }_{\text {H. Shirleyi is a }}$ common member of the late Barstovian Cold Spring Fauna in Texas. $\underline{H}$. tehonense ranged from the early Clarendonian to the early Hemphillian in the Gulf Coastal Plain, and is recognized in the Lapara Creek, Agricola, Love Site, Moss Acres, and Withlacoochee 4A localities, the latter four records being provisional.

The Equini form the sister-group to the Hipparionini. At least seven genera comprise the Equini, of which two, Calippus and Protohippus, are common constituents of Gulf Coastal Plain faunas. They form a monophyletic clade (the subtribe Protohippina) characterized by a short diastema, broadened muzzle, shallow DPOF, and lack of a malar fossa. Protohippus is ancestral to neither Pliohippus nor Equus, as is common1y purported (e.g. Stirton, 1940; Simpson, 1951; Shotwe 11, 1961), nor is it synonymous with Merychippus (contra McGrew and Meade, 1938). Quinn (1955, p. 22) reached a similar conclusion, but his positive contributions have been generally overlooked because of his oversplitting of clades and other incorrect phylogenetic interpretations. The common ancestor of Calippus, Protohippus and 
equines was a small, low crowned, primitive species, probably similar to "Merychippus" carrizoensis or "M." primus.

Al1 four recognized species of Protohippus are known from the Gulf Coastal Plain. Pro. vetus is an early Barstovian species from the older units of the Burkeville Fauna. Pro. perditus, the genotypic species, is well represented in the Devil's Gulch Fauna of Nebraska by numerous crania. These demonstrate that Quinn's (1955) Eoequus wilsoni is a junior synonym of Pro. perditus. Leidy's Pro. supremus has been placed in Pliohippus by most subsequent workers (e.g. Stirton, 1940; Webb, 1969a), but examination of the lectotype tooth reveals that it is referable to Protohippus and not Pliohippus. Protohippus is unique among protohippine and equine genera for increasing the duration of isolated protocones in its upper cheekteeth. In this respect, Protohippus gidleyi $n$. sp. from the very late Clarendonian to early Hemphillian of Florida and Nebraska is the most derived species of Protohippus.

Two subgenera of Calippus are recognized, Calippus and Grammohippus n. subg. They share an uniquely modified muzzle region in which the premaxillae and mandibular symphysis are broadly expanded and massive, and the enlarged first and second incisors are arranged in a straight line rather than the normal equid arcade. The nominate subgenus includes four named small species, all found in the Gulf Coastal Plain. Calippus, unlike most other equid genera, appears to have had distinct lineages in Texas and Florida in the Clarendonian. In Texas, the Barstovian Cal. proplacidus is replaced in the Clarendonian by Cal. regulus and Cal. placidus (Table 51). In Florida, in 
addition to $\mathrm{Ca}$. proplacidus, there is a very small taxon from the late Barstovian and early Clarendonian Bradley and Agricola Faunas that cannot be referred to any of the four named species, but that is too inadequately known to be described as new. It apparently gave rise to the late Clarendonian-early Hemphillian Cal. elachistus $n$. sp., one of the smallest known hypsodont equids. Species of Cal. (Grammohippus) have previously been assigned to Pliohippus or Astrohippus, but differ from those genera in the absence of a malar fossa, short diastema, and broadened muzzle. Cal. martini and Cal. hondurensis are referred to this new subgenus, as are the new species, $\mathrm{Ca}$. cerasinus from the late Clarendonian-early Hemphilitian of Nebraska and Florida, and Cal. maccartyj from the late early Hemphillian of Florida. Species referred to Grammohippus are of moderate size (toothrow lengths of 100 to $130 \mathrm{~mm}$ ).

Members of the Equina are uncommon in the Gulf Coastal Plain until the Blancan (Table 51). Pliohippus is recognized in Texas, but its presence in Florida is questionable. Astrohippus stockii and "Dinohippus" mexicanus are very rare elements of the Palmetto Fauna of central Florida (MacFadden, 1986). A more primitive population of "Dinohippus" is found at the Moss Acres Ractrack Site, including a juvenile cranium with a moderately well developed DPOF.

Results of a phylogenetic analysis of 57 equid species primarily using dental and cranial characters were compared to the traditional phylogeny of the Equinae of Matthew (1926) and Stirton (1940), and the alternate phylogeny of Quinn (1955). Computer-generated cladograms indicated that equid evolution was characterized by a high 
degree of homoplasy; parallel evolution of dental characters and parallel reduction of facial fossae are particularly common. As such, phylogenetic reconstruction using maximum parsimony as a goal is unlikely to arrive at the correct branching sequence, as the evolution of the animals was itself not parsimonious (cf. Kirsch and Archer, 1982). A more probable outline of the major branching sequences was determined using only highly consistent characters (Figure 70). The advanced equids comprise two major clades, here regarded as the tribes Hipparionini and Equini. The relationships of genera within these tribes much more closely resembles the phylogenies of Matthew and Stirton than that of Quinn. In particular, Pseudhipparion is a hipparionine, not an equine (although this is not always its most parsimonious allocation), Calippus and Protohippus are sister-taxa, and "Dinohippus" is the sister-taxon of Equus. Many of the species here recognized as relatively older and more primitive members of advanced genera were arranged paraphyletically by Stirton (1940) into a horizontal grade called Merychippus. For example, "M. " sphenodus is a Cormohipparion, "M. " westoni is a Nannippus, "M." proplacidus is a Calippus, "M." perditus is a Protohippus, and "M." mirabilis is a Pliohippus (Figs. 74,76 ).

With their revised taxonomy and chronologic ranges, equids now become more precise tools for biostratigraphic correlation. Nine biochrons are recognized between 16 and $4.5 \mathrm{ma}$, based on concurrent range zones of equid species. Within a given geographic provenience (e.g. Florida or Nebraska), these could be even further subdivided. Over the last 16 million years, three phases of equid diversity are 
apparent. From about 16 to $12 \mathrm{ma}$, there was rapid diversification, especially by the hipparionines and protohippines. From about 12 to 7 ma, overall equid diversity was remarkably high, yet stable.

Starting at about $7 \mathrm{ma}$, equid diversity began to decline, with two major periods of extinction at 6.2 and $4.5 \mathrm{ma}$. This deciine, which culminated about 11,000 years ago in the extinction of a 11 New World equids, is a component in an overall reduction in numbers of large North American mammals through the late Cenozoic that can be related to climatic deterioration (Webb, $1977 ; 1984)$. As their systematics becomes increasingly more refined, equids can be used with increasing detail to study this important phenomenon. 


\section{REFERENCES CITED}

Ameghino, F. 1904. Recherches de morphologie phylogenetique sur les molaires superiores des ongules. Anales del Museo Nacional de Historia Natural de Buenos Aires, 3rd. Ser., 3:1-541.

Baskin, J.A. 1980a. Evolutionary reversal in Mylagaulus (Mammalia, Rodentia) from the late Miocene of Florida. American Midlands Natura list, $104: 155-162$.

Baskin, J.A. 1980b. The generic status of Aelurodon and Epicyon (Carnivora, Canidae). Journal of Paleontology, $54: 13 \overline{49-1351 .}$

Baskin, J.A. 1981. Barbourofelis (Nimravidae) and Nimravides (Felidae), with a description of two new species from the late Miocene of Florida. Journal of Mammalogy, 62:122-139.

Baskin, J.A. 1982. Tertiary Procyoninae (Mammalia: Carnivora) of North America. Journal of Vertebrate Paleontology, 2:71-93.

Baskin, J.A. 1986. The late Miocene radiation of Neotropical sigmodontine rodents in North America. Pp. 287-304 in Flanagan, K.M. and J.A. Lillegraven, eds., Vertebrates, Phylogeny, and Philosophy. Contributions to Geology, Universtiy of Wyoming, Special Paper 3.

Becker, J.J. 1985a. Fossil herons (Aves: Ardeidae) of the late Miocene and early Pliocene of Florida. Journal of Vertebrate paleontology, 5:24-31.

Becker, J.J. 1985b. Pandion lovensis, a new species of osprey from the late Miocene of Florida. Proceedings of the Biological Society of Washington, $98: 314-320$.

Becker, J. J. 1986. A new vulture (Vulturidae: Pliogyps) from the late Miocene of Florida. Proceedings of the Biological Society of Washington, $99: 502-508$.

Bennett, D.K. 1980. Stripes do not a zebra make, Part 1: a cladistic analysis of Equus. Systematic Zoology, $29: 272-288$.

Berger, J. 1986. Wild Horses of the Great Basin. University of Chicago Press, Chicago, 326 p. 
Bernor, R.L. and S.T. Hussain. 1985. An assessment of the systematic, phylogenetic and biogeographic relationships of Siwalik hipparionine horses. Journal of Vertebrate Paleontology, 5:32-87.

Bernor, R.L., M.0. Woodburne, and J.A. Van Couvering. 1980. A contribution to the chronology of some 01d World faunas based on hipparionine horses. Geobios, 13:705-739.

Berta, A. and H. Galiano. 1983. Megantereon hesperus from the late Hemphillian of Florida with remarks on the phylogenetic relationships of machairodonts (Mammalia, Felidae, Marchairodontinae). Journal of Paleontology, 57:892-899.

Berta, A. and H. Galiano. 1984. A Miocene amphicyonid (Mammalia: Carnivora) from the Bone Valley Formation of Florida. Journal of Vertebrate Paleontology, 4:122-125.

Berta, A. and G.S. Morgan. 1985. A new sea otter (Carnivora: Mustelidae) from the late Miocene and early Pliocene (Hemphillian) of North America. Journal of Paleontology, 59:809-819.

Bode, F.D. 1931. Characters useful in determining the position of individual teeth in the permanent cheektooth series of merychippine horses. Journal of Mammalogy, 12:118-129.

Bode, F.D. 1934. Tooth characters of protohippine horses with special reference to species from the Merychippus Zone, California. Carnegie Institution of Washington Publication, 453:39-64.

Buwalda, J.P. and G.E. Lewis. 1955. A new species of Merychippus. United States Geological Survey, Professiona T Paper, 264G:14T-152.

Christol, J. de. 1832. [untitled]. Annales des Sciences et de 1 'industrie du Midi de la France, 1:180-181.

Clark, C. and D.J. Curran. 1986. Outgroup analysis, homoplasy, and global par simony: a responce to Maddison, Donoghue, and Maddison. Systematic Zoology, $35: 422-426$.

Cope, E.D. 1880. A new Hippidium. American Naturalist, 14:223.

Cope, E.D. 1885. Report on the coal deposits near Zacualtipan, in the state of Hildalgo, Mexico. Proceedings of the American Phi lo sophical Society, 23:146-151.

Cope, E.D. 1886. On two new species of three-toed horses form the upper Miocene, with notes on the fauna of the Ticholeptus beds. Proceedings of the American Philosophical Society, 23:357-361.

Cope, E.D. 1889. A review of the North American species of Hippotherium. Proceedings of the American Philosophical Society, 26:429-458. 
Cope, E.D. 1892. On the permanent and temporary dentitions of certain three-toed horses. American Naturalist, 26:942-944.

Cope, E.D. 1893. A preliminary report on the vertebrate paleontology of the Llano Estacado. Geological Survey of Texas, 4 th Annual Report, $136 \mathrm{p}$.

Cracraft, J. 1981. Pattern and process in paleobiology: the role of cladistic analysis in systematic paleontology. Paleobiology, $7: 456-468$.

Dalquest, W.W. 1978. Phylogeny of American hor ses of Blancan and Pleistocene age. Annales Zoologici Fennici, 15:191-199.

Dalquest, W.W. 1981. Hesperohipparion (Mammalia: Equidae), a new genus of horse from the HemphilTian of North America, with description of a new species. The Southwestern Naturalist, $25: 505-512$.

Dalquest, W.W. 1983. Mammals of the Coffee Ranch local fauna, Hemphillian of Texas. Texas Memorial Museum, Pearce-Sellards Series, $38: 1-41$.

Dalquest, W.W. and T.J. Donovan. 1973. A new three-toed hor se (Nannippus) from the late Pliocene of Scurry County, Texas. Journal of Paleontology, $47: 34-45$.

Dalquest, W.W. and 0. Mooser. 1980. Late Hemphillian mammals of the Ocote local fauna, Guanajuato, Mexico. Texas Memorial Museum, Pearce-Sellards Series, 32:1-25.

Dougherty, J.F. 1940. A new Miocene mammalian fauna from Caliente Mountain, California. Carnegie Institution of Washington Publication, $514: 109-143$.

Downs, T. 1956. The Mascall Fauna from the Miocene of Oregon. University of California Publications in Geological Sciences, 31:199-354.

Drescher, A.B. 1941. Later Tertiary Equidae from the Tejon Hills, California. Carnegie Institution of Washington Publication, $530: 1-24$.

Edwards, S.W. 1982. A new species of Hipparion (Mammalia: Equidae) from the Clarendonian (Miocene) of California. Journal of Vertebrate Plaeontology, 2:173-183.

Eisenmann, V. 1979. Les métapodes d'Equus sensu lato (Mammalia, Peris sodactyla). Géobios, 12:863-886. 
Eisenmann, V. 1981. Les caracteres des crânes d'Hipparion s.1. (Mammalia, Perissodactyla) et leur interprétation. Comptes Rendus des Séances de 1'Académie des Sciences (Paris), Serie II, 293:735-738.

Eisenmann, V. 1986. Comparative osteology of modern and fossil horses, half-asses, and asses. Pp. 67-116, in Meadow, R.H. and H.P. Uerpmann, eds., Equids in the Ancient world. Dr. Ludwig Reichert Verlag, Wiesbaden.

Eisenmann, V. and S. Beckouche. 1986. Identification and discrimination of metapodials from Pleistocene and modern Equus, wild and domestic. Pp. 117-163, in Meadow, R.H. and H.P. Uerpmann, eds., Equids in the Ancient World. Dr. Ludwig Reichert Verlag, Wiesbaden.

Eisenmann, V., P. Sondaar, M. Alberdi, and C. de Giuli. 1987. Is the horse phylogeny becoming a playfield in the game of theoretical evolution? Journal of Vertebrate Paleontology, in press.

Evander, R.L. 1978. Fossil horses of the railroad quarries. Proceedings of the Nebraska Academy of Science, p. 41.

Evander, R.L. 1986. The taxonomic status of Merychippus insignis Leidy. Journal of Paleontology, 60:1277-1280.

Forsten, A. 1975. The fossil horses of the Texas Gulf Coastal Plain: a revision. Texas Memorial Museum, Pierce-Sellards Series, 22:1-86.

Forsten, A.. 1982. The status of the genus Cormohipparion Skinner and MacFadden (Mammalia, Equidae). Journat of Paleontology, $56: 1332-1335$.

Forsten, A. 1983. The preorbital fossa as a taxonomic character in some 01d World Hipparion. Journal of Paleontology, 57:686-704.

Forsten, A. 1984. Supraspecific groups of 01d World hipparions (Mammalia, Equidae). Palaeontologische Zeitschrift, 58:165-171.

Frick, C. 1933. New remains of trilophodont-tetrabelodont mastodonts. Bulletin of the American Museum of Natural History, $59: 505-652$

Galbreath, E.C. 1953. A contribution to the Tertiary geology and paleontology of northeastern Colorado. University of Kansas Paleontological Contributions, Vertebrata, 4:1-120.

Galusha, T., N.M. Johnson, E.H. Lindsay, N.D. Opdyke and R.H. Tedford. 1984. Biostratigraphy and magnetostratigraphy, late Pliocene rocks, 111 Ranch, Arizona. Geological Society of America Bulletin, $95: 714-722$. 
Gervais, P. 1849. Note sur la multiplicité des especies d'nipparions (genre de chevaux à trois doigts) qui sont enfouis à Cucuron (Vaucluse). Comptes Rendus des Séances de 1 'Académie des Sciences (Paris), $29: 284-286$.

Gidley, J.W. 1901. Tooth characters and revision of the North American species of the genus Equus. Bulletin of the American Museum of Natura 1 History, $14: \overline{91-141}$.

Gidley, J.W. 1903. A new three-toed hor se. Bulletin of the American Museum of Natura 1 History, 19:465-476.

Gidley, J.W. 1904. Proper generic names of Miocene horses. Bulletin of the American Museum of Natural History, 20:191-194.

Gidley, J.W. 1906a. New or 1jttle known mammals from the Miocene of South Dakota. Part IV. Equidae. Bulletin of the American Museum of Natura 1 History, 22:135-154.

Gidley, J.W. 1906b. A new genus of horse from the Mascall Beds, with notes on a small collection of equine teeth in the University of California. Bulletin of the American Museum of Natural History, $22: 385-388$.

Gidley, J.W. 1907. Revision of the Miocene and Pliocene Equidae of North America. Bulletin of the American Museum of Natural History, 23:865-934.

Gingerich, P.D. 1985. Species in the fossil record: concepts, trends, and transitions. Paleobiology, 11:27-41.

Gosliner, T.M. and M.T. Ghiselin. 1984. Parallel evolution in opisthobranch gastropods and its implications for phylogenetic methodology. Systematic Zoology, 33:255-274.

Gray, J.E. 1821. On the natural arrangements of vertebrose animals. London Medical Repository Review, 15:296-310.

Green, M. 1956. The lower Pliocene Ogallala Wolf Creek vertebrate fauna, South Dakota. Journal of Paleontology, 30:146-169.

Gregory, J.T. 1942. Pliocene vertebrates from Big Spring Canyon, South Dakota. Bulletin of the Department of Geological Sciences, University of California, 26:307-446.

Harland, W.B., A.V. Cox, P.G. Llewellyn, C.A.G. Pickton, A.G. Smith and R. Waiters. 1982. A Geologic Time Scale. Cambridge University Press, Cambridge, $131 \mathrm{p}$.

Harrison, J.A. 1981. A review of the extinct wolverine Plesiogulo (Carnivora: Mustelidae), from North America. Smithsonian Contributions to Paleobjology, 46:1-27. 
Harrison, J.A. 1985. Giant camels from the Cenozoic of North America. Smithsonian Contributions to Paleobiology, 57:1-29.

Harrison, J.A. and E. Manning. 1983. Extreme carpal variability in Teleoceras (Rhinocerotidae, Mammalia). Journal of Vertebrate Paleontology, 3:58-64.

Hay, 0.P. 1899. On the nomenclature of certain American fossil vertebrates. American Geologist, $24: 345-349$.

Hay, O.P. 1902. Bibliography and catalogue of fossil Vertebrata of North America. Bulletin of the United States Geological Survey, $179: 1-868$.

Hay, 0.P. 1916. Descriptions of some Floridian fossil vertebrates, belonging mostly to the Pleistocene. Florida Geological Survey, 8th Annual Report, pp. 39-76.

Hay, 0.P. 1919. Descriptions of some mammalian and fish remains from Florida, of probably Pleistocene age. Proceedings of the United States National Museum, 56:103-112.

Hay, 0.P. 1924. Description of some fossil vertebrates from the upper Miocene of Texas. Proceedings of the Biological Society of Washington, 38:1-19.

Hennig, W. 1966. Phylogenetic Systematics. University of Illinois Press, Urbana, $263 \mathrm{p}$.

Hesse, C.J. 1936. Lower Pliocene vertebrate fossils from the Ogallala Formation (Lavern Zone) of Beaver County, OKlahoma. Carnegie Institution of Washington Publication, 476:47-72.

Hesse, C.J. 1943. A preliminary report on the Miocene vertebrate faunas of southeast Texas. Proceedings and Transactions of the Texas Academy of Science, 26:157-179.

Hibbard, C.W. 1960. An interpretation of P7iocene and Pleistocene climates in North America. Annual Report of the Michigan Academy of Science, Arts and Letters, 62:5-30.

Hirschfeld, S.E. and S.D. Webb. 1968. Plio-Pleistocene megalonychid sloths of North America. Bulletin of the Florida State Museum, Biological Sciences, 12:213-296.

Hulbert, R.C. 1982. Population dynamics of the three-toed horse Neohipparion from the late Miocene of Florida. Paleobiology, 8:159-167. 
Huibert, R.C. 1985. Paleoecology and population dynamics of the early Miocene (Hemingfordian) hor se Parahippus leonensis from the Thomas Farm site, Florida. Journal of Vertebrate Paleontology, 4:547-558.

Hussain, S.T. 1975. Evolution and functional anatomy of the pelvic limb in fossil and Recent Equidae (Perissodactyla, Mammalia). Anatomy, Histology, Embryology, 4:179:222.

International Commission on Zoological Nomenclature. 1964. International Code of Zoological Nomenclature adopted by the XV Internationa 1 Congress of Zoology. London, $176 \mathrm{p}$.

Jackson, D.R. 1976. The status of the Pliocene turtles Pseudemys caelata Hay and Chrysemys carri Rose and Weaver. Copeia, 1976:655-659.

Jackson, D.R. 1978. Evolution and fossil record of the chicken turtie Deirochelys, with a re-evaluation of the genus. Tulane Studies in Zoology and Botany, 20:35-55.

Janis, C.M. 1984. The use of fossil ungulate communities as indicators of climate and environment. Pp. 85-104, in, Brenchley, P., ed., Fossils and Climate. John Wiley and Sons, New York.

Johnston, C.S. 1937. Calippus regulus from the Clarendon beds of Don ley County, Texas. American Midlands Natura list, 18:905-907.

Kirsch, J.A. and M. Archer. 1982. Polythetic cladistics, or, when parsimony's not enough: the relationships of carnivorous marsupia 1s. Pp. 595-619, in, Archer, M., ed., Carnivorous Marsupials. Royal Zoological Society of New South Wales, Sidney, Australia.

Lance, J.F. 1950. Paleontologia y estratigrafia del Plioceno de Yepomera, Estado de Chihuahua. 1 a Parte: equidos, excepto Neohipparion. Boletín Universidad Nacional Autonoma de Mexico Instituto de Geologia, 54:1-81.

Leidy, J. 1856. Notice of some remains of extinct Mammalia, recently discovered by Dr. F. V. Hayden in the bad lands of Nebraska. Proceedings of the Academy of Natural Sciences of Philadelphia, 8:59-60.

Leidy, J. 1857. Notices of extinct Vertebrata discovered by Dr. F. $V$. Hayden, during the expedition to the Sioux country under the command of Lieut. G. K. Warren. Proceedings of the Academy of Natural Sciences of Philadelphia, 8:311-312. 
Leidy, J. 1858. Notice of remains of extinct Vertebrata, from the Valley of the Niobrara River collected during the exploring expedition of 1857, in Nebraska, under the command of Lieut. G. K. Warren, U. S. Top. Eng., by Dr. F. V. Hayden, geologist to the expedition. Proceedings of the Academy of Natural Sciences of Philadelphia, 10:20-29.

Leidy, J. 1869. The extinct mammalian fauna of Dakota and Nebraska, including an account of some allied forms from other localities, together with a synopsis of the mammalian remains of North America. Journal of the Academy of Natural Sciences of Philadelphia, series 2, 7:1-472.

Leidy, J. 1873. Contributions to the extinct vertebrate fauna of the Western Territories. Pp. 14-358, in, Report of the U. S. Geological Survey of the Territories, F. V. Hayden, U. S. geologist in charge. Washington, D. C.

Leidy, J. 1884. Vertebrate fossils from Florida. Proceedings of the Academy of Natura 1 Sciences of Philadelphia, 36:118-119.

Leidy, J. 1885. Rhinoceras and Hippotherium from Florida. Proceedings of the Academy of Natural Sciences of Philadeiphia, $37: 32-33$.

Leidy, J. 1887. Fossil bones from Florida. Proceedings of the Academy of Natural Sciences of Philadelphia, 39:309-310.

Leidy, J. and F.A. Lucas. 1896. Fossil vertebrates from the Alachua Clays of Florida. Transactions of the Wagner Free Institute of Science of Philadelphia, 4:1-61.

Lindsay, E.H. 1984. Late Cenozoic mammals from northwestern Mexico. Journal of Vertebrate Paleontology, 4:208-215.

Lindsay, E.H., N.D. Opdyke, and N.M. Johnson. 1984. BlancanHemphillian Land Mammal Ages and late Cenozoic mammal dispersal events. Annual Review of Earth and Planetary Sciences, $12: 445-488$.

Linnaeus, C. 1758. Systema Naturae per Regna Tria Naturae, Secundum Classes, Ordines, Genera, Species cum Characteribus Differenti is Synonymis Locis. Editia decima, reformata. Laurentii, Stockhorm, Salvi, 1, 824 p.

MacFadden, B.J. 1980. The Miocene hor se Hipparion from North America and from the type locality in southern France. Palaeontology, $23: 617-635$.

MacFadden, B.J. 1982. New species of primitive three-toed browsing hor se from the Miocene phosphate mining district of centra 7

Florida. Florida Scientist, $45: 117-124$. 
MacFadden, B.J. 1984a. Systematics and phylogeny of Hipparion, Neohipparion, Nannippus, and Cormohipparion (MammaTia, Equidae) from the Miocene and PTiocene of the New World. Bulletin of the American Museum of Natura 1 History, 179:1-196.

MacFadden, B.J. 1984b. Astrohippus and Dinohippus from the Yepomera local fauna (Hemphiltian, Mexico) and implications for the phylogeny of one-toed horses. Journal of Vertebrate Paleontology, $4: 273-283$.

MacFadden, B. J. 1985. Patterns of phylogeny and rates of evolution in fossil horses: hipparions from the Miocene and Pliocene of North America. Paleobiology, 11:245-257.

MacFadden, B.J. 1986. Late Hemphillian monodactyl horses (Mammalia, Equidae) from the Bone Valley Formation of central Florida. Journal of Paleontology, 60:466-475.

MacFadden, B. J. 1987. Fossil horses from "Eohippus" (Hyracotherium) to Equus: scaling, Cope's Law, and the evolution of body size. Paleobiology, 12:355-369.

MacFadden, B.J. and A. Azzaroli. 1987. Cranium of Equus insulatus (Mammalia, Equidae) from the middle Pleistocene of Tarija, Bolivia. Journal of Vertebrate Paleontology, in press.

MacFadden, B.J. and H. Galiano. 1981. Late Hemphillian cat (Mammalia, Felidae) from the Bone Valley Formation of central Florida. Journal of Paleontology, 55:218-226.

MacFadden, B. J. and M.F. Skinner. 1979. Diversification and biogeography of the one-toed horses Onohippidium and Hippidion. Posti11a, 175:1-10.

MacFadden, B.J. and M. F. Skinner. 1981. Earliest Holarctic hipparion, Cormohipparion goorisi n. sp. (Mammalia, Equidae), from the Barstovian (medial MTocene) Texas Gulf Coastal Plain. Journal of Paleontology, 55:619-627.

MacFadden, B.J. and M. F. Skinner. 1982. Hipparion hor ses and modern phylogenetic interpretation: comments of Forsten's view of Cormohipparion. Journal of Paleontology, 56:1336-1342.

MacFadden, B.J. and J.S. Waldrop. 1980. Nannippus phlegon (Mammalia, Equidae) from the Pliocene (Blancan) of Florida. BulTetin of the Florida State Museum, Biological Sciences, $25: 1-37$. 
MacFadden, B.J. and S.D. Webb. 1982. The succession of Miocene (Arikareean through Hemphillian) terrestrial mammalian localities and faunas in Florida. Pp. 186-199 in Scott, T.M. and S.B. Upchurch, eds., Miocene of the Southeastern United States. Florida Department of Natural Resources, Bureau of Geology, Special Publication No. 25, Tallahassee.

MacFadden, B.J. and M.0. Woodburne. 1982. Systematics of the Neogene Siwalik hipparions (Mammalia, Equidae) based on cranial and dental morphology. Journal of Vertebrate Paleontology, 2:185-218.

Marsh, 0.C. 1874. Notice of new equine mammals from the Tertiary formation. American Journal of Science, 7:247-258.

Marsh, 0.C. 1879. Polydactyle horses, recent and extinct. American Journal of Science, 17:499-505.

Marshall, L.G., R.F. Butler, R.E. Drake, G.H. Curtis and R.H. Tedford. 1979. Calibration of the Great American Interchange. Science, $204: 272-279$.

Matthew, W.D. 1924. Third contribution to the Snake Creek Fauna. Bulletin of the American Museum of Natural History, 50:59-210.

Matthew, W.D. 1926. The evolution of the horse. A record and its interpretation. The Quarterly Review of Biology, 1:139-185.

Matthew, W.D. 1932. New fossil mammals from the Snake Creek quarries. American Museum Novitates, 540:1-8.

Matthew, W.D., and R.A. Stirton. 1930. Equidae from the Pliocene of Texas. Bulletin of the Department of Geological Sciences, University of California, 19:349-396.

Mayr, E. 1969. Principles of Systematic Zoology. McGraw-Hill, New York, $428 \mathrm{p}$.

McGrew, P.0. 1938. The Burge Fauna, a lower Pliocene mammalian assemblage from Nebraska. Bul let in of the Department of Geological Sciences, University of California, 24:309-328.

McGrew, P.0. 1944a. An 0steoborus from Honduras. Geological Series of the Field Museum of Natural History, 8:75-77.

McGrew, P.0. 1944b. An early Pleistocene (Blancan) fauna from Nebraska. Geological Series of the Field Museum of Natura 1 History, 9:33-66.

McGrew, P.O., and G.E. Meade. 1938. The bearing of the Valentine area in continental Miocene-Pliocene correlation. American Journal of Science, 36:197-207. 
McKenna, M.C. 1975. Toward a phylogenetic classification of the Mammalia. Pp. 21-46 in Luckett, W.P. and F.S. Szalay, eds., Phylogeny of the Primates. Plenum Publishing Corporation, New York.

Merriam, J.C. 1915a. New species of the Hipparion group from the Pacific Coast and Great Basin provinces of North America. Bulletin of the Department of Geology, University of California, 9:1-8.

Merriam, J.C. 1915b. New horses from the Miocene and Pliocene of California. Bulletin of the Department of Geology, University of California, 9:49-58

Merriam, J.C. 1916. Mammalian remains from the Chanac Formation of the Tejon Hills, California. Bulletin of the Department of Geology, University of California, 10:111-127.

Merriam, J.C. 1919. Tertiary mammalian faunas of the Mohave Desert. Bulletin of the Department of Geology, University of California, $11: 437-585$.

Merriam, J.C. and C. Stock. 1928. A further contribution to the mammalian fauna of the Thousand Creek Pliocene, northwestern Nevada. Carnegie Institution of Washington Publication, 393:5-21.

Miller, W.E. and 0. Carranza-Castaneda. 1984. Late Cenozoic mammals from Central Mexico. Journal of Vertebrate Paleontology, $4: 216-236$.

Mooser, 0. 1960. Un equido fossil del genero Neohipparion de la Mesa Central de Mexico. Anales del Instituto de Btologla, Universidad Nacional Autonoma de Mexico, 30:375-388.

Mooser, 0. 1964. Neohipparion monias n. sp. Equido fosil del Plioceno de la Mesa Central de Mexico. Anales del Instituto de Biologia, Universidad Nacional Autonoma de Mexico, 34:393-396.

Mooser, 0. 1968. Fossil Equidae from the middle Pliocene of the Central Plateau of Mexico. The Southwestern Naturalist, 13:1-12.

Moreno, F.P. 1891. Onohippidion munizi. Breve noticia sobre los restos fósiles de un género nuevo de la familia de los Equidae conservadas en el Museo de La Plata. Revista Museo de La Plata, 2:65-71.

Morgan, G.S. and B. Ridgway. in press. Late Pliocene (late Blancan) vertebrates from the St. Petersburg Times Site, Pinellas County, Florida, with a brief review of Florida Blancan faunas. Papers in Florida Paleontology, 1. 
Munthe, J. 1979. The Hemingfordian mammal fauna of the Vedder locality, Branch Canyon Sandstone, Santa Barbara County, California. Part III: Carnivora, Perissodactyla, Artiodactyla and summary. Paleobios, $29: 1-22$.

Nelson, M.E., B.J. MacFadden, J.H. Madsen and W.L. Stokes. 1984. Late Miocene horse from north central Utah and comments on the Salt Lake Group. Transactions of the Kansas Academy of Science, $87: 53-58$.

Novacek, M.J. 1986. The skull of leptictid insectivorans and the higher-level classification of eutherian mammals. Bulletin of the American Museum of Natura 1 History, 183:1-112.

01 sen, S.J. 1964. An upper Miocene fossil locality in north Florida. Quarteriy Journal of the Florida Academy of Sciences, 26:307-314.

01 son, E.C. 1971. Vertebrate Paleozoology. Wiley-Interscience, New York, $839 \mathrm{p}$.

01son, E.C. and P.0. McGrew. 1941. Mammalian fauna from the Pliocene of Honduras. Bulletin of the Geological Society of America, $52: 1219-1244$.

Osborn, H.F. 1912. Craniometry of the Equidae. Memoirs of the American Museum of Natural History, new series, 1:57-100.

0sborn, H.F. 1918. Equidae of the 01igocene, Miocene, and Pliocene of North America. Iconographic type revision. Memoirs of the American Museum of Natural History, new series, 2:1-331.

Owen, R. 1848. Description of teeth and portions of jaws of two extinct anthracotheroid quadrapeds.... with an attempt to develope Cuvier's idea of the classification of pachyderms by the number of their toes. Quarterly Journal of the Geological Society of London, $4: 104-141$.

Owen, R. 1869. On fossil teeth of equines from Central and South America. Proceedings of the Royal Society of London, 17:267-268.

Patton, T.H. 1969. Miocene and Pliocene artiodactyls, Texas Gulf Coastal Plain. Bulletin of the Florida State Museum, Biological Sciences, $14: 115-226$.

Patton, T.H. and B.E. Taylor. 1971. The Synthetoceratinae (Mammalia, Tylopoda, Protoceratidae). Builetin of the American Museum of Natura 1 History, 145:119-218. 
Petuch, E.J. 1982. Notes on the molluscan paleoecology of the Pinecrest Beds at Sarasota, Florida with description of Pyruelia, a stratigraphically important new genus (Gastropoda:

Melongenidae). Proceedings of the Academy of Natural Sciences of Philadelphia, $134: 12-30$.

Quinn, J.H. 1955. Miocene Equidae of the Texas Gulf Coastal Plain. Bureau of Economic Geology, University of Texas Publication, $5516: 1-102$.

Quinn, J.P. 1984. Geology and biostratigraphy of the Bopesta Formation, Southern Sierra Nevada Mountains, Kern County, California. M.S. Thesis, University of California, Riverside. 237 p.

Reinhart, R.H. 1976. Fossil sirenians and desmostylids from Florida and elsewhere. Bulletin of the Florida State Museum, Biological Sciences, 20:187-300.

Rensberger, J.M., A. Forsten, and M. Fortelius. 1985. Functional evolution of the cheek tooth pattern and chewing direction in Tertiary horses. Paleobiology, 10:439-452.

Richey, K.A. 1948. Lower Pliocene horses from Blawk Hawk Ranch Mount Diablo, California. Bulletin of the Department of Geological Sciences, University of California, 28:1-44.

Robertson, J.S. 1976. Latest Pliocene mammals from Haile XVA, Alachua County, Florida. Bulletin of the Florida State Museum, Biological Sciences, 20:111-186.

Romer, A.S. 1949. Time series and trends in animal evolution. Pp. 103-120, in Jepson, G.L., G.G. Simpson and E. Mayr, eds., Genetics, Paleontology, and Evolution. Princeton University Press, Princeton, New Jersey.

Rose, K.D. and T.M. Bown. 1986. Gradual evolution and species discrimination in the fossil record. Pp. 119-130 in Flanagan, K.M. and J.A. Lillegraven, eds., Vertebrates, Phylogeny, and Philosophy. Contributions to Geology, Universtiy of Wyoming, Special Paper 3.

SAS Institute Inc. 1985a. SAS Users Guide: Basics, Version 5 Edition. SAS Institute Inc., Cary, North Carolina, 1290 p.

SAS Instituite Inc. 1985b. SAS Users Guide: Statistics, Version 5 Edition. SAS Institute Inc., Cary, North Carolina, 956 p.

Schlaikjer, E.M. 1937. A study of Parahippus wyomingensis and a discussion of the phylogeny of the genus. Bulletin of the Museum of Comparative Zoology, 80:255-280. 
Scott, W.B. 1893. The mammals of the Deep River beds. American Natura 1 ist, $27: 659-662$.

Sellards, E.H. 1910. A preliminary paper on the Florida phosphate deposits. Florida Geological Survey, 3rd Annual Report, pp. 21-41.

Sellards, E.H. 1915. The pebble phosphates of Florida. Florida Geological Survey, 7th Annual Report, pp. 25-116.

Sellards, E.H. 1916. Fossil vertebrates from Florida: a new Miocene fauna; new Pliocene species; the Pleistocene fauna. Florida Geological Survey, 8th Annual Report, pp. 77-119.

Schultz, G.E. 1977. The Ogallala Formation and its vertebrate faunas in the Texas and 0klahoma Panhandles. Pp. 5-104, in, Schultz, G.E., ed., Field Conference on Late Cenozoic biostratigraphy of the Texas Panhandle and adjacent Oklahoma. Kilgore Research Center, Department of Geology and Anthropology, Specjal Paper No. 1, West Texas State University, Canyon, Texas.

Shotwe11, J.A. 1961. Late Tertiary biogeography of horses in the northern Great Basin. Journal of Paleontology, 35:203-217.

Simpson, G.G. 1930. Tertiary land mammals from Florida. Bulletin of the American Museum of Natural History, $59: 149-211$.

Simpson, G.G. 1944. Tempo and Mode in Evolution. Columbia University Press, New York, 237 p.

Simpson, G.G. 1945. The principles of classification and a classification of the mammals. Burletin of the American Museum of Natura 1 History, $85: 1-350$.

Simpson, G.G. 1951. Horses. Oxford University Press, New York, $245 \mathrm{p}$.

Simpson, G.G. 1953. The Major Features of Evolution. Columbia University Press, New York, 434 p.

Simpson, G.G. 1986. Recollections of W. D. Matthew. Palaios, $1: 200-203$.

Skinner, M.F. and F.W. Johnson. 1984. Tertiary stratigraphy and the Frick Collection of fossil vertebrates from north-central Nebraska. Bulletin of the American Museum of Natural History, $178: 215-368$.

Skinner, M.F. and B.J. MacFadden. 1977. Cormohipparion n. gen. (Mammalia, Equidae) from the North American Miocene (Barstovian-Clarendonian). Journal of Paleontology, 51:912-926. 
Skinner, M.F. and B.E. Taylor. 1967. A revision of the geology and paleontology of the Bijou Hills, South Dakota. American Museum Novitates, 2300:1-53.

Skinner, M.F., S.M. Skinner and R.J. Gooris. 1968. Cenozoic rocks and faunas of Turtle Butte, south-central South Dakota. Bulletin of the American Museum of Natural History, 138:379-436.

Skinner, M.F., S.M. Skinner and R.J. Gooris. 1977. Stratigraphy and bjostratigraphy of Late Cenozoic deposits in central Sioux County, western Nebraska. Bulletin of the American Museum of Natura 1 History, $158: 263-371$.

Slaughter, B.H. 1981. A new genus of geomyoid rodent from the Miocene of Texas and Panama. Journal of Vertebrate Paleontology, $1: 111-115$.

Sober, E. 1983. Parsimony in systematics: philosophical issues. Annual Review of Ecology and Systematics, 14:335-357.

Sondaar, P.Y. 1968. The osteology of the manus of fossil and Recent Equidae. Verhandelingen der Koninklijke Nederlandse Akademie van Wetenschappen, afd. Natuurkunde, 25:1-76.

Stanley, S.M. 1986. Anatomy of a regional mass extinction: PlioPleistocene decimation of the western Atlantic bivalve fauna. Palaios, $1: 17-36$.

Steinmann, G. and L. Döderlein. 1890. Elemente der Palaontologie. Wilheim Engelmann, Leipzig, 848 p.

Stenze1, H.B., F.E. Turner and C.J. Hesse. 1945. Brackish and nonmarine Miocene in southeastern Texas. Bulletin of the American Association of Petroleum Geologists, 28:977-1011.

Stirton, R.A. 1939. Cenozoic mammal remains from the San Francisco Bay region. Bulletin of the Department of Geological Sciences, University of California, $24: 339-410$.

Stirton, R.A. 1940. Phylogeny of North American Equidae. Bulletin of the Department of Geological Sciences, University of California, 25:165-198.

Stirton, R.A. 1941. Development of characters in horse teeth and the dental nomenclature. Journa 1 of Mammalogy, 22:434-446.

Stirton, R.A. 1947. Observations on evolutionary rates in hypsodonty. Evolution, 1:32-41.

Stirton. R.A. 1952. Are Petaluma horse teeth reliable in correlation? Bulletin of the American Association of Petroleum Geologists, $36: 2011-2025$. 
Stirton, R.A. 1955. Two new species of the equid genus Neohipparion from the middle Pliocene, Chihuahua, Mexico. Journa of Paleontology, 29:886-902.

Stirton, R.A. and W. Chamberlain. 1939. A cranium of Pliohippus fossulatus from the Clarendon Pliocene fauna of Texas. Journal of Paleontology, 13:349-353.

Stirton, R.A. and P.0. McGrew. 1935. A preliminary notice on the Miocene and Pliocene mammalian faunas near Valentine, Nebraska. American Journal of Science, 29:125-132.

Stock, C. 1935. Deep-well record of fossil mammal remains in California. Bulletin of the American Association of Petroleum Geologists, 19:1064-1068.

Swofford, D.L. 1985. PAUP, Phylogenetic Analysis Using Parsimony. (published by the author), Champaign, Illinois. $70 \mathrm{p}$.

Tabrum, A. 1981. A contribution to the mammalian paleontology of the Ogallala Group of south-central South Dakota. M.S. Thesis, South Dakota School of Mines and Technology, Rapid City. 408 p.

Tedford, R.H. 1970. Principles and practices of mammalian geochronology in North America. North American Paleontological Convention, Chicago, 1969. Proceedings F, pp. 666-703.

Tedford, R.H. 1981. Mammalian biochronology of the late Cenozoic basins of New Mexico. Geological Society of America Bulletin, 92:1008-1022.

Tedford, R. H. and M.E. Hunter. 1984. Miocene marine-nonmarine correlations, Atlantic and Gulf Coastal Plains, North America. Palaeogeography, Palaeoclimatology, Palaeoecology, 47:129-151.

Tedford, R. H., T. Galusha, M.F. Skinner, B.E. Taylor, R.W. Fields, J.R. MacDonald, J.M. Rensberger, S.D. Webb, and D.P. Whistler. in press. Faunal succession and biochronology of the Arikareean through Hemphillian interval (late 01igocene through earliest Pliocene Epochs), North America. In, M.0. Woodburne, ed., Cenozoic Mammals of North America: Geochronolgy and Biostratigraphy. University of California Press, Berkeley.

Van Valen, L. 1960. A functional index of hypsodonty. Evolution, $14: 531-532$.

Voorhies, M.R. 1971. Paleoclimatic significance of crocodilian remains from the Ogallala Group (Upper Tertiary) in northeastern Nebraska. Journal of Paleontology, 45:119-121. 
Voorhies, M.R. 1974. The Pliocene horse Nannippus minor in Georgia: geological implications. Tulane Studies in Geology and Paleontology, 11:109-113.

Waldrop, J.S. 1971. The Pliocene Equidae of Florida. M.S. Thesis, University of Florida, Gainesville. $170 \mathrm{p}$.

Webb, S.D. 1964. The Alachua Formation. Pp. 22-29, in, Guidebook 1964 Field Trip, Society of Vertebrate Paleontology.

Webb, S.D. 1966. A relict species of the burrowing rodent Mylagaulus, from the Pliocene of Florida. Journal of Mammalogy, 47:401-412.

Webb, S.D. 1969a. The Burge and Minnechaduza Clarendonian mammalian faunas of north-central Nebraska. University of California

Publications in the Geological Sciences, 78:1-191.

Webb, S.D. 1969b. The Pliocene Canidae of Florida. Bulletin of the Florida State Musuem, Biological Sciences, $14: 273-308$.

Webb, S.D. 1969c. Extinction-origination equilibria in late Cenozoic land mammals of North America. Evolution, 23:688-702.

Webb, S.D. 1973. Pliocene pronghorns of Florida. Journal of Mamma Jogy, $54: 203-221$.

Webb, S.D. 1977. A history of savanna vertebrates in the New Wor 7d. Part 1: North America. Annual Review of Ecology and Systematics, $8: 355-380$.

Webb, S.D. 1981. Kyptoceras amatorum, new genus and species from the Pliocene of Florida, the last protoceratid artiodactyl. Journal of Vertebrate Paleontology, 1:357-365.

Webb, S.D. 1983. A new species of Pediomeryx from the late Miocene of Florida, and $i$ ts relationships within the subfamily Cranioceratinae (Ruminantia: Dromomerycidae). Journal of Mamma logy, 64 :261-276.

Webb, S.D. 1984. Ten milition years of mammal extinctions. Pp. 189210, in Martin, P.S. and R.G. Klein, eds., Quaternary Extinctions: A Prehistoric Revolution. University of Arizona Press, Tucson.

Webb, S.D. in press. Dsteology and relationships of Thinobadistes, the first mylodont sloth in North America. In, Redford, K.E. and J.F. Eisenberg, eds., Ralph Wetzel Memorial Vol ume. 
Webb, S.D and D.B. Crissinger. 1983. Stratigraphy and vertebrate paleontology of the Central and Southern Phosphate Districts of Fiorida. Pp. 28-72, in, Field Trip Guidebook, Central Florida Phosphate District. Geological Society of America, Southeastern Section

Webb, S.D and R.C. Hulbert. 1986. Systematics and evolution of Pseudhipparion (Mammalia, Equidae) from the Late Neogene of the GuTf Coastal Plain and the Great Plains. Pp. 237-285, in Flanagan, K.M. and J.A. Lillegraven, eds., Vertebrates, Phylogeny, and Philosophy. Contributions to Geology, Universtiy of Wyoming, Special Paper 3.

Webb, S.D, B.J. MacFadden, and J.A. Baskin. 1981. Geology and paleontology of the Love Bone Bed from the late Miocene of Florida. American Journal of Science, 281:513-544.

Webb, S.D. and S.C. Perrigo. 1984. Late Cenozoic vertebrates from Honduras and El Salvador. Journal of Vertebrate Paleontology, $4: 237-254$.

Webb, S.D. and N. Tessman. 1967. Vertebrate evidence of a low sea level in the middle Pliocene. Science, 156:379.

Webb, S.D. and N. Tessman. 1968. A Pliocene vertebrate fauna from low elevation in Manatee County, Florida. American Journal of Science, 266:777-811.

Wiley, E.0. 1981. Phylogenetics. The Theory and Practice of Phylogenetic Systematics. John Wiley and Sons, New York, 439 p.

Wilson, J.A. 1956. Miocene formations and vertebrate biostratigraphic units, Texas Coastal Plain. Bulletin of the American Association of Petroleum Geologists, 40:2233-2246.

Winans, M.C. 1985. Revision of North America fossil species of the genus Equus (Mammalia:Peris sodactyla:Equidae). Ph.D. Dissertation, University of Texas at Austin, $264 \mathrm{p}$.

Winkler, D.A. 1985. Stratigraphy, vertebrate paleontology and depositional history of the Ogallala Group in Blanco and Yellowhouse Canyons, northwestern Texas. Ph.D. Dissertation, University of Texas at Austin, $243 \mathrm{p}$.

Wolff, R.G. 1978. Function and phylogenetic significance of cranial anatomy of an early bear (Indarctos) from Pliocene sediments of Florida. Carnivore, 1:1-12.

Woodburne, M.0. 1959. A fossil alligator from the lower Pliocene of Oklahoma and its climatic significance. Papers of the Michigan Academy of Science, $44: 47-50$.. 
Woodburne, M.0. and R.L. Bernor. 1980. On supraspecific groups of some 0ld World hipparionine horses. Journal of Paleontology, $54: 1319-1348$.

Woodburne, M.0. and B.J. MacFadden. 1983. A reappraisal of the systematics, biogeography, and evolution of fossil horses. Paleobiology, $8: 315-327$.

Woodburne, M.0., B. J. MacFadden and M.F. Skinner. 1981. The North American "Hipparion" Datum, and implications for the Neogene of the 01d Wortd. Geobios, $14: 1-32$.

Yarne17, K.L. 1980. Systematics of late Miocene Tapiridae (Mammalia, Perissodactyla) from Florida and Nebraska. M.S. Thesis, University of Florida, Gainesville, $124 \mathrm{p}$. 


\section{BIOGRAPHICAL SKETCH}

Richard Charles Hulbert, Jr., born on May 28, 1955, in San Diego, California, is the son of Harriett Peterson Hulbert and Richard C. Hulbert. After graduating from Memorial High School in Houston, Texas, in May, 1973, he entered the University of Texas at Austin. In May, 1976, he graduated with High Honors, receiving a Bachelor of Science degree in zoology. In the fall of 1976, he re-entered the University of Texas at Austin in the Department of Geological Sciences. He was awarded a Master of Arts degree upon completion of a thesis entitied "Linear Discriminant Analysis and Variability of Pleistocene and Holocene Leporidae of Texas" in December, 1979. In January, 1981, he enrolled in the University of Florida in the Department of Zoology. While at Florida, he held numerous research and teaching assistantships in both the Department of Zoology and the Florida State Museum. Richard is a member of the Society of Vertebrate Paleontology, the Paleontological Society, and the Willi Hennig Society. He is interested in many aspects of mammalian paleontology, notably systematics, evolution, paleoecology and morphometrics. 
I certify that I have read this study and that in my opinion it conforms to acceptable standards of scholarly presentation and is fully adequate, in scope and quality, as a dissertation for the degree of Doctor of Philosophy.

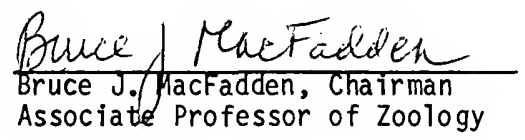

I certify that I have read this study and that in my opinion it conforms to acceptable standards of scholarly presentation and is fully adequate, in scope and quality, as a dissertation for the degree of Doctor of Philosophy.

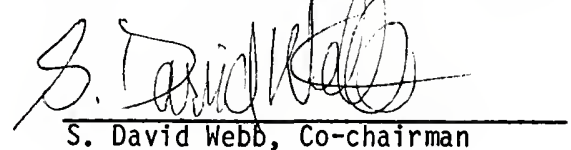

S. David Webb, Co-chairman

Professor of Zoology

I certify that I have read this study and that in my opinion it conforms to acceptable standards of scholarly presentation and is fully adequate, in scope and quality, as a dissertation for the degree of Doctor of Philosophy.

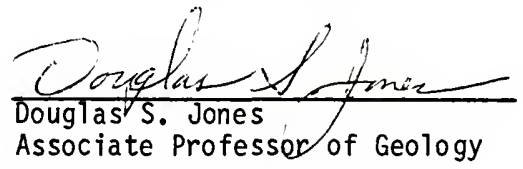

This dissertation was submitted to the Graduate Faculty of the Department of Zoology in the College of Liberal Arts and Sciences and to the Graduate School and was accepted as partial fulfillment of the requirements for the degree of Doctor of Philosophy.

May 1987

Dean, Graduate School 
UNIVERSITY OF FLORIDA

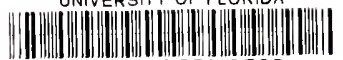

31262085533528 